


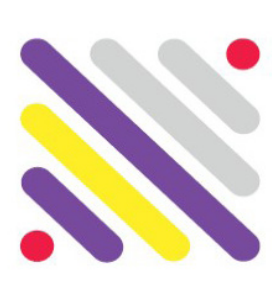

Actas

$14^{\circ}$ Congreso Mundial

de Semiótica: Trayectorias

\section{Buenos Aires}

Septiembre 2019

International Association for Semiotic Studies (IASS/AIS)

Tomo 4

\section{Artes y lenguajes}

\section{Coordinadores}

Mónica Kirchheimer y Gustavo Aprea 
Área Transdepartamental de Crítica de Artes

Actas Buenos Aires. 14을 Congreso Mundial de Semiótica : trayectorias : Proceedings of the 14th World

Congress of the International Association for Semiotic Studies-IASS/AIS : tomo 4 : artes y lenguajes /

editado por Rolando Martínez Mendoza ; José Luis Petris ; prólogo de Mónica Susana Kirchheimer ;

Gustavo Aprea. - 1a ed edición multilingüe. - Ciudad Autónoma de Buenos Aires : Libros de Crítica. Área

Transdepartamental de Crítica de Artes, 2020.

Libro digital, PDF

Edición multilingüe: Alemán ; Español ; Francés ; Inglés

Archivo Digital: descarga y online

ISBN 978-987-47805-3-9

1. Semiología. 2. Semiótica. 3. Arte. I. Martínez Mendoza, Rolando, ed. II. Petris, José Luis, ed. III. Kirchheimer, Mónica Susana, prolog. IV. Aprea, Gustavo, prolog. V. Título.

CDD 401.41

Actas Buenos Aires. 14 Congreso Mundial de Semiótica:

Trayectorias. Trajectories. Trajectoires. Flugbahnen.

Asociación Argentina de Semiótica y Área Transdepartamental de Crítica de Artes de la Universidad Nacional de las Artes, Buenos Aires, Argentina.

Proceedings of the 14th World Congress of the International Association for Semiotic Studies (IASS/AIS)

Buenos Aires, 9 al 13 de septiembre de 2019.

Tomo 4

ISSN 2414-6862

e-ISBN de la obra completa: 978-987-47805-0-8

e-ISBN del Tomo 4: 978-987-47805-3-9

DOI: 10.24308/IASS-2019-4

(C) IASS Publications \& Libros de Crítica, noviembre 2020

Editores Generales José Luis Petris y Rolando Martínez Mendoza

Editores Marina Locatelli y Julián Tonelli

Diseño Andrea Moratti

Todos los derechos reservados. Ninguna parte de esta publicación debe ser reproducida, almacenada en un sistema de recuperación ni transmitida bajo ninguna forma ni por ningún medio, ya sea electrónico, mecánico, de fotocopiado, grabación o cualquier otro medio, sin el permiso de los editores.

Los editores rechazan cualquier responsabilidad en caso de declaraciones falsas o erróneas de los autores, contenido plagiado y uso no autorizado de material con derechos de autor. 


\section{Trayectorias}

Se elegió para la propuesta temática del congreso esta palabra: 'trayectorias', a causa de la extraordinaria pluralidad de sentidos que surge de sus usos contemporáneos.

El ejemplo más claro podemos encontrarlo en la trayectoria de definiciones de la misma palabra semiótica.

En este recorrido se despliegan las múltiples historias de su adopción como nombre de un campo de indagaciones analíticas y de publicaciones.

Sin embargo, el término Trayectorias, en plural, sugiere también que ese recorrido no es ni único ni lineal.

No oculta, en suma, la condición diversa de los caminos recorridos para la percepción de problemáticas intrínsecamente plurales y móviles.

A la vez, la variedad de trayectorias encuentra su razón en la multiplicidad de soportes mediáticos, dispositivos, medios y lenguajes que, en la contemporaneidad, se reclaman, se interpelan y se disputan tiempos y espacios.

Trayectorias, entonces, no se aplica aquí sólo a los desarrollos conceptuales de la disciplina semiótica sino, también, a los recorridos del cambiante conjunto de objetos (mediáticos, comunicacionales, de diseño, biológicos, arquitectónicos) en los que ella fija su mirada.

Las Trayectorias son, de este modo, las memorias, las materialidades y los compromisos que guían las definiciones, las escrituras y las búsquedas por los itinerarios del sentido.

Es por esto que se ha entendido que con el nombre Trayectorias se elegía un modo de reconocimiento de la condición insoslayable de despliegue y recomienzo que configura constantemente el quehacer de la investigación semiótica. 

Entre los días 9 y 13 de septiembre de 2019 se realizó en Buenos Aires, República Argentina, el $14^{\circ}$ Congreso Internacional de Semiótica. Fue organizado por la Asociación Argentina de Semiótica y la Universidad Nacional de las Artes de Buenos Aires (UNA) a través de su Área Transdepartamental de Crítica de Artes. El Congreso convocó a más de 700 expositores de 45 países. El intercambio en los Plenarios, las Mesas y los espacios de socialización fue de gran riqueza y humanamente imposible in situ de abarcar en su totalidad. Por este motivo es que la publicación de sus Actas se propone no sólo como registro del acontecimiento sino como una continuación y complemento del intercambio de ideas y trabajos semióticos que tuvo lugar, por primera vez, en América del Sur. La decisión de hacerlo en 8 tomos temáticos busca facilitar la profundización del diálogo en las áreas comunes de interés. 

Tomo 4

Artes y lenguajes 


\section{ÍNDICE}

Presentación.

Mónica Kirchheimer y Gustavo Aprea 13

\section{MEDIATIZACIONES}

\section{A. APROPIACIONES Y LECTURAS}

El estudio de las transposiciones de la literatura al cine: los aportes que distintas verientes semióticas efectuaron al campo. María Rosa Del Coto

Introducción fílmico-literaria de viajes y transposición(es). María Silvina Tatavitto 33

Retomas del cine de los 80: procedimientos transpositivos de un fenómeno particular. José Tripodero 45

\section{B. LA INSISTENCIA DE FORMAS FÍLMICAS}

La despedida de los amantes en la estación de tren. Pervivencia y mutación de formas fílmicas. Marina Locatelli 53

Temporalidades ficcionales - una exploración de las paradojas temporales en el cine de ficción.

M. Laura Ragucci 71

Posibles Pathosformeln en la historia del cine.

Mabel Tassara 79

\section{CINES REGIONALES}

Configuraciones del cine regional en la prensa de la norpatagonia de los años ochenta.

Ignacio Dobree 99

Tunches, pishtacos y jarjachas: formas enunciativas del miedo en el cine regional andino peruano.

Miguel Ángel Torres Vitolas. 


\section{NUEVAS TEORÍAS SOBRE LO AUDIOVISUAL}

Le cinéma et son double ou le principe de l'asynchronisme revisité. Ivan Capeller

What's in the name live cinema?.

Marga van Mechelen

Trânsito e complexidades sensoriais em imagens comtemporâneas. Lívia Machado

\section{E. FORMAS Y TEMAS EN LA TELEVISIÓN}

Operaciones de ludicidad y autorreferencia en dos casos de animación digital contemporánea.

Maria Alejandra Alonso 161

Si solo si: la discapacidad en la ficción televisiva argentina. Carolina Casali

Casi una serie. Apuntes trasnochados sobre realismo y cine en dos miniseries misioneras.

Mauro Figueredo 185

Télévision et justice : une trajectoire médiatique controversée? Yannick Lebtahi

\section{F. REDES Y CIRCULACIÓN DEL SENTIDO}

Formas de vida migratorias: arte e intimidad Jaime Cordero 209

Lo lúdico, lo social y lo político en dos casos de animación contemporánea. Mónica Kirchheimer

Snuff 2.0: Sobre los videos de violencia y muerte en redes sociales. Julián Tonelli

Dispositivos y enunciación en la postfotografía: algunas trayectorias de la imagen fotográfica digital en redes sociales. Mariano Zelcer 


\section{MEDIACIONES}

\section{A. EXPRESIONES DEL CUERPO}

La autopoiesis del acontecer artístico que emerge a través del diálogo entre diferentes dimensiones de la corporalidad. Daniela Lieban 261

Trasunto \#1: poesía en tránsito. Valentina Paillaleve 273

Lecturas del bioarte en clave semiótica: avances de investigación. Lucía Stubrin 285

\section{B. CUERPO Y MEMORIA}

La intimidad como apuesta política en Recordar 30 años para vivir 65 minutos, de Marina Otero.

Luciana Estevez 293

Danza en primera persona. El giro autobiográfico en las obras del under porteño. María José Rubin 303

Historia, montaje, archivo: para una performatividad de la memoria. Cecilia Tosoratti

\section{OPERACIONES EN FOTOGRAFÍA, HISTORIETA Y PINTURA}

Innovaciones discursivas y nuevas estéticas de la historieta argentina contemporánea Andrea Acosta Camargo, Laura Amarilla y Gaspar Buono 325

Pierre Dupras, bédéiste caricaturiste engagé. Mila Falardeau 343

Trayectorias de la abyección en el arte posmoderno. Amparo Latorre Romero 351

Un no lugar para la fotografia: sobre la serie Archivo Utopia- El proyecto Brasilia. Vanesa Magnetto 


\section{CUERPO Y SENTIDOS}

El gesto musical y la cognición corporeizada: articuladores del sentido en la discursividad musical.

Federico Buján 375

The body as medium: the subversive self-portraitsof Francesca Woodman. Patrícia Fonseca Fanaya 385

\section{E. SONIDOS Y SENTIDOS}

\section{a. Música popular}

La construcción del tango como género musical en los medios masivos. Jimena Jauregui

Cuerpos y palabras en el ritmo: la escena de la voz en el rap Freestyle. Amparo Rocha Alonso

Procedimentos retóricos e semióticos na canção Retrato em branco e preto, de Chico Buarque e Tom Jobim. Robson Costa Bessa y Alfredo Werney Lima Torres

Música y producción de sentido en el cine de Woody Allen. La presencia de obras musicales representativas de un determinado momento como reenvío a manifestaciones culturales del pasado. Carolina Inés Rochi 435

\section{b. Música Académica}

La cadena significante de los cuerpos en los bomarzos argentinos. Jerónimo Brignone 445

Villa-Lobos: symbolical and semiotical. Cleisson Melo 465 



\section{Presentación}

DOI: 10.24308/IASS-2019-4-001

Organizar una compilación de trabajos semióticos que se engloban dentro de una rúbrica tan abierta como "Arte y lenguajes" plantea varias cuestiones. La primera de ellas la amplitud y variedad de la convocatoria. Dentro del campo de la Semiótica se cuenta una extensa trayectoria de investigaciones dentro de esta gran área. EI XIV Congreso de la IASS no resultó una excepción en este sentido. En consecuencia, este volumen es uno de los que más trabajos contiene. Este número de contribuciones, como es de esperar, trae aparejada la diversidad de objetos y enfoques que hacen perentorio algún tipo de ordenamiento que facilite el acceso al material publicado. Los usos previstos de un volumen de actas orientaron nuestros criterios de organización. Las áreas temáticas y las mesas que se desarrollaron durante el encuentro en Buenos Aires quedaron demasiado desfasados por ausencias y cambios en la recolección de las ponencias y hace necesario pensar algún tipo clasificación que la reemplace y delinee un recorrido de los trabajos.

La segunda cuestión tiene que ver con los límites difusos que se presentan partiendo de una perspectiva tan abierta y el modo en que se desarrollan los estudios semióticos. Si se considera el conjunto de los materiales enviados para la edición de las actas, algunos trabajos presentes en este tomo podrían aparecer en otros y algunos compilados en otros volúmenes podrían estar aquí. La labilidad de los límites externos de la convocatoria se condice con las dificultades para establecer clasificaciones internas y excluyentes de los contenidos que finalmente conforman cada volumen.

En tanto que coordinadores del Tomo IV, hemos tomado algunas decisiones. Como decíamos, "Arte y Lenguajes" es un universo amplio 
en el que se incluyen tanto las miradas propias de las distintas disciplinas e interdisciplinas artísticas, como la problematización de objetos estéticos y de objetos no artísticos incluidos en lenguajes. En este sentido, se buscó un ordenamiento que responda a dos condiciones: por un lado, la utilidad para el uso de un lector que se aproxime a las actas (no se espera de este género una lectura lineal), un ordenamiento que resulte lo suficientemente descriptivo como para orientar diversas consultas al Tomo; por otro, como una puesta en diálogo de los propios trabajos compilados. Esto es, una búsqueda por hacer crecer los temas abordados por cada artículo en una conversación con otros con los que se relaciona. Para diagramar las vías de acceso al material establecimos diversos niveles de organización.

En una primera entrada se diferencian los análisis en función de tipos y modalidades de lenguajes, a partir de sus espacios de circulación: mediática o no mediática. En el primero encontramos objetos cuya circulación se produce gracias a las formas articuladas de dispositivos comunicativos y prácticas sociales vinculadas (cine, televisión, redes); mientras que el caso de la circulación no mediatizada encontramos aportes que se centran en problemáticas vinculadas con formas de expresión o de consumo "directo" (el cuerpo, la música, las artes visuales, las performances, entre otros).

Asimismo, se buscó atender a las formas en que son observados los fenómenos estudiados. Cada una de estas grandes entradas se subdividen en secciones menores en pos de una visibilidad que acentúe una clave de lectura. Así se reúnen en un mismo apartado, "Apropiaciones y Lecturas", trabajos que atienden a las pervivencias, relecturas y apropiaciones transpositivas. En "La Insistencia de Formas Fílmicas" se abordan diversas configuraciones y narrativas cinematográficas que persisten a lo largo de su historia. Las cualidades particulares de las formas de producción y circulación cinematográfica más allá de las salas comerciales, se encuentran en el apartado destinado a "Cines Regionales". Las perspectivas teóricas sobre lo fílmico se incluyen en "Nuevas Teorías sobre lo Audiovisual". Las 
novedades de la pantalla doméstica en torno de nuevos temas, formas de representación y de referenciación se agruparon en "Formas y Temas en la Televisión". Finalmente, las miradas sobre objetos de circulación mediática restringida centrada en redes sociales pueden encontrarse en la sección "Redes y Circulación del Sentido".

La segunda parte del volumen está centrada en abordajes a lenguajes y objetos artísticos mediados. Allí encontramos indagaciones en torno de las "Expresiones del cuerpo" que abordan la corporeidad como soporte poético, estético y comunicativo. Temas como la intimidad, la memoria, lo autobiográfico centrados en el cuerpo y la performance se agrupan en "Cuerpo y Memoria". Los trabajos que abordan manifestaciones de diversas artes visuales fueron reunidos en "Operaciones en Fotografía, Historieta y Pintura. En "Cuerpos y Sentidos" se agrupan problematizaciones de lo sensorial como fuentes de procesos de semiotización. Los trabajos que analizan diversos aspectos de lo musical se reúnen en "Sonidos y Sentidos"; en un subordenamiento, un primer conjunto se agrupa en torno de la música Popular, y un segundo grupo trabaja la Música Académica.

Como se evidencia, este Tomo convoca un conjunto amplio de soportes, lenguajes, objetos, temas y retóricas. Esperamos que el ordenamiento presentado facilite el acceso a los trabajos reunidos a la vez que produzca una nueva lectura, ahora, enriquecida por la vecindad.

Dr. Gustavo Aprea, Dra. Mónica S. Kirchheimer 



\section{MEDIATIZACIONES}

\section{A. APROPIACIONES Y LECTURAS}





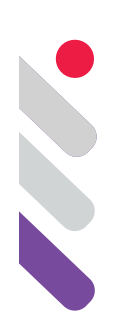

\title{
El estudio de las transposiciones de la literatura al cine: los aportes que distintas vertientes semióticas efectuaron al campo ${ }^{1}$
}

DOI: $10.24308 /$ IASS-2019-4-002

\author{
María Rosa del Coto \\ Facultad de Ciencias Sociales, UBA \\ Departamento de Ciencias Sociales, \\ Universidad Nacional de Quilmes, Argentina \\ mrdelcoto@gmail.com
}

El campo de fenómenos del que se ocupa la ponencia es el que se centra en la teorización y el abordaje analítico de los pasajes de textos narrativos literarios al cine. Como se sabe, dicho fenómeno se presenta como manifestación de una práctica más general, a la que suele referirse con el término "adaptación", pero que, en consonancia con la denominación propuesta por Steimberg, Traversa y Wolf, entre los argentinos, preferimos llamar transposición. Esta decisión se apoya en un conjunto de razones, entre las que se destacan el hecho de que, a diferencia de "adaptación" que presenta -aun cuando en escaso grado-, matices depreciativos, "transposición" pone el acento en la idea de traslado. En efecto, la primera acepción de trasponer -palabra de la que, obviamente, deriva transposición- indica, según el diccionario de la RAE, "poner a alguien o algo más allá, en lugar diferente del que ocupaba". Además, el vocablo se presenta próximo a la forma en que inicialmente se entendía "traducción", ya que esta palabra procede de traducere, que en latín clásico significa "Ilevar al otro lado". Por lo tanto, si adoptamos el término "transposición" es porque entendemos que ni comporta acentos despectivos ni sugiere la división entre forma y contenido. En cambio, afirma, y de modo difícil de objetar, la idea de traslado, de desplazamiento. Pero que elijamos "transposición" en lugar de, por ejemplo, transpolación -que tampoco presenta tonos valorativos-, para aludir a la práctica del pasaje de un relato literario al cine, se debe también a otra

${ }^{1}$ La ponencia forma parte de una investigación en desarrollo: Ubacyt 20020170100446BA de la programación 2018-2021 Retomas discursivas en tiempos de convergencia: producción, circulación, consumo, que dirijo. 
razón que no queremos soslayar aquí: a que la elección permite afianzar, en los estudios nacionales, una terminología que emplean autores ${ }^{2}$ que no leen las diferencias que presentan los textos de llegada respecto de los de partida según la "regla" de las pérdidas y las ganancias; por lo que al preferir "transposición", estamos adhiriendo a un posicionamiento $y$, simultáneamente, tendemos a fortalecer una tradición que juzgamos valiosa.

El objetivo fundamental de la ponencia -que adhiere a la definición postulada por Steimberg 1993, o sea, la que visualiza la transposición como "el cambio de soporte o lenguaje de una obra o género"-, consiste en efectuar un recorrido sobre las concepciones atinentes a los pasajes de la literatura al cine que a partir de los años sesenta del siglo pasado y hasta el presente se han desarrollado primordialmente al interior de la disciplina. Por lo tanto, se presta especial atención a las contribuciones que a la misma realizaron Metz, Bettetini, Casetti, Steimberg, Traversa, Stam y Hutcheon.

Ahora bien, cumplir el objetivo planteado supone atender a una serie de hechos; entre ellos cobran especial importancia, por un lado, el de que mucho antes de que la semiótica se institucionalizara como campo de saber, existía el estudio de las transposiciones -lo que nos llevaría a realizar un relevamiento de los trabajos que han desempeñado un papel decisivo en el tratamiento de la temática y que remiten a temáticas como la de las "relaciones entre las artes", tarea que, por motivos de espacio, limitamos a su mínima expresión. $\mathrm{Y}$, por otro, el hecho de que los posicionamientos de los estudios semióticos, como es obvio pensar, responden a los principios y líneas investigativas que, en el momento en que se formulan, rigen la disciplina, principios y líneas que, a su vez, no resultan independientes de los que dominan el panorama general imperante en las ciencias sociales y humanas del período sociocultural en que se manifiestan. Esto nos lleva a centrar la atención en los textos que adscriben a la Semiótica de Segunda generación (1973/75 hasta el presente), es decir, en los que aparecen como condiciones de producción las pautas rectoras de las lingüísticas discursivas -especialmente de la Teoría de la enunciación-, de la narratología modal "propuesta" por Genette, y que adoptan los conceptos de Dialogismo/ Polífonía bajtinianos y de intertextualidad (Kristeva, Barthes, entre tantos otros).

Concluimos esta introducción dejando claro que nuestra perspectiva teórico-metodológica se inscribe dentro de aquellos estudios sociosemióticos, que permiten superar una visión meramente descriptiva de las modificaciones y permanencias que los hipertextos manifiestan respecto de los hipotextos. ${ }^{3}$ Asimismo, reconoce una serie de premisas entre las que se destacan: a) desechar la relación "fidelidad/no fidelidad" que durante mucho tiempo fue

\footnotetext{
${ }^{2}$ Fundamentalmente Steimberg y Traversa.

${ }^{3}$ Las nociones de "hipotexto" e "hipertexto", provienen de Gerard Genette.
} 
el parámetro para justipreciar la factura de las transposiciones y b) -premisa que está íntimamente vinculada a la anterior- poner el foco de atención en el texto de llegada, o sea, observar las operatorias transpositivas en función del hipertexto, lo que, según nuestro criterio, habilita la instalación de preguntas y el tratamiento de cuestiones que, de entrada, están condenadas a permanecer invisibilizadas si el abordaje del texto transpositor se efectúa "desde" el del hipotexto, preguntas y cuestiones como las que remiten a las condiciones de reconocimiento/producción socio-históricas y/o culturales.

\section{La relación "fidelidad/no fidelidad", ¿criterio rector de las investigaciones?}

Durante muchos años el cuadro de los estudios que nos ocupan, estuvo dominado por la Fidelity Criticism, corriente que, para cumplir con su objetivo fundamental -consistente en justipreciar la factura de la transposición en relación con la del texto que traslada- erigió en parámetro por excelencia la relación "fidelidad/no fidelidad".

Ahora bien, la idea de que el texto de partida posee más valor que el de llegada, que es, como se sabe, el supuesto que la relación implica, halla base de sustentación en un conjunto de argumentos. Algunos remiten a una norma que, aunque en ocasiones ha operado aisladamente, con mayor frecuencia lo ha hecho de consuno con otra. El postulado al que aludimos en primer lugar es ese resabio de cierta lectura devaluadora de la visión que el post-romanticismo (Hutcheon 2006) supo imponer al arte: el "culto a la originalidad", según el cual se aprecian más las obras que, para decirlo según los cánones actuales, no "delatan" sus lazos con producciones anteriores, que las que -como es el caso de las transposiciones- revelan derivar de discursos previos. El postulado al que hicimos referencia en segundo lugar es la tendencia a no juzgar equitativamente las cualidades estéticas y comunicativas de la literatura y del cine, lo que, en definitiva, implica apreciar más las propiedades de aquella que la de ésta, y ello en función de la importancia que se les otorga a las características que se le asignan a uno y otro arte/ lenguaje.

Para organizar el panorama de los trabajos "no semióticos" y semióticos centrados en el pasaje de los textos literarios al cine, tomamos la relación como criterio de clasificación de sus respectivos posicionamientos. Así distinguimos las obras que adhieren a ella a secas ("fidelidad a la letra"); las que adhieren a ella, relativizándola ("fidelidad al espíritu") y aquellas que no adhieren a la relación o que se muestran "indiferentes" respecto a ella. 


\subsection{Textos que adhieren a la relación "fidelidad/no fidelidad" sin "reservas" ("fidelidad a la letra")}

Estos trabajos, por lo general, centrados en casos, y mucho más opinativos que analíticos, se ubican frente a las transposiciones como si hubiera equivalencias o correspondencias absolutas entre artes y/o lenguajes. Pero, dado que tales equivalencias no existen, y porque su meta suele ser la de realizar un juicio sobre el modo en que se efectiviza el pasaje, suelen coincidir en que la mejor transposición es la "más" fiel al "original". Como la afirmación deja entrever, los textos que engrosan las filas del grupo buscan evaluar las diferencias en términos de pérdidas y ganancias; decimos "buscan" aunque el vocablo que les corresponde en verdad es el de "parecen", pues, por un lado se atienen a la idea -que experimentan como axioma-, de que existen jerarquías entre las artes, $y$, de acuerdo con ellas, la literatura es ontológicamente más valiosa que el cine; y por otra, porque, en tanto para ellos rige de manera fuerte la premisa de la "originalidad", invariablemente, goza de mayor estima la obra de partida que la de llegada. No nos detenemos en la presentación de algunos de estos trabajos por dos motivos: porque, según nuestro punto de vista, resultan irrelevantes, y porque no hay exponentes que respondan a ninguna vertiente semiótica.

\subsection{Textos que adhieren a la relación "fidelidad/no fidelidad", relativizándola}

Hay autores que, ante la evidencia de que no existen equivalencias absolutas, apuestan a que la relación continúe manteniendo su poder aun a costa de sufrir alguna mutación en el modo de concebirla; así, se inclinan por lo que denominan "fidelidad al espíritu".

Coincidiendo con los desarrollos de ciertas corrientes traductológicas y de determinadas posturas estéticas, algunos teóricos y críticos cinematográficos admiten que entre las lenguas y el lenguaje cinematográfico pueden hallarse equivalencias "relativas"/parciales. De ahí que la noción de "fidelidad al espíritu" se sustente en el reconocimiento de la capacidad de los lenguajes (y de los traductores y directores) para proponer correspondencias capaces de suscitar en los espectadores de los textos de llegada los "mismos" efectos que los textos literarios de partida permiten generar en los lectores. Así, la noción viene a garantizar la naturaleza artística del texto transpositor $-y$, consiguientemente, la de quienes cumplen la función de llevarlo a la pantalla-, al tiempo que queda a resguardo el sentido que, se presume, el hipotexto comporta.

Algunos de los párrafos en que André Bazin (Bazin1990) reivindica al cine como arte impuro dan fe del peligro que acecha al empleo de la noción, el de plantear una descripción a la que superar una visión impresionista dominada por una exacerbada subjetividad le resulta, si no imposible, muy difícil. Como ejemplo, podemos recordar que, para Bazin, los pretéritos indefinidos de André 
Gide (1919) hallan equivalente, en la Symphonia Pastorale de Delannoy (1946), en "la nieve siempre presente, cargada de un simbolismo sutil y polivalente que modifica insidiosamente la acción" (Bazin 1990: 116).

Cabe agregar que, para este teórico, lo que importa es la equivalencia en el significado de las formas ${ }^{4}$ (Bazin, 2000: 20).

La convicción de que "no hay 'sinonimia' entre sistemas semióticos", lo que hace que en el universo de los sistemas de signos toda posibilidad de redundancia quede descartada, (Benveniste 1985: 56), llevó también a otros estudiosos, que adscriben a una perspectiva semiótica y que no aceptan la idea de la fidelidad al espíritu, a prestar atención a la problemática de la "equivalencia entre signos". Tal el caso de Oscar Traversa, quien entiende que atender a esta problemática posibilitaría describir y explicar, además de algunas de las modificaciones que se dan en los pasajes que comportan cambios de materias significantes, también sus semejanzas. En función de ello considera útil recordar algunos de los conceptos vertidos por Benveniste en "Semiología de la lengua" (Benveniste 1985). Lo que Traversa rescata de las argumentaciones de Benveniste, es el haber advertido que "la transposición, como fenómeno de circulación discursiva conlleva un aspecto de ISOMORFIZACIÓN, de 'equivalencias' directas, pero al mismo tiempo otro, que comporta, en el mismo movimiento, desvíos y diferencias" (Traversa 2014: 108-109). En esa articulación de semejanzas y transformaciones que define a toda transposición, el estudio de las equivalencias está llamado a ocupar, según Traversa, un espacio con peso específico. Y esto porque entiende que, aunque la noción de "equivalente tal cual [la] pensaba Benveniste no designa por el momento más que un enigma, cuando nos hallamos frente a textos cuyas materias significantes no guardan homogeneidad (Traversa 2014: 109-110), las transformaciones sólo son pasibles de captarse "a partir de tener claro cómo funcionan las correspondencias".

\subsection{Textos que no adhieren a la relación "fidelidad/no fidelidad"}

Así como en algunos trabajos que quedan incluidos en el grupo anterior, en los que integran éste se considera que literatura y cine son artes/lenguajes autónomos que poseen especificidad. Por lo tanto, sus autores, en su inmensa mayoría, no buscan equivalencias -lo que no impide que muchos de ellos valoren los productos literarios por sobre los cinematográficos ya sea en términos de lenguaje (ver más adelante, Bluestone), ya sea en términos de objetos textuales "originales" versus objetos textuales "derivados".

Este rápido recorrido no puede ignorar los aportes de los formalistas rusos y, particularmente, de Mijail Eijembaum, quien dedica varios artículos al tema, haciéndolo desde una postura disruptiva para la época.

${ }^{4}$ El subrayado tipográfico pertenece al texto citado. Cabe agregar que todos los subrayados tipográficos que aparecen en las citas que se hallan en la ponencia corresponden a los originales. 
Tampoco puede dejar de lado a Georges Bluestone, autor que en Novels into Fims -obra a la que se considera que inaugura los estudios anglosajones académicos sobre el tema-, no concede validez al criterio de "fidelidad/ no fidelidad", ya que proclama la inevitabilidad de los cambios y sostiene que "las libertades" que el cineasta se tome respecto de la obra literaria que transpone no tienen por qué afectar negativamente al film. Es que Bluestone parte de la idea de que literatura y cine son dos lenguajes tan diferentes como lo son el del ballet y el de la arquitectura y esto debido a que el primero es conceptual y discursivo y pone en juego el percepto de la imagen mental; y el segundo es perceptual y presentacional y pone en juego el percepto de la imagen visual (Bluestone 1957: 5).

No obstante, su propuesta, por continuar aferrada al juicio de valor, termina por exaltar la literatura y subestimar el cine. Tal conclusión se fundamenta en las siguientes aserciones:

"ya que su historia es larga y sus materiales más refinados, la novela es más compleja" (Bluestone 1957: 7);

- debido al "precepto de la imagen visual", el film tiene dificultades para presentar estados mentales, recuerdos, pensamientos, sueños (Bluestone 1957: 47-48);

- la novela posee tres tiempos: la duración cronológica de la lectura, la duración cronológica del tiempo del narrador y la cronología de los eventos narrativos; el film posee solo uno: se despliega en un presente perpetuo (Bluestone 1957: 49).

Ahora bien, entre las voces que también pregonan la inevitabilidad de los cambios se encuentran las de los narratólogos y autores que participan de las corrientes semióticas que reciben los aportes de la Teoría de la enunciación. Las contribuciones que estas corrientes y las de la narratología modal realizaron a los estudios sobre transposición fueron capitales, pues a una perspectiva marcadamente contenidista, centrada en los componentes de la historia y la estructura narrativa, le contrapusieron otra que atiende a los mecanismos que dinamizan discursivamente tal historia.

Un estudioso que propone una aproximación narratológica es Brian McFarlane, quien se propone determinar qué puede trasladarse sin cambios y qué exige modificaciones. Para desarrollar su propuesta, se basa en el "nivel de las funciones" establecido por Roland Barthes. Al respecto, diferencia lo que denomina "transferencia" de lo que llama "adaptación". Emplea el primer término para "denotar el proceso por el que determinados elementos narrativos de la novela" pueden presentarse en el film, y el de "adaptación" para aludir "al proceso por el que otros elementos de la novela deben encontrar equivalentes bastantes diferentes en el medio fílmico" (McFarlane, 1996:13). La transferencia se pone en juego con las funciones cardinales y, en parte, con las catalíticas -ya 
que ni unas ni otras están "sujet[a]s a un sistema semiótico determinado"-; mientras que los indicios pueden ser parcialmente transferibles; "el aparato expresivo que gobierna la presentación y recepción de la narrativa", o sea, lo que el autor identifica como enunciación, "involucra procesos complejos de adaptación a causa de que sus efectos se hallan (...) subordinados al sistema semiótico en el que se manifiesta" (McFarlane, 1993: 30).

El autor propone una línea de investigación que corresponde específicamente al análisis de una transposición concreta, y que pone el acento en el funcionamiento de los factores que, además del texto de partida, "han ejercido una influencia sobre (...) [su] versión fílmica". Por eso, aunque su trabajo manifiesta características que lo entroncan con la Semiótica de Primera Generación, también adscribe, en grado menor, a los principios de la Semiótica de Segunda generación.

Apoyándose en indagaciones previas procedentes de la teoría comparatista de las artes y los lenguajes (en este campo, especialmente en las investigaciones semiológicas), compara el signo verbal con los signos cinematográficos. El primero se caracteriza por su baja iconicidad y su alto grado de función simbólica, lo que le permite operar conceptualmente; los segundos, en cambio, se definen por su alta iconicidad y su escasa dosis de función simbólica, lo que hace que operen sensorialmente.

Por su parte, tomar en cuenta la enunciación, esa dimensión constitutiva de todo objeto textual, le posibilita a Gianfranco Bettetini señalar que "cuando se 'traduce' una novela en una película o en un escenario televisivo se construye, incluso involuntariamente, una nueva estrategia comunicativa, subordinada a circunstancias de consumo completamente distintas (físicamente, fisiológicamente, perceptivamente, psíquicamente, socialmente, antropológicamente) de las características de la primera manifestación del discurso". (Bettetini 1984: 83).

Desde una perspectiva que -como la de Bettetini y, en mínima parte, la de McFarlane-, debe catalogarse de discursiva, Francesco Casetti estima que la literatura y el cine "pueden considerarse como espacios de producción y circulación de discursos, esto es, como construcciones simbólicas que refieren a un conjunto de significados que una sociedad considera posibles (pensables) y factibles (legítimos)" (Casetti 2006: 82). El autor, sugiere examinar los textos audiovisuales y literarios desde un punto de vista foucaultiano, es decir, como "formaciones discursivas". Así, propone considerar la transposición como "reaparición en otro campo discursivo de un elemento (una trama, un tema, un personaje, etc.) que previamente apareció en otro lugar" (Casetti 2006: 82).

Para Casetti, "la adaptación es, ante todo, un fenómeno de recontextualización del texto o, mejor aún, de reformulación de sus situaciones comunicativas. (Casetti 2006: 83). 
Asimismo, señala la existencia de un paquete de factores que junto con el texto, garantizan la interacción comunicativa (el marco interaccional): un conjunto de reglas institucionales y de formas (marco institucional), una serie de discursos previos (marco intertextual) y un cúmulo de experiencias personales y colectivas que ofician como referencia" (marco existencial). (Casetti 2006: 84).

Dentro de las aproximaciones que reivindican el carácter intertextual y que, por ende, sostienen que la originalidad no existe, se encuentra Teoría de la adaptación, de Linda Hutcheon, quien piensa la transposición como "una forma de repetición sin copia, un trabajo que es segundo sin ser secundario [y] que cuenta con su propio espesor palimpséstico" (Hutcheon, 2006: 7, 9). Según la autora, todo fenómeno transpositivo puede describirse: a) "como entidad formal o producto (desde este punto de vista es una transposición anunciada (...) de una o varias obras)" (Hutcheon, 2006: 7); (b) "como proceso de creación [que] involucra un acto de apropiación/ salvataje creativo e interpretativo y (c) como cita intertextual que amplía la obra que adapta (Hutcheon, 2006: 8).

Si Hutcheon circunscribe como una de las metas a lograr por su trabajo, el "insistente descrédito crítico que (...) [la transposición] ha sufrido en todas sus encarnaciones mediáticas" (Hutcheon, 2006: XII), los trabajos que Robert Stam dedica al tema, hacen foco en el criterio de "fidelidad/no fidelidad" para, con sólidos argumentos, mostrar su falta de legitimidad. Una de las razones consiste en negar el presupuesto de que "una novela contiene una esencia extraíble, una suerte de corazón de alcaucil oculto debajo de los detalles de la superficie del estilo" (Stam, 2000: 57) que puede transferirse. Es que la postura de Stam se encuadra dentro de la perspectiva intertextual de un modo tan categórico -o más- que la de Hutcheon. Para él, "el texto literario (...) es (...) una estructura abierta (o mejor, una estructuración, como el último Barthes lo consignó) para ser re-trabajada en un contexto que no conoce límites. El texto alimenta a y es alimentado por un intertexto en infinita transformación, que se observa a través de redes de interpretación en constante modificación (Stam, 2000: 57).

Como puede observarse en la cita precedente, Stam remite a los planteos que Barthes despliega, entre otros textos, en "La muerte del autor" $y$ "De la obra al texto"; pero, además de ellos se encuentran ecos kristeveanos, derrideanos, $y$, por supuesto, bajtinianos, los que se perciben nítidamente cuando, por ejemplo, afirma que "el concepto de dialogismo intertextual propone que cada texto forma una intersección de superficies textuales. Todos los textos están tejidos con fórmulas anónimas, variaciones sobre esas fórmulas, citas conscientes e inconscientes y refundiciones e inversiones de otros textos" (Stam, 2000: 64).

Ahora bien, esta concepción no sólo corresponde al texto que, respecto de un proceso de traslado a otro medio o lenguaje, opera como hipotexto; en efecto, para Stam, una transposición "es menos un intento de resucitar una palabra originaria que una instancia en un proceso dialógico incesante" (Stam, 
2005: 20).

Este recorrido sobre las formas en que la transposición de la literatura al cine se ha conceptualizado, no puede omitir mencionar la revolución copernicana ${ }^{5}$ que se instaura cuando el foco de atención pasa del polo del primer término de la relación "texto de partida/ texto de llegada", al del segundo.

Al respecto, y en paralelo con el emplazamiento de ciertas corrientes de orientación pragmática en la semiótica y en las teorías cinematográficas, surgen en traductología algunas líneas de investigación que observan la traducción interlingüística desde la instancia meta. Se trata de las que se enmarcan en la llamada Teoría de los Polistemas, la que, a través de uno de sus referentes, Gideon Toury, extendió teóricamente su mirada hacia los objetos que nos ocupan, y encontró en la teoría de la AF (adaptación fílmica) de Patrick Cattrysse a su más calificado seguidor en el campo.

Para la teoría de Cattrysse, los cambios y permanencias se explican a partir de las normas, "principio[s] energético[s] que determina[n] la práctica literaria o fílmica de una manera no idiosincrásica, es decir, intersubjetiva o general" (Cattrysse, 1992: 25) que se organizan en modelos -"práctica (o conjunto de prácticas) $\times$ (...) [que operan en tanto] modelo con respecto a una práctica (o conjunto de prácticas y" (Cattrysse, 1992: 27); a su vez, los modelos forman sistemas abiertos, esto es, sistemas en los que no todos sus integrantes son sistemáticos, cualidad que define, en términos diacrónicos, su naturaleza dinámica. Tales sistemas se organizan jerárquicamente dando lugar, por ende, a polisistemas, que, asimismo, "mantienen relaciones laterales con otros (...) [polisistemas] (socioculturales, económicos, políticos, contextuales) con los que establecen interpenetraciones y determinaciones mutuas" (Cattrysse, 1992: 28, 29).

Siendo un estudio "target oriented", la propuesta de Cattrysse aborda la transposición como texto terminado; esto le permite mantener la noción de equivalencia, pero despojándola de su carácter normativo; si, como propone, ella deviene en categoría descriptiva (Cattrysse, 1992: 38) es porque deja de definirse "en función de relaciones preestablecidas de fidelidad y de analogía [respecto del] texto de origen", ya que se da por presupuesta. De ahí que la pregunta acerca de si hay o no equivalencia, se suplanta por la que inquiere sobre el modo en el que la misma "se realizó en un corpus de adaptaciones fílmicas" (Cattrysse, 1992: 38).

No podemos dejar de referirnos a Oscar Steimberg, quien, como Traversa, no se maneja con el criterio de fidelidad/no fidelidad y adopta una posición descriptiva y no evaluativa. De este investigador resaltamos su postura amplia ante la transposición, o sea, no la limita al pasaje de la literatura al cine, lo que le

\footnotetext{
${ }^{5}$ Muchos de los conceptos previamente vertidos implican el desplazamiento al que aquí estamos haciendo referencia puntual.
} 
posibilita adoptar una perspectiva metateórica, capaz de advertir -y considerar críticamente- la "existencia implícita de una jerarquía global, en la calificación de las lecturas sociales" (Steimberg, 1993: 109).

\section{El tratamiento semiótico de cuestiones conexas con la problemática de la transposición}

Los trabajos semióticos hasta aquí reseñados se inscriben dentro de lo que en el desarrollo de la disciplina constituye la Semiótica de Segunda generación ${ }^{6}$; en el período inicial (1960-73/75) no hay estudios centrados en la temática. Esto, como se sabe, se debe a que el interés básico pasa por identificar Sistemas, Códigos; Niveles y unidades. En el territorio de la Semiología del cine, como también se sabe, la figura que se destaca es Christian Metz. En sus primeros textos y a partir de la teoría hjelmsleviana, toca aspectos que hacen a la discusión "clásica" de la estética sobre las relaciones entre las artes y los lenguajes, cuya comparación involucra la identificación de equivalencias/correspondencia entre las mismas. Así, se refiere a las "interferencias semiológicas entre lenguajes"; al respecto, identifica: a) la interferencia localizada; b) la interferencia códica sin transposición sensorial, "caso (...) donde se puede hablar con todo rigor de un único y mismo código manifestado en varias artes o lenguajes (... caso de ciertos sistemas de claroscuro de la pintura pasados a la fotografía en color); y c) la interferencia códica acompañada de transposición sensorial..." Ésta implica "códigos diferentes o ampliamente isomorfos, cada uno de los cuales se manifiesta en un lenguaje diferente" (Metz, 1973: 262 y263).

\section{Conclusión provisoria}

La relación "fidelidad/no fidelidad" sufre un duro golpe cuando las investigaciones empiezan a centrarse en el texto de llegada y en la cultura meta. El viraje permite que los cambios que se efectivizan en el pasaje no se visualicen en términos de pérdidas y ganancias, ni que se expliquen sólo por las particularidades que distinguen a los lenguajes implicados, sino, además, por la incidencia que ejercen factores del contexto meta.

\section{Bibliografía}

BARTHES, Roland. 1987. La muerte del autor. Y De la obra al texto. En El susurro del lenguaje. Más allá de la palabra y la escritura, Barcelona: Paidós Comunicación.

BENVENISTE, Émile. 1985. Semiología de la lengua. En Problemas de lingüística general, Tomo II, México: Siglo XXI.

\footnotetext{
${ }^{6}$ Excepto los de McFarlane que se presenta en la encrucijada entre la Semiótica de Primera generación y la Semiótica de Segunda generación
} 
BAZIN, André. 1990. ¿Qué es el cine? Madrid, Ediciones Rialp.

BETTETINI, Gianfranco. 1984. Las transformaciones del sujeto en la traducción. En La conversación audiovisual Problemas de la enunciación fílmica y televisiva", Madrid: Cátedra.

BLUESTONE, George. 1057. Novels into Film The metamorphosis of fiction into cinema. Los Angeles, The Johns Hopkins Press: Maryland

CATTRYSSE, Patrick. 1992. Pour une theorie de l'adaptation filmique. Le film noir américain, Berna: Peter Lang.

EIJEMBAUM, Mijail. 1998. Literatura y cine. En François Albèra (comp.), Los formalistas rusos y el cine La poética del filme, 197-202, Barcelona: Paidós.

GENETTE, Gerard. 1962. Palimpsestos La literatura en segundo grado, Madrid: Taurus.

HUTCHEON, Linda. 2006. A Theory of Adaptation, Nueva York-Londres: Routledge.

MCFARLANE, Brian. 2004 [1996]). Background, Issues and a New Agenda. En Novel to Film. An Introducciton to the Theory of Adaptation, New York: Oxford University Press.

METZ, Christian. 1973. X2 Interferencias semiológicas entre lenguas. En Lenguaje y cine, Barcelona: Planeta.

STAM, Robert. 2000. Más allá de la fidelidad: la dialógica de la adaptación. En James Naremore, James (ed), Film adaptation, Nueva Jersey: Rutgers The State University.

STAM, Robert. 2005. Introduction: The Theory and Practice of Adaptation. En Robert Stam and Alexandra Raengo (eds), Literature and Film A guide to the Theory and Practice of Film Adaptation, USA, UK, Australia: Blackwell Publishing

STEIMBERG, Oscar. 1993. El pasaje de los medios a los géneros populares. En Semiótica de los medios masivos, Buenos Aires: Atuel.

TRAVERSA, Oscar. 2014. Carmen, la de las transposiciones. En Inflexiones del discurso. Cambios y rupturas en las trayectorias del sentido, Buenos Aires: Santiago Arcos editor/ SEMA.

WOLF, Sergio. 2001. Cine/literatura Ritos de pasaje, Buenos Aires: Paidós. 


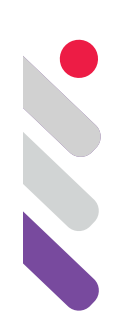

\title{
Inducción fílmico-literaria de viajes y transposición(es)
}

DOI: 10.24308/IASS-2019-4-003

\author{
María Silvina Tatavitto \\ IIEAC (Instituto de Investigación y Experimentación \\ en Arte y Crítica) UNA (Universidad Nacional \\ de las Artes), Argentina \\ silvintata@yahoo.com.ar
}

\section{Introducción}

Este trabajo examina procesos de circulación discursiva en las visitas a sitios asociados con narraciones literarias y cinematográficas, entendidas como formas móviles de fruición, en un encuadre semiótico, articulado con las orientaciones al estudio de la dimensión significante de la movilidad (Salazar, 2013; Creswell, 2010). Contrastaré dos variedades: una es el relato PraghaAusterliz/Europa mater (Lukin, 2018), testimonio de una forma móvil de consumo de la novela Austerliz de Sebald, transpuesta al espacio urbano; la otra en torno a San Antonio de Areco y al circuito Los caminos de Moreira ${ }^{1}$, lugares bonaerenses asociadas a la novela de Güiraldes y el folletín de Gutierrez respectivamente, que se tornan visitables al conectar con una narratividad, cuya amplia circulación migra de su inicial asentamiento en papel, hacia distintos soportes (los de la prensa, la radio, el teatro y el cine) para emplazarse en territorios en un tránsito que atraviesa campos de desempeño semiótico heterogéneos (turístico, económico, artístico, político).

\section{La partida}

El viaje de bodas de Menéndez Pidal replica la ruta del Cid Campeador en su destierro (Moreno, 2012). Tennyson va a Lyme Regis porque allí sucede un episodio de Persuasión (Busby, et al. 2003). Giras por las locaciones de Lord of the rings (Tzanelli, 2004). Visitas a la casa de Victoria Ocampo en Beccar (Tatavitto, 2019). Esta enumeración deliberadamente heteróclita indica la prolongada existencia de un placer que, despegado de papel y pantallas,

${ }^{1}$ Lanzado en el 2014 recorre las localidades de Cañuelas, Roque Pérez, Lobos, Marcos Paz, Navarro, General Las Heras y Monte 
transita por lugares literaria y fílmicamente marcados (Onfray, 2016; Connell, 2012). Se inscribe en un deleite más general ya que los lenguajes del arte suelen incidir (Reijnders, et al. 2015), hecho frecuencia testimoniado por la prensa, que informa sobre proliferación de episodios de una tendencia de alcance mundial (Saretzki, 2013).

Mirar, interpretar, fruir destinos tematizados en tramas novelescas y cinematográficas va configurando discursivamente territorios donde literatura y cine aparecen bajo la forma de trayectos. Sigo acá la adjudicación de carácter textual a desplazamientos y recorridos en estudios de movilidad de Verón (1999, 2013) sobre librerías, exposiciones y subterráneos, este último objeto también examinado desde enfoques greimasianos (Floch, 1993).

\section{Arte y viaje: fruición móvil de la literatura y el cine}

A contracorriente del hábito más instalado de cruzar las variables arte y viaje que concibe el viaje como pretexto de un texto, su origen o tema de una trama, entiendo, por el contrario, que son los textos quienes traman el viaje. Propongo concebir este fenómeno como una forma móvil de consumo fílmicoliterario, porque deambula por el espacio y se plasma en variados trayectostexto por geografías y territorios representados en una novela o en una película, promoviendo inusuales mixturas entre lo ficcional y lo factual.

Tales recorridos implican un acto interpretativo singular de apropiación de la obra de arte que se materializa en itinerarios del cuerpo por el espacio, en el régimen semiótico del viaje (MacCannell, [1999] 2003). El denominado peregrinaje literario - el actual y el del siglo XIX - o ciertas modalidades del fandom y fan art son episodios circunscriptos del horizonte más general de fruiciones móviles: comparten el estatuto de apropiación interpretativa dinámica.

Así, el relato cinematográfico y literario mueve a viajar. Actúa con antelación al efectivo contacto con un lugar y define un régimen doble: el visual y el performático. Urry ([1990] 2002: 3) desarrolla el régimen visual al indicar cómo la mirada ${ }^{2}$ está pre-construida en relación con lo que desea visitar por fuerza de la mediatización ya que:

los lugares son elegidos para ser mirados porque, especialmente a través de la ensoñación y la fantasía, hay una anticipación de intenso placer (...) Dicha anticipación se construye y sostiene a través de una variedad de prácticas no turísticas, como el cine, la televisión, la literatura, revistas, discos y videos, que construyen y refuerzan esa mirada.

\footnotetext{
${ }^{2}$ Vale aclarar que la mirada turística no ancla en las motivaciones individuales para viajar, sino en su construcción social a partir un proceso semiótico de mediatización (Urry, 2002: 3 y 145).
} 
Tal anticipación prescribe qué ver o dejar de ver. Es la génesis del recorrido (textual y performático) de Pragha-Austerlitz / Europa Mater (Lukin, 2018:1) que retrata ese momento previo de fantasía cuando:

el deseo de unas ciudades, sí, de unas construcciones, de una arquitectura, de unos paisajes urbanos contaminados ya por el flujo de imágenes que los registran y hemos visto y leído (fotos, viajes anteriores, atlas, escenarios de vidas, films), el placer de ir en busca de algo ya conocido, para conocerlo 'en verdad', ordena y discierne el itinerario inicial de un viaje.

Esa mirada contaminada, entre otros factores, por el cine y la literatura se prolonga a posteriori, cuando ya en viaje, la topografía transitada se torna texto espacializado que deja leer los signos del arte en:

la alternancia de altura en los tejados y torres, recortan sus ya clásicos contornos góticos (que en la infancia creíamos propiedad de la fantasía de Walt Disney, y más tarde consumimos en toda clase de oscuras escenografías futuristas, copiadas para Batman y llevados al éxtasis por dibujantes de historietas postmodernas ${ }^{3}$ ). (Lukin, 2018:4).

Al calor de la forja artística los sitios se tornan significativos. El viaje imaginario previo al efectivo, cargado de expectativas derivadas del mundo del arte, por una parte, legibiliza lugares y, por la otra, genera, cuando arriba al lugar, un circuito performativo de desplazamiento, según atestigua el narrador de Pragha/Austerliz que:

llevaba, atesoraba para mi goce, las páginas fotocopiadas y abrochadas de la novela Austerlitz, de W.G. Sebald (...) En 2008, como un ritual, haré por él ese camino: seguiré los pasos del personaje Austerlitz, con ese fragmento del texto en la mano, y veré de encontrar lo que él encuentra en la novela (Lukin, 2018:34).

En definitiva, el itinerario en el destino no es más que la reescritura corporalizada y móvil de la narración en papel, de un disfrute que vuelve a activarse ya que "mientras fotografiamos cada puerta, leemos en voz alta" (Lukin, 2018: 6). Y esa escritura performática, en verdad, da cuentas de una re-lectura móvil que persiste en paladear las peripecias del relato de Sebald en el soporte, esta vez, de calles y fachadas. Esa caminata en voz alta es una lectoescritura móvil que desarrolla la narrativa en el tiempo-espacio contribuyendo a la expansión imaginativa del mundo novelado. El narrador - páginas en mano, lectura en voz alta - textualiza el espacio urbano, lo coproduce a medida que, con su hijo, "descifran en el plano de la ciudad las calles nombradas en la novela"

\footnotetext{
3 Énfasis mío.
} 
(Lukin, 2018: 6). Una particular lecto-peregrinación-escritura en compañía del propio Jacques Austerliz:

2

Seguimos al pie de la letra, y avanzamos cada línea con él, eufóricos al encontrar las placas con el nombre de las calles, como si el hecho de que el escritor fuera fiel a la geografía de la ciudad, hiciera de nuestra Praga una ciudad más maravillosa ${ }^{4}$. Y al dar una vuelta más, estamos ya en la calle Sporkova 12. Nos detenemos, fascinados, es aquí, aquí está, decimos y leemos en voz alta (Lukin, 2018:7).

Se configura un apasionado tránsito que no es sólo representación, sino un guion actualizado y actuado en el sitio narrativamente marcado. Cada lugar afanosamente descubierto constituye un marcador sígnico de es aquí: operación indicial del orden de contigüidad con lo existente. De allí su interpretación como evidencia que estimula vívidamente el mundo novelado. Tanto, que su protagonista se une al narrador de Pragha/Austerliz en su lectura móvil y el avanzar juntos cada línea manifiesta un fenómeno de presentificación, por así decir, no ajeno a lugares literariamente marcados (Herbert, 2001). Cada sitio se torna en un operador indicial de la vida de Jaques Austerilz con fuerte carga de realidad, por efecto de esa contigüidad existencial entre la lectura móvil y la ciudad como texto. Los indicadores (el entusiasta "es aquí/ aquí está") contribuyen a dar carnadura a lo que hay en la imaginación.

Nótese el carácter híbrido de este tipo de apropiación, simultáneamente engendrada en el mundo de la imaginación y el material, e involucra dos momentos diferenciados y una corporalidad asimismo mixta: la inicial construcción del cuerpo como mirada es requisito para la posterior puesta en marcha del cuerpo en tanto trayecto por el espacio. Es la mirada contaminada por el cine y la literatura la que funda un espacio como signo indicial, ese signo de existencia que marca una vista dispuesta para el deleite (MacCannell, 2003).

Sin embargo, reitero que este caso o el fandom y fan art no colman el fenómeno: conviven con otras fruiciones, cuyos desplazamientos - lo desarrollo más adelante- no se asocian exclusivamente al consumo de un texto particular o estilo autoral (cinematográfico o literario). No obstante, traer a colación Pragha/Austerliz permite clarificar ese lapso previo de constitución del goce y la mirada y del transcurso gozoso por esos paisajes narrativamente viciados. Tránsito donde se desenvuelve la apropiación dinámica de novelas o films, ese deleite textualizado espacial y corporalmente cuyo, por así decir, output, no siempre ni necesariamente se cursa a través de los géneros de la escritura y los protocolos de la literatura de viaje o de los géneros cinematográficos (e.g. road movies) ¿Qué ocurre con él, que se obstina en el régimen indicial, en los desplazamientos del cuerpo en viaje por el espacio? Porque ese entresijo

\footnotetext{
${ }^{4}$ Énfasis mío.
} 
es vivero de una muy diversificada delectación móvil de narraciones fílmicoliterarias, que se expande ubicua por todo el orbe, si hemos de creer a la multitudinaria oferta de viajes y visitas que distintos países intentan capitalizar comercialmente.

\section{El movimiento invisible}

Desterradas de los análisis al uso sobre la fruición artística, estas prácticas interpretativas móviles han sido recogidas por la geografía cultural y humana para examinar su incidencia en la producción de espacios (Weston, 2016). Atraen, además, el interés de estudios diversamente involucrados en el mobility turn, en su designio de dar cuenta de las movilidades contemporáneas y, asimismo, de la sociología del turismo (Mc Laughlin, 2016). Admiten abordajes performativos, dado que tours de esta clase pueden promover escenificación de partes de novela o películas en el territorio donde fueron ubicadas o bien filmadas (Siripis, et al. 2016).-

Comparativamente con el formato más tradicional del viaje literario datado en el XVIII, aunque puede remontarse al mundo grecolatino (Gentile. y Brown, 2015) - la variante fílmica exhibe la inestabilidad nominativa propia de su conceptualización todavía en curso: film induced tourism, movie induced tourism, film tourism, cinematic tourism, screen tourism, ciné-tourism, media tourism, media pilgrimage. Todas ellas tienen el problema de omitir la dimensión literaria del fenómeno: la circulación de la letra a la pantalla es mayoritariamente achatada o simplificada través de la figura de precursor o antecedente (Kim y Reijnders, 2018; Connell, 2012; Herbert y Watkins, 2003). Un caso que ejemplifica el conjunto: se considera turismo literario la visita asociada a novelas de Austen donde se producen representaciones de escenas de versiones fílmicas de sus textos (Tatavitto, 2016).

Entiendo que la transposición (Steimberg, 1993) aportaría aquí al cumplimiento de la tarea programática de las teorías no reduccionistas de la movilidad de abarcar también sus facetas performativa y simbólica (Creswell, 2010). Permite develar cómo ese plano significante o simbólico es, asimismo, complejo ya que compromete al menos tránsitos mediáticos (papel, pantalla) y performáticos con soporte en el cuerpo, en otros términos, una doble movilidad. Esta particular circulación, sólo resulta visible a la luz de este concepto por cuanto permite desenredar la maraña de trayectos de otro modo invisibilizados, ya que la mayoría de los destinos encuadrados en el film tourism en la bibliografía internacional son fílmico-literarios: Drácula, el Señor de los Anillos, las obras de Jane Austen, de las Brönte, del agente 007 y las de Agatha Cristhie, por ejemplo.

En nuestro país, San Antonio de Areco y Los caminos de Moreira son lugares receptores de flujos de visita porque han sido construidos como dignos 
de ser fruidos por obra de una compleja circulación con migraciones desde el papel, al teatro circense, la radio (en el caso del folletín de Gutiérrez), a la pantalla cinematográfica para recalar en el territorio bonaerense, cuando las políticas locales turísticas a cargo de colectivos públicos y privados lo siembran textualmente con marcadores indiciales de ese mundo ficcional, inspirado, por lo demás, en hechos factuales: el del prontuario policial, en el caso de Gutiérrez, y el resero ${ }^{5}$ en el que al parecer se basó Güiraldes. Se trata, así, de una complejísima semiosis donde la circulación, además de los pasajes mediáticas mencionados, promueve operaciones de reconstrucción histórica (orden museístico y de divulgación de la ciencia), con vocabulario costumbrista (dominio artístico), con el que el que una geografía (dimensión político-territorial) se ofrece como oportunidad para el ejercicio de una fruición, en gran medida modelada por la fuerza de las narrativas ficcionales, que incrementa el flujo turístico (orden económico-industrial), a los efectos de significar una identidad socio-cultural (plano ideológico).

\section{Tierras de transposición y transgénero}

La preconstrucción de la mirada en torno a Los caminos de Moreira y Areco reenvía a productos literarios y fílmicos puntuales, es decir, la sustancia temática o peripecia propias de unos determinados personajes que perduran en sus migraciones intermedios (papel, teatro, radio, pantallas). Sin embargo, su peculiaridad radica en movilizar, además, remisiones a la gauchesca que, en su condición transgenérica, más allá de su inicial asentamiento literario, involucra entidades, sucesos y prácticas diversificadas y activamente promovidos en el intento de definir un régimen de visibilidad que habilite en esos destinos bonaerenses el goce de pulperías, artesanías, orfebrería, gastronomía y habilidades criollas (jineteadas, por caso).

Los distintos soportes, medios y vías de comunicación oficiales o privados, individuales o colectivos dirigen la mirada hacia la posibilidad de disfrutar distintos tipos de sitios. Por una parte, los referidos en los textos ficcionales (pulpería La blanqueada en Areco o el muro donde matan a Moreira), los de asociación factual con esos relatos pero no mencionados en ellos (e.g. la estancia donde Güiraldes escribió la novela) o hacia locaciones de las versiones cinematográficas de Antín y Fabio, casos de on location según clasificación al uso en los estudios de film tourism (Beeton, 2005). Por el otro, la mirada modelizada por la gauchesca - de la que ambos textos, a su vez, participan - produce un marcaje simbólico que se expande por zonas sin conexión directa con dichos relatos. Situación que registran los análisis de viajes fílmico-literario cuando los relatos invisten de significaciones identitarias, al intervenir en la representación

${ }^{5}$ Segundo Ramírez habría sido fuente de inspiración del personaje de Güiraldes (Bordelois, 1966) 
de cuáles valores y sitios celebrar y preservar de lo que se construye como identidad (Frost, 2006; Edensor, 2005; Halewood y Hannam, 2001). Es una clase de fruición menos conectada a una obra o autor particulares, tal como las giras al distrito de los lagos en Inglaterra, menos asociadas a los poetas lakistas y más con nociones nostálgicas de englishness, ruralidad y antiguos estilos de vida (Donalson et al. 2015; Urry, 1995). La fruición en este caso representa una variedad que depende de la memoria para concretar una narrativa y, en muchos casos, hacer tangible el pasado, entendido como patrimonio que vuelve a la vida y se actualiza mediante estos contactos (Reijnders y Van Es, 2016).

El espacio textualizado por la gauchesca en tanto transgénero propone el consumo performativo, móvil que va leyendo en el territorio el relato de la ruralidad pampeana: tipos humanos, oficios, paisaje que, a su vez, reenvían a una narrativa más general, la de la constitución de una identidad nacional identificada con un cierto pasado agrario. De la peripecia particular de un gaucho matrero (Moreira) o ejemplar (Don Segundo) a la peripecia épica que cuenta los trabajos y los días del carácter nacional.

\section{Miradas y fruiciones}

El examen de Pragha/Austerliz revela cómo la novela de Sebald preconstruye la mirada y dispara una fruición móvil circunscripta en un recorrido interpretativo cuya materizalización performativa transpone al espacio urbano la trama novelesca. Pero no agota el espectro posible de otras: las que acabamos de ver no están única y exclusivamente asociadas a una trama individual, sino a un género.

El pasaje transgenérico del tipo de la gauchesca presupondría un tipo de enunciatario cuyo goce no recae únicamente en la invariancia de una configuración temático morfológica particular (Tatavitto, 2011), como en la transposición de Pragha /Austerlitz que define, según Urry (2002), una mirada romántica materializada en desplazamientos regulados pormenorizadamente por el texto espacialmente transpuesto, su re-lectura performativa.

La discursividad en torno a Areco y Los caminos de Moreira construye otro enunciatario, cuya mirada es dirigida a activar en las localidades un goce de marcadores indiciales costumbristas de la gauchesca para promover una experiencia interpretativa móvil que, en su desarrollo en el tiempo y el espacio, contribuye a la expansión imaginativa de los textos puntuales de Güiraldez y Gutierrez. Corresponde, entonces, a la mirada colectiva que fruye narrativas más ecuménicas, reprocesadas según los formatos del discurso patrimonial. La mirada romántica, en cambio, tiende a promover un tipo de goce cuasipersonal, con altos componentes de individualización, deleite de marcadores indiciales que define un recorrido interpretativo personal. 
Ambos tipos de fruiciones tienen en común la puesta en juego de recorridos hermenéuticos cuyos desplazamientos tempo-espaciales recapitulan la aventura, el descubrimiento, el encanto y emoción de historias. Pero cada una de esas apropiaciones interpretativas se testimonia diferencialmente: en un caso, según los géneros de la literatura escrita y, en el otro, según los protocolos indiciales del cuerpo explorador, uno de los principios de inscripción del cuerpo en la semiosis según Fontanille (2004).

\section{Recapitulando}

La conclusión del trabajo hasta aquí reseñado recae en tres aspectos:

\subsection{Interfase arte-viaje}

He analizado cómo los consumos móviles revierten la visión usual sobre la relación arte -viaje (el viaje como génesis del texto que lo tematiza), al ser el arte narrativo cinematográfico y literario lo que mueve a viajar. Hechos diferenciados pero no excluyentes, más bien cara y contracara de una interfase. El gusto por la narrativa de las Brönte empuja a Virginia Woof a Haworth "como quien va al encuentro de un amigo al que lleva mucho tiempo sin ver (...) tan clara era nuestra imagen de Haworth a través de libros e imágenes" (Woolf, 2001:3). La lectora se resuelve en la viajera y una serie de artículos literaturizan sus recorridos.

Este tipo de caso de fruición móvil (el más visible y estudiado) no colma la totalidad del fenómeno: el deleite de narraciones textualizado espacial y corporalmente no siempre, ni necesariamente, es registrado a posteriori a través de la literatura de viaje o de los géneros fílmicos.

\subsection{Articulación disciplinar}

A partir del examen del corpus se vislumbra el valor de las nociones de transposición y transgénero en dos direcciones.

Permiten identificar procesos de vinculación textual particulares según la discursividad puesta en juego durante la circulación, al detectar modalidades diferentes de preconstruir la mirada y la fruición. El pasaje transgenérico del tipo de la gauchesca y la transposición de un relato particular se asocian a dos clases de apropiaciones interpretativas móviles, la que corresponde a la mirada colectiva y romántica, respectivamente.

En segundo lugar, descubren formas de movilidad discursiva frecuentemente omitidas. Creo no necesario insistir más en que desembrollan la complejidad de la circulación cuando los pasajes transpositivos y transgenéricos suponen, por una parte, apropiaciones interpretativas cursadas en regímenes semióticos diversos: simbólicos e icónicos en los tránsitos mediáticos y literarios (de la letra a la pantalla), que se articulan con el indicial cuando ponen en juego 
el cuerpo y sus desplazamientos espaciales durante el viaje a lugares fílmica y literariamente marcados; por la otra, travesías por campos de desempeño semiótico diversificados (turístico, económico, artístico, político).

\subsection{Móvil-fijo y una teoría del consumo (del arte)}

La fruición móvil resuelta en trayectos se distingue de la sedentaria por los compromisos heterogéneos del cuerpo, concretamente en términos de su inscripción en la semiosis (Fontanille, 2004).

En el consumo estático prima la envoltura cenestésica (experimentación sensorial interconectada del cuerpo como superficie de inscripción del mundo circundante). En la móvil se despliega de modo más marcado el principio kinestésico, el cuerpo en movimiento que se proyecta al mundo. Además, se caracterizan por el entre-juego de dos variables. Una es la apropiación de textos narrativos ficcionales que establece diferencias de los desplazameintos asociados a otros lenguajes: la danza (el viaje tanguero Buenos Aires), la arquitectura (itinerarios de la Barcelona modernista de Gaudí) o las artes plásticas (la visita a Giverny).

El estudio de las formas de fruición sedentarias y el interés más reciente por fan-art, turismo literario e inducción fílmica del viaje corren, hasta el momento, por carriles disciplinares separados, no obstante ser capítulos particulares (móviles unos y sedentarios otros) de una teoría más general del consumo del arte, todavía en pañales y sin formalizar. La tipología precedente es un intento introducir criterios en esa dirección para señalar conexiones y diferencias dentro del horizonte común de la experiencia estética en una perspectiva semiótica o discursiva.

Si bien desde los 80 ha prosperado el interés por el consumo del arte, particularmente en el dominio de la semiótica no se han podido experimentar mayores avances por dos obstáculos: el centramiento en textos considerados como excepcionales y el inmanentismo. Las soluciones a la manera de Lector in fábula de Eco bien pueden ilustrar las tensiones entre considerar dialógicamente el arte producido en la interfaz producción-consumo y el impulso inmanentista, ya que la fruición se incorpora en el análisis sólo a condición de estar implicada dentro de los límites de la obra. En los consumos móviles, esa fruición está, por el contrario, inscripta textualmente en el espacio por un cuerpo performático, en una nueva semiosis que expande inusitadamente el mundo narrado.

\section{Referencias}

BEETON, Sue. 2005. Film-induced tourism. Clevedon: Channel View Publications.

BORDELOIS, Ivonne. 1966. Genio y figura de Ricardo Güiraldes. Buenos Aires; Eudeba. 
BUSBY, Graham, Paul BRUNT \& Julia LUND. 2003. Agatha Christie country: resident perception of special interest tourism. Tourism, 51(3), $287-300$.

CONNELL, Joanne. 2012. Film tourism-Evolution, progress and prospects. Progress in Tourism Management 33, 1007-1029.

CRESSWELL, Tim. 2010. Towards a politics of mobility. Environment and Planning D: Society and Space 28, 17 - 31.

DONALSON, Christopher, Ian N. GREGORY \& Patricia MURRIETA-FLORES. 2015. Mapping 'Wordsworthshire': a GIS study of literary tourism in victorian Lakeland". Journal of Victorian Culture, 20 (3), 287-307.

EDENSOR, Tim. 2005. Mediating William Wallace. Audio-visual technologies in tourism. En David CROUCH, Rhona JACKSON \& Felix THOMPSON (eds.) The media and the tourist imagination. Converging cultures. 105-118. Londres: Routledge.

FLOCH, Jean Marie. 1993. Semiótica, marketing y comunicación. Bajo los signos, las estrategias. Barcelona: Paidos.

FROST, Warick. 2006. Braveheart-ed Ned Kelly: historic films, heritage tourism and destination image. Tourism Management 27, 247-254.

FONTANILLE, Jacques. 2004. Soma y sema. Figuras semióticas del cuerpo. Lima: Fondo Editorial Universidad de Lima.

GENTILE, Rosalba \& Lorraine BROWN. 2015. A life as a work of art: literary tourists' motivations and experiences at II Vittoriale degli Italiani"European. Journal of Tourism, Hospitality and Recreation 6 (2), 25-47.

HALEWOOD, Chris \& Kevin, HANNAM. 2001. Viking heritage tourism. Authenticity and commodification. Annals of Tourism Research, 28 (3), 565-580.

HERBERT, David \& Helen WATKINS. 2003. Cultural policy and place promotion: Swansea and Dylan Thomas. Geoforum, 34 (2), 249-266.

HERBERT, David. 2001. Literary places, tourism and the heritage experience. Annals of Tourism Research, 28 (2), 312-333.

KIM, Sangkyun \& Stijn REIJNDERS. 2018. Film Tourism in Asia. Evolution, Transformation, and Trajectory. Singapur: Springer Nature.

LUKIN, Liliana. 2018. Pragha-Austerlitz/Europa Mater. Cuadernos LIRICO 19 https://journals.openedition.org/lirico/6678 (Acceso 17 julio 2019).

MACCANNELL, Dean. 2003 [1999]. El turista: una nueva teoría de la clase ociosa. Barcelona: Melusina. 
MCLAUGHLIN, David. 2016. The work and the world: mobilities and literary space. Literary Geographies 2 (2), 122-127.

MORENO, Sebastián. 2012. Ramón Menéndez Pidal. Un beso al Cid. En Sebastián Moreno La academia se divierte: anécdotas, intrigas y desventuras de los ilustres académicos de la RAE en 300 años de historia. 250-328. Madrid: La esfera de los libros.

ONFRAY, Michel. (2016): Teoría del viaje. Poética de la geografía. Buenos Aires: Taurus.

REIJNDERS, Stijn, Leonieke BOLDERMAN, Nicky VAN ES \& Abby WAYSDORF. 2015. Locating imagination: an interdisciplinary perspective on literary, film, and music tourism. Tourism Analysis, 20, 333-339.

SALAZAR, Noel B. 2013. The (im)mobility of tourism imaginaries. En Melanie SMITH y Greg. RICHARD (eds.) The Routledge handbook of cultural tourism: 3439. Nueva York: Routledge.

SARETZKI, Anja. 2013. Literary trails, urban space and the actualization of heritage. AlmaTourism 8, 61-75.

SIRIPIS, Maltika, Caroline SCARLES \& David AIREY. 2016. Being a tourist or performer? Tourists' negotiation with mediated destination image in popular film. En Jo-Anne LESTER \& Caroline SCARLES (eds.) Mediating the tourist experience: from brochures to virtual encounters. 321-339. Londres: Routledge.

STEIMBERG, Oscar. 1993. Semiótica de los medios masivos. Buenos Aires: Atuel.

TATAVITTO, María Silvina. 2019. Literatura y patrimonio: el caso de la Villa Ocampo. Ponencia presentada en las XIII Jornadas de Sociología, Universidad de Buenos Aires, 26- 30 Agosto.

TATAVITTO, María Silvina. Mediación narrativa: arte y movilidad. Ponencia presentada en X Congreso Argentino y V Congreso Internacional de Semiótica, Universidad Nacional del Litoral, Universidad Nacional de Paraná, Asociación Argentina de Semiótica, 15-17 Septiembre.

TATAVITTO, María Silvina. (2011). De sorpresas, circulaciones e interfaces. Fig-

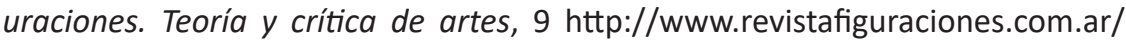
numeroactual/articulo.php?ida=193\&idn=9\&arch=1\#texto (Acceso 10 Agosto 2019).

TZANELLI, Rodanthi. 2004. Constructing the 'cinematic tourist'. The 'sign industry' of The Lord of the Rings". Tourist Studies 4 (1), 21-42.

URRY, John. 2002 [1990]. The tourist gaze: leisure and travel in contemporary societies.Londres: Sage. 
URRY, John. 1995. The making of the Lake District. En John Urry Consuming places. 193-210. Londres: Routledge.

VERÓN, Eliseo. 2013. La semiosis social, 2: ideas, momentos, interpretantes. Buenos Aires: Paidos.

VERÓN, Eliseo. 1999. Esto no es un libro. Barcelona: Gedisa.

WESTON, Daniel. 2016. Contemporary literary landscapes: the poetics of experience. Londres: Routledge

WOOLF, Virgina. 2001. Viajes y viajeros. Barcelona: Plaza y Janés. 


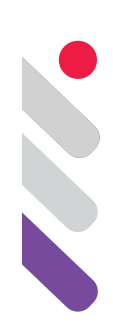

\title{
Retomas del cine de los 80: procedimientos transpositivos de un fenómeno particular.
}

DOI: 10.24308/IASS-2019-4-004

\author{
Vicente José Tripodero \\ Crítica de Artes - Universidad Nacional del Arte \\ josetripodero@gmail.com
}

\section{Remake o Retoma}

Hay una dinámica propia en la relación de los espectadores y los medios audiovisuales que ha generado una gran cantidad de estudios sobre el tema de las remakes. Desde intertextualidad (Kristeva, 1978), transtextualidad (Genette, 1989), transducción (Maestro, 1996), transficcionalidad (Saint-Gelais, 1999), hasta traducción extralingüistica (Torop, 1995) entre otras etiquetas dejan entrever la dificultad que existe en el orden de la inestabilidad nocional. El término "retoma" es el ulitizado por María Rosa del Coto y Graciela Varela (2017: 9) y es el que mejor resume la operación de intertextualidad, es decir es un texto en el que se lee al menos otro, en términos de Kristeva. Como dicen las autoras: "Si 'intertextualidad' nombra una propiedad definitoria de la semiósis, 'retoma' supone detenerse en las operaciones involucradas, es decir, en el tipo específico de absorción, transformación o reenvío que se pueden detectar en las relaciones entre diferentes textos".

La línea argumental de las producciones fílmicas (en términos de Genette, llamamos hipotexto e hipertexto, a la producción de partida y de llegada respectivamente) ha sido objeto de estudio casi en exclusiva, privilegiando así la idea de "fidelidad" a la obra original. También aparecen como foco de análisis las estructuras dramáticas o algunas particularidades estilísticas de los personajes, los escenarios, etc. Una serie de términos son utilizados al momento de analizar estos procesos transpositivos: "fidelidad/traición", "deformación", "profanación", "bastardización", etc. Cada uno de estos términos tiene una carga negativa particular que indican sacrilegio, perfidia ética, degradación, etc.

Es curioso como el cine que presenta un espesor estético más vasto al construir un entretejido de materias de la expresión en comparación con la literatura, que solo se basa en una, se desprenda de él casi como prioridad una 
sola línea de estudio, anclada en la fidelidad o no de las líneas argumentales o temáticas, siendo el cine un arte que absorbe otras artes. Es así que los estudios y análisis sobre las transposiciones cinematográficas deberían incluir, además de la dimensión argumental, las operaciones de retoma, en la condición intertextual de la semiosis y las cualidades semióticas del cine.

Por un lado está la teoría comparatista, la que plantean el binarismo "fidelidad/no fidelidad" y que ha quedado algo arcaica, en la idea de pensar que una obra que no evidencia lazos con textos previos tiene un valor singular por sobre otra que sí delata conexiones con discursos anteriores. La tendencia de pensar la equivalencia estética entre la literatura y el cine, o hipotexto e hipertexto es un proceso que se ha actualizado por lo que la relación entre fidelidad/no fidelidad se ha ido diluyendo. Sin embargo esa relación de superioridad entre el hipotexto por sobre el hipertexto ahora se ha trasladado a la figura de film original vs remake o retoma. Es preciso tomar la idea de Traversa, que a su vez retoma de Benveniste: En el proceso de transposición como fenómeno de circulación discursiva conlleva un aspecto de isoformización, de equivalencias directas pero al mismo tiempo otro que comporta desvíos y diferencias (Traversa, 2014). El problema de la transposición está en el pasaje y no en la llegada, en el texto final.

En el caso de las transposiciones sin cambio de soporte, el cine como principal lenguaje en el que se perciben estos procesos de transformación, la materia de la expresión narrativa sigue siendo el principal objeto de análisis, incluso al tratarse de un proceso que tiene como texto fuente al lenguaje, como vimos, que absorbe otras artes y así varias posibilidades de comparaciones estéticas y estilísticas.

\section{La dimensión temática}

Dentro de las miradas sobre las transposiciones cinematográficas de un mismo film encontramos que la narración es el eje de los estudios, de los metadiscursos y de las teorías sobre este proceso. La temática, dentro de la narración, es la principal dimensión que se tiene en cuenta en la tarea de pensar la comparación entre un film y otro, en el respeto y la fidelidad del origen. Una preocupación narratológica que es prioridad en el análisis reflexivo sobre el fenómeno actual de las retomas, es si el núcleo temático y hasta muchos de los motivos logran pasar al hipertexto sin sufrir modificaciones sustanciales, tan solo se esperan transformaciones de época, políticas, socio-económicas pero la "esencia" temática debe estar presente en el texto final provisorio. En tal caso, hay una idea de "apropiación" de la que se hallan comprometidos tres niveles: el sociohistórico (ej. Estados Unidos 1960), el estético (el relacionado con ciertos movimientos artísticos) y el vinculado con un autor o con un modelo de producción. 


\section{Actualización}

La actualización es un término de Genette, él daba el ejemplo de "Las Damas del Bosque de Bologna" de Bresson como caso en el que deshistorizaba el texto de partida para situarlo en un contexto intemporal eliminando toda huella de época. El procedimiento de la actualización también puede operar bajo un efecto de traslación geográfico y social, no solo temporal. En el caso del corpus seleccionado, ejemplos que operan como casos testigo, se puede evidenciar este procedimiento en el que tenemos films de llegada con eliminación de huellas de época, sustitución de espacios sociales, sustituciones geográficas pero principalmente la relación con el público es la que circunscribe estos procedimientos de actualización, es decir como estos textos fílmicos de origen se vinculan con un público pero a partir de actualizaciones, no solo en los tres niveles ya mencionados sino también a partir de cambios narrativos, en la aceleración de las estructuras, en la condensación de personajes, en el agregado-sustitución-eliminación de temas y motivos pero que mantienen una esencia (la conexión) con el texto de origen. "El cine para ser producido debe ser consumido" y esa exigencia es la que marca una tendencia, en la que las transposiciones aparecen como parte principal de las estrategias que las industrias utilizan para generar nuevos contenidos. El reciclaje es una práctica común porque permite poner en circulación obras que ya han demostrado su eficacia (o que al menos poseen algún elemento, así sea embrionario en su texto de destino en relación con el de origen). En la brecha que separa las obras de origen y de destino está la clave para la práctica de reciclaje, en cómo la aceleración temporal indica: 1) La necesidad imperiosa de las industrias en expandir más las propuestas de nuevos contenidos, 2) En como las nuevas generaciones ya no solo exigen nuevas retomas que mantengan la esencia de la obra original que propongan cambios retóricos sino que eliminen la huella de época.

\section{Corpus}

La selección del corpus pretende establecer casos testigos, es decir que el caudal de transposiciones de films de los 80 realizados en los últimos años representan un fenómeno particular urgente, no solo por su número sino también por la ausencia de homogeneidad en los tipos de films de origen. Es así que encontramos casos de diferentes géneros que abarcan desde lo fantástico a la comedia, del policial al terror, como así también algunos films híbridos y más complejos de clasificar en términos de género textual. A priori podríamos pensar que una comedia de situación, en la que la huella de época no figuraría de manera transparente, no ofrecería cambios, transformaciones, alteraciones, etc. en el pasaje a una retoma realizada veinte años más tarde aproximadamente. 


\section{Equivalencias y diferencias narrativas}

Uno de los casos seleccionados para este corpus es el par Diabólico (Raimi, 1981) y su retoma Posesión Infernal (2013). En el primer caso tenemos una película de fórmula sobre un grupo de adolescentes que queda atrapado en una cabaña, ya sea por un mal materializado de carne y hueso o por un ente intangible, como demonios o seres con la capacidad de poseer, incluso, a objetos inanimados. Tanto en la película de origen como en la de destino se repite esta premisa. En el primer caso la película se convirtió en una referencia del género por su estrategia rupturista en cuanto al uso del gore y en su ensamble con la comicidad, aunque no entraremos en esta veta por el momento. En la película de destino, la trama tiene un tejido sentimental más dramático, en el sentido de la motivación para que los cuatro personajes se congreguen en esa cabaña en el medio del bosque. Mientras en la primera película el objetivo era simplemente pasar un fin de semana de descanso y de goce sexual, en su retoma tres personajes aparecen confabulados para ayudar a un cuarto en su lucha contra una adicción. Los acontecimientos, es decir esas situaciones que marcan un antes y un después en la historia, se repiten: el hallazgo del Necronomicón y la posesión de la protagonista. En la película del 2013 la huella cómica, no solo en la dimensión narrativa sino también la retórica, está opacada por el dramatismo ubicado a un nivel más cercano al suspenso. En el pasaje está el conflicto. Otros casos del género: como El Enigma de Otro Mundo (Carpenter, 1982) y su retoma de 2011, La Niebla (Carpenter, 1980) y su homónima del 2005, La Hora del Espanto (Holland, 1985) y su versión Noche de Miedo (2011), entre las numerosas remakes exponen este renacer por el cine de género fantástico de la década de 1980. La vuelta a esa década no solo incluye la repetición de las estructuras narrativas sino también la estética de esos años, en una suerte de nostalgia que excede a un fenómeno particular.

\section{Cambio - ruptura de escala}

El tránsito de un espacio mental a otro es lo que Verón denomina cambio o ruptura de escala, o sea se trata de un proceso meta-cognitivo a partir de un cambio de tiempo o de espacio. Cuando se trabaja sobre materiales concretos, en el caso de la narración cinematográfica podemos pensar en el punto de vista, en el montaje, en el uso de la cámara lenta o acelerada, etc. Desde esta idea podemos pensar las diversas formas de transposición como cambios de escala. La observación de estas transformaciones permite tomar conciencia de estas operaciones que provocan un pasaje de un estado mental a otro.

En el caso de estos films que comprenden el corpus, salvo el de La Niebla, todos pertenecen a una franquicia, es decir son ahora primero una marca, y dicho en el sentido más estricto de la palabra porque son productos cuyos derechos de autor pertenecen a grandes corporaciones del entretenimiento. El 
cambio de escala, en este micro fenómeno (todavía en proceso) de las retomas del cine de los 80 , no solo se halla en esa transición textual sino también en una transformación profunda en la dinámica económica de una industria inexistente: la de las franquicias (cuanto mucho en un estado embrionario) al momento de las obras de origen. Si bien Hollywood, como industria, nunca fue muy diferente de la automotriz de Detroit, por citar un ejemplo dentro del mismo país, tampoco había desechado por completo la marca autoral, al menos hasta el período del Nuevo Hollywood en los 70. Las retomas de estos films pertenecen a los estudios, a las corporaciones y no a los autores. Incluso hoy el sintagma "cultura pop" es enunciado para determinar un elemento de pertenencia, no solo de las películas sino de personajes, de estilos, de citas textuales, etc.

\section{Cambios de rumbo en la mediatización de los relatos y los géneros}

Steimberg, en el texto Las dos direcciones de la enunciación transpositiva: el cambio de rumbo en la mediatización de relatos y géneros plantea que en los primeros ochenta años de cine la transposición carecía de una complejidad en el tratamiento de los textos fuentes que se revierte en los 90 con una "personalización de la historia que podría imaginarse como una autocrítica a esa cultura transpositiva". Como señala, además, el dar lugar en sus dinámicas "a la complejidad y a la tensión" invierte el sentido habitual de sus producciones y lo hace, en algunos casos, recuperando sentidos ocultos o perdidos. En el ejemplo de Diabólico (hoy como marca de franquicia se llama Evil Dead, título original del film) la expansión y la mutación de ese obra ha derivado en nuevas relaciones interdiscursivas, no solo se han hecho secuelas, spin-offs y otras variantes de relecturas cinematográficas sino que también ha atravesado hacia otros productos textuales como la televisión y los videojuegos. En el tránsito de la expansión de este mero film de adolescentes atrapados en una cabaña está la clave para entender su inestabilidad en el contrato de lectura porque se ven afectadas las expectativas de permanencia de un transgénero en el viaje entre medios y lenguajes.

De esta manera podemos pensar que la problematización de las transposiciones está en el pasaje, como ya lo había advertido Traversa, pero que su agudización se puede percibir en micro fenómenos particulares, como el caso de las retomas de los films de los 80 que no solo comprenden las huellas narrativas que perviven o desaparecen sino también los procesos involucrados en la dimensión formal y enunciativa dentro de los diferentes espacios de circulación interdiscursiva. 
Bibliografía:

DEL COTO, María Rosa. 2017. Medios y retomas. Escrituras y encuentros textuales. En María Rosa del Coto, Graciela Varela (eds.). Notas sobre la adaptación cinematográfica, 31-44. Buenos Aires: Editorial Biblos.

GENETTE, Gerard. 1989 [1962]. Palimpsestos. La literatura en segundo grado. 2nd edición. Madrid: Taurus.

STEIMBERG, Oscar. 2003. Las dos direcciones de la enunciación transpositiva: el cambio de rumbo en la mediatización de relatos y géneros. Revista Figuraciones 1-2.

TRAVERSA, Oscar. 2014. Inflexiones del sentido. Cambios y rupturas en las trayectorias del sentido. Buenos Aires: Santiago Arcos Editor.

VERON, Eliseo. 2013. La semiosis social, 2. Ideas, momentos, interpretantes. Buenos Aires: Paidós. 


\title{
MEDIATIZACIONES
}

\author{
B. LA INSISTENCIA DE FORMAS FÍLMICAS
}





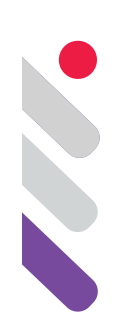

\title{
La despedida de los amantes en la estación de tren. Pervivencia y mutación de formas fílmicas
}

DOI: 10.24308/IASS-2019-4-005

\author{
Marina Locatelli \\ IIEAC - ATCA - Universidad Nacional de las Artes, \\ Buenos Aires, Argentina \\ amarinalocatelli@gmail.com
}

\subsection{Preludio}

El tren está a punto de partir; ya se adivina el "todos a bordo" del guarda. Ella, rauda, apura su paso por la plataforma, esquivando valijas, transeúntes y baúles. Él, con un pie puesto en el estribo del vagón, todavía no la ve. No la espera $y$, sin embargo, la presiente. Con sutileza, el ruido del ajetreo de los pasajeros sobre el andén va dejando paso a una música que se hace cada vez más presente. De pronto, se ven. Corren el uno hacia el otro. Se abrazan, se besan. Quieren decirse todo, pero la partida es inminente; la separación, irremediable. Ya no queda tiempo. Como una sentencia suena el silbato y ellos deben despedirse, pues no hay otra solución. Entonces, el tren se aleja y él va tornándose cada vez más lejano. Ella permanece sobre la plataforma, triste, desolada. Su imagen también se empequeñece. La música, ahora, acalla todos los demás sonidos, inclusive el murmullo sordo de sus lágrimas.

Esta es, sin dudas, una forma cinematográfica, puramente cinematográfica, que se encuentra en el imaginario social y a la que pocos espectadores son ajenos. A todos nos resulta familiar, aunque no podamos asociarla a un film específico. En el cine, nos encontramos aquí frente a una verdadera forma de forma o forma formante.

\subsection{Introito}

El presente trabajo se inscribe en el proyecto de investigación, de carácter exploratorio, Perspectivas diacrónicas en el estudio de estéticas audiovisuales contemporáneas (2018-2019), radicado en el IIEAC de la UNA, y su objetivo es poner en relación formas estilísticas de cines contemporáneos con poéticas cinematográficas históricas. La recurrencia de ciertas configuraciones 
semióticas a lo largo de la historia del cine viabiliza la indagación acerca de vínculos establecidos entre su producción de sentido y diferentes aspectos del contexto socio-histórico. Se parte, entonces, de la concepción de que el mundo entra al lenguaje a través de formas y por ello, dentro de las varias dimensiones constitutivas de las producciones cinematográficas (como, por ejemplo, esquemas retórico-expresivos; motivos temáticos, visuales o musicales; modalidades de compaginación audiovisual recurrentes; particularidades de las propuestas enunciativas), se busca delimitar diferentes formas fílmicas.

En esta oportunidad, la propuesta es focalizar analíticamente una forma fílmica ligada al género melodrama, que es posible hallar en discursividades contemporáneas. Desde una perspectiva diacrónica, se trata de emprender el seguimiento de sus recorridos históricos, es decir, su consolidación, continuidades, resurgimientos y transformaciones. La circunscripción de las formas filmicas en las distintas series de producción semántica de los films viabiliza el análisis del comportamiento que estas formas de formas manifiestan cuando se presentan en discursividades actuales, tanto en lo que hace, como en el caso del melodrama, a reescrituras del género de origen como a la presencia de algunas de sus formas en otros géneros

\section{Antecedentes de la perspectiva diacrónica}

El abordaje antropológico de las formas cinematográficas es un área de notoria vacancia en el campo de los estudios sobre cine. La perspectiva diacrónica propuesta aquí para el estudio de las formas fílmicas torna necesario, entonces, recurrir, como punto de partida, a estudios en esta línea desplegados en otros lenguajes artísticos como las artes visuales o la literatura.

La directora del presente proyecto ya ha detallado los antecedentes que esta perspectiva posee tanto en otros campos de investigación como, aunque moderados, en el mismo ámbito cinematográfico (Tassara 2019). Sin embargo, a modo de resumen, resulta pertinente nombrar, por ejemplo, la focalización en la poética histórica que el movimiento formalista ruso puso en juego en la literatura, en particular cuando este enfoque es trasladado por algunos de sus miembros -Piotrovsky, Tynianov, Eikhenbaum, Shklovski- al lenguaje cinematográfico. Estos autores proclaman la especificidad del cine como lenguaje, promueven su análisis y emprenden de manera temprana el estudio de las formas fílmicas. También, desde esta perspectiva es menester nombrar, en otros espacios, los insoslayables aportes de las investigaciones de Aby Warburg, Erich Auerbach, Georges Didi-Huberman o Giulio Carlo Argan, entre otros.

En este sentido, no se puede dejar de aludir al concepto de Pathosformel que Aby Warburg desarrolla, en particular, con relación a la pintura y con el 
que se designa a esas formas recurrentes -como la de la figura de la ninfaque perviven más allá de sus manifestaciones singulares, y que desaparecen y resurgen a todo lo largo de la historia del arte. En un intento de definición de este concepto, Pathosformel, que se vuelve a veces un tanto elusivo y que, otras, se lo simplifica de tal manera que se lo vacía de significado, Georges DidiHuberman señala, devolviéndole su complejidad:

Pienso que Warburg se sentía insatisfecho de la territorialización del saber sobre las imágenes porque estaba seguro de al menos dos cosas. En primer lugar, que no nos encontramos ante la imagen como ante una cosa cuyas fronteras exactas podamos trazar. Es evidente que el conjunto de las coordenadas positivas - autor, fecha, técnica, iconografía... - no basta. Una imagen, cada imagen, es el resultado de movimientos que provisionalmente han sedimentado o cristalizado en ella. Estos movimientos la atraviesan de parte a parte y cada uno de ellos tiene una trayectoria - histórica, antropológica, psicológica- que viene de lejos y que continúa más allá de ella. Tales movimientos nos obligan a pensar la imagen como un momento energético o dinámico, por más específica que sea su estructura. (2009: 34-35)

Es importante recalcar que, para la perspectiva de esta investigación, exploratoria y con ciertos fines abductivos, es condición sine qua non pensar estas configuraciones recurrentes en la historia del cine en los términos en los que Warburg pensaba la imagen y que Didi-Huberman explica como "el resultado de movimientos que provisionalmente han sedimentado o cristalizado en ella" (2009: 34-35). Es decir, nos planteamos pensar estas formas fílmicas como formas dinámicas en continuo movimiento.

Por su parte, Tassara (2019), quien en el decurso de sus investigaciones se ha topado y ha estudiado diferentes formas fílmicas, discernibles debido a sus particulares configuraciones y a su aparición con cierta frecuencia (como el personaje que se aleja de espaldas a la cámara o el combate final entre el bien y el mal), no duda en sostener que "la Pathosformel es en Warburg una forma recurrente, que más allá de su significado inteligible, variable muchas veces en sus apariciones, se caracteriza por su carga emotiva". Tassara aclara que "la propuesta [de este proyecto de investigación] no pretende forzar la noción de Pathosformel para vincularla a imágenes fílmicas", sin embargo, resulta evidente que en la historia del cine hay formas que perviven y resurgen, y que, a pesar de su transformaciones o mutaciones, son "reconocibles en sus repetidas apariciones". Además, una vez enfrentados a estas configuraciones semióticas, es inevitable no percatarse de la emocionalidad que acarrean, carga emocional que "viene de lejos y continúa más allá de ella", parafraseando a Didi-Huberman. 


\section{Forma fílmica: la despedida de los amantes en la estación de tren}

Este trabajo no pretende explayarse sobre los antecedentes de la perspectiva adoptada ni convencer sobre los beneficios que aportaría al campo de los estudios cinematográficos tal modelo investigativo. En cambio, el objetivo es presentar un primer intento de abordaje, un caso que ejemplifica esta recurrencia discursiva. La exposición, entonces, se circunscribe a una de esas formas (aunque imposible hacerlo de manera exhaustiva en este primer acercamiento) que es la constituida por la despedida de los amantes en la estación de tren. Esta configuración audiovisual posee un amplio reconocimiento social (no es necesario ser un espectador avezado para darse cuenta cuando se está frente a ella) y una larga historia dentro de la cinematografía internacional. De hecho, es posible encontrar ejemplos de esta configuración en las más variadas cinematografías nacionales, por caso, en la argentina, existe un caso paradigmático en la película El secreto de sus ojos (Juan José Campanella, 2009) que no será analizado aquí.

A pesar de que el carácter exploratorio de este primer intento de sistematización de la forma fílmica en cuestión impide aún señalar sus primeras manifestaciones, es incuestionable que el tren -avance tecnológico coetáneo al cinematógrafo francés y a sus similares- en su carácter de motivo cinematográfico se remonta al inicio mismo del cine como medio, baste para ello señalar una de las primeras vistas de los hermanos Lumière, La llegada de un tren a la estación de La Ciotat [L'arrivée d'un train à La Ciotat] (1896), o el primer proto-western de Edwin S. Porter, Asalto y robo al tren [The Great Train Robbery] (1903).

Más allá de la recurrencia del motivo temático -es posible ubicar variados ejemplos en diferentes poéticas históricas del cine, tanto en el período clásico, como en el moderno y el contemporáneo-, también se detecta una recurrencia en una determinada configuración audiovisual que estas formas de formas presentan en cada una de sus manifestaciones. Así, se pueden observar temas y motivos musicales que están asociados, en parte, a una mayor presencia de ciertos instrumentos musicales (de cuerdas, en general) sobre otros, o a un cierto tempo musical. También existe una disposición particular del espacio en el cuadro; se privilegian ciertos tipos de tomas cinematográficas. Por ejemplo, es notoria la preferencia por ubicar en el plano al objeto tren de forma perpendicular. Se remarca así, a través suyo, el punto de fuga, tal como lo hicieran los hermanos Lumière en aquella primera vista.

\subsection{Consolidación de la forma fílmica en el melodrama}

Es durante el período clásico -es decir, durante lo que algunos han caracterizado como modo de representación institucional (Burch [1987] 2006) y otros como narración clásica de Hollywood (Bordwell [1985] 1996) y que puede 
señalar tanto una poética cinematográfica determinada (Tassara 2018) como una etapa cronológica precisa dentro de la historia del cine (ubicada, grosso modo, dentro de las décadas del 30, 40 y 50 del siglo pasado)- que esta forma fílmica, la despedida de los amantes en la estación de tren, se consolida como tal y lo hace, en particular, asociada al género melodrama.

Peter Brooks (1974) caracterizó al melodrama como un modo en el que prima el "exceso" y señaló que su análisis "debe apuntar directamente a lo que la crítica desdeña con frecuencia: los aspectos molestos del melodrama, su énfasis, sus excesos, las exageraciones de su retórica. Estos rasgos no son de ninguna manera fortuitos, sino intrínsecosa la forma" (p. 32). Es posible establecer algunos caracteres dominantes del género: en primer término, en relación con rasgos temáticos-narrativos (situaciones estereotipadas, personajes convencionales que encarnan ideas morales, esquemas narrativos habituales del tipo pecadocastigo-expiación, la casualidad -y no la causalidad, como en la tragediarigiendo las acciones). Estas son, en general, las características del melodrama que en sus momentos de auge el público reconocía inmediatamente. Y, aunque muchas veces bajo otras modalidades expresivas, ellas no han dejado de estar presentes en diferentes medios y lenguajes. En segundo lugar, en el tratamiento retórico-expresivo de los rasgos temáticos encontramos la propuesta retórica del género, asentada sobre sus tres grandes figuras: hipérbole, antítesis, oxímoron. El tratamiento de la trama adquiere un carácter espectacular pues intervienen emociones fuertes, patetismo violento, sentimientos exagerados, situaciones excepcionales, aunque, a la vez, convencionales.

En la película La extraña pasajera [Now, Voyager] (dirigida por Irving Rapper), de 1942, cuyo modo de representación es incuestionablemente clásico, el componente melodramático del film -su construcción hiperbólica, en términos de Brooks- se ve acentuado en el momento de la despedida, mediando las tres cuartas partes de la película. El personaje de Bette Davis (Charlotte) se apresura por el andén para despedirse de su amante (Jerry, interpretado por Paul Henreid), un hombre casado, a quien no volverá a ver. Mientras se dicen adiós y se besan, sobre ellos se refleja la sombra del tren en el que debe partir el hombre, llegando a la estación y, al mismo tiempo, la banda sonora conjuga el sonido de la locomotora en marcha, las campanadas que anuncian la partida, el "all aboard" del guarda, y la música que va, en forma paulatina, subiendo de volumen. En el final de la secuencia, Jerry sube al tren en movimiento y Charlotte camina por la plataforma, como acompañando el trayecto de la máquina. La cámara queda con ella, acercándose a su rostro lloroso, de maquillaje corrido por las lágrimas, hasta que, por último, la cámara realiza un plano detalle de la camelia marchita que prende sobre su tapado, flor que Jerry le había regalado y que simboliza el amor de la pareja. La música, por su parte, se incrementa en intensidad y dramatismo. 


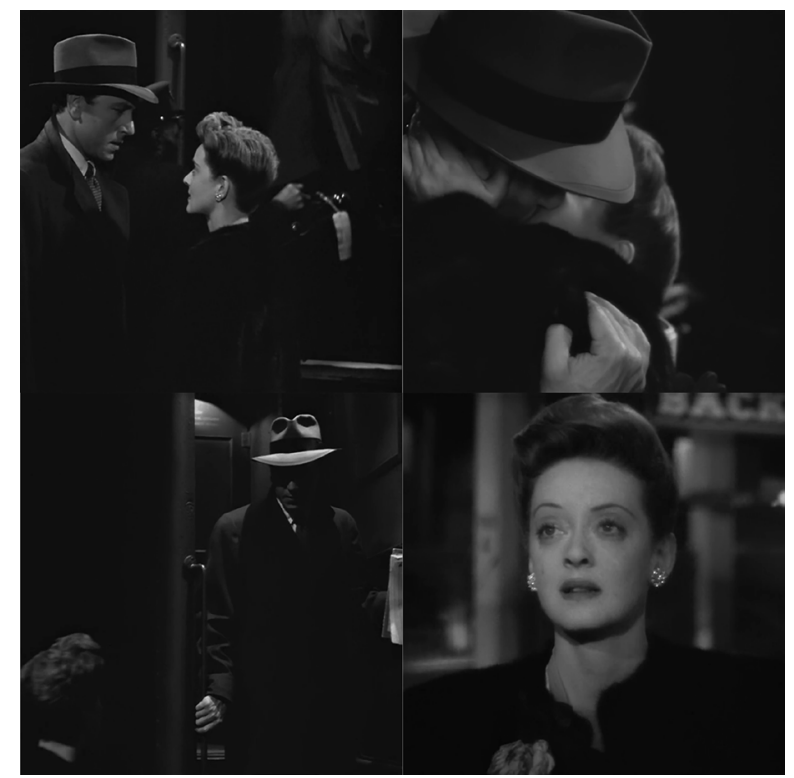

Figura 1: La extraña

pasajera (1942)

Breve encuentro [Brief Encounter] -un film de David Lean, de 1945-es un caso paradigmático, aunque particular a la vez, en relación con las despedidas en la estación de tren. Al suceder la mayor parte de la narración en la estación de tren, la pareja protagónica (casados, aunque no entre ellos) tiene más de una despedida en el andén y, sin embargo, la despedida final no ocurre en la plataforma, sino en el bar de la estación. En ese momento, frente a la presencia de una tercera persona, la despedida de los amantes es muda: Alec (Trevor Howard) solo puede poner su mano en el hombro de Laura (Celia Johnson) a modo de adiós. (Este gesto mudo, pero cargado de emocionalidad lo va a retomar Todd Haynes en Carol, de 2015). Es en este sentido que resulta un caso un tanto atípico, sobre todo por tratarse de un melodrama clásico. Sin embargo, antes del final, ofrece en varias oportunidades una configuración audiovisual característica de esta clase de forma fílmica: la música que adquiere intensidad, el humo que envuelve a las figuras humanas en el andén, la urgencia por inminente partida, las campanadas que anuncian la salida del tren.

Figura 2: Breve encuentro (1945)

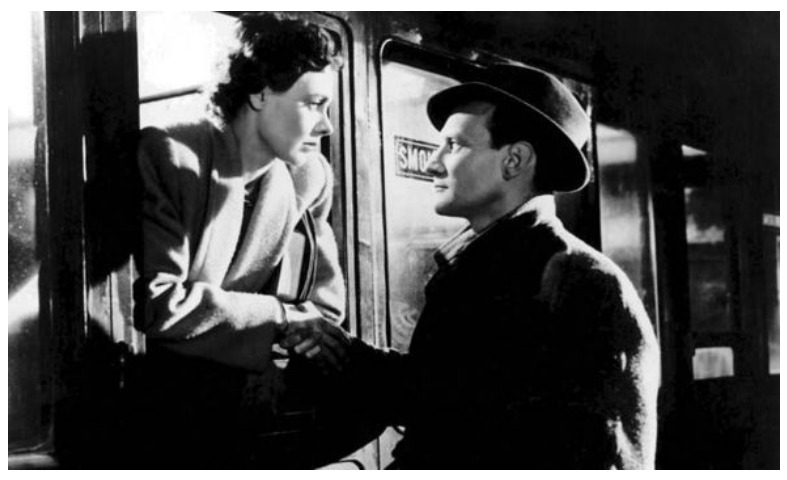


David Lean vuelve a apelar a la misma forma fílmica en su película de 1955, Verano en Venecia [Summertime], protagonizada por Katharine Hepburn y Rossano Brazzi. Una vez más, se trata de un melodrama en el que la posibilidad de un amor duradero de la pareja protagónica se ve impedida, en mayor medida, porque él es un hombre casado y, luego, porque ella es una turista americana, de vacaciones en Italia, que debe volver a su país. La despedida en sí tiene todas las exageraciones propias de la retórica del melodrama y su configuración se establece como modélica dentro de la forma. Cuando se piensa en una despedida de amantes en la estación de tren, tanto convencional como ejemplar, dentro del lenguaje cinematográfico, es posible traer a colación este caso: el semáforo de la vía cambia de rojo a verde, dando inicio a la marcha del tren; la protagonista, asomada por la ventanilla del vagón, con la angustia de la separación en el rostro, se despide haciendo gestos de adiós hasta que ya no se distingue la figura de su amante; el galán corre a lo largo del andén, con el símbolo de su amor (otra vez, una flor) en una de sus manos; el silbato del tren anuncia la partida; el punto de vista adoptado por el relato es el de ella; etc. La forma fílmica se configura aquí con una característica que es de suma importancia, vinculada con la carga emotiva que conlleva, y que colorea todas sus manifestaciones. Me refiero al carácter de cierre narrativo, de conclusión, que posee esta posible Pathosformel. Cuando uno se enfrenta a esta configuración audiovisual, tiende a suponer que se halla frente al final de la historia y, aunque a veces esto no sea así (por ejemplo, en La extraña pasajera o en Breve encuentro, los protagonistas vuelven a encontrarse luego de esta secuencia), en general la suposición resulta verdadera en tanto, muchas veces, la despedida en la estación posee un carácter premonitorio porque después, finalmente, la separación existe. Con todas estas aristas es como la forma fílmica se fue consolidando durante el período clásico.

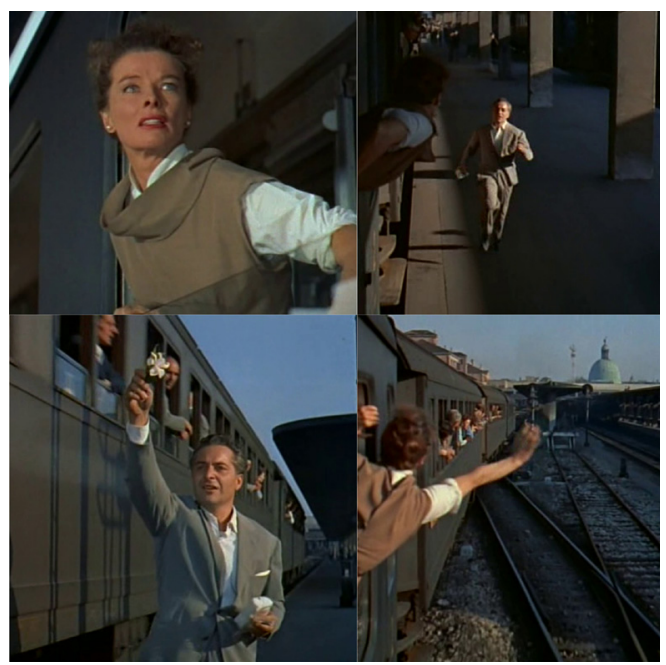

Figura 3: Verano en Venecia (1955) 


\subsection{Quiebres de la forma fílmica}

\subsubsection{Dentro del cine clásico}

Todavía dentro de la poética clásica (aunque, cronológicamente, en sus últimos coletazos), pero ya no en el género melodrama, sino en la comedia romántica, Amor en la tarde-film de 1957, dirigido por Billy Wilder e interpretado por Gary Cooper y Audrey Hepburn- propone, de manera interesante, un quiebre en la forma fílmica, con el cual consigue sorprender las expectativas del público frente a esta configuración. La jovencísima Ariane (Hepburn) se despide del maduro playboy, Frank (Cooper). La infatuación de la protagonista debe terminar y, para ello, a pedido del padre de la joven, el galán se marcha de París. En la secuencia de la despedida en la estación de tren, la última de la película, se hallan todos los elementos mencionados con anterioridad. La bruma los envuelve mientras se desplazan por el andén; ella, con su rostro surcado por las lágrimas del adiós, se aferra a la flor que quitó del ojal de él y que lo caracteriza; se escuchan el silbato del tren, el "en voiture" (versión francesa del "all aboard") y el resoplar de las ruedas del tren. Frank sube al estribo del vagón cuando el tren comienza la marcha y Ariane camina a su lado por la plataforma hasta que debe empezar a correr para sostener la marcha. La música, entonces, se vuelve cada vez más apremiante. Todo hace suponer la despedida trágica a la que el melodrama clásico nos ha acostumbrado. Sin embargo, a último momento, cuando ya parecía que la muchacha no puede continuar el paso y que el andén está a punto de terminar, el protagonista levanta a la muchacha y la lleva consigo a su vagón. Estamos, a no olvidar, frente a una comedia romántica. Si Wilder puede jugar de esta manera con la forma fílmica es porque ya se encontraba consolidada como tal para ese momento y lo mismo ocurría con el horizonte de expectativas que traía consigo. Es justamente a causa de la manipulación de la forma fílmica que la conclusión de este film resulta notable.

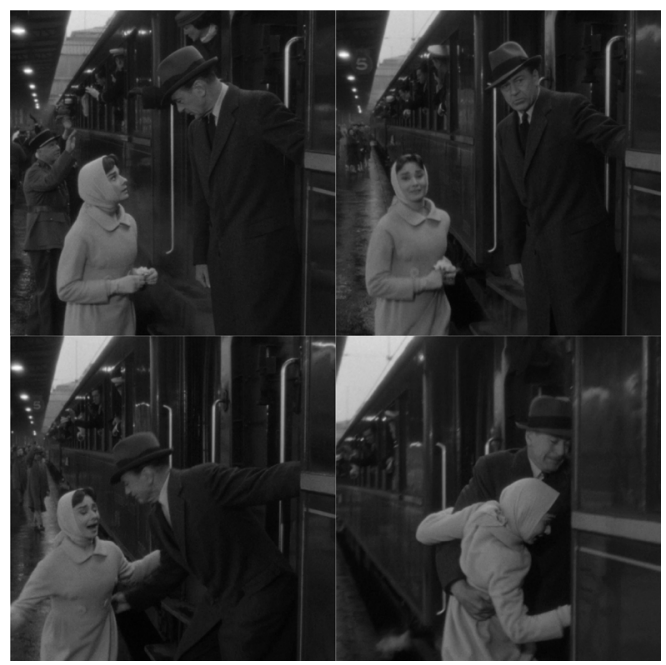

Figura 4: Amor en la tarde (1957) 


\subsubsection{Dentro del cine moderno}

En el modo de representación del cine denominado moderno, la búsqueda estética de cierto naturalismo por parte de las nuevas corrientes cinematográficas (el Neorrealismo italiano, la Nouvelle Vague francesa, el Cinema Novo brasilero y la Generación del Sesenta argentina, entre otras) se oponía, en general, a los excesos y al énfasis visual habituales del género melodrama. Pareció entonces emerger un realismo distinto al anterior que se contraponía al exceso del melodrama tradicional. En la estilística que suele catalogarse de "moderna" había un rechazo de aquellos rasgos retóricosexpresivos melodramáticos asentados durante el período clásico. Así, las tres grandes figuras (la hipérbole, la antítesis y el oxímoron), características de la retórica del melodrama, se vieron desdibujadas en esta nueva estilística. Esta desestimación del exceso es una de las razones por la cual la forma fílmica de la despedida no posee una gran aceptación durante este período.

Sin embargo, un rasgo habitual del cine moderno es su tendencia a la autorreflexión: el lenguaje cinematográfico se refiere a sus propios medios constitutivos. Es por ello que, cuando encontramos la forma filma estudiada, lo hacemos como cita, como reescritura de la historia del cine. Un ejemplo emblemático es Los paraguas de Cherburgo [Les parapluies de Cherbourg]. Surgido del núcleo menos duro de la Nouvelle Vague, el film de 1964, de Jacques Demy, es un musical ¿melodramático?, cuya estetización visual reposa en la poderosa banda sonora creada por Michel Legrand. La joven pareja protagonista de la película, interpretada por Catherine Deneuve y Nino Castelnuovo, debe separarse en la secuencia final del primer capítulo del film; lo hacen en la estación de tren. Primero, en el bar de la estación, la escenografía y el vestuario evidencian el carácter de artificio del relato (rasgo muy marcado en muchas corrientes de los nuevos cines de la época del 60 y posteriores -pienso,

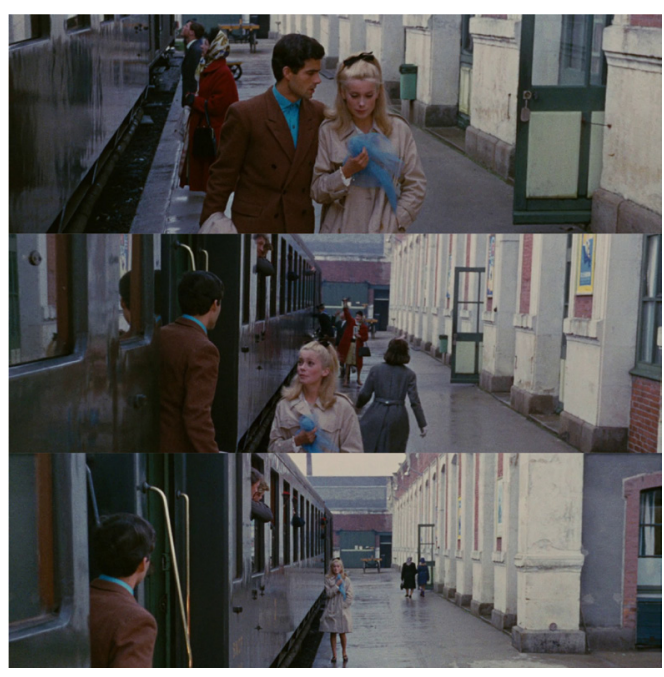

en particular, en los melodramas de Fassbinder). Luego, los jóvenes caminan por el andén mientras se cantan y se repiten una y otra vez "mon amour" y "je t'aime" el uno al otro. Geneviève (Deneuve) no tiene una flor en la mano, pero sostiene un pañuelo, del color de la camisa de su amado, aferrándose a él. Guy (Castelnuovo), desde

Figura 5: Los paraguas de

Cherburgo (1964) 
el estribo del vagón se despide y ella queda sola y empequeñecida sobre la plataforma. Una vez más, la configuración de la forma fílmica se repite, aunque esta vez lo hace con la exacerbación propia de la cita: la intensidad musical acompañada de los típicos elementos de la partida (el traqueteo de las ruedas del tren, el vapor que despide)-, que va escalando hasta llegar a un cierre cuasi operístico, patentiza el dramatismo de la separación.

\subsection{Pervivencias contemporáneas de la forma fílmica}

Lo atrayente de pensar las formas fílmicas como Warburg pensaba las Pathosformeln es que los significados no son estancos, están en perpetuo movimiento. Cada manifestación de la forma de alguna manera renueva y sedimenta la forma misma, y al mismo tiempo.

En resumen, aquello de lo que se acuerdan las supervivencias no es el significado - que cambia en cada momento y en cada contexto, en cada relación de fuerzas en la que está incluido- sino el trazo significante mismo. Pero hay que entenderlo bien: no se trata tanto del trazo como contorno de la figura figurada cuanto del trazo en acto - acto dinámico y superviviente, singular y repetido a la vez- de la figura figurante. No la Gestalt, sino la Gestaltung misma. Es en ese sentido en el que, a ojos de Warburg, la imagen presenta una «función simbólica» (symbolische Funktion) únicamente en la medida en que la memoria que en ella se transmite (Mneme) es la de una «impronta de movimiento», algo que queda resumido, en las notas manuscritas de los últimos años, en la extraña expresión de «engrana energético» (energetisches Engramm). (DidiHuberman, 2009:163)

En este sentido, esta primera investigación nos ha llevado a advertir que la despedida de los amantes en la estación de tren sobrevive en el cine contemporáneo. No solo sobrevive: resurge. Y no solo eso. La supervivencia de esta forma fílmica es firme y sostenida, y lo hace en las más variadas modalidades y géneros cinematográficos.

\subsubsection{Primer modo de pervivencia: paródico}

Ronda por allí un adagio que reza que nunca está más consolidado un género que cuando aparece su parodia. Lo mismo es factible de señalarse respecto a la forma fílmica de la despedida de los amantes en la estación de tren. Mel Brooks la parodia en su película El joven Frankenstein [Young Frankenstein], de 1974. La pareja que se despide sobre el andén; vapor, mucho vapor; el siempre presente "all abord" del guarda; los resoplidos de los engranajes de la locomotora en funcionamiento; el blanco y negro del melodrama clásico; la inminencia de la partida. Todos los elementos que configuran la forma fílmica se hacen presentes. Sin embargo, cuando el protagonista (Gene Wilder) quiere saludar por última vez a su amada (Madeline Kahn) no puede besarla en los 
labios porque le corre el maquillaje; no puede tocarle el cabello porque la despeina; no puede tomarla de las manos porque le arruina la manicura; no puede abrazarla porque le arruga el vestido que es de tafeta. Entonces, no tienen más remedio que saludarse tocando codo con codo (¿quién diría que Mel Brooks tenía poderes adivinatorios?).

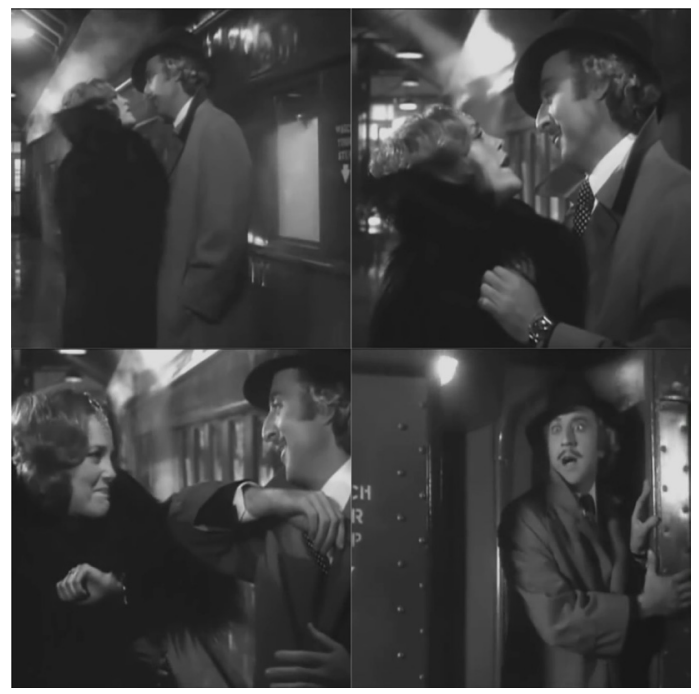

Figura 6: El joven Frankenstein (1964)

\subsubsection{Segundo modo de pervivencia: continuidades en géneros distintos al melodrama}

En Antes del amanecer [Before Sunrise] (1995), Richard Linklater narra el encuentro de dos desconocidos que deciden pasar un día juntos, recorriendo una ciudad como turistas. Desde el comienzo del relato, el tiempo de la partida pende sobre ellos, pues solo tienen unas cuantas horas para estar juntos. Los jóvenes, Jesse (Ethan Hawke) y Céline (Julie Delpy), se despiden aquí, tal vez para siempre, en la estación de trenes de Viena. No se trata, en absoluto, de un melodrama; y la forma parece no presentarse tampoco como cita. Sin embargo, el motivo como tal pervive; la urgencia de la situación pervive; la sensación de vivir un tiempo contra reloj, también. Ellos hablan atropellándose con las palabras, se besan y prometen reencontrarse.

Lo mismo puede apuntarse de Llámame por tu nombre [Call Me by Your Name] (2017), de Luca Guadagnino. Es decir, que no conforma un melodrama y que tampoco la forma fílmica aparece marcadamente como cita. Si bien, en el cine contemporáneo, se podría señalar que, en cada aparición de esta configuración semiótica, su manifestación se realiza como cita, en el sentido de que trae consigo, aunque de manera inconsciente, todas sus materializaciones precedentes, y el espectador poco distraído así la lee.

En Llámame por tu nombre, quienes se despiden son Oliver (Armie Hammer) y Elio (Timothée Chalamet). El primero debe retornar a América y el 
segundo vuelve a la casa de sus padres. Lo secreto de su relación no permite que se besen ni que se digan nada. Toda la emoción -se trata de la secuencia climática del fin, antes del reposo del final-está contenida en apenas un abrazo y un par de miradas entre ellos.

La compaginación audiovisual presenta en ambos casos rasgos recurrentes de esta forma de forma -la pareja en el andén; la disposición en el espacio (en línea de fuga) del objeto tren; el apremio de la partida; los ruidos típicos de la estación-, rasgos que hacen que se la reconozca con facilidad como forma fílmica. Pero en estos dos ejemplos los elementos se hallan depurados, como relevados de su carga hiperbólica. En este sentido, hay que destacar la ausencia tanto de las lágrimas como de la música. No es arriesgado suponer que todo el dramatismo de la secuencia descansa, por un lado, en la habilidad de los actores, en cada caso, para representar la emotividad de la partida, y, por el otro, en la disposición del espectador para evocar la emocionalidad de escenas similares dentro de la historia del cine.

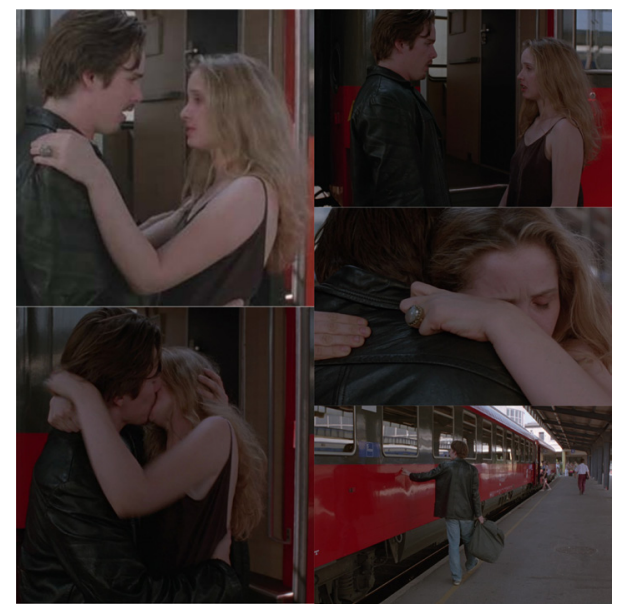

Figura 7: Antes del amanecer (1995)

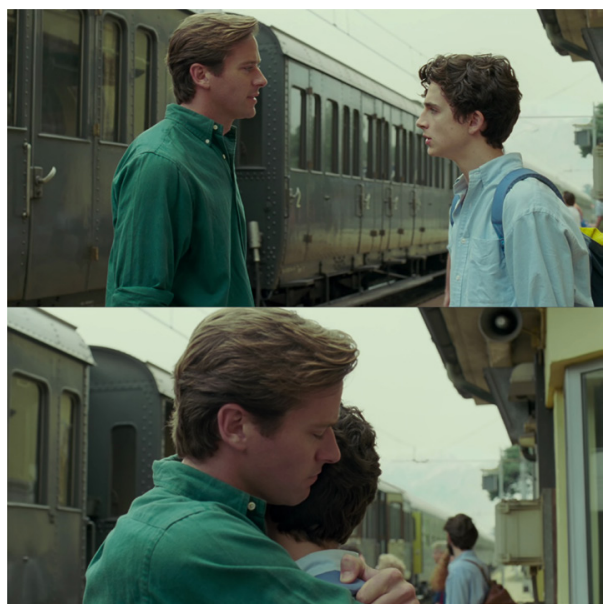

Figura 8: Llámame por tu nombre (2017)

\subsubsection{Tercer modo de pervivencia: continuidades en el género melodrama}

\subsubsection{Homenaje a la forma}

En ciertos cines contemporáneos existe una marcada intertexualidad, y una apelación a la propia historia del cine. Este es el caso de Lejos del paraíso [Far from Heaven] (2002), película en la que Todd Haynes homenajea a una figura señera del melodrama clásico, Douglas Sirk, y a una de sus películas más emblemáticas, Lo que el cielo nos da [All That Heaven Allows] (1955). En una suerte de manierismo al cuadrado, Haynes reescribe el melodrama manierista del director alemán y lo hace él mismo en clave manierista. De un esteticismo 
manifiesto, la paleta de colores y la combinación cromática de decorados, escenarios naturales y vestuario denotan la artificiosidad de la construcción del relato. La despedida entre el ama de casa, de familia acomodada, Cathy (Julianne Moore), y su jardinero negro, Raymond (Dennis Haysbert), posee la censura propia de la época en la que está asentada la narración, los años cincuenta. Otra vez, como en el caso de los adúlteros en Breve encuentro (el cine clásico jamás mostraría la consumación sexual de este amor prohibido -o de ninguna clase, en realidad-, pero, de cierta manera, esto está implícito) y en el de la pareja gay en Llámame por tu nombre, la despedida no puede sino ser silenciosa, muda, construida sin diálogos, respaldada por la carga emotiva que trae consigo esta configuración semiótica.

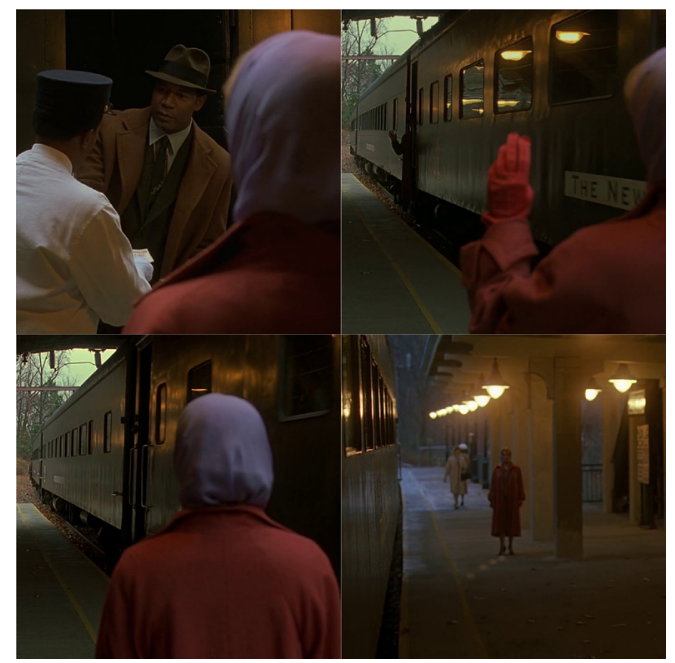

Figura 9: Lejos del paraíso (2002)

\subsubsection{Desvío de la forma}

En un film de factura reciente, que es posible ubicar dentro del género melodrama, puede advertirse un pequeño desvío de la forma. Se trata de la película de James Kent, Viviendo con el enemigo [The Aftermath], estrenada a principios de 2019. Rachael (Keira Knightley) decide abandonar a su marido (Jason Clarke) y dejar la Hamburgo de posguerra junto a su amante (Alexander Skarsgård). Nuevamente, la forma fílmica se ubica en el clímax dramático, en secuencia anterior al final. Una vez en la estación, con la partida del tren apremiándola, la mujer se da cuenta, en el andén mismo, que la historia de amor con su esposo merece una nueva oportunidad. Despedirse de su amante es irremediable; y mientras ella se aleja de espaldas a la cámara, el sube al tren ya en movimiento. 


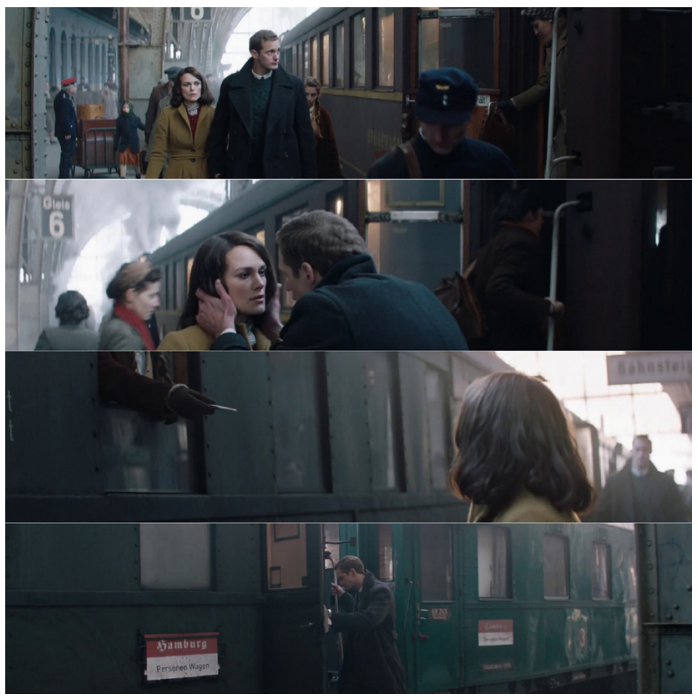

Figura 10: Viviendo con el

enemigo (2019)

\subsubsection{Cuarto modo de pervivencia: mutación}

El último caso seleccionado para ejemplificar la forma fílmica de la despedida de los amantes en la estación de tren se trata, justamente, de una despedida que no ocurre en la estación de tren y es por ello que la designamos como un cuarto modo de pervivencia, asociado a la mutación de la forma. Basada en una historia real, en Las estrellas de cine nunca mueren [Film Stars Don't Die in Liverpool] (2017) Annette Bening interpreta a la conocida actriz del periodo clásico, Gloria Grahame, quien, hacia el final de su vida, tiene un romance con Peter Turner (Jamie Bell), un muchacho aspirante a actor, mucho más joven que ella. El romance debe terminar a causa de la enfermedad de la actriz, que obliga a su hijo a ir a buscarla a Liverpool y llevarla de regreso a Estados Unidos para internarla en un sanatorio. El dramatismo intrínseco a la forma fílmica de la despedida se hace presente, pero esta vez no ocurre con un tren mediante. La otrora celebridad es subida a un auto y su amante se despide de ella. Luego, la cámara permanece en el interior del vehículo y lo filma a él, tras la ventanilla, con su mano pegada al vidrio y su rostro surcado por las lágrimas, mientras acompaña caminando la marcha inicial del automóvil. Es por esto que llamamos esta modalidad de la forma mutación. El personaje masculino es quien se queda solo, en medio de la calle, llorando; y quien se aleja es la protagonista. El tren ha mutado por el auto, pero ciertos rasgos característicos de la configuración

${ }^{1} \mathrm{Si}$ bien hemos analizado otros casos en los que el hombre es quien permanece en la plataforma mientras ve marcharse a su amante (por ejemplo, es lo que sucede en Antes del amanecer o en Llámame por tu nombre), se trata de manifestaciones de la forma fílmica en relatos que no pueden ser catalogados de melodramáticos, sino que, por el contrario, en ellos la emotividad está depurada. Los personajes masculinos no lloran (rasgo físico propio del melodrama) como lo hace el protagonista de Las estrellas de cine nunca mueren. 
permanecen: el desgarro de la separación como motivo temático; la resistencia al alejamiento por parte de uno de los personajes; el carácter conclusivo que posee la secuencia.

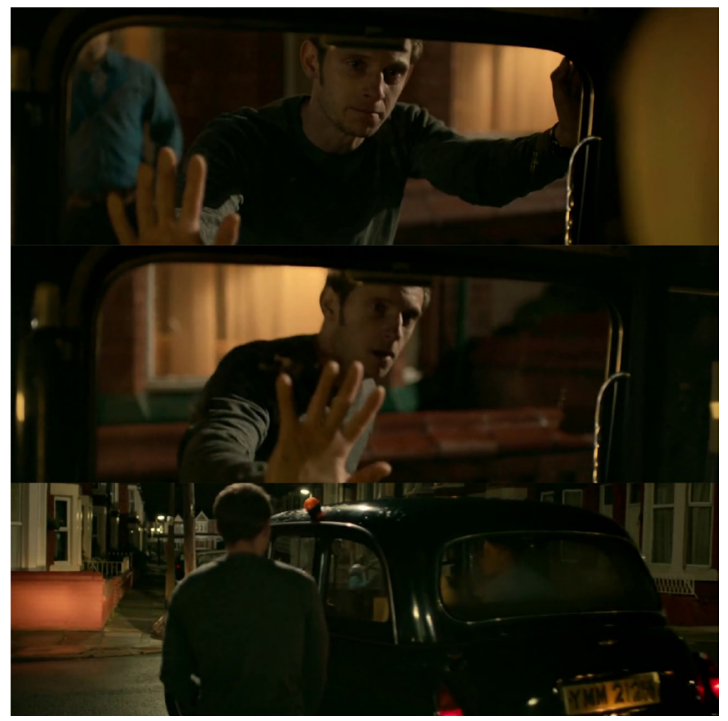

Figura 11: Las estrellas de cine nunca mueren (2017)

\section{Conclusiones}

El estudio de las formas fílmicas desde una perspectiva diacrónica ofrece un vasto campo de investigaciones. Esta ha pretendido ser solo una primera exploración, un primer intento de abordaje con modestos fines abductivos. A modo de apresurada conclusión es preciso señalar lo evidente de la recurrencia semiótica de una forma de forma a lo largo de la historia del lenguaje cinematográfico. Esta posible Pathosformel, la despedida de los amantes en la estación de tren, más allá de todas sus variaciones -algunas de sus materializaciones hemos tratado de mostrar, con mayor o menor suerte, en este trabajo-, se manifiesta con rasgos, con características -determinada disposición de los elementos en el plano, empleo particular de la banda sonora, motivos temáticos reiterados, privilegio de ciertas tomas sobre otras, carácter conclusivo de la secuencia en términos narrativos- que facilitan su reconocimiento por parte de los espectadores. Al mismo tiempo, estas formas fílmicas traen consigo un horizonte de expectativas y una carga emotiva que el público identifica, evoca, acepta y agradece.

Entonces, esta primera exploración en el terreno de las formas fílmicas ha permitido observar de qué manera una configuración semiótica recurrente como la despedida de los amantes en la estación de tren -tal como la hemos descrito, plenamente audiovisual- es utilizada en modos distintos por géneros cinematográficos del presente, con propósitos distintos. La forma fílmica 
pervive en la comedia como burla al exceso y al dramatismo propios del melodrama. O revive como homenaje a la poética clásica. O resurge para sellar relatos depurados, que trabajan cierto realismo. O se transforma para actualizar lo melodramático. En definitiva, la forma fílmica es soporte de operaciones semióticas específicas de géneros y estilos diferentes todo a lo largo de la historia del cine. La imagen superviviente existe y se encuentra en continuo movimiento.

\section{Referencias}

BORDWELL, DAVID. 1996 [1985]. La narración en el cine de ficción. Barcelona: Paidós.

BROOKS, Peter. 1974. El melodrama, una estética del asombro. Poétique 19, 90 111.

BURCH, NÖEL. 2006 [1987]. El tragaluz del infinito, 5ta. ed. Madrid: Cátedra.

DIDI-HUBERMAN, Georges. 2009. La imagen superviviente. Historia del arte y tiempo de los fantasmas según Aby Warburg. Madrid: Abada Editores.

TASSARA, Mabel. 2018. Figuras, figuraciones. Momentos retóricos del cine. Buenos Aires: Prometeo Libros \& UNA, Crítica de Artes, Publicaciones.

TASSARA, Mabel. 2019. Posibles Phatosformeln en la historia del cine. Ponencia presentada en el $14^{\circ}$ Congreso Mundial de Semiótica IASS/AIS. Buenos Aires, Argentina, 9-13 de septiembre de 2019.

\section{Filmografía}

BROOKS, Mel. (Director). 1974. El joven Frankenstein [Young Frankenstein] [Film]. Gruskoff/Venture Films; Crossbow Productions; Jouer Limited.

DEMY, Jacques. (Director). 1964. Los paraguas de Cherburgo [Les parapluies de Cherbourg] [Film]. Parc Film; Madeleine Films; Beta Film.

GUADAGNINO, Luca. (Director). 2017. Llámame por tu nombre [Call Me by Your Name] [Film]. Frenesy Film Company; La Cinéfacture; RT Features; Water's End Productions; M.Y.R.A. Entertainment; Ministero dei Beni e delle Attività Culturali e del Turismo (MiBACT); Lombardia Film Commission; Merchant Ivory Productions.

HAYNES, Todd Haynes. (Director). 2002. Lejos del paraíso [Far from Heaven] [Film]. Focus Features; Vulcan Productions; Killer Films; John Wells Productions; Section Eight; Clear Blue Sky Production; TF1 International; USA Films 
KENT, James. (Director). 2019. Viviendo con el enemigo [The Aftermath] [Film]. Amusement Park Films; Fox Searchlight Pictures; Scott Free Productions.

LEAN, David. (Director). 1945. Breve encuentro [Brief Encounter] [Film]. Cineguild.

LEAN, David. (Director). 1955. Verano en Venecia [Summertime] [Film]. Lopert Films; London Film Productions.

LINKLATER, Richard. (Director). 1995. Antes del amanecer [Before Sunrise] [Film]. Castle Rock Entertainment; Detour Filmproduction; Filmhaus Wien Universa Filmproduktions; Sunrise Production; Columbia Pictures.

McGUIGAN, Paul. (Director). 2017. Las estrellas de cine nunca mueren [Film Stars Don't Die in Liverpool] [Film]. Eon Productions; Synchronistic Pictures.

RAPPER, Irving. (Director). 1942. La extraña pasajera [Now, Voyager] [Film]. Warner Bros.

WILDER, Billy. (Director). 1957. Amor en la tarde [Love in the Afternoon] [Film]. Billy Wilder Productions. 


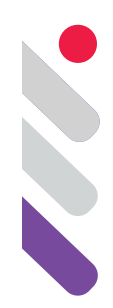

\section{Temporalidades ficcionales - una exploración de las paradojas temporales en el cine de} ficción

DOI: 10.24308/IASS-2019-4-006

M. Laura Ragucci

UNA, Buenos Aires, Argentina

laura.ragucci@educ.ar

\section{Una breve historia del viaje en el tiempo}

La literatura ha fantaseado con la idea del viaje en el tiempo desde hace más de un siglo. En 1895 el británico H. G. Wells, uno de los padres de la ciencia ficción, se apoya en una cuarta dimensión: el tiempo, para explicar de qué manera su máquina puede desplazarse de un año a otro sin dificultad, pero es incapaz de salir de la habitación en la que fue ensamblada. Isaac Asimov, en su novela El fin de la eternidad sienta las bases para la mayoría de los textos venideros: el viaje en el tiempo no como exploración científica, sino con el propósito de cambiar algo en el pasado; evitar una muerte o conquistar a la persona amada son los ejemplos clásicos.

Hollywood aplicó el potencial del lenguaje audiovisual para adueñarse de la temática y sacarle provecho. En la década de los 80 abundan los films basados en la posibilidad de realizar viajes temporales. Volver al Futuro nos presenta en clave humorística una máquina del tiempo posible, un DeLorean DMC-12, que no utiliza gasolina sino plutonio para su propulsión. Por los mismos años Terminator también logra volver al pasado, aunque sin dar muchas explicaciones acerca del cómo, para asesinar a la madre de un líder por nacer. El cuerpo del asesino se materializa en el tiempo-destino, completamente desnudo. Aparentemente los elementos del mundo físico, como ropa o armas, no soportan el traslado. El principio de teletransportación fue retomado, casi sin variación, en otras películas de viaje en el tiempo, como 12 Monos o Dejávu.

En todos los casos citados se cae siempre en la paradoja del abuelo, que puede rastrearse hasta la novela El viajero imprudente, escrita en 1943 por René Barjavel, pero que quizás sea aún más antigua. La idea es sencilla: un supuesto viajero en el tiempo mata al padre de su padre biológico. En consecuencia su 
padre no es concebido y el viajero no llega a nacer, para retroceder en el tiempo y matar a su abuelo. Con este argumento queda demostrado que un viaje hacia atrás en el tiempo debe ser imposible. Alguien podría objetar que no todo viajero en el tiempo pretende cambiar el curso de la historia, sin embargo, su sola presencia en un tiempo que no le es propio, alteraría los acontecimientos de ese presente, volviendo poco probable que los hechos subsiguientes transcurran inalterados. Resulta evidente que cualquier cambio realizado, por menos significativo que parezca a nuestros ojos, debe producir tremendas diferencias en el presente que da origen al viaje.

Sin embargo hay otro tipo de travesías temporales que son absolutamente plausibles y pueden desplegarse ante los ojos de los espectadores no sólo gracias a efectos especiales sino principalmente merced a la creatividad de los narradores. Hay tiempos que se detienen o dilatan, tal como propone Borges en El milagro secreto y otros que se dividen, como un rayo de luz atravesando un prisma, en todas las posibilidades del espectro. Son estos los viajes temporales de los que se ocupa esta ponencia.

\section{Haciendo foco en el tiempo}

Antes de examinar el uso de las paradojas temporales en el cine es imprescindible establecer de qué hablamos cuando hablamos del tiempo. La cuestión del devenir y la inmanencia han sido objeto de análisis profundo por parte de estudiosos de todas las ciencias. Uno de los primeros planteos corresponde a los estoicos. Estos filósofos hablan de los "estados de cosas":

"En el límite, hay una unidad de todos los cuerpos en función de un Fuego primordial en el que se reabsorben y a partir del cual se desarrollan según su tensión respectiva. El tiempo único de los cuerpos o estados de cosas es el presente. Porque el presente vivo es la extensión temporal que acompaña al acto, [...]" (Deleuze, 2005,.11)

Los estoicos no conciben un devenir en el que ciertos acontecimientos son causa de otros, que deben ser pensados como un efecto de los primeros. Para ellos todos los cuerpos son causas y efectos en distintos momentos de ese presente perpetuo al que denominan "presente cósmico".

En las antípodas de esta forma de ver al mundo encontramos al cristianismo. Uno de sus pensadores más lúcido, San Agustín, obispo de Hipona, también reflexionó sobre el tiempo en sus Confesiones:

Lo que sí digo sin vacilación es que sé que si nada pasase no habría tiempo pasado, y si nada sucediese no habría tiempo futuro; y si nada existiese, no habría tiempo presente. Pero aquellos dos tiempos, pretérito y futuro, ¿cómo pueden ser, si el pretérito ya no es y el futuro todavía no es? Y en cuanto al presente, si fuese siempre presente y no pasase a ser pretérito, ya no sería tiempo, sino eternidad. (San Agustín, 397, XI, XIV, 17) 
En el mismo texto San Agustín se plantea dudas acerca de la posibilidad de medir el tiempo, algo que pocas veces nos cuestionamos. Es cierto que podemos fragmentar el devenir guiándonos por los períodos de luz y sombra que la rotación del planeta produce y que los relojes miden, con abrumadora naturalidad. Pero ¿qué es exactamente eso que medimos?, se pregunta el filósofo. No puede ser el futuro, que aún no es, ni tampoco el presente, que es absolutamente efímero, un instante entre lo que ya fue y lo que vendrá. Estos planteos, lejos de superarse, fueron complejizándose.

Husserl, un filósofo contemporáneo con el surgimiento de la psicología, busca una salida a estas paradojas y desglosa el tiempo en inmanente y trascendente. Un tiempo de la conciencia, que es a su vez conciencia de la temporalidad y otro del objeto, que es condición de posibilidad de la experiencia y sólo perceptible a través del primero. Tenemos así en el primero el tiempo de San Agustín, que forma parte de nuestra estructura de pensamiento (como diría Kant varios siglos más tarde) y en el segundo el tiempo de los estoicos, un presente cósmico que permite la existencia de los objetos y que es pura extensión. Este planteo lejos de resolver la cuestión duplica el problema, dado que habría que explicar la duplicidad en la esencia de estas temporalidades o la dualidad de su comportamiento.

En el libro La lógica del sentido citado anteriormente, el filósofo francés Giles Deleuze se ocupó del análisis de las aporías. Su relectura del análisis de los estoicos provee una solución más elegante e interesante a nuestros propósitos:

"Sólo existe el presente en el tiempo, y recoge, reabsorbe el pasado y el futuro, pero sólo el pasado y el futuro insisten en el tiempo, y dividen hasta el infinito cada presente. No son tres dimensiones sucesivas, sino dos lecturas simultáneas del tiempo." (Deleuze, La lógica del sentido, p. 9)

Nuestra conciencia opera en esa división del presente que nos habilita a pensar en líneas temporales, pero el tiempo en esencia es un perpetuo presente, en el que se desarrollan nuestras percepciones. Si el tiempo no puede fluir y a su vez se escinde para abarcar el mundo real y la conciencia, eso no le deja más que una posibilidad: la de dividirse en múltiples líneas o capas.

\section{Sumidos en la paradoja}

En la medida en que se esquiva el presente, el devenir no soporta la separación ni la distinción entre el antes y el después, entre el pasado y el futuro. Pertenece a la esencia del devenir avanzar, tirar en los dos sentidos a la vez. (...) la paradoja es la afirmación de los dos sentidos a la vez. (Deleuze,2005, 8)

La cantidad de películas en las que el cine mainstream ha tratado el tema del tiempo "bifurcado" o "indefinido" es mucho menor a las que se abocan al viaje en el tiempo convencional. Sin embargo puede afirmarse que el uso de las 
paradojas temporales fue mutando con el transcurso del tiempo, volviéndose cada vez más cotidiano y audaz.

\subsection{Un abanico de posibilidades}

El día de la marmota es quizás uno de los films que plantea un viaje temporal no convencional más conocido. En el film de Ramis los protagonistas viven un mismo día incontables veces. La paradoja radica en que los hechos son los mismos, pero a su vez diferentes. Haciendo una analogía con los programas de computación puede afirmarse que el sistema está trabado, prisionero en un bucle, es decir en una repetición cíclica indefinida, del que sólo puede salir por la acción de un agente libre, que introduce una variación. En el caso de la película que nos ocupa el protagonista, un ególatra y egoísta presentador televisivo, es el único que percibe el bucle y puede, a través de un cambio radical en su actitud y forma de vida, llevar a la salida del loop temporal.

Es evidente que estamos ante el planteo de un presente cósmico, propio de los estoicos, que puede ser transitado innumerables veces. Se trataría de un presente que se bifurca en sus ilimitadas posibilidades a partir de un hecho puntual y sólo por un cierto tiempo, en este caso 24 horas, para volverá al punto temporal origen de la bifurcación. La causalidad es muy débil, ya que el protagonista es capaz de cambiar su reacción ante los mismos estímulos, a medida que la trama avanza. La paradoja queda claramente planteada, como anomalía de la realidad. Los mecanismos que posibilitan escapar de ella desde el punto de vista argumental del film tampoco ofrecen misterio alguno. Sin embargo queda por resolver el origen de la paradoja temporal y discernir si se trata de un retroceso en el tiempo, donde los recorridos son sucesivamente anulados, sobreescritos en cierta manera; o bien si efectivamente hay una división de la corriente temporal y cada línea sigue su curso independientemente.

En Las vidas posibles de Mr. Nobody, la paradoja temporal por multiplicidad no implica repetición alguna. En un inicio parecemos asistir al relato del último mortal en un futuro distópico, en el que gracias a los adelantos científicos la vejez ha sido abolida por completo. El anciano relata a un periodista sus experiencias, que en un inicio se nos antojan banales. Sin embargo, a medida que avanza el film, algunas escenas se repiten con variaciones y otras son directamente disruptivas de la lógica argumental, como la irrupción de un coche de juguete rojo en medio de un conjunto de edificios. Estos detalles nos llevan a comprender que estamos asistiendo al despliegue de la fantasía de un niño.

Se trata entonces del tiempo psicológico, tal como lo plantea Husserl y no del presente cósmico. El film completo transcurre en un instante, que parece coincidir con el momento en que ambos padres lo llevan a la estación de trenes y él debe decidir si quedarse o partir. El efecto de este trauma y el estress que genera en la criatura resulta en la representación de todas las opciones 
posibles, tanto del pasado que lo condujo a tan terrible elección, como del futuro que se despliega ante él. El director lo plasma en una imagen de rieles entrecruzándose, en clara alusión a los distintos caminos que son transitados en uno u otro sentido, sin que sea evidente si estamos avanzando o retrocediendo. Aquí tenemos entonces una explicación plausible de por qué se produce la bifurcación temporal en la mente del niño. Suponemos que cuando tome una decisión, la paradoja se resolverá por sí misma.

\subsection{El tiempo en Marienbad}

Quizás la mayor paradoja temporal se da en films como El hombre que miente de Alain Robbe-Grillet o el de Alain Resnais El año pasado en Marienbad, en los que la indefinición es la clave de toda la película. Robbe-Grillet se propuso cuestionar la idea de verdad. En su película es imposible determinar qué es lo que sucedió en realidad, las escenas se repiten, con o sin alteraciones y la sucesión temporal es arbitraria, dado que las líneas narrativas se entrecruzan, sin que nunca estemos seguros acerca de cuál punto de vista es el que nos ofrece el autor en ese momento. En el film de Resnais a partir del vagabundeo inicial de la cámara, acompañado por la descripción entrecortada de los detalles del decorado, producto de la labor de artistas de otro siglo y la insistente mostración de puertas, que encierran los marcos de muchas otras, corredores atestados de objetos y espejos que multiplican tanto los espacios como los rostros; la película lleva a la sensación de hallarse en un espacio fuera del tiempo. La cámara trata de la misma manera objetos, personajes y escenarios, como si tuviesen la misma entidad. Los decorados en primer plano, enmarcados por monótona descripción de fondo, tienen el mismo encuadre y duración que los close-ups sobre los rostros de los actores. Las primeras líneas de diálogo hacen mención a la espera, al tiempo, unos segundos unos minutos, un pasado de mármol, rígido y frío, muerto, que despierta a la vida ante la palabra "ahora" (maintenant). En ese presente incierto, mezcla de pasado y futuro se desarrolla toda la película, deteniéndose sin causa aparente y caracoleando para volver al inicio.

En esta película resulta difícil discernir de qué tiempo se trata, si del de la conciencia o el de los objetos. Incluso resulta imposible afirmar qué escenas corresponden a un recuerdo y cuáles a un deseo o a una realidad presente. La acción bien podría transcurrir en el tiempo subjetivo del narrador en off, pero en ese caso ¿por qué el objeto de sus ansias no lo reconoce y él repite incesantemente las condiciones de su primer encuentro? También sería plausible que se trate de un recuerdo, pero entonces ¿por qué los sobresaltos y la incertidumbre? ¿Y cómo explicar la existencia de los vacíos sin sonido y de personajes que accionan por fuera de la trama? La película tiene algo de onírico, cosa que los mismos personajes plantean, pero si se encuentran en un sueño, donde prima el inconsciente, sin las represiones propias del yo ¿por qué temer 
y no dar rienda suelta a la pasión? Quizás ninguno de los dos sea real y todos sean producto de la imaginación de un tercero.

En estos films se reconoce la lógica de la imagen-cristal, donde la imagen actual ya no encadena con otra imagen actual sino con su propia imagen virtual. Cada imagen se separa de las restantes y se abre a su propia infinidad, por lo que las imágenes del pasado, que se conserva, se funden con las del presente volviéndose así indiscernible el tiempo de la acción. En este tiempo difuso la narración no puede progresar, está atrapada y no puede fluir en ningún sentido. En vez de avanzar se profundiza, capa tras capa, encuentro tras encuentro, gana en espesor, en detalle. Un espacio de líneas rectas pero laberintico en el que los personajes se pierden.

\section{Un final anunciado}

El cine es un lenguaje privilegiado para representar el fluir del tiempo. Los efectos especiales han permitido que, en los últimos tiempos, la cantidad de películas mainstream y series en las que se apela a las distintas variantes de paradojas temporales se ha multiplicado. La mayoría hacen uso de la vieja receta de la máquina del tiempo, pero apelando a una vuelta de tuerca para escapar a la paradoja: el futuro tal como era deja de existir en el preciso instante en que el protagonista lo abandona. ¿Será quizás que muchas personas se sienten atrapadas hoy en un presente que sienten como hostil y ajeno? ¿Estamos viviendo la Entzauberung de la que hablaba Benjamin: ese hastío que se siente cuando ya se ha "experimentado todo" y no queda lugar para la esperanza y el cambio? Benjamin responsabiliza a esta Entzauberung de las patologías sociales que denunciaba el marxismo, es decir la alienación y reificación de las relaciones sociales. Es por eso que se opone a esta secularización o desmitificación, que siguiendo a Weber percibe como resultado de la aplicación de los ideales de la ética calvinista a los conceptos de progreso y mercado, su propia concepción de la temporalidad. Niega el nexo lineal y cronológico entre los hechos para reemplazarlo por unidades complejas de la vida humana que llama constelaciones. Estas constelaciones implican la elaboración y el descubrimiento de afinidades y correspondencias entre experiencias vitales, las experiencias pasadas se actualizan en la experiencia actual.

Deleuze plantea en la imagen-cristal la imposibilidad de salir del presente, dado que no hay una concatenación lógica de acciones que se pueda establecer a partir del pasado y fluya hacia el futuro. Benjamin sostiene en total concordancia que el declive de la narración responde a la imposibilidad de transmitir la experiencia, es decir de realizar la conjunción del pasado en el presente con aspiración a proyectarla hacia el futuro. Como ejemplo toma a los soldados que volvían de la guerra incapaces de transmitir su experiencia, dado que la tecnología bélica los había abrumado y llevado a la alienación, tal como 
la tecnología industrial llevaba a la alienación a los obreros.

Quizás estas narraciones fragmentarias, que evitan los encadenamientos cronológicos y lógicos por igual, constituyan la nueva forma de narración preanunciada por Benjamin: la del narrador urbano, que finalmente va encontrando sus propios canales expresivos.

\section{Corpus de películas (en orden cronológico)}

1950 - Rashomon - Akira Kurosawa

1961 -El año pasado en Marienbad (LastYear In Marienbad) -Alain Resnais

1962 - La Jetée - Chris Marker

1968 - El hombre que miente (L'homme qui ment)- Alain Robbe-Grillet

1984 - Terminator (The terminator) - James Cameron

1985 - Volver al futuro (Back to the future) - Robert Zemeckis

1993 - El día de la marmota (Groundhog Day) - Harold Ramis

1995 - 12 Monos (Twelve Monkeys) - Terry Gilliam

2001 - Donnie Darko -Richard Kelly

2004 - El efecto mariposa (The Butterfly Effect) -Eric Bress y J. Mackye Gruber 2006 - Déjà Vu -Tony Scott

2009 - Las vidas posibles de Mr. Nobody (Mr. Nobody) - Jaco Van Dormael

2010 - El origen (Inception) - Christopher Nolan

2011 - 8 Minutos antes de morir (SourceCode) - Duncan Jones

2012 - Looper. Asesinos del future (Looper) - Rian Johnson

2013 - Mindscape - Jorge Dorado

2014 - Al filo del mañana (The Edge of Tomorrow) - Doug Liman

2016 - ARQ -Tony Elliott

\section{Bibliografía}

CHOI, Domin. 2019. El fin de lo nuevo: Un panorama aleatorio del cine contemporáneo. Buenos Aires. Libraria,

DELEUZE, Guilles. 2016. La imagen tiempo - Estudios sobre cine 2. Buenos Aires.Paidós comunicación de cine.

DELEUZE, Guilles. 2005. La lógica del sentido. Buenos Aires. Paidós http://www. medicinayarte.com/img/biblioteca_virtual_publica_deleuz_logicasdelsentido. pdf 
HLEBOVICH, Ludmila. 2016. Crisis y reconfiguración de la experiencia. Una conceptualización del rol del cuerpo en la filosofía de Walter Benjamin. Buenos Aires: Universidad Nacional de La Plata tesis. http://www.memoria.fahce.unlp. edu.ar/tesis/te.1504/te.1504.pdf

HUSSERL, Edmund. 1928. Vorlesungen zur Phänomenologie des inneren Zeitbewusstseins. Freiburg. Max Niemeyer Verlag. https://freidok.uni-freiburg.de/ data/5974

JÄGER, Lorenz. 2017. Walter Benjamin. Das Leben eines Unvollendeten, Berlin. Rowohl Verlag,

SAN AGUSTín. 397/400. Confesiones en Obras completas de San Agustín online: http://www.augustinus.it/spagnolo/confessioni/index2.htm

SIMON, Louis. 1997. Narrative and simultaneity: Benjamin's image of Proust in Studies. In 20th Century Literature vol 21 Issue2 article 4 https://pdfs.semanticscholar.org/ff6f/c3f6d4a406ed14ab40e95674952c29052fa0.pdf

WATZLAWICK, Paul. 1979. ¿Es real la realidad? Confusión, desinformación, comunicación. Barcelona. Herder Editorial

http://data.over-blog-kiwi.com/1/27/13/86/20141014/ob_a0a07c_watzlawickpaul-es-real-la-realidad.PDF 


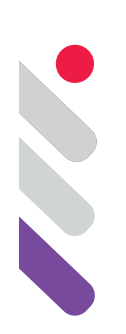

\title{
Posibles Pathosformeln en la historia del cine
}

DOI: 10.24308/IASS-2019-4-007

\author{
Mabel Tassara \\ Universidad Nacional de las Artes, Argentina \\ tassaramabel@gmail.com
}

La ponencia se inscribe en la temática del proyecto Perspectivas diacrónicas en el estudio de estéticas audiovisuales contemporáneas (2018-2019, IIEAC, UNA, Argentina). La línea interna del proyecto a la que se encuentra vinculada se ocupa específicamente de cine y continúa investigaciones anteriores radicadas en la misma institución conectadas con el estudio de formas fílmicas vinculadas con poéticas filmicas históricas (Tassara 2008).

El estudio de las formas fílmicas, puestas en relación con su potencial semántico, desarrollado en momentos liminares de la teoría del cine, recibió posteriormente una atención dispar, con momentos gloriosos, pero sin continuidad. De manera particular, el seguimiento histórico de esas formas -la mirada sobre sus continuidades, quiebras, mutaciones, desvíosy la consideración del repetido y constante trabajo formante que en sus reapariciones estas llevan a cabo en el cuerpo de las obras, a pesar de su enorme interés antropológico -más allá de su importancia semiótica, estilística, estética-, ha estado aún menos presente. Al cerrarse sobre ellas, resulta difícil para los estudios que abordan las discursividades presentes internarse en la dinámica de sus rasgos constitutivos y evaluar sus potencialidades semánticas. En oposición, la propuesta se asienta sobre la convicción de que solo es posible acercarse al presente si se lo contempla en configuración histórica con el pasado. La investigación a la que haré referencia tiene carácter exploratorio. La puesta en relación de formas fílmicas con su historia no pretende obtener respuestas conclusivas a objetivos semióticos o semánticos sino atender a una línea de estudios con escasa tradición en el área. Si esta perspectiva muestra una débil presencia en el ámbito audiovisual, ello no implica que no haya antecedentes en otros espacios que resultan orientadores para su implementación en este.

Por su mayor cercanía con la dirección de los objetivos, he prestado atención preferencial al concepto de "montaje" desarrollado por Georges DidiHuberman respecto de la apreciación de imágenes en la historia. Se encuentra 
en este autor una concepción de los estudios históricos que se sustenta sobre la aceptación del anacronismo como modo de conocimiento. Este enfoque es dominante en su obra (por ejemplo, Didi-Huberman 2006, 2010, 2013, 2014) y ocupa en ella un lugar capital la referencia a autores que sustentan posiciones concordantes en lo que hace a la mirada sobre imágenes en la historia; como Aby Warburg, Walter Benjamin o Carl Einstein. Este enfoque resulta fructífero para la presente búsqueda en tanto aporta indicadores operativos para su aplicación en otros territorios. Dentro de ese contexto he atendido especialmente a la noción Pathosformel, desarrollada por Aby Warburg.

Otra línea de estudios con aportes enriquecedores para la perspectiva es la encarada por el formalismo ruso. Sus autores se interesaron en gran medida por poner en relación las obras literarias con el entorno socio-cultural-histórico. Una obra que no puede dejar de tenerse en cuenta aquí es el trabajo de Propp La transformación de los cuentos maravillosos (1981) en el que se observan conversiones de formas en el tiempo. Podría citarse, también, el seguimiento del mito de Ulises como Pathosformel en la civilización occidental, encarado por José Emilio Burucúa, así como su planteo acerca de la presencia de Pathosformeln propias de culturas americanas prehispánicas en obras de las vanguardias visuales (2006).

En el territorio audiovisual, era esperable que fuera en los abordajes sobre el cine, el lenguaje audiovisual de la modernidad con más larga tradición, donde se encontrara el mayor interés por estas cuestiones; pero la atención a ellas es escasa, incluso en el espacio de la imagen, el componente del lenguaje del que más se ha ocupado la teoría. Las historias del cine han seguido patrones positivistas; a lo sumo se presentan asociaciones entre filmes y entornos socio-culturales y políticos, pero habitualmente desde los efectos de sentido producidos por los filmes, muy rara vez desde los procedimientos que producen esos efectos de sentido.

No obstante, podrían mencionarse contribuciones aisladas sumamente fértiles. El mismo Didi-Huberman se ha ocupado específicamente del cine observando en filmes de Pasolini, a partir de nociones acuñadas por Warburg (Pathosformel) y Erich Auerbach (Passio), la recuperación de gestos provenientes de espacios culturales marginales en la Italia contemporánea al autor; los que se entiende como gestos de supervivencia y, al mismo tiempo, de resistencia (Didi-Huberman 2014) ${ }^{1}$.Asimismo, los desarrollos llevados a cabo por autores del formalismo ruso especialmente para el cine. Varias figuras del movimiento -como Boris Eikhenbaum, Viktor Shklovski, Yuri Tynianov, Boris Kazanski, Adrian Piotrovski- se acercaron al entonces nuevo medio. Integrada en lo que es una exhortación recurrente en sus trabajos hacia el desarrollo de estudios teóricos sobre el cine que contemplen su especificidad como nuevo lenguaje,

\footnotetext{
${ }^{1}$ Tassara 2015 a y b.
} 
se incluye la reflexión sobre géneros filmicos. Esta se plantea en el marco de la propuesta compartida de elaboración de una poética fílmica que, en fidelidad a los lineamientos generales del grupo, sostiene siempre una relación estrecha entre el análisis minucioso de los textos y sus relaciones con el entorno sociocultural. En los comienzos del cine la discusión sobre los géneros se hace capital, porque algunos géneros están vinculados a la importación al cine de temáticas, conflictos, personajes que en su desarrollo en el teatro o la novela se hallaban ligados a una cierta "forma del contenido" (Hjelmslev 1984) y la polémica que se entabla a su alrededor gira en torno a que esa forma sea o no pertinente para su funcionamiento en el cine, ya que sus posibilidades expresivas indican otras orientaciones. Ello hace que se desplieguen atentos análisis de las formas cinematográficas en comparación con las teatrales y las literarias (Piotrovski 1998). Mencionaré más adelante algunos otros aportes.

Este trabajo, específicamente, se interroga sobre la posibilidad de pensar la pervivencia de algunas formas en la historia del cine desde la Pathosformel warburgiana. La Pathosformel ${ }^{2}$ es en Warburg una forma recurrente, que más allá de su significado inteligible, variable muchas veces en sus apariciones, se caracteriza por su carga emotiva (entre otros textos, Warburg [1893]2014, [1925, 1926, 1929]2010). Emerge dominantemente en su observación de imágenes visuales, pictóricas o escultóricas; las más presentes en lo que es su legado más notorio, el Atlas Mnemosyne, pero no necesariamente, ya que también se encuentran en el Atlas referencias en espacios de la ilustración y la fotografía. Y, según surge de diversos escritos, las observaciones abarcan asimismo puestas en escena teatrales y representaciones en fiestas en el momento renacentista (por ejemplo, Warburg [1893] 2014 y [1926] 2010); así como gestualidades, movimientos e implementos vestimentarios ligados a lo teatral y al ritual, presentes tanto en ejemplos renacentistas como en documentos conectados con la cultura de los indios pueblo (por ejemplo, Warburg $[1923,1927] 2017)$. Si bien la propuesta no pretende forzar la noción de Pathosformel para vincularla a imágenes fílmicas, recorriendo la historia del cine se hace evidente que existen formas que perviven y reaparecen, en perpetua movilidad, pero sosteniendo rasgos que, más allá de las transformaciones, las hacen reconocibles en sus repetidas apariciones. Y que arrastran con ellas una carga emotiva singular.

\section{Algunas formas fílmicas recurrentes}

Con objetivos a veces relativamente concordantes con esta investigación, otras con objetivos distantes, formas fílmicas recurrentes son observadas y comentadas por algunos autores. La presencia de estos reconocimientos no

\footnotetext{
${ }^{2}$ La denominación es utilizada muy escasas veces por Warburg, aunque alude claramente en esas ocasiones a las configuraciones en estudio. No obstante, el nombre se ha difundido posteriormente por su uso en autores que refieren a ellas.
} 
es alta pero sí oportuna en cuanto pone en ejercicio miradas poco frecuentes sobre el fenómeno fílmico. Es el caso de referencias fílmicas a la configuración pictórica Pietà (Balló 2000) ${ }^{3}$ o el de la remisión a una puesta en escena cara al western clásico, la conversación nocturna frente al fuego, en una obra de muy diferente extracción (Rancière 2012)4. Yo misma me he encontrado más o menos azarosamente con estas formaciones en medio de otras investigaciones. Es el caso, por ejemplo, del personaje que se aleja de espaldas, dejando la escena (Tassara 2018). Otros investigadores del presente proyecto proporcionan nuevos ejemplos, como es el caso de la despedida de los amantes en la estación de trenes (Locatelli 2019).

Me ocuparé aquí específicamente de una forma que denominaré el combate final entre el bien y el mal. Es evidente que la confrontación entre las fuerzas del bien y del mal es el gran tema que atraviesa todo el cine norteamericano de acción y aventuras. Podría decirse que en el momento de los grandes géneros no dejaba de estar presente en todas partes; sin duda en el melodrama pasional y hasta en las vertientes de la comedia romántica, si pensamos en los obstáculos que debía disolver la pareja para llegar al final feliz; sin olvidar a la maldad de turno (humana o no) que hacía la vida imposible a Charlot o a los personajes de Keaton y otros cómicos de la etapa muda. Pero no es mi intención hilar demasiado fino en lo que es un primer intento de abordar estas cuestiones; me limitaré por eso a los llamados géneros de acción. Y también dominantemente, aunque no con exclusividad, comenzaré observando filmes del período clásico hollywoodense, porque es el momento del cine donde ya consolidado como discurso audiovisual, se afianzan dentro de los géneros formas que después perdurarán a través del tiempo; y del espacio, ya que emergen asimismo en otras cinematografías. Una gran parte del cine hecho con posterioridad al momento clásico suele implementar formas clásicas aggiornadas, trabajar con variaciones a esas formas o tomarlas como referencia para apartarse de ellas.Una obviedad, pero no siempre recordada. Por lo habitual, el enfrentamiento moral articulado en las historias de esos géneros culminaba en un combate final entre las figuras que representaban las dos fuerzas en pugna. Despierta mi interés la muy notable pervivencia de este motivo temático, pero, a los fines de la propuesta, en lo que respecta a su plasmación en una forma fílmica, esta vez expresada a través de una puesta en escena espacio-temporal recurrente. Recurrente pero dinámica, esto es que sufre variaciones que no afectan, a mi entender, los caracteres que le dan su rasgo distintivo y que hacen que, creo, merezca ser puesta en foco, aunque se abre a modalidades de construcción diferentes; unas pocas, pero que, como hipótesis, me atrevo a considerar generan efectos de sentido diferentes. Me ocuparé en la

3 Tassara 2015b y 2018.

${ }^{4}$ Tassara 2015b. 
presente ponencia de dos de esas modalidades: llamaré a la primera el combate de los pares y a la segunda la caza a partir del asedio. Consideraré aquí la forma definida dominantemente por la configuración espacial y la dinámica de los personajes en el espacio. De acuerdo con ello, el combate de los pares tiende a aislar a los protagonistas del entorno físico y social y convertir el encuentro en un juego de competencias individuales. La caza a partir del asedio, en cambio, moviliza grupos y compromete al entorno social en el conflicto.

\subsection{El combate de los pares}

Esta modalidad aparece en todos los géneros del cine de Hollywood ligados a acción y aventura, desde sus inicios, aunque tomaré aquí ejemplos posteriores al sonoro; por ejemplo, en el film de piratas, en el llamado en su momento de capa y espada, en el western. Las historias de esos géneros suelen estar atravesadas por el antagonismo entre un héroe y un malvado. Existen otros personajes que se agrupan detrás de estos opuestos, pero, por lo general, uno y otro son representativos de esos contextos. Si bien estos personajes pueden responder a ideologías más o menos precisas y pueden marcarse conflictos sociales en su rededor, las historias suelen terminar con el indicado combate final, que supone una resolución de los conflictos. No se desarrolla habitualmente un planteo sobre un anclaje del mal combatido en el cuerpo social, con la consiguiente posible encarnación en otros personajes; por ende, vencido el malvado en el duelo final, la historia termina con el supuesto triunfo del bien, sin reflexión sobre la posibilidad de una nueva derrota futura. Leves variaciones argumentales no cambian la estructura básica. Tal vez más de un personaje puede estar ubicado en el lugar del héroe pero, finalmente, este es un actante que representa el bien en el más neto sentido greimasiano. Pero si esto sucede en el relato, en el duelo suelen visualizarse solo dos personajes. Y, como surge a menudo en el transcurrir de estas formas, algunas variaciones pueden llevarse a cabo porque preexiste como sentido acuñado la estructura original. Es el caso de Il buono, il brutto, il cattivo (Sergio Leone, 1966), con muchos rasgos paródicos respecto al western clásico, donde el combate final entre tres personajes se hace célebre en la historia del spaghetti por su transgresión a la forma histórica. Del mismo modo, el hecho de que el disparo exitoso sea de un tercero es el eje estructurador de toda la historia en The Man Who Shot Liberty Valance (John Ford, 1962); para el pueblo espectador, el héroe debe ser como siempre fue el que enfrenta al bandido, el tercero debe ser ocultado.

Una característica de la forma es que la acción se va desarrollando hacia la situación del combate aislando a estos caracteres de otros personajes o grupos humanos que hasta allí habían rodeado a los contrincantes. Son ejemplos los dos personajes en un duelo a espadas alejándose hacia ambientes vacíos, subiendo por escaleras desiertas de castillos, a veces culminando la lucha en 
torres, terrazas o campanarios; o los combatientes en el buque pirata alejándose mientras pelean a espacios del barco sin gente, a veces trepando por mástiles o cables. Peleas anteriores -muchas veces estos géneros contaban varias, entre los mismos personajes o entre el héroe y malvados segundos- podían tener lugar en espacios poblados, pero no la final. Esta configuración concentra en cada actante todo el bien y todo el mal y hace llegar con fluidez a la resolución final que transmite la derrota total del mal (Figuras 1 a 3 ).

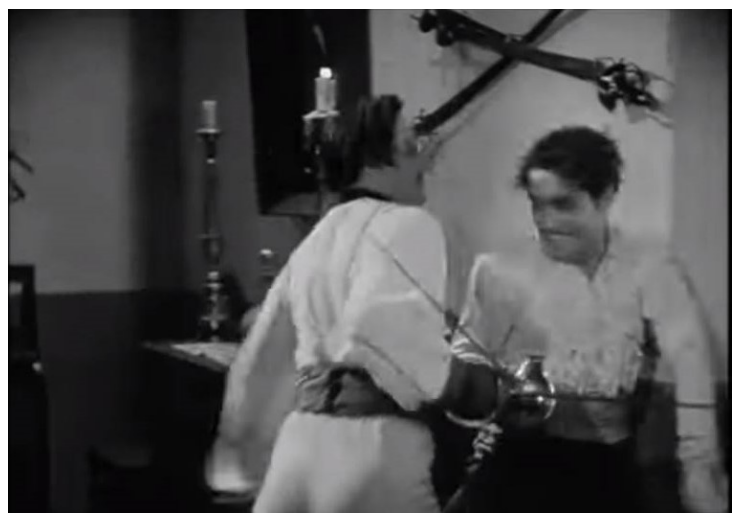

Fig.1 The Mark of Zorro, 1940

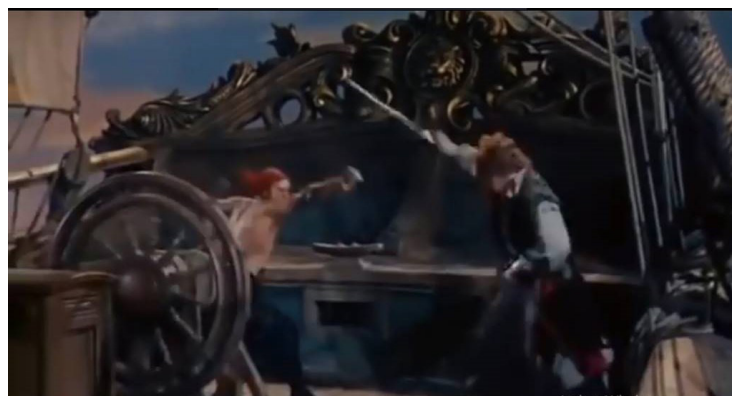

Fig. 2 The Black Swan, 1942

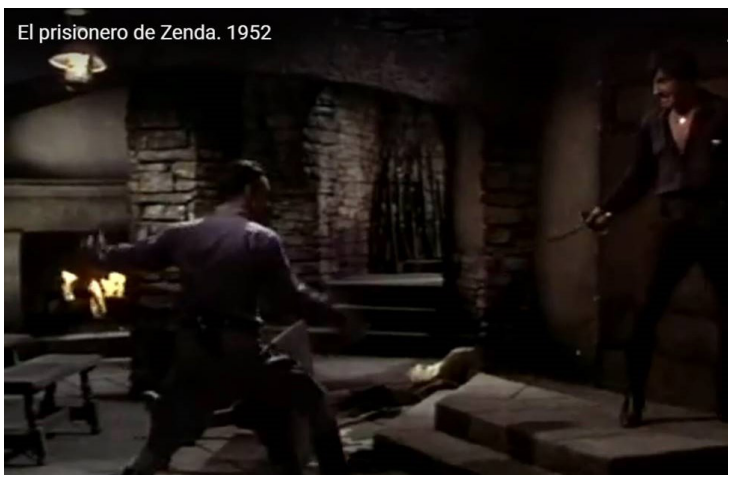

Fig.3 The Prisoner of Zenda, 1952

La forma descrita en términos estructurales se mantiene a través del tiempo en los géneros de acción, aunque cambien muchos de sus aspectos. En 
Drug War (2012), de Johnnie To, un policía que se ha enfrentado a lo largo de la historia a un narcotraficante, en el combate final es herido mortalmente, pero logra antes de morir cerrar una esposa en el pie de su enemigo, lo que hace que este no pueda escapar. Ese momento es precedido por una muy larga secuencia de combate entre múltiples personajes, pero, finalmente, los dos personajes centrales quedan solos, aquí entre un tendal de muertos. Dentro del habitual pesimismo frente a un espacio y el otro en la obra de To, no obstante, una cierta fidelidad al policial clásico en términos de factura fílmica, sostiene la forma. $Y$ no puede evitar dejar como efecto de sentido una toma de partido por el personaje policía (Figura 4).

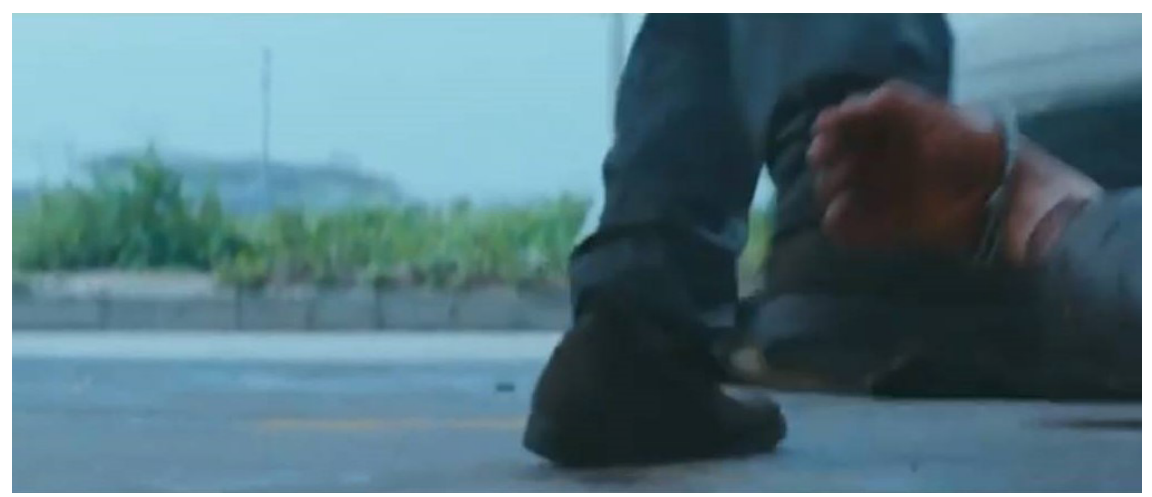

Fig.4 Drug War, 2012

Es que el combate de los pares presenta antagonistas que se miden en razón de su competencia: física pero también intelectual; ya que intervienen en ella destrezas diversas (fuerza y elasticidad corporales, alto desempeño en artes de combate, experto manejo de armas, etc.) y astucias varias (percepción de las fortalezas y debilidades del adversario, capacidad para adelantarse a sus reacciones, habilidad para el engaño, etc.). Si en el inicio los combatientes se bastaban a sí mismo, el tiempo ha ido incorporando ayudas que exceden el orden natural. Algo muy habitual en sagas contemporáneas como Star Wars, The Avengers o Transformers, pero siempre recae en los héroes la competencia final para hacer uso de esos poderes. Una de las variaciones incluidas en estas sagas es la reiteración de los combates finales, que nunca terminan de ser definitivamente finales, ya que las fuerzas de los contrincantes multiplicadas por los poderes sobrehumanos que poseen hace muy difícil la resolución; in embargo, el episodio IX de Stars Wars (The Rise of Skywalker, J.J. Abrams, 2019), anunciado como fin de la saga, presenta una heroína que finalmente vence al poderoso enemigo, enfrentados ambos, en solitario, en un espacio vacío. El combate final tiene lugar y con una configuración fílmica que no se aparta de la clásica (Figuras 5 y 6 ). 


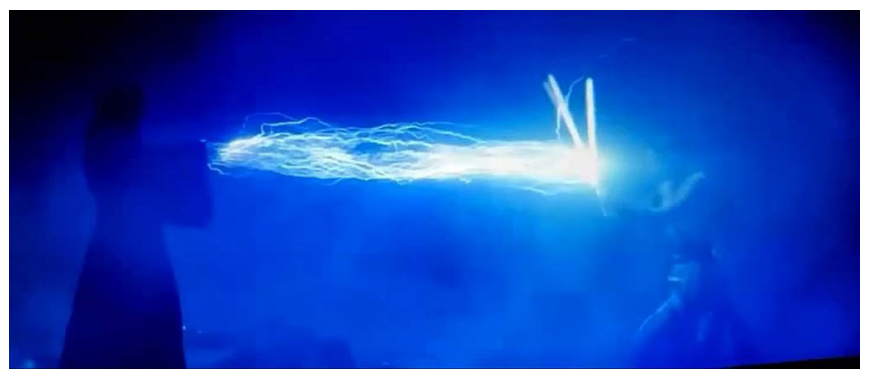

Fig. 5 Star Wars: The Rise of Skywalker, 2019

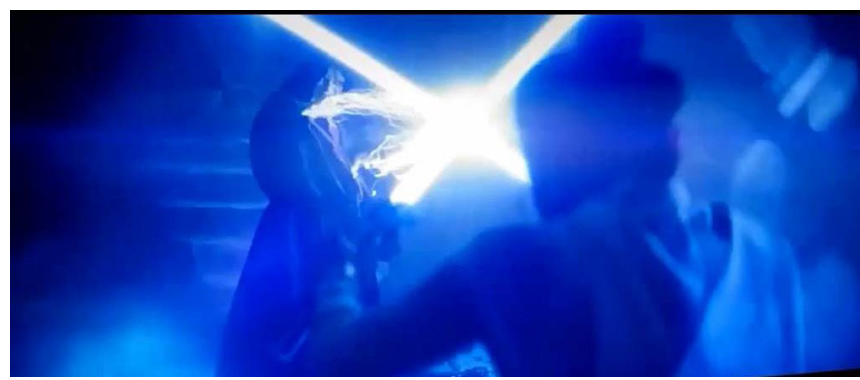

Fig. 6 Star Wars: The Rise of Skywalker, 2019

En el caso de la saga Avengers, en que el actante ubicado en el espacio del bien se articula a través de varios personajes, en el combate final (Avengers Endgame, 2019) pueden aislarse momentos en que cada uno de los personajes protagónicos tiene su destaque (Figura 7).

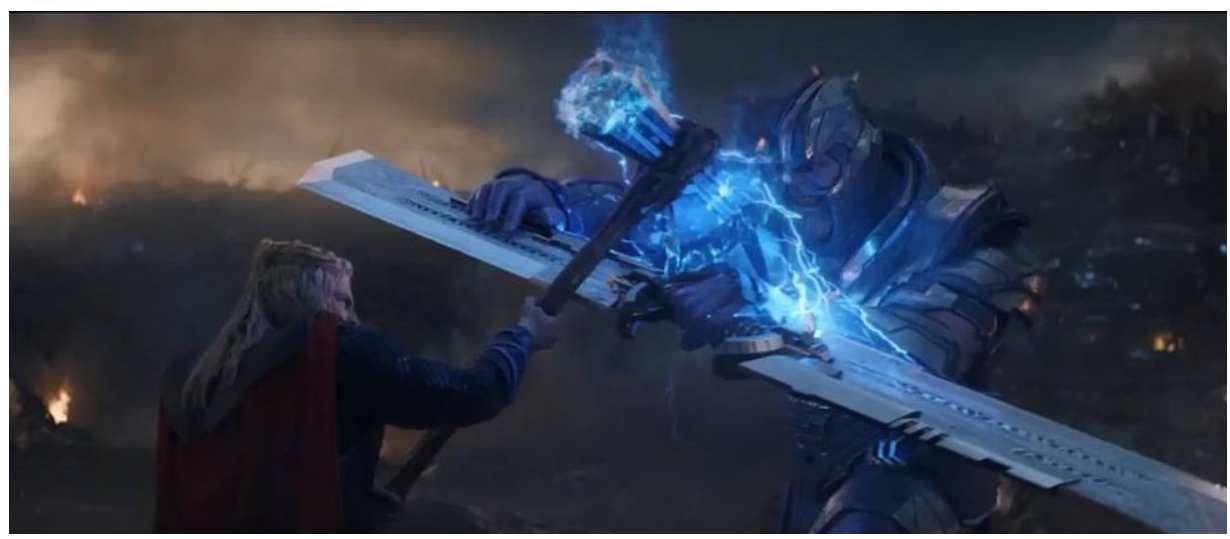

Fig. 7 Avengers: Endgame, 2019

\subsection{La caza a partir del asedio}

Es evidente el maniqueísmo moral de la modalidad descrita así como de su individualismo triunfalista. Algo bastante diferente a lo que sucede con la segunda variante. Esta se difundió bastante en la estilística del policial denominada habitualmente noir. Aunque la mirada crítica acostumbra fijar su apogeo en los años cuarenta, como suele suceder -en tanto no hay cortes estilísticos sino procesos- varios de los rasgos que se le adjudican se presentan 
anteriormente; al menos los que ahora me interesa considerar. Un ejemplo es You Only Live Once (Fritz Lang, 1937). Empujado por la imposibilidad de conseguir trabajo a raíz de una condena por un delito menor, el protagonista se ve obligado a continuar en la vía delictiva, único camino que encuentra para la sobrevivencia de su familia. Acusado injustamente de un asesinato que no cometió y condenado a muerte, un hado adverso lo lleva a convertirse efectivamente en homicida. Es fácil detectar en el tratamiento de la historia la incorporación de una cierta ambigüedad moral. Por una parte, el punto de vista narrativo en el delincuente, uno de los rasgos del noir, obstaculiza su ubicación simplista en el territorio de lo otro; Eddie Taylor es aquí alguien que se conoce: se muestran sus sentimientos y expectativas, su frustración ante el fracaso, su angustia ante la imposibilidad de cambiar los hechos. En este caso particular, la trama coloca al protagonista en el lugar aciago de los héroes trágicos, aquellos que no pueden evitar su destino. Pero asimismo el desenvolvimiento de los sucesos no permite desentenderse de la responsabilidad social en lo que acaece; es otra característica del noir.

Todo esto es conocido; lo cito a los fines de llegar a la forma fílmica objeto del trabajo. Esta se presenta en el desenlace, cuando Eddie y la mujer que lo ama, que ha decidido acompañarlo en su huida sin esperanzas, son cercados en una zona boscosa por fuerzas policiales (Figura 8).

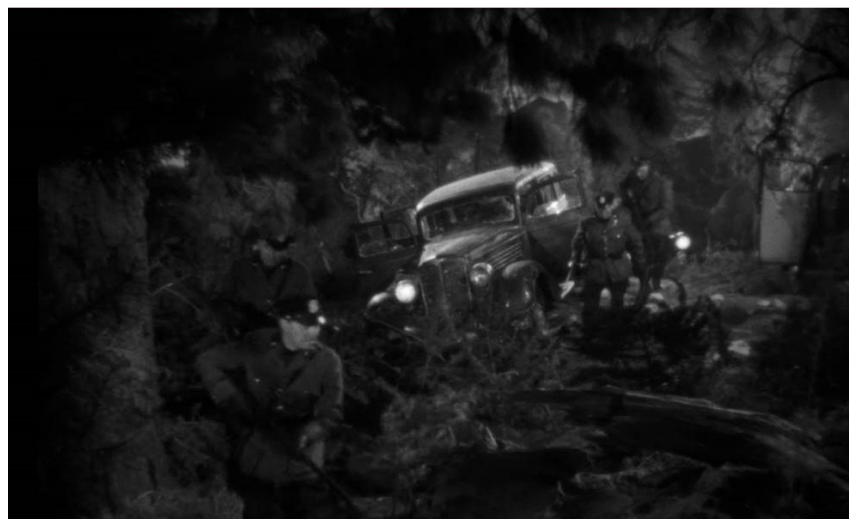

Fig. 8 You Only Live

Once, 1937

El contraste entre los perseguidos y los perseguidores, en número mucho mayor, es alto; y recuerda las escenas de caza. Es interesante señalar que la mujer es alcanzada primero por los disparos y al continuar Eddie huyendo con ella en brazos, se presenta con fuerza la imagen de la Pietà, unos minutos antes de que también Eddie sea abatido (Figura 9). 


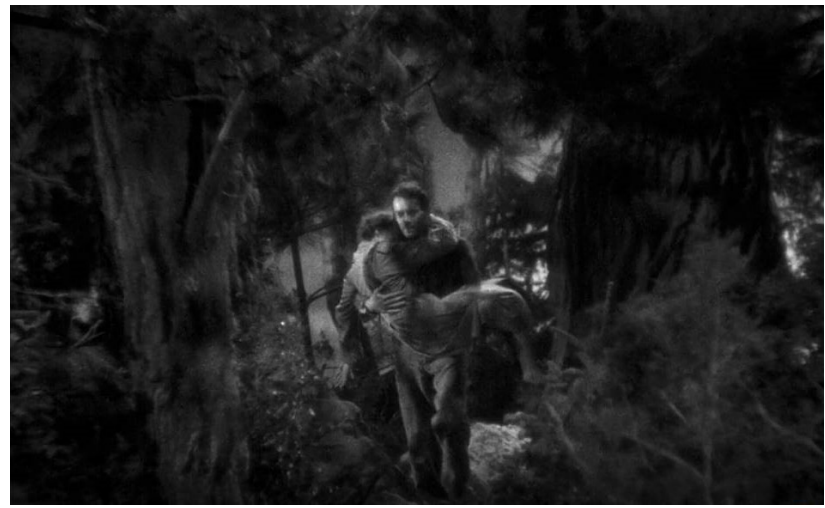

Fig. 9 You Only Live Once 1937

Me he tomado un tiempo en relatar esta historia porque aquí se hace evidente que la forma en cuestión se integra con fluidez en el tratamiento que recibe el tema $-y$ he comenzado por este film porque creo que es donde existe más acuerdo- pero creo que ello no obsta para que la forma fílmica se imponga en sus rasgos intrínsecos.

El segundo ejemplo es High Sierra (Raoul Walsh, 1941). El protagonista, Roy Earle, planea un atraco con un grupo de compinches, pero todo sale mal y es acorralado en una sierra por los guardias. El trazado moral de Roy como carácter posee facetas controvertidas pero en el film se destaca la feroz persecución del final, con el personaje trepando solitario y el cuerpo policial en alto número rodeando la sierra. Nuevamente, parece recrearse la imagen de un animal que escapa de sus perseguidores; algo bastante distinto en lo visual a la pelea entre pares (Figuras 10 y 11).

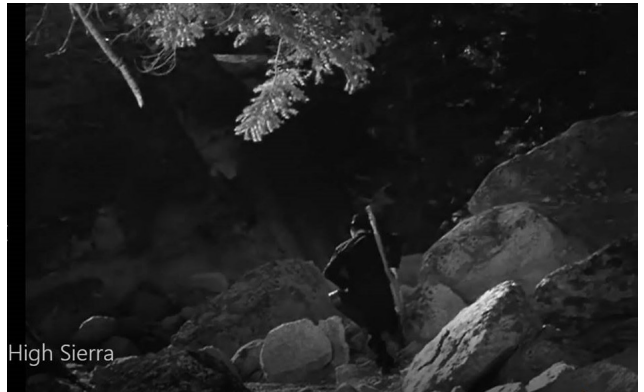

Fig.10 High Sierra, 1941

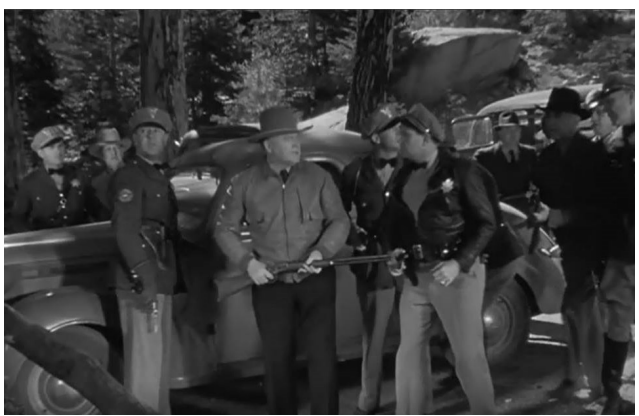

Fig.11 High Sierra, 1941 
El tercer ejemplo, They Live by Night (Nicholas Ray, 1948), es también un relato acerca de un ex convicto que busca probar su condena injusta, sin lograr evitar volver a involucrarse con el mundo delictivo. Nuevamente, la pareja que huye con su bebé es descubierta y se repite el asedio del personaje por el cuerpo policial hasta su muerte (Figuras 12 y 13).

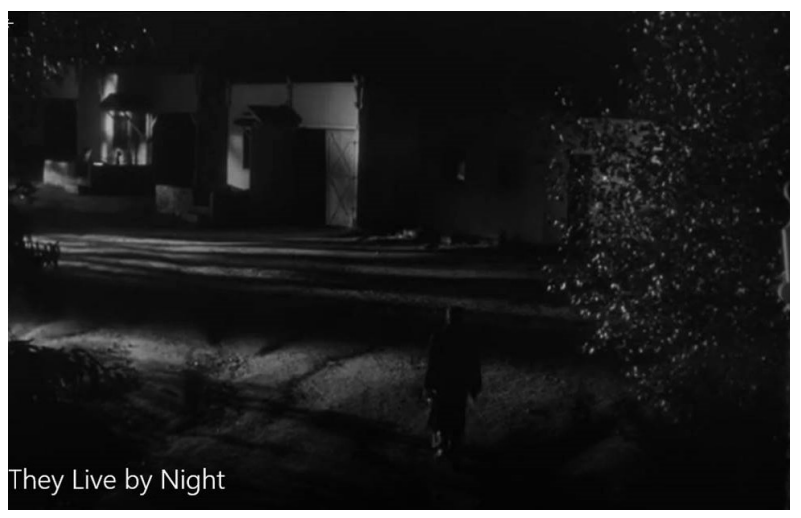

Fig.12 They Live by Night,

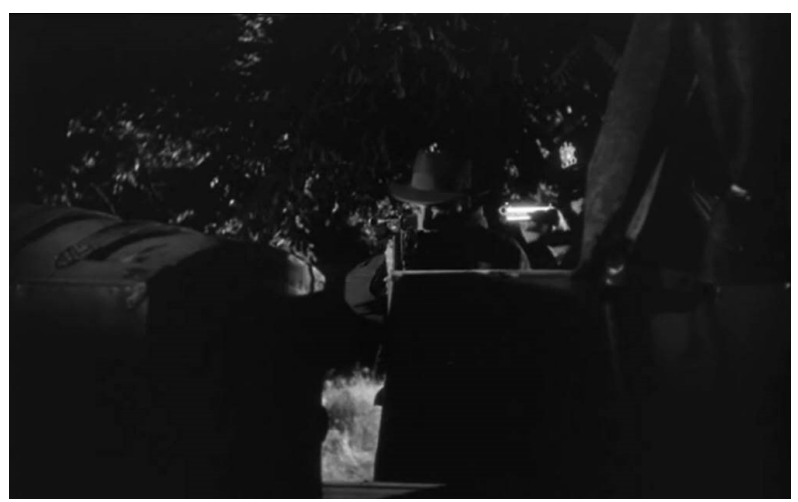
1948

Fig.13 They Live by Night, 1948

La construcción de la puesta en todos estos casos, y podrían citarse muchos más, destaca por la sola visión de uno frente a muchos la vulnerabilidad del perseguido frente al grupo de perseguidores, realzada esta connotación por la construcción espacial que enfrenta el espacio del perseguido, donde el personaje es mostrado en soledad, y el espacio de los perseguidores, articulados como grupo acechante.

Una variación al acorralamiento en un espacio natural tiene lugar cuando el perseguido se encuentra atrincherado en un edificio. Es una modalidad muy frecuentada por el cine de todas las épocas. Son ejemplos las versiones de Scarface (Howard Hawks, 1932; Brian De palma, 1983) y, fuera de Hollywood, la muy célebre Le jour se lève (Marcel Carné, 1939). Este último film, inscripto, en lo que la crítica ha denominado realismo poético, un movimiento que, entre otros rasgos, comparte con el film noir personajes sin esperanza signados por un destino adverso, se caracteriza por estar estructurado argumentalmente sobre 
la situación de asedio: el protagonista que ha matado un tanto azarosamente se encuentra en el inicio refugiado en su casa con la policía rodeando el edificio y el resto de la historia se articula en torno a sus recuerdos sobre los hechos que lo han llevado allí. Finalmente, al no percibir salida, el personaje se suicida. En esta variante comienza a advertirse la presencia de público en medio de la policía (Fig. 14 y Fig. 15).

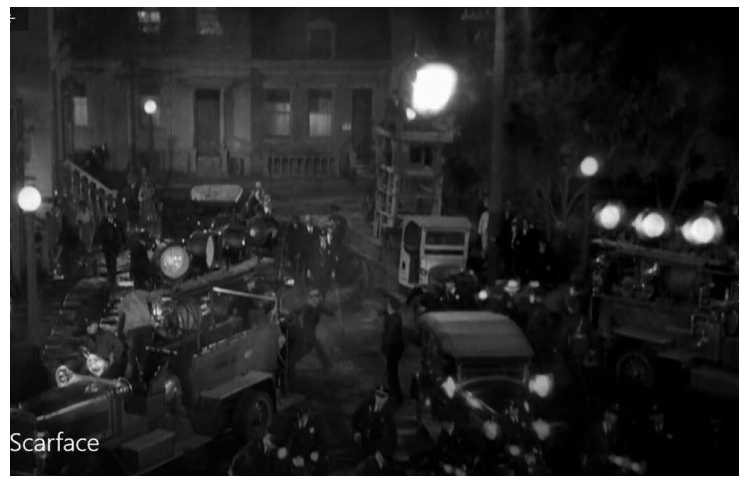

Fig.14 Scarface, 1932

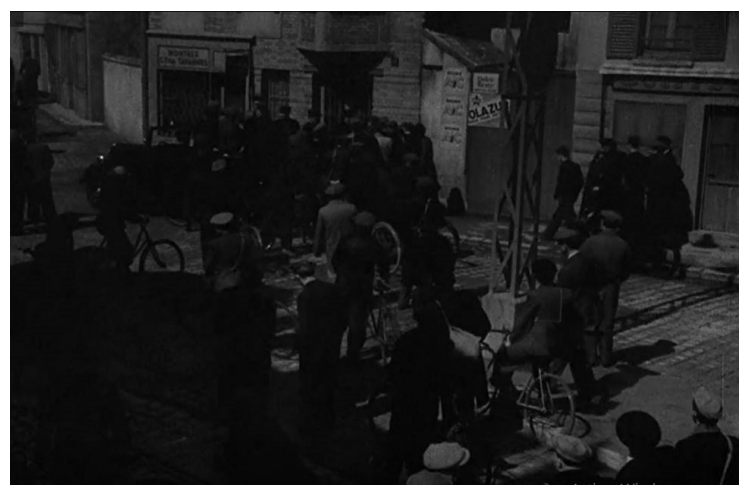

Fig.15 Le jour se lève, 1939

Otra de las formas de lo que he llamado combate final entre el bien y el mal, de la que no me ocuparé aquí, es la que podría denominarse la aniquilación. Esta era muy habitual en los géneros ligados en el momento clásico a la aparición de monstruos diversos, habitualmente generados por catástrofes o experiencias científicas que revivían criaturas prehistóricas, daban nacimiento a seres extraordinarios o producían mutaciones insólitas; cuando no se trataba de seres originarios de otros universos. Aquí el monstruo, absolutamente lo otro en la historia, ya que nunca merecía ser objeto del punto de vista narrativo, era siempre eliminado en el final, muy frecuentemente a partir de explosiones, incendios, armas químicas u otro mediador de poder exterminador superlativo ${ }^{5}$. El transcurrir de esta forma en el tiempo y su combinatoria con

\footnotetext{
${ }^{5}$ Salvo curiosas excepciones, como La guerra de los mundos (primera versión: Byron Haskin, 1953), en que, siguiendo la novela de Wells, los marcianos mueren por la contaminación de bacterias terrestres.
} 
otras en los géneros contemporáneos ligados a la ciencia-ficción y el fantástico, con aperturas diversas de no poca complejidad, no son objeto de la ponencia, pero la cito porque me parece interesa señalar que en los pocos casos en que el monstruo sí recibía atención narrativa, el exterminio incorporaba rasgos de la caza a partir del asedio. Es lo que sucede con Frankenstein; en las versiones en las que su construcción se encuentra más cercana a la creatura doliente de Mary Shelley, donde tiene lugar la persecución feroz del personaje por una muchedumbre y su acorralamiento y muerte por el fuego. $Y$ también con King Kong acribillado en la cima de colosales edificios, después de haberse conferido una cierta humanización al personaje, sutilmente incorporada en la versión de Cooper y Schoedsack (1933) y abiertamente manifiesta en la de John Guillermin, (1976), donde la persecución del gorila se liga a posturas críticas acerca de la destrucción de la naturaleza y la eliminación de lo distinto.

Un ejemplo más cercano en el tiempo del asedio policial en un edificio es La ley del deseo (Pedro Almodóvar, 1987). Me he ocupado en otra oportunidad de este final (Tassara 2018), por lo que solo recordaré que muerto por su propia mano el personaje perseguido es levantado en brazos por su amante, configurando una Pietà (Figuras 16 y 17).

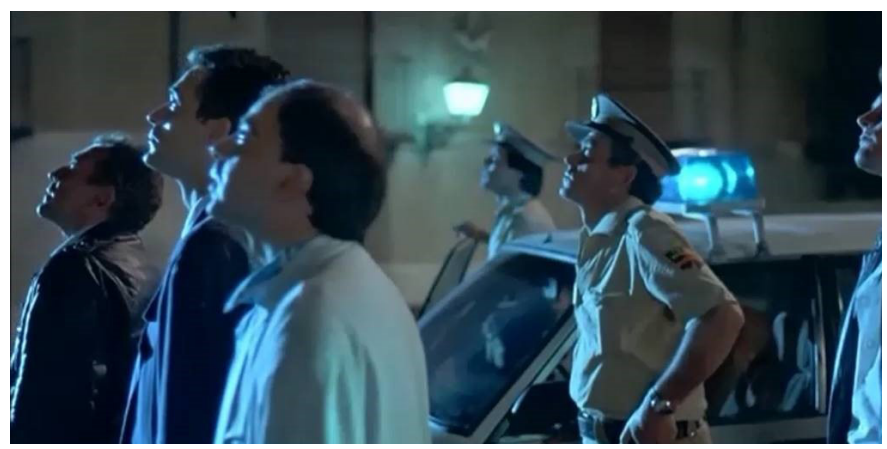

Fig. 16 La ley del

deseo, 1987

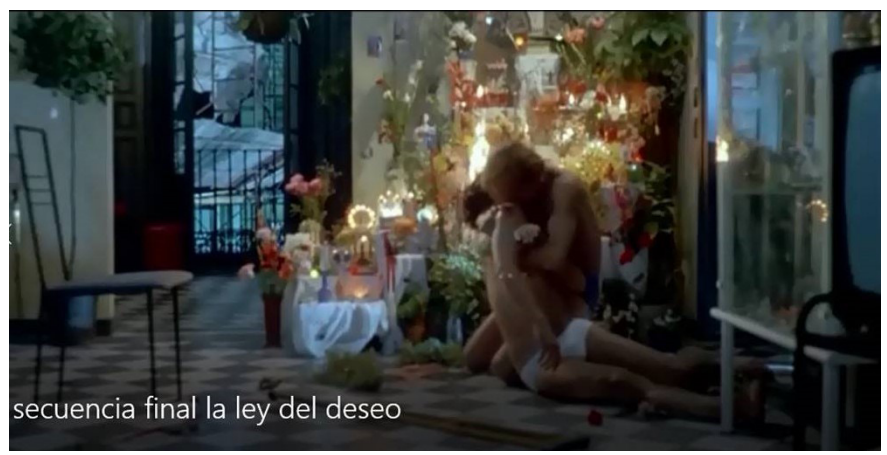

Fig. 17 La ley del

deseo, 1987

En varios de los casos descritos podría encontrarse una cierta empatía enunciativa, mayor o menor, con el personaje que se pone fuera de la ley construida por la producción semántica global del texto fílmico; no obstante, 
aparecen ejemplos en que esto no podría afirmarse. He citado antes dos versiones de Scarface, y hay otros. Un film paradigmático en esta línea es White Heat (Raoul Walsh, 1949). Cody Jarret, el protagonista, es descrito a lo largo de la historia como un gánster despiadado. En el final es acorralado en lo alto de los tanques de una refinería de petróleo por un número importante de fuerzas policiales. Dándose cuenta de que ya no puede escapar elige morir en la explosión de un depósito. El personaje que queda solo y aislado en lo alto con la policía rodeando el lugar recrea con fidelidad la forma que estoy considerando (Figuras 18, 19 y 20).

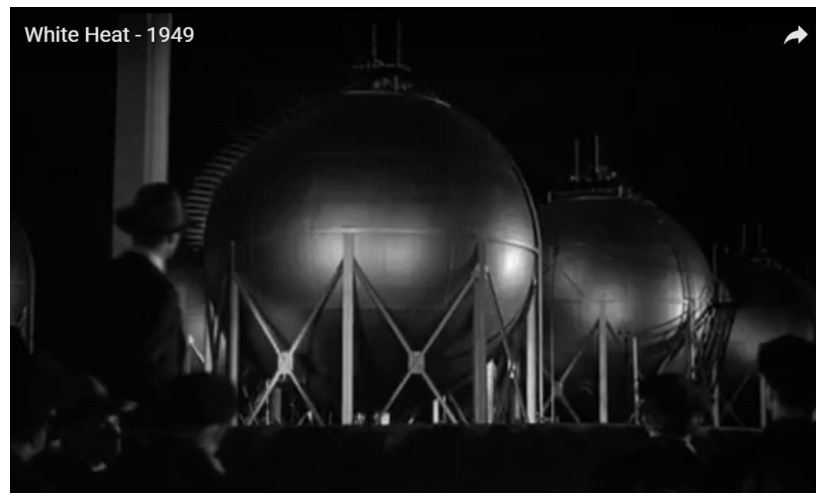

Fig.18 White Heat, 1949

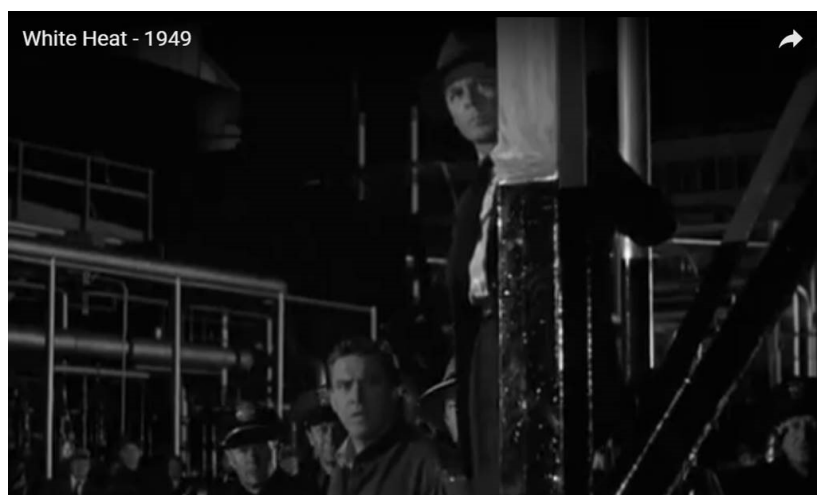

Fig.19 White Heat, 1949

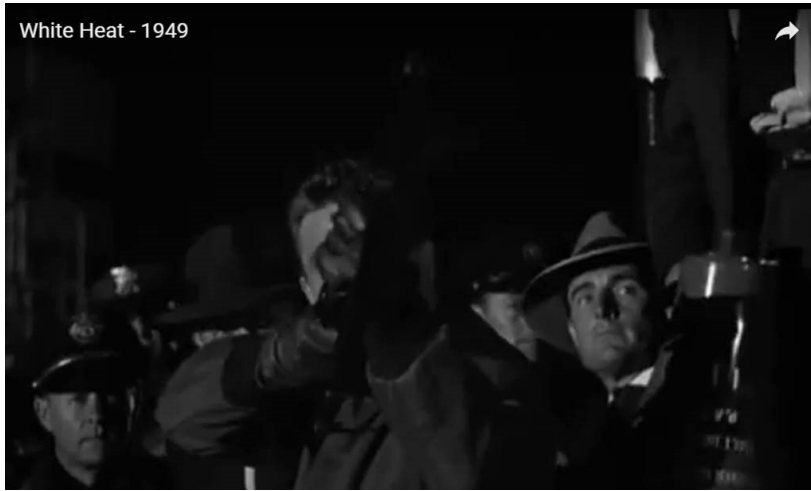

Fig.20 White Heat, 1949 
La actitud triunfante del personaje (verbalizando exultante su llegada a la cima como prometía a su madre) le da un realce heroico. En la referencia Cody Jarret es un mal bicho, por fin abatido, pero en el discurso fílmico el personaje adquiere ribetes heroicos, y esta adquisición deviene, me parece, y solo como hipótesis, en gran parte de una forma que no deja de generar identificación con el personaje. Un ejemplo bastante reciente, repite creo este efecto de sentido: en la argentina El ángel (Luis Ortega 2018), el protagonista, retrato de un personaje real, un asesino serial muy joven pero aún más despiadado que Cody Jarret, es cercado en su casa y mientras la policía avanza sobre la vivienda, él baila eufóricamente con el fondo musical de una canción muy difundida en la época (Figura 21).

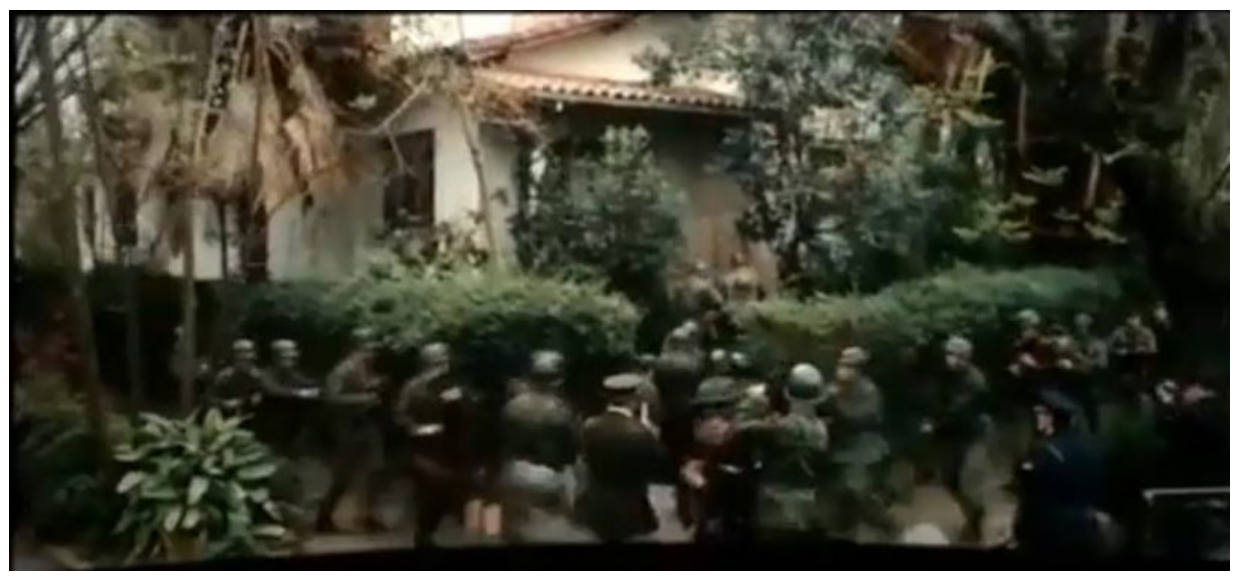

Fig. 21 El ángel, 2018

Nuevamente, la forma elegida confiere realce al personaje; aunque no hay que olvidar aquí la convocatoria sensual proveniente del tema musical, creo que esta no actúa de manera independiente, sino que se integra en la configuración fílmica que la contiene.

Más allá del grado de acierto de las lecturas que he intentado en términos de posibles efectos de sentido producidos, parece indudable que la recurrencia de formas es en el cine un hecho. La extensión de este trabajo no permite seguir en los recorridos de las formas sus interacciones con poéticas del cine (en tanto modos de ver, pensar, sentir epocales expresados en formas fílmicas) que son el hábitat en que ellas encarnan en cada reaparición; pero es un seguimiento que merece continuidad. Más de un siglo de imágenes en movimiento es una larga historia. 
BALLÓ. Jordi.2000. Imágenes del silencio. Barcelona: Anagrama

BURUCÚA, José Emilio.2006. La noción de alteridad. El caso de la historia de Ulises entre Boccaccio y Pierre Bayle y La vuelta a la vida de civilizaciones heridas de muerte. Reflexiones sobre la pintura de Alejandro Puente. En Historia y Ambivalencia. Ensayos sobre arte. Buenos Aires: Editorial Biblos.

DIDI-HUBERMAN, Georges. 2005. Ante el tiempo, Buenos Aires: Adriana Hidalgo.

DIDI-HUBERMAN, Georges. 2010. Ante la imagen, Murcia: Cendeac, Ad Literam.

DIDI-HUBERMAN, Georges. 2013 Cuando las imágenes toman posición. Madrid: A. Machado Libros.

DIDI-HUBERMAN, Georges. 2014. Poemas de pueblos. En Pueblos expuestos, pueblos figurantes. Buenos Aires: Manantial.

HJELMSLEV, Louis. 1984. Prolegómenos a una teoría del lenguaje. Madrid: Gredos.

LOCATELLI, Marina. 2019. La despedida de los amantes en la estación de tren. Pervivencia y mutación de formas fílmicas. Ponencia presentada en el $14^{\circ}$ Congreso Mundial de Semiótica. Buenos Aires, Argentina.

PIOTROVSKI, Adrian. 1998. Hacia una teoría de los cine géneros. En Los formalistas rusos y el cine, Comp. F. Albèra. Barcelona: Paidós.

RANCIERE, Jacques.2012.Conversación alrededor del fuego. Straub y algunos otros. En Las distancias del cine. Buenos Aires: Manantial.

TASSARA, Mabel. 2008. Las periodizaciones del cine. En El volver de las imágenes. Mirar, guardar, perder. Buenos Aires: La Crujía.

TASSARA, Mabel. 2015 a. La presencia de la forma. Ponencia presentada en el II Congreso Internacional de Retórica e Interdisciplina. Córdoba, Argentina.

TASSARA, Mabel. 2015b. Sobre historias del cine. En Sobreescrituras. Diálogos entre críticas, teorías, memorias y experiencias de las artes Nro 1. Revista del Área Transdepartamental de Crítica de Artes, UNA, Argentina. http:// moodleiunacritica.com.ar/sobreescrituras/index.html

TASSARA, Mabel. 2018. Figuras, figuraciones. Momentos retóricos del cine. Buenos Aires: Prometeo/ Crítica de Artes. 
WARBURG, Aby. 2010. The Franz Boll Lecture (1925), Conferencia sobre Rembrandt (1926), Conferencia en la Hertziana (1929). En Atlas Mnemosyne. Madrid: Akal/Arte y Estética

WARBURG, Aby. 2014.El nacimiento de Venus y La primavera de Sandro Boticelli (1893). En Aby Warburg La pervivencia de las imágenes. Buenos Aires: Miluno Editorial.

WARBURG, Aby. 2017. Recuerdos de un viaje al país pueblo en Norteamérica (1923), Proyecto de viaje a Norteamérica (1927). En Michaud, Philippe- Alain. Aby Warburg y la imagen en movimiento, Buenos Aires: UNA Enfoques. 


\title{
MEDIATIZACIONES
}

\author{
C. CINES REGIONALES
}





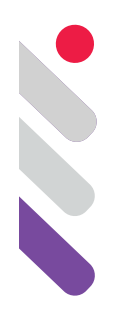

\title{
Configuraciones del cine regional en la prensa de la norpatagonia de los años ochenta
}

DOI: 10.24308/IASS-2019-4-008

\author{
Ignacio Dobrée \\ Universidad Nacional de Río Negro / \\ Universidad Nacional del \\ Comahue, Argentina \\ nachodobree@yahoo.com
}

\section{Introducción}

La década del ochenta fue un momento de intensa actividad para el cine dela región del Alto Valle de Río Negro y Neuquén, ubicada en la zona norte de la Patagonia argentina. Una serie de condiciones favorables a la producción, circulación y recepción de películas permitieron que el cine regional se hiciera presente no solo en las pantallas, sino también en otras zonas de la discursividad social.

En ese contexto, las películas producidas en esta parte de la Patagonia comenzaron a ocuparde forma regular un lugar privilegiado en las crónicas, reseñas y críticas publicadas en la sección cultural del diario más antiguo y de mayor tirada de la región: el Río Negro. A pesar de cierta idea de unidad que inicialmente pueden llegar a promover textos reunidos en las páginas de un mismo medio gráfico, la concepción de cine regional no aparece allí como una categoría homogénea, ya definida y fácilmente reconocible. Lo que sucediófue algo más bien diferente.

En textos escritos por diferentes autores -solo a veces identificables con firma- el concepto de cine regional se fue constituyendo a partir de referencias a una práctica en formación que asomaba como una oportunidad de reconocimiento y expansión de la cinematografía zonal, perosobre la cual se articularon una serie de tensiones y disputas respecto a lo que debería llegar a ser esa produccióny los procedimientos para alcanzar la meta fijada. Se trató, en todo caso, de una especie de dispersión, de la conformación de un objeto heterogéneo, difícil de asir, con emplazamientos verificables -las películas reseñadas y las proyecciones anunciadas-, pero perfilado desde diferentes perspectivas al interior de las páginas del mismo diario. 
En virtud de la relación establecida entre las películas y la prensa diaria que las observa, vale recordar lo planteado por Oscar Traversa (1984) respecto a que la especificidad del cine es menos la consecuencia de sus propiedades inmanentes que el resultado de las prácticas sociales productoras de sentido que lo rodean. ¿Cómo se constituyó desde los textos impresos que lo abordaron por aquellos años, entonces, el cine regional?

Entre las prácticas sociales que proponen sentido es posible incluir la manera en la que un texto fílmico, o conjunto de ellos, aparecen acompañados de una serie de otros textos diversos modelados en diferentes materias significantes. Estos textos acompañantes -entre los que la prensa ocupa un papel destacado por su capacidad de circulación, y su condición de manifestación de la libre expresión y objetividad que desde posiciones de enunciación legitimadas se le asigna (Traversa, 1984)- contribuyen a delinear las cualidades que se le confieren y la proyección de su utilidad social.

Como sostiene el mismo autor(1984: 55), "atribuirle una funcionalidad determinada (al cine) depende de supuestos que se formulan acerca de sus posibilidades y de la articulación con lo social". En estos términos, por lo tanto, el cine puede asumir, además de los usos más corrientes ligados los modos comerciales y los de entretenimiento, otros diferentes vinculados a prácticas del orden de lo revolucionario, científicaso de archivo, entre otras tantas opciones.

Esta perspectiva interesa particularmente porque nos evita preguntarnos sobre qué es el cine regional (o, más bien, qué fue durante aquella época), para orientar nuestra mirada hacia los modos en los que apareció representada esta categoría en el contexto de la prensa gráfica observada y proponer algunas hipótesis respecto a cuáles son las prácticas sociales con las que se articuló, o se buscó articular,este particular tipo de cine.

En definitiva, estudiar los metadiscursos que toman como su objeto al cine regional para reconocer -en el sentido que plantea Gustavo Aprea(2008: 92) respecto a los medios en general pero aplicable a nuestro caso particular"el lugar que cada medio ocupa dentro de un sistema mediatizado y determinar con qué tipo de prácticas sociales se relaciona".

Frente a esta propuesta, el trabajo que sigue a continuación se concentra en analizar textos encuadrados en diversos géneros, publicados por el diario Río Negro durante los primeros cinco años de la década del ochenta, referidos al cine de la región de la Norpatagonia. Su objetivo es lograr identificar las diferentes cualidades que desde los discursos que allí se materializan se le atribuyen al cine regional con el fin de postular las funciones que se espera desempeñe. En determinadas ocasiones las diversas consideraciones aparecen de forma complementaria, en otras dejando entrever mayores escenarios de disputa.En estos términos, es posible anticipar la presencia de tres ejes sobre los cuales se va a configurar el cine norpatagónico de los primeros ochenta: como una 
práctica vinculada al desarrollo regional por la vía industrial, como un espacio de expresión de acuerdo a ciertos criterios formales desligados de intereses comerciales y como un recurso de preservación de la cultura y la memoria de los pueblos.

\section{Algunas condiciones para la visibilización del cine regional}

El cine regional fue motivo de atención del diario Río Negro a partir de una serie de experiencias que actuaron como condiciones de posibilidad de su desarrollo. Entre ellas se encuentra el trabajo de Lorenzo Kelly y Carlos Procopiuk, precursores de la producción cinematográfica en la región. Durante el período abordado, los cineastas estrenaron un conjunto de películas que fueron objeto de crónicas y reseñas. Los maestros (Lorenzo Kelly, 1981); Al final de un frágil puente (Carlos Procopiuk, 1983); La gente de la tierra (Kelly y Procopiuk, 1983) y Francisco flor y arcilla (Carlos Procopiuk, 1983), fueron identificadas en los textos periodísticos como característicamente regionales.

La tarea de Kelly y Procopiuk -hasta entonces los únicos que en la zona producían cine con circulación pública- dejó de ser solitaria apartir de la aparición del Grusu 8. El nuevo colectivo había surgido de un taller de manipulación de cámara Súper 8 que en 1980 Lorenzo Kelly dictó en Cipolletti bajo auspicio municipaly su conformaciónsignificó una ampliación en la base de productores cinematográficos con asentamiento en la zona. El grupo se abocó en los años siguientes a su formación a la producción de cortometrajes, principalmente de carácter documental, y a la organización del Concurso Nacional de Cine Independiente, cuya primera edición se realizó en 1983 y continúa hasta nuestros días.

Todos ellos, precursores y seguidores, apelaron durante el período trabajado al Súper 8, un formato fílmico que no sólo presentaba menores costos económicos para los productores sino también brindaba la posibilidad de trabajar con equipos humanos y técnicos reducidos, adaptables a las condiciones de producción imperantes en la zona.

A pesar de lo incipiente que parecía el impulso del cine en la Norpatagonia, este no era aislado ya quese integraba al movimiento superochista que cobraba fuerza en el país y que se presentaba como una opción frente a las producciones de carácter comercial. En este contexto, se conocían dos noticias que daban fuerza al momento que estaban viviendo los cultores del formato de paso reducido. En 1983 se anunciaba la constitución de la Federación Argentina de Cine Independiente (FACI), a concretarse en una Asamblea Nacional que se realizaría en Rosario (Río Negro, 24-11-1983: 22), algo que colocaba a la actividad en el camino de la institucionalización. Y con un efecto similar también se anticipaba la realización en Argentina, prevista para 1985, de UNICA, el festival de la Unión Internacional de Cineastas Amateurs que por primera vez 
en su historia se realizaría fuera del continente europeo.

Parecía evidente que la consolidación de un cine diferente al comercial necesitabaapoyarse en un soporte que fomentara los intercambios entre las diferentes regiones y la posibilidad de generar espacios de proyección, objetivos ligados a la puesta en marcha del Concurso de Cine Independiente en Cipolletti.

Entre las condiciones de posibilidad que dieron fuerza al cine regional es pertinente señalara la vez el trabajo de los cineclubes que funcionaban por aquellos días. El Cine Club Don Lumiere había sido fundado en General Roca en 1977 y desde entonces desarrollaba una constante actividad. Por otro lado, el Cine Club Cipolletti, de la misma ciudad de su nombre, había sido constituido tres años más tarde y rápidamente comenzó a concretar algunos proyectos que ubicaron a sus actividades en la agenda cultural de toda la región.

\section{El cine regional desde diferentes perspectivas}

\subsection{Testimonio de la realidad regional}

Entre las características atribuidas al cine regional por los textos aparecidos en el diario Río Negro, su función como medio para testimoniar la realidad circundante es de las más frecuentes. Esto sucede, sobre todo, en las noticias, crónicas de filmación y reseñas de las películas firmadas por Lorenzo Kelly y Carlos Procopiuk.

En estos casos, los fines atribuidos son bastante claros y explícitos, ya que las películas de ambos cineastas, asociados en Producciones LEK, son consideradas el resultado de una "esforzada labor de documentación de la vida y la historia del Valle" (Río Negro, 4 de noviembre de 1981: 16).

Por ejemplo, sobre el mediometraje de KellyLos maestrosse afirma que "trasluce un doble valioso testimonio: el de la citada realidad regional y el de esta dupla de cineastas consecuentes con su acción y claros en sus objetivos" (Rithner, 14 de mayo de 1981:18). En la misma línea, El país del viento, de Procopiuk, aparece como producto del trabajo que "va más allá de las fronteras provinciales y se enraíza en lo regional" (Río Negro, 19 de junio de 1981: 14).

Las observaciones en este sentido abundan respecto a todas sus producciones. Francisco flor y arcilla, un largometraje de ficción filmado en Súper 8 en El Bolsón, logra difundir para el diario "la filosofía de vida de muchos lugareños y las características socio-geográficas de esta localidad cordillerana rionegrina" (Río Negro, 15 de marzo de 1983: 19).

Los objetivos del cine regional se presentan fijados con certeza y cualquier rasgo que los aleje de ellos debe ser no solo señalado, sino también erradicado. Parece no haber lugar aquí para las búsquedas formales que cubran con un manto de opacidad la supuesta transparencia que se le asigna al medio en su capacidad testimonial. Total rechazo entonces a los "juegos experimentalistas y de ciertas onanistas posturas pretenciosas (típicas de una "provincia" clase 
media intelectual)" (Río Negro, 6 de diciembre de 1981).

Al mismo tiempo, la posibilidad de hacer visible la realidad de la región Norpatagónica -que cubre tanto el Alto Valle como la zona Andina de Río Negro y Neuquén- se va constituyendo sobre una concepción del cine regional que aspira a refundar las bases de un cine nacional que se entiende ha sido modelado desde Buenos Aires. En este sentido,Francisco flor y arcillafue presentada como un punto de quiebre al ser considerada comola manifestación de que "algo nuevo ha nacido (un paso sólido en el cine nacional creado íntegramente en el interior, o al menos con una concepción integradora de país)" (Río Negro Suplemento Cultural, 20 de marzo de 1983: 3).

Es importante señalar que las páginas del diario se hacen eco de esta situación de una manera ambigua, porque si bien en ocasiones retoman la posición crítica de realizadores y gestores de pantallas de la región,como en el caso anterior, en otras no hace más que afirmar esa nominación que desconoce la diversidad de las producciones regionales al reducir lo nacional a aquel cine que tiene en el enclave porteño sus coordenadas geográficas, históricas y sociales.No es extraño notar, por lo tanto, que la categoría de cine nacional se emplea cada vez que se hace referencia a todas aquellas proyecciones y muestras que durante el período se organizaron en diferentes ciudades de la región, con invitados y grilla de programación conformada exclusivamente por películas de origen capitalino. El mejor ejemplo de esta operación tal vez sea la "Semana del Cine Argentino" organizada en San Martín de los Andes por la Fundación de Amigos de la Cultura local y la cooperativa telefónica locales, cuya programación e invitados estuvo cubierta en su totalidad por películas y artistas provenientes de Buenos Aires (Río Negro, 3 de agosto de 1984: 20).

Como ya mencionamos, el diarioapela a otras voces que cuestionan esa misma homogeneidad cuando se refiere al cine regional. Además de la referencia a Francisco flor y arcilla, se sostiene que "cada región, cada zona del país, debe contar con equipos capaces de registrar su realidad particular para intercambiarla, para hacerla conocer" y que "si somos capaces de convencernos que es imperioso mirar hacia nuestras raíces, el cine nacional puede volver a florecer" (Río Negro, 6 de diciembre de 1981).

La experiencia del Concurso Nacional de Cine Independiente venía a contribuir en este sentido. Desde sus días tempranos se entendió como una oportunidad de hacer del cine regional una vía paradar a conocer las diversas realidades que conviven en el país, y en el mismo movimiento cuestionar una concepción de aquel cine nacional de carácter homogéneo por responderde forma casi exclusiva a las películas surgidas de la matriz de producción porteña.

Frente a esta situación, el concurso -en el que se exhiben películas quepor "sus características no comerciales no son habituales para el público de 
la región", que integran un cine que "lucha por ser considerado parte integrante de la cinematografía nacional" (Río Negro, 19 de octubre de 1984: 23)-, "es una forma más de integración del movimiento superochista, a la vez que constituye un elemento de descentralización de los grandes centros cinematográficos" (Río Negro, 15 de octubre de 1984: 19).

En esta línea también se inscribe el trabajo de la nueva generación de cineastas regionales, el Grusu 8 y el GR Súper 8, constituido en General Roca. Los primeros, se encuentran "enmarcados de lleno en la problemática regional", e intentan "reflejar la vida, las actividades, el sentimiento de los hombres y mujeres que habitan la zona y rescatar el esfuerzo anónimo de aquellos que colaboran en el desarrollo de la cultura de la provincia y en especial del Valle" (Río Negro, 19 de octubre de 1984: 23). En cuanto a los segundos, de menor actividad, su formación fue descripta como "creadora de cine regional que nuclea a unos diez nuevos registradores de esta realidad particular" (Río Negro, 6 de diciembre de 1981).

\subsection{Demandas expresivas}

El cine regional se perfila a la vez como posibilidad de expresión desligada de intereses económicos, como espacio viable a la manifestación artísticaen el marco de los modos legitimados del lenguaje cinematográfico. Hay, aquí, una exigencia sobre las formas cuya satisfacción permitiría cobijar al cine de paso reducido bajo el manto institucional que ofrece el arte.

La referencia alos usos del lenguaje cinematográfico asociados a determinadas tradiciones como una necesidad para la inscripción artística de las películas se efectúa generalmente en el momento de las evaluaciones finales, cuando los cronistas asumen la función de críticos -que los pone en situación de elaborar juicios de valoración-, o cuando el discurso en la prensa referencia la opinión de los jurados del Concurso en el que participan.

Se hace, sobre todo, con los realizadores nuevos, dadoque a los precursores se los preserva de la críticaque aconseja y sugiere,ya que estos últimos "expresan cabalmente la calidad cinematográfica, la riqueza temática y las posibilidades de desarrollo de un cine regional de jerarquía" (Río Negro, 21 de agosto de 1983: 21).

En este aspecto, el anuncio del estreno de Al final de un frágil puentefirmado por Juan Raúl Rithner- sostiene que el mediometraje "fluye con armonía en este sencillo relato que trasunta (anécdota e imagen) la frescura de una poesía cotidiana capaz de emocionar a todos los sectores del público" (30 de agosto de 1983: 17). En tanto, el mismo autor sostiene que en La gente de la tierra, "la fotografía es excepcional, el montaje oportuno y sintetizador" (30 de agosto de 1983: 17).

Como anticipamos entonces, las valoraciones cambian de tenor cuando 
recaen sobre la nueva generación de realizadores. Si los iniciadores ya gozan del reconocimiento de la crítica y de otros actores que se presentan con cierta legitimidad como los cineclubes que programan sus películas yfuncionarios ligados a áreas culturales, quienes le siguen deben todavía probar en sus películas que han abandonado definitivamente las modalidades de cine familiar de donde provienen. En ocasión de la primera incursión pública del Grusu 8, una reseña aseguraba que en la mayoría de ellos "por inseguridad o por falta de comprensión del fenómeno fílmico, persisten en fotografiarse a sí mismos o en temáticas insustanciosas desarrolladas, además, sin fuerza expresiva" (Rithner, 27 de diciembre de 1980).

A lo largo del período trabajado, que coincide con los años iniciales y de mayor actividad colectiva del Grusu 8, las exigencias de adecuación a cierta idea de cine vinculada al arte se repiten.

En este sentido, por ejemplo, se les demanda a los nuevos cineastas la concientización "en sus propias limitaciones y en su necesidad de dar mayor sentido autocrítico y de formación teórica" (Río Negro, 12 de octubre de 1983: 18). A la vez, el diario referencia las conclusiones del jurado de la segunda edición del Concurso en las que se rescata positivamente la actitud de "mirarse a sí mismo" y asumir su "identidad cultural", pero en las que también se observa "que sería profundamente deseable una mayor preocupación por la búsqueda de recursos estilísticos ya que el cine de paso reducido debe ser también muy expresivo en el plano estético para potenciar el mensaje que se desea transmitir" (Río Negro, 23 de octubre de 1984: 23).

De esta forma, lademanda de manejo delos recursos del lenguaje cinematográfico pone en evidencia la exigencia de abandonar la condición de amateur por la vía de la formación antes que de la profesionalización.

La producción de los nuevos realizadores no se compara solamente con la de sus predecesores, quienes en ese momento ya cuentan con una reconocida trayectoria y cuyo dominio del lenguaje cinematográfico parece estar probado de acuerdo a los textos publicados. Las nuevas películas tienen que medirse también con la idea de un cine de calidad que establecen las actividades de las instituciones que toman a su cargo la exhibición de material que por su recorrido se alejan del mote de "comercial": los cineclubes.

Son estas instituciones las que contribuyen a delinear el horizonte para el cine regional ya que establecen los parámetros del "buen cine como instrumento de educación y cultura" (Río Negro, 14 de agosto de 1981: 17), son las que brindan a la comunidad local y regional "muestra de filmes considerados jalones en el desarrollo del lenguaje cinematográfico" (Río Negro, 6 de octubre de 1981: 15).

Es preciso señalar, no obstante, que las referencias al cine regional como práctica artística o como medio con función testimonial no son excluyentes. $\mathrm{Si}$ 
las expresiones artísticas se constituyen desligadas de los intereses económicos atribuidos al cine industrial, la producción de cine regional como una forma de preservación de la cultura y la memoria de los pueblos se define en oposición a las películas de matriz productiva porteñocéntrica que, no solo es identificada con objetivos de rédito económico, sino a la que también se le atribuye el papel de haber desconocido las realidades que se tejen en las diversas regiones que pueblan las provincias.

Este cruce, suerte de hibridación entre lo testimonial y lo artístico, se hace patente en la caracterización de los trabajos de los cineastas precursores, pero también empieza a dejar su huella en las valoraciones sobre las películas de algunos de los integrantes del Grusu 8, como Alberto Vilanova. En Recuperando la cultura mapuchese rescata un "sólido trabajo de uno de los cineastas rionegrinos que empieza a vislumbrarse con mayores posibilidades de calidad y de preocupación por la función social del cine" (Río Negro, 9 de octubre de 1983: 25).

Al mismo tiempo, el anhelo de orientar la noción de cine nacional hacia una concepción que contemple la diversidad regional podría ser considerado, a modo de hipótesis, como una de las condiciones para que en las páginas del diario se refieran cada vez más al cine independiente y no tanto al cine regional. ¿’Por qué? Porque el proyecto que se sostiene es construir otra idea de lo nacional, que el acento sobre la dimensión regional tal vez socaba, acaso fragmenta. $\mathrm{Si}$ la intenciónes refundar lo nacional a través de los vínculos entre las distintas regiones, se vuelve estratégico por lo tanto el trabajo complementario realizado entre la dimensión testimonial -que ofrece la posibilidad de verse y hacerse ver al resto del país- y el esfuerzo en profundizar los intercambios entre las distintas regiones, como se manifiesta en el Concurso y los viajes que los realizadores regionales realizaron durante el período a diferentes puntos del país.

\subsection{Posibilidad de desarrollo industrial}

Una tercera caracterización del cine regional apunta a inscribirla en prácticas vinculadas a su desarrollo industrial a partir de la explotación comercial. Llaman particularmente la atención en este sentido una serie de notas firmadas por Carlos Carrillo, uno de los fundadores del Cine Club Don Lumiere quien presentaba además en su legajo los atributos de la formación académica. Esta perspectiva tiene un menor volumen cuantitativo, pero es presentada desde una posición de enunciación que le brinda peso específico no solo por la rúbrica que acompaña los artículos sino también por la sistematicidad de las publicaciones y el armado lógico de sus ideas. Se despliegan allí una serie de argumentos que exploran la posibilidad de que las producciones regionales logren "vigencia y permanencia" (Carrillo, 11 de abril de 1983: 17) por la vía industrial.

Frente a las dificultades financieras de la producción amateur y los 
condicionamientos temáticos que impone la de carácter institucional (solo se pueden abordar temas que respondan a las necesidades de las instituciones financistas), Carrillo sostiene que "no podrá hablarse de una producción regional absolutamente consolidada, al menos en países de economía capitalista, mientras no exista una producción comercial estable" (18 de abril de 1983: 19).

A lo largo de los diferentes textos publicados, expone tanto ventajas que la región ofrece a la producción cinematográfica, como consejos para sortear los diversos obstáculos que se presentan. En el primer aspecto, los ambientes naturales por sobre los estudios y las temáticas regionales favorecerían el desarrollo de la cinematografía de la región. Mientras que las dificultades técnicas podrían ser salvadas mediante el aprovechamiento de equipos cinematográficos de $16 \mathrm{~mm}$.que por obsoletos ya no utiliza la televisión, la búsqueda de recursos humanos y el apoyo del Estado a través de incentivos y medidas de carácter federal (Carrillo, 26 de abril de 1983: 18; 3 de mayo de1983: 20; 9 de mayo de 1983: 21; 30 de mayo de 1983: 18).

Esta mirada también deja su huella en los discursos de algunos funcionarios de la gestión cultural provincial al limitar la posibilidad de lograr un cine regional de importancia a "tener siempre la mira puesta en tratar de profesionalizarnos" (Río Negro, 22 de diciembre de 1985: 28).

\section{Conclusiones}

Tras repasar las diferentes maneras en las que se configura la noción de cine regional en las páginas del diario Río Negro, es posible asumir que la unidad material que supone un mismo medio no es garantía de que los objetos a los que refiere presenten siempre las mismas cualidades o estén asociados a similares prácticas. En el caso analizado, algo tan complejo como el cine regional -que implica no solo un conjunto de películas producidas bajo ciertas condiciones, sino también sus particulares modos de circulación y de recepción- aparece representando desde posiciones que pugnan por establecer sus potenciales funciones a partir del recorte y presentación de sus características. Si el cine regional es una cuestión de testimonio y preservación de la memoria regional, de diferencias antagónicas con el cine comercial o alternativa de desarrollo de una industria cultural es algo que no está del todo definido en las páginas del diario. Estas se convirtieron, más bien, en un espacio de la discursividad social en el que se dirimieron las batallas para definir tanto lo que el cine regional es como aquello que debería ser.

Ahora bien, resulta más o menos claro después de haber repasado los tres ejes reconocidos que la función de preservar y visibilizar la cultura regional parece tener mayor presencia y fuerza que las otras dos. No resultaría arriesgado afirmar, aun en este momento de conclusiones, que el regreso a la vida en democracia operó como una condición que estimuló la necesidad de 
reafirmar identidades y de restablecer los vínculos entre los diferentes actores de la vida cultural de las diversas regiones. En ese marco, la idea de refundación también se aplicaba a la manera en la que se había constituido el cine nacional y los cines regionales tenían algo para decir al respecto.

Los ejes restantes, concentrados en el orden del deber ser -más eficientes en términos de producción industrializada, menos amateurs en términos expresivos- fueron sufriendo desplazamientos en los años subsiguientes. Como hipótesis de trabajos futuros, estos se pueden haber sido efectos de las derivas de la industria cinematográfica nacional en su conjunto y la aparición de una nueva generación de realizadores que vendrá con el crecimiento de las carreras de cine y audiovisual.

\section{Bibliografía}

APREA, Gustavo. 2008. La construcción de la memoria mediática en la Argentina: el registro de la aparición de los medios de comunicación a través de la prensa gráfica. En Oscar STEIMBERG, Oscar TRAVERSA. \& Marita SOTO (eds),El volver de las imágenes. Mirar, guardar, perder, 91-104. Buenos Aires: La Crujía.

TRAVERSA, Oscar. 1984. Cine: el significante negado. Buenos Aires: Hachette.

\section{Referencias artículos periodísticos}

Rithner, Juan Raúl (27 de diciembre de 1980). Muestra anual 1980 del "Grusu 8" de Cipolletti. Río Negro.

Rithner, Juan Raúl (14 de mayo de 1981). Sobriedad y testimonio. Río Negro, p. 18).

Hacer esta obra no fue sólo soplar... hubo que poner amor (19 de junio de 1981). Río Negro, p. 14.

Consolidación de un Cine Club (14 de agosto de 1981). Río Negro, p. 17.

Muestra retrospectiva de cine-arte en Cipolletti (6 de octubre de 1981). Río Negro, p. 15).

Dos argumentales obtuvieron los premios mayores (9 de octubre de 1983).Río Negro, p. 25).

Filmes de Procopiuk y Kelly en Buenos Aires (4 de noviembre de 1981). Río Negro, p. 16.

Cine regional. Un espejo necesario para crecer (6 de diciembre de 1981). Río Negro. 
Debutó con tres funciones un filme rionegrino (15 de marzo de 1983). Río Negro, p.19.

La historia ha comenzado en El Bolsón (20 de marzo de 1983). Río NegroSuplemento Cultural, p. 3.

Carrillo, Carlos (11 de abril de 1983). Recapitulando. Río Negro, p. 17.

Carrillo, Carlos (18 de abril de 1983). Posibilidades de producción. Río Negro, p. 19.

Carrillo, Carlos (26 de abril de 1983). Posibilidades técnicas. Río Negro, p. 18.

Carrillo, Carlos (3 de mayo de1983). Posibilidades humanas. Río Negro, p. 20.

Carrillo, Carlos (9 de mayo de 1983). El papel del Estado. Río Negro, p. 21.

Carrillo, Carlos (30 de mayo de 1983). Posibilidades temáticas. Río Negro, p. 18.

Estreno local de dos filmes regionales se realiza en Cipolletti (21 de agosto de 1983). Río Negro, p.21.

Rithner, Juan Raúl (30 de agosto de 1983). Poética sencillez para una historia. Río Negro, p. 17.

Para que la frustración no detenga un nuevo despertar (12 de octubre de 1983). Río Negro, p. 18.

Constituirán la Federación Argentina de Cine Independiente (24 de noviembre de 1983). Río Negro, p.22.

Semana del Cine Argentino en San Martín de los Andes (3 de agosto de 1984). Río Negro, p. 20.

Comienza hoy el Concurso Nacional de Cine Independiente (15 de octubre de 1984). Río Negro, p. 19.

Finaliza mañana el festival de cine en Cipolletti (19 de octubre de 1984). Río Negro, p. 23.

Conclusiones del jurado de cine independiente de Cipolletti (23 de octubre de 1984). Río Negro, p. 23.

Lazarini habló del cine independiente (22 de diciembre de 1985). Río Negro, p. 28. 


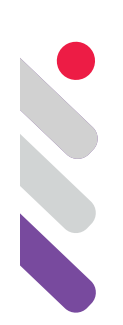

\title{
Tunches, pishtacos y jarjachas: formas enunciativas del miedo en el cine regional andino peruano
}

DOI: 10.24308/IASS-2019-4-009

\author{
Miguel Ángel Torres Vitolas \\ Pontificia Universidad Católica del Perú \\ matorres@pucp.edu.pe
}

\section{El desarrollo de un "cine regional" en Perú}

¿Podemos pensar en alguna película de terror nacional que dada su popularidad haya producido más de una secuela? Aún más, dado el inmenso centralismo del país, ¿podemos recordar rápidamente alguna película nacional exitosa comercialmente que no provenga de Lima? Las películas consagradas al personaje mítico andino de la Jarjacha cumplen con esas dos condiciones. Se han producido varias sobre el personaje: Jarjacha, el demonio del incesto (2000) de Mélinton Eusebio, Incesto en los Andes: La maldición de los jarjachas (2002) y La maldición de los jarjachas 2 (2003) de Palito Ortega Matute, y Jarjacha vs. Pishtaco: La batalla final (2011) de Nilo Escriba Palomino, entre otras. Además, y es en especial el caso de la primera, se trata de películas que reunieron una cantidad considerable de público.

Lo que el caso de estas cintas de horror nos revela es la relevancia en términos de la respuesta por parte del público de una forma de hacer cine y de difundirlo fuera del circuito comercial y cultural tradicional, pues estas producciones han aparecido en el marco de lo que se ha denominado el "cine regional peruano", una forma de hacer cine y de distribuirlo que no involucra las productoras de cine tradicionales, ni los circuitos de sala de cine, ni —acaso está demás decirlo- casi ninguna forma de apoyo estatal. Podemos así plantearnos algunas preguntas inocentes a partir de los ejemplos citados: ¿Cuántas cintas nacionales han recogido motivos de origen andino? ¿Cuántas cintas producidas fuera de Lima han recibido una respuesta del público similar? ¿Cuántas películas nacionales de género han situado su narrativa fuera de Lima? Las respuestas que podamos proponer o la dificultad para darlas pueden darnos un indicio de la relevancia de un fenómeno cultural como el que nos interesa. 
Lo que nos parece importante de abordar en el cine es cómo este nos puede ayudar a reconstituir dinámicas de producción y recepción de objetos culturales. Más allá de sus contenidos y representaciones, coincidimos con Marc Ferro en que "Agente de la historia y documento de la historia, la película es también un objeto cultural de la sociedad que la produce, de la sociedad que la recibe. Por lo tanto, la película está conformada desde varios lugares: proviene tanto de la cultura popular con su memoria como de los objetos culturales de las élites que expresan la voluntad, los símbolos de las instituciones o del artista." (2003: 115). Si la afirmación de Ferro toma sentido dentro de la lógica del cine comercial tradicional, que involucra costos de producción y distribución altísimos, lo que lo confina a una proximidad irremediable a las élites económicas y culturales, es bueno repensar cómo bajo formas de producción distintas el cine puede ser testimonio de referentes culturales distantes de los hegemónicos.

En el Perú, como en otras partes, el avance tecnológico que ha permitido el desarrollo de las cámaras digitales y el acceso a la edición en computadoras personales ha producido como correlato una mayor producción de obras audiovisuales, bastante menos onerosa que cuando la única opción era la de trabajar con celuloide. Si el número de las producciones ha aumentado, tanto de cortos, como de mediometrajes o largometrajes, ello no ha significado, sin embargo, una mayor presencia de las producciones nacionales en los canales oficiales de difusión y distribución (distribución en salas o difusión por televisión). Con escaso apoyo del Estado, cuando siquiera lo hay, la industria nacional del cine se confronta a condiciones de distribución a menudo adversas. El modo en que el cine nacional ha buscado enfrentar dichas dificultades y hacer rentable el de todos modos costoso alto riesgo de una producción cinematográfica ha sido recurrir a actores, personajes y narrativas venidas de la televisión y del mundo del espectáculo, así como asumir formas genéricas inteligibles como la comedia o el terror.

En paralelo a esta situación, los últimos veinte años han visto también formarse proyectos audiovisuales diversos en varias regiones del país, como Ayacucho, Cajamarca y Puno, en condiciones bastante más precarias. Se trata de producciones hechas con muy pocos recursos, autofinanciadas, de cualidades a menudo artesanales en términos de edición, iluminación y fotografía. Estas películas se distribuyen además por medio de canales informales (principalmente, salas locales improvisadas o alquiladas). Un fenómeno similar ha sido observado en Nigeria y merecido, en ese caso, una producción bibliográfica importante sobre sus contenidos, sus formas de difusión o su impacto en el público de las regiones; se ha denominado Nollywood a esa industria paralela (Adesokan 2014; Stanislaus 2016). Como en aquel caso, en el Perú, estas películas han sido en general ignoradas en los circuitos culturales tradicionales donde muchas veces no se sabe siquiera de su existencia. Se trata, sin embargo, de obras valoradas 
por los públicos alejados de dichos polos culturales y geográficos. Muchas de estas producciones pueden así ser bastante populares y reconocidas en su ámbito precario de distribución y completamente ignoradas fuera de este.

Al respecto, Bedoya (2015: 227), así como Bustamante y Luna (2017), identifican el año 1996 como aquel que señala un momento inicial crucial para estas producciones. Este será el año en que aparecen en Ayacucho las películas Lágrimas de fuego (Mélinton Eusebio y Luis Berrocal) y Dios tarda pero no olvida (Palito Ortega Matute). Las dos son producciones autofinanciadas y realizadas en video VHS, sin actores profesionales y exhibidas, en un principio, a nivel local. En distintas regiones del país (en particular en Ayacucho y Puno), a partir de entonces aparecen varias iniciativas audiovisuales de cineastas locales bajo las formas descritas. Desde entonces hasta el 2015, señalan Bustamante y Luna, 216 películas, entre mediometrajes y largometrajes han sido producidas en las regiones, excluyendo de dicha lista a Lima Metropolitana y el Callao (2017: 34). Como han descrito Bustamante y Luna, las condiciones económicas son de autofinanciamiento, recurriendo a familiares y a actores no profesionales, y en varias ocasiones bajo la figura de un taller pagado de actuación previo que ayuda a recaudar fondos para la producción, con el incentivo de que los mejores alumnos actuarán en la cinta (2017: 34-38). De Taboada señala a su vez que debe reconocerse en las prácticas de estos creadores audiovisuales no solo una motivación artística, la búsqueda de algún grado de reconocimiento y notoriedad social y artístico, sino también una iniciativa empresarial que busca rentabilizar su inversión o al menos recuperarla (de Taboada 2015: 245-246). Si a ello añadimos que las formas de exhibición y distribución no siguen los canales oficiales y pasan por el alquiler de salas, la organización de festivales, la venta de DVD y VCD (Bustamante y Luna 2017: 53-58), nos encontramos con la descripción de un circuito de producción y difusión que se configura dentro de su precariedad e informalidad. Por ejemplo, como señala de Taboada, a menudo los directores no hacen accesibles sus películas en forma de DVD o VCD y se limitan a exhibirlas en las funciones que organizan, por temor a la difusión por internet y al pirateo (de Taboada 2015); si bien ello protege sus intereses, tiene a su vez por resultado la inaccesibilidad a estos contenidos, lo que termina de cerrar el círculo de confinarlas a sus circuitos locales. Algunas de las películas producidas bajo estas condiciones han conseguido ser exhibidas en salas comerciales en Lima (El huerfanito de Flaviano Quispe y El último guerrero chanka de Víctor Zarabia, por ejemplo), pero por lo general, por sus condiciones mismas de producción, su presencia suele estar confinada a sus circuitos locales.

Nuestra aproximación a las películas sobre la Jarjacha y el Pishtaco buscará establecer, como lo sugería la cita anterior de Marc Ferro, qué nos revelan estas películas sobre el cine regional y sobre el circuito cultural que se configura. El interés semiótico que proyectamos no está entonces restringido a un análisis 
de contenido per se, sino que busca comprender la circulación de contenidos dentro del marco comunicativo en el que toma sentido. Nuestra perspectiva es entonces, siguiendo a Roger Odin, semiopragmática. Recordemos entonces que frente a una postura inmanentista que es la de la semiótica canónica, desde la Semiopragmática se plantea una postura que busca precisar la semiosis desde el contexto que la precisa. Odin afirma que esta "se interesa por los condicionamientos que rigen la construcción de los actantes de la comunicación y la forma en la cual estos son conducidos a producir el sentido" (Odin 2011: 21). Es decir, dentro de la perspectiva semiopragmática es el contexto el punto de partida para establecer las relaciones de significado. Bajo este modelo, el espacio de comunicación aparece como el que determina los ejes de pertinencia bajo los cuales el texto en cuestión debe ser comprendido, es el que fija la inteligibilidad. Dice así Odin que para los actantes de la comunicación, el no respetar las restricciones del espacio de comunicación en el que se encuentran se paga de una manera u otra (Odin 2011: 40).

\section{El cine de terror en el "cine regional" andino: formas enunciativas del horror en la figura del monstruo}

Apoyándose en Cuéllar Barona, Roche (2017) distingue los términos de horrory terror, estableciendo que "mientras que el horror alude a lo monstruoso, lo vil, lo intangible, lo atroz, etc., el terror apunta hacia el sentimiento que estremece en el momento en el que el miedo se introduce en el cuerpo y bloquea todo pensamiento racional." (515). Lo que nos parece interesante en la distinción es que esta describe un recorrido interpretativo y sensible, desde lo aterrador representado, enunciado, hasta la experiencia del miedo, tanto cognitiva como sensible, por parte del espectador.

Roche (2017) establece el rastro de lo aterrador en el cine fantástico señalando cómo este sitúa el origen de este miedo en un horizonte de alteridad, sobre el cual lo distinto, lo extraño al nosotros, reviste en su ser ajeno el principio del miedo que provoca. Lo aterrador que describe, así, se sostiene sobre la idea de que el público occidental de King Kong veía en la figura de este simio monstruoso la realización figurativa, presencial, de su miedo a lo otro.

$\mathrm{Si}$ reconocemos en la enunciación cinematográfica la estrategia desplegada por el hacer enunciativo para obtener de parte del enunciatario y su hacer interpretativo la lectura que se busca actualizar, así como evitar en lo posible las lecturas divergentes, podemos plantear que en una cinta de terror el recurso a la representación figurativa del monstruo es parte de esta estrategia que persigue, de ser exitosa, la experiencia de terror por parte del espectador. La estrategia cinematográfica de ocultamiento, develación, exposición u otras, son así los recursos que el enunciador cinematográfico despliega para mejor obtener este objetivo. 
En su distinción entre una lectura ficcionalizante y una documental, Roger Odin propone que en la praxis de la recepción, más allá de las indicaciones paratextuales del texto (que lo sitúen como una ficción, como un documental u otro género), el espectador proyecta luego sobre este una lectura que identifica un Enunciador que cumpla con los requisitos del horizonte de lectura asumido (2011: 53-55). Así, el espectador puede proyectar un Enunciador ficcionalizante o uno documentalisante según vea el film como una ficción o como un testimonio documental de la realidad. De una ficción, el espectador puede así esperar su coherencia y su verosimilitud, lo que permite la aparición de extraterrestres o monstruos mientras estos guarden coherencia diegética con lo visto; mientras que de un texto documental se espera la veracidad sobre el contrato de lectura, lo que dejaría perplejo a un espectador que encuentra extraterrestres o monstruos en un este caso. Dice así Odin que en este segundo caso, el Enunciador es comprendido como alguien a quien se le puede interrogar sobre la veracidad o falsedad de sus afirmaciones (que no son entonces juzgadas solo como representaciones) (2011: 57). Es decir que en este caso, el espectador proyecta sobre el film la figura de un enunciador que debe en alguna medida portarse garante sobre la veracidad de sus afirmaciones.

Las cintas de terror que nos interesan, aquellas que plantean a nivel figurativo la presencia de monstruos como el pistacho o a la jarjacha, se inscriben dentro de su dispositivo enunciativo como cintas de ficción. Para ello, se apoyan en motivos culturales, míticos, que son aún vigentes dentro de las tradiciones culturales fundamentalmente orales. La jarjacha es un monstruo mítico producto del incesto que asesina devorando a sus víctimas; mientras que el pistacho es un personaje foráneo a la comunidad que asesina y destaja a sus víctimas para comercializar con su grasa. Con algunas diferencias, son motivos narrativos que se han podido establecer con un origen incluso pre-incaico (Terbullino 2018: 224); así como con algunas variantes. A dichas diferencias, sea en su modo de ser nombrado, como a las variantes figurativas y narrativas, se debe que además de las citadas, hayan películas en estos ámbitos consagradas al Kharisiri y al Nakaq, que son sin embargo figuras emparentadas con la del pistacho: El misterios del Kharisiri (Henry Vallejo, 2004) y Nakaq (José Huertas y Luis Berrocal, 2002). La vigencia de estos motivos narrativos, que circulan aun en la actualidad y que son tomados incluso por referentes de incidentes reales puede verse en casos observados hasta años recientes en que algunas personas han sido acusadas de ser pishtacos o han estado cerca de ser ajusticiadas por la población por la sospecha de serlo (Terbullino 2018: 224-225).

Señala Ferro que "En lo esencial, las películas de cine son productos situados entre el arte y la industria, y la historia de la fabricación de una película, de su producción y de su recepción debe analizarse también como se examinaría el destino de un automóvil." (2003: 116). Podemos así interesarnos 
sobre cuáles son algunas de las características formales de estas cintas y qué nos muestran ellas sobre estas películas como objetos culturales en circulación en un espacio de comunicación alternativo al hegemónico y tradicional. De los varios aspectos que podrían tomarse en cuenta, nos centraremos en uno que nos parece determinante: el género.

Consideramos que en el caso de esta industria en formación que se está formando en el cine regional se observa de parte de productores y directores una voluntad de hacer cine que asume y acoge sin ambigüedades las formas genéricas como un formato que permite la expresión, garantiza su inteligibilidad y facilita así su comercialización. Ello es evidente en el cine regional en general, en el cual abundan las películas de horror, así como los melodramas. El género fílmico, género textual finalmente, ocupa un rol determinante dentro de este cine, que no duda en asumirlo, y da de alguna forma así sentido al discurso que se puede estar formando: se trata de un circuito cultural comercial fuertemente emparentado al del cine comercial hegemónico pues sus formas no difieren en la estrategia enunciativa, sino en las representaciones figurativas y temáticas. Si como dijimos antes, el cine nacional ha buscado asegurar la rentabilidad de sus proyectos recurriendo a figuras de la televisión y a géneros reconocidos, podemos reconocer en el caso del cine regional, como industria, una estrategia similar, dentro de las limitaciones de sus recursos. Acaso una particularidad de este cine con respecto del cine comercial nacional es el de la cantidad de películas de terror y melodramas que forman la mayor parte de las producciones, a diferencia del cine comercial, proveniente de Lima, que asume como forma comercial por excelencia a la comedia. La comedia como género desarrollado, en cambio, se encuentra muy poco presente en las producciones regionales. Esta presencia considerable de películas de terror en el circuito de producción y exhibición del cine regional es el que ha conducido a algunos a identificar en ello la manifestación de temores presentes socialmente, que se verían canalizados por medio de estas ficciones (Terbullino, 2018; Cano, 2010: 26-27).

El acogerse a un género textual reconocido como garantía de inteligibilidad y, gracias a ello, como una posibilidad de lograr alcanzar posibilidades de éxito comercial con mayor facilidad, es un gesto enunciativo que se observa en la mayor parte de producciones de este cine. Las sagas de películas de terror, los melodramas y las cintas de acción que han aparecido nos parecen confirmar esta afirmación. Ello nos parece evidente en el caso de películas como Jarjacha, el demonio del incesto (2000) de Mélinton Eusebio, Incesto en los Andes: La maldición de los jarjachas (2002) y La maldición de los jarjachas 2 (2003) de Palito Ortega Matute, y Jarjacha vs. Pishtaco: La batalla final (2011) de Nilo Escriba Palomino. Son todas ellas bastante ceñidas a las formas enunciativas típicas del género de terror: el empleo de una música extradiegética empática, la maldad arquetípica del monstruo, la exposición figurativa explícita del hecho 
violento, la risa macabra que invade el plano y lo supera, etc. Es decir, no son solo películas que se sitúen en el género del terror, y que persigan por lo tanto situar al espectador frente a la desazón y al miedo, sino que a su vez los recursos enunciativos que emplean para conseguirlo son por lo general los mismos a los que el cine comercial de terror recurre.

En la utilización de motivos de la mitología andina, como el del Pishtaco, la Jarjacha, el Nakaq o el Kharisiri, dentro de las espacios diegéticos de sus narrativas, el cine regional se distingue del cine hegemónico en el país, que ha excluido completamente este tipo de representaciones de sus narrativas. Si la presencia de este tipo de motivos provenientes de tradiciones culturales periféricas a los intereses de la capital señala, sin duda, al menos un horizonte de representación figurativa que lo distingue, de otro lado observamos que las formas de estrategia enunciativa que se observan son más bien muy próximas del lenguaje audiovisual que el cine comercial emplea. Las formas del cine de horror que se observan en este cine, más allá de las particularidades propias a la carencia de recursos o a su desarrollo desde entornos no profesionales, nos parecen señalar una subordinación considerable a las estrategias de exhibición o de ocultamiento propias del cine de género comercial. Si se obvian los problemas de composición, de continuidad o la impericia de los actores, uno parece en muchos de estos casos confrontar películas muy próximas del cine de serie $B$, es decir, un cine que no resalta porque intenta expresarse de un modo diferente, sino porque intenta recurrir a los mismo medios de expresión canónicos pero sin la habilidad profesional necesaria.

Acaso un elemento que sí destaca en estas películas, que no parece emparentarse necesariamente con la impericia formal o con la sujeción a formas genéricas intuidas, son los momentos álgidos de un profundo pathos en los que se suelen detener estas películas. Ello no es propio del género, donde estos momentos no suelen extenderse tanto como sí se observa en este cine. Los momentos de una gran emotividad, de emociones profundas desatadas, demoran en pantalla en estas películas mucho más del tiempo habitual visto en el cine comercial: el hecho violento, la persecución, el momento emotivo pueden tardar así extenderse por minutos en pantalla para el espectador. Creemos percibir en ello una característica propia de la estrategia enunciativa que este cine de horror propone en estos espacios de comunicación, una característica propia de las formas enunciativas desplegadas, tan o más particular a este cine de lo que lo es la presencia de motivos narrativos como lo son sus monstruos (Jarjacha, Nakaq, etc.). Ello se confirma transversal a los distintos géneros que se suelen ver desarrollados en este cine, como es evidente en el drama que se produce en grandes cantidades, el cual, por dicha característica, suele parecer para un espectador foráneo un melodrama. 
Bajo la perspectiva semiopragmática asumida, podemos entonces señalar que el cine regional de horror se rige por un espacio de comunicación en el que predomina la actualización de un enunciador fictivo, con cierta presencia de un enunciador realizante. Dentro del horizonte de coherencia en que operan estos films las películas recurren generalmente a las formas enunciativas habituales propias del género comercial de horror, por lo que las estrategias de ocultamiento o de exposición del motivo de horror, del monstruo, suelen parecerse (la oscuridad, la violencia figurativa, la risa tenebrosa) de las que habitualmente acompañan al monstruo del cine comercial. Si algunas características destacan, que lo demarcan del cine exhibido en los circuitos hegemónicos tradicionales, estos son el recurso a motivos de narrativos provenientes de las tradiciones culturales, muchas veces orales, andinas, y la presencia central dentro de las estrategias enunciativas de momentos de un intenso pathos que se invita a compartir al espectador.

\section{Bibliografía}

ADESOKAN, Akin. 2014. Nollywood: Outline of a Trans-ethnic Practice". Black Camera: An International Film Journal (The New Series), (2), 116.

BEDOYA, R. 2015. El cine peruano en tiempos digitales. Lima: Universidad de Lima, Fondo Editorial.

BUSTAMANTE, Emilio y Jaime LUNA VICTORIA. 2017. Las miradas múltiples. EI cine regional peruano. Lima: Universidad de Lima - Fondo Editorial

Bustamante, E. y Luna J. 2014. "El cine regional en el Perú". Contratexto n.o 22, pp. 189-212.

CANO, José Carlos. (2010) El cine de terror. Historias de vampiros y qarqachas. Tesis para obtener el Magister en Comunicaciones. Pontificia Universidad Católica del Perú, Escuela de Posgrado.

DE TABOADA, Javier. 2015. ¿Y cómo lo hacen? Breve guía para entender el cine regional. Noriega, J. y Morales J. (ed). Cine andino. Lima: Pakarina ediociones. pp. 243-252.

FERRO, Marc. 2003. El cine:agente, producto y fuente de la historia. Diez lecciones sobre la historia del siglo XX. México D.F.: siglo veintiuno editores. pp. 105-119.

ODIN, Roger. 2011. Les espaces de communication. Grenoble: Presses Universitaires de Grenoble.

STANISLAUS, Iyorza. 2016. Film Content Evaluation: Nollywood in the Mirror of African Movie Academy Awards (AMAA). Journal of Arts and Humanities, Vol 5, Iss 9, pp 75-83 (2016), (9), 75. 
TERBULLINO, Vladimir. 2018. La posmemoria del trauma de la violencia políticocultural en dos películas regionales peruanas. Analecta Política, 8(15), 283-300. 


\title{
MEDIATIZACIONES
}

\author{
D. NUEVAS TEORÍAS SOBRE LO AUDIOVISUAL
}





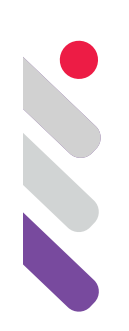

\title{
Le cinéma et son double ou le principe de l'asynchronisme revisité
}

DOI: 10.24308/IASS-2019-4-010

\author{
Ivan Capeller \\ Professeur à l'École de Communication de \\ I'Université Fédérale de Rio de Janeiro (ECO/UFRJ) et \\ Directeur d'Études Associé à la Fondation de \\ la Maison des Sciences de l'Homme (DEA/FSMH) \\ ivan.capeller@eco.ufrj.br
}

\section{L'écoute d'Ulysse}

Au début de son Livre à Venir, Maurice Blanchot postule une dichotomie entre les protagonistes de l'Odyssée et de Moby Dick, Ulysse et Achab, qui remonte à l'épisode homérique du chant des sirènes (BLANCHOT, 2005). II s'agit d'un moment paradigmatique de la littérature occidentale. Étant donné que la ruse d'Ulysse consiste à profiter du beau chant des sirènes, autant sublime que mortel, sans courir le risque de succomber à ses charmes, Ulysse peut être considéré comme le prototype du barde ou de l'aedo de la tradition épique, capable d'évoquer l'enchantement mythique des sirènes dans une chanson dont on se souviendra par l'expérience narrative transmissible au fil des temps. La poésie épique d'Homère marque le passage du mythe à la fabulation narrative; ce passage marque la distance formelle par rapport au matériau mythique, qui remet à la distance d'Ulysse au chant des sirènes, une distance qui lui permet de contrôler la destination et les effets de son voyage-passage par l'enchantêment d'un tel chant. Dans le texte de Blanchot, Achab s'oppose à Ulysse dans la mesure où sa confrontation avec la baleine Moby Dick finit dans l'autodissolution du héros et le naufrage de son navire. Tandis qu'Ulysse est le prototype narratif du héros, Achab est le prototype narratif de sa dissolution. En ce sens, on peut dire que l'opposition entre les deux représente le sort du récit lui-même dans l'histoire de la littérature occidentale, car, s'il naît avec Homère, il atteint son apogée et sa dissolution ultérieure avec le roman moderne, dont Melville est l'un des premiers représentants.

Il semble, là, qu'il y a deux types de voix narratives distinctes, et même opposés. Au cinéma, la notion de voix narrative englobe, à la fois, la conception monologique d'une voix intérieure qui se place en position du sujet 
de la narration, et des conceptions plus complexes, basées sur le dialogue, la neutralité ou même l'aphonicité. (PARENTE, 2000). Cependant, si la présence de la voix au cinéma ne correspondait qu'à la notion d'un sujet de l'énonciation narrative, nous nous trouverions dans l'œil abyssal d'une herméneutique infinie, puisque au cinéma, si la voix apparaît comme un point d'articulation privilégié entre la vision et l'écoute, ce n'est pas seulement parce qu'elle est capable de fonctionner, sur le plan de l'expression signifiante, comme sujet d'un discours (c'est-à-dire à partir du discours compris comme le discours du film ou de son narrateur). Cela est dû au fait que la voix s'articule également, dans un film, au plan matériel du son en tant qu'objet. En d'autres termes, si la voix peut prendre la place du sujet de la narration, c'est parce que, lors de l'articulation entre le son (plan de l'expression matérielle) et les signes de la parole (plan du contenu signifié), la voix a tendance à se offusquer en tant qu'objet. En fait, les techniques de capture, d'édition et mixage des sons traitent la voix d'un film de manière à souligner son rôle de porteuse du discours signifiant, au lieu de souligner son caractère sonore en tant qu'objet lui-même.

Néanmoins, une telle dissimulation n'est pas totalement réussie, car la voix renvoie sans cesse l'élément discontinu du sens à la continuité matérielle qui l'englobe et le contient, à travers un enchantêment presque musical, susceptible de rompre avec les limites du discours, et également avec celles du cadrage visuel. Dans cette mesure, une narratologie appliquée au cinéma est insuffisante pour sa compréhension, car c'est d'une telle disjonction fondamentale entre le continu et le discontinu qui dérive le processus génératif du sens au cinéma.

Cela s'articule à partir de la double disjonction audiovisuelle entre les images et le regard, d'une part, et entre l'écoute et les sons, d'autre part. C'est-ce que nous appellons la composante génératrice du sens au cinéma. Dans cette double articulation disjointe du regard à l'écoute et de l'image au son, le dispositif cinématographique mimétise la possibilité de l'expérience humaine en tant que telle, surtout d'une expérience capable de soulever ou non la question de sa propre signification. Il y a un court texte de Kafka qui nous permet de penser à la composante génératrice du cinéma. Ce n'est peut-être pas un hasard s'il s'agit d'une variation narrative autour de l'épisode homérique sur les sirènes et leur chant, ainsi que sur Ulysse et son écoute.

\section{Le silence des sirènes}

Le texte de Kafka, connu sous le nom Le silence des sirènes, s'offre au lecteur comme une variante du récit homérique. Kafka, dans sa variation «midrashique» du récit homérique, nous a fourni une allégorie parfaite de la composante génératrice du cinéma, qui sera appréhendée comme un dispositif audiovisuel. Tout comme Blanchot a fait d'Ulysse un paradigme pour la 
composante générative du récit littéraire en Occident, Kafka a fait de son Ulysse un paradigme pour la composante génératrice audiovisuelle du cinéma. Selon Kafka, Ulysse a mis de la cire dans ses propres oreilles et a fait face au chant des sirènes avec une intrépidité naïve, car celles-ci, à leur tour, "ont une arme plus terrible que leur chant: leur silence» (KAFKA, 1998: 209). Ce n'est pas au chant des sirènes qu'Ulysse a dû s'affronter, mais à son absence. Ulysse a dû vaincre le charme muet des sirènes pour revenir d'une rencontre abyssale avec le plus oppressant des silences - le silence provenant du son consideré en tant qu'objet dépourvu de sens.

Cette absence de sens est du à la présence du son comme tel: "la rupture, la fente, le trait de l'ouverture fait surgir l'absence - comme le cri non pas se profile sur fond de silence, mais au contraire le fait surgir comme silence" (LACAN, 1973). Ulysse n'entend pas ce silence, et cela lui permet de passer indemne devant les sirènes, en résistant au regard que lui est adressé. De la même façon, le spectateur d'un film muet ignore l'absence des sons. Ainsi, Ulysse reconfigure-t-il, dans l'expérience de l'écoute, la fascination suscitée par ce regard, confirmant le caractère audiovisuel de l'expérience cinématographique «muette», à partir notamment de la position du spectateur/auditeur et non du narrateur.

Dans sa version du récit homérique, toutefois, Kafka ajoute une dernière variante de cette rencontre entre Ulysse et les sirènes, permettant de réfléchir à la situation du spectateur/auditeur d'un film sonore. Tout comme celui-ci peut entendre divers sons dans un film sans réellement les écouter, Ulysse, astucieux, aurait perçu le silence des sirènes, mais faisant semblant de ne pas l'entendre: «et il s'est opposé à eux et aux dieux, comme une sorte de bouclier, à la tromperie susmentionnée» (KAFKA, 1998: 209). L'Ulysse de Kafka met en scène ainsi la suspension de l'incrédulité qu'un film exige de son spectateur: les sirènes avaient-elles chanté ou gardé le silence? Et, dans les deux cas, Ulysse aurait-il entendu leur chant/leur silence, ou non?

Si le texte de Kafka est indécidable sur la vraie nature des sirènes et de leurs chants, il nous laisse aussi indécis sur l'attitude réelle d'Ulysse en tant que spectateur et auditeur. Dans ce vide minimal dans lequel l'écart entre le son et le silence est réduit, se trouve précisément le principe de l'a-synchronie audiovisuelle, auquel Ulysse est confronté dans la variante kafkaïenne de cette histoire. Cela remet à une réinterprétation allégorique de la position paradoxale dans laquelle le spectateur/auditeur d'un film est placé par rapport à la composante génératrice du dispositif cinématographique. Une telle position n'est pas simplement celle d'une attitude d'identification passive ou imaginaire à une instance narrative/d'auteur implicite dans le discours cinématographique, même si elle n'exclut pas nécessairement cette possibilité. II s'agit plutôt d'une attitude douteuse, provoquée par un silence doublé. 


\section{Une double articulation du silence}

Il y a au moins deux types de silence différents à considérer au cinéma: le silence qui précède ou succède aux signes de la parole (corporelle ou vocale, sonore ou visuelle) et le silence inaudible du son, compris comme un objet mûr de vibrations potentiellement importantes, toujours contenues dans son propre mutisme. Le premier silence est le silence de la pause qui élargit l'expression, le silence de la parole et du geste, lié au rythme de la phrase et au compas de la musique; c'est le silence lié au sens, un silence signifiant. Ce sens du silence cache, néanmoins, un deuxième silence, bruyamment inaudible et a-signifiant, situé en dessous de tout sens.

Edvard Münch, dans son célèbre tableau Le Cri, présente une expression visuelle du double silence comme la superposition de deux plans distincts: au premier plan, l'expression qui visualise le cri muet comme potentiellement signifiant et, à l'arrière-plan, le confinement du matériau sonore par les limites de l'image, dans laquelle l'espace lui-même est envisagé comme une sorte de coque acoustique inversée, où le cri et le visage qui l'émet sont entièrement absorbés par un autre silence encore plus grand. Le silence de ce tableau traduit l'a-signifiance de la vibration sonore étant comprise comme perturbation mécanique de la matière. La composante génératrice du cinéma est déjà pleinement révélée dans ce tableau, contemporain de l'invention du cinématographe. Dans la mesure où les deux plans visuels de ce tableau présentent le double silence comme un objet et du regard et de l'écoute, la question des relations entre ce qui est " à l'intérieur » et ce qui est " à l'extérieur » de son cadre (entre la limite et son absence, entre le continu et le discontinu) révèle un problème, non exclusivement visuel, même si son expression matérielle se présente comme telle.

Dans I'histoire du cinéma, l'exemple plus emblématique de la double articulation du silence, comme condition de possibilité et d'impossibilité d'une écoute à travers l'œil, se trouve dans La Passion de Jeanne d'Arc, de Carl Dreyer (1928). Dans ce film, il y a un très court moment où la protagoniste, après avoir été attachée au poteau où elle sera brûlée, s'exclame devant une petite foule rassemblée autour d'elle: "Serai-je avec vous ce soir au paradis? ». Ceci est immédiatement suivi d'un plan admirable d'un nouveau-né qui, en train d'être allaité, interrompt son activité de succion pour regarder Jeanne d'Arc comme si'l l'avait entendue, retournant ensuite, avec un air d'indifférence, au sein de sa mère. L'enfant venait-il d'entendre une voix et de réagir à son son, ou avait-il compris, à cause de son innocence "paradisiaque", la prière de Jeanne d'Arc? Ou bien l'enfant ne regarda-t-il dans cette direction, et à ce moment-là, tout simplement comme par une étrange coïncidence? Bien que le sens d'un tel plan soit délibérément ambigu et ouvert à de multiples lectures, de telles hypothèses interprétatives supposent la double articulation d'un silence qui 
n'apparaît lorsqu'on regarde l'écoute d'une supplication, en même temps qu'on écoute le silence d'un regard.

Dans La Chute de la Maison Usher, de Jean Epstein, de la même année 1928, le double silence qui révèle la composante génératrice du cinéma est directement énoncé par les pages d'un immense livre: "Il y a un silence double; l'un est le silence corporel; ne le crains pas. Mais, si quelque urgente destinée te fait rencontrer son ombre, elfe sans nom qui hante les solitaires régions que ne foule aucun pied humain, recommande-toi à Dieu!" Dans l'ombre du silence du corps, il y a le silence vertigineux d'un contenu continu et illimité, immergé dans sa propre absence de forme. Dans ce film, la tension qui s'articule entre les sons qu'on peut supposer et les images qu'on peut voir (le long d'une reconfiguration incessante des multiples oppositions qui s'établissent entre l'intérieur et l'extérieur du cadre, le visible et l'invisible, l'audible et l'inaudible) projette le dispositif cinématographique. Cela renvoie, d'une façon auto-réflexive, à une cinématique de la perception audiovisuelle.

Dans cette cinématique, la médiation entre le film et le spectateur, représentée par les signes du discours cinématographique, est constamment menacée par la contagion mimétique provoquée par le regard en tant qu'objet (LACAN, 1973) et/ou par l'écoute en tant que écoute réduite (CHION, 1990). De la surface presque visible du vent, qui tout au long du film distrait et perturbe incessamment les corps et les objets, aux violentes perturbations «magnétiques» et vibratoires qui animent le corps de Lady Usher, culminant dans sa crise de catalepsie et la "résurrection» qui s'ensuit, Epstein module le plan visuel des images au ralenti. De cette manière, il dévoile les variations d'un flux d'intensités et de durées qui, en tant que telles, ne sont pas représentables et ne veulent rien dire, mais qui menacent de déborder l'écran à partir d'un tourbillon de mouvements et de vibrations qui plonge le regard dans l'image, d'où s'arrache un plan "sonore», duquel de multiples objets-sons pénètrent l'image dans toutes les directions. A l'inconscient optique, déjà théorisé par Walter Benjamin, Epstein ajoute un inconscient acoustique. Et tout comme les images recouvrent ce regard-objet, dont parlait Lacan, sous les mille et un déguisements de l'expression visuelle, les sons - entendus comme des signifiants - recouvrent également les innombrables objets sonores qui se présentent à l'ouïr, mais pas à l'écoute. Cela reste évident quand le cinéma trouve ses limites, selon les besoins du spectacle audiovisuel.

L'objet-son et le regard-objet résultent de la réduction, au sens phénoménologique du terme, de la composante génératrice du cinéma à sa double articulation audiovisuelle. Le regard, considéré comme un objet, est l'inverse de l'image comprise en tant que signe, ainsi que la perception du son en tant qu'objet est l'inverse de l'écoute comprise comme la compréhension du sens. Une même relation disjonctive avec le signe articule donc le regard à 
l'écoute, par le biais de la vision et de l'audition.

Cependant, il n'y a pas de correspondance entre la désubjectivation du regard et la désubjectivation de l'écoute, seulement l'isomorphie d'une disjonction. Tandis qu'une écoute réduite révèle immédiatement la matérialité objective du son comme bruit ou vibration mécanique dérangeant la compréhension du sens, l'œil, seul, de la caméra peut dévoiler la matérialité du regard-objet sous-jacent aux images. D'où l'extrême importance, dans le domaine de l'audible, de la sémantisation de l'écoute, car celle-ci est très sensible au dévoilement du son en tant qu'objet, c'est-à-dire en tant que plan matériel qui soutient l'expression du sens, musical ou verbal. Autrement dit, l'image acoustique (ou sonore) est d'une constitution beaucoup plus fragile que les images visuelles - et c'est exactement pour cela que l'œil mécanique de la caméra est le seul a être capable de révéler pleinement le regard-objet, obscurcit par l'image, quand elle est perçue comme un signe inséré dans une séquence narrative.

\section{La composante générative du cinéma}

On est là face à la clé de la composante génératrice du cinéma, qui ne peut être considérée comme une simple opposition binaire, convergente ou divergente, des images aux sons ou d'une séquence visuelle à une bande sonore. Il s'agit plutôt d'une relation doublement articulée, qui engage à la fois le champ du visible et le champ de l'audible dans la disjonction entre un plan de contenu et un plan d'expression (ouir/écouter, voir/regarder). La manière dont ces deux plans s'articulent est cependant fondamentale, car on ne doit pas simplement attribuer la fonction expressive à un champ (disons, celui de l'image), où la fonction du contenu signifié à l'autre. Dans la génération audiovisuelle du sens, la dichotomie entre plan de contenu et plan d'expression traverse à la fois le champ du visible et le champ de l'audible.

Dans la mesure où ces deux champs présupposent, par inversion, l'invisibilité du regard-objet et l'opacité des objets sonores, la composante génératrice du cinéma peut être conçue comme um carré sémiotique dans lequel l'axe du contenu audiovisuel (signifié) est constitué par l'articulation signifiante des images à l'écoute dite sémantique (CHION, 1990), tandis que l'axe de l'expression (matérielle) s'articule par l'asynchronisme inhérent à la relation entre la bande visuelle du film et sa bande sonore: 


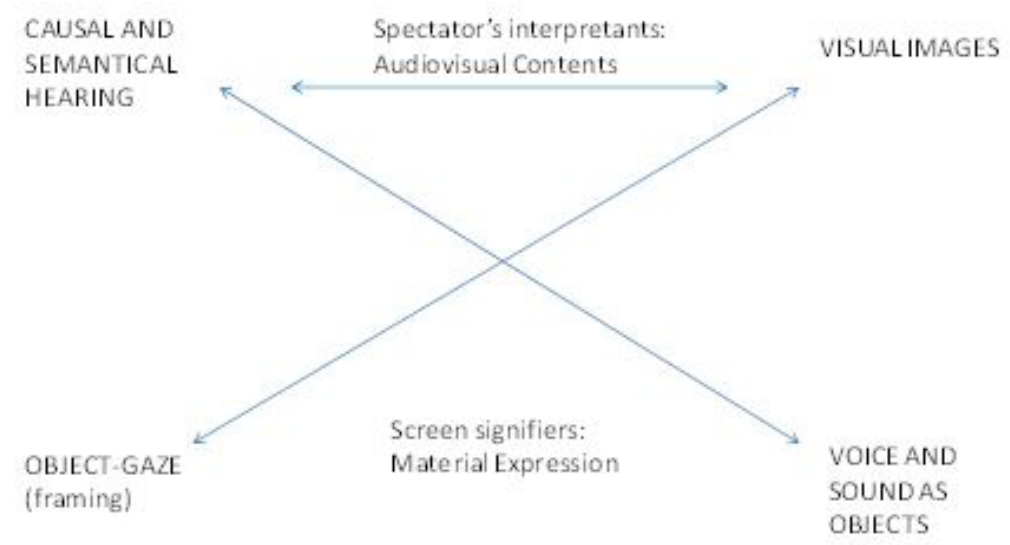

FIGURE 1 - Composante générative du cinéma

La flèche horizontale qui relie les images visuelles à l'écoute (causale et sémantique) constitue le plan de contenu audiovisuel signifié par le film, qui devra être décodé par ses spectateurs/auditeurs avec l'aide de leurs intépretants. Le plan de l'expression matérielle est situé sur le côté ouvert du carré, sans ligne d'articulation horizontale, car il n'y a jamais de correspondance pré-établie entre les signifiants visuels et sonores d'un film. En fait, dans un film, les images et les sons sont enregistrés, édités et traités séparément, y compris au moment de la projection. C'est juste son contenu audiovisuel qui apparaît, pour ses auditeurs/spectateurs, comme un champ unifié de visibilités et de sonorités ; ceux-là, idéalement, ne doivent pas percevoir le truquage technique qui relie la bande sonore et la bande visuelle d'un film.

Les flèches diagonales indiquent la double relation d'inversion entre l'image et le regard, l'écoute et le son, telle qu'elle a été montrée plus haut. Puisque l'image est le champ de signification du visible, le regard, en tant qu'objet, se situe précisément à son inverse, comme condition d'(in)visibilité, ce qui, au cinéma, s'identifie aux successifs (re)cadrages permis par la caméra. Le son, également perçu comme un objet, se situe à l'inverse de l'écoute, perçue comme une écoute causale/sémantique, c'est-à-dire l'écoute de ce qui, dans le domaine de l'audible, se prête au sens. C'est bien pour cela que l'écoute et les images visuelles sont reliées par la flèche horizontale qui indique leur implication mutuelle dans la génération des signes et des figures (verbales, visuelles, sonores), constituant ainsi le texte audiovisuel d'un film. On retrouve là le rôle de la voix comme objet audiovisuel par excellence, car c'est exactement son articulation - et aux images et aux sons - qui permet d'établir un champ unifié 
(imaginaire) apte à générer le sens d'une expression audiovisuelle quelconque.

Le nom technique de cette articulation est synchronisme. Le fait que l'écart historique entre le cinéma muet et le cinéma parlé soit essentiellement dû à l'échec des tentatives précédentes de synchronisation de l'image avec le son, ne veut pas dire que le diagramme de la composante génératrice de l'audiovisuel, concerne seulement les films sonores. En effet, dans n'importe quel film, la présence de la parole et du silence, ainsi que d'autres types de sonorité, est une caractéristique intrinsèque de ses contenus signifiés, qu'il soit muet ou non. Ce n'est que lorsque le silence des films muets devient flagrant que le caractère audiovisuel du cinéma - et pas seulement visuel - se révèle, tout comme ce n'est qu'avec l'émergence des films sonores qu'un cinéma du silence, comme objet d'écoute, devient possible.

\section{Le principe de l'asynchronisme revisité}

La composante audiovisuelle générative du cinéma ne dévoile, qu'en ce moment-là, le principe moteur de son dispositif: le principe de l'asynchronisme. Celui-ci consacre la disjonction isomorphe du plan de l'expression au plan du contenu (image/regard; écoute/son), au lieu de la simple correspondance entre le synchronisme labial et la synchrèse audiovisuelle. Alors que celle-ci ne remet qu'à un principe purement mécanique de détermination causale de la synchronie image/son (ou, du moins, d'une correspondance conventionnelle, même si par contraste ou contrepoint, entre les deux termes), le principe d'asynchronisme est machinique, puisqu'il articule - dans deux plans simultanés mais distincts - le synchronisme des bandes visuelle et sonores, au niveau technique, et la synchronie sensorielle des images aux sons, au niveau esthétique. C'est le principe de l'asynchronisme qui démarque les lignes de suture ou de césure, de soudure ou de fracture qui parcourent les différentes couches d'image et de son qui composent le film, afin de les combiner et/ou les disjoncter, selon les besoins du discours cinématographique.

Le principe de l'asynchronisme ne constitue pas, simplement, le contraire du principe du synchronisme, mais il marque son inverse. C'est-à-dire, il ne propose pas la synchronie asynchrone comme alternative esthétique, ou comme un nouveau langage expressif, mais permet, en même temps, la synchronicité et son absence, la conjonction et la disjonction audiovisuelle, en associant et/ ou dissociant les images et les sons, pour mieux jouer simultanément avec les éléments du plan de contenu et du plan d'expression. D'ailleurs, c'est bien cela qui fait que la composante audiovisuelle générative du cinéma soit radicalement différente de celle liée à ses prédécesseurs illustres, le théâtre, l'opéra, la danse.

En effet, ces différents modes d'articulation audiovisuelle du dispositif cinématographique, alternent d'une part continuités et discontinuités, le synchrone et l'asynchrone, mais également l'intérieur et l'extérieur du cadre, le 
diégétique et l'extra-diégétique; d'autre part, ces modes de jonction dénotent et connotent des nappes de significations à partir de la double articulation entre un cadre visuel délimité, mais ouvert, et une bande sonore non dépourvue de limites, mais sans cadre défini. Ce manque de correspondance dans la corrélation entre l'image visuelle et la bande sonore peut être temporaire ou permanent, partiel ou total, et peut également être postulé, de façon autoréflexive, comme règle de corrélation.

La voix, en tant qu'objet d'une synchronisation précise avec un corps, nous permet d'articuler l'écoute aux images en regardant un visage qui parle. La synchronisation labiale, c'est-à-dire la conjonction d'une voix avec un visage, se présente ainsi comme l'expression audiovisuelle hégémonique qui voile la disjonction asynchrone du regard à l'écoute. Dans ces processus, des lignes et des marques d'expression, encore préformées (optiques et acoustiques), seront captées par le film, compris alors comme support matériel des images et des sons. La composante audiovisuelle générative du cinéma est ainsi configurée de manière conventionnelle et réductrice, dans la plupart des films effectivement produits. En effet, on prend pour évident, en général, la correspondance audiovisuelle de la piste sonore à la bande visuelle comme un circuit fermé de sens, garantie par le synchronisme labial. Celui-ci permet d'attacher les voix aux visages et aux corps pour mieux oblitérer la nature objectale du regard et de la voix, masquant leur absence d'une relation réelle. Pour le spectateur/auditeur, le principe de l'asynchronisme en tant que composante génératrice du cinéma ne se révèle que sous la forme inversée du synchronisme, qui régule le flux de projection tout en garantissant le sens du contenu audiovisuel signifié.

En conséquence, le synchronisme n'est que la forme d'asynchronisme la plus courante, celle d'une identité réinscrite dans la différence comme mode disjonctif de sa propre fondation. L'identité du contenu audiovisuel d'un film s'oppose, donc, à la réelle différence qui constitue son expression matérielle. On ne peut entrevoir son émergence que dans la distinction imperceptible entre un objet et son double, et dans l'indécidabilité inhérente au signe audiovisuel ainsi constitué.

De l'ambiguïté portée par le contenu signifié d'un film, on passera à I'indécidabilité structurelle qui caractérise le principe de l'asynchronisme, comme principe moteur de la composante génératrice du cinéma. Cette indécidabilité n'est pas liée au sens plus ou moins ambigu des signes dans le plan du contenu signifié, mais à une oscillation constitutive de tout objet audiovisuel, dans son propre plan d'expression matérielle. Cela se réalise, non à partir d'un modèle de référence visuel, sonore ou littéraire qui permet d'attester sa vérité ou sa fausseté par rapport au monde réel, mais comme le simulacre d'une réalité qui se présente ostensiblement comme récit.

Bref, le principe de l'asynchronisme n'est pas une option esthétique 
parmi d'autres, encore moins le «vrai» langage spécifique du cinéma. C'est le contraire justement : un principe génétique de composition audiovisuelle (la composante générative du cinéma) qui dévoile la corrélation entre deux processus asymétriques, voire laisse paraître la double articulation d'un plan de contenu audiovisuel dans sa relation avec un plan d'expression matérielle. Il ne s'agit pas seulement du principe technique de synchronisation des sons aux images, ni de la synchronie comme principe esthétique de la composition audiovisuelle, mais les deux éléments à la fois, dans leur corrélation disjointe, et de l'indécidabilité structurelle extraite de cette différence imperceptible, mais comprise comme intervalle ou oscillation entre un objet et son double.

En conclusion, on peut affirmer que la dualité Ulysse/Achab permet de penser le cinéma, non à partir de problématiques issues de l'univers esthéticolittéraire de la représentation, comme le rôle du narrateur et/ou de la voix narrative dansl'énonciation, mais au vu de ce quel'expérience cinématographique présente de plus particulier, c'est-à-dire la double disjonction du regard et de l'écoute. Devant l'écran, nous nous trouvons comme Achab devant la baleine Moby Dick, plongés dans la monstruosité d'un regard inhumain. Face aux sons, nous agissons comme Ulysse devant les sirènes et leur chant, prenant de la distance, la plus sûre, de l'écoute. C'est pour cette raison que le contraste entre Ulysse et Achab est aussi une disjonction entre le regard ( $d$ 'Achab) et l'écoute (d'Ulysse): "On ne peut nier qu'Ulysse a un peu entendu ce que Achab a vu, mais il s'est tenu ferme à l'intérieur de cette écoute, tandis qu'Achab était perdu dans l'image. Cela signifie que l'un a refusé la métamorphose, dans laquelle l'autre est entré et a disparu » (BLANCHOT, 2005: 10-11).

Dans I'histoire du cinéma, Ulysse et Achab se présentent, donc, comme les pôles antithétiques du même devenir en disjonction, le devenir audiovisuel du film. Celui-ci oscille constamment entre le naufrage (d'Achab) et la traversée réussie (d'Ulysse), mais il s'avère, en général, plus favorable à la position d'Ulysse - du moins lorsqu'on considère les conditions de la spectatorialité comme aussi pertinentes par rapport à la composante génératrice du cinéma, que les conditions d'énonciation du récit cinématographique. Pour le spectateur d'un film, si le naufrage ne doit jamais être complet, la victoire sur le chant des sirènes ne peut pas non plus être totale. Même le plus conservateur des films d'aujourd'hui mène le spectateur/auditeur à traverser une série de perturbations visuelles et auditives d'un caractère hallucinatoire, dans un tourbillon écrasant d'images et de sons qui le frappe et le submerge physique et psychiquement, pour, ensuite, lui ramener à la normativité narrative classique. Dans le cinéma actuel, Ulysse remporte toujours sur les sirènes, mais à condition de survivre aux tourments et aux délices de l'expérience d'Achab.

On voit alors qu'il est possible de placer la composante générative du 
cinéma sous le signe d'Ulysse, tant qu'il ne soit pas perçu comme l'Ulysse d'Homère/Blanchot, voire comme le conducteur d'un récit reconfiguré d'une forme transmissible. Cet Ulysse là n'est simplement opposé à Achab, en tant que principe ou emblème allégorique, mais il constitue un "Ulysse-Achab ", capable de se confronter au tourbillon écrasant des images et des sons, et en sortir indemne. En effet, il traverse la mer de l'audiovisuel pour arriver à bon port.

Cet Ulysse-Achab oscille en permanence entre le regard et l'écoute, la durée et l'instant: durée du chant des sirènes comme événement (pas nécessairement narratif, mais diégétique) dans lequel le regard s'enfuit dans la mise en abîme du sens/non-sens, moment inintelligible d'un flagrant (pas nécessairement signifiant mais mimétique) dans lequel l'écoute capture la différence entre le silence et l'inouï, comme le moment indécidable de la défaite et/ou de la victoire sur la mort.

\section{Bibliographie}

ALBERA, François. 2011. Munch cinéaste, l'Amateur Récalcitrant. In: LAMPE, Angela; CHÈROUX, Clément (orgs.). Edvard Munch - L'Oeil Moderne. Paris: Centre National d'Art et de Culture Georges Pompidou, p. 183-190.

BLANCHOT, Maurice. 2005. O Livro por Vir. São Paulo: Ed. Martins Fontes.

CHION, Michel. 1990. L'Audio-vision, son et image au cinéma. Paris: Éd. Armand Collin.

LACAN, Jacques. 1973. Les Quatre Concepts Fondamentaux de la Psychanalyse, Le /Séminaire, Livre XI. Paris, Éditions du Seuil.

PARENTE, André. 2000. Narrativa e Modernidade - Os Cinemas não-narrativos do Pós-Guerra. Campinas: Papirus Editora.

PASOLINI, Pier Paolo. 1976. L'Expérience Hérétique - Langue et Cinéma. Paris: Payot.

ZISCHLER, Hans. Kafka vai ao Cinema. 2005. Rio de Janeiro: Jorge Zahar Editor.

WELLBERY, David E. Neo-retórica e Desconstrução. 1998. Rio de Janeiro: Ed. UERJ. 


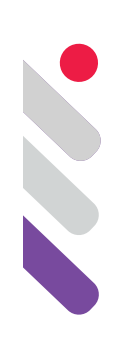

\title{
What's in the name live cinema?
}

DOI: 10.24308/IASS-2019-4-011

\author{
Marga van Mechelen \\ University of Amsterdam, The Netherlands \\ m.k.vanmechelen@uva.nl
}

Live Cinema is a complex, syncretic sign system. It is the name of a branch in audiovisual art that is now used for almost twenty years (Van Boven 2019). ${ }^{1}$ It is related to VJing but there are a few significant differences. Differences concerning the preference of platforms, the spatial disposition of the artist(s) and the audience, the experience of the event as such, authorship, intentionality and autonomy, and all that has to do with new technological developments. ${ }^{2}$ Besides being positioned in relation to VJing it will in this text also be placed in the tradition of one of the first interdisciplinary multimedia electronic art works: Edgar Varèse's Poème Electronique (1958).

\section{Video Art (VJ)}

Video art created by Video Jockeys (VJs) has its roots in the club scène of the eighties and nineties and was born out of a feeling of necessity considering that DJing was poor visually and the House and Techno music quite monotone (Dekker 2005, Faulkner 2006, Van Mechelen 2006, Turco 2014). Both asked for something more spectacular, namely visuals. The VJing to a certain extent was considered as the visual counterpart of DJing, though DJ's usually had and still have a much higher status. ${ }^{3}$ The DJ stands in front of an audience and communicates directly with the audience, the VJ (if visible at all) generally is faced to the screen. In the Netherlands a couple of foreigners gave VJing an important impulse at an early stage. As for example the video pioneers Steina

\footnotetext{
${ }^{1}$ Van Boven (2019) does not mention a particular year, but in 2000 Live Cinema was an established genre already.

${ }^{2}$ Van Boven (2019) mentions:visual programming languages as Max / MSP,

Pure Data and sound software for audio synthesis and live sonic performances such as MetaSynth, 1 SuperCollider 2 and LiSa, 3 software developed by STEIM.

${ }^{3}$ See for the competition between the DJ and VJ Van Mechelen 2006.
} 
and Woody Vasulka ${ }^{4}$ and Peter Rubin in particular, who came to Amsterdam in the 1970s and became between 1979 and 1988 the designer and director of the Amsterdam ultra-hi-tech multimedia club Mazzo. Two decades later Peter Greenaway gave an important boost to the status of VJing and the application of new technological devices. He entered the field in 2005 when he did his first VJ performance in Club 11 in Amsterdam. ${ }^{5}$ In his performance, he stood behind a desk with a giant touchscreen, divided in blocks at an angle of approximately 45 degrees to the front. He was not faced towards the audience. In fact, he took more the spatial disposition of a conductor, though not as central and at the edge of the stage. Both this disposition, the impressive touchscreen and not to forget his stature were important signs of a new status. Greenaway's cinematographic imagery were stored in 800 loops and came from his Tulse Luper Suitcases movie of 2003; the music from DJ Radar. For four years he toured with this VJ performance around the world, presenting it in theaters, concert halls, opera-houses, museums, open squares etc. He opened new and more doors.

\section{Live Cinema}

Live Cinema in general is more horizontally organized. Usually there is a big screen in the center of the stage, while the performance is carried out by different parties, dispersed over the stage what indicates a more equal role for every performer. In general the performers are standing behind a wide range of devices facing the audience or the other persons on the stage. Although the program and credits usually give a suggestion of who is the leading or creative artist, he is not always instantly recognizable by his disposition. Also the platform of Live Cinema, both physically and conceptually, is a different one. Live Cinema artists searched for platforms other than the club scène avoiding if possible the battlefield of DJ and VJ and the commercial DJ culture (Van Mechelen 2006). ${ }^{6}$ They usually perform in the setting of a concert hall at festivals or more traditional theaters. There are more differences as for example the construct of authorship and a sense of autonomy. In the club scene the branding of both the DJ and the VJ defines their authorship, requiring the identification of a particular "style", where in Live Cinema branding seems to be less important, at least less identifiable.

\footnotetext{
${ }^{4}$ On the occasion of Wonderwall, an exhibition in the early 2005s in the Nederlands Instituut voor Mediakunst (Netherlands Institute for Media Art), Woody Vasulka relates his and Steina's move to Amsterdam both to the fruitful creative environment of the Netherlands ("the Mekka for the arts") and their aversion against the US. Around that time the symposium and contest Visual Sensation put the discussion of VJing on the agenda.

${ }^{5}$ NOTV was founded that year and kicked off with Peter Greenaway's Tulse Luper VJ Performance in Club 11.

${ }^{6}$ Even before the famous Dutch VJ's came to the stage (Tiesto, Armin van Buren and Martin Garrix) this inequality was strongly felt by the $\mathrm{VJ}$.
} 
Instead the performance is considered as the result of more flexible forms of cooperation and a temporary phase in new technological developments, even as an experiment. ${ }^{7}$ It puts more emphasis on how the audiovisual performance is composed and diverse technologies are applied. In another respect however there is a common ground. Both their audiences expect in the end an immersive experience; staging and performing are an integral part of it. This makes the differences between VJ and Live Cinema in practice often more fluent. These characteristics influence spectatorship both in VJing and Live Cinema. Live Cinema is attractive for a public that is involved in or at least familiar with modern technologies and is curious to experience something different from the daily, preconceived digital media. In VJing the public comes primarily for the music. Live Cinema that still has the attraction of entertainment, offers also the undefined, even the promise of a mystery that might be revealed during the performance. The traditions of both performance and video art, and expanded cinema (Youngblood 1970) is modelling its position.

It is clear from these descriptions that an approach of Live Cinema has to start from the event, the experience of hearing and seeing. As Lozano (2014) and others have argued, cognitive semiotics has a lot here to say, incorporating the insights of phenomenology and cognitive sciences. For semioticians and other theorists the name of Live Cinema at first sight is a paradoxical name. It refers to its live character, that is to say to an event that is never the same and therefore once only, but it also refers to cinema, an art form that is endlessly repeatable. Although this last characteristic of film does not count for Live Cinema, the screen is, at least until this day, central to Live Cinema. To conclude, Live Cinema operates in or between different domains, and though it is considered a media art form, it seldomly is presented in the white box of a museum space. ${ }^{8}$

\section{Poème Electronique (1958)}

Before continuing a semiotic approach of Live Cinema, I first want to go a bit deeper into one particular history of an interdisciplinary audiovisual production, namely Poème Electronique that premiered at the World's fair in Brussels in 1958, in a special designed pavilion. It started when Louis Kalff, the General Art Director of Philips Industries Eindhoven, asked the Swiss architect Le Corbusier to build a pavilion for the World's Fair in Brussels, an environment for a magnificent show, resulting in a synthesis of sound and light effects, and meant to illustrate the imago of Philips. Le Corbusier accepted the commission with the words: "I will create an electronic poem". "Everything will take place

\footnotetext{
${ }^{7}$ This especially counts for the early years of Live Cinema. Van Boven mentions the $Q$ \& $A$ sessions after the performances and workshops in which the audience could take part. ${ }^{8}$ Of course Live Cinema performances can be used by museums to listen up an opening of an exhibition.
} 
in the interior - sound, light, colour and rhythm". (Sofia 2001) He asked lannis Xenakis, who we know as a composer, but who also was an engineer, to make a mathematical "translation" of his sketches. ${ }^{9}$ And he approached the composer Edgard Varèse. Varèse, who was born in France in 1883, had lived most of his life in New York and is considered to be one of the precursors of electronic music, though Poème Electronique was the only electronic piece he composed. ${ }^{10} \mathrm{He}$ started working in the laboratories of Philips in Eindhoven and the composition immediately got the form of three tracks of organized sounds on magnetic tape (Varèse 1959). ${ }^{11}$ Varèse used different sound sources, real musical instruments, machine noise and synthetic sounds. When the pavilion was ready, he put 425 loudspeakers all around while Le Corbusier projected a film mainly consisting of black and white stills, and a variety of colours and visual effects on the walls. ${ }^{12} \mathrm{An}$ immersive installation was intended, an experience of architectural and sound design and a synchronization of music to graphic visuals, at the basis of which laid mathematical and scientific methods. Just to give you the most cited experience of Poème Electronique: "One no longer hears the sound; one finds oneself in the heart of the sound source. One does not listen to sound, one lives it". ${ }^{13}$ This indeed expresses the idea of immersion, of deep listening and an integration of musical and visual elements. ${ }^{14}$ Translation ánd integration. The name "Poème Electronique" already points to what Le Corbusier had in mind right from the start: modern technology applied on something that should feel like a poem. The use of an implicit comparison, in this case "poem", is not exceptional. Words that have a metaphorical meaning are often used to express the unknown by what is better known. Reviewed in the press as a grandiose canonical work, music critic called it at the same time "a grandiose failure" (Vermeulen 1984) because sound and image were finally not synchronous. The composition was rather primitive and there was hardly any relation between sound and images

\footnotetext{
${ }^{9}$ Kalff had Benjamin Britten in mind - Varèse was hardly known in the Netherlands. The general opinion is that finally the share of Xenakis was much more important than that of Le Corbusier (Lootsma 1984). Xenakis first composition date from 1950, his first electronic composition from 1957-58.

10 Already for Déserts (1954-1961) he used electronics but not in a satisfying way (Schönberger 1984 and Hering 2009). Twelve years old he composed an opera about Jules Verne, a sign of his interest in space, time and the future. The history of Poème Electronique is well documented and analysed in a number of essays collected by Willem Hering and Lieven Bertels (2009).

11 The Natlab (physics laboratory) of Philips was famous for the early development of colour tv as well as the music of the future; Dick Raaijmakers and Henk Badings a.o. worked here.

12 See for the reconstructions of this installation Lootsma (1984), Sofia (2001) and Taselaar (2013).

${ }^{13}$ The source is not clear.

${ }^{14}$ The concept of 'deep listening' as applied in the arts, originates in the compositions, writings and program of Pauline Oliveros (1932-2016) in the mid-eighties.
} 
(Vermeulen 1984)..$^{15}$ However, it did not hold back the ideal of synchronization, that still exist, to this day. The endeavour could be named "synergetic", but in greimassian semiotic terms it is also a "syncretism". ${ }^{16}$ Though these three notions, synchronization, synergetic and syncretism, and not mentioned yet, "synesthetic", describe different things, the common particle "syn" is telling. While Poème Electronique is a key moment in the history of synergetic cooperation as well as a clear example of a syncretism of image and sound, it is not the milestone in synchronization it wanted to be. Live Cinema stands in this tradition, and believes to have reached the ideal of "visual music" (Van Boven 2019: 303), a synthesis of image and sound. ${ }^{17}$ How did the possibility of one "harmonious" experience came within reach? ${ }^{18}$ This will be discussed in the next paragraph. The Philips pavilion was pulled down after the World Fair and so there was no second live for Poème Electronique in its original form. Nevertheless two reenactments followed. In 1984 the ASKO ensemble took the initiative to make "a reconstruction/interpretation" of Varèse's work (Schönberger 1984) which was performed by the ensemble together with the Residentie Orkest, the Slagwerk Den Haag and the Circle Ensemble. In the concert hall they gave a suggestion of the space of the original pavilion using the original scenario of images and colours, translated by new technologies. Travelling sounds came not through the original 425 loudspeakers, but through 72 loudspeakers. Part of the project was also an exhibition in the Technical University of Eindhoven called Poème Electronique - Le Corbusier - Varèse - Iannis Xenakis (curator Bart Lootsma) where Xenakis gave a lecture on the day of the premiere. Decades later, six specialists in the field could not accept the ones onlyness. They decided to make a virtual reality reconstruction of Poème Electronique, what was considered by the initiators as the only way of bringing it to live again. ${ }^{19}$ They carefully migrated the old material with new technologies to a new presentation form and finally to a VR experience. It was finished in $2009 .{ }^{20}$ When it was ready, two eyewitnesses of the first and only

\footnotetext{
${ }^{15}$ It is important to remember that the (moving and still images) images of Poème Electronique were organized as a narrative, telling the birth and development of mankind. The images showed seven episodes, starting with Genesis and Dinosauria's, African statues of Gods, and ending in the twentieth century with concentrations camps, the atomic bomb and Le Corbusier's own architecture. It is compared with iconostases. The choice of the images might be influenced by André Malraux.

${ }^{16}$ It comes closes to the way it is used by Arjan van Baest (2000), where it concerns libretto and music in the opera.

${ }^{17}$ Roger Odin talks about l'ecoute filmique (film hearing); mentioned by Lozano (2014).

${ }^{18}$ I rather would like to avoid the word "harmonious" that is often used in this context, because it is too loaded with value.

19 These specialists came from four different universities, amongst them Kees Tazelaar. See Lombardo et all (2009) and Tazelaar (2013).

${ }^{20}$ In that year STRP Eindhoven organized a symposium around Poème Electronique. See also: https://www.youtube.com/watch?v=pOFAqVKVnA4.
} 
performance of 1958 were asked to undergo the VR experience. They described the reconstruction as realistic and a recalling of the original sensations. ${ }^{21}$ The main differences between Poème Electronique and Live Cinema, at least at first sight, are already mentioned. Other resemblances are obvious such as the mixing of concrete sound objects, the combination with the visuals and the role of technical devices. However, one thing is easily overlooked and that is the wish of keeping it in the hands of a limited number of people (creative artists), deliberately keeping musicians that interpret and translate the score out. What I left out in this summary of Poème Electronique is the role of Xenakis, who was chronologically speaking the second person involved in the project. He paradoxically got the order of "making a translation", with the adjective "mathematical" that points to a degree of objectivity and not subjective interpretation. Another reason to draw the attention to Xenakis is the position as such of the technician or better to say of technology as an actant.

\section{A breakthrough in audio-visual synchronization}

Synchrony of sound and image is put in a tradition that survived in Live Cinema. It is approached as a technological problem that has to be solved and is (almost) solved technically. However the idea is also part of a larger discourse about sound and image relations. In audio-visual art and Live Cinema in particular cultural background and intentions of the artists play a major role. Almost every biographical sketch of media and Live Cinema artists, written by critics or the artists themselves start with "where they come from". Not only for the purpose of a curriculum vitae but also to explain their position in and approach of either the audible (sound) or the visible (images). A Dutch artist duo in media art for example explained in an interview their position as follows: "When I (Salvador Breed) started to work with Nick (Verstand), he was coming from a visual standpoint while I was coming from a sound standpoint, but where we really found each other was in space itself" (Breed 2019). This quote that oddly enough brings Poème Electronique to mind again, explains not only what I said about background, but is also a good example of how artists and others give words to their purposes. Another example is Jaap Drupsteen, a notorious Dutch graphic designer who worked many years for several Dutch broadcast companies and put his mark on one of them in particular, the VPRO. The connection between moving images and sound always had his interest but synchrony in live performances became a new challenge to him in the late nineties. Together with his son Floris, he used the VJ platform for a while for his explorations, waiting for the moment in which measuring time in both music and video would become equal. ${ }^{22} \mathrm{He}$ often worked with composers of

${ }^{21}$ Though one can doubt if this information is reliable after such a long time.

${ }^{22}$ Traditionally music measures in beats per minute, in variable speeds, while video has (fixed) 
contemporary classic music to make the structure of the compositions better understandable by way of his visuals. The traditional concert hall as a rule is the platform for these performances. He is an interesting though exceptional example of an artist who contributed to the development of a very precise and fundamental synchrony. Another impulse came from the Dutch Live Cinema artist Tarik Barri who attended the Audio Design School of Music and Technology where he learned about sound synthesis, acoustics and programming. In his free time he developed interest in visuals. While he got a professional education in music technology, he was "an amateur" in relation to visual material. In one of his interviews he brought forward that he became addicted to creating his own synergies between music and visuals and that the next, important step was to create an audio-visual paradigm to show where the sounds were coming from; one mutual source for the audio and the visual. To reach this goal, he created Versum, an audiovisual composition tool that worked intuitively. "Like in a first person shooter game" (Vdovin and MacLeod 2011). Versum was able to "work" in real time and grow to a hybrid real-time tool, as he names it, for both purely visual purposes and for creating and performing 2D audio-visual compositions. Within this space he placed objects that can both be seen and heart, like in reality: the closer the camera comes in, the louder the sound. In the beginning it was all very basic, but he draw the attention of Monolake (Robert Henke), quite a well-known name in this world, and for the following years Barri became responsible for his visuals, so becoming his VJ, while developing Versum further. Also other artists used it and developed it further, often in close collaboration with Barri. Tools like this made it possible "to develop audiovisual compositions within the same data realm" (Van Boven 2019: 303). In more recent works he creates a 2D world which is seen and heart from the viewpoint of a moving camera that moves through space. It seems to anticipate future (3D) developments. Both Barri and another Dutch Live Cinema artist, Martijn van Boven, show us that new tools are more than mere instruments. They are an agency of meaning-making, an actant on the stage and by their capacity a cultural expression that is telling for the state of art in audio-visual media art. Working methods in this field changed by these tools. What is so crucial for Live Cinema in general is that due to the limited sustainability of the technology it is always in a state of development. The Live Cinema artist accepts this and explores it, by developing his machines and software in-between and even during the performances. Nothing remains the same. The battle of sound and image, the subject of a paper of mine in the early 2000s, became a battle on a deeper level, in the basic structural elements of the performance. Or as Martijn van Boven puts it: "The next

frames per seconds. Software for music was for a long time more advanced compared to video software. 
generation felt that the VJ had been constrained in his connection with the audience. New tools became available, that made it possible for this new generation of audiovisual artists to communicate with a variety of sensors, controllers, data input and complex data analysis to manipulate, modulate and generate audio-visual environments in real time" (Van Boven 2019: 302). ${ }^{23}$ Van Boven speaks about visual music and how this concept, as well as synaesthesia, became central in the Image and Sound department of The Royal Academy of Arts in The Hague in the early 2000s (Van Boven 2019: 303), both expressing the ideal of a multi-sensorial art and of the interrelations of the senses. Inspiration not only came from visual art and music traditions but also from (abstract) filmmakers such as Joost Rekveld, Oscar Fischinger, Norman McLaren and John \& James Whitney.

\section{Live Cinema: a challenge to a semiotics of the audiovisual}

In the last couple of decades, whether it concerns film or the performing or the visual arts, semiotics was mainly focused on the performance of these practices and how they were understood by the spectators. Since Christian Metz' Le signifiant imaginaire of 1977, the cognitive turn in (audio) visual semiotics in the nineties and the performative turn (Fischer Lichte 2004) a few years later, semiotics became interested in the performance at large and in spectatorship experience, meaning making and the interplay of the senses. Semioticians like Herman Parret with a background in philosophy, went back to phenomenology, to Merleau Ponty in particular and to epistemology. While Merleau Ponty speaks about the communication of the sensorial experiences in terms of touch and affect, the epistemological approach to Parret's view (1995) focusses more on the symbiosis of the experience itself as a product of the subject's imagination. Both the immersive experience and the creative force of imagination became a focal point to theorists, but not only to them, also to the artists, certainly in VJing and in Live Cinema. However these are not the only appeals to the audience. There is another intentionality at stake, which lays in the roots of Varèse's explorative electronic pieces and his approach of music, and can be summarized as " not an expression of emotions but an auditive report of a scientific investigation of sounds" (Calis 1984). ${ }^{24}$ Similar ideas we come across with Live Cinema artists. ${ }^{25}$ These can best be marked as

\footnotetext{
${ }^{23}$ When Van Boven (2019) talks about a next generation he has Dutch artists like Barri, Lucas van der Velden, Gideon and David Kiers of Telcosystems, Paulien Oltheten and Rosa Menkman in mind.

${ }^{24}$ This statement is of historical importance. More radical than Schönberg and Stravinsky as is confirmed by later composers such as Luigi Nono whose Promoteo-Tragedia dell'ascolto (1981/85) should be mentioned in this context. See Van Mechelen 1984 ('Reiziger tussen twee werelden. De Prometheus van Luigi Nono in première in Venetië'). Xenakis' purposes came to close to Varèse.

${ }^{25}$ Barri however does not shy away from emotions.
} 
the understanding of sound and image relations by showing and experiencing. Immersion and understanding might seem to be quite opposite to each other, and theoretically they indeed are, in practice however artists tried to bridge the gap. It is a challenge, in the first place to the artists, but in the end also to the spectator to relate to both. In order to bridge this gap, semioticians have to bridge another gap: that between the "new" semiotics of the performance and the "old" semiotics of "languages", in this case the concept and "language" of Live Cinema or of visual music.

The consequences of Live Cinema for an audio-visual semiotics are far reaching. It not only questions a semiotic approach in terms of "translation" of one "language" to another, it also makes the distinction between "music as a sign" and "the visual as (another) sign", that stayed afloat with other syncretisms (Van Baest 2000), more problematic. This does not imply that semioticians should mimic the vocabulary of Live Cinema too easily, and neither the metaphors of which we mentioned a few, nor the concept of visual music. Critical questions should surely be asked about this concept as well as about the usefulness and misuse of metaphors in these circles. Another question and of a different nature is: does the dominant direction of experiencing sound first and seeing the images or visuals second, remain in Live Cinema or is something else going on? I just want to point to the acoustically and visually positioning of the audience that has not changed so much in the last couple of decades and to the spatially structured sounds that still surround the audience, while in Live Cinema, like in most film projections, the visuals are forward oriented. This might change in the near future, however. Other consequences are strictly related to the significance of highly specialized tools in Live Cinema, like Versum, and their role of actant and cultural expression. ${ }^{26}$ These recent developments are waiting to be further investigated.

\section{References}

BREED, Salvador. 2019. https://salvadorbreed.com/Between-Mind-and-Matter (accessed 17 February 2020).

BOVEN, Martijn. 2019. Live Cinema. In Sanneke HUISMAN and Marga VAN MECHELEN. A Critical History of Media Art in the Netherlands. Platforms. Policies. Technologies. Prinsenbeek: Jap Sam Books, 302-313.

CALIS, Hein. 1984. Luisteren naar Edgar Varèses geworstel erg ontroerend. de Volkskrant Monday 13 February.

${ }^{26}$ A comparison with A.I can be made. 
CREVITS, Bram. 2006. The Roots of VJing: A Historical Overview. In Michael FAULKNER (ed.) VJ: Audio-Visual Art and Vj Culture. London: Laurence King, 14-19.

DEKKER, Annet. 2003. Synaesthetic Performance in the Club Scene, paper presented at the conference Cosign: Computational Semiotics. University of Teesside, Middlesbrough UK.

DEKKER, Annet. 2005. VJ Culture: A Phenomenon in History, Presentation, and Perception, http://www.vjcultuur.nl/vjculturereportEnglish.pdf (accessed 2 March 2020).

FISCHER-LICHTE. Erika. 2004. Ästhetik des Performativen. Frankfurt am Main: Suhrkamp.

HERING, Willem. 2009. The -One-All-Alone. Notes on Espace and Déserts. In Willem HERING and Lieven BERTELS (eds.). Varèse $360^{\circ}$. Holland Festival Amsterdam.

LOMBARDO, Vincenzo et al. 2009. A Virtual-Reality Reconstruction of Poème Electronique Based on Philological Research. Computer Music Journal 33 (2), 24-47.

LOOTSMA, Bart. 1984. Poème Electronique. De reconstructie van een ontstaansgeschiedenis. In Elmer SCHÖNBERGER (ed.). De bevrijding van de klank. Teksten van en over Varèse. Amsterdam: ASKO, 53-66.

LOZANO, Jorge Tadeo. 2014. The Role of Sound in Filmic Experience. A Cognitive Semiotics Approach. In Kristian Bankow (ed.) New Semiotics Between Tradition and Innovation. Proceedings of the 12the World Congress of the International Association for Semiotic Studies (IASS/AIS) Sofia: New Bulgarian University, 946957.

PARRET, Herman, 1995. Synesthetic Effects. In Th. A. Sebeok and J. UmikerSebeok (eds.), Advances in Visual Semiotics. The Semiotic Web 1992-93 (Coll. Approaches to Semiotics, 118), Berlin/New York: Mouton de Gruyter, 335-347.

SOFIA, Sal. 2001. An Analysis of Edgar Varése's Poéme Électronique. PhD Diss., University of Washington Seattle.

SCHÖNBERGER, Elmer (ed.). 1984. De bevrijding van de klank. Teksten van en over Varèse. Amsterdam: ASKO.

SCHÖNBERGER, Elmer. 1984. Poème Electronique. Vrij Nederland 45, 11 February.

TAZELAAR, Kees. 2013. On the Threshold of Beauty: Philips and the Origins of Electronic Music in the Netherlands 1925-1965. Rotterdam: V2_Publishing. 
TURCO, Marina. 2014. Dancing Images: Text, Technology, and Cultural

Participation in the 'Communicative Dispositif' of VJing, PhD diss., Utrecht University.

VAN BAEST, Arjan. A Semiotics of Opera. Delft: Eburo 2000.

VAN MECHELEN, Marga. 1984. Reiziger tussen twee werelden. De Prometheus van Luigi Nono in première in Venetië, De Groene Amsterdammer 10 October.

VAN MECHELEN, Marga. 2005. Kritiek van de visuele sensatie. https://www. mediamatic.net/en/page/12950/kritiek-van-de-visuele-sensatie (accessed 18 February 2020).

VAN MECHELEN, Marga. 2006. The Battle of the DJ and the VJ, Or of Sound and Image. Amsterdam: ASCA Publication, Salon Synesthesia.

VARÈSE, Edgar. 1984. Ruimtelijke muziek (1959). In Elmer SCHÖNBERGER (ed.). De bevrijding van de klank. Teksten van en over Varèse. Amsterdam: ASKO, 4648.

VARÈSE, Edgar. 1984. Het elektronische medium (1962). In Elmer SCHÖNBERGER (ed.). De bevrijding van de klank. Teksten van en over Varèse. Amsterdam: ASKO, 21-22.

VERMEULEN, Ernst. 1984. Componist Edgar Varèse, altijd op zoek naar nieuw instrumentarium. de Volkskrant Thursday 9 February.

VDOVIN, Marsha and Ron MACLEOD. 2011. An interview with Tarik Barri. Cycling '74: Tools for Sound, Graphics, and Interactivity. 15 March.

YOUNGBLOOD, Gene. 1970. Expanded Cinema. New York: E.P. Dutton \& Co. 


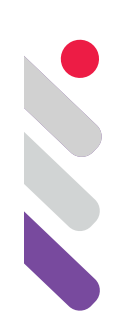

\title{
Trânsito e complexidades sensoriais em imagens contemporâneas
}

DOI: 10.24308/IASS-2019-4-012

\author{
Lívia Machado \\ Universidade de São Paulo, Brasil \\ liviamachado@usp.br
}

\section{Introdução}

O presente artigo surgiu de tema recorrente em grupo de pesquisa: a sensorialidade nas imagens contemporâneas em distintos objetos audiovisuais. O processo sensorial se manifesta como motivo de inquietações na engrenagem de distintas experiências fruitivas e procedimentos criativos - em seus enquadramentos, misturas, texturas e espacialidades - mesmo quando abordado por diferentes recortes teóricos, corpus e metodologias. A via pela pesquisa de exploração das sensorialidades possibilita estudar imagens em uma perspectiva que foge de parâmetros segmentadores e individualizantes da visualidade. Técnicas, formas, mídias e a própria percepção de imagens se inserem em contextos de integração, hibridismos e traduções sensoriais que criam teia onde relações de esbarram - o corte visual com o ritmo sonoro, pigmentos ou números com tatilidades, natureza com cultura, corpos com máquinas, vibrações com movimentos.

A proposta não é uma tentativa de refutar a ideia da dominação do olho no processo de comunicação contemporânea, mas sim problematizar abordagens enraizadas com ênfase da visão, inclinando para perspectivas abrangentes das linguagens como sensorialidades polivantes e plásticas, sobretudo em espaços expositivos. Atenta-se para procedimentos sensoriais múltiplos, dentro de contextos que expandem a hegemonia visual como 1) emergência de formas híbridas da imagem em eterno processo de deslocamento e ressignificação; 2) relações de tradução na circunstância tecnoimagética; 3) processos cognitivos singulares que nascem de experiências estéticas e interativas em espaços expositivos: sci-nestesias. 


\section{Emergência de formas híbridas da imagem: deslocamento e ressignificação}

As condições sócio-tecnológicas do pós-guerra legam ao senso comum a ideia de que esta é uma sociedade de visualidades. Sociedade que se apropria e interage imageticamente de formas cada vez mais complexas e plurais. Todavia, o que se percebe é a habitação do ser humano em um cenário de misturas de imagens, sobretudo na contemporaneidade em período de emergência de imagens técnicas ${ }^{1}$, industrializações e sistemáticas de codificação de imagens em dados numéricos.

O conceito de visualidade torna-se parcial quando observado no contexto de uma era de hibridismos e de composições sensoriais, uma vez que as sensorialidades se manifestam de forma difusa e expansiva, mais do que convergente, em sentido háptico. Tal sensibilidade tátil "confronta imediatamente a questão da dimensão física do toque, por meio de uma operação corporal que envolve os olhos e o cérebro. As mãos não são parte dela, exceto como uma 'projeção' imaginária". (Huhtmano 2009: 114). O olhar não se limita à visualidade, mas contextualiza ambiências que resultam fruições pelo corpo. Um exemplo apontado por Huhtamo é a montagem de filmes de Sergei Eisenstein: "montagem intelectual radical, incluindo o princípio de 'atração do choque' usado em seu clássico O Encouraçado Potemkin' (Huhtmano 2009: 120). A visualidade, também, está inserida em uma subjetividade intracorpórea que opera em sensorialidades que não são segmentadas, mas que se atravessem enquanto linguagens em meios e corpos.

Hibridismos no panorama háptico nos conduz a identificar misturas dinâmicas de movimento que ocupam determinadas espacialidades na criação de atmosferas, que envolvem o corpo como um todo. Exemplos são multitelas em espaços expositivos, onde o fruidor explora paisagens através de seu deslocamento e salas de cinema com sistemas de som surround. A temperatura do ambiente onde o espectador assiste ao vídeo, assim como sensações por meio de audiovisualidades inscritas na tela - neve, fogo, vento - compõem imagens táteis e vibratórias para além do visual. As relações de corpos com estímulos audiovisuais não se manifestam como absorções segmentadas, mas na composição de um fluxo entre sentidos, onde não existe separação absoluta.

Em seu entendimento de expansão, observam-se imagens misturadas em uma lógica de movimento, de fluxo - que, nesse sentido, é categorizado como trânsito. Mesmo imagens estáticas estão inseridas em um jogo de fluxo e fruição. Imagens nunca são captadas como um todo, apenas pelas bordas do

\footnotetext{
${ }^{1}$ Imagens técnicas são imagens geradas por aparelhos no período pós-histórico, ou seja, de automatização e mecanização na reprodução de imagens da aparelhagem fotográfica (Flusser 1985). Essa invenção trouxe quebra de paradigmas de como conceber o mundo, a realidade e a própria essência e condição de imagens. As imagens, de forma geral, seriam "superfícies que pretendem representar algo" (1985:7). Já sua forma técnica, por sua vez, seria a impressão "de forma automática sobre suas superfícies, como se fossem impressões digitais" (Flusser 1985:10).
} 
seu movimento, de uma cinesia de imagens. Tais imagens podem ser entendidas como plásticas, em movimento, visuais, sonoras, audiovisuais, táteis, cíbridas, técnicas, digitais, futuristas, sinestésicas. Entretanto, dificilmente encaixotadas somente em uma categoria única. A dinâmica de imagens está ancorada nas multiplicidades de experiência para além do que se percebe como um único estímulo, por meio da complexificação e prolongamentos de elementos da imagem. Contudo, não somente a percepção corpórea propicia aberturas para hibridismos sensoriais, tampouco a multiplicidade de combinações espaciais. A condição de produção, armazenamento e processamento técnicas da imagem em si também é um acelerador de hibridismos.

A circunstância da contemporaneidade possibilita técnicas distintas para criação e maneiras de lidar, processar e fruir por imagens. A plasticidade que envolve características das imagens de nosso tempo está impregnada de condições que englobam o advento de imagens técnicas, numéricas e de interfaces. Uma vez situadas no tempo e no espaço, essas imagens podem ser entendidas como passíveis de estetização, recriação, modificação e movimentação a cada novo advento. Suas características sensoriais são, dessa forma, pertinentes à era pós-industrial e pós-histórica da contemporaneidade. Agambem (2009:65) identifica uma tentativa frustrada e desafiadora de estudar as dinâmicas da contemporaneidade como "perceber nesse escuro uma luz que, dirigida para nós, distancia-se infinitamente de nós. Ou ainda: ser pontual em um compromisso ao qual se pode apenas faltar".

O conceito de contemporaneidade acompanha, em certa medida, esse movimento: o surgimento de imagens técnicas que tem como marco o advento da fotografia e que abriu espaço para uma ambiência propícia à novas tecnologias e formas de reprodução de imagens: filmografias, cinematografias, montagens, colagens, tecnologias de informação, códigos binários, imagens numéricas, imagens de interface. Distintas técnicas e estéticas acontecem nesse lugar entre sensibilidades e inventividades como, por exemplo, imagens digitais e desenvolvimento participativos, espaciais e virtuais. No encontro de suas múltiplas especificidades, a condição de visualidade exclusiva da imagem pode ser questionada como um lugar redutor de uma organização mista. A proposta da observação da imagem sob o ponto de vista de sua sensorialidade se constitui como uma forma de complexificação de um conglomerado de características.

O encontro híbrido implica na diminuição da prevalência visual e da exclusividade do olho. O cenário de suportes, materialidades distintas, texturas, pigmentos, ruídos reorganizam o equilíbrio perceptivo e dividem sensorialidades, na medida em que não há uma restrição absoluta de sentido. O próprio contexto espacial e físico que engloba essas visualidades, tais como multitelas, monocanais de vídeo, caixas sonoras, subwoofers e a própria curadoria acarretam diluição de uma possível alta resolução visual. Por estar em 
um lugar com estímulos de imagens e materialidades híbridas, os sentidos se reorganizam. O próprio lugar do movimento não fica abreviado ao visual, mas sim em relações do corpo e da pele com a espacialidade, deslocamentos e o processo perceptivo que acontece mais "entre" os sentidos do que segmentados ou individualizados no meios deles.

O trânsito da audiovisualidade e dos espaços multimídias, resultante de traduções intersemióticas, auxilia essa mistura: de permeabilidade de sentidos e imagens, deslocamentos, envolvimentos. "Essas linguagens transcodificadas efetivam a colaboração entre os diversos sentidos, possibilitando o trânsito intersemiótico e criativo entre o visual, o verbal, o acústico e o tátill". (Plaza 2001:66). Para além dos hibridismos que acontecem numa dinâmica de experimentações artísticas e culturas de arrojo criativo, o período da contemporaneidade pós-industrial traz à tona uma cultura de excessos midiáticos de misturas que transbordam as cidades, em seus estímulos publicitários, informativos e sonoro-visuais.

Também, no contexto de excessos (urbanidades, virtualidades, informações, visualidades) são cada vez mais presentes formas visuais que se realizam na confluência/encontro de códigos e suportes. Experiências que, valendo-se de diferentes técnicas, instigam um processo de semiose ininterrupto e reprocessamento da percepção. Estruturas inestáveis e, segundo Lótman (1996), fronteiriças. A ambiência híbrida propicia trocas semiósicas e tradutórias por serem locais de alta permeabilidade, deslocamento e ressignificação. Neste habitat de efervescência de trânsito e criatividades, se estabelecem caminhos para o novo, experimentações imprevisíveis e procedimentos tradutórios, que também flexibilizam a sugestão de monopólios visuais.

\section{Relações de tradução na circunstância tecnoimagética}

A proposta da tradução, em seu fazer prático e sobretudo estético, se configura como forma de valorização de uma conjunção sensorial e não a primazia de um sentido em detrimento de outro. Jakobson (1974) conjecturou três estilos de traduções, entre elas a intralingual, interlingual e tradução intersemiótica. Este último termo, aprofundado por Júlio Plaza (2001) a partir das leituras e conceitos de tradução de Roman Jakobson, acarreta na transposição de um sistemas de signos em outro. Exemplos seriam o visual no pensamento, a fotografia na cinematografia, a literatura para o teatro, entre outros. O próprio pensamento, em certa medida, demanda a tradução intersemiótica, pois há entre signos e entre processamento cognitivo e comunicativo, uma rede de relações que tende a se estender ao infinito e se modificar no ato triádico signoobjeto-interpretante. Um pensamento jamais será exatamente como o anterior nessa lógica de encadeamento. 
Júlio Plaza foi além no termo teórico e ao associar com McLuhan, trouxe luz à tradução como uma forma de intercurso entre sentidos. Segundo McLuhan (2016:76), "as tecnologias são meios de traduzir uma espécie de conhecimento para a outra" e a tradução seria "um desvendamento de formas do conhecimento". Não apenas "a interação entre nossos sentidos é permanente" como cada nova tecnologia daria "acento ou ascendência" a um ou mais deles (1972:34-40). Em certa medida, essa problematização nos permite entender as tecnologias e assim suas mudanças e emergências como possibilidades transpositivas, o que abre respaldo para indagar também hibridismos. O equilíbrio sensorial perante o surgimento de dispositivos midiáticos na cultura insere o corpo na lógica tecnológica, cujo ato perceptivo também se molda nessa circunstância.

A tradução implica em reorganização de sentidos. Nessa medida existe uma inscrição sensorial inerente à materialidade proposta em cada sistema de signos. Segundo Júlio Plaza (2001:46): "Se os meios e, por extensão, as linguagens que eles veiculam são ampliações diferenciadas da diversidade do nosso sistema sensório, de uma forma ou de outra, o caráter desse sistema sensório fica inscrito ou traduzido nesses meios". A produção, a percepção e as relações cognitivas que se estabelecem entre signos é condicionada às materialidades sensoriais. Fotografias, televisão, cinema, sistemas digitais, cada um constitui de peculiaridades sígnicas e sensoriais. Entretanto, a questão visual, condição de uma era ocidental pós-industrial, pode ser questionada se observada no contexto de traduções e hibridismos, onde o processamento sígnico não pára na percepção do olho: se estende pela mente e na interseção entre sentidos e entremeios.

A relação ocular possui intrínsecas relações culturais, tais como os sentido perceptivos, o que expande canais de visualidade para além do corpo físico. Júlio Plaza (2001: 57) apresenta distinções entre o olho e o tato na medida em que o canal visual é um receptor a distância que tende a um isolamento e distanciamento - o olho se isola dos demais sentidos ao invés de complementá-los - enquanto o tato é um receptor imediato que inclina-se para uma percepção mais integrada e menos especializada. Todavia, a visualidade transparece materialidades que aguçam atmosferas táteis, sensórias, assim como montagens e colagens audiovisuais, por meio de cortes e ritmos. No âmbito filosófico e biológico, várias explorações acenam para a integralidade dos sistemas perceptivos.

A expografia do Museu do Amanhã, no Rio, se aproxima desses dois aspectos abordados anteriormente: das hibridizações no espaço expositivo e da tradução intersemiótica como interfluxo de sentidos. Tanto a disposição de misturas de dispositivos diversos pelo espaço, quanto a própria configuração das máquinas em si, migram para uma proposta que, embora proporcionem estímulos visuais, decorrem em experiências de sensorialidades múltiplas. Os 
espaços do museu denominados Cosmos, Terra, Antropoceno, Amanhã e Nós possuem distintas asserções midiáticas, mas que, em algum grau, se fundem e influenciam. Mesmo no aspecto das imagens geradas em um segmento específico - por exemplo, documentários que aparecem em monitores individuais com curiosidades sobre moléculas - acabam reiterando uma perspectiva corpórea mais ampla.

Na projeção 360 de Cosmos, o visitante é convidado a se deitar no chão para observar à um vídeo sobre a história do universo com conexões entre temas como vida, biologia, constelações. $\mathrm{O}$ ato de se deitar no chão e assistir vídeo com caixas de som em alta definição abrange a experiência para além do visual. 0 próprio ritmo da montagem na narrativa que propõe pensar o universo em uma constante multiplicação a partir da expansão do Big Bang, o alcance dos elementos audiovisuais habitando periferias do espaço acústico e a qualidade sonora da voz feminina que descreve essa jornada, criam esse caráter atmosférico: um repercussão háptica em corpos deitados.

Entre Cosmos e Terra, vários monitores com interatividade touch screen são distribuídos e apresentam temas como matérias, células, o tamanho do universo, proporções. Essas máquinas individuais estão abertas para toques, explorações e podem criar uma vivência curatorial do visitante baseada na decisão sobre qual totem multimídia tatear. Para além desses monitores interativos - informativos e pedagógicos - que se moldam de acordo com as preferências desse visitante-interator, ao final da visita, existem uma série de jogos como O Jogo das Civilizações, fundamentado em um modelo da Nasa, e que permite pensar em modos de consumo e parâmetros para o futuro. Em um ato de apertar botões, característica de uma cultura digital e interativa, em grande parte o museu aciona a possibilidade da vivência da expografia por meio de touch screen: sem deixar de ser informativo, mas com uma composição da participação corpórea através de uma curadoria de dedos. Dissolve-se um imaginário de

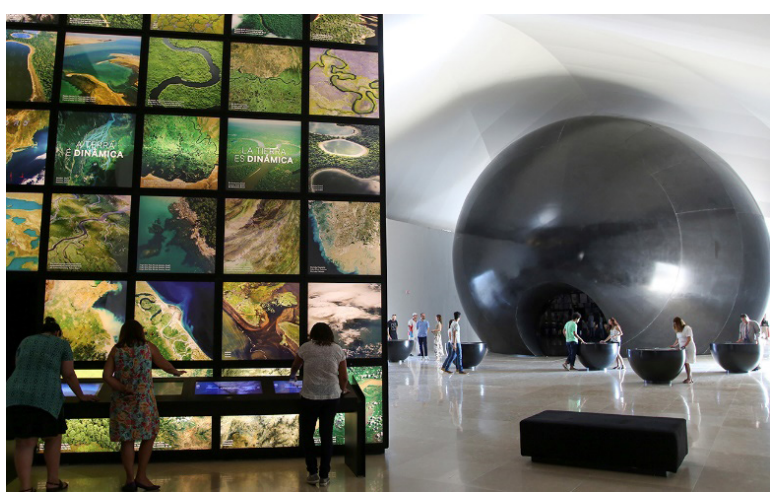
museu como lugar de velharia, com patrimônios materiais, propriedades exclusivas e intocáveis para um museu de corpos ativos e participativos.

Figura 1: Espaço interativo entre Cosmos e Terra²

\footnotetext{
${ }^{2}$ Fonte: https://museudoamanha.org.br/pt-br/exposicao-principal.
} 
Outra parte da exposição, o Antropoceno, mostra como a curadoria favorece hibridismos entre obras, gerando uma conjuntura de misturas na espacialidade, interferência e fluxo de sentidos entre dispositivos. Seis totens com dez metros de altura apresentam conteúdo audiovisual sobre perturbações do ser humano no planeta e natureza, dentre outros problemas como desigualdade social, poluição, consumo excessivo. Entretanto, a disposição do áudio dessa instalação de totens interfere na ambiência do museu. $O$ fato das caixas de áudio serem posicionadas de uma maneira abrangente pela curadoria acaba transgredindo a circunferência audiovisual em dois sentidos: por gerar relações hápticas para além visual, que compõem uma atmosfera pelo museu de forma abrangente e por gerar fluxos de sentido. Tais fluxos produzem ruídos e efeitos de traduções quando esbarram em atmosferas de outras obras, o que acaba influenciando outras possibilidades de semioses em demais partes da exposição.

A sessão de fotografias, por exemplo, assim como a sessão "Nós", acabam recebendo ruídos sonoros de elementos de áudio da exposição Antropoceno. Dessa forma, as visualidades de ambos ambientes serão compostas pela interferência da sessão Antropoceno. De alguma maneira, estímulos sonoros de uma parte específica contaminam outros locais da exposição e deslocam sentidos isolados para sonoridades de ruídos que se atravessam e que atuam em composição audiovisual, resultando em intercurso de sensações do fruidor pelo espaço. Como o caráter do sistema sensório está inscrito e traduzido por meios (Plaza 2001), pode-se comparar a difusão de estímulos do Museu do Amanhã - visualidades, interatividades táteis, sonoridades na composição de atmosféricas hápticas onde sentidos de fundem - com a hibridização do próprio sistema sensório do qual o corpo está submetido na expografia do museu, uma vez que os meios são extensões desses sentidos.

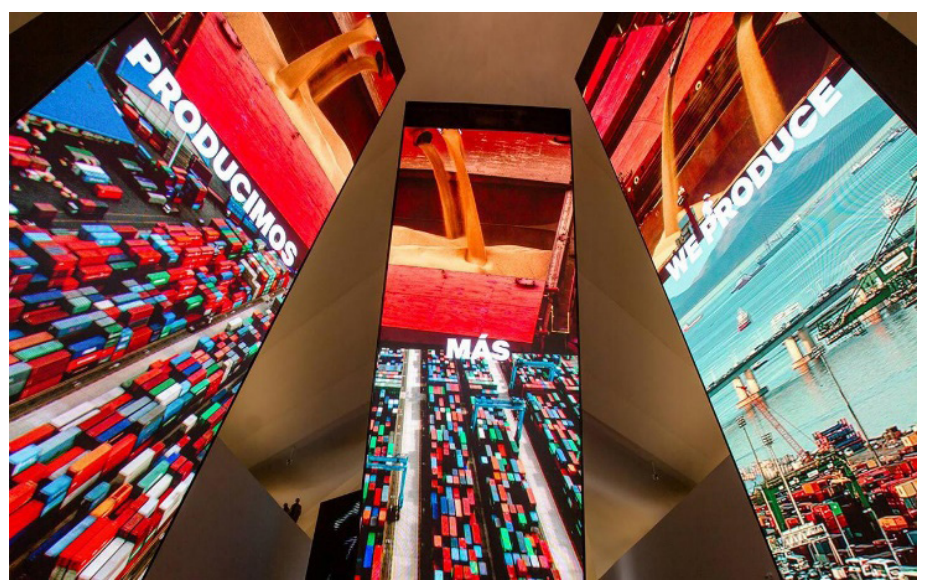

Figura 2: Totens

da sessão

Antropoceno $^{3}$

${ }^{3}$ Fonte: https://museudoamanha.org.br/pt-br/antropoceno 


\section{Processos cognitivos singulares que nascem de experiências estéticas e interativas em espaços expositivos: sci-nestesias}

Os espaços expositivos em geral - museus, centros culturais, galerias de arte - possibilitam novas maneiras de se misturar linguagens em um mesmo ambiente. A observação de espaços expositivos, por ter uma natureza espacial abrangente - um lugar por onde andar e interagir com diferentes telas, modos de ver, textos pra ler e fruir, teclas e botões e imagens em deslocamento facilita a análise de experiências polivantes, de distintas sensorialidades em detrimento das restritas à um órgão específico. Embora o cinema, o teatro, a literatura, tenham, em algum grau, dimensões sensoriais diversificadas, o espaço expositivo oportuniza ainda mais a identificação de complexa amálgama, por ter a competência de englobar tais práticas de forma conjunta.

A plasticidade sensorial do contato com distintos meios em conjunto com a moldagem curatorial é explorada por diversos dispositivos: acústicos, visuais, performances, cheiros, temperaturas, ruídos. Na subordinação do corpo perante essas experimentações criativas, processos cognitivos singulares podem ser reestruturados e emergirem como novos hábitos e condicionamentos perceptivos e sensíveis. 0 processo sinestésico se configura nesta dinâmica qualitativa de abertura e possui duas perspectivas centrais de abordagem: uma que segue as conjunturas de figura de linguagem e combinações de processos, como a cruzamento de sentidos do ponto de vista da estrutura textual e também do ponto de vista corpóreo, na relação do organismo com o seu ambiente. Júlio Plaza (2001) pensou ambas concepções sobre sinestesia e que acabam se relacionando, em certa medida, com o processo da tradução intersemiótica.

Ao retomar as reflexões de McLuhan (2001, p.64), Plaza discorre sobre o movimento de tradução, ou seja, a transposição de uma estrutura de linguagem em outro meio, determinado por características específicas de cada veículo comunicacional. A tradução reajusta e recria linguagens em novos sentidos na medida em que acena para a sensorialidade de uma maneira ampla, complexa e descerrada de uma exclusividade visual. Movimenta-se, assim, um "entre" sentidos, recriando atmosferas sígnicas. As transposições semióticas de linguagens de meios quentes para meios frios, por exemplo, trazem à tona essa fresta de passagens.

As características dos meios frios, de baixa definição, condiciona maiores possibilidades para aberturas interativas - e também sinestesias - em oposição ao caráter quente, de alta definição e fechado dos meios. A alta definição implica em uma segmentação de sentidos - uma linguagem majoritariamente visual ou sonora - enquanto a baixa procederia em interatividade. A participação acontece a partir do preenchimento de espaços sensoriais, o que condiciona maior trânsito entre sentidos e possibilidades de experiências sinestésicas. Apesar dos instrumentos de alta definição especializar-nos em certos sentidos, 
eles acabam nos impedindo de explorar demais sentidos em seu conjunto.

Para além do horizonte conceitual da sinestesia atrelada aos meios, existe uma área de estudos da qual Plaza (2001) não se desprende por completo: o âmbito corpóreo da experiência sinestésica como fator biológico na cultura. Embora tal experiência se condicione em reorganizações e equilíbrio de sentidos a partir de estímulos eletrônicos e digitais na cultura, há um quê biológico, que não está descosturado do ambiente e acompanha os efeitos da criação simbólica. A hibridização, por ser um compilado de experimentações midiáticas e sensoriais - acústico, visual, tátil, inputs, outputs, binário e elétrico - é um procedimento maquínico que possibilita vivências híbridas e também sinestésicas, saindo do protagonismo da visualidade como exclusividade sensível e se expandindo para demais sensorialidades.

$\mathrm{Na}$ via da tradução intersemiótica, a sinestesia pode ser entendida como sistema de transmutação sígnica na relação do corpo biológico em seus campos de descobertas perceptivas: seja em sua versão de pesquisa mais atrelada aos estudos da ciência cognitiva ou em sua vertente de trânsito de linguagens - entendendo ambas as áreas como campos separados, mas que se complementam. Nos dois casos entende-se a sensorialidade como algo fluído, tanto resultante de hibridizações que geram interatividades, como um corpo que funciona, por si só, como um sistema integrado.

Na margem conceitual que aproxima biologia e cultura, depara-se com o concepção de Umwelt (Uexküll J. 1928; Uexküll T. 2004). Umwelt significa organismo e sugere junção bastante simbiótica de um ambiente externo com as estruturas que coabitam seu meio. Em sentido extensivo e ostensivo, as hibridizações não estão somente fora de um organismo em um ambiente, mas são, todavia, incorporadas por ele. Umwelt, por sua vez, absorve e opera novas misturas e dispersam em seu ambiente. A lógica de cruzamento de procedimentos, processamento e armazenamento de imagem também tem implicações de trânsitos sensoriais, por organismo e ambiente que estão mais do que conectados - são inseridos em processos de contaminação mútua em área de permeabillidades. Assim, não só o corpo, mas estímulos diversos no ambiente determinam a experiência sinestésica do Umwelt.

Na compreensão dos sistemas híbridos como diluição de um protagonismo visual e da sinestesia como condição qualitativa de misturas - biológica, cognitiva e processual - propõe-se a imersão sci-nestésica como hipótese de interatividades em distintas espacialidades ${ }^{4}$. A conjunção tecnológica se impõe como um fator de experimentações digitais, elétricas e virtuais em ambiência de alto grau de desprendimento de fronteiras perceptivas. A hibridização, no conjunto de suas combinações, sobretudo no ambiente curatorial, gera uma sinestesia condicionada às especificidades de inteligência digital do próprio

${ }^{4}$ Hipótese central da minha tese de doutorado. 
meio, numa versão virtualizada entre imagens numéricas: o que diferencia a sinestesia da sci-nestesia. Esta segunda funciona como proposta de neologismo pra se pensar a sinestesia em ambientes específicos de virtualidades.

A sci-nestesia é uma proposta de se pensar a mistura de extensão tecnológica do numérico com o efeito biológico tradicional da sinestesia do organismo. A sinestesia é entendida e estudada tanto como processamento de linguagens e como efeitos de diluição de fronteiras entre os sentidos no organismo, podendo ser de alto grau - constitutiva, congênita, recreativa, induzida pelo uso de drogas, trocas neuronais e crossmodais - ou percebida discretamente devido ao hábito segmentador da percepção na cultura. A versão quase futurista da sinestesia acelerada por aparelhos e alta tecnologia a sci-nestesia - parece estar presente mesmo que discretamente ao redor dos corpos, em suas circunstâncias atmosféricas: mesmo diante de exposições que englobam obras analógicas e digitais ao mesmo tempo, e em espaços urbanos, onde parece que estamos alheios aos efeitos sci-nestésicos e digitais das luzes que emanam dos aparelhos celulares.

A sci-nestesia, por ser uma experiência "entre" sentidos, mediadas por máquinas e binariedade, pode ser constatada mesmo em locais inesperados, como na realidade da cidade, no campo, no museu tradicional que argumenta não ser tecnológico e até em lugares aparentemente remotos, com a inclusão digital de balões, drones e satélites. Esta acelera possibilidades de movimento e fluxos de sentidos por meio de hibridizações e, por isso, tende a ser redutora da centralidade visual.

Estéticas e interativas em espaços expositivos, como os museus, alcançam cruzamentos de possibilidades sci-nestésicas. Deslocamentos que provém de artifícios digitais-numéricos, não somente pelo frutos de hibridizações tecnoartísticas de obras em sua individualidade, mas no contexto da apresentação de um espaço como um todo. Nessa conjugação de um espaço fruto de interrelações, o curador torna-se agente de sentido no caráter da integralidade fruitiva em sua espacialidade e endereçamento estético. Os espaços expositivos, por isso, estão inseridos na lógica da prática sinestésica e sci-nestésica: um conjunto de artefatos, muitas vezes em alta definição se vistos individualmente, mas quando estão em conjunto, de acordo com a curadoria, surgem efeitos de baixa definição, sendo táteis e interativos. São também lugares cada vez mais explorados sob a vivência da multissensorialidade e multimídia.

A função do curador não passa desapercebida como modalidade de geração de sentido - consequência de um fazer curatorial que acontece sob a conjuntura da emergência de espaços expositivos diversos, tais como galerias independentes, museus de diferentes temáticas, espaços audiovisuais. 0 gesto curatorial, segundo curador e pesquisador Luiz Osorio (2019: 29), carrega uma dimensão crítica e atribui-se uma "forma de pensar a articulação entre arte, 
exposição e produção de conhecimento que tem, no dispositivo da montagem, sua razão de ser". Proponho pensar além do lugar do curador como gerador de tensões e debates em linhas de forças discursivas dimensionadas nas articulações da montagem e disposição de objetos em uma sala ou galpão que mistura televisores, corpos, avisos informativos, aparatos pedagógicos e sons. Sugiro pensar no curador como agente de condução para reorganização dos sentido e deslocamentos perceptivos, que geram sci-nestesias para além da obra em si.

Osorio (2019: 38), parafraseando Foucault, vê o lugar do curador como "um disparador de discursividades e de formas outras de ver as obras - formas essas que se dão no interior do campo semântico proposto pela montagem e suas articulações estéticas e conceituais". Para além desse disparador que negocia subjetividades em obras no arranjo da montagem, entendo o curador como dispositivo de ordenamentos de sentido e articulador de deslocamentos fruitivos e sensoriais. Possui, o curador, importância na diluição de demarcações perceptivas e no trato das negociações subjetivas dos sentidos: não só os que emanam da obra em si, por meio de indeterminações e aberturas para experiências estéticas, mas também dos códigos e inputs absorvidos pelo corpo no processo perceptivo e fruitivo. Nesse aspecto, não só a arte em si é um lugar de experimentos de traduções e hibridizações que fragilizam o status quo de protagonismos visuais e acena para abertura de sensorialidades, mas também espacialidades estabelecidas por uma curadoria.

\section{Referências}

AGAMBEN, Giorgio. 2009. O que é o contemporâneo? e outros ensaios. Chapecó, SC. Argos.

FLUSSER, Vilém. 1985. Filosofia da Caixa Preta. Editora: Hucitec. São Paulo.

HUHTMANO, Erkki in DOMINGUES, Diana (org). 2009. Arte, Ciência e Tecnologia. Passado, presente e desafios. Ed: Itaú Cultural, São Paulo, SP.

LAPLANTINE, F.; NOUSS, A. 2002. A Mestiçagem. Lisboa: Piaget.

LÓTMAN, I. 1996. La semiosfera: semiótica de la cultura e del texto. Vol I. Frónesis Cátedra: Universitat de Valencia.

McLUHAN, Herbert Marshall. 1972. A galáxia de Gutemberg. São Paulo: Companhia Editora Nacional, Edusp. 
McLUHAN, Marshall. 2016. Os Meios de Comunicação como Extensões do Homem. São Paulo: Cultrix.

MENOTTI, Gabriel (org). 2018. Curadoria, Cinema e outros modos de dar a ver. Vitória, ES: Edufes.

OSORIO, Luiz. 2019. A função-curador: Discurso, Montagem, Composição. ARS 17 (37), 29-44. http://www.revistas.usp.br/ars/article/view/164117 (acesso em 9 de janeiro de 2020).

JAKOBSON, Roman. 1974. Linguística e comunicação. São Paulo: Cultrix.

PLAZA, Júlio. 2001. Tradução Intersemiótica. São Paulo: Perspectiva.

UEXKÜLL, Jakob von. 1928. Theorische Biologie. Berlim: Springer.

UEXKÜLL, Thure von. 2004. A teoria da Umwelt de Jacob von Uexküll. Galáxia, 7, 19-48. https://revistas.pucsp.br/galaxia/article/view/1369 (acesso em 9 de janeiro de 2020) 


\title{
MEDIATIZACIONES
}

\author{
E. FORMAS Y TEMAS EN LA TELEVISIÓN
}





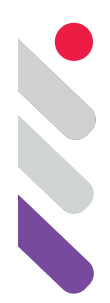

\title{
Operaciones de ludicidad y autorreferencia en dos casos de animación digital contemporánea
}

DOI: 10.24308/IASS-2019-4-013

\author{
Maria Alejandra Alonso \\ Institución: Universidad Nacional de las Artes - \\ Universidad de Buenos Aires \\ paraalonso@yahoo.com.ar
}

La historia de la animación puede ser abordada atendiendo a los lugares que ocupa la autorreferencia en las tramas y los temas de los cortometrajes animados, estableciendo diferentes juegos de centro y periferia. "Los gestos metadiscursivos y de metalenguaje se destacaron como temática propia del contenido de los dibujos animados fuertemente en tres momentos: surgimiento del cine de animación; comienzos de la televisión y renacimiento del cine de animación con la aparición de imágenes generadas por computadora (CGI)." (Alonso 2016:7) Mientras que en los tiempos estables en que un medio se posiciona como hegemónico (organizando al resto del sistema mediático) las animaciones allí asentadas desarrollan narraciones y temáticas universales, desplazando o abandonando los juegos sobre el propio lenguaje, género o historia.

Didácticas

Críticas

Lúdicas

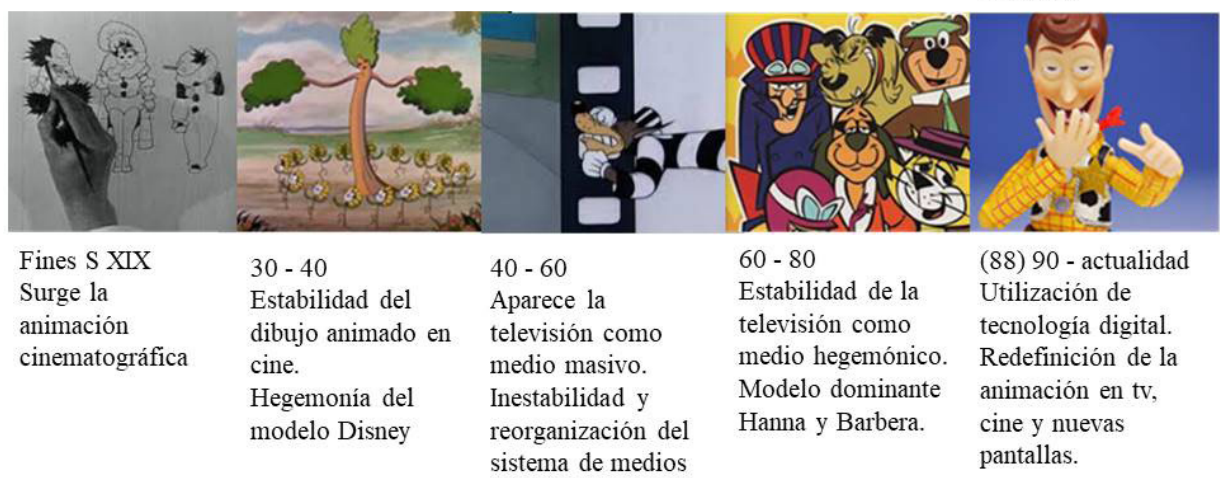


un proceso posible de apreciar, en un futuro, como dos o más periodos, aunque esto resulta imposible de definir de manera contemporánea a su desarrollo.

Como primera aproximación, y de modo exploratorio, se detectan y describen operaciones de autorreferencia presentes en dos series animadas televisivas: Phineas y Ferb (transmitida desde 2008) y Los Jóvenes Titanes en acción (transmitida en Latinoamérica desde 2013) producidas con técnicas de animación digital.

Desde una perspectiva sociosemiótica (Verón), se describen, comparan y clasifican operaciones meta presentes en estas animaciones que permiten reconstruir sus relaciones interdiscursivas en diferentes niveles. Los juegos de autorreferencia se ordenan retomando conceptos trabajados por autores que piensan operaciones similares en otros lenguajes o campos como las nociones de género (Bajtín y Steimberg), transtextualidad (Genette), verosímil y cine (Metz) y metalenguaje (Jakobson).

\section{1- Operaciones de autorreferencia en la animación}

"La meta-animación implica una distancia crítica entre el texto referente y el nuevo texto creado" (Siragusa y Asís Ferri 2014: 130). La recurrencia de estas operaciones y la configuración semántica observada en las animaciones del período de transición entre el cine y la televisión como medio hegemónico ('40 - '60) hacen que ese momento se destaque por su enunciación de denuncia, por su permanente crítica en un sentido similar al de las vanguardias.

En un primer acercamiento a la animación contemporánea es posible detectar comentarios sobre otros textos animados, relaciones entre la historia y el presente del medio, el lenguaje, los estilos. Esas lecturas se articulan con juegos interdiscursivos presentes también en otros lenguajes y textos de la cultura a través de una "búsqueda de formas -y en su valorización- en la que asistimos a la pérdida de la integridad, de la globalidad, de la sistematización ordenada a cambio de la inestabilidad, de la polidimensionalidad, de la mudabilidad" (Calabrese 1994: 12). Son textos que funcionan como patchwork, ya que lo que estos traen de otros espacios y estéticas aparece yuxtapuesto y sus "costuras" son evidenciadas (Tassara 2001). Se presenta también una estética de la nostalgia, en la medida en que mantiene una mirada hacia el pasado, evocándolo a través de la cita (Jameson 1999).

Nos preguntamos si en la animación contemporánea las relaciones entre el texto referente y el nuevo texto creado deben ser consideradas como meta-animación o si se trata de un tipo de lectura diferente con otra propuesta enunciativa.

Para el análisis se retoman las categorías utilizadas en investigaciones anteriores atendiendo a la posibilidad de ajustar la metodología, si fuera necesario, luego de considerar las particularidades del corpus. 
Entendiendo al dibujo animado como un lenguaje que articula múltiples materias de la expresión (Metz 1974), resulta estimulante pensar la función de metalenguaje (Jakobson 1985) en relación con los cortometrajes seleccionados y sus configuraciones discursivas particulares. Se consideran desde esos desarrollos conceptuales las operaciones de autorreferencia que recaen sobre el dispositivo ${ }^{1}$ en general y sobre el lenguaje en particular.

Las operaciones metadiscursivas y sus vínculos explícitos e implícitos pueden ser en relación con animaciones como también con otros textos de la cultura. Por un lado, señalan clasificaciones discursivas como las de género o estilo en el que se inscribe y con los que dialoga; por otro lado, la incorporación de referencias a textos específicos a través de citas, parodias u otros tipos transtextuales (Genette 1989 [1982]).

\section{2- Dos casos de animación digital contemporánea}

"Parece haber una relación simbiótica entre las innovaciones técnicas y tecnológicas, el cambio de paradigma y las necesidades de autodefinirse cada vez, como si la innovación y el cambio de medio pusieran en duda las cualidades que definen al dibujo animado." (Alonso 2016: 30)

Observamos dos series televisivas contemporáneas, realizadas con técnicas de animación digital, para identificary clasificar tipos de autorreferencia y la propuesta enunciativa que se conforma a partir del funcionamiento del conjunto de operaciones.

Ambas series son norteamericanas y se emiten para Latinoamérica por canales de televisión por cable con estilos aparentemente opuestos: Disney Channel y Cartoon Network.

\footnotetext{
${ }^{1}$ Entendemos que dispositivo es un concepto actualmente en revisión al interior de las diversas teorías semióticas. Reponemos el concepto de dispositivo retomando los desarrollos de Traversa (2011) y lo articulamos con algunas conversaciones académicas no formalizadas aún sobre este concepto. "En torno de la noción de dispositivo indicábamos que se recurría a la articulación entre dos instancias: la correspondiente a la puesta en obra de técnicas de producción sígnica y de procesos que hacían posible la circulación discursiva, de manera que la suma de ambos recursos no resulta indiferente en lo que concierne a la producción de sentido (...) es necesario atender al componente principal que opera en las relaciones vinculares, del lado de lo que denominamos 'técnicas constructivas': la enunciación. En tanto ella define un lugar relacional inscripto en la fuente (en los textos en producción) respecto del posible universo de reconocimientos" (Traversa 2011: 72)
} 


\section{Phineas y Ferb}

Emitida desde 2008 por la señal Disney Channel. La serie sigue las vivencias de Phineas Flynn y su hermanastro británico Ferb Fletcher durante las vacaciones de verano. Cada día, los chicos se embarcan en un gran proyecto nuevo, lo que molesta a su hermana

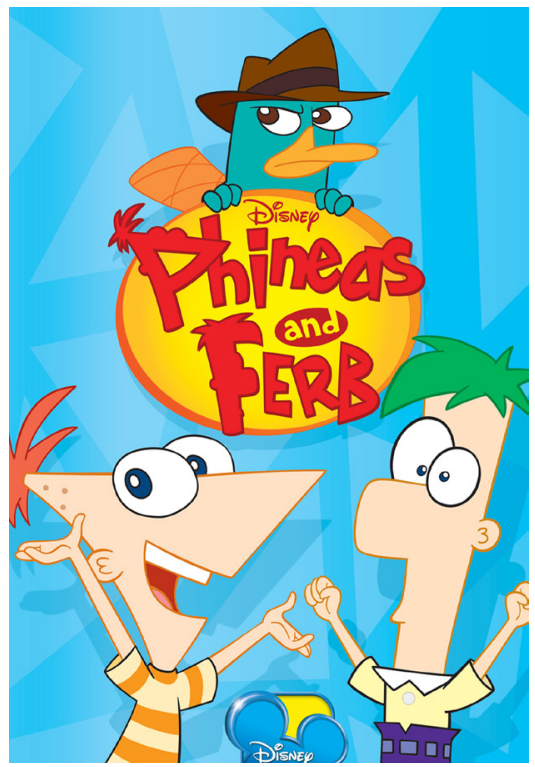

Candace, quien trata de revelar sus travesuras a la madre. La serie sigue un sistema de trama estándar; haciendo bromas en cada episodio, y con una trama-b casi siempre centrada en Perry el ornitorrinco trabajando como un espía. Las dos tramas se cruzan al final de cada episodio para borrar todas las huellas del proyecto de los niños justo antes de que Candace pueda mostrarlo a su madre, cosa que normalmente deja muy frustrada a Candace. (Wikipedia 2018)

\section{Los Jóvenes Titanes en acción (Teen Titans Go!)}

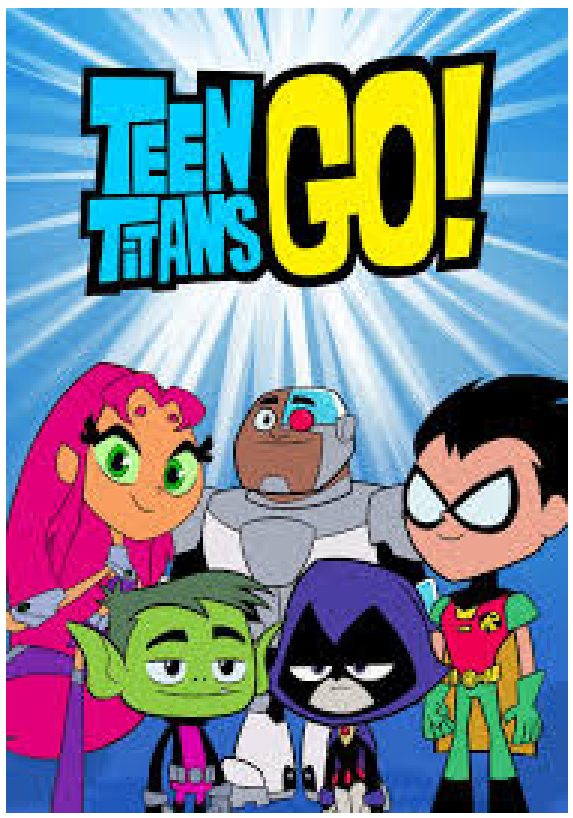

Emitida para Latinoamérica desde 2013 por Cartoon Network, basada en el equipo de superhéroes de DC Comics, Jóvenes Titanes. "Teen Titans Go! es una serie de animación que sigue las aventuras de los Jóvenes Titanes cuando no están salvando el mundo mientras viven juntos como adolescentes sin adultos que se entrometan. Las situaciones son, a diferencia de la mayoría de las series superheroicas, cómicas, alocadas y paródicas; por ejemplo, bromas juveniles que alcanzan nuevas cotas de peligrosidad, obtener el permiso de conducir tras destrozar 
el Batmóvil o lavar los trajes tras mancharlos al luchar contra sus enemigos." (Wikipedia 2018)

Si bien las nuevas tecnologías habilitan estéticas hiperrealistas ${ }^{2}$ y posibilidades de múltiples juegos de textura, volumen, profundidad, perspectiva, color y movimiento, estas series animadas digitales se configuran en dos dimensiones manteniendo el estilo plano de personajes y fondos propios de los dibujos animados analógicos. Aunque se incorpora eventualmente el uso de otros tipos de imágenes como fotografías, animación 3D, estética de comic, con propuestas poéticas que articulan esos recursos plásticos al servicio de la narración.

Los episodios de ambas series están organizados como relatos aunque no comparten el mismo tipo de estructura.

Phineas y Ferb presenta una trama principal y otra secundaria, que se cruzan sobre el final para restaurar el equilibrio inicial, en el que dos niños se aburren durante las vacaciones en el patio de su casa junto a su ornitorrinco mascota. Desde los primeros capítulos de la serie se evidencia un conjunto de frases recurrentes que operan como comentario sobre esa misma estructura fija. El relato de aventura inicia con Phineas diciendo "ya sé que vamos a hacer hoy" y continúa compartiendo el plan para la construcción de una maquinaria inverosímil (una diferente en cada episodio) para una aventura increíble junto a su hermano y amigos. Luego da pie al inicio de la segunda trama con la pregunta "¿Y Perry?", los personajes pierden de vista al ornitorrinco que se pone un sombrero (que funciona como máscara y protege su identidad) y se introduce en algún pasadizo que lo lleva hasta la base de una guarida de agentes secretos donde recibe su misión del día, la cual concuerda con detener los planes malvados del villano de siempre que otra vez intenta apoderarse del Área Limítrofe (la ciudad en la que viven).

Volviendo a la trama principal, la hermana mayor de Phineas y Ferb intentará en todos los episodios acusar a sus hermanos por sus aventuras, "iMamá, mamá!, mira lo que están haciendo Phineas y Ferb". El fracaso recurrente por la misteriosa desaparición de las hiperbólicas máquinas construidas en el patio trasero de la casa es acompañado por la frase de Candace "pero, pero, pep..." cada vez que su madre mira y solo ve a los chicos y el ornitorrinco aburridos debajo del árbol. Antes de que la madre observe hacia el patio, la última acción del ornitorrinco en la segunda trama frustra los planes del villano y, de manera lateral y como consecuencia no intencionada, provoca la desaparición del invento de los chicos de cada día. El remate opera con la

\footnotetext{
2 "El periodo digital se completa con la regularización y el asentamiento de estas operaciones. Actualmente los lenguajes animados digitales adquirieron un desarrollo con amplias posibilidades expresivas, logrando incluso emular a las imágenes de captura, o superando a las mismas con sus detalles hiperrealistas." (Alonso 2016: 33)
} 
frase de la madre "quien quiere pastel".

Esa estructura fija y estable de la trama de todos los episodios de la serie, acompañada por la invariancia de las frases que señalan los momentos de transformación, funcionan como el instante en que se muestra la "verdad de un código libremente asumido" (Metz 1970: 29) y se logra escapar al verosímil por delante, tal como lo explica Metz en relación con los films de género. Esto se refuerza en los episodios especiales en los que el musical se vuelve el género principal y el relato de aventura permanece como género secundario (Steimberg 2013).

La mayoría de los episodios de Los Jóvenes Titanes en acción también se organizan como relatos tradicionales, aunque esa estructura no es tan estable ni recurrente. En ocasiones también se presentan relatos truncados, sin restablecimiento del equilibrio o conclusión. Incluso puede suceder que la descripción se expanda tanto que se vuelve central en el episodio desplazando las acciones de transformación a un segundo plano.

Tal vez con menos nitidez, esta serie también escapa al verosímil en ocasiones, aunque lo hace por detrás. Metz señala como posibilidad de escape ese momento propio de los films verdaderamente nuevos donde ocurre un "advenimiento al discurso de un nuevo posible, que ocupa el lugar conveniente a una convención vergonzosa." (Metz 1970: 29). Los Jóvenes Titanes en acción juega a ser una serie de superhéroes evidenciando o comentando lo patético de la vida cotidiana - o incluso de la adolescencia- de los superhéroes. Son los personajes de un tipo de discursos operando en otro género inhabitual o inesperado desde lo que se conoce de ese universo ficcional.

Las referencias a la propia serie, con citas o comentarios sobre capítulos anteriores, se incorporan luego de muchos episodios en los que se establece y expande el universo semántico y horizonte de expectativas. En Phineas y Ferb suceden a partir de la tercera temporada, por ejemplo, en el capítulo que viajan en el tiempo y revisan la trama de un capítulo anterior, pero desde otra perspectiva o el capítulo en el que revisan la lista de aventuras que propone la canción de presentación de la serie para considerar lo que les falta realizar:

[...]

Lanzar un cohete, luchar con las momias,

subir la torre Eiffel por fuera, descubrir un ser que jamás existió, duchar monos en la bañera.

Surfing practicar, crear nano-robots, los sesos de Frankestein ver, un dodo encontrar, a un país pintar, tu hermana furiosa poner.

[...] 
En Los Jóvenes Titanes en acción también se revisan otros capítulos a partir de la cuarta temporada, por ejemplo, cuando se incorpora al equipo la Chica Abeja y para evitar que quede afuera de las conversaciones sobre anécdotas compartidas viajan al pasado y la hacen vivir esos momentos especiales como si hubiera estado ahí. Los resultados son tragicómicos ya que alteran los recuerdos de los personajes provocando que todos olviden los momentos visitados. También hay canciones de la primera temporada que vuelven a ser cantadas en situaciones similares en los siguientes episodios. Canciones que en general operan como catálisis expandiendo aspectos de los personajes y demorando el avance las acciones. Chico Bestia y Cyborg suelen cantar sobre comida mientras desarrollan alguna coreografía:

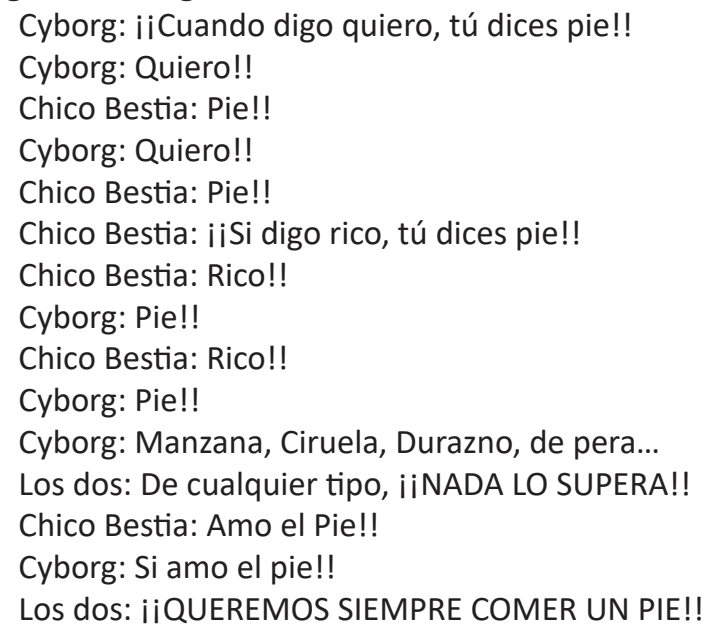

Aunque las citas, comentarios o incluso las parodias y sátiras son más recurrentes en relación con otros textos audiovisuales o literarios que sobre sí mismo.

Phineas y Ferb propone juegos de transposición o adaptación de textos clásicos de la cultura desde los títulos de los capítulos hasta los motivos temáticos identificados y cristalizados en relación con esos textos que retoma. En ese sentido se destacan capítulos como: Yo hermano-bot, Viaje al centro de Candace, Isabella y el templo de la savia, El mago de ocio, Elemental, mi querida Stacy, entre otros.

Los Jóvenes Titanes en acción presentan otras propuestas de transtextualidad, principalmente en relación con el universo de superhéroes de DC, y en especial con las series Jóvenes Titanes y Batman. Los cuentos populares y leyendas en ocasiones son narrados por alguno de los personajes a modo de parábola para explicar algún problema o argumentar una propuesta frente al equipo. En general son versiones distorsionadas de las historias clásicas, ya sea porque el personaje que la narra ignora la versión tradicional o porque 
intencionalmente manipula los motivos temáticos a favor de lo que pretende argumentar. Este uso de la narración retoma (y comenta) el uso social de la narración como recurso argumentativo.

Las referencias a las series de superhéroes suelen incorporar cambios en el estilo del dibujo, muchas veces porque operan desde la imaginación o el deseo de Robin de pertenecer a esos otros equipos o universos semánticos. El personaje anhela permanentemente convertirse en el líder de un grupo de superhéroes "de verdad" y dejar de ser un grupo de adolescentes indisciplinados (como si tuviera conciencia del género en el que se inscribe la serie, sitcom, y deseara estar en una de acción o de superhéroes).

En el mismo sentido son recurrentes los comentarios, la parodia y sátira sobre el género. En múltiples episodios Robin insiste en las cualidades propias de los superhéroes y la necesidad de un entrenamiento y conducta apropiada para convertirse en uno "verdadero". En general esos sermones y propuestas (o imposiciones) de entrenamientos lo terminan poniendo en ridículo ya que es el único del equipo que no posee superpoderes. Es solo un humano adolescente (frustrado y arrogante) entrenado por Batman, mientras que los otros tienen fuerza ilimitada, vuelan, se transforman y/o disparan rayos con los ojos o las manos.

Otro modo de autorreferencia puede encontrarse en los juegos de palabras. Las reflexiones sobre la lengua y el habla o el lenguaje en un sentido saussuriano ocupan lugares especiales en ambas series. Los episodios incorporan permutaciones o sustituciones de palabras por otras fonéticamente similares que articulan el nombre de algún personaje o un tema a desarrollar en la trama con otro término. Estas propuestas son utilizadas de manera aislada y también en la organización de la trama. ${ }^{3}$

Algunos episodios de Phineas y Ferb desarrollan especiales tratamientos en relación con el lenguaje. Invierano es uno de los inventos de los protagonistas que conjuga las cualidades de ambas estaciones permitiendo practicar durante sus vacaciones de verano actividades propias del invierno. Incluso se retoma la canción que explicaba qué es el verano en un capítulo previo y se readapta la letra para explicar qué es el invierano.

En el episodio La palabra del día se articulan el lenguaje verbal con los rasgos de los programas educativos en los que se invita a un color, una letra o un número para organizar la trama en torno a la enseñanza de ese concepto y donde cada vez que se lo nombra se realiza una pausa en la que se destaca y repite como método de aprendizaje. En este caso se trata de una palabra, la cual es definida y luego puesta en uso en diferentes enunciados a lo largo del episodio, incluso en una canción (con coreografía y videoclip).

\footnotetext{
${ }^{3}$ Las versiones para Latinoamérica mantienen este tipo de juegos al doblar las voces al español latino considerando especialmente que los juegos de palabras sigan operando significativamente.
} 
Los juegos sobre la lengua y el habla se despliegan especialmente en el episodio Latín Ferb. La familia de los protagonistas está formada por los norteamericanos Flynn (Phineas, Candace y la madre) y los británicos Fletcher (Ferb y el padre). Ferb es un personaje que habitualmente no habla (los chistes sobre el estilo británico también son recurrentes, aunque moderados), y en este episodio Phineas propone inventar un idioma apropiado para que Ferb pueda expresarse: Latín Ferb. Se construyen y explican las reglas gramaticales y modos de uso (de modo indicativo y luego con una canción y videoclip) y se lo pone en práctica durante todo el episodio logrando conquistar el habla de los habitantes del Área Limítrofe. Al final se restaura el uso habitual del lenguaje. Son juegos sin moraleja evidente sobre la dimensión política del lenguaje ni tampoco enseñar nada al respecto, ni la inmutabilidad y la mutabilidad del signo, ni la arbitrariedad del signo (De Saussure 2003 [1945]), ni el funcionamiento de los géneros como correas de trasmisión entre el habla y la lengua (Bajtín 1998 [1979]). Es una propuesta lúdica y efímera que parece agotarse en la dimensión poética de lo verbal.

En Los Jóvenes Titanes en acción el uso de la lengua es menos correcto, las palabras inventadas son más frecuentes y menos destacadas. En algunos episodios esos juegos operan sobre la lógica de la trama afectando el devenir de las acciones. En una ocasión Rose Wilson, una de las villanas, le quita sentido a las palabras de Robin a partir de respuestas con juegos de palabras. Esto sucede por ejemplo cuando Robin dice "Titanes al ataque" (frase recurrente que indica el inicio del enfrentamiento) y ella responde "Titanes al escape", lo que paraliza (por el absurdo) al resto del equipo que no entiende si debe atacar o escapar. Luego sigue una serie de bromas y rimas similares que terminan por seducir a Raven, quien se siente más identificada con la villana que con los titanes y se va con ella, dejando atónitos a los otros personajes.

También se incorporan juegos sobre los lenguajes animados y los dispositivos audiovisuales, aunque son menos frecuentes. Operan de manera poética y no como crítica o reflexión acerca de las condiciones de producción o los contextos sociopolíticos. Tampoco parecen criticar las restricciones del dispositivo, no están tematizadas las pantallas en las que las series se exhiben (televisión, computadora, celulares, internet, señales de televisión) o las fallas técnicas propias de la inestabilidad de la señal de internet o el agotamiento de la batería de los soportes inalámbricos. Cuando aparece la tematización de las pantallas se pone el foco en los formatos de los programas que se transmiten en ellas dejando de lado las características del dispositivo. Esas maneras de hablar (o no hacerlo) sobre el dispositivo se distancian del tipo de operaciones que podemos encontrar en las animaciones del período de transición entre el cine y la televisión anteriormente analizado: cuando el Lobo Feroz de Tex Avery corre más allá de los márgenes del fotograma y sobrepasa las perforaciones laterales 
del film, o cuando el pato Lucas de Chuck Jones salta entre el fotograma superior y el inferior, o sufre el desfasaje o desincronización entre las imágenes y el sonido, entre otros.

En el episodio Breakfast Cheese el villano dice, mirando una pantalla de televisión en la que se emite un programa de unicornios y pegasos cariñosos y amigables: "Es bonito ver un dibujo animado donde no se resuelven los problemas con violencia" y con su control remoto especial atrapa y envía a los titanes a ese programa de televisión en el que deben aprender a resolver los problemas con amor y diálogo para poder salir. Al volver a su mundo atacan violentamente al villano.

En Los Jóvenes Titanes en acción también se establecen relaciones con los videojuegos, ya sea a partir de simulaciones de fallas técnicas propias de los lenguajes digitales (especialmente los pixels) o incluso con capítulos en los que los personajes realizan las acciones en el interior de un videojuego. Se producen cambios en la configuración del personaje a partir del pasaje al entorno del videojuego, en el que se evidencia un tipo de imagen propia de los videojuegos, ya sea por la pixelación (emulando los primeros videojuegos) o por el hiperrealismo y la calidad de la imagen (similar a los videojuegos contemporáneos). Esa diferencia se tematiza en comparaciones como "videojuegos vs. realidad virtual".

Phineas y Ferb tiene menor tematización del videojuego, aunque dedica al menos un capítulo a la construcción de un videojuego en el que los personajes pueden ingresar y jugarlo desde el interior de ese otro universo. Sin embargo, no presentan juegos plásticos o cambios en el tipo de imagen utilizada, mantienen su morfología, color y movimiento habitual. La serie mantiene la estética de dibujo animado de manera regular sin incorporar cambios en las técnicas de animación o los lenguajes (ni simular esos cambios que son posibles desde la animación digital).

En Los Jóvenes Titanes en acción se incorpora la mixtura de imágenes a partir de la proyección de deseos, sueños y recuerdos de los personajes. Dibujos más realistas, con volumen y perspectiva, sombras moduladas y escenarios más oscuros y estética de comic dan forma a los pensamientos de Robin, mientras que fotografías de gatitos en collage con dibujos naif nos llevan a los sueños o deseos de Starfire. En ocasiones también se incorporan fragmentos de audiovisuales de acción en vivo.

En síntesis, las operaciones de autorreferencia están presentes desde la primera temporada en ambas series, privilegiando los comentarios sobre diferentes textos de la cultura y no necesariamente sobre animaciones. Las referencias a la propia serie se incorporan en las siguientes temporadas. Los juegos con el lenguaje y los comentarios sobre las reglas del género se incrementan temporada a temporada. 


\section{3- La autorreferencia lúdica y sus complicidades}

En estas series los juegos de autorreferencia recurrentes funcionan a favor de la trama, permitiendo en ocasiones la configuración del chiste o la broma sobre la regularidad del género y la posibilidad/imposibilidad de quebrar ese horizonte de expectativas. Aunque estas reflexiones no parecen constituirse como una denuncia, resistencia, ni revolución, sino como la asunción de las reglas del juego como parte del mismo juego. Un saber gozoso sobre ese universo (ficcional) compartido entre enunciador y enunciatario, que habilita un vínculo lúdico y comentativo sobre un pasado que vuelve para ser celebrado. Si Traversa definía hace unas décadas al espectador de cine como un "erudito forzoso que se ignora" (1984), estos textos contemporáneos parecen traer la figura de un erudito gozoso que se celebra como tal.

Esas necesidades de autodefinirse, como si la innovación y el cambio de medio pusieran en duda las cualidades que definen al dibujo animado, tematizada en animaciones de otros períodos, no están presentes en estas series.

Tanto las tramas como los comentarios sobre sí mismas juegan en otra dirección, señalando particularidades de las series animadas y no de los lenguajes de la animación.

El conjunto de operaciones de autorreferencia presentes en estas series puede ser considerado como otro tipo de meta-animación, no se plantea necesariamente una distancia crítica, aunque sí se convoca un saber enciclopédico y erudito sobre la animación. Los textos animados sobre los que se habla a partir de distintos juegos interdiscursivos son evocados desde el goce, la nostalgia, el homenaje y la celebración.

Se puede considerar que los modos en que la autorreferencia al lenguaje como juegos plásticos o poéticos al servicio de la narración ganan la escena y abandonan cualquier búsqueda de moraleja. Esa ausencia de reflexión sobre el lenguaje (la animación en general, la digitalidad en particular) puede estar restringida principalmente por dos condicionamientos: el estilo de época y el saber social sobre la animación y las tecnologías digitales.

El estilo de época contemporáneo suele ser caracterizado por su recurrente e intensa intertextualidad, polidimensionalidad y mudabilidad (Calabrese 1994) que opera como patchwork (Tassara 2001). Esas relaciones interdiscursivas se postulan desde una posición privilegiadamente nostálgica evocando un saber compartido sobre el pasado. Este período incorpora la autorreferencia como estilo y no como crítica de sus modos de producción en múltiples tipos de textos.

Por otro lado, las animaciones que conforman el corpus pertenecen a un momento tardío del período digital. Las primeras animaciones digitales surgen a fines de la década del 80 y se desarrollan de manera más expandida a partir de 
la década del 90. Es posible considerar que luego de dos décadas se ha instalado una primera estabilización del lenguaje y los dispositivos. Tal vez ya se conformó un saber social y dejó de ser necesario hablar, enseñar o reflexionar sobre la animación digital y sus modos de factura.

El período de transición entre la animación televisiva y la digital se da en paralelo al pasaje desde una única pantalla a las múltiples pantallas habilitadas por internet, pero con un desfasaje: la estabilidad del juego que proponen los textos del corpus parece mostrar que la expansión y consolidación del arché (1994) de la animación digital ha sucedido antes del cambio del sistema mediático.

Las conclusiones de esta primera aproximación a las operaciones de autorreferencia son parciales y nos invitan a continuar analizando corpus conformado por animaciones de otros momentos y espacios de su era digital.

Nos queda mucha animación por mirar.

\section{Bibliografía}

ALONSO, Maria. 2016. El dibujo animado siempre a la vanguardia. Metadiscursividad y metalenguaje en los dibujos animados de(sde) los ' 50 . Tesis de Maestría. Maestría en Crítica y Difusión de las Artes, Universidad Nacional de las Artes, Buenos Aires.

BAJTIN, Mijail. 1998 [1979]. "El problema de los géneros discursivos", en Estética de la creación verbal, Siglo XXI, Buenos Aires.

CALABRESE, Omar. 1994. La era neobarroca, Madrid, Editorial Cátedra.

DE SAUSSURE, Ferdinand. 2003 [1945]. Curso de lingüística general, Buenos Aires, Losada.

GENETTE, Gérard. 1989 [1982]. Palimpsestos. Madrid, Taurus.

JAKOBSON, Roman. 1985. Ensayos de lingüística general, Barcelona, PlanetaAgostini.

JAMESON, Fredric. 1999. El giro cultural. Escritos seleccionados sobre el posmodernismo 1983 - 1998. Buenos Aires, Ed. Manantial.

METZ, Christian. 1970. "El decir y lo dicho en el cine: ¿hacia la decadencia de un cierto verosímil?, en AAVV: Revista Comunicaciones, Lo Verosímil, Buenos Aires, Editorial Tiempo Contemporáneo.

1974. "El estudio semiológico del lenguaje cinematográfico", en revista Lenguajes nro.2, Buenos Aires, Nueva Visión. 
SCHAEFFER, Jean Marie. 1994. La imagen precaria. Sobre el dispositivo fotográfico, Madrid, Cátedra.

STEIMBERG, Oscar. 2013 [1993]. "Proposiciones sobre el género" en Semióticas: Las Semióticas de los géneros, de los estilos, de la transposición. Buenos Aires: Eterna Cadencia.

TASSARA, Mabel. 2001. El Castillo de Borgonio. La producción de sentido en el cine, Buenos Aires, Atuel-Colección del Círculo.

TRAVERSA, Oscar. 1984. Cine: el significante negado. Buenos Aires: Hachette. 2014. Aproximaciones a la noción de dispositivo. En Inflexiones del discurso. Cambios y rupturas en las trayectorias del sentido. Buenos Aires: Santiago Arcos. [2001]

VERÓN, Eliseo. 1989 [1987]. La semiosis social: Fragmentos de una teoría de la discursividad. Barcelona: Gedisa.

Wikipedia para la entrada Teen Titans Go! (serie animada), https://es.wikipedia. org/wiki/Teen_Titans_Go!_(serie_animada) consultado el 2/12/2018

Wikipedia para la entrada Phineas y Ferb, https://es.wikipedia.org/wiki/ Phineas_y_Ferb consultado el 2/12/2018 


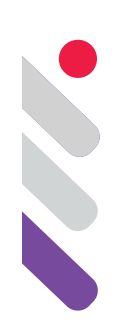

\title{
Sí solo sí: la discapacidad en la ficción televisiva argentina ${ }^{1}$
}

DOI: 10.24308/IASS-2019-4-014

\author{
Carolina Casali \\ Universidad Nacional de Córdoba, Argentina \\ carolina_casali@yahoo.com.ar
}

\section{Problema y perspectiva}

En su dimensión productiva, cada sociedad -en un tiempo y espacio determinado-se despliega mediante una serie de mecanismos que habilitan y modelan configuraciones identitarias, las cuales se traman y emergen en la discursividad. Así, se construyen/proponen modelos identitarios que regulan los modos posibles de ser, hacer, pensar, sentir y desear. En este horizonte el del deber ser-, la persona con discapacidad ${ }^{2}$ emerge históricamente en el imaginario social -al igual que aquellos identificados como el loco, el pobre, el homosexual, el transexual, el negro, la mujer, el niño, entre otras figurascomo otro negativo frente a un sujeto-norma capaz, constituyendo así un "otro deficiente" (Skliar 2002) ubicado en la liminalidad social, marginado -material y simbólicamente- de los circuitos sociales, económicos, políticos y culturales.

Asimismo, en el horizonte de la discursividad contemporánea, la persona con discapacidad experimenta un fenómeno doble que atenta contra su reconocimiento social: por una parte, la invisibilización en la esfera públicamediática donde se observa una escasa o nula participación, lo cual conlleva la negación simbólica de su existencia -sobre todo si se tiene en cuenta que, según el Censo 2010, el 12,7\% del total de la población de Argentina está en esta condición-; por otra parte, la estigmatización al constituir una

\footnotetext{
${ }^{1}$ El presente trabajo fue realizado en el marco del proyecto de investigación En los márgenes: sujetos, discursos y políticas de vida en la contemporaneidad, financiado por SECYT período 2018-2021 y radicado en el Centro de Estudios Avanzados de la Facultad de Ciencias Sociales, Universidad Nacional de Córdoba.

${ }^{2}$ Tomamos esta denominación puesto que es el modo utilizado por la ONU en el texto de la Convención Internacional sobre los Derechos de las Personas con Discapacidad. Esta refiere a aquellas personas que "tengan deficiencias físicas, mentales, intelectuales o sensoriales a largo plazo que, al interactuar con diversas barreras, puedan impedir su participación plena y efectiva en la sociedad, en igualdad de condiciones con los demás" (Art1ํ).
} 
identidad social menospreciada (Goffman 2006), ejemplo de ello es el modo estereotipado -ligado a una axiología negativa- a través del cual emergen en los medios de comunicación argentinos aquellos quienes son re-presentados como personas con discapacidad: “(...) son infantiles, asexuados/as, dependientes, improductivos/as, santos/as, malvados/as, resentidos/as, vengativos/as, ventajeros/as, manipuladores/as, superhéroes, etcétera" (AFSCA et al. 2014: 13).

Sin embargo, en las últimas décadas se han producido ciertas transformaciones que conllevaron la emergencia y la visibilización creciente de otras formas de significar la discapacidad, las cuales tensionan la modalidad dominante centrada en la individualidad y el déficit, asumiendo una perspectiva paternalista y minusvalizante de la persona con discapacidad. Estos cambios son correlato de la lucha y la movilización de las personas con discapacidad quienes -nucleados en diferentes organizaciones nacionales e internacionales- cuestionan el modo en que son presentadas, representadas y tratadas socialmente; señalan y repudian las prácticas discriminatorias y estigmatizantes a las que se encuentran sujetos. Estos movimientos enfatizan la dimensión socio-histórica de la discapacidad, en tanto constructo; sitúan a la persona con discapacidad como sujeto de derechos civiles, apelan a ladesmedicalización y a la desinstitucionalización, a la vida independiente y a las prácticas emancipadoras de estas; asimismo, pretenden la "rehabilitación de la sociedad" (Toboso\& Guzmán 2009) -este posicionamiento es recuperado por la Convención Internacional sobre los Derechos de las Personas con Discapacidad ${ }^{3}$ (Organización de Naciones Unidas 2006)-. A partir de ello, estos movimientos cuestionan la visión médico-biologicista-capacitista-minusvalizante -sostenido mediante, por ejemplo, las clasificaciones de la Organización Mundial de la Salud, de 1980 y 2001-, la cual conforma la matriz representacional aún dominante en el marco de la hegemonía discursiva.

En nuestro país, la proliferación de discursos que da cuenta de esta tensión -es decir, entre matrices representacionales y modos de configurar la discapacidad- se dinamiza a partir de la reconfiguración del tejido social que la crisis del 2001 trae aparejada y logra una visibilidad creciente luego de que, en 2008, la Argentina ratifique vía Ley 26.378 su adhesión a la mencionada

\footnotetext{
${ }^{3}$ Este documento pretende promover y asegurar la dignidad esencial de todas las personas con discapacidad en igualdad de derechos y libertades con el resto de la sociedad. Entre sus principios destaca el respeto de la dignidad inherente, la autonomía individual, la libertad de toma de decisiones, la no discriminación, la participación efectiva e inclusión plena en la sociedad de todos sus miembros. Así, pretende restituir el estatuto persona para los miembros de este colectivo, convirtiéndolos en sujeto de derecho. Establece la igualdad-como principio universalen relación a derechos, obligaciones y oportunidades, para lo cual estipula una directriz práctica: la accesibilidad, que habilita a recorrer y ocupar distintos espacios y ámbitos que hasta entonces estaban obturados para estas personas.
} 
Convención-sancionada por la ONU en diciembre de 2006-, jugando así el Estado un rol manifiesto en vista a la inclusión y ampliación de derechos. En este horizonte, nuestro objetivo central es comprender los modos de construcción semióticos de la discapacidad y de las identidades de la persona con discapacidad, en la discursividad argentina contemporánea.

Ahora bien, frente a la vasta discursividad, tomamos al discurso audiovisual ${ }^{4}$ dada su preminencia como modo de acceder, conocer y construir el mundo. Como dispositivo de significación, este atrae y estimula dos sentidos perceptivos. Da a ver y a oír, ofrece un punto de vista -construye un modo de mirar-, monta una estrategia de identificación y proyección entre el espectador y aquello que allí se muestra/narra, ubicándolo en determinada perspectiva visual, auditiva y axiológica. De este modo, a partir de diferentes operaciones de colocación de sentido a la hora de presentar y narrar la discapacidad, entendemos que los discursos audiovisuales exponen en su materialidad las temáticas y visiones de mundo, los sistemas axiológicos e ideologemas (Angenot 2010) que circulan en la sociedad que los engendra; radicando allí nuestro interés -es decir, en el carácter constitutivamente interdiscursivo de todo discurso (Verón 1998).

Ligado a las transformacionesen torno al modo de significar la discapacidad ya mencionadas, desde hace más de una década, en nuestro país se ha producido una creciente presencia de la temática en los discursos audiovisuales, a través de distintos géneros y formatos: largometrajes documentales y ficcionales, series ficcionales televisivas unitarias, campañas de sensibilización, magazines y segmentos específicos dentro de programas periodísticos televisivos. Sin desconocer los emprendimientos de entidades privadas o vinculadas a organizaciones sin fines de lucro, el apoyo material y simbólico del Estado a fin de favorecer este proceso ha sido de vital importancia -ya sea mediante el impulso de planes de fomento para la producción de contenidos audiovisuales o los reconocimientos públicos otorgados mediante distintas reparticiones y órganos del estado (Rivero 2018). En este contexto, en 2016, la TV pública pone al aire la miniserie de ficción nacional Si solo si, televisión integrada ${ }^{5}$, la cual como señala en su sitio oficial: “(...) es el primer producto televisivo que integra en su elenco a actores con y sin discapacidad, acercando la inclusión de personas con discapacidad al público de manera masiva"; la cual constituye el material de

\footnotetext{
${ }^{4}$ Aquel que es construido a partir del lenguaje audiovisual, caracterizado por ser multisensorial puesto que articula elementos visuales y elementos sonoros a partir del montaje. A nivel de producción, incluye una toma de decisión sobre los distintos componentes - puesta en escena, fotografía, sonido y montaje-, enmarcadoen la elección de distintas técnicas y estratégicas que permiten configurar sentido mediante estos (Bordwell\& Thomson 1995).

${ }^{5}$ En octubre de 2018, se estrena la segunda temporada de 8 capítulos; la cual emitiéndose los sábados a las 19.30 por canal 7. Durante septiembre y octubre de 2019 se rodó la tercera temporada.
} 
análisis de esta comunicación. Ahora bien, a través de un análisis interdiscursivo -el cual nos permite leer este discurso-objeto como "fragmento del tejido discursivo", el cual recupera y reelabora una serie de sentidos que circulan, modelan y significan la discapacidad en y a partir de la discursividad argentina contemporánea-, abordamos esta serie a fin de analizar las representaciones sociales (Verón 1998), específicamente cómo son presentadas y valoradas las personas con discapacidad teniendo en cuenta los atributos del ser, el hacer y el poder, los roles atribuidos y los espacios donde son ubicados, entendiendo que estas operaciones modelan ciertas identidades ${ }^{6}$.

\section{Si solo si: algunas puntas de análisis}

Esta miniserie nace en 2012 , en formato serie-web y con una producción de escaso presupuesto, impulsada de Sebastián Suárez, actor y director de teatro, quien coordinaba un taller de teatro integrado. Tras superar las 50.000 reproducciones en su sitio oficial, consigue mayor presupuesto y se profesionaliza. De este modo, la primera temporada, de ocho capítulos de 26 minutos de duración, se estrena en la Televisión Pública Argentina el sábado 7 de mayo de 2016 a las 11h00, como antesala del magazín Desde la vida ${ }^{7}$, también vinculado a la temática de la discapacidad. Cabe destacar que, pese a no estar programada en una franja horaria preferencial,la serie ha contado con un buen nivel de audiencia; ${ }^{8}$ ha sido tendencia en las redes y ha recolectado diferentes reconocimientos y nominaciones ${ }^{9}$; todo ello dan cuenta de la buena

\footnotetext{
${ }^{6}$ Entendemos que la identidad emerge y se transforma a partir de un entramado relacional de negatividad múltiple, en la articulación entre lo desemejante y lo similar -o en términos de Paul Ricœur (1996) lo ipse y lo ídem-: "Entre lo mismo y lo otro se abre, así el territorio material y simbólico de la identidad" (Solórzano-Thompson \& Rivera-Garza 2009: 144). No hay un solo rasgo o atributo propio que pueda definir de modo absoluto la identidad del ser. Así esta, que no es original, atemporal y acabada, se teje y desteje a través de múltiples relaciones. Aquellos rasgos que nos singularizan, que nos distinguen de otros, configuran nuestra identidad. Asimismo, dado su carácter dinámico, esta constituye "una posición relacional sólo temporariamente fijada en el juego de las diferencias" (Hall 1996, citado en Arfuch 2005), siempre en construcción y abierta a la temporalidad.

7 Conducido por FenaDellaMaggiora, este programa "apunta a generar conciencia sobre la importancia de valorar y respetar a las personas por su diversidad y promover la aceptación para la integración plena de personas con discapacidad [...] brinda la información necesaria para una mejor calidad de vida, no solamente de las personas con discapacidad y su familia, sino también de toda la comunidad", según señala la página oficial http://www.tvpublica.com.ar/programa/ desde-la-vida/. [Consultado el 09 de marzo de 2020].

${ }^{8}$ En su primera entrega registró un nivel de audiencia de 0,7 .

${ }^{9}$ Entre ellos al premio Martín Fierro 2017 como "Mejor Unitario y/o Miniserie"; nominada a los Premios TAL América Latina; Nominada a los premios FUNDTV; premiada por el Instituto Nacional contra la discriminación, la xenofobia y el racismo (INADI); por Cilsa (Centro de Integración Libre y Solidario de Argentina); y por RSC Argentina (Responsabilidad Social y Comunicativa Argentina), seleccionada por PrixJeunesse para el catálogo 2018 "QualityChildren Tv Worldwide"; fue nominada al Premio Diversify Tv ExcellenceAwards entregado en Cannes.Además fue declarada de interés por el INADI, el Ministerio de Cultura de la Nación, la Legislatura de la Ciudad Autónoma
} 
repercusión que ha tenido tanto en el público, como en la crítica especializada.

Si sólo si establece algunas diferencias con los modos hegemónicos de presentar la discapacidad en las ficciones audiovisuales argentinas. En esta serie la discapacidad no es presentada como un obstáculo, un problema a resolver; no es un elemento que esté incluido en el mundo ficcional a fin de darle dramatismo a la trama. Tampoco la persona con discapacidad es envestida con el ropaje del héroe de cualidades extraordinarias que compensan su falta, por las cuales recupera su valía social. Por el contrario, a través de esta se presentan historias ordinarias, con personajes ordinarios, ubicados en cualquier barrio de una ciudad cualquiera de Argentina.

A nivel narrativo, esta ficción, de tipo realista-costumbrista, tiene como conflicto central la posible disolución del taller protegido y escuela de panadería Si solo si, al cual asisten jóvenes adultos con discapacidad.Sin embargo accedemos a este a través de los vaivenes de dos familias protagonistas: por una parte, aquella integrada por Diego (Suárez), nieto de Roberto -un pintor solitario (Roberto Carnaghi)-, quien trabaja como repartidor de bidones de agua, es padre de Felipe -un niño de 10 años, de quien se ha hecho cargo mientras su expareja está en España- y es responsable de su hermano Jorge (Diego Albarenga) que tiene síndrome de Down; por otra parte, Julieta (Paula Kohan) quien -dado ciertos conflictos con la nueva pareja de su padre- se ha hecho cargo de sus dos hermanas: Valentina (Johanna Francella) y Lucía (Florencia Fazzino). Ambas familias se entrecruzan a partir del ingreso de Lucía al taller donde asiste Jorge.Aunque el tema de la integración de la persona con discapacidad es transversal, la serie desarrolla diferentes tramas de carácter universal en torno a los vínculos: la relación amorosa entre Diego y Julieta/ Lucía y Jorge/ Felipe y Antonella; los conflictos cotidianos intrafamiliares de convivenciaentre Julieta/Lucía/Valentina y Diego/Jorge/Felipe/Roberto; los lazos de amistad y compañerismo entre los asistentes al taller, entre otros.

Si bien durante la serie no se nombra la discapacidad, la temática queda sugerida en el título: $<$ Si solo si $>$, televisión integrada. Teniendo en cuenta que este elemento desempeña múltiples funciones semióticas en la apertura o clausura de sentidos (de la Fuente González 1998: 185-201), nos detenemos en su análisis. En este caso, el título está constituido por dos segmentados. El primero de ellosremite al espacio físico que aglutina a los protagonistas y es el eje del conflicto -el taller protegido y escuela de panadería Si solo si-, adquiriendo así una función referencial vinculada a la historia que se narra. Sin embargo, en el campo de la lógica, esta expresión tiene otros significados: indica la equivalencia lógica entre dos posiciones, formula representada gráficamente por los símbolos " $\leftrightarrow=$ ", los cuales son retomados dentro del universo ficcional; en el marco de esta serie y en el horizonte interdiscursivo que configura la de Buenos Aires y por el Municipio de Quilmes. 
temática/problemática de la discapacidad, la recuperación y reacentuación de esta fórmula lógica es leída aquí como una exhortación a la igualdad de derechos y de oportunidades, contra la discriminación y la desigualdad. En cuanto al segundo segmento del sintagma denominativo -"televisión integrada"- este da cuenta de un posicionamiento en torno a la discapacidad y a este medio de comunicación específico, al cual le atribuye una cualidad y/o una función: la de ser integrada, la de ser un medio para la integración; delineando un modo particular de producir contenido para televisión.

Si bien la serie -en su sitio web-se presenta como un producto novedoso -en tanto otorga visibilidad a una temática marginal dentro de la agenda pública-mediática- y como portador de una perspectiva que pretende la nodiscriminación e integración de la persona con discapacidad, identificamos -a partir de indagar en su trama, en los atributos de los personajes y el modo de resolución del conflicto central- tres tensiones centralesque remiten al estado actual de la discursividad argentina en torno a la discapacidad:

- La construcción de su autonomía personal en oposición a la imagen infantil ${ }^{10}$ a la que está asociada la persona con discapacidad

En la serie se despliega diferentes estrategias -sobre todo a nivel narrativo-que configuran a lapersona con discapacidad como sujeto autónomo, con capacidad de hacer, decir y decidir:durante el primer capítulo, tanto la coordinadora del taller como la portera se deben marchar y el grupo se queda "solo"trabajando de modo organizado, lo cual da cuenta de la no necesidad de supervisión/tutela por parte de otros adultos. A su vez, este sentidoes reafirmadominutos más tarde con la llegada al taller del cartero con la cartadocumento quien demanda la presencia de "algún mayor de edad", Jorge responde: "Nosotros", el cartero insiste y pide el DNI para verificar.Asimismo, durante la toma del taller, los personajes deliberan, deciden y accionan, demostrando su potencia y agenciamiento. También se expone su capacidad de desear, en tantolos personajes centrales -Jorge y Lucía- desarrollan unvínculoamoroso, sexualizando a la persona con discapacidad. Por otra parte, a partir del humor, la confidencia y la complicidad entre Diego y Jorge se presenta una relación de relativa paridad entre hermanos, la cual pretende alejarse de la posición tutelar y el trato paternalista; asimismo esta idea de paridad está

\footnotetext{
${ }^{10}$ Recordemos que infancia proviene de infanstérmino el cual, en el marco derecho romano, remite "a aquellos que pronuncian palabras y expresan ideas cuyo exacto sentido desconocen". En la Antigua Roma, durante este período de la vida -que finaliza al cumplir la persona los siete años- la incapacidad de obrar del infans es total, no pudiendo realizar por sí mismo acto jurídico alguno. Sin embargo, se atribuye a un tercero - bajo la figura de tutor- la función de suplir o integrar con su propia capacidad aquélla que este no tenía. [Información recuperada a partir de https://www.derechoromano.es/2011/12/las-tutelas.html, consultada el 25/08/2019]
} 
presente -como lo hemos señalado- en el isologotipo del programay en la banda de sonido: la canción Hermanos de Fito Páez y PaulihnoMoska.

En oposición a ello y de modo simultáneo, este discurso configura una representación infantilizada de las personas con discapacidad: a nivel de la puesta en escena, específicamente del decorado y el attrezzo -cartulinas y afiches que emulan dibujos realizados por niños-, la recepción del taller parece una sala de jardín de infantes; en el modo de referirse a los asistentes al taller mediante el uso de diminutivos de tipo apreciativo-afectivos -"quedarse solitos", "Jorgito", "chicos"-. A su vez, a nivel narrativo, durante la toma del taller quien cumple la función de aliado del grupo es Felipe -un niño de diez años-, lo cual implica una operación de semejanza e identificación entre ambos; asimismo, durante la negociación para poner fin a la toma,-además de pedir el no cierre del taller- los integrantes del taller exigen a sus familiares una serie de pedidos de índole individual -un modo análogo al pedido de deseos de cumpleaños-, a través de ello no sólo se banaliza la toma -al pasa del reclamo colectivo al deseo individual-, sino que se infantiliza a sus protagonistas.

- Entender que el acceso a las oportunidades para la persona con discapacidad son generadas a partir de acciones solidaridad de personas particulares, en oposición a considerar la cuestión dentro de una perspectiva de derechos donde el Estado juega un rol central como garante.

Esta tensión la reconstruimos interdiscursivamente a partir de observar cómo se resuelve el conflicto central: frente a la disposición de desalojo del taller por parte del Poder Judicial y la posible separación y redistribución de los integrantes en otros talleres de la zona, Julieta y Diego se presentan en el estudio de abogadosque representa a la empresa constructora, la nueva propietaria del terreno -es decir, intereses privados- para pedir una prórroga que, finalmente,no se concreta. Ante el apremio por el desalojo, lejos de apela a algún organismo estatal a fin de mediar y garantizar el funcionamiento del taller en otro inmueble, es Roberto -el abuelo de Diego y Jorge- quien acepta, luego de algunas resistencias, la instalación de este en su casa. Asimismo, hasta que esta última opción se efectiviza, tanto Diego como Julieta apela a "hacer un esfuerzo y alquilar una casa nueva", para tal iniciativa la coordinadora y la portera ofrecen donar parte de su sueldo. De este modo, la serie le otorga una centralidad a las acciones solidarias promovidas por familiares, voluntarios y filántropos -reactualizando el rol de las organizaciones benéficas- a fin de sostener este tipo de proyectos; todo ello, diluye la posibilidad de inscribir los reclamos de este colectivo en el espacio público-político y mediático, de colocar a la discriminación y marginación de la persona con discapacidad como 
un problema de índole social -no individual, voluntarista-: horizonte en el cual el Estado -en tanto regulador de las relaciones sociales, gestor, administrador y distribuidor de recursos tanto materiales como simbólicos (Porras Vallejos 2009)-debe bregar para poner fin a las situaciones de desigualdad, protegiendo a los sectores de la sociedad que se encuentran en situaciones de vulnerabilidada partir de la implementación de una serie de políticas públicas que garanticen sus derechos -como en este caso, la existencia de varias leyes específicas que resguardan los derechos de las personas con discapacidad, entre ellas la Convención Internacional sobre los derechos de las personas con discapacidad-.

- La segregación a partir de la construcción de un circuito diferenciado de circulación social de las personas con discapacidad frente a la inclusión a partir del principio de igualdaden el acceso a las oportunidades, en el marco de una sociedad diversa.

Si bien -tomado en cuenta entre otros aspectos su nombre- la serie pretende la integración de la persona con discapacidad, constituye una contradicción que el espacio material y simbólico que aglutina a los protagonistas sea un taller-escuela de empleo protegido, puesto que es un espacio de formación laboral orientado exclusivamente a las personas con discapacidad.De este modo, al construir un circuito diferencial, la participación en la sociedad de las personas con discapacidad es parcial y condicionada, estableciéndose asíen un gueto.En tal sentido, señalamos que este tipo de espacios institucionales son reconocidos y promovidos por el Estado a partir de una política de discriminación positiva; no obstante, dado que las reglamentaciones-pensadas en un primer momento como mecanismos temporarios para facilitar la integración efectiva-, se vuelven una práctica habitual negativa al apelar a la "solidaridad", en desmedro del principio de igualdad universal inherente al género humano y de la equidad en las condiciones de acceso a las oportunidades, reproduciendo un estatus de ciudadanía degradada (Palacios 2008).

De este modo, pese a que los modo de representar a de la persona con discapacidad se han complejizado, incorporando aspectos que son valorados positivamente -en el contexto del discurso sobre la diversidad y la inclusión- , no se observa en la discursividad una disolución de las tradicionales matrices representacionales sobre la discapacidad -ligadas a una perspectiva individualizadora, paternalista y minusvalizante-; estas se han desplazado y siguen operando, en convivencia con nuevos sentidos otorgados a la discapacidad y al ser discapacitado. Quizás este fenómeno de convivencia de cuenta de lo que señala críticamente Carlos Skliar (2005): 
Está claro que el mismo sistema político, cultural, educativo, etc., que produce la exclusión no puede tener la pretensión de instalar impunemente el argumento de un sistema radicalmente diferente - llámaseintegración, inclusión, o como bien se llame-. A no ser que aquí la inclusión sea, como decía Foucault (2000), un mecanismo de control poblacional y/o individual: el sistema que ejercía su poder excluyendo, que se ha vuelto ahora miope a lo que ocurre allí afuera -y que ya no puede controlar con tanta eficacia - se propone hacerlo por medio de la inclusión o, para mejor decirlo, mediante la ficción y la promesa integradora. Al tratarse de un mismo sistema - reitero: político, cultural, jurídico, pedagógico - los procesos de exclusión e inclusión acaban por ser muy parecidos entre sí, siendo entonces la inclusión un mecanismo de control que no es la contra-cara de la exclusión, sino que lo substituye (18).

\section{Bibliografía}

AFSCA, INADI y CMN. 2014. "Observatorio de discriminación de radio y TV". Recuperado a partir de http://www.obserdiscriminacion.gob.ar/wp-content/ uploads/2014/12/MONITOREO_DISCAPACIDAD_VERSION_FINAL1.pdf(acceso03 marzo 2020]

ANGENOT, Marc. 2010. El discurso social. Buenos Aires: Siglo XXI.

ARFUCH, Leonor. 2005. Problemáticas de la identidad. En Leonor ARFUCH (Comp.) Identidades, sujetos y subjetividades, 21-44. Buenos Aires: Prometeo.

BORDWELL, David y THOMPSON, Kristin. 1995. El arte cinematográfico. Barcelona: Paidós.

DE LA FUENTE GONZÁLEZ, Miguel Ángel. 1998. Función de los títulos en la decodificación lectora.Tabanque: Revista Pedagógica, 12-13, 185-201. https:// dialnet.unirioja.es/servlet/articulo?codigo=127584 (acceso 03 marzo 2020)

GOFFMAN, Irving. 2006 [1970]. Estigma. La identidad deteriorada. Buenos Aires: Amorrurtu.

ORGANIZACIÓN DE NACIONES UNIDAS. 2006. Convención sobre los derechos de las personas con discapacidad. http://www.un.org/esa/socdev/enable/ documents/tccconvs.pdf (acceso 03 marzo 2020).

PALACIOS, Agustina. 2008. El modelo social de discapacidad: orígenes, caracterización y plasmación en la Convención Internacional sobre los Derechos de las Personas con Discapacidad. Madrid: Cinca. 
PORRAS VALLEJO, Ramón. 2009. Marco conceptual. En PilarSAMANIEGO

DE GARCÍA (directora) Personas con discapacidad y acceso a los servicios educativos en Latinoamérica. Breve análisis de situación,27-71. Madrid: Cinca.

RICCEUR, Paul. 1996. Sí mismo como otro. España: Siglo XXI.

RIVERO, Ezequiel. 2018. La ficción televisiva en Argentina: el fomento estatal y la crisis de la producción privada (2011-2016).Comunicación y Medios, 27(37) 168-183. https://comunicacionymedios.uchile.cl/index.php/RCM/article/ view/48288 (acceso 03 marzo 2020).

SKLIAR, Carlos. 2002. La invención de la alteridad deficiente desde los significados de la normalidad. Propuesta Educativa 22. Buenos Aires: Novedades educativas.

2005. Poner en tela de juicio la normalidad, no la anormalidad. Políticas y falta de políticas en relación con las diferencias en educación. Revista Educación y pedagogía, Vol. XVII, № 41, (enero-abril), 11-22.

SOLÓRZANO-THOMPSON, Nohemy y RIVERA-GARZA, Cristina. 2009. Identidad. En Mónica SZURMUK y Robert MCKEE IRWIN (Coord.) Diccionario de estudios culturales latinoamericanos. 140-146. México: Siglo XXI.

TOBOSO, Mario y GUZMÁN, Francisco. 2009. Diversidad funcional: hacia la deconstrucción del cuerpo funcionalmentenormativo". http://digital.csic. es/bitstream/10261/23424/1/MarioToboso-FranciscoGuzman_I-CongresoSIEG-2009.pdf(acceso 03 marzo 2020).

VALLEJOS, Indiana. 2011.Entre el modelo médico y el modelo social, algunas reflexiones sobre conceptos y prácticas. Conferencia en el marco de Primera Reunión Anual de la Comisión Interuniversitaria "Accesibilidad y Derechos Humanos 2011", en Universidad Nacional de Luján. http://www.unsj.edu.ar/ descargas/institucional/comisionDiscapacidad/modeloMedicoSocial.pdf(acceso 03 marzo 2020]

VERÓN, Eliseo. 1998. La semiosis social. Barcelona: Gedisa. 


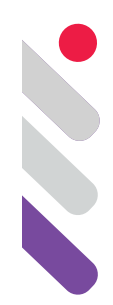

\title{
Casi una serie. Apuntes trasnochados sobre realismo y cine en dos miniseries misioneras
}

DOI: 10.24308/IASS-2019-4-015

\author{
Mauro Figueredo \\ UNaM, Argentina \\ maurofigueredo.cc@gmail.com
}

\section{Despertar no es encontrarse con lo real}

"Se escribe siempre para dar vida, para liberar la vida allí dónde esté presa, para trazar líneas de fuga" (Deleuze)

Me despierto en un horario indefinido. Me doy cuenta dejé, nuevamente, la radio encendida. Suena, además del bullicio pendenciero de un lunes gris, casi de trasfondo-casi a contrarreloj, "Asilo en tu corazón" de Spinetta-Paez. Camino los pocos pasos que separan mi dormitorio del baño, el trayecto que parecía interminable se va volviendo realidad con cada una de mis pisadas. Me siento preocupado, hay algo que debo hacer y no lo sé con certeza. Una imagen se desliza sutilmente, la de un escritor bloqueado cuyos balbuceos de escritura se consumen junto al fuego ¿Dónde la vi? Algo me resulta muy conocido, sin embargo. Esto sucede también cuando vemos un film, es como si soñáramos, una fusión entre un mirar nuestro y un mirar desde el punto de vista del personaje o de la cámara (Avellar, 2015).

Un deseo de escribir, me digo, pero no una lengua para contar. Casi un anatema del discurso en la comunidad lingüística misionera obligada a adquirir los patrones narrativos del "amo". La pregunta capital de todo escritor/guionista misionero debería ser ¿en qué lengua narrar si, en realidad, la lengua con la cual produzco culturalmente es la lengua del otro? Como dice Derrida (2012), algunos hombres deben ceder su lengua a la lengua dominante, acaso simplemente para sobrevivir o, en el mejor de los casos, modificar sus condiciones estructurales. De hecho, en una cultura como la nuestra, marcada por el sustrato guaraní y el portuñol (como una especie de lengua de contacto) esta "constipación" de la 
palabra no resulta casual. Es decir, más allá de tratarse de una figura simbólica propia del ejercicio escritural -traducida al cine-:la hoja en blanco, borroneada, arrojada al fuego, etc., señala un repliegue/despliegue del signo.

Más allá de esto, la sensación de que todavía ni siquiera empecé lo inunda todo. Inclusive hasta podría decir qu eme siento partícipe de una nueva/ vieja discusión acerca del cine que va de lo fotoquímico a lo digital. Ahora bien, según sabemos, la problemática de lo real o la realidad en el cine es un camino lleno de bifurcaciones, sinuoso, espiralado. El cine, en sus inicios, al igual que la pintura y la fotografía, ha tenido que lidiar con la potencia de lo indicial (Andermann-Bravo, 2013).Sabemos, además, que el efecto de lo real es inherente al dispositivo audiovisual "el mundo invade la cámara apenas ésta se pone en marcha" (Oubiña, 2013). Por tanto, el cine ha tenido diversas maneras de aprovechar, transformar, exacerbar o contrarrestar esta marca. Y es que ha coincidido, en sus comienzos, con múltiples líneas epistemológicas, científicas, artísticas, culturales, etc. entre finales del siglo XIX y a lo largo de todo el siglo $X^{1}$.

Sospecho que no es el momento ni el lugar para ponernos a indagar acerca de esto... sospecho, además, que Comolli-Sorrell (2015)tienen razón cuando dicen que "el cine se hace en presencia"; y que ese excedente no siempre es controlable, ya que se mediatizan signos a través del "encuentro entre cuerpos y máquinas" en un entramado narrativo equis. Y aunque hayan cambiado los tiempos y las posibilidades de los dispositivos se hayan tecnificado de un modo brutal siempre habrá planos, tomas y duraciones. Lo que en verdad cambia es que esos planos o esas tomas "ya no son la huella de algo existente y que era previo a ellas, de un referente" (Comolli-Sorrel, 2015).

Siento que aquí lo real o eso que podemos distinguir como lo real desaparece. No lo objeto no obstante, antes y después, en el pre y en el post del cine siempre hubo, siempre habrá, magia (Machado, 2015). Esto es, la pregunta pasa por el hecho de indagar por qué esos fragmentos arrancados de lo real se descomponen, pero sólo para recomponerse en una sala oscura, y, si seguimos el orden lógico de este razonamiento cuál es la extraña metamorfosis de esos elementos que, como sombras, vuelven para atormentarnos (Machado, 2015).

Podríamos pensar que la visibilidad es "calculada", aunque creo que la pregunta debería ser otra:¿cuándo no lo fue? y el cuestionamiento que trae aparejada esta pregunta tiene que ver conla relación deesa "espectacularidad" con lo real, con la "visualidad"2. La cuestión pasa por ver cómo esa realidad, la

\footnotetext{
${ }^{1}$ Se vislumbran, de este modo, dos tendencias en los albores del cine: el naturalismo y el realismo. El primero será la representación fiel en cada uno de los detalles, el segundo, en cambio, sería una intensa búsqueda de una totalidad orgánica, es decir un proceso que tiende hacia lo no-visible inmediato, a lo que se escapa de la mirada común (Xavier, 2008).

${ }^{2}$ En este aspecto, es fundamental que la indagación se sitúe sobre el punto de partida de lo que real es ya visual y que nada de lo que definimos como "realidad" está pro fuera de una mirada, de
} 
que llamamos nuestra realidad, se fundamenta a partir de los signos ideológicos de los dueños de la industria, del pensamiento hegemónico como única e indeleble huella de lo real (Xavier, 2008). Si pienso en el Nuevo cine argentino aquí hay un punto de quiebre y, por ende, de discusión muy proteico.

Si a todo lo señalado le sumamos la problemática de lo real en un mundo asediado por pantallas la cuestión puede complejizarse, y mucho. Aún en la antesala escritural escucho que algunos se preguntarán ¿Por qué otra vez lo real? Si la superabundancia de imágenes de la realidad a través de diversos dispositivos comunicacionales no hace ya de por sí intolerable este bombardeo perpetuo. Es más: cacaso los nuevos realismos en el arte, ese real traumático que Hal Foster leía en algunos textos contemporáneos, ya serían un asunto perimido en el ocaso de la segunda década del milenio?Pero si aún asíinsistimos es dado preguntarse, ¿̇hasta qué punto la relación del mundocon las gramáticas tecnoperceptivas no provocarían aquello que Vattimo (1990), nietzscheanamente, señalara: "la erosión del principio de realidad"?3

Podemos concordar que a partir de la irrupción de lo visual y lo audiovisual (el cine, la fotografía, etc.), como bien lo ha entrevisto tempranamente Benjamin, ya nada ha vuelto a ser como era antes. En este mundo "posmo" en el que habitamos gran parte de lo que conocemos está encuadrado, pues resulta que "el encuadre está en todas partes" y, en consecuencia el cine pierde ese "valor didáctico de mostrar lo no-visible", y, a la vez, lo borra, porque si el encuadre está en todas partes, borgianamente, no está en ninguna (Comolli-Sorrel, 2015). En este sentido, la pregunta acerca de lo real se vuelve más pertinente que nunca. Porque ser espectador no es algo de lo cual sólo unos pocos pudieran gozar, pues "cómo puede ser que el mundo se haya convertido en una enorme y muy eficiente fábrica de espectadores" (Bauman, 2012).

\section{Toda película comienza frente al espejo}

Mientras intento salir de esta fase REM, me pregunto, así, de entrecasa, ¿por qué es tan difícil comenzar cuando se trata de lo real? ¿Por qué tengo que mencionar al espectáculo o al encuadre de un mundo filmado? Entonces:¿Debemos comenzar por el concepto... por la experiencia... por la

una visión o, precisamente, de una visualización. La trampa de la transparencia de lo real dificulta su comprensión: lo real se halla, justamente, sobre la opacidad" (Dipaola, 2015).

${ }^{3}$ Ginzburg (2010), en El hilo y las huellas, dice que los cientistas sociales solemos poner un manto de sospecha cuando queremos hablar de la realidad material, es decir, terminológicamente, cuando la mencionamos la entrecomillamos; la mimamos con diversas piruetas discursivas que destacan el distanciamiento y la sospecha hacia la misma. Me pregunto si esta forma de "mimarla" ¿no sería también una forma de encorsetarla, de negarla? Asimismo, si este "escozor", ¿no se lo debemos al advenimiento -a la erupción, a la simultaneidad, al pastiche, al presente perpetuo, etc.-, de la dominante cultural de los medios masivos de comunicación? Asimismo, debemos tener en cuenta que, como dice Dipaola (2017), las sociedades contemporáneas, globalizadas, "se definen por una indiscernibilidad (y hasta una superposición) entre imágenes y lo social". 
estética... por los elementos semióticos que hacen de los films, de los cuales voy a hablar hoy, "realistas" ? (Badiou, 2015).

En todo caso, eso bien lo sabemos, comenzar por el concepto es una especie de sustracción, una pérdida de lo real (Badiou, 2015). Y, al mismo tiempo, meter todo en la misma bolsa equivale decir: si todo es realista nada, en realidad, lo es. Drama. Lo único que sé es que debería escribir algo acerca de dos series webs misioneras Urú con otros relatos, de Guerín y Manduricio, de Acosta-Bellocquio y que en esta oportunidad me pre-ocupa la dimensión filosófica del realismo.

A ver, dicho rápidamente: la serie Urú... se divide en tres historias narradas de ocho capítulo sque oscilan entre los cinco y doce minutos. Ismael, devenido en vagabundo, emigra del campo a la ciudad. Escapa del delirums tremen sy del dolor de la pérdida de su fiel compañero Toribio.Del narrador y sus asuntos con la escritura, con la hoja en blanco (ah, ahí está mi imagen familiar), y con los misterios que rodeaban la figura su padre y su accionar en el mundo base (madre, novia, etc.). Y, por último, la peculiar historia del "Mencho" Gómez, cuya profesión de urú le da nombre a todo el texto ${ }^{4}$.

Manduricio, en cambio, consta de sólo cuatro capítulos de quince minutos cada uno. En esos cuatro capítulos se cuenta la historia del primer asesino serial de la provincia de Misiones (si bien, sospechamos, habría un anacronismo deliberado en el contar acerca de esta criminal mind local). $\mathrm{O}$ sea que tenemos dos géneros: una trama que podría pensarse desde el incipit del relato a partir de un cierto aire de familia con el realismo y otra, en cambio, que sería un policial con los consabidos condimentos del suspense y de la búsqueda del asesino.

En fin, hay que despertarse, no queda otra. El haberme detenido más de lo habitual en el umbral de mis comienzos diarios, con culpa, pues debería estar atendiendo otras obligaciones más urgentes, hace que reaccione de golpe y que al fin pueda verme en el espejo del baño y que el reflejo me devuelva una mirada extraviada y un rostro que conozco tan bien pese a su mutación a lo largo del tiempo. ¿Qué hay de mí en ese rostro? -Todo, contesto apresuradamente. Sin embargo, las personas que dicen conocerme ¿qué ven en él? 0 , mejor aún, ¿pueden ver a través o más allá de él? Tal vez. El rostro, el yo, la identidad, la subjetividad son lo más cercano a nosotros pero a la vez lo más ajeno (Coccia, 2011). El rostro es, como dice Le Breton, un medio decir.

En este relato de mí mismo, en el que sobreabunda el "primerísimo primer plano", ya aparecen todos estos conceptos con los cuales convivimos diariamente-subjetividad, individualidad, identidad, yo, persona, escritura,

\footnotetext{
${ }^{4}$ El film parte de un texto literario escrito por Sergio Alvez. Esta traducción intersemiótica nos dice que "el cine puede recuperar la tradición de un modo desviado, porque traduce una obra literaria a otro tiempo y otro espacio, con otra lengua y otra sintaxis" (Speranza, 2009:127).
} 
espectador/otredad- $y$, dicho sea de paso, nos dan cuenta de que persiste algo "inmaterial". ¿¿ónde está lo real? ¿'Se lo puede palpar? ¿Es parte del aire? Frente al espejo recuerdo que Ettore Scola ha dicho "el cine es un espejo pintado" y, más aún, Comolli-Sorrell (2015) han dicho: "La tentación del espectador no puede ser sino llevar todo hacia él mismo, a su persona, a su vida, el cine hace inevitablemente de su espectador el espectador de él mismo". Y es que, ċlas series a las que me remito no dejan de hablar de mí mismo? Más bien, no dejan de hablar de un nosotros.

Entonces, ahí, frente al espejo, recuerdo que el primer capítulo de Urú... tiene tres primeros planos y tres instantes junto al fuego. Las miradas parecen perderse en el fuego y, por tanto, mirarse hacia adentro. Manduricio, asimismo, posee largas tomas en primer plano frente al espejo, pero su rostro, a diferencia de los otros actantes, no deja traslucir ningún sentimiento sino una vaciedad que aterra.Veo también esa misma indeterminación en el narrador de Urú... esto es, no miedo sino esa especie de mutismo frente a lo inexplicable.

¿Si hacemos un plano secuencia imaginario qué vemos? El film de Guerín nos lleva hacia un juego rizomático (recordemos, de paso, que en un rizoma no hay centro), a un entrecruzarse permanente, a un fluir y confluir de historias, a nudos que se hacen y deshacen en un entramado narrativo, a ecos y resonancias. No es casual, entonces, que el fuego sea un elemento clave. El fuego heraclíteo que según la metáfora clásica puede remitir tantoal "cambio" como a la "sustancia" primegina, primordial. Las historias se desvanecen, se hacen ceniza, pero sólo para mutar en imágenes y en palabras. Si el hombre, como decía Peirce, es un signo, entonces, el fuego consume los cuerpos y, a la vez, les da entidad (como la historia del padre del narrador).

En el film de Acosta-Belloquio, el signo es un índice anamórfico porque remite a la búsqueda en un sentido dual. Es decir, seguir las huellas para Castels es encontrar al asesino, en tanto para el espectador es encontrarse con la opacidad de Manduricio. Por eso existe la posibilidad que nos demos de lleno, conforme pasan los minutos, con la "máscara de lo real". Por tanto, lo real es siempre arrancamiento de una máscara, acto que, si bien instituye activamente la distinción entre el real y el semblante, para operar tendría que asumir paradójicamente que hay un real de la máscara (Badiou, 2016).

Pero volvamos al silencio que, desde mi punto de vista, podría ser considerado como un signo clave en ambas series webs. El signo del silencio es muy diferente cuando se trata del Mencho Gómez o el Narradoro Manduricio. En Manduricio, cuando su pareja, Josefa, le grita preocupada "¿qué pasó?, ¿adónde vas?", su respuesta es el puro mutismo; lo mismo ocurre cuando le preguntan "¿qué te pasa?", nuevamente la nada misma. Y es que, como dice Chéjov "como siempre, la máxima expresión de la felicidad o el dolor es el silencio". Es decir, para entender el cambio de mentalidad de Manduricio 
cuando mata la cámara utiliza una estrategia que los norteamericanos llaman reaction cut, la cual refleja y refracta la metamorfosis de su rostro, el instante antes de ser poseído por una fuerza extraña, incomunicable (Jost, 2015).

No tiene nada que ver con la mirada de Ismael, que es una mirada perdida en una especie de más allá, una mirada que delira, ya que los signos que Ismael intenta atrapar se desbordan de lo cotidiano. En él veo todo el universo de la creencia (el Gauchito Gil, por ejemplo), todos los signos de la tierra, esas manos curtidas por la zafra y la precariedad. O bien la mirada del narrador que parece ir a la búsqueda de palabras, de signos que lo ayuden a hacer crecer su jardín de historias acumuladas. El close up puebla los relatos de Urú... y Manduricio, los sobrecarga, los altera al introducir una variable de indeterminación.

Ahí estaría, me imagino, la profunda complejidad de lo real y la semiosis tecnoperceptiva; en ese roce sutil de esta gramática cinematográfica y el mundo. En esa controversia nunca resuelta entre imagen, realidad y sujeto. Visto desde aquí las series a las que me remito serían como un organismo anfibio, ya que viven en el adentro y en el afuera del texto, del encuadre, del mundo base.

\section{La búsqueda, los segundos comienzos}

Me siento como en el mundo de Matrix (más cerca de Morfeo, por cierto). Entonces trato de hablar, de materializar mis ideas en una imagen acústica, sin embargo soy el puro cero de una primeridad. Digo dos o tres palabras lanzadas al aire..., la verdad es que debería dejar de pelear con la prosa, pienso. Es decir, si así como nuestro discurso no es sólo palabra sino un cúmulo de posibilidades paraverbales (los gestos, la mirada, los ademanes, la posición del cuerpo, etc.); así el cine, de alguna manera, es un arte que exacerba este punto. Acaso su costado más proteico, además, resida en la posibilidad de la configuración de un régimen de interacción con otros medios (Speranza, 2006).Esto es, entre el acto y la potencia de lo oral y los vasos conectores, los reenvíos y las pervivencias de distintos medios artísticos y tecnológicos.

No obstante, si aún así persisto en mi empeño de escribir quizá encuentre un refugio en la etimología. Quizá podría hacerle una finta a esta complejidad de lo preiconográfico y de lo iconográfico. Una zona de confort para empezar a desandar las dimensiones realistas de los films. Así recorro, al pasar, los basaltos guaraníticos de la palabra urú y no logro distinguir de dónde provienen. José Google, como siempre, me "ilustra" y me sorprende. Leo indistintamente: ave, metal ficticio de Asgard, madre de Mufasa y Scar en El Rey león, pueblo indígena de Perú y Bolivia, idioma, palabra determinista en la escritura cuneiforme y, más abajo, como perdido, el diccionario guaraní que me lleva a "cabecilla, capataz o juez".

Sin dudas el variopinto signo de la palabra urú me pone en un aprieto. Pero después me enteraré que aquí/allá, en Misiones, el urú es utilizado como 
sinónimo de encargado del secadero de yerba, y obtiene su nominación del pájaro que lleva este nombre debido a su particular forma de actuar (como cantar, otear, levantar la cabeza, etc.). Es un gesto semiótico en el complejo sistema de los secaderos de yerba que tiene que ver con un saber-hacer que se parece mucho al de los rabdomantes, y que en las latitudes misioneras responde a una metodología, el barbacuá, que tiende a desaparecer conla tecnificación de los secaderos.

Pero ese tampoco parece ser un buen comienzo. Quizá puede ser que encuentre algo si empiezo mi relato en el mismo momento que el Urú (El Mencho Gómez) corre por su vida en el medio de los montes misioneros. Huye después de haber matado a un capataz que lo increpó por haberse negado a aceptar un trago/trabajo. De hecho Gómez es un signo dual, ya que es tanto "culpable" por la muerte del yerbatero hacendado como "inocente" por haberlo realizado en defensa propia. Es tanto "culpable" por esa muerte como "inocente" por la soberbia y la animalización del otro impuesta desde tiempos inmemoriales en la semiosfera de los yerbales, y que, aún hoy, no ha dejado de tener vigencia.

Resulta que en esa "huida" voy volver a encontrarlo, más allá, al borde de un río, pero con otro nombre aunque su rostro siga siendo el mismo (Recordemos que uno de los actores de Urú... es Cristian Salguero que, curiosamente, es el actor principal de Manduricio). ¿Una coincidencia? Claro que sí, pero también una continuidad, un correlato. Ambos tienen las manos llenas de sangre, han matado, corren por su supervivencia y, como si esto fuera poco, en ambos se vislumbra la marca misionera del yerbal con sus ríos de sangre y muerte (los tareferos, los capangas, los mensúes, la profesión "diabólica" del urú), la larga lista de la opresión. Un signo que, dicho sea de paso, recorre todo el universo discursivo de las dos series, como si en cada uno de los procesos de esta semiosis pudiera leerse un doblez, un pliegue de lo trágico.

A ver, veamos un poco esta relación con la tierra. Por un lado, las huellas que deja Manduricio en sus andanzas son las que persigue Castells. Son huellas emborronadas por la impericia de la policía científica al contaminar la escena. Es el recorrido por los márgenes, por piringundines de medio pelo y por la casa de su padre (Esta escena no deja de ser simbólica, pero dejémosla ahí).Pero en Urú... la tierra es un signo persistente: está en las manos llenas de tierra del narrador al plantar una planta de lima en la chacra de su padre después de haberse enterado de múltiples facetas para él desconocidas. Es la chacra misma. Es el camino de Ismael.

Pero si volvemos a la historia de Gómez, lo concreto es que una cierta nostalgia por el oficio, no lo sabemos, lo hace volver a presentarse para trabajar en el Chaco boreal y, ahí mismo, ser ajusticiado por los poderosos -de sus garras es imposible escapar-. No ocurrirá lo mismo con Manduricio (perdón por el spoiler). Aunque aquí sabemos desde un primer momento quién es el asesino 
y todos esos juegos sociales, culturales, quela serie del enigma propone (desde Poe hasta Lynch)son suturas del investigador, no del espectador/investigador.

Lo real es lo que es y no puede ser de otra forma, ha dicho Rosset (2016), pero en esa conexión permanente con la vida hay un fluir perpetuo de signos, y esos signos delatan el sentido político de la vida y el sentido de ser de lo sensible. Deleuze (2009), precisamente, en el primer ensayo que abre Crítica y clínica dice que devenir es una continuidad, un fluir que desborda "lo vivido y lo vivible". Que se derrama, que salpica, pues "Devenir no es alcanzar una forma (identificación, imitación, mímesis), sino encontrar la zona de vecindad, de indiscernibilidad o de indiferenciación tal que el devenir siempre está 'entre'" (Deleuze, 2009). Es ese entremedio el que se transforma en devenires en las dos historias, que despliega un rizoma de $n$ conexiones. En consecuencia, sería, creo, un punto clave del cifrado de estos textos audiovisuales.

\section{A través del espejo}

Estas indagaciones me acompañan mientras junto dos o tres cosas tiradas por el suelo, el yo que se hace presente todos los días con su cúmulo de actividades, con sus obligaciones, con lo que deberá de Hacer para Ser. Eso que otros le han impuesto, su mantra diario, su eterno y bípedo rumiar. Pero hay una pregunta que me sobrevuela desde párrafos atrás y me gustaría explorarla. ¿Vivir significa, ante todo, ser a través de lo sensible? ¿Vivir, como diría Peirce, es andar entre signos? Mirar, oler, degustar, percibir; pero también acceder a nuestro pasado (algún aroma, una imagen, un relato) o proyectar nuestro futuro, e incluso ser conocidos por el otro... Todo, exclusivamente todo lo que hacemos como humanos-como homo narrans es la "ininterrumpida actividad de producción de realidades sensibles" (Coccia, 2011). Por eso, lo sensible no es sólo aire, ideas, pensamientos, o cosas, sino también es cuerpo.

Concuerdo con Badiou (2016) en el hecho de que si buscáramos lo real aquí le estaríamos errando de cabo a rabo, porque el signo de lo real es indirecto. $\mathrm{Y}$, además, porque acceder a lo real significa romper una máscara, dividirla, sólo para encontrarse con otras máscaras, con nuevas formas de lo real. Y, continúa Badiou, en el mundo de la modernidad líquida esa máscara es casi imposible de quebrar. Tanto es así que podríamos decir que es tan real como que ya está lejos de nuestro alcance.

En este sentido, los cuerpos que Manduricio va dejando desperdigados por el territorio Misionero son el signo de la voz política de turno, es decir, una forma de jerarquizar la muerte y los cuerpos (Ya que se le pide a Castells que indague sólo lo que tiene relación con el yerbatero asesinado). Sin embargo, el terror y el miedo quedan flotando en el aire. El signo "Manduricio" puede mutar. Manduricio puede estar en cualquier territorio, es una especie fantasma que atormenta a Castells y una muestra cómo se moviliza el sistema jurídico- 
político; es la historia de una vida surcada por el odio y el desprecio, etc.

En efecto, el texto audiovisual nos habla, a través de una escena, de lo que está allí, pero, paradójicamente, se refiere también a lo que no está allí (Avellar, 2013), al fuera de campo. Sólo apuntaremos en esta ocasión que Manduricio, el Padre del narrador de Urú..., el Urú mismo, Toribio, etc., son "la cosa ausente", pero también la cosa deseada y temida. La gramática tecnoperceptiva de Urú y Manduricio es también un frágil puente tendido sobre esas variables, que se hacen carne, realidad, en los mapas semióticos del suelo misionero.

Resulta que ese trozo, ese fragmento de lo real que está frente al espectador es una conjetura, no una respuesta. Cuando la cámara empieza a rodar no lo hace en busca de una contigüidad-como decía Adorno en Dialéctica de la ilustración acerca de los productos de la industria cultural- entre el mundo del cine y el mundo real. Como en Hamlet la sala de cine pasa a ser la ficción de una ficción, es decir, no importa tanto saber si un film es ficcional o documental o si es un híbrido entre ambos (como tiende a generalizarse en los nuevos documentales y en el arte contemporáneo) sino que al salir de nuestras casas o de las salas de cine lo que creemos reconocer como mundo real parece una vil copia, una deslucida imagen de lo que acabamos de percibir/sentir (Oubiña, 2013).

Los textos audiovisuales serían, desde este punto de vista, otras formas que tenemos de darnos a lo sensible. Modos diversos, múltiples, polimorfos, de acceder a otros mundos posibles y de volver a mirar las cosas del mundo base, tal vez con ojos alienígenas. Barthes (2011) ha dicho que las fuerzas de "libertad" no dependen del "compromiso" del escritor ni del contenido doctrinario de su obra sino del desplazamiento que éste pueda ejercer sobre la lengua. Podemos extrapolar esta cita al lenguaje audiovisual. Lo que implica decir que independientemente cómo, bajo qué género o medio y desde qué postura ideológica todo producto cultural es "categóricamente realista: ...es la realidad, o sea, el resplandor mismo de lo real" (Barthes, 2011).

\section{A modo de cierre: entre la opacidad y la transparencia}

Como sabemos, todo final anuncia siempre otro principio. Así que para cerrar este trabajo, ya sea completamente despierto, ya sea completamente dormido, me gustaría apuntar un par de cosas que, en el mejor de los casos, podrían producir un esguince en lo que vengo diciendo. Primero, concuerdo con Andermann y Bravo (2013) que postulan que el NCA nace de la crisis entre los medios de producción y la economía. Lo cual generó nuevos modos de hacer que posibilitaron un retorno de ese real "traumático", porque surgió de la precariedad y del azar, ya que, en otro orden de cosas, redescubre la ciudad que estaba fuera del encuadre habitual. Films de los bordes sociales con ciertos 
grados de desprejuicio observan al mundo más allá de la solemnidad y del mero artificio alegorizante del cine de los ochenta (Oubiña, 2013). Clásicos como Pizza birra y faso, Bolivia, Buena vida: delivery, entre otros, dan cuenta de ello.

La pregunta capital es qué relación tiene el NCA con las producciones audiovisuales misioneras. Resulta que el problema de lo real en los films misioneros parece correr por otros senderos, desandar otros derroteros. Sobre todo porque gran parte de la producción audiovisual misionera se yergue sobre la consigna carpentiana de lo real maravillo americano: lo profundo está ahí, sólo tenemos que buscarlo para empezar a narrar y, a la vez, escomo si también fuese perentorio recuperar la memoria. Una fusión entre el mito, la oralidad y la memoria de un pasado lejano o reciente.

Si bien es cierto que habrían ciertos guiños a la realidad, sobre todo porque marcan una reescritura de ese real la propuesta parece ser muy diferente. En Manduricio, por ejemplo, se recurre a la crónica roja de la prensa y los incipit de Urú... nos llevan a un replanteo de lo real a partir de un juego rizomático. Pero ninguna se aleja demasiado del naturalismo ni tampoco del realismo crítico.

Aún así, creemos, que estos realizadores nos llevan al territorio político en el cual la semiosis tecnoperceptiva ejerce nuevas iluminaciones sobre lo cotidiano, marca las asimetrías del poder, se traza sobre un aparente manto de oscuridad, y plantea, por tanto, formas dialógicas con la realidad. Los textos fílmicos son políticos, como dijo Rancière (2004), no porque posean una conexión directa con el referente político, sino más bien como un recorte, como una postura. Son políticos porque disponen de nuevas formas de ver y de operar con lo real. Es importante, entonces, indagar acerca de los vasos conectores que sostienen la praxis humana con eso que se llama lo real y, cómo "éste funciona como un imperativo (categórico) de sumisión o si se puede o podría funcionar como un imperativo abierto a la posibilidad de una emancipación" (Badiou, 2016).

\section{Referencias}

ANDERMANN, Jens -FERNÁNDEZ BRAVO, Álvaro. (comp.). La escena y la pantalla. Cine contemporáneo y el retorno de lo real. 2013. Buenos Aires: Colihue.

AGAMBEN, Giorgio. 2019 [2016]. ¿Qué es real?Buenos Aires: Adriana Hidalgo Editora.

BADIOU, Alain. 2016 [2015].En busca de lo real perdido. Buenos Aires, Amorrortu.

BAUMAN, Zigmut. 2012 [2011].La sociedad sitiada. Buenos Aires: FCE.

COCCIA, Emanuelle. 2011 [2010].La vida sensible. Buenos Aires: Marea. 
COMOLLI, Jean Louis-SORREL, Vincent. 2016 [2015].Cine, modo de empleo. De lo fotoquímico a lo digital. Buenos Aires: Manantial.

DELEUZE, Giles.2009 [1993].Crítica y clínica, 3a edn. Barcelona: Anagrama.

DIPAOLA, Esteban (comp.). 2017. Producciones imaginales. Cultura visual y sociedad contemporánea. Adrogué: La cebra.

DERRIDA, Jacques.2012 [1996]. El monolingüismo del otro. Buenos Aires: Manantial.

GINZBURG, Carlo.2010 [2006]. El hilo y las huellas. Buenos Aires: FCE.

JOST, Francois. 2015. Los nuevos malos. Buenos Aires: Libraria.

MACHADO, Arlindo. 2015. Pre-cine y post-cine en diálogo con los nuevos medios digitales. Buenos Aires: La marca.

RANCIÈRE, Jacques.2011 [2004]. El malestar de la estética. Buenos Aires: Manantial.

ROSSET, Clement. 2015 [1976]: Lo real y su doble. Santiago de Chile: Hueders.

SPERANZA, Graciela.2006. Fuera de campo. Literatura y arte argentinos después de Duchamp. Barcelona: Anagrama.

XAVIER, Ismail. 2008 [2005]. El discurso cinematográfico. Opacidad y transparencia. Buenos Aires: Manantial.

\section{Filmografía}

Manduricio (Acosta, Sergio-Bellocquio, Diego)

Urú con otros relatos (Guerín, Elian) 


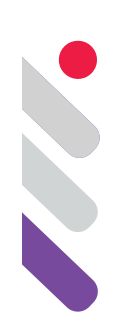

\title{
Télévision et justice: une trajectoire médiatique controversée?
}

DOI: 10.24308/IASS-2019-4-016

\author{
Yannick Lebtahi \\ Université de Lille, France \\ yannickelebtahi@orange.fr
}

En déconstruisant, les cycles marquants d'une relation complexe et tensionnelle entre la télévision et la justice française, nous pouvons comprendre et partager aujourd'hui de manière unanime l'idée que la télévision est un intermédiaire privilégié et nécessaire de la justice.

La télévision est un bon outil pédagogique et d'acquisition de connaissances, car elle rend visible l'invisible du travail de la justice et ses mécanismes et ceux sont les séries télévisées, la fiction plus globalement, qui ont indéniablement contribué à ces avancées.

Par ailleurs, bien qu'elles puissent être aussi des voies esthétiques de contestation envers l'institution judiciaire, les fictions ont largement répandu une figure du juge trop figée ou désincarnée selon Philippe Lemaire Procureur Général de la Cour d'appel d'Amiens.

Cette représentation contre laquelle les acteurs de la justice se sont mobilisés tout au long de ces dernières années est maintenant une représentation révolue.

Mon propos n'est pas de m'attarder davantage sur les apports ou les enjeux de la fiction, mais plutôt de me pencher sur ceux du genre documentairetout aussi présent dans les grilles de programmes, car les chaînes de télévision françaises pré-achètent ou participent largement au financement des documentaires.

Pour les documentaires traitant de la justice, il faut noter que dans bien des cas l'institution judiciaire est à l'origine du projet filmique - elle le commande à un auteur ou dans le cas inverse, elle a de fait un droit de regard sur la démarche de l'auteur, car c'est bien elle qui donne ou non un certain nombre d'autorisations ou d'accords tout au long des étapes de production.

En intégrant ces contextes et ces enjeux de production, la télévision se met en quelque sorte au service de l'institution judiciaire ce qui apparaît 
d'autant plus légitime si c'est une chaîne de service public.

C'est la complexité de ces liens en jeu dans la démarche documentaire d'un auteur qui m'intéresse de saisir pour tenter de déchiffrer ce que les phénomènes de saillance traduisent de la trajectoire médiatique de la justice et de ses rapports à la télévision.

Je formulerais quelques brèves pistes d'analyse à partir de l'étude du documentaire de 70 minutes, Des juges et des enfants, réalisé par Cyril Denvers diffusé dans le cadre de l'émission Le monde en face, le 7 février 2017sur France5 la chaîne publique.

La diffusion du documentaire a été suivie d'un débat animé par Marina Carrère d'Encausse. Et enfin l'émission est restée disponible pendant 7 jours en replay.

Ma collaboration avec Émilie Dewaele l'avocate présente dans le documentaire a permis une lecture critique plus structurante.

Bien qu'il ne soit pas sans imperfection, ce documentaire contribue à la construction d'une image plus dynamique et humaniste du juge ce que convoitent maintenant les acteurs de la justice.

Ce qui est assez novateur, c'est que celle-ci symbolise celle de la protection et non plus seulement celle de la sanction, car comme je vous l'ai précisé plus haut, jusqu'alors la figure du juge précisément était très souvent représentée comme celle d'une femme ou d'un homme assis à son bureau caché derrière une pile de dossiers - sans interaction avec l'environnement.

Avant d'aller plus loin dans l'approche sémio-pragmatique de cette problématique, il est à convenir que la représentation audiovisuelle dans le cas du documentaire ne vise pas seulement à l'innovation créatrice, mais se doitd'assurer aussi la reproduction de l'existant : les images documentaires tiennent à la fois d'un projet énonciatif intentionnel et d'une empreinte du réel.

À la croisée de ces deux logiques contradictoires, le documentaire est pris sans cesse dans cette tension entre la représentation et la reproduction, entre sa nature de discours et sa finalité d'attestation du réel.

Ce qui se complique dans le cadre d'une commande via l'institution judiciaire comme dans le cas du documentaire Des juges et des enfants.

Le dispositif de filmage doit permettre de capter la réalité au plus près, sans venir la bousculer ou l'influencer. La caméra doit s'effacer, se fondre dans l'espace. II ne faut pas donner à penser que le fait de filmer puisse être à l'origine de nouvelles orientations factuelles, la crédibilité et l'authenticité du documentaire sont alors en jeu.

La conception du réel est davantage une promesse que fait le réalisateur à son public, elle ne peut être complètement effective, en particulier dans un lieu si spécifique comme le tribunal de Lille.

L'objectivité documentaire relève de la croyance. Le documentariste est 
un observateur d'une réalité environnante - un témoin surplombant les faits, laissant entendre que son immersion sur son lieu de tournage ne provoque aucune vague venant l'affecter ou la modifier.

Effacée, intégré au réel des individus et loin d'être l'outil d'une simple restitution de la réalité indépendante et positive, la caméra est en fait au cœur d'interactions multiples, mais les faits sont pluriels et se reconfigurent sans cesse au contact de la caméra au moment du tournage, avant même de devenir la matière du récit final, via le montage.

La question fondamentale est celle de la représentation du réel et de sa diffusion médiatique ce qui implique en quelque sorte pour le téléspectateur d'être en capacité d'analyser le document en fonction de la nature du regard documentaire posée sur le réel.Ce qui n'est pas du tout acquis.

De plus, face aux faits révolus, la télévision et la justice appartiennent à deux logiques antagonistes : les diffusions - accrues par les rediffusions médiatiques ne cessent de raviver la mémoire des faits, alors que la justice fait tout pour mettre en place les conditions du droit à l'oubli pour ceux qui ont été condamnés et qui sont en train de régler leur dette envers la société.

Dans le cadre du documentaire Des juges et des enfants, la technique du floutage ou du recours à l'anonymat est une contrainte imposée par la loi en matière de protection de l'image des mineurs. Cette invisibilité médiatique est le revers de l'invisibilité sociale des mineurs ayant affaire avec la justice. II faut noter que le temps médiatique n'est pas le même que celui de la justice. Cependant, ces techniques posent des questions de fond directement en lien avec le droit à l'oubli, car les membres de la famille, les amis, les voisins, l'entourage du jeune le reconnaissent forcément d'autant que certaines personnes ne sont pas floutées comme ici la cousine de Kenza et puis il y a les indices visuels comme les vêtements. François Jost dans son ouvrage Pour une éthique des médias(Jost 2016) a montré que le floutage ou la déformation de la voix ne sont pas des techniques qui garantissent l'anonymat, ni même la protection du témoin.

Très souvent les documentaires traitant de la justice et diffusés à la télévision publique française sont suivis d'un débat pour les contextualiser, pour cadrer la démarche et la visée en cohérence avec la mission de la chaîne, et pour désamorcer aussi par avance tout reproche possible à la chaîne face au contenu du document qui pourrait poser un éventuel problème à la réception.

En forme de prolongement au documentaire, le débat, qui n'apportera pas de réponse, se construit autour de 4 invités :

- Gisèle Delcambre,Vice Présidente du Tribunal des juges des enfants de Lille,

- Pierre Joxe, avocat spécialisé dans la défense des mineurs (ancien juge et ministre), 
- Holy Fatma, réalisatrice qui a été placée en foyer à l'âge de 11 ans et demi,

- Stéphane Danancier, Éducateur à l'Aide Sociale à l'Enfance de la ville de Montrouge.

Plus qu'un débat, il s'agit d'un échange d'expériences en forme de Talkshow notamment par le témoignage de Holy Fatma qui apporte une vision positive, mais orientée (?) en faveur de l'action sociale à l'enfance.

Pour sa part, Pierre Joxe met en garde contre les défaillances de la société par rapport à la protection qui entache la démocratie.

Quant à Stéphane Danancier, il confirme que l'engagement affectif est inhérent à la fonction des professionnels face à la population en danger que sont les enfants.

Le ton qui est donné à ces échanges par la chaîne nous rappelle celui d'émissions comme Vie Privée, vie publique de Mireille Dumas (France3 de 2000 à 2011) ou Toute une histoire de Sophie Davant (France2 de 2010 à 2016) (JeanLuc Delarue de 2006 à 2010).

En fin d'émission, la chaîne France 5 manifeste son identité et son positionnement de chaîne culturelle et éducative. En effet, Marina Carrère d'Encausse fera la promotion du livre de Pierre Joxe Pas de quartier ? Délinquance juvénile et justice des mineurs(Joxe 2012), celle du Court métrage de Holy Fatma (Please love me forever), celle de la bande dessinée de Stéphane Danancier (aliasPavoProjection de l'enfance), et enfin celle du documentaire de Cyril Denvers via de la diffusion d'une séquence inédite du tournage entre Gisèle Delcambre et Kenza la jeune fille qu'elle a suivie.

Cette séquence, en forme de conclusion, insiste sur la figure maternelle et la personnalisation du juge en faveur de la protection.

À cette occasion, la télévision en profite pour parler d'elle-même, elle réaffirme sa mission de service public (Informer, Éduquer, Cultiver et Distraire) et le fait qu'elle offre un espace de médiation et de promotion aux productions artistiques qui sont autant d'instruments au service de la réflexion critique.

Présenté par la chaîne comme exceptionnel, le documentaire Des juges et des enfants traite de la protection de l'enfant au travers de la figure du juge.

Il faut savoir qu'en France, l'éducation prime sur la répression depuis l'ordonnance du 2 février 1945 signée par le Général de Gaulle pour protéger les enfants.

Les constats actuels dénoncent le fait que cette ordonnance estlargement menacée et a été remise en question au cours de ces dernières années. (Par les lois de Nicolas Sarkozy et de Dominique Perben).

Que nous dit le résumé du documentaire : 
Dans le plus important tribunal pour enfants de France, à Lille, cinq juges ont accepté de lever le voile sur une profession dont le huis clos est un principe sacré. Crise économique, déclassement social, migration, déscolarisation, communautarisme : apparaissent en filigrane les grands maux dont souffre actuellement le pays, et dont les mineurs en errance sont les plus jeunes victimes. Ces magistrats, spécialisés, qui consacrent $80 \%$ de leur temps à la protection des mineurs, évoquent aussi leurs inquiétudes face au manque de moyens dont souffre le département.

La bande-annonce précise que le documentaire révèle les inquiétudes des juges face à la remise en cause de leur mission confrontée au manque de moyens dont souffre le département du nord de la France où se déroule ce documentaire.

En réalité, le documentaire ne dénonce pas ou que très timidement le fait que la protection des mineurs ne semble plus possible faute de lieux d'accueil et d'asile.

La diffusion médiatique nécessite de créer l'événement et l'accroche spectatorielle.Il est important que la chaîne puisse rassembler une audience significative.

Selon le discours de la chaîne ce documentaire vient lever le principe du sacré : le huis clos ce qui lui confère un caractère inédit à la télévision.

Le huis clos est un principe sacré du point de vue de la justice française lorsqu'il s'agit de personnes mineures.

Ce que ne précise pas la chaîne c'est que ce documentaire est une commande du Ministère de la Justice.

Et qu'en 2008, un documentaire d'Adrien Rivollier, Au tribunal de l'enfance, diffusé sur France2- autre chaîne française publique - dans le cadre de l'émission Infrarouge levait déjà le principe du sacré au sein du tribunal de Lyon. (reportage de 6mn22-journal télévisé de 20h-France2-04/12/2015). Donc rien d'inédit en 2017 !

Le regard documentaire privilégie la personnalisation de la figure du juge au détriment d'une analyse de la situation.

Pourtant les juges et les professionnels de la justice insistent sur la nature de leur engagement et leurs difficultés à mener leur mission face aux institutions et à une société qui n'est plus en capacité d'accueillir et de protéger les enfants mineurs par manque de place et de moyens.

Le réalisateur semble prendre le parti de ne pas s'avancer sur ce terrain alors que l'intention documentaire, mise en avant par la chaîne au travers de la bande annonce, est venue poser un horizon d'attentes chez le téléspectateur qui ne sera pas complètement comblé.

Sous la forme de portraits, 5 juges témoignent de leur engagement face aux défaillances sociales et familiales et de cet ensemble de témoignages se 
dessine les contours de ce que recouvre la notion de protection des mineurs aujourd'hui en France.

\section{Cécile Nounou}

Il faut préciser que le département du Nord, dont les missions se cristallisent autour de la protection, du handicap et des personnes âgées, a perdu 700 places d'hébergement pour les mineurs. Et que ce même département n'est plus en mesure d'assumer les actions de prévention.

Mais en réalité dans le documentaire, contrairement aux autres juges, la juge Cécile Nounou ne fera qu'une brève apparition pour dénoncer la situation du département et affirmera que la protection des mineurs ne semble plus possible faute de lieux d'accueil et d'asile.

\section{Gisèle Delcambre}

Vice Présidente du Tribunal des juges des enfants, Gisèle Delcambre est une figure centrale, sa parole est accès sur la souffrance des enfants et leur sécurité. Elle s'affronte aux parents en leur rappelant la loi, mais surtout ce que nous montre le document c'est qu'elle insiste sur les principes éducatifs et maternels. Elle évoque la manière d'exercer son métier toujours en quête de connaissance, d'accompagnement et d'adaptation de ses mesures en fonction des mineurs qu'elle suit de près. Le juge est un avant tout humain.

Elle dira à la mère de Kenza « je ne suis pas là pour vous juger, j'essaie de comprendre, madame ".

Gisèle Delcambre semble se confier, nous sommes dans le tribunal de I'intime. Elle symbolise la figure maternelle de substitution via le cadre juridique tout en mesurant le poids de son jugement et ses conséquences.

\section{Johann Ruocco}

Lejuge, Johann Ruocco évoque la dimension gratifiante de sa mission dont l'objectif premier est de venir en aide aux enfants. II montre comment face à la défaillance parentale qui peut être à l'origine de dérives menant au placement, l'assistance éducative en direction des adultes est primordiale.

En inscrivant sa démarche dans le temps, il cherche à leur faire prendre conscience dans l'exercice de leurs responsabilités éducatives ce qu'est être parent même dans la co-parentalité. Son objectif étant de les associer à la perspective du retour de l'enfant dans le foyer familial.

Cet homme revêt la figure de l'autorité, peut-être celle du père ou celle de notre société. Il symbolise la valeur éducative qui se niche au cœur même de la notion de protection. 


\section{Christine Soyez-Martin}

Le juge, Christine Soyez-Martin insiste sur le fait que chaque enfant est un cas à part - une histoire particulière et qu'il n'y a pas de solution toute faite à appliquer.

Et que la mission du juge ne relève pas d'une science exacte. Pourquoi ? Parce qu'en matière de ressources humaines, il n'y a pas de rationalité totale, pas de situation optimale.

Elle précisera d'ailleurs « on travaille avec des êtres humains » et partagera son inquiétude par rapport à ses convictions « tout faire pour que la situation familiale s'améliore ", mais les situations sont tellement dégradées que les frontières de l'impossible et de l'inconcevable sont en train d'être franchies en matière de protection des mineurs.

Ici la parole du juge pointe les dérives de notre société démocratique et ses conséquences en matière de protection de l'enfance.

L'assistance éducative passe notamment par le travail des éducateurs qui sous la responsabilité du juge vont opérer une certaine médiation. Le documentaire leur consacre une large place.

\section{Judith Haziza}

La jeune juge, Judith Haziza, explique le passage de l'assistance éducative au pénal - le centre éducatif fermé pour éviter l'incarcération.

Et comment, en dépit de la mobilisation des différents acteurs, le juge arrive-t-il à prendre la décision de l'incarcération et par quel processus ?

C'est à elle que reviendra le mot de la fin - le propos se referme sur luimême comme pour insister sur l'impasse de la situation dans le département du Nord.

Elle indique à nouveau, en forme de synthèse, les difficultés de leur mission :

- La difficulté à mettre de la distance entre son statut et l'individu qu'elle est

- Se laisser toucher sans être dans l'attachement

- Prendre en compte la dimension humaine

Et tenant compte des paradoxes de leur mission, les juges doivent rendre des décisions tout en gardant la tête froide.

Le juge Haziza symbolise le renouveau de la justice française, le nouveau souffle face à cette institution en crise d'identité et de légitimité, elle réaffirme la mission d'information et d'éducation de nos institutions publiques et enfin elle montre comment les lignes de partage entre la protection et l'incarcération s'effacent et se confondent.

Parmi ces 5 portraits, celui de LaVice Présidente du Tribunal des juges des enfants de Lille, Gisèle Delcambreest central, son argumentation est axéesur la 
souffrance des enfants, leur sécurité et sur la dimension humaine de son métier.

Symbole maternel de substitution via le cadre juridique, nous sommes avec Gisèle Delcambre dans le tribunal de l'intime.

En forme d'insistance et pour réactiver la promesse de la chaîne, l'émission se clôt sur une séquence inédite du tournage dans laquelle la juge Gisèle Delcambre personnalise la justice en faveur de la protection et non de la répression.

Dans la poursuite de sa trajectoire médiatique, la figure désincarnée du juge semble évoluer vers une nouvelle figure plus maternelle, pour une représentation audiovisuelle peut-être plus féminine de la justice.

On peut citer à ce sujet le récent documentaire belge Ni juge, ni soumise réalisé par Jean Libon et Yves Hinant sorti le 7 février 2018 en France.

Paradoxalement la protection rendue impossible est un des aspects que le documentaire ne traite pas - la protection rendue impossible se situe du côté du non-dit?

Du point de vue de la réception, ces non-dits que le documentaire laisse en suspens posent la question du statut et de la destination de ce document.

L'externalisation du regard contribue à accentuer l'apparente neutralité du point de vue ou son objectivisation.

Le réalisateur semble se placer du côté du commanditaire et de la chaîne.

L'orientation éducative et civique du documentaire est pleinement assumée.

Mais ce parti-pris de réalisation n'est pas sans provoquer un certain nombre de remous et de débats tumultueux au sein des professionnels de la justice et encore plus pour ceux qui ont participé au projet documentaire.

En forme d'écho, je vous cite l'avocate ÉmilieDewaele :

Lorsque Cyril Denvers m'a contactée, m'a-t-elle dit, pour ce documentaire, j'ai immédiatement saisi l'occasion pour faire état de la gravité de la situation des jeunes mineurs isolés étrangers qui vivent dans la rue.

Mais le rendu n'était pas ce à quoi je m'attendais.

Je n'y ai pas retrouvé les explications de cette situation de détresse et de grande vulnérabilité que traversent mes clients. À aucun moment, les autorités administratives sont interrogées. À aucun moment, elles sont mises en cause dans l'absence de solutions. À aucun moment, les responsables sont entendus ni même accusés de leur carence.

J'ai vraiment eu le sentiment que rien n'était fait pour expliquer la réalité.

Certes, on y voit des jeunes ou des familles en détresse. On y voit des juges sous les projecteurs. Mais on ne comprend pas bien l'enjeu de ce documentaire malgré une annonce alléchante.

Bien que la contestation semble délicate à entreprendre dans un projet filmique, la production des documentaires en France soutenue par la télévision 
rend compte, me semble-t-il, à leur manière de la crise d'identité de l'institution judiciaire qui évolue à son gré alors que l'espace multi médiatique lui, dans une tout autre temporalité, est sans cesse en quête de renouvellement, de sensations... d'innovations créatives ce qui expliquerait pourquoi ces productions diffusées à la télévision semblent trop timorées face aux attentes des différents acteurs/professionnels et que bien souvent elles font l'objet de controverses au moment de leur diffusion, et donc rejetées par manque de légitimité elles finissent dans un tiroir.

Par delà une trajectoire médiatique controversée, l'enjeu sémiotique ne se nicherait-il pas alors dans ses brèches que sont les apparents rendez-vous manqués entre la télévision et lajustice?

\section{References}

JOST, François. Éd. de l'Aube (eds.). Pour une éthique des médias. Les images sont aussi des actes.2016. La Tour-d'Aigues.Coll. Monde en cours.

JOXE, Pierre.Éd.Fayard(eds.). Pas de quartier? Délinquance juvénile et justice des mineurs.2012. Paris. 


\section{MEDIATIZACIONES}

\section{F. REDES Y CIRCULACIÓN DEL SENTIDO}





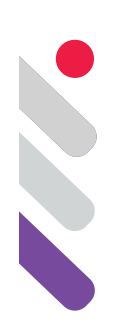

\section{Formas de vida migratorias: arte e intimidad}

DOI: 10.24308/IASS-2019-4-017

Jaime Cordero

Universidad de Chile

Jcordero@uchile.cl

\section{Presentación}

En un artículo anterior relacionado con el tema de esta ponencia, nos referimos al cuerpo (en un sentido extenso del sujeto y de sus derechos) y a la intimidad, en general, expuestos por necesidad o por obligación y, de manera particular, a las artes donde la intimidad era voluntariamente expuesta (Cordero, 2016).

Con un telón de fondo postorgánico, la intimidad surge hoy como espectáculo, sostiene Paula Sibilia (2005 y 2017); quien quiera exhibir su cuerpo o su intimidad puede hacerlo, ayudado, además, por las nuevas tecnologías que han permitido un movimiento desconocido hasta hace poco observado en las redes, movimiento al que hemos denominado, metafóricamente, nomadismo, por el continuo desplazamiento, que no implica,necesariamente,como sostiene Deleuze (2004:321-332), un cambio de lugar, sino un cambio volitivo, el tránsito desde un querer hacer hasta un poder hacer o deber hacer, de una virtualidad a una actualización, provocando con ello una "desterritorialización" y una ruptura de fronteras, un cambio violento en la axiología existente, en los valores deónticos, pudiendo entonces la intimidad manifestarse abiertamente, creando, por consiguiente, un nomadismo físico y psíquico, real y virtual, una dehiscencia reversible.

Esta apertura, ha permitido que no solo la mujer, a lo largo del tiempo relacionada en ciertos medios sociales con el diario íntimo y el cuarto propio, pueda mostrarse, sino

también el hombre, y todas las diversidades sexuales. Y con ayuda de las tecnologías, sujetos solos o parejas han dejado para la posteridad experiencias íntimas, algunas de las cuales dadas a conocer por los mismos interesados o bien por terceras personas, y muchas de ellas con el propósito de ganar un lugar más público como la televisión o recuperar el lugar perdido en ella.Todo lo cual ha pasado a constituir para actores y artistas una forma de vida con variedades 
formales de acuerdo a las culturas. Para entender esta nueva forma de vida y el consiguiente nomadismo haremos un corte transversal en algunas de las líneas de fuga por donde transitó el actor y el artista. Acudiremos, al menos, a dos fuentes históricas; la religión y el derecho, ambas constituidas como "máquinas de guerra burocráticas despóticas" (ibíd.), barreras para la libre expresión aún hoy: la religión, en cuanto a la ordenación moral y el derecho en cuanto a la organización jurídica que se dieron los Estados en algunos periodos que hemos considerado importantes para este estudio. Además, apelaremos al psicoanálisis, en relación con lo que significa la represión de las pulsiones en el actuar y crear del sujeto social y las líneas que el arte ha tomado en su propia manera de expresarse.

No entraremos a discutir las ontologías de estas manifestaciones culturales, sino aquellos aspectos de ellas que han incidido en el sujeto: deberes, obligaciones, prohibiciones, castigos y confesiones, en las normativas religiosas y jurídicas. Y dos vías de escape: arte y psiconálisis.

\section{Intimidad y religión}

No entenderemos, aquí, la religión como un lugar al que se recurre para religarse a lo desconocido y misterioso sino a esa institución que desde los inicios del cristianismo tuvo que ver con la confesión y observancia de los mandamientos impuestos dogmáticamente por la Iglesia, y a ese pecado original que cada sujeto debía cargar desde su nacimiento y que debía ser lavado a través del bautismo, poniendo al individuo en estado de represión y de castigo. No respetar esta hoja de ruta significaba un pecado cuya penitencia iba de la tortura física a la tortura moral, de la confesión pública, seguida de penitencia pública, a la privada, con penitencia privada y tarifada, desde actos de constricción que demostraran el arrepentimiento, verificado a través de indicios observables como el enrojecimiento del rostro en señal de vergüenza por el pecado cometido, hasta limosnas a los pobres, a la Iglesia, incluso al confesor. Lo íntimo, si bien dejó de ser una confesión pública, quedó confiscada por el confesor quien podía hacer uso de lo confesado de ser necesario. Las penitencias fueron múltiples, incluso podían ser cumplidas por un reemplazante, situación que terminó por agudizarse con la venta de indulgencias en tiempos delos Papas Sixto IV hasta julio II, papa que decreta la indulgencia para construir San Pedro en Roma en 1507, la que será confirmada por León X, lo que conducirá a la llamada disputa de las indulgencias oponiendo a Martín Lutero con el Papa en Roma.

La Iglesia a través de su religión quiso privar al sujeto de lo íntimo, de lo oculto en lo más profundo de su ser psíquico, buscando extraer ese mundo interior con las tenazas de la amenaza inquisidora; lo íntimo es el secreto que solo se comparte con otro íntimo, aquel en quien se confía como ser singular, pero que puede tratarse también de un ser social, como nos lo narra una obra 
de Lope de Vega, que no se dejó intimidar por el poder, y ante la pregunta insistente e incisiva que los instaba a revelar el autor del crimen, una sola voz se oyó: Fuenteovejuna fue. Un hito importante para los siglos que le sucederán.

\section{La confesión jurídica y religiosa}

La confesión y la resistencia son dos conceptos importantes en la obra de M. Foucault (2014), en tres momentos de la humanidad, tres periodos donde el sujeto experimenta transformaciones culturales en Occidente en los que el tema de la confesión es fundamental, con valores diferentes. Foucault toma de la Antigüedad el mito de Edipo en relación con el tema de la acusación, por parte de los jueces, respecto del parricidio y del incesto cometidos, actos realizados en desconocimiento de las identidades de los afectados. Los jueces esperan de Edipo la confesión (aveu), molestos y ofendidos, además, por elacto de rebeldía de Edipo ante los dioses al no considerar la predestinación, consignada en la predicción del oráculo. La confesión del pastor encargado de asesinar al niño será considerada como conclusiva, no sin antes escuchar las confesiones de Teresías, quien, ciego, ve lo que Edipo, gozando de la vista no logra ver. Confesiones (aveux) ligadas con la justicia, sostiene Foucault (2011:9099), más que con la religión. Para estoicos y pitagóricos la confesión es parte de un examen de conciencia, muy distinto aloque el cristianismo y la pastoral desean: controlar desde su poder a toda la sociedad, aduciendo la salvación de ella si respetan las escrituras y si confiesan sus pecados. En esta era pastoral encontramos también algunos casos como los señalados en el libro de Hermas, para quien el hombre no debería padecer toda la vida si se confesaba, confesión que lo obligaba solo a una penitencia que le permitiría recuperar la pureza del bautizado, ya que, al haber recibido un primer bautizo, ya estaba "iluminado" y podía recibir una segunda penitencia.Las penitencias solían ser corporales y no verbales. El cuerpo recibía la humillación de tener que arrastrarse en medio de llantos y gemidos. Siglos después se instala la confesión en instituciones monásticas, cenobitas, las que exigían la obediencia, pues someterse era considerado virtuoso. La confesión no apuntaba solo a los actos, sino también a los pensamientos, pues estos, los malos, deben ser confesados, pues son satánicos. K. Dreyer lo expone de manera magnífica en su filme Juana de Arco (1928).

Después del concilio de Letrán, otros cambios se experimentan, ya no es tanto el haber relacionado el cuerpo con otro cuerpo el pasible de sanción, sino el tocar su propio cuerpo, masturbarse, razón por la que los niños en internados debían ser vigilados y castigados si recurrían a esta práctica. 


\section{Intimidad y derecho}

El derecho pone al sujeto al abrigo de las miradas o de la intromisión de su vida privada; protege el goce en su doble sentido. El derecho protege el cuerpo íntimo mientras éste no se exponga a situaciones como la embriaguez o la prostitución, o cuando se desvía del camino que la moral exige. El cuerpo es una propiedad privada del mismo modo como lo es una casa, el sujeto tiene derecho a su uso y goce, es su propiedad.

\subsection{El secreto}

El secreto pasa a ser tan privado como lo es la correspondencia, no así el diario íntimo, utilizado en ocasiones por uno de los cónyuges para probar una falta del otro. El secreto hace que para la ley haya un hombre público y un hombre privado; en la privacidad se sustrae a lo público, se sustrae a responder por algo que, de ser público, le estaría prohibido, de modo que el hogar no se encuentra en la esfera de las prohibiciones públicas. Bernard de Mandeville (2011), ya en 1705, en su libro La fábula de las abejas, que lleva por subtítulo "los vicios privados construyen el bien público", hacía ver que las pasiones debían seguir su curso, no debían ser controladas por ningún tipo de autoridad. Una complicación para el ojo jurídico pues no sabe qué validar o qué invalidar. Debe cerrar los ojos en casos y abrirlos en otros. En todo caso, el hombre, por hecho de no tener que rendir cuenta a nadie superior, ni poder, ni al Estado, adquiere confianza, y aparece así el fuero interior (en cuanto a expresión ya había aparecido). La deóntica jurídica no golpea la puerta de la casa, pero la religiosa entra por debajo de ella.

\subsection{Derecho a la intimidad}

La intimidad, si bien relegada al "encierro" donde puede mostrarse, de acuerdo a las normas de orden público y buenas costumbres, deja de estar sometida a un código burocrático. Sin embargo, aunque no medien códigos, si una práctica íntima se expone abiertamente, ésta es considerada como un atentado a las buenas costumbres, y en tal caso es la ley la que tipifica el caso, remitiendo al sujeto de ese actuar a prisión o a un asilo, es decir al encierro institucional, y es ahí donde florecen, dice Deleuze (1972 y 2004), las burocracias, es decir, surge un medio de codificación. La intimidad es intensidad $y$, por consiguiente, se produce un desplazamiento, un "viaje inmóvil" hacia el mundo interior o hacia el exterior mediatizado por los medios tecnológicos a su disposición.

Con el término mónada, además de lo se expresó más arriba, Deleuze (ibíd)alude a las comunidades que pudieron dejar atrás su primitivo estado de rurales; evitando ser atrapadas por el poder o máquina burocrática despótica; se mantienen en la periferia y forman una unidad nómada o máquina de guerra 
nómada cuya gran importancia radica en que se alejan del código anterior, se descodifican sin dejarse sobrecodificar. Sin embargo, si se produce oposición entre los estados no hay total ruptura. Siendo solo similar, los rasgos relativos a la intimidad/extimidad también han hecho recorridos con sus respectivas máquinas de guerra, pasando del sedentarismo al nomadismo como forma de vida.

\section{Libertinaje}

Un capítulo importante en el tránsito de la opresión del cuerpo, y la violación de lo íntimo y de la intimidadlo constituye el tema del libertinaje erudito, adjetivado de ese modo para evitar la acepción más corriente o única actualmente.El historiador René Pintard (1943), considera al libertinaje erudito como pilar fundamental para el que sería posteriormente llamado siglo de las luces, particularmente en Francia, destacando la obra de François La Mothe Le Vayer, quien ha sido estudiado con detención al igual que su obra por varias razones; dos en particular, pues se trata del preceptor por diez años del hermano del futuro Rey Sol, Luis XIV y luego, porque con cierta sutilezademuestra no solo la importancia de cambios en la educación, sino la necesidad de ellos, proponiendo leer a los antiguos en oposición a las lecturas del gobierno pastoral que se ocupaba de los hombres tanto a nivel colectivo como individual, (Foucault, 1975); es decir, el hombre era vigilado tanto a nivel privado como público, Estado e Iglesia. El siglo XVII parece ser un siglo de cambios en países como Francia, por lo ya expresado; sin embargo, la confesión para los fieles constituía una obligación. No así la vigilancia, llevada a cabo por el Estado, la que empieza a ser insuficiente y, por esa razón, la forma pastoral, que había sido desplazada del Estado, vuelve a ser incorporada.

\section{Psicoanalisis, íntimo e intimidad}

Dejar de lado algo, separarlo de todo lo que uno pueda o quiera decir, es una posible definición de secreto. Quien guarda un secreto se somete a una prohibición absoluta. Para el psicoanálisis se trata de una experiencia que el sujeto interioriza con todo lo que conlleva la estructuración del aparato psíquico que debe tener suficientemente construidos sus movimientos pulsionales y defensivos. Esa es la razón por la cual un niño no es capaz de guardar un secreto pues no discierne lo que puede significar respecto de su lenguaje común, habitual. La carga de complejidad con la que es revestido el aparato psíquico hace que el trabajo para el especialista también sea complejo, ya que el secreto puede estar guardado en proximidad o en profundidad y las introyecciones no siempre son las que corresponden.

A fin de no desviarnos de nuestro propósito, volvamos al caso de lo íntimo considerado como un valor privado, no exponible. La pregunta que cabe 
hacerse es qué sucede con aquel o aquella que decide exponer su intimidad en un gesto de desplazamiento axiológico o deóntico, ya sea en las redes o en otro medio visual (cine, teatro, performances artísticas, etc.). La respuesta podría llegar desde distintas disciplinas que se ocupan ya sea del comportamiento social, de la vida psíquica y conductual, etc. Nos detendremos en la propuesta de Serge Tisseron (2001), para quien el paradigma social deeste siglo cambió, lo que no implica en absoluto que la intimidad haya desaparecido; lo que surge es el deseo de mostrar lo que antes se ocultaba. Este querer mostrar o exteriorizar es lo que él denomina extimo, tomado este vocablo de Lacan quien lo utilizó pocas veces según J.A Miller (1985-86) y podría relacionarse con el Das Ding (la cosa, causa) y con el Nebenmensch (el prójimo, el próximo), pero la Cosa es el Otro del mismo sujeto, lo más próximo, lo más cercano, de ahí que para Tisseron (2011), íntimo no es lo contrario de extimo, sino lo más íntimo. Tisseron lo entiende así, pero, además, lo considera como un proceso;como un deseo de mejorar la autoestima, y no como exhibicionismo, vocablo que reúne aquello que se repite constantemente, y es poco estético.

El superlativo de intus (íntimo) es intimus, y quiere decir muy adentro, o

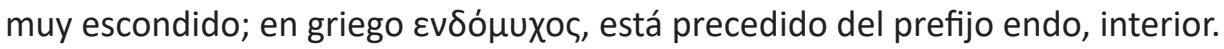

De lo dicho anteriormente podemos inferir que si la intimidad, aunque reprimida, desea mostrarse y deviene extimidad, sin perder la intimidad, entonces el desplazamiento de un estado al otro es mental y valórico, juego de movimiento que podemos considerarlo nómada. Podríamos hablar, también, desde Foucault (2004), de una desviación, como la vejez respecto de la juventud; la casa de reposo sería un lugar heterotópico para el anciano.

La intimidad se exhibía en privado, ante el otro, compartiendo ese mismo mundo, pero también sin ese otro, solo, ante el espejo, lugar utópico, según Foucault, que no muestra sino una imagen, ya que el sujeto proyectado no está ahí, pero se ve ahí, en un lugar que sería heterotópico. En este nomadismo de la intimidad, el espejo sería, ahora, para el otro, la pantalla donde quien mira en ella encuentra la intimidad proyectada de quien la exhibió al otro lado de la pantalla. La intimidad reprimida contenía entonces estas briznas de querer ser/hacer, modalidad que se encontraba en estado virtual para devenir actual. Podríamos igualmente pensar que lo actualizado potencia otro estado futuro. Nada nuevo, es una semiosis ilimitada o como en uno de los capítulos de "Diálogos" de Deleuze (1980), éste nos muestra un continuo, pero la meseta, para ocupar uno de sus términos, es inmanente, es el momento congelado que contiene ya ese movimiento de toda imagen.

\section{Arte y psicoanálisis}

Si el espejo actúa como una pantalla donde aparece la imagen del reflejado, la pantalla televisiva en ciertos programas nos muestra un adentro 
proyectado hacia afuera, figuras televisivas que más que exponer un cuerpo abren su "alma", su intimidad a los demás; un querer mostrar como parte del comportamiento consciente que oculta, diría el psicoanálisis, un fondo inconsciente, pero ahora, al borrar las restricciones impuestas, emergen incluso, a veces, como provocación, sobre todo en los casos de quienes se han visto más reprimidos y marginados. No olvidemos que el cuerpo, a través del biopoder, ha debido sufrir la violencia soberana manteniéndolo en la cuerda floja entre la vida y la muerte, ese cuerpo es un "cuerpo biopolítico" expuesto al orden político, al poder y a toda clase de totalitarismos.

Cine y televisión funcionan, en cierto modo, como un espejo para un tercero: vemos imágenes. El arte performático desde hace mucho tiempo también viene exponiendo el cuerpo y la intimidad con fines variados, insistiendo que intimidad y corporalidad no son sinónimos, pues exhibir el cuerpo puede significar exhibir lo íntimo, pero la inversa no es así, lo íntimo bien puede ser un pensamiento, una idea, un hecho que se oculta, etc.

En la historia del desnudo podemos arbitrariamente trazar tres grandes fronteras partiendo por la venus esteatopigia, cuya desnudez fue y es considerada un símbolo para el ser humano, la desnudez de estatuas y pinturas también fue considerada como símbolo de la perfección en la Grecia clásica, y con el advenimiento del cristianismo, la edad media, en función de una enseñanza, lo utiliza de modo muy particular en los mandamientos y en su función materna, como es el amamantamiento.

Muchas mujeres, sobreviviendo el paso del tiempo, como dirían Didi Huberman y antes que él, Warburg; ingresaron en escenas con sus vestimentas transparentes que delineaban el cuerpo desnudo de ellas y la Iglesia no se opuso, pues de ese modo se podía contrastar la ninfa pagana proveniente de la antigüedad griega de la mujer renacentista formada en el ideario bíblico cristiano.

El cuerpo ha servido como soporte en algunas performances de Santiago Sierra cuyo propósito ha sido denunciar precisamente el abuso del cuerpo, cayendo en contradicciones, ya que ha recurrido, por ejemplo, a sujetos con necesidades económicas para llevar a cabo su denuncia, es el caso de Los penetrados. Marina Abramovic o bien Orlan, también denuncian casos sociales, pero a diferencia de Sierra, ambas lo hacen con sus propios cuerpos. En los casos mencionados, las modalidades quedan expuestas de manera diferente, en el caso de Sierra, los "actores" no quieren, pero deben hacer lo solicitado por el artista por una necesidad económica, creando el sentimiento de desagrado en el espectador que dispone de esa información. La analogía que se hace entre estos hombres y mujeres penetrados con América Latina es que este continente fue penetrado por los conquistadores. Estamos ante un artista-destinador que manipula al sujeto no deseante. En el segundo caso las propias artistas exponen 
sus cuerpos, quieren y consideran que deben hacerlo, pero además pueden y saben hacerlo, modalidades, estas dos últimas,que no están presentes en los actores de Sierra.

En una obra de Manet, Almuerzo campestre, se exponen al espectador dos sujetos vestidos y una mujer desnuda. El escándalo producido entre el público francés del siglo XIX no se debió a que hubiese una mujer desnuda, sino a que esta mujer no fuese un personaje mitológico o religioso, motivos aceptados para la época, pero la molestia, sobre todo y fundamentalmente,radica en que esta mujer, considerada socialmente de estrato bajo, compartiera con dos jóvenes de la burguesía parisina, contradicción insostenible. Sin embargo, si la modelo exhibida en el cuadro hubiese pertenecido a la misma clase de los retratados, Manet entre ellos, tampoco habría sido aceptado, simplemente porque la intimidad no debía ser exhibida públicamente.

\section{Conclusiones}

La obra de arte es una construcción, es un producto del artista, por lo que ha pasado por los mismos avatares del creador, desplazándose y mostrando solo lo que las instituciones morales y política le permitían. De aquí que el arte holandés del siglo XVII era imposible que se replicara entre sus vecinos cercanos, al menos en lo que se refiere a exponer las costumbres, cuerpo e intimidad. Los protestantes no toleraron la prepotencia religiosa-vaticana, que disponía no solo del poder sino de facultades autoasignadas, y no impidieron obras que en el mundo católico habrían sido destruidas.

El poder civil también se hizo poderoso, disponiendo de todas las licencias para impedir cualquier hecho alejado de las normas: vigilar y castigar fue una constante que se ha extendido hasta el presente. El artista tuvo que atenerse a la norma impuesta y el cuerpo es expuesto solo en las temáticas autorizadas.

Resulta difícil entender hoy, en la era de la intimidad como espectáculo (Paula Sibilia, 2017) que parte importante del mundo hubiese vivido con la camisa de fuerza de la confesión y del castigo. Los periodos que siguieron a ese nubarrón negro se tornaron poco a poco más rizomáticos, el cuerpo y la intimidad como un síntoma aparece y desaparece.

Lo íntimo se ha tornado extimo especialmente en el mundo de las redes y nuevas tecnologías. El cuerpo íntimo del mañana ya en su etapa preliminar tendrá otro paradigma cuyo sintagma nos mostrará un cuerpo desencarnado, un cuerpo robótico, sin órgano, expuesto sin complejo ni vergüenza, el ciborg, el cuerpo prostético.

Foucault (2001) en el prefacio de El Anti-Edipo, decía que lo que es productivo no es sedentario sino nómade. El espacio en que aparece lo íntimo y 
luego lo más profundo de él, lo extimo constituye un espacio que se encuentra cruzado por puntos de fuga, por multiplicidades, por lo tanto, abierto, inmanente, contrario al sedentario, trascendente; sigue las líneas, los puntos de fuga, se encuentra por todas partes.

La desnudez fue permitida con fines valóricos y normativos, o bien en temas religiosos o míticos. El cuerpo sufriente fue expuesto en occidente, sobre todo el del Cristo crucificado, pero también ese cuerpo de quienes lo rodean, sobre todo el de María Magdalena. El Compianto sul Cristo morto de Niccolò dell'Arca es un trabajo de expresiones, todas, de dolor, de lamento ante ese Cristo que yace a sus pies. El teatro medieval recuperó la pasión del cuerpo en una época de primacía aristotélica que lo escondía. Como sostiene Tisseron (2001), el deseo de mostrarse es parte de la condición humana, y su prohibición hará que los impulsos sociales y psíquicos reprimidos, vuelvan a aparecer no solo en sueños disfrazados, sino también en metáforas y metonimias reales de destrucción como la historia nos lo enseña. La confesión pública pasó a ser privada, y el arte, especialmente en los Países Bajos, como ya dijimos, pudo plasmar las costumbres donde la intimidad tenía una puerta de escape. Sin duda la batalla dada por los libertinos tuvo su fruto en el siglo de las luces y de las nuevas tecnologías con su correspondiente arte.

\section{Bibliografía}

CORDERO, J. 2016. Intimité et corps politique. Les photos d'Abou Ghraib, in L'homme disparu, Photographie \& corps politiques, 9, Paris, France : L' Harmattan.

DELEUZE, G. 1972. Pensée nomade, in Nietzsche aujourd'hui ? tome 1: Intensités, Paris, Francia : Hermann.

DELEUZE, G. ,PARNET, Cl. 1980. Diálogos, Valencia, España : Pre-Textos.

DELEUZE, G., GUATTARI, F. 2004. Tratado de nomadología in Mil mesetas, Valencia, España: Pre-Texto.

FONTANILLE, J. 2008. Pratiques Sémiotiques, Paris, France : Presses universitaires de France.

2015. Formes de vie, Belgique : Presses universitaires de Liège.

FOUCAULT, M. 1975. Surveiller et punir, Paris, France : Editions Gallimard.

2001. Préface de Michel Foucault à la traduction américaine du livre de Deleuze, G., et Guattari, F.L'Anti-Oedipe : capitalisme et schizophrénie. 
In Michel Foucault,M. 2001. Dits et Ecrits II, 1976-1988 (1ère Edition 1994), p. 133-136, Paris : Gallimard.

2012. Mal faire, lire vrai, fonctions de l'aveu en justice, Belgique : Presses universitairs de Louvain.

2014. Obrar mal, decir la verdad: Función de la confesión en la justicia, Buenos Aires, Argentina : siglo veintiuno editores.

MANDEVILLE, B. de .2011. La fable des abeilles, Les vices privés font les vertus publiques, Paris : Institut Coppet.

PINTARD, R. 1943. Le Libertinage érudit dans la première moitié du XVII' siècle, Paris, France : Slatkine reprints.

SIBILIA, P. 2005. El hombre postorgánico : Cuerpo, subjetividad y tecnologías digitales, Buenos Aires, Argentina : Fondo de Cultura Económica.

2017. La intimidad como espectáculo, Buenos Aires, Argentina : Fondo de Cultura Económica.

TISSERON, S. 2001. L'intimité surexposée, Hachette, Paris, France : Pluriels, 2007. De l'intimité librement exposée à l'intimité menacée, Paris, France in VST № 93, ERES.

2011. Intimité et extimité , in Communications $n^{\circ} 88$, Paris, France, Le Seuil, Paris.

En linea:

FOUCAULT, M. 1978. Sécurité, territoire et population, 4e leçon, 1er février 1978, En linea : http://www.guillaumenicaise.com/wp-content/ uploads/2014/08/foucault-le\%C3\%A7on-du-25-janvier-1978.pdf.

2004. Des espaces autres ERES « Empan » 2004/2 №54 . pages 12 à 19. Article disponible en ligne à l'adresse : https://www.cairn.info/revueempan-2004-2-page-12.htm.

2011. Oedipe roi ou l'invention de la vérité judiciaire, disponible en ligne : https://www.cairn.info/revue-esprit-2011-1-page-90.htm.

MILLER, J-A. 1985-1986. Extimité, en lineajonathanleroy.be > wp-content > uploads > 2016/01 1985-1986. 


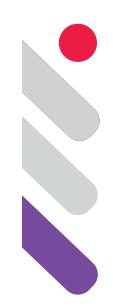

\section{Lo lúdico, lo social y lo político en dos casos de animación contemporánea}

Mónica S. Kirchheimer

Universidad Nacional de las Artes monicakirch@gmail.com

\section{ANIMACIÓN Y SÁTIRA POLÍTICA}

\subsection{UNA MARCA DE NACIMIENTO}

La animación en Argentina cuenta con una extensa tradición de comentario político y social. Es decir, se trata como en todos los casos de un lenguaje y no de un género, a pesar de que es habitual pensarla como destinada a los niños y solo vinculada con la narrativa de tipo mitológica. Desde los orígenes mismos de la animación, e incluso antes de su generización más popular, sus temáticas fueron adultas y tuvieron consecuencias sociales y políticas. Nos referimos no sólo a la animación documental o comercial, sino en los espacios de ficcionalidad y ficcionalización la producción de animaciones con alto contenido político-social.

Más aun, el inicio del cine de animación de largometraje comercial (1917) argentino estuvo signado por estas temáticas:

La sencilla pero efectiva trama del film El apóstol consistió en satirizar los altos objetivos del presidente electo recientemente. En este largometraje, Hpólito Yrigoyen recostado en su modesta cama reflexiona sobre los vicios morales de los argentinos, quedándose profundamente dormido. En la representación del sueño el espíritu de Yrigoyen se desprende de su cuerpo, dirigiéndose vestido de apóstol al Olimpo donde se encuentra con distintas divinidades a las que les relata las indecorosas actuaciones de los porteños. La diatriba será acompañada por una sucesión de personajes de la política nacional que comentarán sobre el caos administrativo de la Municipalidad de Buenos Aires, o sobre la situación económica del país. Con ánimos de redención, el Apóstol le pedirá a Zeus sus rayos para purificar la ciudad de Buenos Aires, dando la escena más costosa y espectacular del film: el incendio del Congreso, la Municipalidad, la Aduana, el edificio de Obras Sanitarias, entre otros, reproducidos minuciosamente en maquetas de gran tamaño por Andrés Ducaud. Luego de la destrucción vendrá la reparación, dando pie a las interpretaciones del público. (Gionco, 2009: 183-184) 
El Apóstol es el primer largometraje estrenado mundialmente, fue dirigido por Quirino Cristiani, animador de los Estudios Valle y dibujante. La película sucede a una serie de viñetas animadas que Cristiani hacía para el noticiero cinematográfico. Como afirma Bendazzi, "Un buen cine de noticias, en un país como la Argentina. Acostumbrado a las viñetas políticas, tenía que ofrecer alguna caricatura" (2008: 42), las que tenían también el formato y la temática del cuadro de humor gráfico en el que se animaba una escena (lighting sketch) de contenido político. En El Apóstol "establece una representación visual de la caracterización mítica de Hipólito Yrigoyen, configurando una imagen (y una narración satírica) de la idea de rectitud moral del personaje político." (Gianoco 2009: 184) En 1919 estrenó Sin dejar rastros, un largometraje que trabajaba el hundimiento de la goleta Monte Protegido, durante la primera guerra mundial.

Sin dejar rastros (1918) fue claramente una obra que apuntaba a satirizar el conflicto desde una perspectiva crítica, ya que retomaba el suceso desde lo anecdótico. Al margen del intercambio diplomático, los diarios comentaban los comunicados emitidos por el embajador prusiano en Argentina, el Barón von Luxemburg, que se habían dado a conocer en el marco de las negociaciones, entre los cuales se le ordena a un submarino alemán que hunda al Monte Protegido "spurlos versenkt", traducido como "hundido sin dejar rastros", frase que fue muy comentada en la sociedad porteña. (Gionco, 2009: 186)

En 1918 se estrena Una noche de gala en el Colón bajo la dirección de Andrés Ducaud, con la colaboración del dibujante Diógenes Taborda y del animador Quirino Cristiani. El largometraje contó con animación de muñecos que permitió establecer, junto con las maquetas a los personajes y el espacio icónico en el que se desarrolla el film y la ópera misma desarrollada con dibujos animados en los que "mostró la representación de la ópera, con Yrigoyen haciendo de Carmen y sus ministros y amigos como Don José Escamillo, Micaela, el Remendao, etc. La orquesta, según cabía esperar, estaba formada por gatos." (Di Núbila 1959: 26) Además, presenta caricaturas de personajes reconocibles de la vida social y política de la aristocracia porteña.

Más adelante, en 1931 estrenará el largometraje Peludópolis, primera película sonora estrenada mundialmente. En ella sonido se realizó a través del sistema Vitaphone, un sistema de grabación de sonido de disco que acompaña a la película durante toda su duración. 


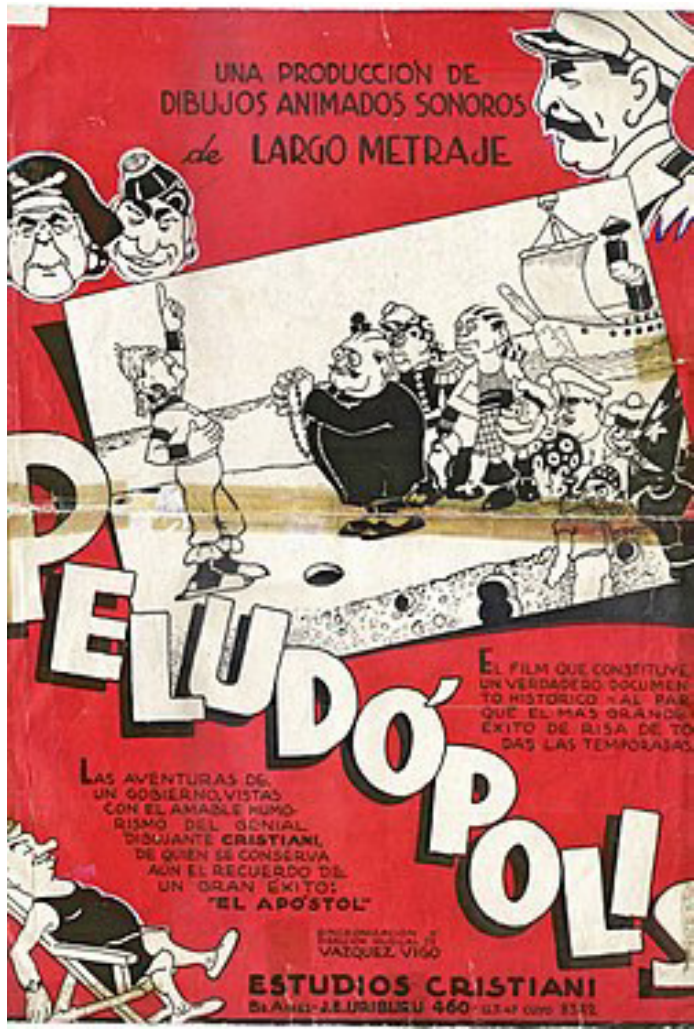

IMAGEN 1: Afiche del

largometraje Peludópolis

Peludópolis tuvo un camino algo torturado, ya que en 1930 con el golpe militar de José Félix Uriburu cambió la situación política nacional, y por tanto también la narrativa de Cristiani para su largometraje, ya bastante avanzado. "Tuvo que sacarle el énfasis puesto en las escenas de Yrigoyen y los tiburones, y agregarle las figuras de los generales como los héroes de la película. También le incluyó un personaje llamado Juan Pueblo, que representaba al ciudadano común, para que se convierta en el centro moral de la película. Cristiani, así pudo estrenar 'Peludópolis' el 16 de septiembre de 1931 con la bendición del gobierno provisional del General José Félix Uriburu, quien presenció el estreno del film." (Di Pasquo 2009)

En palabras de Gianoco,

Basándose en la larga tradición de humor gráfico político en la Argentina [en la que se incluyen los realizadores reseñados], estas sátiras animadas llevaron a la pantalla un modo de expresión legitimado como la caricatura, que permitía a los dibujantes editorializar sobre la actualidad política, dando un punto de vista que no dejaba de ser un comentario de las situaciones cotidianas. Esta característica fue quizás la de mayor relevancia para el cine social y político posterior, que en el futuro arbitraría diversos medios expresivos y técnicos para, en definitiva, hablar del propio presente político. (2009: 193)

Como vemos, desde el afianzamiento del cine como medio la animación ocupó un lugar importante en la comunicación de ideas, no solo graciosas (cortos orientados a lo risible), sino también sociales y políticas. Las críticas morales de los films de Cristiani aparecían también en los cortometrajes, en los que además la sátira y la caricatura ocupan un lugar destacado. 


\subsection{LA ANIMACION MODERNA NO ABANDONA SU ROL CRÍTICO}

Esta tradición continuó en otros dibujantes y animadores. El caso de Landrú, por ejemplo, en la década de 1960, del que se ha encontrado un corto humorístico denominado Encuentro en el que un general se encuentra con otro y le pregunta: “¿De qué revolución nos conocemos? ¿De la del 6 de septiembre?" El otro responde "No" ¿De la del 4 de julio? El otro responde "No", "¿De la del 16 de Julio?" "No", ellos siguen en esta recurrente conversación, pero la música se impone y ya no los podemos oírlos. Asumimos que las fechas continúan. La operatoria humorística aquí se centra en la operatoria de la repetición y ella habilita la visión crítica. En este caso poniendo en evidencia la inestabilidad democrática. No obstante, la banalidad con la que está presentada en ese encuentro casual entre dos militares de alto rango la vuelve irónica, construyendo una enunciación que encuentra en un diálogo tan sencillo un espesor político y crítico, a la vez que introduce el giro de la comicidad. El corto recuperado sólo dura unos dieciocho segundos, cuenta con una placa final que refiere al noticiero cinematográfico Sucesos Argentinos. Se trata más de una viñeta que de una animación narrativa completa. En este sentido, contiene la lógica de los cuadros dibujados por los que el autor es famoso.

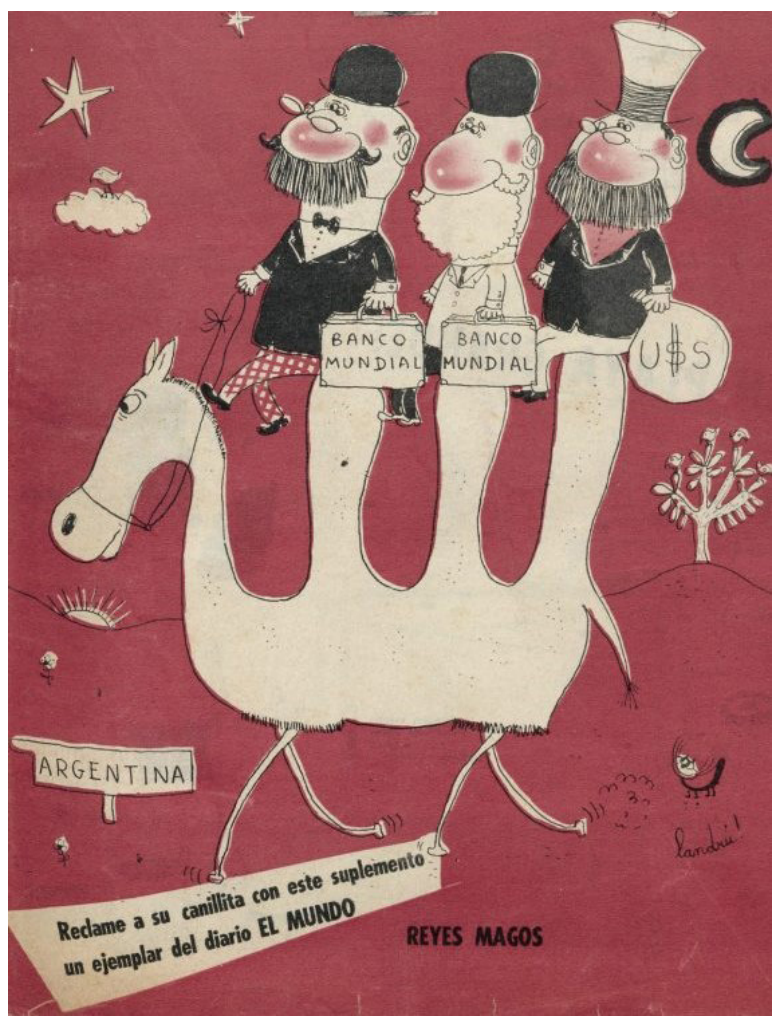

IMAGEN 2: Recorte de Tapa Tia Vicenta Nro. 289. Año1965

En lo que respecta a la crítica social, la serie Mafalda, realizada a comienzos de la década de 1970, retoma la creación de Quino. En ellas el personaje 
protagónico, Mafalda, narra una pequeña escena de la vida cotidiana o social, y su reflexión suele escalar hacia la crítica social, de costumbres o política.
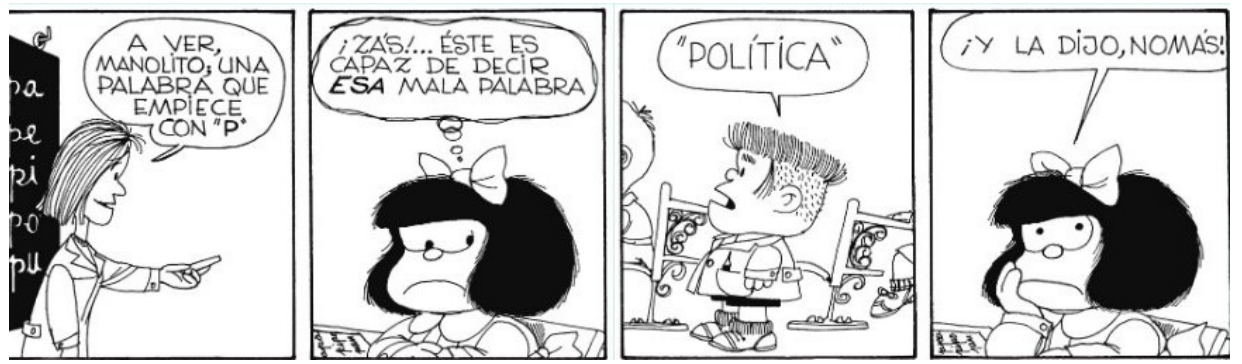

IMAGEN 3: Tira de Mafalda, por Quino

Los cortos de un minuto fueron emitidos en 1973 por la señal de televisión abierta Canal 11, producidos por Daniel Mallo, donde los personajes de Quino dialogaban. Estos cortos fueron compilados en la película de Mafalda, la cual fue realizada en el año 1979 y estrenada en Argentina en el año 1981. Posteriormente se volvieron a realizar, en la década del 90 , tanto las animaciones del dibujante que publicó originalmente en revistas, llamada Quinoscopio, y nuevas versiones de Mafalda. ${ }^{1}$

Estos videomunuto se orientaron más hacia una crítica de la vida social, con un tono si se quiere suave. Se trata en general de situaciones domésticas en las que la protagonista realiza una pregunta remate orientada hacia el wit, es decir, hacia un humor intelectual por sobre un humor soportado en la corporalidad y las transformaciones físicas. Por ejemplo, la madre le pide a Mafalda que limpie el globo terráqueo, y ella responde "¿Limpio todos los países o solo los que tienen malos gobiernos?" Es decir, el efecto de comicidad aparece por el cambio de escala, de lo doméstico a la referencia de política internacional o a la inversa. Así, el personaje funciona como un actante que quiebra el verosímil en el que el corto parece situarse para transformarse en un personaje de sketch cómico. "Una propiedad de la caricaturización de los programas cómicos (...) es que recae sobre estereotipos sociales contemporáneo. (...) la caricaturización no recae únicamente en la configuración del personaje, sino también en su carácter de actante narrativo". (Fraticelli 2019: 75) La estructura reidera de Mafalda se ubica en un espacio lúdico habilitado por un bromista, en este caso el personaje protagónico. ${ }^{2}$

\footnotetext{
${ }^{1}$ Un dato interesante es que en el sitio oficial de Quino no se refiere a las producciones animadas de los 70 y los 80 , sino sólo a la referente de la década del 90.

${ }^{2}$ Fraticellli establece que a diferencia del bufón y el humorista, que operan de manera distina, el bromista construye una escena enunciativa en la que el personaje que lleva adelante la broma "es consciente de las reglas que transgrede. (...) El bromista establece una relación de superioridad con respecto al objeto de sus burlas y, como el bufón, incentiva al público enunciatario a ser su
} 
El espacio de lo lúdico, siguiendo a Schaeffer (2002) lo tomamos como un espacio de fingimiento en el que se caen las reglas que ordenan el mundo y entramos en el mundo de la ficción en tanto tal. El salto de la ficción doméstica al comentario político refuerza el efecto de comicidad.

Ya en el cierre de la década del 90 y gracias a la aparición y popularización de dispositivos y programas de generación de imágenes digitales, así como la capacidad de distribución por internet de la difusión, aparecen una nueva serie de animaciones que se hacen cargo de la crítica social y política. La mayoría a cargo de jóvenes animadores, que llegaron luego a espacios de exhibición como Locomotion o MTV, y que oscilan entre el espacio comercial y/o masivo y los espacios de distribución personal en las redes. "El final de la década del ' 80 y principios de la del '90 dieron un nuevo aporte a la técnica de animación: la computadora se hace accesible a todos. Esto redundará en nuevas explosiones formales y de contenido" (González 2005)

Es en este momento en el que empieza a re-aparecer una conversación explícita sobre lo político. La frivolización de la política que define en Argentina la década de 1990 fue fuertemente criticada por la serie EI Mono Mario. Creado en 2000, los cortos creados por Pablo Forconi, como un entretenimiento en sus ratos libres. El Mono Mario es un personaje machista y seductor que solo vive el momento y despilfarra el dinero, rompe hogares. El consumo culposo de internet escaló a MuchMusic para volver años después a la plataforma de youtube.

Si personajes como Mercano el marciano y El Mono Mario son dos ejemplos exitosos, detrás se encolumna un ejército de decenas de proto personajes de difusión reducida y a veces ni siquiera eso. Mejor o peor realizados, crudos o elaborados, en su anonimato forman parte de una fauna del cartoon criollo actual (Manrupe, 2004: 110)

Para el año 2004, los personajes de la serie comentaban la realidad política y del espectáculo en un segmento del programa de América TV, Intrusos en la noche. Se trataba de animaciones pre-armadas con diálogos en vivo. La popularidad de lo que a la vez afirma y rechaza El mono Mario en relación con el tomarse a broma una estética y una forma de vida de la década del 90 en Argentina, no por criticarla, sino por abrazarla de manera de demostrar la banalidad y superficialidad de sus valores. Es por ello que encaja bien en un programa como lo fue el de política y espectáculos. 


\subsection{LAS MIRADAS LÚDICAS Y CRÍTICAS DE LA ANIMACIÓN CONTEMPORÁNEA}

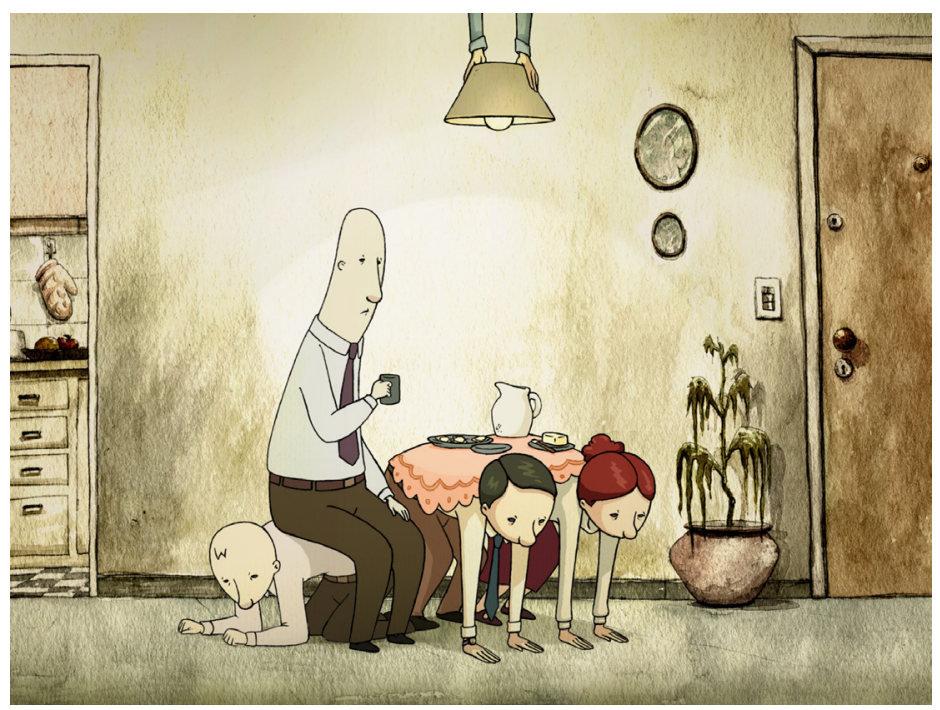

IMAGEN 4:

Fotograma de $E I$

Empleo (2008)

Santiago Bou Grasso, es un animador que interesa reseñar antes de entrar en el corpus específico del que buscamos dar cuenta. Se trata de un animador meticuloso, que ha trabajado temas vinculados con la memoria política argentina, Padre, como con la crítica social no complaciente. En El Empleo la animación es dibujada. En Padre la materialidad animada es resultado de un milimétrico stop motion. No se trata de entender la técnica por sí misma, sino por la expresividad que aportan. En el caso del dibujo animado se logra lo que Bras señala como cualidad propia del lenguaje "El mundo del dibujo animado en realidad es un mundo rosa donde la principal, casi única exclusiva direccional es como destacáramos el absurdo impregnado de gracia y de ternura. Cuanto más absurdo mejor." (1990:15) Esta definición del objeto del dibujo animado destaca el absurdo y la gracia -de formas y movimiento- y es eso lo que el corto de Santiago Bou Grasso pone en evidencia. Como puede apreciarse en la imagen que reproducimos (imagen 4) el corto explora un mundo en el que las personas sirven a otras en roles sorprendentes, hacen de pie de lámpara, de tapete, de perchero, de semáforo, etc. etc. El relato nos presenta el inicio del día de un personaje hasta llegar a su empleo como tapete de puerta. Esta construcción de mundo coherente y risible, permite encontrar una clave de inmersión lúdica (Schaeffer 2002) y nos ubica en el espacio del humor. Entendemos esta construcción con Fraticelli (2019) quien afirma que "el humor no sólo se sirve de la retórica o los imprevistos de las situaciones y el cuerpo, sino que se vale de ambos para generar placer". (84) En nuestro caso, este valerse se vincula con la particular manera en que el dibujo animado nos da a ver el mundo que habitamos, pausado, del fragmento a la totalidad, en una escala que se va 
incrementando, de una mirada cercana y cotidiana a la descripción con una mirada que se acerca al paisaje urbano, para volver, finalmente, al fragmento, a la espalda tapete. Así, El empleo "plantea una crítica mordaz al empleo y al lugar que ocupa el ser humano dentro del sistema de producción capitalista, cuestionando las relaciones de producción que fundamentan el modelo económico que colapsa en diciembre de 2001" (Vicente Fenoll 2016: 114)

\section{UN CORPUS CONTEMPORÁNEO}

Como vemos, en la historia animada argentina hay numerosos antecedentes y modos de tratamiento de lo político y lo social por parte de la animación. Nos interesa centrarnos en dos producciones en especial, por sus diversos derroteros exhibitivos, ya que su circulación contemporánea si bien es distinta, abordan formas de problematización de la realidad con especial énfasis en lo social y lo político, y de los que cabe esperar un cierto efecto gracioso. Son el caso de Tino y Gargamuza (emitido hasta 2018 en el marco del programa político de opinión $A$ dos voces, por la señal de cable TN) y el de Gente Rota, que se distribuye a través de redes sociales (especialmente Instagram y Youtube). Con trayectorias distintas, ambos textos comparten algunos rasgos que nos proponemos desarrollar: el particular estilo de la animación, que se trata de una digitalidad audiovisual cuyo efecto no busca (como sucede en otros espacios animados) una estética realista; temáticas de la vida social y política argentina; una expectación vinculada con la risa. Interesa destacar que, si bien las temáticas trabajadas pueden ser comparadas, el material de la vida social en el que se sustentan las diferencia: mientras que una serie se centra en el comentario acerca de la realidad política y social, el otro audiovisualiza material que puede considerarse documental y con él construye micro animaciones.

\subsection{TINO Y GARGAMUZA. UN VIEJE POR EL HUMOR POLÍTICO}

Los personajes de Tino y Gargamuza aparecieron por primera vez en un programa de humor absurdo a cargo de Alfredo Casero, Cha cha cha, emitido por América televisión (1996), luego pasa al programa de metatelevisión -es decir de un programa de televisión que se hace cargo de comentarios críticos sobre televisión- (Carlón 2006) Televisión Registrada también en América Televisión (1999-2005). En la misma señal de televisión abierta contaron con dos emisiones especiales: La noche de los muertos re-vivos en diciembre de 2003 y La navidad de Tino y Gargamuza en diciembre de 2004. Entre 2005 y 2008, luego de una discontinuidad, vuelven con Televisión Registrada, primero en El Nueve (2012-2013) y luego en El Trece (2005-2008). El cambio radical de temas sobre los que opinan los personajes Tino y Gargamuza es su incorporación en el programa político de opinión Periodismo para Todos de Canal 13 (2015-2016), Su paso en las tandas de MuchMusic (2010) funcionaron como una retoma del 
espíritu original de Cha cha cha. Su última aparición fue en la señal televisiva de noticias TN (2017-2018) en el programa A Dos Voces de Marcelo Bonelli y Edgardo Alfano. Se trata de un programa de análisis político y económico de la actualidad.

Observando los pasajes y cambios de programas y de canales en los que los segmentos de Marchesini Cartoons aparece, vemos cómo la mutabilidad de la animación permite juegos más allá de los contenidos que soportan. De todas formas, podríamos identificar una primera etapa de humor absurdo (Cha cha cha y las emisiones independientes) y un juego de lecturas crítico-social y crítico-político desde su incorporación en Televisión Registrada hasta su última aparición.

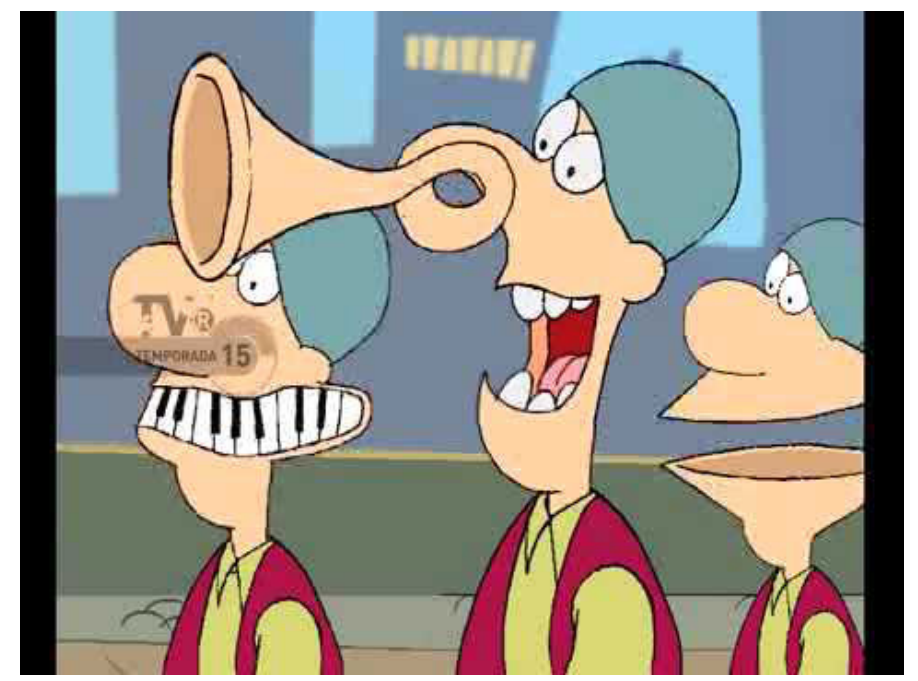

IMAGEN 5: Tino $y$ Gargamuza

Sucede que Tino y Gargamuza hace un uso extenso de algunas de los principios de la animación, en particular el de estirar y encoger, que es uno de los primeros principios de animación ${ }^{3}$ que muestran la deformación física de objetos y sujetos, que permiten otorgar aspectos graciosos a los dibujos en su sucesión además de otorgar fluidez al movimiento de las imágenes. Pero decíamos que estos personajes hacen un uso muy alejado de este principio, alejándose también del efecto realista de la animación disneyana. Por el contrario, ponen en escena la deformación como acentuación o comentario, y estas deformaciones son exaltadas y evidenciadas en el espacio de la audiovisualidad. A ella acompañan otras formas de construcción vinculadas con la búsqueda de efectos humorísticos, como son la repetición o el ralenti. A estas operaciones discursivas sobre sus propios personajes se suman las caricaturas que aparecen de los personajes criticados. En el caso de las figuras de conocimiento público y políticos, las caricaturizaciones. Recordemos con Gombrich (2002) que "La

\footnotetext{
${ }^{3}$ Sobre los principios de la animación realista, ver Johnston, Ollie y Frank Thomas (1981)
} 
caricatura se basa en la comparación cómica. Cualquier garabato servirá, si presenta un parecido sorprendente" (296). Este procedimiento hace evidente la diferencia en la configuración de los personajes caricatura y los personajes caricaturizados. En los segundos, este efecto de retrato es más evidente, cambia el delineado de los rostros y las formas expresivas se vuelcan hacia la caricaturización. Este soporte animado es el que hace posible el desplazamiento de los personajes públicos a espacios imaginaros, comentados, editorializados. Se los ubica en lugares en los que "deberían estar", se "especula que estén", se imagina como sería si...

Así, la caricaturización, logra lo que Gombrich afirma:

son dos las condiciones que explican el éxito de esa ilusión de vida que puede prescindir de toda ilusión de realidad: una es la experiencia que generaciones de artistas han adquirido sobre el efecto de las pinturas, y otra es la disposición del público a aceptar el grotesco y lo simplificado, en parte porque su falta de elaboración garantiza la ausencia de indicios contradictorios. (2002: 284)

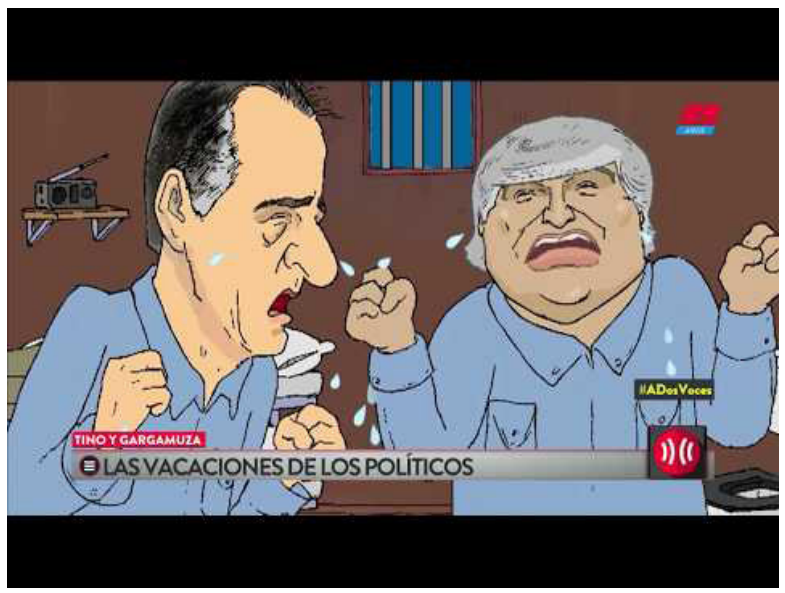

IMAGEN 6 Tino $y$

Gargamuza

Como vemos en este caso, se trabaja especialmente varias formas de la comicidad: la propia de la sátira política en los comentarios de los

personajes, la que se combina con una serie de juegos de palabras que enmarcan y cierran el comentario mismo, habilitando que el juego de lo gracioso pase del plano del significante al del significado. Un ejemplo, el extenso "eeeehhhhh", "Daaaale", se vuelcan sobre la demorada extensión del parlamento, pero a ella sigue lo comentado, situación política imaginada; o bien lo cierra. Este modo de enmarcar se produce como decíamos también en las escenas que presentan los personajes en el cambio de dibujo animado a caricatura animada. Se trata, de este modo de un juego de yuxtaposición de dos verosímiles, el del cartoon como género animado y el de la página de humor político por otro. Ambos verosímiles se alejan de la realidad, y de los verosímiles realistas, pero a través de los cuales se editorializa y refiere a la actualidad política. 


\subsection{GENTE ROTA. UNA MIRADA MICROSCÓPICA A LA VIDA SOCIAL}

En este caso estamos frente animaciones de muy corta duración que ilustran audios de Whatsapp recibidos por su creador por parte de gente que los envía. Estas animaciones son subidas al canal de Youtube y de Instagram y que en muchos casos también circulan en diversos grupos de Whatsapp. En estos audios hay temáticas diversas, entre los cuales la vida social y política ocupa un lugar de importancia.

De acuerdo con Gabriel Lucero "Gente rota es lo primero que se me vino a la mente al escuchar los audios. A todos nos pasa que, en las situaciones de todos los días, lo cotidiano nos rompe y saca lo peor de nosotros. Decimos lo que se nos pasa por la cabeza", declara en una entrevista periodística a con Martínez (2018).

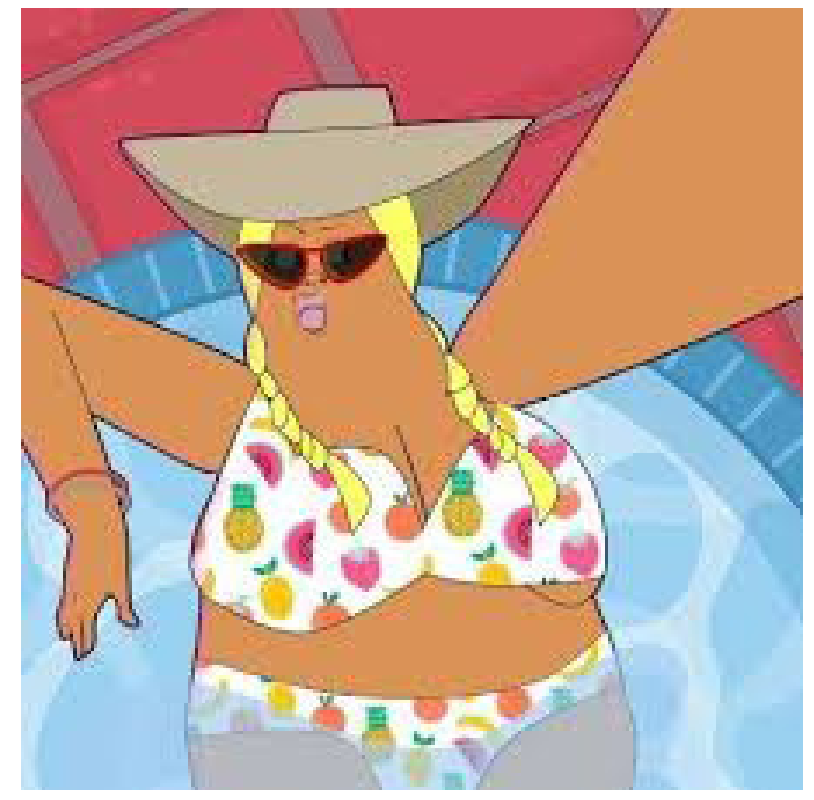

IMAGEN 7: Gente Rota

\section{Claramente}

el nombre de la serie es una mirada del realizador sobre el estado de los audios que utiliza para su animación, ya que estas compilaciones tienen audios de carácter documental. Estos audios recibidos no son alterados sino ilustrados. Esta

ilustración, así como en el caso anteriormente analizado, se hace uso de técnicas y verosímiles de la animación. En este caso se trata de una utilización contraria al canon mencionado de los principios de la animación, ya que en muy pocos casos se respeta la regla de Acción continuada y superpuesta. Esta regla supone que en una animación realista se mueven todos los elementos presentados en pantalla y no sólo el personaje actuante. En el caso de las animaciones de Lucero este principio es expresamente quebrado, acercando sus animaciones al universo satírico y no realista. Así lo explica: Gente rota es más una sátira que una comedia. La sátira no siempre te hace reír. A veces, te hace pensar o te hace decir: mirá cómo estamos. Tengo un audio que es 100 por ciento realidad y sobre él, con lo que me sale de la imaginación, armo una historia" (Martínez 2018). 


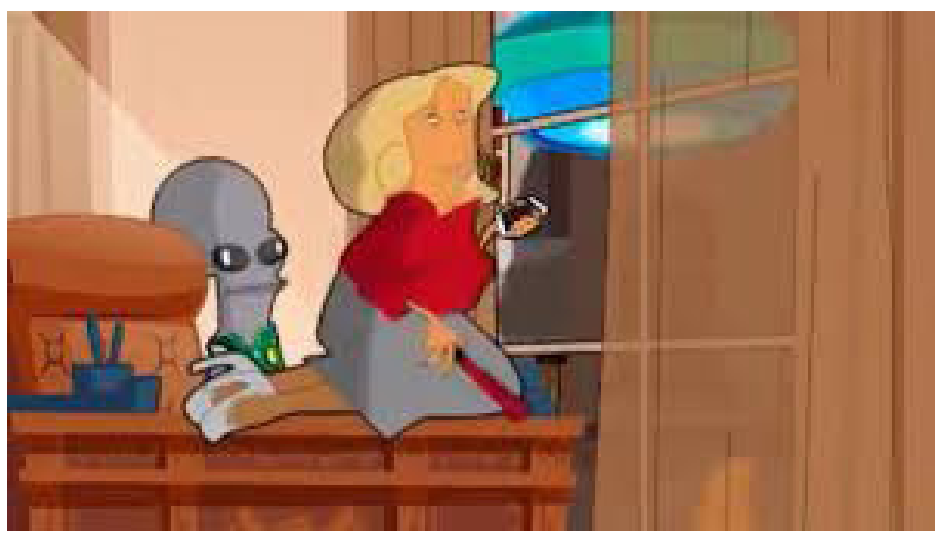

IMAGEN 8:

Gente Rota

Entre estos la operatoria insiste en la inclusión de las locuciones recibidas en un espacio determinado, incluyendo al personaje en un emplazamiento y realizando acciones que se vinculan con el audio. Por ejemplo, el audio de $\mathrm{El}$ Ferretero que critica a la selección lo encontramos dándole indicaciones a Messi durante el mundial. Se trata de algo más que una ilustración, es una escenificación. Es esta puesta en escena la que aleja a las animaciones del fisgoneo de la vida privada de la gente, es esa puesta en escena en la que aparecen reiteraciones del movimiento, comentarios y acentuaciones de las formas, los colores, las transformaciones de los personajes lo que organiza una enunciación centrada en la enunciación del bromista. como veíamos antes, sino del humorista: "El enunciador quiebra las reglas irónicamente. Al tiempo que las degrada, admite estar sujeto a ellas, lo que hace que él mismo se convierta en objeto de la degradación. Pero de esta situación penosa el humorista se distancia habilitando el marco metacomunicacional de lo reidero. Su ironía niega el valor de la norma y, luego, niega esa negación" (Fraticelli 2019: 78) Es este juego enunciativo el que permite la circulación social. Los audios animados no son necesariamente graciosos. En muchos casos somos testigos de momentos que habitualmente se considerarían vergonzosos: problemas de pareja, desengaños, engaños, fallas en cuentas matemáticas sencillas, desconocimiento de la cantidad de patas que "trae un pollo", etc., etc. Otros son de clara crítica de la norma social, de la vida y los roles de género asignados, de la política y de las respuestas políticas. La animación garantiza la enunciación humorística.

\section{LO LÚDICO, LO SOCIAL Y LO POLÍTICO}

En ambos casos se juegan verosímiles de lo real, aunque soportados de manera singular. Como se desarrollará, las formas de tratamiento de la animación coadyuvan a la construcción de enunciaciones diferenciadas en 
uno y otro caso, así como su diferente emplazamiento y contexto de consumo articulan expectaciones diferenciadas. Podemos comprender dónde recaen, en el proceso de semiosis social (Verón, 1987), las potencialidades de construcción de sentido vinculadas con la ludicidad en uno y otro caso, y como se explica el particular modo de circulación que estas series animadas presentan.

La animación, por ser considerada un lenguaje "menor", destinada a públicos ininteresantes (especialmente niños) tiene libertades que para lenguajes otros audiovisuales serían imposibles. Así, las animaciones se escurren como vemos en canales y programas tanto políticos como humorísticos, como si fueran inofensivas para la palabra pública. $\mathrm{O}$ bien, llegan destinadas en espacios interpersonales como es el teléfono celular, lo que además pone en un lugar aun más marginal la producción, ahora asociada como una ocurrencia. Lejos de perjudicar el valor crítico de estas circunstancias de circulación, lo potencian tanto estéticamente como temáticamente.

Las estrategias comunicativas de la animación, ya que se espera que si es animado es gracioso, se acercan a la hipérbole, a la parodia y a la sátira. En ambos casos las formas de esta sátira dependen más de su relación con un estado de la realidad que con su propia producción. Tino y Gargamuza se burlan de los políticos y la política en sus editorializaciones, Gente Rota niega y afirma la verdad de la banda sonora.

Autoconsciente de su propio lugar, los casos analizados explotan sus potencialidades expresivas. Por una parte, el exceso de usos del mickeymousing, esto es de las operatorias de exageración, distorsión y acentuación como una forma de construcción de pactos lúdicos metacomunicativos. Por otra, la presentación de una animación animada. Se trata de una animación que dice soy una construcción dibujada, y se alejada de las formas de construcción de la animación realista propia del largometraje animado disneyano que gobierna la inmensa mayoría de los estrenos comerciales.

El recorrido que lleva a Tino y Gargamuza desde un programa de humor a programas de reflexión política permite a los personajes mantenerse en una posición comentativa, transformando lecturas de los acontecimientos de relevancia en elementos de editorialización política. Comparten con las primeras animaciones el carácter crítico ahora opinando acerca de la actualidad social. Este posicionamiento resulta ambiguo: aleja a la serie de su lugar lúdico original, a la vez que es justamente lo lúdico lo que permite la mirada política

El surgimiento de Gente Rota pone el acento en las formas "espontáneas" de comunicación ciudadana política, cortando un flujo comunicativo para transformarlo en llamadas de atención sobre nuestras maneras de pensar, de expresar, de vincularnos. Al transponerse de dispositivos sonoros a medios de reproducción audiovisual construye lo reidero, lo lúdico, y de alguna forma también un espacio editorial. 
A diferencia de las animaciones que se vincularon con la crítica política a lo largo de la historia, los casos analizados hacen entrar lo político como tematización de costado. Estas animaciones permiten atender como, a través de las operatorias propias de una ludicidad animada las formas de procesamiento social de su cotidianeidad política en un sentido amplio. No es lo político el tema de las animaciones sobre lo que ellas critican. Es la crítica misma la que se vuelve política.

\section{REFERENCIAS BIBLIOGRÁFICAS}

BENDAZZI, Gianalberto. 2008. Quirino Cristiani, pionero del cine de animación. (Dos veces el océano). Buenos Aires: Ediciones de la Flor.

BRAS, Luis.1990. Formas de hacer cine animación. Rosario: Universidad Nacional de Rosario.

CARLÓN, Mario. 2006. De lo cinematográfico a lo televisivo. Metatelevisión, lenguaje y temporalidad. Buenos Aires: La Crujía.

DI NÚBILA, Domingo.1959. Historia del Cine Argentino. Buenos Aires: Ed. Cruz de Malta, Tomo I.

DI PASQUO, Christian "Dipi". 2009. Quirino Cristiani, 35 años sin el pionero de la animación. https://medium.com/@Dipi1981/quirino-cristiani-35-a\%C3\%B1ossin-el-pionero-de-la-animaci\%C3\%B3n-9d02777c1839 (accedido: 15 de septiembre de 2019).

FENOLL, Vicente. 2006. "Crisis y renovación en el cine de animación argentino. El caso de El Empleo". En $452^{\circ}$ F. Revista de Teoría de la Literatura y Literatura Comparada. Nro. 15. Barcelona. Universitat de Barcelona y la Asociación Cultural 452ํ․ https://revistes.ub.edu/index.php/452f/issue/view/1370 (accedido 1 de marzo de 2018).

FRATICELLI, Damián. 2019. El ocaso triunfal de los programas cómicos. De Viendo a Biondi a Peter Capusotto y sus videos. Buenos Aires: Teseo Editorial.

GIONCO, Pamela. 2009. "Primeras manifestaciones argentinas de sátira política animada", en LUSNICH, Ana Laura y Pablo Piedras. Una historia del cine político y social en Argentina: Formas, estilos y registros (1896-1969). Buenos Aires: Editorial Nueva Librería.

GOMBRICH, Ernst. 2002 [1960] Arte e llusión. Estudio sobre la psicología de la representación pictórica. Londres y Nueva York: Phaidon. 
GONZÁLEZ, Alejandro. 2005. "La Animación en Argentina”. en Revista: Miradas: Revista del Audiovisual. San Antonio de los Baños: Escuela Internacional de Cine y Televisión. (accedido el 14 de julio de 2010).

JOHNSTON, Ollie y Frank THOMAS.1981. The illusion of life. Disney Animation. New York: Disney Editions.

MARTÍNEZ, Milagros. 2018. La historia detrás de \#GenteRota: audios de WhatsApp con vida animada", en La voz del interior, martes 22 de mayo. https://vos.lavoz.com.ar/ tv/la-historia-detras-de-genterota-audios-de-whatsapp-con-vida-animada (accedido el 23 de agosto de 2018).

MANRUPE, Raúl. 2004. Breve historia del dibujo animado en la Argentina. Buenos Aires: Libros del Rojas.

SCHAEFFER, Jean Marie. 2002 [1999]. ¿Por qué la ficción? España: Lengua de Trapo.

VERÓN, Eliseo. 1987. La semiosis social. Barcelona: Gedisa. 


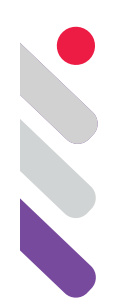

\title{
Snuff 2.0: Sobre los videos de violencia y muerte en redes sociales
}

\author{
Julián Tonelli \\ Universidad Nacional de las Artes (UNA), Argentina \\ Juliantonelli84@gmail.com
}

\section{Introducción}

El presente trabajo toma como eje de análisis el realismo y la impresión de realidad, considerando el desarrollo evolutivo de los dispositivos de reproducción vinculados al cine; así como la configuración y la inserción social de aquellas imágenes que se han asumido y se asumen como realistas en el contexto de la cultura audiovisual moderna.

En la actualidad nos hallamos ante un fenómeno propiciado por Internet, a saber, el de las muertes -por asesinato, suicidio o accidente- que se emiten (ya sea en directo o unos minutos después) a través de las redes sociales. Aquella que registra mayor cantidad es Facebook Live. A partir del abordaje de algunos de los casos más resonantes, la meta aquí es dilucidar algunas características fundamentales de este objeto novedoso, conectado al video amateur y al rol determinante de Internet en la evolución contemporánea del mito snuff.

A continuación, dos definiciones tradicionales de snuff:

"Snuff films depict the killing of a human being - a human sacrifice (without the aid of special effects or other trickery) perpetrated for the medium of film and circulated amongst a jaded few for the purpose of entertainment" (1994: 7).

Kerekes, David, y Slater, David (1994): Killing For Culture: An Illustrated History of Death Film from Mondo to Snuff.

"La snuff movie es una película que muestra el asesinato real de un ser humano; producida, perpetrada y distribuida únicamente con fines económicos".

Del documental Snuff: A Documentary About Killing On Camera (Paul Von Stoetzel, 2008).

Remitiéndonos a una definición convencional de snuff, su existencia en la red no ha sido probada aunque los rumores siempre abundan, especialmente cuando se habla del lado oscuro de Internet, la Deep $W e b^{1}$. Ahora bien, si se

1 Los términos "Internet profunda", "Internet invisible" o "Internet oculta" se utilizan frecuentemente para aludir al contenido de Internet que, por distintos motivos, no aparece en 
prescinde de una parte de dicha definición (la existencia de un mercado negro de películas snuff), ya no sería necesario recurrir a la Internet profunda.

Inicialmente restringido a los clientes VIP, el streaming de video en vivo comenzó a estar disponible para todos los miembros de Facebook en enero de 2016, tan solo haciendo clic en un botón de la página principal. Luego de un conteo de tres segundos, el usuario puede empezar a filmar. Ese usuario, además, opta entre ser visto solo por sus amigos o por cualquiera. Las grabaciones pueden durar hasta cuatro horas. Hay una opción para reportar contenido inapropiado.

Facebook Live no es el único espacio de live streaming involucrado en hechos trágicos. Acaso uno de los más recordados haya tenido lugar en una plataforma similar, la de Instagram. El 21 de julio de 2017, en una ruta de California, la joven de 18 años Obdulia Sánchez se transmitió en vivo al estrellar su auto contra una cerca de alambres. Jacqueline, su hermana de 14 años, quedó tendida en el pasto. Obdulia salió ilesa y continuó filmando con su celular. El video consiste en primeros planos -bruscos, temblorosos- del cadáver ensangrentado y de la protagonista hablando nerviosamente a cámara: "Jacqueline, por favor, despierta. Maté a mi hermana... sé que voy a la cárcel de por vida. Amo a mi hermana... esto es lo último que pensé que nos iba a pasar. Maté a mi hermana, pero no me importa. Maté a mi hermana. Sé que voy a ir a la cárcel pero no me importa. Lo siento, bebé" ${ }^{2}$.

La mayoría de estos eventos, no obstante, ocurrió o tuvo mayor circulación en Facebook Live. A continuación, algunos de los más impactantes; gran parte de ellos proviene de Estados Unidos ${ }^{3}$.

- El 16 de junio de 2016, en Chicago, el pandillero Antonio Perkins (28) fue abatido a disparos en plena calle. Entre gritos y movimientos de cámara frenéticos, lo último que se advierte en el video es el pasto ensangrentado y la huída del auto del asesino.

- El 6 de julio de 2016, en St. Anthony, Minnesota, Philando Castile (33) fue fatalmente tiroteado en su auto por un policía. Segundos después de los disparos, su novia, sentada en el asiento del conductor, comenzó a transmitir todo por Facebook, incluyendo una discusión con el oficial mientras Castile yacía a su lado cubierto de sangre. La grabación dio la vuelta al mundo, exponiendo la enorme tensión racial que atravesó el interior de los Estados Unidos ese año.

- El 30 de diciembre de 2016, en Cedartown, Georgia, Katelyn Nicole Davis (12) se colgó de un árbol luego de contar que su padrastro la había

los motores de búsqueda convencionales (Google, Yahoo, etc.).

${ }^{2}$ http://www.dailymail.co.uk/video/news/video-1506787/Driver-kills-sister-car-crash-livestreaming.html

${ }^{3}$ https://www.thesun.co.uk/news/3426352/facebook-live-clips-murder-suicide-shootingsreport/ 
abusado sexualmente.

- El 25 de enero de 2017, en Miami, Nakia Venant (14) se colgó en el baño de su casa al finalizar un streaming de dos horas. Ocurrió tres semanas después del suicidio de Katelyn Davis.

- El 23 de abril de 2017, en Winnipeg, Canadá, Serena McKay (19) fue encontrada muerta. Poco antes, el video de una joven siendo salvajemente golpeada y torturada había circulado en Facebook Live durante cuatro horas. Se cree que la víctima del video era Serena.

- El 25 de abril de 2017, en Phuket, Tailandia, Wuttisan Wongtalay (20), acusó a su mujer de infidelidad antes de colgar al bebé de 11 meses de la pareja. El video permaneció disponible en Facebook casi un día entero.

- El 26 de febrero de 2018, en Wingate, Carolina del Norte, Prentis Robinson (55) fue asesinado a tiros mientras se filmaba en vivo caminando por un parque. Al ver que otro hombre se acercaba, Robinson le apuntó con su cámara. La mirada subjetiva permite observar la llegada del homicida y luego, desde el suelo, su escape.

Estos son algunos de los incidentes registrados en Facebook Live. $\mathrm{Si}$ pretendiéramos hallar puntos de contacto con la película snuff, hay un caso que sobresale y que analizaremos más adelante.

\section{Extremismo islámico y Caght On Tape}

En su ensayo "Snuff 2.0: Real Death Goes HD Ready" Mark Astley (2016) plantea lo siguiente:

Since the kidnap and filmed murder of the Wall Street Journal reporter, Daniel Pearl, in February 2002, the urban myth of the "snuff video", where the death of a human being is staged primarily for the benefit of the unblinking eye of the camera, has been transformed into an easily accessible and quotidian reality. In light of the historically and culturally varied interpretations of the term, what we mean here by "snuff" is simply a premeditated human death that would not exist without the intention of pointing a camera and capturing the event for a variety of sexual, political, and financial purposes. The dissemination of execution videos, as radical Islamist propaganda and macabre entertainment at the turn of the millennium, established a pattern of transmission and reception that endures to present (2016: 153).

El texto de Astley ilustra un escenario audiovisual propicio para el snuff. "New technology has radically affected how the transgressive representations of the body in death media ${ }^{4}$ have been produced, represented, distributed, and consumed" (2016: 154). Podría decirse, según el autor, que el snuff ahora se volvió mainstream, con videos que muestran la decapitación de sujetos

${ }^{4}$ El término death media designa, en aspectos generales, la presencia de muertes violentas en los medios, tanto masivos como nuevos. 
involucrados en el mundo de los cárteles mexicanos haciéndose virales en Facebook. El fenómeno alerta a los guardianes morales entre las fuentes de los medios tradicionales de Occidente frente a una nueva tensión, habilitada por una imaginería de asesinatos y mutilaciones libremente disponible.

Internet, entonces, marcó un paso radical en la evolución del snuff, extendiendo su sombra más lejos de lo concebible en épocas del VHS y del DVD. Tal desarrollo se asocia con el pasaje del dominio analógico al dominio digital, de la mítica cinta $8 \mathrm{~mm}$. al mucho más maleable formato mpeg. La idea ficcional de snuff como una actividad cerrada, oculta y clandestina parece haber cedido su lugar a una realidad de distribución abierta y acceso fácil, a un par de clics de distancia.

Astley señala algo interesante con respecto a los videos de ejecuciones por parte de terroristas islámicos:

Early high profile execution videos of western hostages, like those of Nick Berg and Ben Bigley, were characterized by a grainy, chaotic aesthetic redolent of the manner in which snuff has manifested in the fictional cinematic realm. In contrast, the majority of recent IS atrocities are glossy, professional, and technically accomplished. The release by IS of the execution video of the kidnapped American Journalist, James Foley, in mid-August 2014 (which did not depict the beheading itself but rather its grim preamble and his mutilated body instead), saw the emergence of Snuff 2.0, which IS producing and distributing a sequence of visually sleek representations of body horror and death that heralded in a new professionalism in the use of the tormented and ruined body as propaganda. If the iconography of the IS videos was consistent with their AI Qaeda forebears, with captives in orange jumpsuits and executioners swathed in black or wearing military apparel, the technical limitations and disorganization that marked the emergence of snuff has acceded to a slickly choreographed and skillfully edited new media product $(2016: 154,155)$.

Los ajusticiamientos islámicos suponen un capítulo importante de lo que se dio a llamar "Snuff 2.0". Sin embargo, teniendo en cuenta la reciente "profesionalización" y los "logros técnicos" mencionados por Astley, dichos contenidos no se corresponderían en términos representacionales con aquello que hemos presenciado en redes sociales. $Y$ es en este punto donde podríamos recurrir, como se ha hecho en un trabajo anterior", al concepto de "Caught on Tape". Tal denominación refiere a una modalidad estilística frecuente en la Reality TV de los años ochenta; más concretamente, a un tipo de realismo crudo, desprolijo, sin procesar, asociado a los videos caseros de aficionados. Amy West (2005) lo describió así en su ensayo "Caught on Tape: A Legacy of Low-Tech Reality": "Compromises in audio and visual pleasure which this mode

5 “Una imagen muda. El misterioso caso de Elisa Lam” (2017, Cuadernos del Instituto. Investigación y Experimentación en Arte y Crítica, Universidad Nacional de las Artes). 
of production may entail [imagen texturada, fuera de foco, etc.] are traded off against a heightened felling of the real- a trade audiences are more than willing to make" (2005: 86).

El objeto de captura del Caught on Tape es un momento de crisis: "A natural disaster, a criminal act, a private perversion, a hilarious physical blunder, Because the incident is unforeseeable, the circumstances of capture can be characterized as inadvertent, meaning that the recorded moment arises out of a critical co-incidence of rolling camera and spontaneous or aberrant incident" (2005: 83). Un león que ataca a su cuidador, un avión de acrobacias que explota sobre una multitud, un tiroteo entre pandillas, son acontecimientos cuya captación resulta azarosa y no premeditada. Pero esta aserción de autenticidad del contenido, según la autora, no es suficiente:

Without a correlative promise of a truthful medium, this putative reality is as suspect as that of any other represented event. This is why the flag of amateurism is waived s high in the field of caught-on-tape television. The self-evident nonprofessionalism of footage screened under the caught-on-tape banner certifies that the represented event is not staged, because both the technology utilized and the operator controlling it lack the sophistication to fake. The amateur image production is coded as transparent. (2005: 85).

Dos categorías conforman el Caught on Tape: cámara móvil (usualmente portátil) y cámara fija (de vigilancia). En la primera

The hand-held handycam si the embodiment of human point-of-view image capture, resonating as it so often does with the psychological responses of the operator. (...) [It] 'feels real' because it 'fulfils a powerful urge for a sense of contact with the real, as it inscribes this psychological contact on the recorded text ${ }^{6}$. This is a kind of real which is heightened by evidence of human error-the swoops and slips of a running, dancing, laughing, crying camera- which testifies to the amateur authenticity of production (2005: 85 ).

Un rasgo importante en este sentido es el impulso de aprehender el hecho extraño, único e inmediato. Seguir filmando hasta el final, incluso si la situación se pone peligrosa para uno mismo. Ese documento audiovisual expresará, por lo tanto, el estado físico y emocional del operador. West alude a una interconexión entre el cuerpo humano y el dispositivo de filmación. Las respuestas físicas y verbales de quien maneja la cámara -manifestando asombro, excitación, miedo, placer, etc.- pueden ser rastreadas en la representación de los acontecimientos registrados, otorgando de este modo una estética específica para un real vívido, instintivo, subjetivo, visceral.

${ }^{6}$ Texto citado por West: Fetveit, Arild. 2002. "Reality TV in the Digital Era: A Paradox in Visual Culture?" en James Freidman (ed.): Reality Squared: Televisual Discourse on the Real. Nueva Jersey y Londres, Rutgers University Press, 130. 
Originados - cuenta la leyenda- por el reclamo de varias estaciones de cable a partir de una huelga de guionistas en Hollywood; devenidos "otredad" de la producción televisiva profesional, los contenidos Caught on Tape de los años 80 y 90 incitaban a las audiencias a invertir en una inocente cámara; una que, al carecer del arte de aparentar, siempre diría la verdad. Pero esta modalidad estilística, en buena medida, empezó a agotarse hacia el comienzo del siglo veintiuno con las elaboradas producciones de lo que West denomina "Reality TV de segunda generación". Fue entonces que reality shows de aspecto profesional como Gran Hermano, Survivor y otros similares pasaron al centro de la escena.

No nos importa mucho el carácter imprevisto del acontecimiento documentado sino la dimensión amateur del Caught On Tape, la premisa de que cualquiera puede hacerlo. Su consigna de realización sería -con mayor o menor grado de parcialidad- la del "do it yourself". Dicho imperativo parece reclamar a su vez una determinada ligazón entre lo público y lo privado. Rasgo esencial, acaso, de la telerrealidad (una telerrealidad que, como los videos del ISIS, se profesionalizó).

Los dos objetos que exploramos en esta sección, de tal modo, asumieron el trayecto inverso al de una estética propiamente snuff: tanto las ejecuciones filmadas de extremistas islámicos como la Reality TV -terreno del Caught On Tape- han avanzado hacia imaginerías cuya apariencia estilística espectacular realza su elaboración profesional. En consecuencia, queda abierto el interrogante acerca de un snuff 2.0 que es diferente y que existe, así como de sus recursos y posibilidades de manifestación.

\section{Situación actual}

Manteniendo la definición amplia de snuff que ya se dio anteriormente, los dos videos más recordados en la web son Three Guys, One Hammer (2007), en el cual tres adolescentes ucranianos torturan y apuñalan por el ojo a un hombre, y 1 Lunatic, 1 Ice Pick (2012), donde un joven actor porno canadiense Ilamado Luca Magnotta degüella a su novio. Junto a estos dos ejemplos aislados encontramos uno de Facebook que reviste enorme interés y que pasaremos a describir.

Todo ocurre en menos de un minuto. La cámara es un celular. Su dueño se baja del auto sin dejar de grabar. Los movimientos bruscos enfocan el interior del coche, el paisaje soleado, el asfalto de la calle. El encuadre se estabiliza mientras la cámara se acerca a un anciano que camina con una bolsa en la mano. No hay exactamente mirada subjetiva, aunque el efecto se aproxima bastante. Ahora el anciano es tomado en plano medio. Quien lo está filmando le pide que diga el nombre de una mujer, Joy Lane. Luego le dice: "Ella es la razón por la que estoy a punto de hacerte esto". Inmediatamente el hombre comienza a 
gritar, levantando su brazo derecho y cubriéndose con la bolsa. En menos de un segundo, la mano derecha del improvisado cameraman irrumpe en el campo empuñando un revolver. La perspectiva se asemeja a la de un videojuego de disparos en primera persona. El tiro suena con un ruido seco, el encuadre vuelve a desestabilizarse y da veloz un giro de 360 grados para volver a centrarse en la víctima, que yace en el suelo sobre un reguero de sangre. El balazo parece haber impactado en su rostro. El asesino avanza unos pasos y la capta de cerca, después se aleja. Observamos su sombra en el pavimento mientras camina de regreso al auto. Tras otra serie de movimientos agitados, el video termina como empezó, mostrando el interior del vehículo en marcha.

Si bien la cara del responsable no aparece en el video, Steve Stephens (37) fue, durante cuarenta y ocho horas, uno de los hombres más buscados de Estados Unidos. Minutos antes de matar a Robert Godwin (74) el 16 de abril de 2017 en Cleveland, Ohio, había subido otro video a Facebook en el que manifestaba su intención de cometer un asesinato al azar. Minutos después de hacerlo volvió a grabarse, esta vez en directo, confesando el crimen y atribuyéndose trece más (los cuales nunca pudieron confirmarse). Stephens achacaba su comportamiento homicida a una ruptura amorosa. Perseguido y acorralado por la policía, terminó suicidándose en una zona rural de Pennsylvania.

Podemos encontrar, algunos años antes, un antecedente claro de este caso. Sucedió el 26 de agosto de 2015 en el condado de Franklin, Virginia. El video, de 57 segundos de duración, comienza con movimientos agitados y erráticos, igual que el de Stephens. La escena nos ubica en el punto de vista de quien está filmando, el lugar es una terraza. Nos acercamos a tres personas. Dos de ellas, la periodista Alison Parker y el reportero gráfico Adam Ward, están de espaldas entrevistando a la tercera, Vicky Garner, una líder de la cámara de comercio local. Ninguno parece percatarse de la presencia del recién llegado, ni siquiera cuando en la parte inferior del cuadro aparece una mano apuntado con un arma directamente hacia Parker, a menos de un metro de distancia. Luego, la mano armada desaparece del cuadro. El encuadre titubea y vuelve a las tres personas, que insólitamente siguen con la entrevista sin darse cuenta de nada. En el segundo 40, y tras alejarse un poco, la pistola irrumpe y comienzan los disparos. Parker, quien será la primera víctima, empieza a correr. Luego la imagen se corta y todo se torna negro, aunque los gritos y los disparos continúan. El asesino de Parker y Ward era Vester Lee Flanagan (41), un ex empleado de la cadena televisiva donde trabajaban las víctimas que había sido despedido por problemas de conducta. Después de subir el video a sus cuentas de Facebook y Twitter, se mató de un tiro. En ese entonces no existía Facebook Live. Actualmente el video se halla fácilmente en varias plataformas. 


\section{Conclusiones}

Nuestras conclusiones son, desde ya, provisorias. Retomemos los ejes de análisis descriptos al principio del artículo. En cuanto al estilo realista de los videos de redes sociales que abordamos, el Caught On Tape con cámara móvil se impone. Amy West ha dicho que en esa modalidad resuenan las reacciones corporales y emocionales del operador, y que por ello "se siente real". El video de Steve Stephens, sin duda, expresa su estado físico y psicológico. Lo mismo podría decirse del de Vester Flanagan. Que el concepto de Caught On Tape se haya pensado inicialmente para el registro de hechos fortuitos e inesperados cuando estos eventos, por el contrario, son notoriamente intencionales, no invalida tal apreciación. En épocas de telerrealidad las emisoras se encargaban de seleccionar el material amateur enviado por sus televidentes. Ahora los aficionados no solo pueden provocar el acontecimiento, hacerlo ocurrir; también pueden darlo a conocer sin necesidad de atravesar una instancia de selección.

El estilo realista mencionado da cuenta de una impronta cruda y sin pulir, vinculada en este caso a la digitalidad. Si para el lenguaje fílmico la codificación documental se valía de artilugios como grietas, cambios de rollo improvisados, etc., no queda duda de que actualmente las características son otras. En principio, la textura granulosa del cine cede su lugar a la pixelación del digital. Los movimientos bruscos de cámara en mano siguen conformando un rasgo importante, aunque en el nuevo Caught On Tape esa cámara es la del teléfono celular, o bien una mini cámara portátil, dando como resultado unos impulsos cuya conexión visible con las decisiones y las torpezas del cuerpo operador parece ser más directa e inmediata que antes (claro que aquí no se incluye el registro de la webcam, otra variable del video difundido en redes sociales).

Estos videos de violencia y muerte encarnan, además, una ruptura. Por un lado, con respecto a la apariencia espectacular de las ejecuciones más recientes del ISIS, aquellas que en el texto de Mark Astley recibieron la denominación de "snuff 2.0". Los crímenes perpetrados, documentados y transmitidos por Stephens y otros killers similares a través de la web constituyen, junto a otros que hemos visto, un ejemplo patente de snuff 2.0, si bien bajo una modalidad que en buena medida recupera la estética pobre, primitiva, descuidada y amateur de las imaginerías tradicionales. Por otro lado, la discontinuidad apunta, como recién hemos visto y amén de lo formal en sentido riguroso, a lo que las redes sociales muestran. Las muertes rompen con las costumbres y actividades regulares que fundan ese espacio complejo, a medio camino entre lo público y lo privado. Rompen con la regla pero quizá, valga aclararlo, no sean estrictamente la excepción. Poder hablar de un snuff 2.0 en los nuevos medios, en las redes sociales, supone referirse a algo más que un caso único o una rareza. 


\section{Bibliografía}

ASTLEY, Mark. 2016. "Snuff 2.0: Real Death Goes HD Ready" en JACKSON, Neil; KIMBER, Shaun; WALKER, Johnny y WATSON, Thomas Joseph (eds.): Snuff: Real Death and Screen Media. Nueva York, Estados Unidos: Bloomsbury.

GRAHAM, Regina y PARRY, Hanna. “California girl, 18, who live-streamed 'drunken' crash that killed her younger sister, 14, on Instagram breaks down in tears in court as she's denied lower a bail". Daily Mail, 18/08/17, Reino Unido. https:// www.dailymail.co.uk/news/article-4740490/No-bail-reduction-California-crashrecorded-Instagram.html. Accedido el 24/11/18.

HARPER, Paul y MULLIN, Gemma. "Death On Camera: How Facebook Live murder and suicide videos are spreading online and what you should do if you spot inappropriate content". The Sun, 28/02/2019, Reino Unido. https://www. thesun.co.uk/news/3426352/facebook-live-clips-murder-suicide-shootingsreport/. Accedido el 5/03/2019.

KEREKES, David y SLATER, David. 1995. Killing for Culture: An Illustrated History of Death Film from Mondo to Snuff. Londres, Reino Unido: Creation Books.

TONELLI, Julián. 2015. “Limites de la realidad, límites de la ficción. El caso de Efectos especiales" en Lexia. Rivista di Semiotica núm. 21. Centro interdipartimentale di ricerche sulla comunicazione, Università di Torino. Turín, Italia: Aracne Editrice.

2017. "Una imagen muda. El misterioso caso de Elisa Lam" en Cuadernos del instituto núm. 1. Buenos Aires, Argentina: Universidad Nacional de las Artes.

WEST, Amy. 2005. “Caught on Tape: A Legacy of Low-Tech Reality” en KING, Geoff (ed.): The Spectacle of the Real. Bristol, Reino Unido: Intellect Books. 


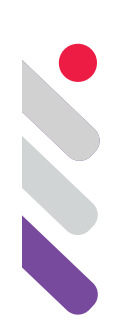

\title{
Dispositivos y enunciación en la postfotografía: algunas trayectorias de la imagen fotográfica digital en redes sociales
}

DOI: 10.24308/IASS-2019-4-020

\author{
Mariano Zelcer \\ Universidad Nacional de las Artes - \\ Universidad Nacional de La Plata, Argentina \\ marianozelcer@yahoo.com.ar
}

\section{Introducción}

Existe en la contemporaneidad un complejo de prácticas ligadas a la producción y el intercambio de imágenes fotográficas digitales que ha sido denominado postfotografía (ver Fontcuberta, [2016] 2017). En este marco, se reconoce un conjunto de fenómenos que consiste en el intercambio de fotografías a través de las plataformas de múltiples redes sociales de Internet. Las distintas posibilidades que abre cada una de estas redes para la obtención, manipulación, edición, publicación y envío de las fotografías instauran regulaciones específicas que, en cada caso, modelan de un modo diverso la imagen fotográfica digital. En el presente trabajo nos proponemos revisar tres de esos funcionamientos, trabajando con la noción de dispositivo (Traversa, 2001). Para ello, circunscribimos para el análisis ciertos usos específicos de algunas redes sociales que involucran la generación, edición y difusión de fotografías, con el objetivo de caracterizar las variaciones que se producen sobre el estatuto que tradicionalmente caracterizó la imagen fotográfica (Barthes, [1980] 1989) y sus efectos enunciativos: hemos escogido el uso canónico de Instagram, las imágenes tipo snap de la red Snapchat, y las historias o stories, también inauguradas por Snapchat, pero luego adoptadas por otras redes (fundamentalmente, Instagram).

\section{El uso canónico de Instagram}

Como es conocido, en el funcionamiento canónico de la red Instagram, cada usuario publica sus fotografías, a las que puede intervenir con el empleo de los llamados "filtros". En las prácticas habituales, cada quien sube las fotos 
que él mismo ha tomado, o que le han tomado a él con su cámara. Esas fotos quedan publicadas para siempre, y pueden ser vueltas a ver una y otra vez cada vez que se ingrese a la "biografía" de ese usuario en la red social. En este empleo, las fotografías se atesoran y conservan en una suerte de álbum digital compartido. El gesto aquí es de selección y atesoramiento: no todas las fotos se publican, sino sólo algunas que han sido elegidas y que pasarán a formar parte de ese conjunto público o semipúblico que construye una cierta narratividad. La inclusión de una fotografía en la biografía implica habitualmente algún tipo de criterio curatorial, de selección de imágenes que implican la construcción del usuario como desempeñándose en ciertas prácticas o esferas de la vida social (el viajero, la madre, el ídolo popular, el fotógrafo urbano, etc.). En ese sentido, la denominación de biografía (y no "perfil" o "cuenta", como en otras redes) tematiza ya esa selección de fotos como una cierta historia fotográfica del usuario, que -de distintas maneras-constituye un registro temporal de una vida en imágenes. Instagram es, en ese sentido, el espacio en el que pervive un vínculo con las imágenes fotográficas más cercano al que predominaba en los tiempos del papel: las fotografías son menos numerosas, se reúnen en un espacio, se comparten, se conservan.

\section{Las snaps}

La segunda articulación entre fotografías digitales y redes sociales que queremos señalar fue inaugurada por la red Snapchat: nos referimos al envío de fotografías en tiempo real que se borran segundos después de ser vistas; en la jerga de la aplicación, se trata de las snaps. En ellas, un usuario le envía una fotografía a uno o varios usuarios que tiene en su lista de contactos; el o los usuarios que reciben estas fotografías sólo pueden verla una vez y por pocos segundos, y de inmediato, esta imagen desaparece para siempre de su teléfono. ${ }^{1}$ El borrado de las snaps no se debe a algún tipo de limitación técnica, sino que es deliberado. Dicho de otro modo: es el dispositivo digital de Snapchat el que instaura esta regulación de los intercambios para el caso de las snaps, introduciendo una restricción allí donde la técnica no la determina: el borrado de las fotografías. ${ }^{2}$ Este borrado va en contra de la lógica general de conservación que maneja el mundo de las computadoras, en la cual los archivos nunca desaparecen, siempre se acumulan, a menos que sean deliberadamente eliminados por el usuario.

El envío en tiempo real y el borrado automático inmediatamente posterior hacen que las snaps sean apenas un parpadeo, una imagen que dura casi tan poco como la que tenemos con nuestra visión ordinaria, que

${ }^{1} \mathrm{~A}$ menos que el usuario que la recibe las capture justo en ese momento, tomando una foto de pantalla.

2 Fotografías que, además, pueden estar intervenidas de múltiples maneras, como veremos enseguida. 
sólo podemos retener en forma duradera en nuestra memoria. Si la fotografía tradicional generaba un efecto de detención del tiempo, en las snaps el borrado instantáneo lo debilita: el tiempo sí está detenido en esa fotografía, pero sólo por unos instantes; el gesto del borrado es casi la reanudación del fluir de la temporalidad; aquello ya pasó, esa imagen ya no está; habrá eventualmente nuevas, en las que también la duración será efímera. La imagen no se conserva y el tiempo no se detiene: en este funcionamiento de Snapchat, la técnica fotográfica está modelada jugando contra su propia historia. En ese sentido, si el estatuto de la fotografía en el uso canónico de Instagram es muy cercano al originario (testimonio de un haber estado allí3, momento detenido destinado a ser conservado), en el caso de Snapchat cambia por completo: son imágenes destinadas a desaparecer, casi de inmediato. El borrado compulsivo vuelve las imágenes drásticamente temporarias, y las señala como tales: "esta imagen no es nada que esté destinado a ser conservado" / "esta imagen está destinada a desaparecer ahora mismo". Este dispositivo parece preconfigurar la discursividad de los snaps como cabalgando entre dos esferas que a la vez se intersecan: la de lo lúdico, con imágenes que proponen guiños, juegos visuales o humoradas, y la de lo prohibido, que se sintetiza en el uso de las snaps para el envío de fotos de las partes íntimas del cuerpo (fenómeno conocido como sexting).

Las snaps fueron precursoras de una práctica hoy muy extendida en múltiples formatos y redes sociales: la intervención de las fotografías o videos, ya no sólo con el agregado de filtros o marcos, como lo permitía Instagram, sino también con la sobreimpresión de objetos o elementos y el agregado de textos o trazados, como se ve en la figura 1.
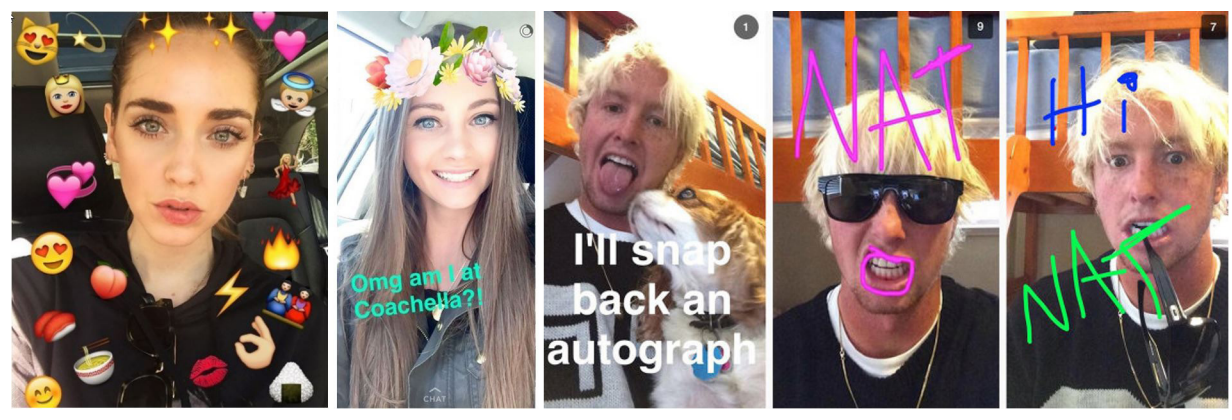

Sin embargo, la novedad que distinguió a Snapchat en términos de la intervención de las imágenes fueron los efectos llamados "lentes", posteriormente imitados por Instagram en sus "face filters". Las lentes tienen la particularidad de modificar las fotografías o videos, no sólo con

Roland Barthes resume el noema o la esencia de la fotografía como "Esto ha sido": "nunca puedo negar en la Fotografía que la cosa haya estado allí. Hay una doble posición conjunta: de realidad y de pasado." (Barthes, [1980] 1989:23 
sobreimpresiones, sino también con cambios en la apariencia de los rostros: se agrandan los ojos, se modifican los pómulos, se adquieren los rasgos de un anciano, se agregan orejas, nariz y lengua de un perro, etc. Algunos ejemplos de estas intervenciones pueden verse en la figura 2 . Las lentes tienen además la particularidad de no ser un efecto de posproducción, sino concomitante a la toma de la imagen: la lente se selecciona entre las opciones disponibles, y en la pantalla del celular, donde se previsualiza la imagen que será capturada, ya se observa la imagen con el efecto de la lente aplicada; es decir, no hay una vista de la imagen sin intervenir. Las lentes intervienen, desde el punto de vista de la experiencia de quien genera la foto, en la instancia de la toma o el registro; mientras que los demás efectos (filtros, agregados de texto, de trazados, de emoticones o ilustraciones sobreimpresas) se añaden con posterioridad a la toma.

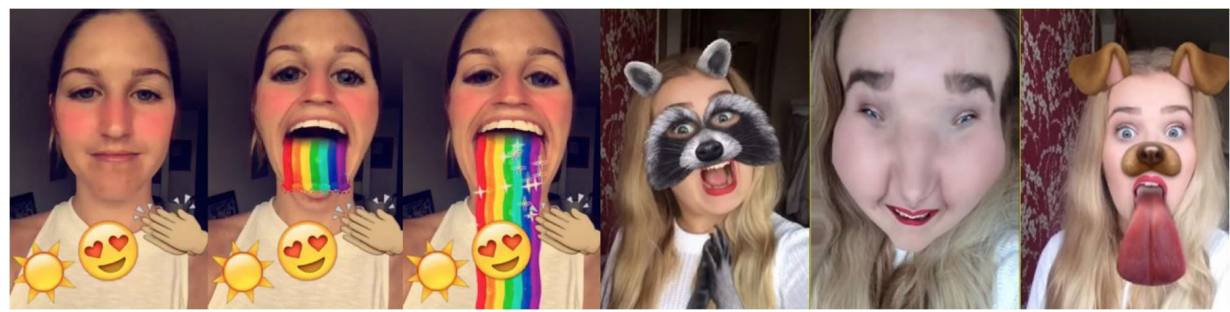

La edición en estas imágenes es ostensible: la enunciación es opaca, y predomina por sobre el enunciado. Cada snap es un ejercicio lúdico de intervención de selfies o retratos; casi como si lo que cada imagen llamara a observar es el juego de efectos visuales que ha tenido lugar sobre esa fotografía o video esa vez, antes que lo que aparece figurado. Con el uso, sin embargo, los efectos comenzaron a repetirse, y enseguida la novedad parece haberse agotado. Si originalmente la posproducción era un gesto de rebeldía (producir cambios sobre una imagen fotográfica, que nació justamente para mostrar las cosas tal cual son), con el tiempo el molde de Snapchat terminó por instalar un horizonte de previsibilidad, donde lo esperado es precisamente la imagen intervenida: de una imagen que llega por Snapchat no se espera ya la fidelidad de una fotografía, sino un juego visual que la tome como base.

\section{Las stories}

En las figuras 1 y 2 también puede observarse otra particularidad de las snaps: su formato vertical. Esta disposición, que es la propia del modo en el que se sostienen los teléfonos celulares, es sin embargo novedosa en relación con las interfaces culturales, e implica una ruptura en una historia en la cual los formatos apaisados u horizontales dominaron la escena, desde el cinematógrafo, hasta la televisión y las computadoras personales. Señalaba Manovich al respecto: “Otra característica de la percepción cinematográfica que persiste en las interfaces 
culturales es el encuadre rectangular de la realidad representada" (Manovich, [2001]2006:131)

Esta historia del predominio de la horizontalidad se bifurca desde el momento en que los smartphones se expanden en el uso cotidiano como la cámara más empleada: mientras que en las computadoras y los televisores el formato apaisado permanece y se extiende en las pantallas wide (cada vez proporcionalmente más anchas), en la producción de fotografías y videos con teléfonos celulares aparece el uso del formato vertical, dominante en las snaps. El formato vertical es, en forma evidente, una restricción técnica que proviene de la forma de las pantallas que se ha terminado por imponer como la dominante en estos teléfonos celulares.

La disposición vertical es también la propia de otro formato inaugurado por Snapchat, conocido como stories. Las stories consisten una fotografía o video de corta duración, o una breve sucesión de ellos, que pueden ser intervenidos al modo de una snap, y que tienen la particularidad de estar disponibles por 24 horas desde su publicación en la biografía del usuario. A diferencia de lo que ocurrió con las snaps, las stories fueron emuladas por una multiplicidad de redes sociales -Facebook, Instagram, WhatsApp-que las añadieron como una opción más de publicación por parte de los usuarios. Al ingresar a estas plataformas, se encuentra un espacio en el cual se observa quiénes han publicado una story ese día; el usuario puede elegir cuál o cuáles quiere ver ${ }^{5}$ y la imagen de la story se visualiza ocupando la totalidad de la pantalla. Además, las stories están visibles habitualmente al ingresar a las plataformas, lo que las prioriza por sobre los posteos regulares. En esas plataformas las imágenes de las stories también pueden ser editadas con filtros, textos, íconos y efectos.

Las stories se instalaron en los intercambios cotidianos de las redes sociales como un espacio en el que se tematiza la propia situación del día: no necesariamente lo cotidiano -que implica repetición, rutina, regularidad-, sino predominantemente lo distintivo de la jornada: el viaje, la celebración, el evento singular; 0 , en otros usos, simplemente aquello que se tiene para decir (por ejemplo, la adhesión a una causa). ${ }^{6}$ Todas "historias" que, como la historia, pasan, y están sólo para ser vistas sólo durante un día. Algunos ejemplos de pueden verse en la figura 3.

\footnotetext{
${ }^{4}$ En WhatsApp, las stories aparecen en la sección de "Estados".

${ }^{5}$ Aunque muy habitualmente, cuando el usuario accede a ver la primera de ellas, las plataformas le muestran las restantes una tras otra.

${ }^{6}$ Dejamos fuera de la indagación el empleo del espacio de stories con fines publicitarios o promocionales, al modo de los "influenciadores".
} 

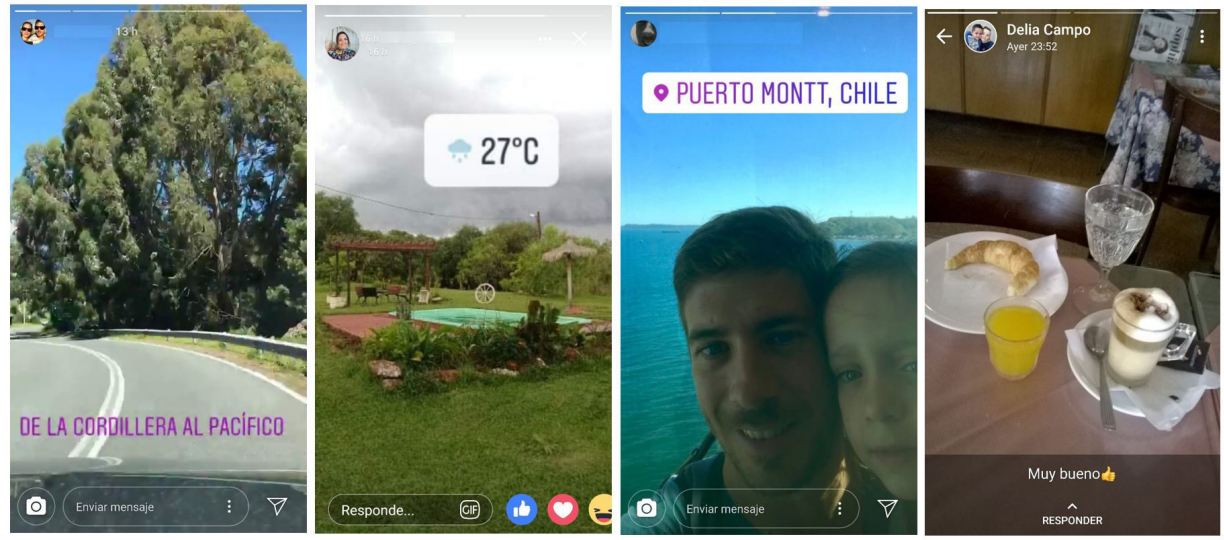

Desde que incluyó las stories dentro de sus opciones de publicación, fue Instagram la red en la que predominó este formato. Los últimos datos disponibles a la fecha de escritura de este texto muestran un crecimiento vertiginoso (ver figura 4).

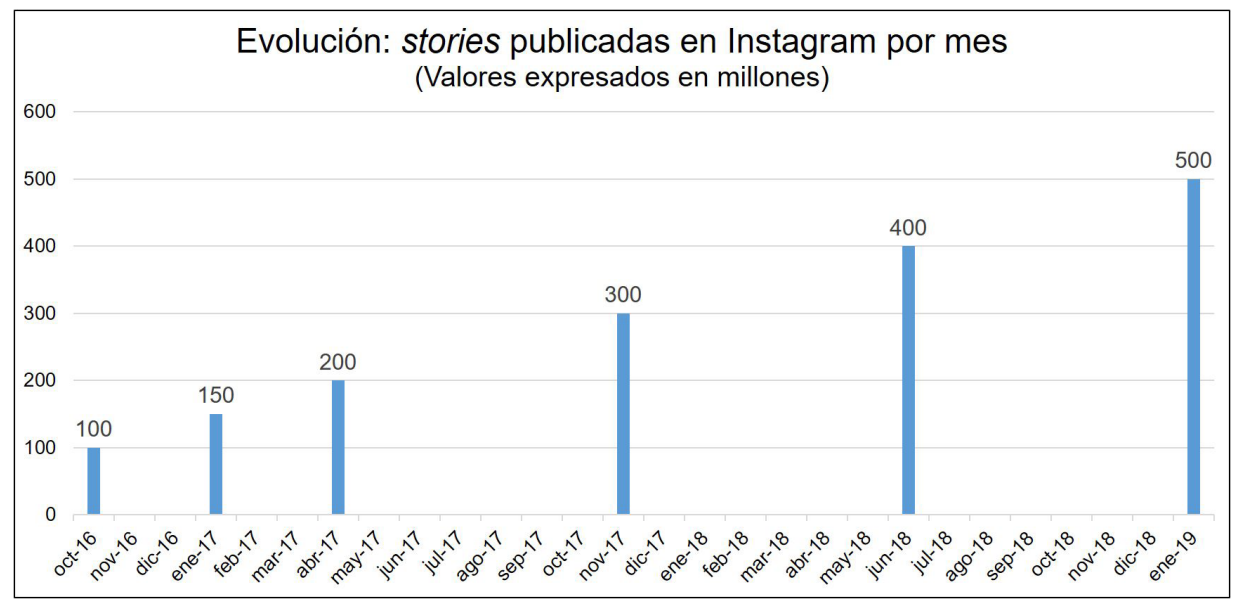

\section{Dispositivos y enunciación}

Cada una de estas modalidades de regulación de la intervención y el intercambio de las imágenes fotográficas puede ser pensada como un dispositivo diferente, que instaura distintas propuestas enunciativas. La noción de dispositivo que manejamos aquí retoma la perspectiva de Oscar Traversa (2001), quien atiende no sólo a la técnica, sino también al aspecto vincular al que da lugar cada dispositivo, es decir, a sus funcionamientos como reguladores de la gestión del contacto, en configuraciones vinculares específicas. Así pensado, el dispositivo es un "lugar soporte de los desplazamientos enunciativos" (Traversa, 2001:242) 


\subsection{Instagram}

El uso canónico de Instagram ilustra cómo incluso en tiempos de la postfotografía persisten usos de la fotografía ligados a prácticas más tradicionales: las fotografías se seleccionan, se muestran, se conservan. Carlón (2016) califica este tipo de vínculo con la fotografía como "moderno". En contraposición, serían posmodernos los usos que implican la intervención o la manipulación de la fotografía (los primeros propios de las snaps, los segundos habituales en las stories). En el marco de estos usos modernos, probablemente Instagram es el espacio en el que más se juega una cierta estetización de la imagen fotográfica: a través de los filtros, la plataforma propone intervenir en las temperaturas, la iluminación, los colores, los grados de saturación o el contraste. La biografía de Instagram de cada usuario se presenta como el resultado de una selección de fotos, cada una de las cuales además ha sido editada (pero no intervenida). Esas biografías parecen oscilar entre el "este soy yo", el "esto soy yo", y el "así me presento yo" (puesto que oscila entre el "así me veo" y el "esto es lo que veo"). Se trata de un espacio en el que la imagen es cuidada, donde se acentúa su función poética y hay un menor anclaje con la inmediatez o incluso la cotidianidad.

\subsection{Las snaps}

En las snaps, en cambio, hay un predominio de la función fática con componentes lúdicos; de algún modo se pone por delante la acción de la intervención; el enunciador de estas fotografías parece decir "así juego con las imágenes", con un gesto de originalidad y de rebeldía sobre esas imágenes de registro que, como se vio, tiende con el uso extendido a volverse una suerte de grado cero en relación con las expectativas de la plataforma. La novedad tiende a pasar así por los nuevos filtros que puedan emplearse; la enunciación entonces se ve como escindida entre ese fotógrafo fotografiado, y una enunciación institucional del dispositivo que renueva las posibilidades de intervención con la publicación de filtros. ${ }^{7}$

\subsection{Las stories}

La adopción del dispositivo de stories por parte de Instagram representó una ruptura en relación con las lógicas que gobernaban las dinámicas de esa red: si originalmente era una suerte de refugio moderno en el cual las fotografías continuaban conservándose, las stories vinieron a traer, en ese mismo espacio, una caducidad programada y un sentido de lo temporario o pasajero ligado a las imágenes. Sin embargo, como se observó, las stories fueron adoptadas por los usuarios y se transformaron en un espacio más de esa red social, incluso

\footnotetext{
${ }^{7}$ Los usos del sexting asociados a las snaps merecerían un análisis por separado por la singularidad de los efectos que se producen cuando el dispositivo se articula con ese particular campo de desempeño; lo dejamos fuera de la indagación por un tema de espacio.
} 
destacado por sobre el clásico feed.

Puede sugerirse, como hipótesis, que el éxito de las stories en Instagram se debe a una suerte de "encuentro fecundo" (Cuesta y Zelcer, 2002) entre una propiedad del dispositivo y una cierta área temática del "conversar con imágenes": las conversaciones cotidianas, que versan sobre el día a día, hallaron en las stories un dispositivo que se renueva precisamente día a día, y que además cuenta con recursos que permiten construir una cierta narratividad. Como efecto de sus regulaciones, la enunciación de las stories parece decir "esto es lo que me pasó" / "esto es lo que tengo para contar/para decir hoy en imágenes": es lo que decido compartir, pero no atesorar. Bajo esta enunciación determinada por el dispositivo se encuentran muy variadas propuestas discursivas, que según el caso recorren incluso distintos campos de desempeño: las stories pueden mostrar la visita diaria a la plaza con las hijas, la participación en una manifestación por los derechos de la mujer o la planta de la terraza que hoy ha dado una flor.

\section{Fotografía / postfotografía}

\subsection{La intervención en vivo}

La intervención de las imágenes fotográficas que observamos tanto en las stories como en las snaps reconoce múltiples antecedentes. Dubois menciona el trabajo de los pictorialistas en su discusión acerca del acto fotográfico, y destaca -para el mundo de la fotografía tradicional- que cualquier intervención en la imagen fotográfica es posterior a la toma: "no se puede intervenir en la imagen que se está haciendo" (Dubois, [1990] 2015:176). Esta observación es válida no sólo para las viejas prácticas de intervención manual sobre las fotografías, sino también para los programas informáticos destinados al tratamiento de imágenes: en todos los casos, la imagen primero es tomada, y luego alterada por edición.

Las "lentes" de Snpachat presentan, en ese sentido, una novedad: la imagen no intervenida nunca es visible para el usuario, que directamente ve su imagen ya modificada en su iconicidad con antelación a realizar la captura de la imagen o el video. Alteraciones que históricamente se encontraban en un momento posterior a la generación de la imagen son ahora concomitantes al momento de la toma. Mientras que los efectos de edición y retoque tradicionales constituían una suerte de maquillaje de esa fotografía (se añadían por sobre lo fotografiado), las lentes de Snapchat son una suerte de máscara, con la que los rostros cambian su aspecto: la imagen nace ya intervenida, el rostro con su iconicidad inalterada nunca es visible en esa pantalla; permanece oculto, como si estuviera escondido detrás de esas nuevas apariencias. 


\section{2. ¿A qué se llama "fotografía" hoy?}

En su conceptualización acerca de la postfotografía, Fontcuberta señala que, a diferencia de lo que ocurrió con la pintura cuando se expandió la fotografía -que, según dice el autor, cambió de rumbo, pero sin salir del mapa- "todo lo contrario (...) ha sucedido con la postfotografía y la fotografía, pues esta última parece haber quedado engullida. Y esta disrupción ha sido invisible porque los usuarios no han notado el cambio y, con todo candor, siguen llamando fotografía a lo que hacen" (Fontcuberta, [2016] 2017:28).

Acordamos plenamente con Fontcuberta en el hecho de que estas sustituciones han tenido lugar en numerosos usos de la fotografía; sin embargo, no estamos tan seguros de que se trate de un "engullir"; de hecho, los usos tradicionales de la fotografía aún permanecen, e incluso encuentran espacios en las redes sociales, como en el uso canónico de Instagram que ya hemos revisado. Por ello, antes que pensar en la persistencia de la denominación de "fotografía" para estos nuevos fenómenos como indicio de un posible candor o ingenuidad de los usuarios, nosotros la entendemos como una señal de que aquello que socialmente se llama fotografía se ha diversificado. Si se sostiene una misma denominación, seguramente sea por ese núcleo persistente que la caracteriza: el origen en una captura y la generación de una imagen estática que es a la vez semejante y prueba de existencia de esa entidad o estado de hecho figurado. ${ }^{8}$ Esa fotografía, empero, puede ser de entrada de dos materialidades diferentes (de película o digital), y puede estar trabajada por múltiples operaciones tanto en el nivel del dispositivo como en los juegos discursivos que multiplican sus posibilidades del decir.

Mario Carlón coincide con estas apreciaciones. Este autor no habla de fotografía y postfotografía, sino de prácticas fotográficas modernas y prácticas fotográficas posmodernas: "en la era contemporánea subsisten prácticas fotográficas modernas y posmodernas, incluso en las redes sociales" (Carlón, 2016: 39).

$\mathrm{Si}$, como dice Fontcuberta, "la fotografía nos hablaba del pasado, [y] la postfotografía nos habla del presente" (Fontcuberta, [2016] 2017:114), debemos al mismo tiempo señalar que la innovación de las redes sociales ha sido el empleo postfotográfico de la fotografía, pero que ambos persisten. Probablemente sea Instagram, con la coexistencia del uso canónico y de las stories, la red que mejor ilustra cómo ambas modalidades conviven hoy en estos espacios. El doble juego con la temporalidad que se propone en esta plataforma (lo actual y efímero en las stories, lo que se selecciona y se conserva en el feed

\footnotetext{
8 Estamos llamando aquí la atención sobre el estatuto icónico indicial de la fotografía, siguiendo a Jean-Marie Schaeffer. Ver Schaeffer, Jean-Marie (1990) La imagen precaria del dispositivo fotográfico, Madrid, Cátedra. Edición original: (1987) L'image précaire du dispositif photographique, París, Seuil.
} 
o biografía) resume dos grandes tipos de vínculos que se establecen hoy con las fotografías: la tematización pasajera del ahora, propia de la postfotografía o fotografía posmoderna, y la conservación en un álbum de imágenes, al estilo de la fotografía tradicional o moderna.

\subsection{Lo cotidiano y lo extraordinario}

Múltiples circunstancias habían hecho que, en el empleo de las cámaras fotográficas hogareñas tradicionales, la toma fotográfica se dedicara sólo al registro de circunstancias excepcionales, o a lo excepcional en lo cotidiano: las vacaciones, la fiesta de cumpleaños, el acto escolar, etc. Entre estas circunstancias debemos contar, al menos, los tiempos extensos entre toma, revelado e impresión y los altos costos económicos asociados a estas prácticas. Esta causalidad material había terminado por generar una jerarquización de lo fotografiado: si inicialmente sólo se fotografiaba lo relevante, luego todo lo fotografiado en la vida cotidiana adquirió relevancia por el solo hecho de ser fotografiado. ${ }^{9}$ Con el advenimiento de la fotografía digital, estas circunstancias desaparecieron, al tiempo que se abrió la posibilidad de compartir estas imágenes en tiempo real, lo que habilitó que nuevas múltiples tematizaciones ingresaran en el mundo de las imágenes fotográficas.

Carlón discutió precisamente este punto acerca de la fotografía digital, y presentó dos interpretaciones contrapuestas y a la vez complementarias acerca de la profusión de fotografías en la contemporaneidad. Por un lado, propuso pensar este fenómeno en el marco de lo que él entiende "un cambio en el régimen de historicidad" (Carlón, 2016:47), que se evidencia en el fenómeno del presentismo. ${ }^{10}$ Siendo que el presentismo propone justamente vivir cada momento presente con mayor intensidad, "todo momento puede ser considerado significativo y merecer, por lo tanto, una fotografía" (Carlón, 2016:47). Por el otro, el autor propone pensar lo contrario: que en la vertiginosa contemporaneidad la vida ha perdido significación. Razona el autor: "Si es así la fotografía vendría, entonces, a cumplir otra función. No viene ya a registrar momentos significativos, sino a intentar darle sentido a momentos que no lo tienen" (Carlón, 2016:48). Luego de exponer ambos argumentos, el autor concluye que probablemente ambos tengan su parte de verdad. Al tiempo que no podemos dejar de coincidir con ello, proponemos una tercera vía interpretativa para estas fotografías. Tanto en uno como en otro caso, Carlón da por sentado que el acto de fotografiar está vinculado con lo notable o lo significativo: o se fotografía lo que ya se considera significativo (sobre lo que

\footnotetext{
${ }^{9}$ Este razonamiento ya había sido adelantado por Barthes: “En un primer tiempo, la Fotografía, para sorprender, fotografía lo notable; pero muy pronto, por una reacción conocida, decreta notable lo que ella misma fotografía" (Barthes, [1980] 1989:68).

${ }^{10}$ Carlón toma este término de Hartog, François (2007) Regímenes de historicidad. Presentismo y experiencias del tiempo, México: Universidad Iberoamericana. Edición original: 2003.
} 
habría un corrimiento: hoy son significativos fenómenos que antes no lo eran), o se busca que el mismo acto de fotografiar lo vuelva significativo. En un análisis de campo que hemos realizado sobre las fotografías compartidas en tiempo real a través de WhatsApp (ver Zelcer, 2017), encontramos que uno de los atributos históricos de la fotografía que comienzan a cuestionarse o debilitarse es justamente la notabilidad; en ese sentido, coincidimos con Fontcuberta en que ya no sólo se fotografía lo extraordinario: "La fotografía ya no solemniza un episodio de la vida, porque todo está fotografiado (...) El registro ya no se reserva a lo extraordinario" (Fontcuberta, [2016] 2017:174).

Probablemente el uso de la fotografía digital que ilustra con mayor claridad la ausencia de notabilidad asociada a ciertas imágenes fotográficas digitales sea la fotografía de compras. Como es sabido, es una práctica habitual en la contemporaneidad el envío desde las tiendas de fotografías en las que se ven artículos cuya compra se está evaluando o terminando de decidir entre más de una persona: el comprador envía una fotografía del producto que podría ser adquirido para solicitar opinión o aprobación (ver figura 5).
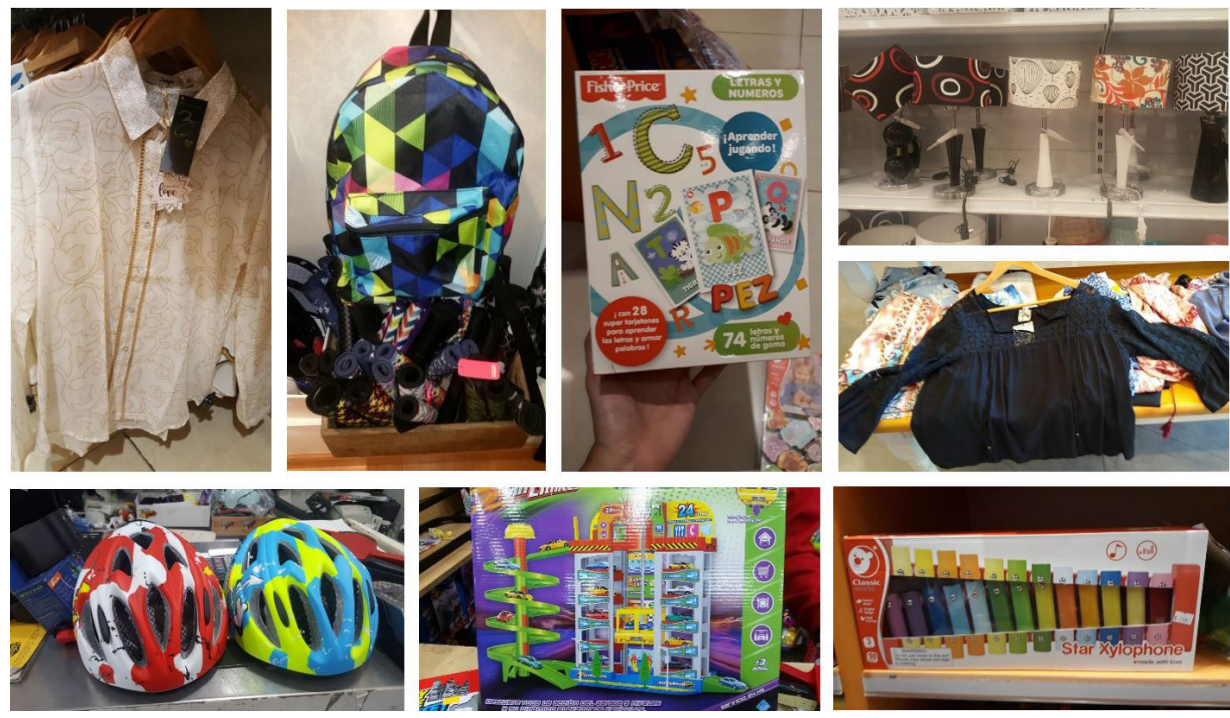

La fotografía de compras no supone que el artículo fotografiado sea notable, ni pretende volverlo notable al fotografiarlo: se trata, eventualmente, de un caso de uso de lo que Carlón llama "comunicacional", y se relaciona con el hecho, señalado por este mismo autor, de que una fotografía brinda "abundante información" acerca de lo fotografiado (Carlón, 2016). En estos empleos, la fotografía simplemente releva de complejas o extensas descripciones verbales a quienes se encuentran en las tiendas. Puede pensarse que en la fotografía de compras se hace probablemente el uso más macluhaniano ${ }^{11}$ del hiperdispositivo

${ }^{11}$ En un libro coescrito con Quentin Fiore, afirma McLuhan: “Todos los medios son prolongaciones 
compuesto por la fotografía digital y las redes sociales en tiempo real: como una extensión del sentido de la vista, la cámara del celular que toma la foto y la pantalla de los que la reciben permiten que usuarios que no están cerca del producto puedan conocer buena parte de sus propiedades. La función principal de los dispositivos aquí es franquear la distancia espacial; una suerte de "tele-fotografía": como en el teléfono, lo que prima es hacer accesible a la percepción (en el teléfono al oído, en este caso a la vista) aquello que se encuentra demasiado alejado para nuestros sensores biológicos.

\section{Bibliografía}

CARLÓN, Mario. 2016. "Registrar, subir, comentar, compartir: prácticas fotográficas en la era contemporánea", en Pablo CORRO y Constanza ROBLES (editores) (2016) Estética, medios y subjetividades, Santiago de Chile, Universidad Pontificia Católica de Chile. Disponible en http://estetica.uc.cl/ images/stories/librovsimposio/02_mario\%20carlon.pdf [Consulta: 16/10/2018].

CUESTA, Andrés y ZELCER, Mariano. 2002. "Acerca de la conformación de gramáticas en los nuevos medios: el caso de los diarios electrónicos". Ponencia presentada en las VI Jornadas Nacionales de Investigadores en Comunicación, Córdoba, Argentina y en las Jornadas de Formación en el Periodismo y la Comunicación Social en la Convergencia Digital, organizadas por REDCOM en Buenos Aires, Argentina.

FONTCUBERTA, Joan. 2017. La furia de las imágenes. Notas sobre la postfotografía, Barcelona, Galaxia Gutenberg. Edición original: 2016.

MANOVICH, Lev. 2006. El lenguaje de los nuevos medios de comunicación: la imagen en la era digital, Buenos Aires, Paidós. Edición original: (2001) The Language of New Media, Cambridge, Massachusetts, The MIT Press. Traducción de Òscar Fontrodona.

MCLUHAN, Marshall y FIORE, Quentin. 1997. El medio es el masaje. Un inventario de efectos, Barcelona, Paidós Ibérica. Edición original: (1967) The Medium is the Massage. An Inventory of Effects, Nueva York/Londres/Toronto, Bantam Books. Traducción de León Mirlas.

RITCHIN, Fred. 2010. Después de la fotografía, Oaxaca de Juárez, Ediciones Ve. Edición original: (2009) After Photography, Nueva York, W.W. Norton \& Company.

TRAVERSA, Oscar. 2001. "Aproximaciones a la noción de dispositivo" en revista Signo y Seña número 12, Buenos Aires, Instituto de Lingüística, FFyL UBA. Páginas 233 a 247.

de alguna facultad humana, psíquica o física" (McLuhan y Fiore, 1967[1997]:26). 
ZELCER, Mariano. 2017. "Las imágenes fotográficas en tiempo real: una aproximación", en revistas L.I.S. Letra, Imagen y Sonido número 18. Disponible en https://publicaciones.sociales.uba.ar/index.php/lis/article/view/3873) [Consulta: 27/10/2019].

\section{Origen de las imágenes}

Imagen 1. http://www.blairkaplan.ca/ snap-chat/, https://www.vogue.mx/agenda/ cultura/articulos/tu-guia-para-un-snapchat-perfecto/5999, y http://culturageek. com.ar/snapchat-dicen-vos-los-filtros-mas-usas/ [Consulta: 14/10/2018].

Imagen 2. https://www.moboplay.com/download-\%EF\%BB\%BFeffect-lensessnapchat-tip-apk-10136.html y https://www.buzzfeed.com/bibibarud/la-guia-maspractica-para-usar-snapchat. [Consulta: 14/10/2018].

Imagen 3. Capturas de las "historias" de Instagram y de Facebook, y de "estados" de WhatsApp de contactos personales del 14/1/2019

Imagen 4. Presentaciones internas de Facebook/Instagram de marzo de 2018 y octubre de 2019.

Imagen 5. WhatsApp personal. 


\section{MEDIACIONES}

\section{A. EXPRESIONES DEL CUERPO}





\section{La autopoiesis del acontecer artístico que emerge a traves del diálogo entre diferentes dimensiones de la corporalidad}

DOI: 10.24308/IASS-2019-4-021

Daniela Lieban

Universidad Nacional de las Artes, Argentina. danilieban@gmail.com

\section{Introducción}

A partir de los conceptos de bucle autopoiético, como retroalimentación creativa, y de corporalidad, entendida por Erica Fischer Lichte como materialidad de la acción que prevalece sobre la signicidad (2011, p 36), este trabajo reflexiona acerca de la articulación entre 4 cuerpos diferentes conviviendo en un mismo espacio escénico: el performatico, el objetual el digital y el receptivo.

Vinculando ambas ideas con la dimensión bachelardiana de la poética del espacio, enfocándome en sus nociones de miniatura y refugio, con sus efectos semióticos de identificación, analizaré la obra CIELO EXPANDIDO. InstalAcción Performática: juego de palabras que integra el accionar performático en una instalación, en el cual movimientos, sonidos, visuales interactivas, objetos mecánicos y lumínicos, se conjugan de manera integrada y significativa, retroalimentándose mutuamente.

El performance, como acto de intervención efímero, interrumpe circuitos de industrias culturales que crean productos de consumo, afirma Diana Taylor en sus Estudios avanzados de la performance. (Taylor, 2011, p8).

Considerando que en el presente tanto la tecnología como los objetos, se incorporan a la cotidianeidad y al consumo, investigo en modos artísticos de creación y uso de la tecnología, con el cuerpo humano como mediador, para constatar si puede usarse disruptivamente en las artes escénicas. Pongo en valor el desarrollo de la imaginación creadora conel aporte de innovación a sus múltiples aplicaciones, para generarun contagio poético en los espectadores.

Esta obra propone un ritual contemporáneo que comunica en varios planos, de manera poética, una atmósfera cósmica que evoca una intemperie, en la que se encuentra instalado un iglú central. El cuerpo objetual gira en torno a ese refugio de manera cíclica y repetitiva. Acontecen relaciones entre 
los cuerpos de la performer y el objetual, que refieren a las posibilidades humanas del arrullo, del cuidado y la solidaridad como acciones y como una elección consciente. El tercer cuerpo digital crea en vivo un paisaje sonoro, a la vez que aparececomo huella y reflejo de los otros dos cuerpos.Construye la espacialidad, con la proyección deimágenes en la pantalla de fondo. Interactúa con los movimientos y con la voz de la performer. Todos ellos sevinculan a la vez con un cuarto cuerpo receptivo, incluido en la mirada singular de cada espectador, que será su mapa de ubicación y de sentido.

Se pone en valor el uso de la imaginación en los procedimientos singulares de creación interdisciplinaria con el uso de nuevas tecnologías. Mediante el bucle de retroalimentación, se procura generar un contagio poético en los espectadores, frente a esa intemperie sugerida en la escena propuesta.

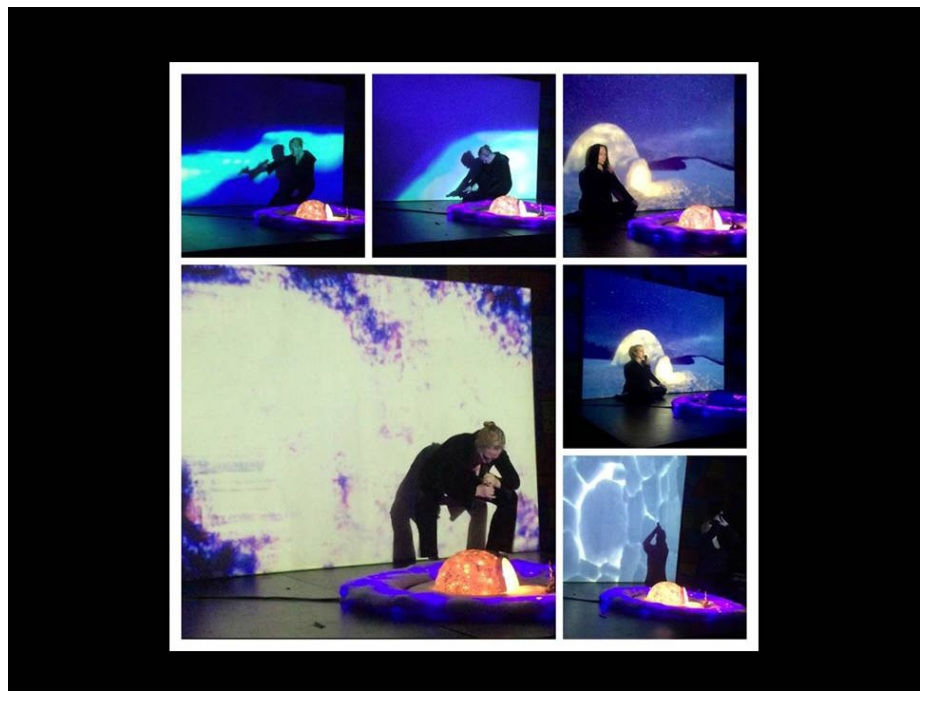

Fig.1. Cielo Expandido en el $x$ Festival Danza BA. Ph Teresa Duggan

\section{Antecedentes. Bitácora del proceso creativo}

Desarrollando un procedimiento de composición "radicante", descripto por el especialista en arte contemporáneo Nicolás Bourriaud, como un organismo que hace crecer sus raíces a medida que avanza, comencé por realizar la instalación objetual "Cielo de ti", inspirada en el tema de Luis Alberto Spinetta. Generando una creativa traducción actual, mediante el procedimiento de transposición de la canción al formato de instalación objetual. Esta obra la realicé como Tesis de la Especialización en Teatro de Objetos, Interactividad y Nuevos medios de la UNA, exponiéndola en la muestra colectiva Trama de Objetos, con curaduría de la Directora Ana Alvarado, quien publicó luego, una fotografía de la obra en su libro Cosidad, carnalidad y Virtualidad. También la exhibí en la muestra Plus+ Arte 2016 en el Festival Wine Rock en Mendoza. 
Continuando con mi trabajo académico dentro de la UNA, la presenté como ponencia del Congreso Internacional Revueltas del Arte 2017, donde coordiné la mesa "Narrativas Contemporáneas". El profesor e investigador Aníbal Zorrilla participó de la mesa, contando su experiencia como director del proyecto de investigación, Intad (nuevas tecnologías aplicadas a la escena), y me invitó a formar parte del equipo.

En 2018 continué capacitándome en la Maestría en Performance, investigando las implicancias del cuerpo en la performance y en los lenguajes del video arte y la video performance. Realicé una tríada en formato digital en relación a esta obra, en la cual vinculé el cuerpo mediatizado por el registro de la performance, con el registro de la instalación

Me incorporé al proyecto Intad como investigadora formada a comienzos del 2018, con mi proyecto Cielo Expandido conformando un equipo de artistas para incluir en esta nueva etapa, al cuerpo en escena, proponiendo cruzar los lenguajes de la danza, el canto y la voz en vivo; la instalación mencionada y las imágenes digitales interactivas proyectadas en tiempo real, mediante Isadora, aplicación creada especialmente para las artes escénicas.

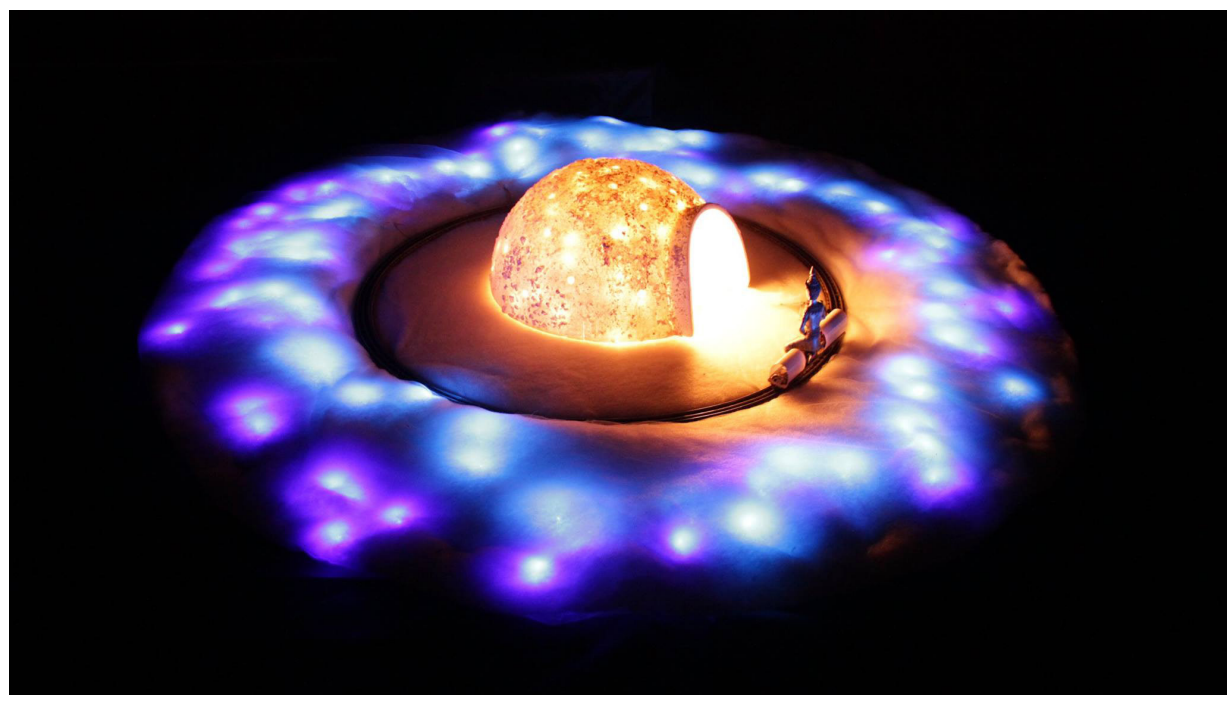

Fig.2. Cielo de Ti Instalación objetual de Daniela Lieban. Ph Alejandra Dagostino.

\section{Flujos Colaborativos: Diálogo y vínculos con otros artistas y su obra}

Se produjo un cambio perceptual del espacio mediante la modificación de escalas, desde el universo en miniatura de la instalación, hacia la expansión en el cuerpo humano y en la video proyección, generando a partir de los movimientos, la gestualidad y la voz en escena, un universo particular. 
Las visuales interactivas realizadas por Gabriela Baldoni, se producían de la siguiente manera: Los movimientos eran capturados por una cámara web y mediante el uso de Isadora, se disparaban las proyecciones en tiempo real, produciendo diversos efectos visuales relativos a la coreografía y a la instalación. Si bien se programaron "escenas visuales" la diseñadora las operaba en vivo, de modo que las proyecciones eran modificadas por mis movimientos, otorgando un carácter azaroso a la performance. Las imágenes proyectadas también buscaban dar profundidad espacial, transformando la percepción plana de la pantalla que enmarcaba el espacio de la escena.

Buscando expandir la instalación objetual y sacarla de las tres dimensiones del espacio físico, para llevarla a un espacio virtual temporal donde la imagen de la instalación y el movimiento de la performer se ven modificados, desplazados y son transportados en el imaginario a un espacio cósmico.

La percepción auditiva se transformó a través de un dispositivo interactivo en el cual utilicé un micrófono como interfaz, para producir cambios de efectos en mi voz y en la banda de sonido, procesada en vivo por Fabian Kesler.

El bucle autopoiético, se producía también en tiempo real, proponiendo una estructura abierta, en la cual improvisaba junto al diseñador de audio. Los efectos producidos por mi voz, se alteraban y transformaban según frecuencia y volumen, y Kesler los procesaba y completaba con sonidos ambiente generando una dimensión de espacialidad a través del sonido. La pista de la canción de Spinetta, también era intervenida con efectos en vivo.

Kesler creaba un entorno sonoro de naturaleza ruidista procesado en tiempo real. Modificaba con efectos la voz de la performer posibilitando un diálogo constante de acciones e interacciones sonoras.

Luego de 5 meses de ensayos, investigación y experimentación artística Cielo Expandido se presentó en la Muestra Colectiva Desbordes, Cuerpos e interacciones 2, laboratorio de investigación INTAD en el Centro Cultural Matta de la Embajada de Chile, el 13 de julio de 2018.

Fuimos seleccionados para el $x$ Festival Buenos Aires Danza Contemporánea en el cultural San Martin, con una función a sala llena, para la cual ajustamos y profundizamos, las escenas que construyen la obra

Al tratarse de un Festival con un marco de producción más completo y con una mayor convocatoria y llegada al público, amplié el equipo, sumando a excelentes y talentosos artistas, con los cuales el intercambio y retroalimentación se multiplicó de manera muy enriquecedora. Tuvimos una excelente repercusión y pudimos ampliar la propuesta, invitando al público estimulado a probar el dispositivo interactivo al terminar la función, y abrir un espacio de debate y diálogo, para responder a sus preguntas. 


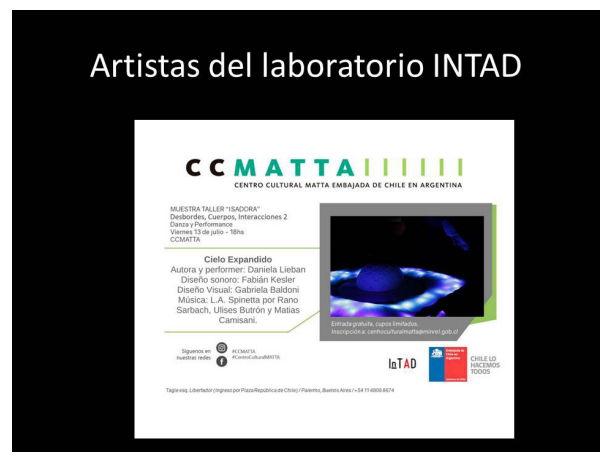

Fig. 3 y 4 . Flyers de presentaciones de Cielo Expandido en 2018.Ph A. Dagostino

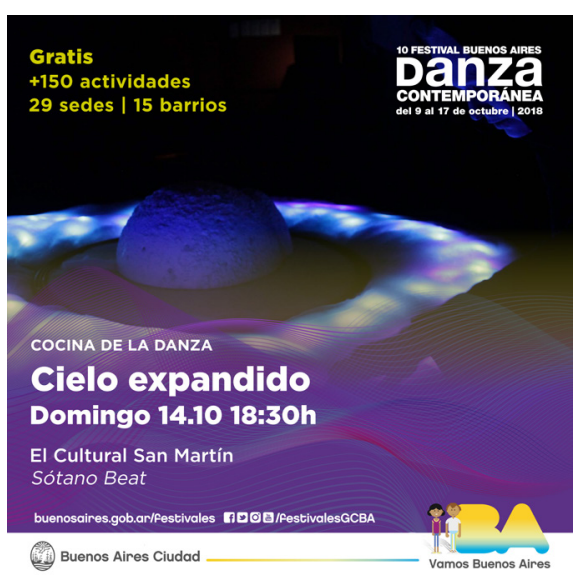

\section{Inscripciones y filiaciones artísticas}

Esta obra se inscribe en la línea multimedia, de cruce de las artes escénicas, visuales y musicales con la tecnología tomando como referentes a grandes artistas comoLaurie Anderson, entre otras cosas porque en sus puestas todos los elementos y lenguajes artísticos cobran igual valor en función de un resultado poético, Su singularidad vocal y la creación de universos particulares me estimularon a explorar mi propia voz y universo poético.

Sebastián Gordín, por su concepto de micro universos paralelos, y el uso de iluminación leds para sus miniaturas en su muestra Un extraño efecto en el cielo, emulando la mirada de niño, con lo lúdico que aportan los objetos.

Margarita Bali destacada referente como Artista argentina polifacética; sus obras de danza contienen una fuerte impronta visual. Amplió su lenguaje a la Video danza e instalaciones. Me formé en su escuela orientada al cruce de la danza con otras disciplinas.

Dave y Christie Mc Guire destacados artistas ingleses que .realizan Instalaciones que combinan objetos, miniaturas, proyecciones y sonidos con nuevas tecnologías.

\section{Realización escénica y materialidades de Cielo Expandido. \\ 5.1 Espacio}

"Todo el universo se encuentra en unas curvas. Lo pequeño contiene un universo en ese núcleo. Lo grande es contenido en lo pequeño".

Gastón Bachelard. Poética del Espacio

Mediante la creatividad y los alcances del desarrollo tecnológico, el artista radicanteencuentra las reglas del propio discurso, en pos de investigar en modos de comunicación no lineales, sin fábula aleccionadora, pero con 
profundidad y provocación para despertar la emoción a través de la ampliación perceptiva de los sentidos en el receptor.

La posibilidad de activar sonidos, objetos e imágenes en vivo y desplegar acciones que nacen a partir de la canción, expande el sentido dramatúrgico de la misma, posibilitando al espectador hacer foco en la letra, o en un sonido, o en una imagen o en un movimiento o gesto. Al tratarse de un lenguaje poético, el espectador construye sentido y completa con su propia interpretación los significados posibles de la obra.

La retroalimentación se realizapor un lado entre los 3 artistas: la performer (bailarina, coreógrafa y cantante), el diseñador de audio y la diseñadora visual mediante el uso de las máquinas y los sistemas descriptos. Simultáneamente el público completa el círculo presencial y construye sentido con su mirada particular, favorecida por la disposición espacial planteada.

Fischer Lichte introduce la idea de bucle de retroalimentación entre artistas y público en el espacio performativo, afirmando que: "La condición medial de la realización escénica radica en la co-presencia física de los actuantes y observantes, congregados en un mismo lapso de tiempo, en un espacio concreto. Se origina en ese encuentro en interacción.

La tarea de la dirección consiste en desarrollar estrategias de escenificación con las que se pueda componer y producir una disposición experimental de los elementos. Para favorecer en este caso el bucle de retroalimentación entre artistas y espectadores, el diseño del espacio performativo es circular: Allí el público asistente se ubicó en semicírculo de frente a la instalación, completando la 'ronda" generada por la imagen proyectada que los recibía mostrando un movimiento giratorio.La instalación objetual como un círculo más pequeño, quedaba dentro de ese círculo mayor compuesto por el público y la proyección. Se propuso un cambio perceptivo en los distintos puntos de vista donde podía ubicarse cada espectador.

Bachelard hace hincapié en la geometría, afirmando que el espacio tiene propiedades métricas, proyectivas y topológicas. Señala que en la imagen poética se supera lo abstracto de la geometría para humanizarse.

Analizando cómo se traducen los signos de las imágenes poéticas de la canción en este espacio performativo, se observa el iglú esférico colocado en el centro del paisaje circular externo, sugiriendo una casa en medio de una intemperie, que según la fenomenología de Bachelard, transmite seguridad, protección e intimidad. Su posición central evoca un refugio desde su concepción. Y en un nivel más abstracto, remite a una cosmicidadantropo-cósmica: Todo un mundo, el espacio que habitamos para comenzar a formar lo que somos, nuestro mundo interior. De modo que la mirada del espectador se incluye como apelación, desde la dirección y puesta en escena de esta performance, que inspirada en "Cielo de Ti" tradujo ese título también como una invitación del 
compositor Spinetta, a despertar en cada uno el propio cielo, su propia poética, como metáfora de la imaginación creadora que todos podemos desarrollar, y que yo misma busqué plasmar en esta obra.

El cuerpo humano, con sus gestos, movimientos y voz, irrumpe en ese universo en miniatura que evoca una intemperie, ante la cual también la mirada singular del espectador, afectado sensorialmente, conformará con su lectura su propio refugio. $\mathrm{O}$ sea, su modo de ver y pensar la obra, lo posicionan en un lugar, habitando el iglú-casa de su propia conciencia.

La relación producida por la diferencia de tamaños entre el cuerpo performático y el cuerpo objetual, propone un movimiento de acercamiento desde arriba, cual ser superior, poseedor de ese micro universe que contempla en su totalidaddesde la lejanía, hasta acercarse y agacharse, para poder ver adentro. Bachelard vincula ese movimiento lúdico, que provoca la miniatura, a la Mirada fresca de un niño, curiosa y asombrada ante algo nuevo que descubre por primera vez, señalando que "la miniature es uno de los albergues de la grandeza" debido a que esa forma de vision resulta amplificadora y expansiva.

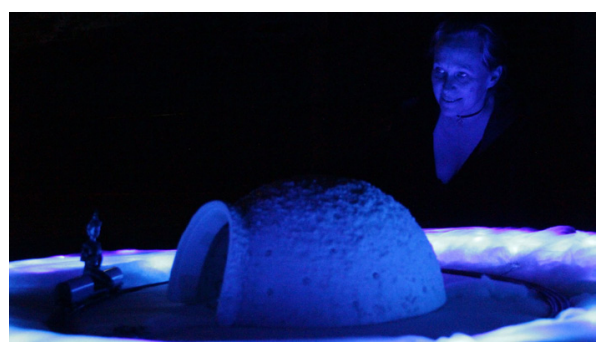

Fig 5 y 6 . Cielo Expandido:

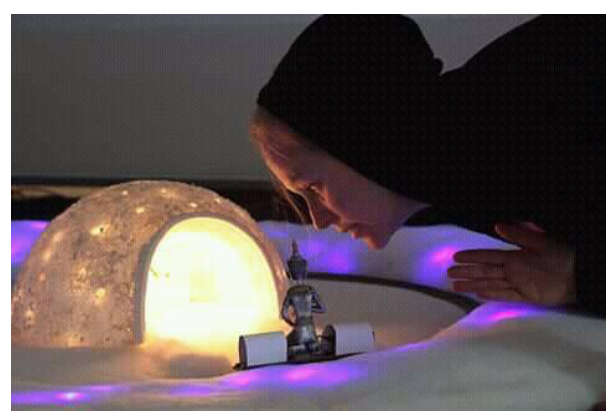

Miniatura y Refugio inspirada en la Poética del espacio de Bachelard.

Ph. A. Dagostino

\subsection{Corporalidad}

"No obstantecualquiera sea la escala del evento, el performance siempre está mediatizado: Los cuerpos de los artistas y de los espectadores participantes re-activan un repertorio de gestos y significados" Diana Taylor. Estudios avanzados de performance

Esta obra expande la corporalidad en varios niveles: El cuerpo orgánico de la performer es el cuerpo grande y real que acciona con sus movimientos y voz, una irrupción en el tiempo mecánico y cíclico de la miniatura objetual. El cuerpo performático se completa con el de los otros dos performers músico y videasta que desde su lugar de operación participan con su presencia física en tiempo real. El cuerpo digital interactúa con el orgánico mediante imágenes y sonidos procesados. Por último el cuerpo del espectador que observa y completa la 
composición integral de la performance.

El cuerpo humano en el arte escénico, sigue siendo un límite irreductible para la digitalización, y es ahí donde reside el interés de esta investigación y lo que la diferencia de otras formas de arte tecnológico.

Fischer Lichte señala que a partir del giro performativo se trabajan técnicas y prácticas para generar presencia a través del cuerpo energético de los performers. El cuerpo fenoménico se presenta como cuerpo energético que incita al espectador a sentirse él mismo, como un cuerpo energético.

De ese modo en esta obra la performer despliega sus acciones de manera presentativa, o sea, sin representar un rol o personaje, sino poniendo en funcionamiento su sistema energético y un estado de alerta para componer con los otros dos artistas, según los estímulos dados y recibidos entre los tres; es así como la acción se hace gesto.
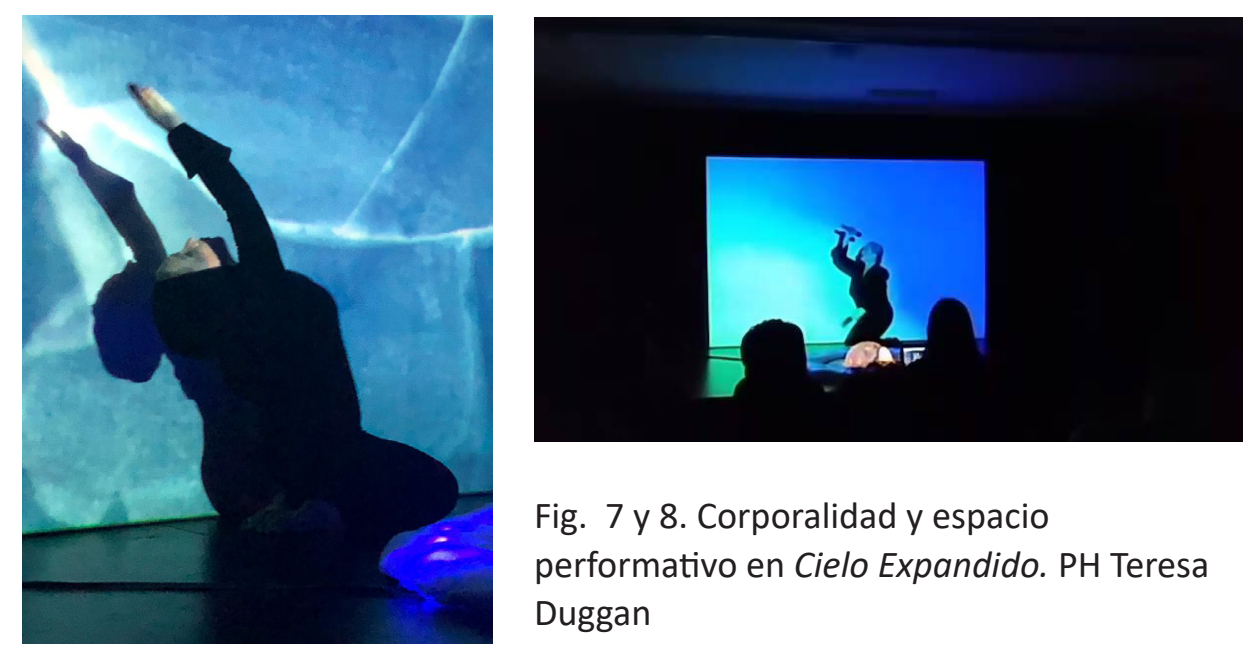

Fig. 7 y 8 . Corporalidad y espacio performativo en Cielo Expandido. PH Teresa Duggan

\subsection{Transposición: objetos, luces, sonidos, imágenes, movimientos.}

Al comienzo se observa en la pantalla una sombra proyectada similar a la forma del iglú, esa sombra se produce con la cabeza de la performer que recibe al público sentada delante del proyector. La luz que emite servirá de iluminación en la performance, así como las luces leds de la instalación objetual que evocan un suelo estrellado, que se prolonga en las imágenes cósmicas procesadas en base a una foto de la misma instalación, y se proyecta en la pantalla como una Iluvia galáctica.

El buda, cuerpo objetual, se encuentra fuera del refugio. A modo de posibilidad o pregunta, se enciende la luz interna del iglú, cuando pasa por la puerta, en un ritmo cíclico. La performer interviene, acercando su cabeza a la entrada del iglú, estableciendo una metáfora de la capacidad humana 
de "'iluminarse" llevando el foco hacia el interior. En la pantalla de fondo se proyecta un iglú real y se aquieta la imagen. En medio del paisaje frío y nocturno la performer también se aquieta para entonar la canción de Spinetta que termina con la frase "sin saber cómo entrar o salir?" mientras el buda sigue girando, encendiendo y apagando a su paso la luz interna del Iglú.

Esa intermitencia traduce dicho interrogante, mediante el procedimiento de trasposición en la puesta en escena de materialidades, objetos, y acciones.

\subsection{La Voz Polimorfa}

Se genera también, una relación entre corporalidad y sonoridad como acción: La voz de la performer se oye como palabra cantada o hablada, emitiendo sonidos, gritos, frases inventadas, es amplificada en directo o reproducida y afectada digitalmente. Esta "voz polimorfa" origina tres tipos de materialidad: corporalidad, espacialidad y sonoridad. Fischer Lichte afirma que el emisor conmueve con su voz a quien la oye.

El espacio sonoro que genera, se experimenta como liminar, espacio de continuas transiciones, mudanzas y transformaciones y esa dilución de los bordes, es lo que quisimos investigar en esta performance, donde la voz se fragmenta, se deforma y se expande, reproducida por el espacio sin llegar a desmaterializarse a pesar de ser atravesada por los medios digitales.
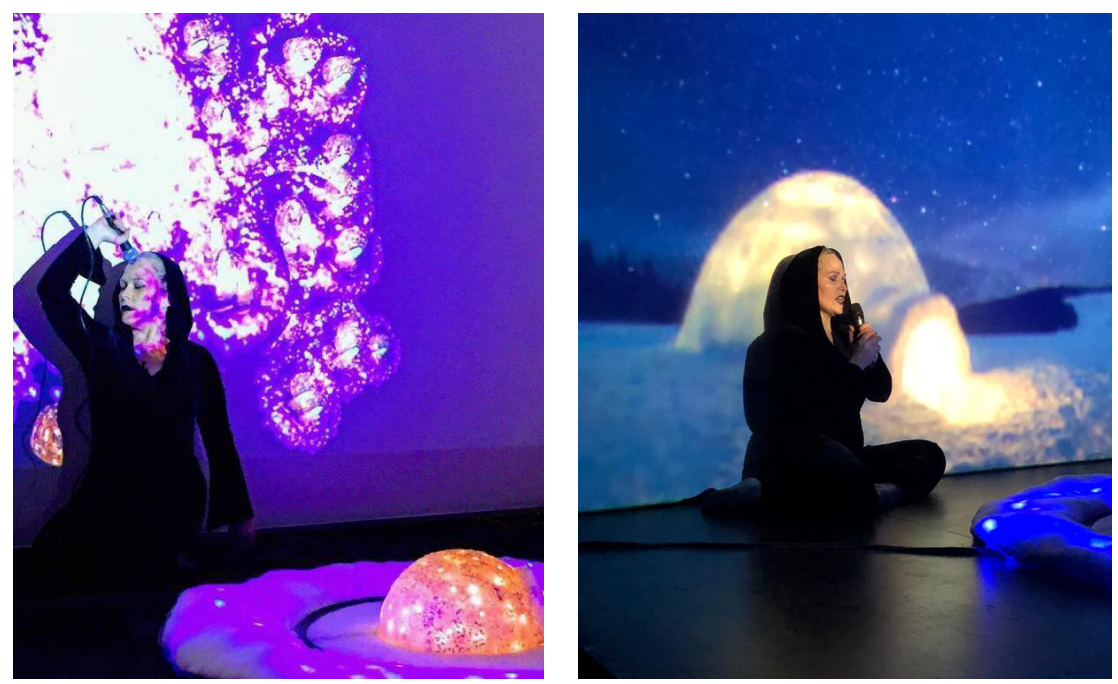

Fig. 9 y 10. En Cielo Expandido el micrófono y los movimientos de la performer son las interfaces para la producción digital de sonidos y visuales interactiva. PH Teresa Duggan. 


\section{Transposición de signos para crear un infinito particular.}

Cielo Expandido vuelve fluidos los límites de cada lenguaje artístico integrado. A la manera de un semionauta o navegante de los signos, descripto por Bourriaud esta performance plantea poner las formas en movimiento, inventar a través de ellas y con ellas signos poéticos que abran espacios de sentido en quien las comparta con su presencia.

Es una performance abierta al estado de flujo y a la negociación entre los artistas participantes, una realización donde la intersubjetividad se revela como mecanismo de creación, su naturaleza procesal hace de la obra un acontecimiento, un opus.

Se conjugaron movimientos, sonidos, imágenes, objetos, luces, cuerpos físicos y digitales creando una performance que incluyó puntos de conexión y enlace entre diversas prácticas específicas, de tal manera que como resultado de ese cruce se produce un modo de hacer intermedia, de carácter efímero y abierto, con la proximidad del público que conformó en forma semicircular la construcción de este universo curvo expandido.

Al crear esta performance me propuse abordar un nuevo territorio con la temática planteada en las etapas anteriores. Gracias al desarrollo tecnológico aplicado a las Artes Escénicas, pude recuperar la emoción que produce el cuerpo orgánico en escena con la vibración sonora y la gestualidad en acción y en presencia real, vinculándolo a las posibilidades creativas del universo digital y objetual.

Contemplando que el artista contemporáneo reconoce una pertenencia a su condición de errante y se mueve en una multiplicidad de arraigos simultáneos o sucesivos, dominando lo que Bourriaud denomina forma trayecto, utilicé procedimientos que consistieron en intercambiar, traducir, y tras codificar las imágenes, trasplantar los signos poéticos, de un terreno a otro para poner en escena mi propio universo poético.

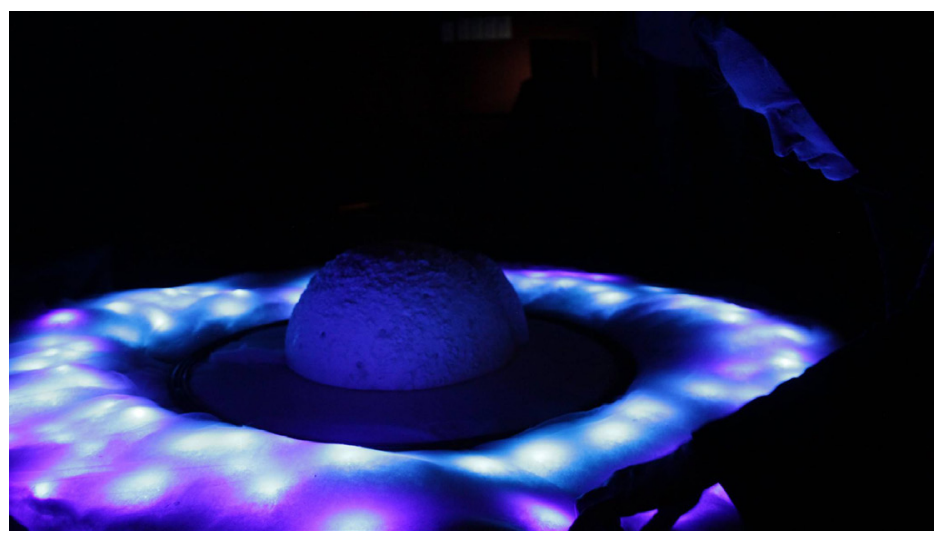

Fig.11.

Transposición de signos en Cielo Expandido de la canción de Spinetta a objetos, luces, acciones, imágenes. PH. A. Dagostino 


\section{Bibliografía}

ABUIN GONZALEZ Anxo. 2006. Escenarios del caos Entre la hipertextualidad y la performance en la era electrónica. Valencia: Tirant lo Blanch.

BACHELARD, Gastón. 1975. La poética del espacio, México: Fondo de Cultura Económica.

BOURRIAUD, Nicolás. 2009. Radicante.Buenos Aires: AH Adriana Hidalgo. 2009. Postproducción.Buenos Aires: AH Adriana Hidalgo.

CABALLERO, Alberto El cuerpo y el espacio como productos de la acción http://www.geifco.org/actionart/actionart01/secciones/01-cuerpo/articulos/ caballero/a-caballeroFotoPerf.htm

FERRANDO BARTOLOMÉ, La performance. Su creación. Elementos.

http://performancelogia.blogspot.com.ar/2007/01/la-performance-su-creacinelementos.html . Consultado entre diciembre 2018 y agosto 2019.

FISCHER, Lichte, Erika. 2011. Estética de lo performativo. Madrid: Abada Editores.

KOZAC, Claudia. 2012. Tecno poéticas Argentinas. Claudia Kozak (ed.) Buenos Aires

LARRAÑAGA, Josu. 2001. Instalaciones, Colección "Arte Hoy" Editorial Nerea SA, Guipúzcoa, España.

SAGASETA, Julia Elena. 2012. El teatro performático. Buenos Aires: Editorial Nueva Generación/Departamento de Artes Dramáticas (IUNA).

TAYLOR, Diana, 2012. Performance. Buenos Aires:; Asunto Impreso

Links (consultados entre noviembre 2018 y agosto 2019)

Cielo Expandido https://www.youtube.com/ watch?v=vPCIzCYGjN8\&feature=youtu.be

\section{Obras de Daniela Lieban}

https://www.facebook.com/Daniela-Lieban-Obras-1087312627952533/

Muestra en el CCMattahttps://www.youtube.com/watch?v=RYxgeg8G15w 
Cielo de Ti Instalación muestra Plus+ Arte

https://www.youtube.com/watch?v=-L3jLuCYZL8

Cielo de Ti Instalación muestra UNA https://www.youtube.com/ watch?v=OrU5ZL6yqIU\&t=8s 


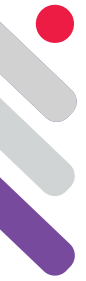

\section{Trasunto \#1: poesía en tránsito}

DOI: 10.24308/IASS-2019-4-022

\author{
Valentina Paillaleve \\ Pontificia Universidad Católica de Chile \\ Universidad de Chile \\ valentina.paillaleve@gmail.com
}

\section{Introducción}

Comúnmente en la danza se presenta el problema de la puesta en escena de textos literarios que terminan por operar como un elemento secundario frente a la corporalidad de los intérpretes, más que como un ensamble de lenguajes complementarios, ya sea por una cuestión de investigación escénica, por un enfoque disciplinar o por las limitaciones en la atención de los espectadores frente a las obras como situaciones altamente estimulantes. Así también ocurre con la difusión de la poesía, proceso en el que se suele desplazar el rol del cuerpo, ya sea en la lectura individual o en formatos masivos como las lecturas de poesía. Ante esta problemática es interesante estudiar el caso de Trasunto \#1, obra dirigida por la chilena María Siebald.

Dicha obra consiste en la interpretación corporal de siete textos de poetas contemporáneos mediante composiciones coreográficas basadas en el lenguaje de señas. Esta compleja operación semiótica resuelve el problema de la puesta en escena de la poesía mediante el cuerpo como soporte de discursividades y lenguajes múltiples. Por lo tanto, esta experimentación constituye un antecedente importante para las artes escénicas en Chile.

La propuesta del presente artículo desemboca en dos grandes aspectos en torno a la pregunta por la interpretación, por lo trasunto: por una parte, la renuncia a la búsqueda de equivalencias exactas al original en la relación de la lengua verbal con la lengua de señas y, por otra, la apertura a nuevas posibilidades de significación a través de la danza/performance, los audios de los poetas, la proyección de sus textos, la construcción de la escenografía y la sonorización en la obra. Por lo tanto, el presente texto se propone abordar ambos aspectos a partir de las posibilidades que despliega la semiótica en torno a la poesía, el cuerpo, la representación, la performance y la lengua de señas. 
En suma, es preciso señalar que la revisión y el análisis de estos elementos conduce a la valoración del potencial interpretativo de los lenguajes en su amplitud más bien como herramientas y procesos, por ende, como trayectorias posibles en la promoción de sensibilidades y en la construcción de sentido a partir de la mixtura de lenguajes artísticos.

\subsection{Caracterización de la obra desde mi propio cuerpo}

Pese a que no conozco de los lenguajes de señas más que una aproximación teórica reciente, he tenido la oportunidad de explorar las temáticas que presento en este texto con mi propio cuerpo, particularmente desde la práctica escritural de poesía y desde investigaciones en torno a la danza y la performance en distintas instancias, experiencias que me han conducido por años a preguntarme cómo lograr una participación orgánica de los lenguajes que las posibilitan. Dentro de dicha búsqueda me encontré con Trasunto \#1, dirigida por la artista escénica chilena María Siebald - quien investiga con lengua de señas desde el 2009 -, propuesta escénica que considero un antecedente crucial para todos aquellos que transiten por preguntas similares

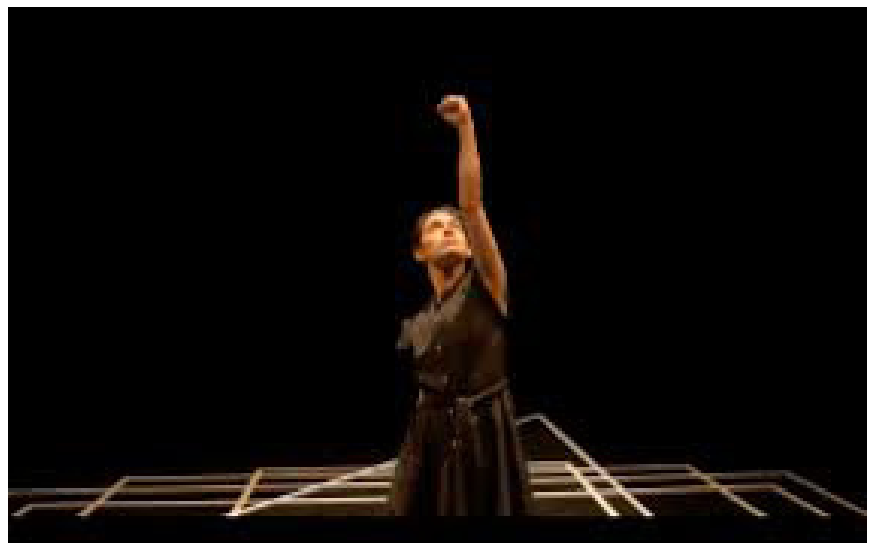

(Imagen 1: María

Siebald en Trasunto $\# 1)$.

Creo en la importancia de esta exploración en un mundo altamente visual, en el que muchas veces las lenguas y sus análisis discursivos parecen desplazar la importancia del cuerpo, en el que aún queda mucho por explorar en las artes más allá de las barreras disciplinares. En este marco, el año pasado tuve la oportunidad de asistir a esta obra en el marco del Festival Internacional de Danza Contemporánea EscenaUno DanzaSur. Se trata de un proyecto que lleva años formulándose gracias al apoyo de becas y residencias en el país.

Este festival cuenta con la participación de diversos artistas, dada la fusión disciplinar que propone. En primera instancia, se invitó a siete poetas contemporáneos - Catalina Gré, Daniela Catrileo, María José Garcés, Juan Santander, Ignacio Mardones, Catherina Campillay Rodrigo Olavarría, bajo la curatoría de este último - a crear poemas en función de este mismo proyecto, 
que luego fueron grabados por Paulo Gallo, "considerando que serán adaptados a una coreografía corporal y sintaxis propia de la lengua de señas" (NAVE, web), la que posteriormente fue interpretada por bailarines/performers - Luisa Peña, Isabel Torres, María Siebald, Lucas Balmaceda, Simón Pascal y José Luis Vidal - , asesorados en la práctica de la lengua de señas por Juan Pablo Ibarra, en el diseño sonoro por Fran Straube y en la iluminación por Johnatan Insotroza. Esta obra contó con un registro audiovisual, a cargo de Paula Esp, disponible en YouTube casi completa, además de ser presentada en vivo en instancias como el festival mencionado. A través de esta obra se vislumbran contrastes no solo en el espacio/tiempo discursivo, sino también en el potencial interpretativo de los hablantes en dos sentidos: en el ejercicio de transliteración y en el ejercicio interpretativo de la danza y la poesía.

Respecto al primer sentido, la obra presenta claramente el problema de la representación que supone la traducción entre lenguas desde su título hasta la estructura en que es presentada. Para abordar este aspecto posteriormente es preciso repasar los elementos escénicos que la componen, que describiré a continuación. Trasunto \#1 se compone de seis momentos en un escenario casi completamente negro, a excepción de una serie de polígonos superpuestos, dibujados en blanco, dentro de los que los performers desplegarán la interpretación de los textos poéticos acompañada de una sonorización. Los primeros cinco son interpretados por un performer a la vez con relación a un poema y el último es ejecutado por todos ellos a la vez. No obstante, antes de empezar cada momento, el poema correspondiente es proyectado al fondo del escenario y leído por la voz de sus autores

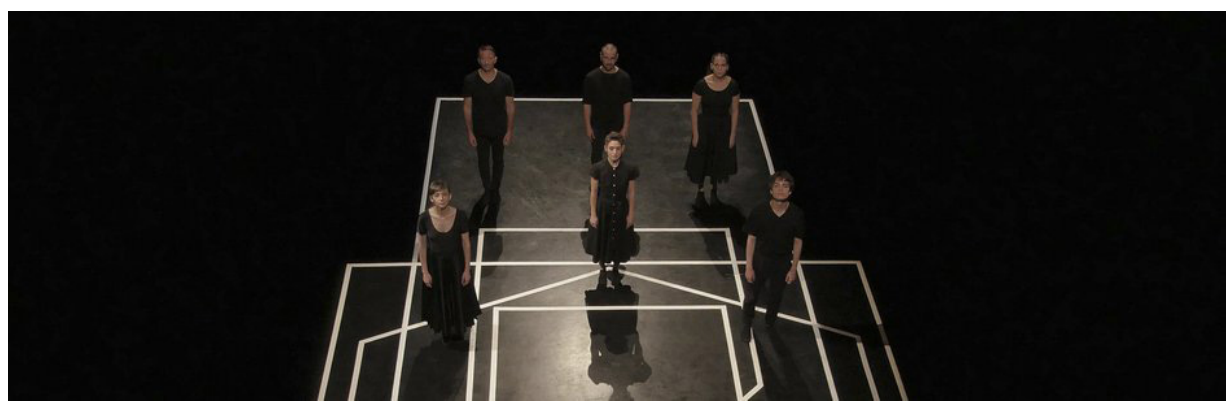

(Imagen 2: visión aérea del escenario).

Los cuerpos de los performers visten ropas negras e interpretan los textos, creados originalmente en español, en lengua de señas que, dada su neta riqueza corporal en el espacio, es conducida a un siguiente nivel mediante los desplazamientos por el plano en sus cuatro dimensiones. 


\subsection{El lugar de la poesía, el gesto en acción}

Barthes señala en la Lección inaugural a la cátedra de Semiología Literaria del College de France (2014) que la literatura correspondería a aquel espacio en el lenguaje en que es posible subvertir los signos, jugar con ellos para torcer las formas de poder que rigen las sociedades. En este sentido, afirma, además, que la poesía constituye la forma más libre dentro de este espacio (p.97). En este sentido, ¿qué ocurre con la escritura poética a través de un cuerpo en escena, cuerpo que interpreta el juego del lenguaje más allá de sus formas convencionales?, ¿qué ocurre con la poesía en acción a través de signos no lingüísticos?

Así no hay que sorprenderse si, en el horizonte imposible de la anarquía del lenguaje -allí donde la lengua intenta escapar de su propio poder, a su propio servilismo-, se encuentra algo que guarda relación con el teatro (...). Puede decirse que la tercera fuerza de la literatura, su fuerza propiamente semiótica, reside en actuar los signos en vez de destruirlos, en meterlos en una maquinaria de lenguaje cuyos muelles y seguros han saltado; en resumen, en instituir, en el seno mismo de la lengua servil, una verdadera heteronimia de las cosas (p.104)

En dicha caracterización de la semiótica, hacia el final, aparece una pista de lo que podría significar un abandono, o bien, un quiebre de la idea de representación. Al mismo tiempo, la semiótica operaría como una propuesta urgente y consistente para abordar aquellas cuestiones que la lingüística decidió abandonar. Si bien esta puede parecer una discusión más o menos zanjada, para efectos de este análisis es importante comprender el salto teórico que propuso Barthes y sus acertadas observaciones acerca de la poesía.

Para Barthes aquel tercer elemento que llamaría semiología “(...) sería desde entonces ese trabajo que recogería la impureza de la lengua (...): nada menos que los deseos, los temores, las muecas, las intimidaciones, los adelantos, las ternuras, las protestas, las agresiones, las músicas de las que está hecha la lengua activa" (p.107). Todas estas constituyen marcas evidentes mediante el cuerpo en situación. Por lo tanto, la semiótica sería un sistema capaz de recoger la importancia de la corporalidad como vector discursivo.

Por su parte, y con la amplitud de perspectivas que otorga el tiempo, Paolo Fabbri en El giro semiótico (2000) efectúa una recapitulación de las principales corrientes de análisis semiótico, que posibilita una crítica, bajo su perspectiva, hacia la falta de rigurosidad en los análisis de Barthes para aterrizar el estudio, pese a la importancia de haberlo esbozado, de todas aquellas impurezas de la lengua, como los gestos y las emociones. Este identifica que

(...) existe una organización de los contenidos lingüísticos, si se quiere de los conceptos, al margen del hecho de que se interprete a través de una sustancia de la expresión. Lo cual significa que es posible que unas formas de signos distintas del lenguaje verbal sean 
capaces de organizar formas de contenido, o significantes, que el lenguaje verbal no es necesariamente capaz de transmitir. Algo que por otro lado no es tan nuevo, sólo que no estaba contemplado en la organización teórica de la primera semiología, la cual, por definición, suponía que sólo lo que es decible es de alguna manera pensable (p.44)

Fabbri afirma que es preciso establecer una distinción entre signo y representación mediante la noción de narratividad y la de pasiones, que convierten a la semiótica en una teoría de la acción nutrida de afectividades de cuerpos, hasta ahora, desplazados del análisis. Dicho cambio paradigmático permite, al fin, abordar los signos no lingüísticos como el gesto (p.49), para lo que propone como ejemplo la lengua de señas, como señala el siguiente fragmento:

No sólo no existe una lengua universal de los que hablan "(por señas», con gestos, no sólo no hay una lengua universal de los sordomudos, sino que hay hasta dialectos, idiomas locales que no se entienden muy bien entre sí. Por su puesto, siempre es posible la traducción. Precisamente por eso el lenguaje de los sordomudos plantea cuestiones de gran interés. Ante todo porque es un lenguaje visual (...). Es una forma expresiva completamente paralela al lenguaje, y capaz de expresar toda la sintaxis con sus configuraciones.

Para nosotros es una cuestión fundamental, porque se trata de afirmar que el gesto, y por consiguiente la imagen, ha podido especializar una parte de sí mismo en la gramaticalidad (pp.74-76)

A través de la incorporación del análisis del lenguaje de los sordomudos vinculado al origen del lenguaje es que Fabbri vislumbra una reconciliación de la verbalidad con el gesto, con lo que sitúa su mayor interés tanto en el carácter performativo del lenguaje como en las pasiones vinculadas en él (p.62). Con ello resalta, entonces, la importancia de la visualidad en los análisis de los signos en acción.

Respecto a la posibilidad de ser traducido, como apunta Sacks, un lenguaje caracterizado por la riqueza de su gramaticalización del espacio dado que emplea las tres dimensiones del movimiento combinados con el uso del tiempo en dicho entorno - , puede presentar facultades infinitas en las artes del movimiento, más que en transliteraciones escritas, así como indica Oliver Sacks en Veo una voz. Viaje al mundo de los sordos (2003):

Veamos, pues, que en el lenguaje de señas, en todos los niveles (léxico, gramatical, sintáctico), se hace un uso lingüístico del espacio: un uso asombrosamente complejo, ya que mucho de lo que en el habla es lineal, secuencial y temporal, es simultáneo, coincidente e incluye muchos niveles en la seña. La «ssuperficie» de la seña puede parecer simple, como la del gesto o de la mímica, pero pronto se descubre que es una ilusión, y lo que parece tan simple es sumamente complejo y consiste en innumerables pautas espaciales unas en otras tridimensionalmente (p.139) 
Por lo mismo es que este sea tan difícilmente traducible al lenguaje escrito y, en combinación con un ejercicio poético - cabe recordar, el lugar más parecido al lugar fuera del lenguaje - además de potenciar sus cualidades cuatridimensionales, es que aparecen posibilidades escénicas tan interesantes como se aprecian en Trasunto \#1. Incluso, autores como Strokoe (como se citó en Sacks, 2003) caracterizan este lenguaje como inherentemente escénico, en cuanto se enuncia observando y considerando el modo en que los otros participantes observan la realidad para poder describirla, por ejemplo, mediante una exhaustiva descripción visual de aquello a lo que es referido.

\subsection{Poesía en cuatro dimensiones}

Si bien las lenguas verbales convencionales establecen relaciones en sus distintos niveles de análisis, puede existir aún en ellas restricciones lineales, secuenciales y temporales, como indica Sacks, cuestión que, como se explica en la web de Trasunto \#1, es conducida a un siguiente nivel en el caso de la lengua de señas, que "es un lenguaje abstracto basado en movimiento, expresión corporal, expresión facial y un alto grado de compromiso emotivo en cada una de las señas, pero a la vez es un lenguaje concreto situado en el espacio que explota sus posibilidades sintácticas a través de su medio de expresión cuatridimensional (n.p).

De esta descripción destaca la idea de la gran carga emotiva de esta lengua, que permitiría, entonces, aterrizar aquello a lo que Barthes se aproximaba a nivel de lenguaje/poesía y lingüística/cuerpo, que finalmente comparten el factor de las formas de representación resolviéndose en la semiótica y posiblemente en la performance. Este último aspecto será revisado más adelante, pero antes cabe vincular y matizar esta línea argumental con la manera en que Artaud concibe la poesía.

Estos poemas gestovisoespaciales, como son adjetivados en la web del festival en que se enmarcaba la obra, recuerdan lo que este autor señala en el emblemático texto El teatro y su doble acerca de trasladar la poesía del lenguaje a la poesía en el espacio:

la sustitución de la poesía del lenguaje por una poesía en el espacio que habrá de resolverse justamente en un dominio que no pertenece estrictamente a las palabras (...). Esa poesía, muy difícil y compleja, asume múltiples aspectos, especialmente aquellos que corresponden a los medios de expresión utilizables en escena, como música, danza, plástica, pantomima, mímica, gesticulación, entonación, arquitectura, iluminación y decorado.

Cada uno de estos medios tiene su poesía propia, intrínseca, y además una suerte de poesía irónica, que nace de sus posibles combinaciones con los otros medios de expresión; y es fácil advertir las 
consecuencias de esas combinaciones, con sus reacciones y destrucciones mutuas (p.43)

Para recapitular, se destaca de todo lo anterior la importancia de la semiótica por las herramientas que ofrece para comprender el valor de la lengua de señas, así también de los cruces disciplinares que se establecen en esta obra en particular. En particular, a través de las concepciones de representación que ensaya, por ejemplo, en el rastreo que Héctor Ponce de la Fuente, semiótico y académico de la Universidad de Chile, establece en su texto Aproximaciones a una teoría de la representación II sobre esta:

En la perspectiva de Greimas \& Courtés (1982), la representación es un concepto de la filosofía clásica que en términos semióticos señala la función referencial del lenguaje: "insinúa -de manera más o menos explícita- que el lenguaje tendría como función estar en lugar de otra cosa, representar otra "realidad" (...) Las palabras no serían sino signos, representaciones de las cosas del mundo". (1982, p.340). Pero también representación es entendida en términos de la referencia que, en un sentido general, "designa la relación orientada -la mayoría de las veces no determinada- que se establece (o se reconoce), entre dos magnitudes cualesquiera". (Ibid., p.335) De tal modo que la referencia se constituye en una palabra bisagra, una especie de continuo a la idea de representación (p.75)

Una vez comprendida la representación a nivel lingüístico, queda preguntarse qué ocurre en la dimensión artística de la obra, qué ocurre con las formas disciplinares de representación

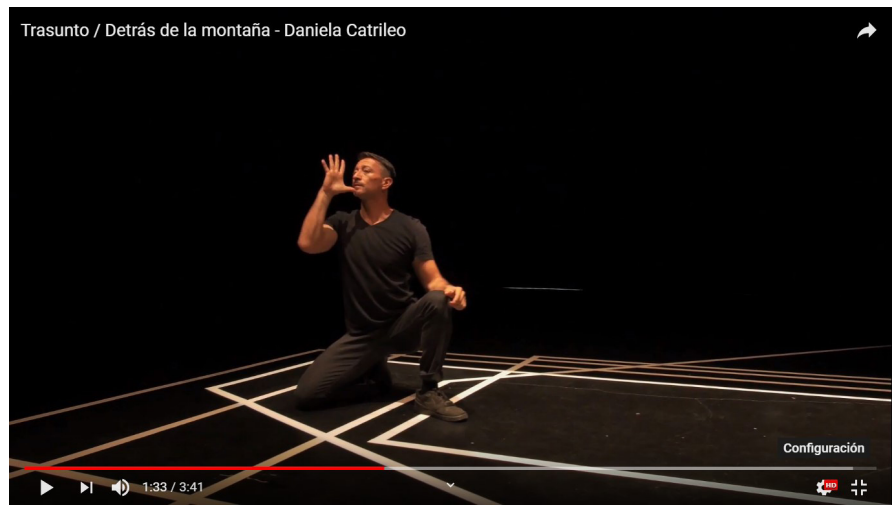

(Imagen 3:

fotograma de la interpretación del poema Detrás de la montaña).

\subsection{Más allá de la danza}

Mauricio Barría, dramaturgo y Doctor en Filosofía, declara en Performance y políticas del acontecimiento. Una crítica a la noción de espectacularidad (2011) que: "la performance, en tanto práctica de alteración de la representación y en cuanto tal, [es] una forma de reflexión práctica sobre el acontecimiento 
[que] devela y cuestiona las políticas de la visualidad que configuran nuestra cultura" (p.116). Si bien él identifica principalmente el carácter hegemónico de ciertas formas de visualidad, espectacularidad y ficción, para efectos de la obra de Siebald es importante resaltar el nuevo sentido que adquiere la visualidad desde la gramaticalización poética del espacio, con lo que se establece el salto disciplinar necesario para superar las barreras que identifiqué en un principio en torno a la corporalidad de la poesía y a la textualidad de la danza en este caso.

En este mismo artículo Barría concluye que

Bajo estas premisas es que cabría preguntarse cómo el cuerpo es él mismo un relato. Cómo le viene eso a la literatura y hasta donde es posible concebir una relación entre literatura y performance. Tal vez una posible solución, provenga de la lectura que hace Derrida del Teatro de la Crueldad de Artaud, en la que entiende el cuerpo como estigma, escritura, pero también soplo: materialidad sonora (pp.117-118)

Frente a esto, Trasunto \#1 podría funcionar como aquella posible solución a dicho cuestionamiento. Aquella cuatridimensionalidad que caracteriza a la lengua de señas se torna danza mediante los desplazamientos en el espacio es decir, al emplear recursos como giros, suelo, amplitud de los movimientos y otros - en un registro propio de las danzas contemporáneas, concepto, por lo demás, bastante amplio.

A esto se le suman una serie de matices en la poetización de la lengua de señas que para un espectador no hablante pasan desapercibidas más allá de la belleza que se pueda percibir y que autores como Klima y Bellugi, destacados investigadores de lengua de señas, ya han estudiado (1976), aunque de manera detallada, solo en función del American Sign Language (ASL). En dicho estudio profundizaron en el análisis lingüístico y visual de la representación de ciertos poemas de E.E. Cummings, como se evidencia a continuación: "if one looks at the flow charts (Figure 7) of the movement of the hands in the non- poetic and poetic renderings of that one line, it becomes clear that in the poetic rendering there has been a further distortion of the signs which creates an enlarged pattern of movement" (p.66). 
Figure 7. FLOW CHARTS OF MOVEMENT: unlabelled sections of the arrows in the straight ASL version represent transitions.

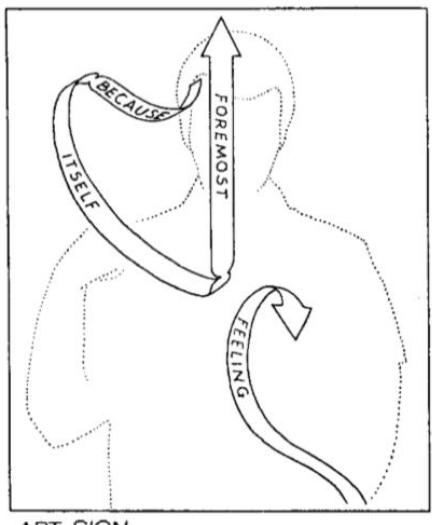

$\underline{A R T-S I G N}$

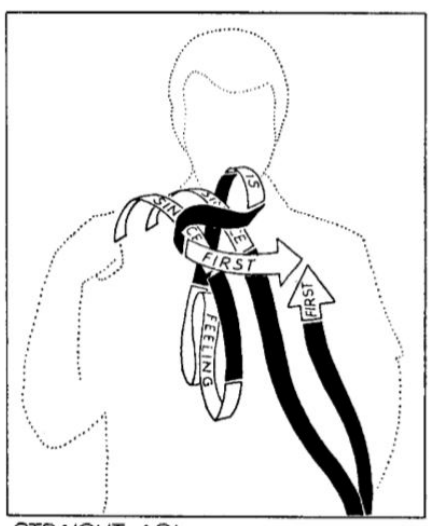

STRAIGHT ASL
(Imagen 4:

comparación de diagramas de flujo).

En dicho estudio se

propone examinar la función poética en el ASL - que de por sí asume otras posibilidades de organización que las lenguas verbales - mediante lo que llaman art-sign, que es estudiado en distintos niveles de estructura, como la estructura poética interna, a partir de cuatro parámetros de constitución de los signos: configuración de la mano, lugar de articulación, movimiento y orientación (p.94).

Table 1.

Comparison of art-sign and straight ASL by Bragg
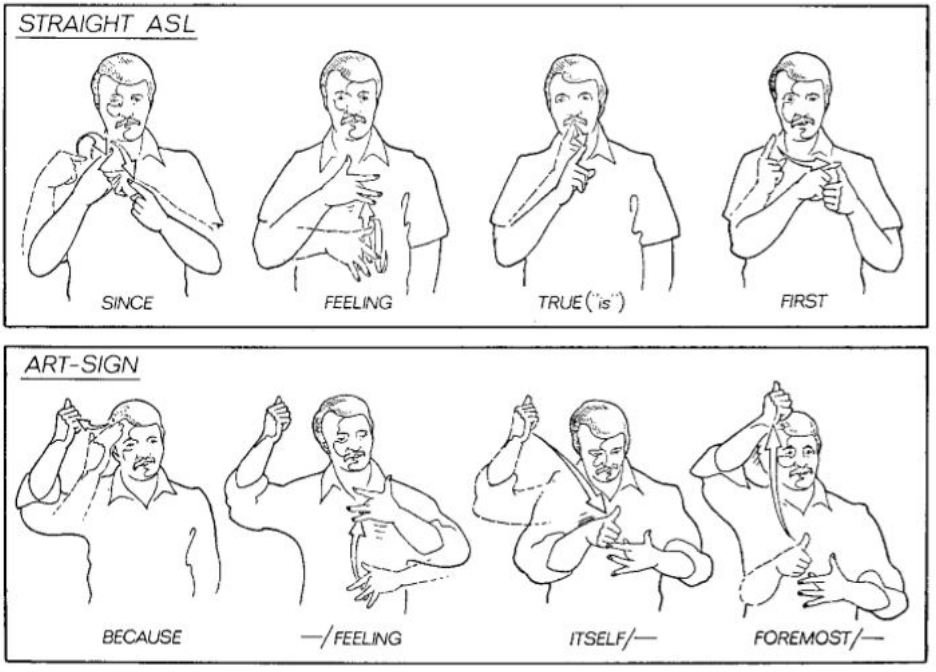

(Imagen 5:

comparación

literal y poética del poema Since feeling is first según Bernard Bragg).

De todas formas, esta propuesta no necesariamente podría ser aplicable al dialecto de la obra y esta no necesariamente calificaría por completo dentro de la categoría de performance según las premisas que Barría señala, tampoco dentro de la danza, pero es esta misma ambigüedad categórica la que permite 
que transite entre disciplinas sin importar, al final, dónde situarla, sino más bien, qué instrumentos teóricos se deciden aplicar y por qué, en función de una crítica a la representación, como aplica el crítico y curador de estudios de la performance, danza y teatro André Lepecki en Agotar la danza. Performance y política del movimiento (2008).

\section{Conclusiones}

De esta manera, la investigación de María Siebald constituye un doble ejercicio de representación, de lo trasunto: primero, en tanto traducción de la poesía desde el nicho verbal a las posibilidades gestovisioespaciales que ofrece la lengua de señas y, segundo, desde esta hacia un registro artístico. En este sentido, es posible proyectar el análisis de la relación poesía/cuerpo mediante la lengua de señas en conjunto con la revisión teórica de Greimas en torno a sus concepciones acerca de la metáfora o de Peirce respecto a la noción de inferencia.

Personalmente, creo que un aspecto importante que la experiencia de la obra produjo en mi fue el de que uno, como no hablante de lengua de señas, accede al texto escrito y al audio, pero se pierde o se imagina la reinterpretación que implica la puesta en escena, lo que termina por estimular el interés por la aproximación a esta lengua, además de gatillar un ejercicio de empatía opuesto: es uno, aunque mayoría lingüística, quien tiene que adaptarse a la minoría lingüística. Ahora es el arte el lenguaje que permite permear las brechas lingüísticas. En esta línea, sin duda Trasunto \#1 constituye un completo sistema de cuestionamiento respecto a la representación en distintos niveles que permite movilizar un gran aparato teórico y sensible necesario de explorar en profundidad.

A propósito de esto, podría ser interesante observar qué ocurre en términos de transliteración - ya no desde la representación artística, sino desde la traducción como área de la lingüística - con uno de los poemas en específico vinculado al ejercicio corporal que propone la obra, similar al ejercicio propuesto por Klima y Bellugi (1976), cuestión que no pude abordar dado mi desconocimiento de esta lengua.

Por último, concluyo que tal vez las respuestas en las disyuntivas artísticas de la poesía como forma de arte aun poco corporal podrían encontrarse, entonces, fuera de su lengua de origen: en la traducción e interpretación a otra lengua más corporal y más visual, como es la lengua de señas. Frente a la pregunta de qué otras alternativas podrían existir para este problema del cuerpo en la literatura en relación a las artes escénicas/performativas espero indagar a futuro desde mi propio ejercicio escritural y corporal. 


\section{Referencias}

ARTAUD, A. (2001). El teatro y su doble. Barcelona, España: Edhasa.

BARRÍA, M. (2011). Performance y políticas del acontecimiento. Una crítica a la noción de espectacularidad. Aletria: Revista de Estudos de Literatura, 21(1), 111-119.

BARTHES, R. (2014). El placer del texto y Lección inaugural: De la cátedra de Semiología Literaria del Collège de France. Buenos Aires, Argentina: Siglo Veintiuno Editores.

FABBRI. P. (2000). El giro semiótico. Barcelona, España: Gedisa.

GREIMAS A. J \& COURTÉS J. (1982) Semiótica. Diccionario razonado de la teoría del lenguaje. Madrid, España: Gredos.

KLIMA, E. \& BELLUGI, U. (1976). Poetry and song in a language without sound. Cognition, 4(1), 45-97.

LEPECKI, A. (2008). Agotar la danza. Performance y política del movimiento. España: Universidad de Alcalá de Henares.

PONCE DE LA FUENTE, H. (2019) Aproximaciones a una teoría de la representación II. De la materialidad y la producción de sentido. Revista Chilena de Semiótica, 10(1), 74-88.

NAVE, (s.f). NAVE. Recuperado de http://nave.io/residencias/trasunto-1/

SACKS. O. (2003). Veo una voz. Viaje al mundo de los sordos. Barcelona, España: Anagrama.

SIEBALD, M. (2017). Trasunto \#1 poemas en lengua de señas. Recuperado de http://www.youtube.com/user/mariasiebald

-- (s.f). Trasunto. https://trasunto.cl/ 


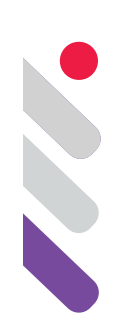

\title{
Lecturas del bioarte en clave semiótica: avances de investigación
}

DOI: 10.24308/IASS-2019-4-023

\author{
Dra. Lucía Stubrin \\ Universidad Nacional de Entre Ríos, Argentina \\ lucia.stubrin@uner.edu.ar
}

El presente trabajo deriva de un nobel proyecto de investigación denominado Biosemiótica, Arte y Técnica (radicado en la Facultad de Ciencias de la Educación de la Universidad Nacional de Entre Ríos). El mismo se propone reflexionar sobre la construcción del campo de la biosemiótica, como parte integrante de la gran disciplina propia de las ciencias de la comunicación, que es la semiótica. Recuperando los aportes de los principales referentes teóricos de la biosemiótica, se buscará reconstruir y aprehender el aparato conceptual que la sostiene. Desde esa mirada, entonces, se intentará realizar una lectura innovadora sobre las poéticas tecnológicas relacionadas con la manipulación de vida en el arte contemporáneo.

El denominado bioarte ha sido mayormente estudiado desde la estética y la filosofía de la técnica, como un caso de colaboración interdisciplinaria entre artistas y científicos. Las transformaciones que trajo su práctica pueden asociarse con tres líneas principales: replanteos epistemológicos sobre la producción de conocimiento; discusiones ontológicas sobre la distinción vivo/ no vivo (así como la creación de seres híbridos); y debates estéticos relacionados con la aparición de un nuevo formato de obra: la obra viva. En este sentido, la posibilidad de releer al bioarte en clave biosemiótica puede considerarse un aporte significativo dentro del campo de la comunicación y la cultura, en consonancia con el entramado científico-tecnológico que define la sensibilidad técnica de la contemporaneidad.

Se trata de un proyecto de carácter eminentemente reflexivo, no obstante lo cual supone una extensa revisión bibliográfica que permitirá situar el problema a la altura de algunas discusiones actuales, dado que, como es de suponer, la indagación en el corpus biosemiótico resulta una novedad en la tradición de investigación de la FCEdu-UNER, más aún, si se logra articular como 
marco teórico de expresiones artísticas asociadas a la práctica contemporánea del cruce arte-ciencia- tecnologías de lo viviente.

\section{Estado actual del conocimiento sobre el tema}

Cabe pensar la ontología del signo como punto de contacto con la idea de ser que hasta el descubrimiento de las técnicas de manipulación genética, se distinguía naturalmente del no-ser. Los cambios simbólicos que supone la crisis del pensamiento binario a partir de la igualación ontológica de todos los entes del planeta, tiene su origen en el descubrimiento de la molécula de ADN y su construcción discursiva en tanto 'receta de la vida'.

Pero la transferencia de información genética entre seres de distinta escala física así como la creación artificial de vida, no son los únicos focos tecnocientíficos que circulan entre la opinión pública. Existen otros procesos semióticos vinculados a áreas como la matemática, la física, la ingeniería nuclear, la informática, etc. que contribuyen a la naturalización de una determinada imagen de la ciencia, la técnica y la sociedad.

El tratamiento mediático de los nuevos descubrimientos que se van dando a conocer en materia de ciencia y tecnología no es inocente. La ideología de los medios masivos de comunicación sobre estas problemáticas carga muchas veces con imaginarios que buscan paralizar el accionar de quienes no poseen el conocimiento específico que suponen estas investigaciones. De esta manera, se instauran líneas imaginarias que separan esferas de conocimiento por fuera de lo que la epistemología y la metodología de la ciencia hace tiempo rechazan.

Por otra parte, no son sólo los medios masivos quienes contribuyen a la naturalización de sentidos que buscan configurar el rol que cada uno debe jugar en tanto especialista de una determinada área de estudio o ciudadano común. La conciencia del lugar que nos corresponde dentro de la sociedad también es una operación del lenguaje que encontramos presenta en la investigación científica de todo tipo. En este sentido es que puede resultar esclarecedor como ejercicio semiótico incorporar otras maneras de comunicación como las que genera el arte.

Las relaciones entre arte y ciencia siempre formaron parte de la cultura. El Renacimiento fue el momento más alto de fusión entre ambas esferas al punto en que no se concebía la distinción entre artista, artesano, arquitecto, médico, anatomista, inventor. La figura de Leonardo Da Vinci destaca en ese contexto como una referencia obligada de análisis.

Resumidamente, los siglos posteriores no tuvieron esa misma impronta de clasificación social y comenzaron a establecer separaciones virtuales de la mano de la especialización educativa. Entrando al Siglo XX, vemos cómo el impacto del movimiento impresionista (incorporación de teorías ópticas, ejercicio de la pintura fuera del estudio, temas cotidianos, entre otras cosas) repercute en las 
vanguardias europeas ocasionando la transformación de la idea de arte como objeto de contemplación retiniana pensado para su exposición en el museo. No sólo nuevas técnicas se incorporan sino también nuevas formas de pensar, de construir el mundo que buscan vincular el arte con la vida.

Después de la segunda guerra mundial estas transformaciones se hacen más radicales aún y ya se vuelve difícil asociar la práctica del arte a la pintura y a la escultura. Todo se vuelve más conceptual, se desborda el canon y se incorporan elementos extradisciplinares (es el momento de apogeo de los happenings y las instalaciones).

En Argentina podemos pensar en la producción del grupo CAYC (Centro de Arte y Comunicación) como pionero local en los cruces arte, ciencia, tecnología pero no es hasta finales de la década del noventa en que los artistas resignan la tematización de cuestiones vinculadas a la esfera de la ciencia en general, para volcarse a la experimentación con los mismos materiales que utilizan los científicos en sus mismos lugares de trabajo: el laboratorio.

Si pensamos en los cambios que produjo el descubrimiento del ADN en la ontología de la materia e incorporamos las prácticas de arte-ciencia como el bioarte -donde el artista y el científico trabajan en forma colaborativa más allá de poseer distintas trayectorias educativas-, nos preguntamos cómo desde la semiótica podemos identificar estos deslizamientos que trastocan operaciones de sentido naturalizadas tanto en arte como en ciencia.

La semióloga Silvia Barei sostiene que:

Articular Semiótica de la Cultura y Biosemiótica a partir de la categoría teórica de modelización, permite analizar el modo en que el ser humano se vincula con el mundo natural y fundamentalmente, de qué manera una competencia distintiva de la especie como lo es el lenguaje, le ha permitido un tipo de desarrollo cognitivo cuya capacidad para la referencia simbólica es la definitiva marca de separación con el resto de los seres vivos del planeta. (Barei, 2016: s/p)

Esta relocalización de lo humano en el mundo de la vida va en línea con la igualdad óntica que mencionábamos al comienzo gracias a la instalación del paradigma de la biología molecular y con las posibilidades de pensar al arte, única herramienta expresiva propia de la especie, como actualizadora y problematizadora de sentidos en definición y disputa. Al respecto, Lotman señala:

La construcción secundaria de la realidad por medio del arte... revive en nuestra conciencia, nuestra experiencia de mundo de una manera doble como si recreara en nosotros la curiosidad intelectual y emocional de un Adán mirando el mundo por primera vez. (Lotman, 2013:202) 
Mirar el 'texto artístico' tecnológico contemporáneo en clave biosemiótica es quizás una de las tareas pendientes en el ámbito de trabajo de las humanidades y las ciencias sociales, especialmente en el cruce de la semiótica con las ciencias de la comunicación. Por ello proponemos relevar el corpus teórico que sostiene este andamiaje y presentar las siguientes hipótesis de trabajo.

\section{Hipótesis de trabajo}

En el marco del proyecto Biosemiótica, Arte y Técnica, integrado por María Juliana Cattaneo (Lic. en Filosofía), Nélida Zubillaga (maestranda en Antropología Social) y María Laura Rosell (doctoranda en Ciencias Sociales), planteamos diversos interrogantes e hipótesis.

En primer lugar, el uso artístico de conocimientos científicos -tanto de las ciencias biológicas, la informática, la física, la robótica, etc. en el contexto de las sociedades de control (Deleuze, 1999)- puede ser analizado desde la transformación de la categoría moderna del Ser, a la luz de corrientes contemporáneas semióticas que discuten la dimensión ontológica de todo artificio.

En segundo lugar, nos preguntamos si la práctica artística contemporánea que experimenta con losmismos materialesque los científicos puederesignificarse en términos políticos asumiendo un nuevo rol en la disputa por la definición de lo vivo y la visibilización de los procedimientos que forman parte de la esfera de producción de conocimiento tradicional.

Finalmente, en función de las opciones humanistas y poshumanistas que pueden adoptar las poéticas tecnológicas de lo viviente, ¿cuáles son las condiciones actuales de sentido en las que lo 'casi-vivo' podría convertirse en una categoría semiótica?

Por otra parte, pero en consonancia con las hipótesis planteadas, podemos definir los siguientes objetivos de investigación:

a) Establecer las reflexiones más relevantes de la biosemiótica y la semiótica de la cultura sobre la vida (y su intervención técnica) en función de una lectura pormenorizada de y desde 'textos artísticos' (I. Lotman) sobre el tema y de la bibliografía secundaria más reciente.

b) Identificar las relaciones que pueden establecerse entre ambas corrientes mencionadas y determinar qué concepto de vida supone y explicita cada uno de ellos, señalando similitudes y diferencias.

c) Contribuir desde la perspectiva problematizada a la reflexión sobre nuestra actitud ante la vida, lo viviente y su manipulación técnica, incorporando la mirada del arte. 


\section{Avances de investigación}

Considerando que el proyecto todavía se encuentra en plena actividad, podemos dar cuenta de una serie de acciones que se han desarrollado dentro del grupo de investigación, favoreciendo el desarrollo de la misma. A partir de reuniones quincenales que hemos venido sosteniendo durante doce meses, se han realizado lecturas y debates en seminarios internos sobre todo el corpus bibliográfico seleccionado y clasificado en función de tres grandes áreas: biosemiótica, bioarte y filosofía de la técnica.

Asimismo, se ha presentado el proyecto en el marco de congresos internacionales donde ha sido discutido y mejorado, gracias al aporte de otros intelectuales y especialistas del campo. En particular, hemos establecido vínculos con referentes de la Escuela de Tartu, en particular con el Dr. Oscar Castro García, con quien mantenemos una fluida comunicación e intercambio de conocimientos sobre el marco teórico de la biosemiótica (nuestro principal objetivo de formación) y el marco teórico del objeto de investigación bioarte (nuestro punto de partida).

Del mismo se ha avanzado en la elección de los bioartistas y sus respectivas obras que serán analizadas en el marco del cruce teórico propuesto. Los artistas seleccionados son de diversas nacionalidades y espectros dentro del universo del bioarte. Cubriendo de esta manera todas las aristas que el género posee y que dan cuenta de su condición interdisciplinaria. La elaboración de artículos científicos a cargo de cada una de las integrantes del proyecto se dará a conocer en revistas especializadas durante el presente año.

El proyecto ya ha contribuido a la formación de recursos humanos de la unidad académica a la que pertenece y espera iniciar una serie de reflexiones en el campo de intersección de la semiótica, el arte y la comunicación (entendiendo en este caso a la biosemiótica como una de las perspectivas que realiza aportes significativos en la comprensión del fenómeno de la comunicación y la cultura).

Asimismo, ha instalado una mirada crítica sobre la evolución del proceso de intervención técnica de la vida, analizando su repercusión en ámbitos como el arte, la filosofía y la comunicación social. En función del contexto técnico en el que estamos inmersos y la demanda de innovación permanente, así como de convergencia tecnológica para la producción de conocimientos, la pertinencia de un proyecto de investigación que asuma la apropiación crítica de estas epistemologías y metodologías de trabajo resulta necesario en pos del enriquericimiento mutuo que puede acontecer entre los distintos perfiles de investigadores que habitan hoy la Universidad. 


\section{Bibliografía}

ARAN, Pampa. 2001. "Jurilotman: actualidad de un pensamiento sobre la cultura" en Escritos. Revista Centro de Ciencias del Lenguaje. BUAP. N² 24. Juliodiciembre, pp. 47-70

DELEUZE, Gilles y PARNET, Claire. 1977.Diálogos. Valencia: Pre-textos.

FLUSSER, Vilém [1988]. 2007. "Arte vivo" en Artefacto. Pensamientos sobre la técnica. $\mathrm{N}^{\circ}$ 6. Buenos Aires: edición independiente. P. 77-80.

FOX KELLER, Evelyn. 2002.El siglo del gen: cien años de pensamiento genético, Barcelona: Península.

HOFFMEYER, Jesper... [et.al.] 2013.Semiótica de la cultura, ecosemiótica, biorretórica, 1a ed., Córdoba: Facultad de Lenguas, Universidad Nacional de Córdoba, Argentina.

KAC, Eduardo. 2010.Telepresencia y bioarte. Interconexión en red de humanos, robots y conejos. Madrid: CEDEAC.

LOTMAN, Iuri. 1996.La semiosfera I. Semiótica de la cultura y del texto. Madrid:EdicionesCátedra.

MITCHELL, Robert. 2010.Bioart and the vitality of media, Seattle: University of Washington Press.

SLOTERDIJK, Peter.2001. "El hombre operable" en Revista Artefacto. Pensamientos sobre la técnica $\mathrm{N}^{\circ} 4$. Buenos Aires: editorial independiente.

SNOW, Charles P. 2000.Las dos culturas. Introducción de Stefan Collini, Buenos Aires: Nueva Visión. 


\section{MEDIACIONES}

B. CUERPO Y MEMORIA 



\title{
La intimidad como apuesta política en Recordar 30 años para vivir 65 minutos, de Marina Otero
}

DOI: 10.24308/IASS-2019-4-024

\author{
Luciana Estévez \\ Universidad Nacional de las Artes, Argentina \\ lutelutiana@gmail.com
}

Empieza la obra. Se proyecta un video de unas niñas, que reconozco que se corresponde con la época de mi infancia. Las niñas se hacen bromas entre sí sobre cuestiones amorosas y una de ellas confiesa que Bárbara está enamorada de Mariano Pandolfeli. La edición salta por diferentes momentos del encuentro, cuyo éxtasis es la entonación del tema Será testigo el sol, de Alejandro Lerner, que murmuro con ternura desde mi butaca. Súbitamente la imagen se detiene en un primer plano. Una chica que estuvo mirando el video desde otra butaca, dice "esa soy yo" y comienza a contarnos que a sus 6 años le diagnosticaron epilepsia luego de varios episodios de ausencias, razón por la cual estuvo medicada hasta los 13. Pienso en mi sobrina Julieta... i Igual! Recuerdo la angustia del diagnóstico, la medicación, los análisis de sangre, los estudios periódicos, naturalizar el tema y, finalmente, el alta... La intérprete de la obra cuenta que un día a sus 13 años le hicieron el último electroencefalograma y los médicos le dijeron que se había curado. Allí el video recobra el movimiento y aparece el título Recordar 30 años para vivir... que da inicio a la cuenta regresiva de 60 minutos... Así comienza la obra Recordar 30 años para vivir 65 minutos, de Marina Otero, objeto de estudio que se propone aquí como exponente del fenómeno artístico que apuesta a la construcción de la intimidad como una herramienta transformadora en el contexto del auge neoliberal. Tomando las herramientas técnicas y subjetivas disponibles, los artistas contemporáneos invierten la lógica de lo individual para enfrentar al "actual sujeto narcisista del rendimiento" (Han 2014: 11) con una exposición personal cargada de afectividad, apostando a la intimidad como una afirmación política, como una posibilidad de reconstrucción del lazo social.

Marina Otero, que tomó la palabra desde una butaca y comenzó a hablarnos a los ojos, de frente, encarna aquello que Érika Fischer-Litche (2017) 
nombra como el "giro performativo", ubicando en primer plano al cuerpo y desplazando la preponderancia del status sígnico de las acciones hacia la corporalidad específica de la intérprete. Su condición de sujeto-objeto en el entramado de la obra despliega una doble aparición en virtud de la dimensión del ser y del hacer: aborda el espacio vestida de calle con una caminata que focaliza la atención en la acción del decir, poniendo en acto el dispositivo estructural de la obra, explicitado en el título: recordar para vivir. Mecanismo escénico de una intérprete que simplemente recuerda frente al público, encarnando de manera literal (pero múltiple) la "restauración de la conducta" propia de las performances rituales estudiadas por Richard Schechner (2000). La "conducta restaurada" describe la acción performática ensayada, reconstruida, recordada, al mismo tiempo que señala su carácter efímero dado que cada restauración es única e irrepetible. Así, la acción de recordar instaura el binomio repeticiónfugacidad como el problema central de la representación del tiempo en la obra, donde resuena la lectura que Paul Ricoeur hace de la idea del tiempo en San Agustín. Ricoeur (2004: 113) afirma que "el tiempo se hace tiempo humano en la medida en que se articula en un modo narrativo, y la narración alcanza su plena significación cuando se convierte en una condición de la existencia temporal". La acción de recordar funciona como la constatación narrativa de la existencia de Marina en el tiempo y, con ella, la de mi propia existencia con mis asociaciones-recuerdos enlazados a los suyos, evocando la noción de "triple presente" de San Agustín: un presente de las cosas presentes, donde se manifiesta un presente de las cosas pasadas, mediante la memoria como imagen-huella, y un presente de las cosas futuras mediante la expectación y la idea de la imagen-signo (Ricoeur 2004).

En Recordar para vivir..., este procedimiento de sustantivación de la memoria con la imagen-huella materializa el tiempo a través de los objetos, las imágenes proyectadas y el propio cuerpo de la intérprete como el soporte del triple presente cuya tensión espacio-temporal estructura la representación. El espacio de la obra se configura como un vacío con objetos distribuidos por el piso, dando cuenta de la preponderancia del objeto en la búsqueda de la intimidad de las prácticas artísticas contemporáneas: un tocadiscos, un revólver, un banquito acostado, dos tapas de discos de Charles Aznavour, ropa, un libro, fotos, un megáfono, una botella de whisky, una bolsa de residuos llena, una mesa de operación técnica a la izquierda y una proyección en la pared del fondo. Todo un conjunto de objetos vivos, cuya condición inanimada está determinada por cómo ellos fueron vividos por la intérprete. Esta noción de vitalidad sistematizada por Shaday Larios (2018: 15) define una actividad de intercambio que nos incluye íntimamente en la objetualidad, visibilizando a los objetos como "potenciadores de relaciones sensibles y acciones socioculturales". Los objetos vivos que componen Recordar para vivir... se definen por la indocilidad 
de lo inanimado, eso que desborda la objetualidad de manera desobediente y se resiste a la objetivación, permitiendo la emergencia de un territorio de encuentro entre el individuo y la materia. No funcionan como simple testimonio, sino que representan el reservorio de la experiencia en tanto testigos y agentes de la historia materializando el universo de las relaciones sociales. Objeto, en su raíz latina, es aquello que está delante o en contra de mí, dejando implícita una confrontación que se disuelve solamente con la posibilidad de paridad que le otorga el calificativo de vivo. Larios postula esta fórmula en concordancia con la inversión de las modalidades relacionales del capitalismo neoliberal, a partir de la clasificación que hace José Ferrater Mora de los objetos. De su taxonomía, nos interesa aquí la categoría de "objetos reales" donde se encuentran incluidos los "objetos físicos" que están determinados por las coordenadas de la espacialidad y la temporalidad, elementos constitutivos de la puesta en escena. La idea del objeto real, físico y cotidiano, utensilio con finalidades prácticas, redondea la noción de "objeto antropocéntrico" vinculada al "objeto funcional" de Jean Baudrillard, a partir de la cual se establecen sus dos funcionalidades: la de ser utilizado y la de ser poseído. Desde esta categorización, el objeto cotidiano en nuestra obra constituye un reencuentro del ser que, en la latencia de sus distintas vitalidades se convierte en un objeto vivo: un objeto descotidianizado, que mantiene una equidad con Marina, conmigo, con todos los presentes en la sala, y puede tender a confundirse simbólicamente con cualquier sujeto.

Las dimensiones del cuerpo y del objeto, desde la perspectiva de la intimidad, se integran a las modalidades propias de las tecnologías digitales, que representan el tercer basamento de las prácticas artísticas contemporáneas funcionando como grandes sensores de la experiencia. En Recordar para vivir..., el soporte objetual y el cuerpo de la intérprete reafirman su entidad mediante las proyecciones de fotos y videos, donde aparece su ser no-escénico en diversas situaciones, tiempos y espacios, realzando la condición de imagenhuella de la materia del aquí y ahora. La capacidad de la tecnología digital para capturar y almacenar la vivencia se actualiza, en nuestra obra, con la edición y (re)producción en tiempo real en el proceso de conversión de lo digital a lo analógico. Recordar para vivir... constituye la memoria como el presente de las cosas pasadas apropiándose de las matrices perceptivas propias del dispositivo fotográfico analizadas por Roland Barthes y Jean-Marie Schaeffer para expandirlas a la multiplicidad de los elementos escénicos. Según Roland Barthes (2013: 120-121), "nunca puedo negar en la Fotografía que la cosa haya estado allí". Lo que constatan las imágenes proyectadas en la obra es que Marina y los objetos han estado allí, certificando el estatus de imagen-huella constitutivo del triple presente. Cada imagen parece decirnos "esto ha sido", esa frase que Barthes señala como el noema de la Fotografía donde se confirma su doble posición simultánea de realidad y de pasado. 
Pero esa cualidad indicial sostenida en su principio de existencia se complementa, en las políticas de la intimidad de las prácticas artísticas contemporáneas, con el plano de la similitud de su dimensión icónica. Schaeffer (1990), distingue el signo fotográfico por su condición icónico-indicial, que implica reconocer la simbiosis entre la semejanza y la existencialidad como el fundamento de la relación referencial de la imagen con su impregnante real ${ }^{1}$. En la obra de Marina, esta dimensión icónica de la imagen produce un efecto de reconocimiento a partir de la semejanza, que no solo resignifica los elementos de la escena en su enlace con la indicialidad, sino que rebota en múltiples direcciones transformándose en un sentido de identificación. Esa similitud que existe entre Marina, sus objetos y las imágenes proyectadas es semejante a la que existe conmigo, con mis objetos, con mis experiencias. Así, el mecanismo documental de la escenificación como imagen-huella del pasado del presente abre la circulación del sentido a partir del carácter icónico de la foto y, por extensión, de todos los componentes de la escena. Entonces, si la indicialidad es lo que une los elementos de la escena con lo real del recuerdo por la relación existencial, la iconicidad enlazada a la indicialidad produce una apertura de la materialidad presente de la memoria hacia la dimensión interpersonal de la representación por la relación de semejanza.

Ese reconocimiento de semejantes anudado a la relación existencial con el referente constata esa presencia inmediata en el mundo compartido que produce la fotografía. Esa copresencia que Barthes (2013: 132) describe con la pregunta política y metafísica que ocurre frente a una foto de "¿por qué razón vivo yo aquí y ahora?", que parece el puntapié inicial de la obra cuando Marina enuncia su pregunta guía: “¿para qué carajo había venido al mundo?”. Preguntas que resuenan en las exaltaciones neoliberales del yo, y que estas apuestas artísticas responden en el enlace con el otro.

De esta manera las políticas de la intimidad desarrolladas por las prácticas artísticas contemporáneas ofrecen resistencia al rol que parecen cumplir los dispositivos tecnológicos en el contexto neoliberal. Las reflexiones de Éric Sadin sobre esta cuestión desarrollan la noción de tecnolibertarismo para describir la supremacía del individualismo en la era de la libertad incondicional de las personas y la economía no regulada. El tecnolibertarismo "disuelve progresivamente todos los fundamentos históricos de la economía y de lo político (...) [valiéndose] de una a-política o una tecno-política" (Sadin 2018:

\footnotetext{
${ }^{1}$ Consideración desarrollada por Schaeffer en su libro La imagen precaria. Cabe aclarar que para Schaeffer la dimensión indicial de la fotografía no se sustenta en los mismos principios que esgrime Roland Barthes desde su lógica estructuralista. Para Schaeffer la indicialidad está vinculada al dispositivo fotográfico (no a un caudal mítico) y, por ende, a lo que él denomina el "saber del arché". Esto tiene que ver con el fenómeno físico y químico que supone el origen de la imagen fotográfica, entendida culturalmente como la impresión química de un fenómeno físico en el que un flujo de fotones procedentes de un objeto (por emisión o reflexión) toca la superficie sensible.
} 
126). En este contexto, Sadin señala la emergencia de la antrobología como una nueva condición humana, aún más secundada o duplicada por la tecnología. Un nuevo estado antropológico despojado de integridad, de juicio crítico y de autonomía, que fomenta un modo de civilización bajo la gobernabilidad digital, que no tiene un fin político sino mercantilista y global destinado a satisfacer intereses privados. A contrapelo de estos fenómenos, las políticas de la intimidad del arte contemporáneo trabajan los dispositivos tecnológicos como elementos fundamentales para el registro y la resignificación de la experiencia sensible. Invierten la tendencia a-histórica del tecnolibertarismo en virtud de la conservación archivista y el almacenamiento de la vivencia, para producir signos que, lejos de buscar el progreso hacia adelante, construyen y reconstruyen la historia pasada en el presente.

Esta lógica analizada en los procedimientos de montaje se anuda a los mecanismos discursivos con que se estructura Recordar para vivir... Las escenas de la obra, lo que distinguimos desde la teoría de la enunciación como el enunciado, arman una línea de tiempo entre el 2007 y el hoy, como un proceso de historización que, en términos de Walter Benjamin ${ }^{2}$, sustituye la visión cronológica de la historia (esa sucesión causal de hechos ligada a la imagen del reloj) por una visión lógica que traza un caledario a partir de fechas y acontecimientos. Así, el enunciado despliega un calendario de cuadros que picotean del transcurrir del reloj: un episodio ocurrido en septiembre del 2007, el encuentro con un libro en 2009, el estreno de la obra Andrea en 2012 sobre el personaje del libro, la convocatoria de una peña folklórica en 2008 para hacer de Telesita, la lesión de la columna por la que comienza a hacer teatro, los ensayos de 2009, su tía abuela Margarita, actriz fallecida en un accidentesuicidio de tren, el recorrido por sus novios, la navidad de 2009, un viaje a Glew en 2010 para filmar a Lucy, la vestuarista, la experiencia artístico-espiritual en el cementerio de la Chacarita en 2011 sobre Andrea y Margarita, la filmación de un video en la terraza de un Pablo, la última función de la obra Andrea, el verano del 2013 en la playa, hoy, que hace 8 años que Andrea la persigue, hace un par de semanas cuando recibió un mensaje de un admirador, hace 7 meses, cuando se mudó, y el 24 de septiembre de 2007 cuando se quiso matar. Luego, acciones desarrolladas en presente que no evocan un pasado, sino que operan sobre el aquí y ahora de la representación. La primera, la denuncia a un Pablo manipulador, con un asistente que la filma mientras ella con las tetas al aire se cuelga del público y sale a la calle a provocar transeúntes. La segunda, tres acciones con la participación de tres espectadores a quienes llamará Pablo 1, 2 y 3, (también filmada por uno de los asistentes). La tercera, un desplazamiento dentro de una bolsa de residuos, un texto cíclico con micrófono y un baile con una mano sobre el tema How deep is your love, de los Bee Gees. La cuarta, la

${ }^{2}$ A partir de su Tesis de filosofía de la historia, publicada por primera vez en 1955. 
enumeración de todo lo que fue capaz de hacer por 65 minutos. Y la quinta, el final, sentada en el banquito hablando de su presente en relación a las preguntas y anhelos que atravesaron la obra. Por último, un video filmado por ella saliendo de bañarse que, en dinámica de karaoke, y casi sin darnos cuenta, nos hace terminar cantando a gritos Nada es para siempre de Fabiana Cantilo.

El plano de la historia que constituye el enunciado de Recordar para vivir... construye este calendario como la cartografía de un proceso creativo, con más errores que aciertos, con más incertidumbres que inspiraciones, con más anécdotas personales que búsquedas estéticas. Una erraticidad que, con sus anclajes de fechas, lugares, intenciones y fracasos, nos interpela como contemporáneos, como cohabitantes del territorio argentino-porteño, como artistas, como sujetos deseantes trazados por la falta. La historicidad lógica del plano de la historia dialoga con la iconicidad e indicialidad de la configuración espacio-temporal de la escena produciendo, a partir de la semejanza y la existencialidad, esa microcomunidad mencionada por Nicolás Bourriaud (2013) en su Estética relacional. Recordar para vivir... asume, entonces, aquello que Georges Didi-Huberman (2008: 24-25) nombra como la tendencia a "confrontar las historias de un sujeto (...) con la historia del mundo entero (la Historia con H mayúscula) (...) [que ubica] el problema de la historicidad en el horizonte de toda cuestión de intimidad y de toda cuestión de actualidad". Nuestra historia, la de Marina, la mía, la de los espectadores sentados a mi lado, arman el entramado de historias con minúsculas que se constituye en agente de la Historia con mayúscula situada en cada ubicación de fecha y lugar del discurso.

Este horizonte de intimidad y de actualidad trazado por el plano de la historia, se ordena en el plano del relato, donde la historización de Recordar para vivir... direcciona su apuesta política a la dimensión vincular de la representación. El discurso se estructura con una dinámica de monólogo cuyas condiciones de enunciación se encuentran constantemente enunciadas y referidas. Las marcas enunciativas del tipo "más adelante les voy a contar", "voy a hacer una rápida cronología de cómo llegué hasta acá", "la escena que viene la vamos a saltear", "este es el final", "hay un video más y no jodo más, me voy", son las figuras recurrentes con las que Marina va organizando el relato. La entidad semiótica que estructura el discurso llega a su máxima expresión con la sintaxis relacional que clasifica a los hombres que tuvieron con ella algún encuentro sexual como Pablos sumisos, Pablo pulsión de muerte o Pablo un amor fugaz, y a los otros hombres con las iniciales de sus nombres. En relación con las situaciones que componen el enunciado, algunas son relatadas con cierta figuración en las proyecciones, en el vestuario o en los objetos, otras son actuadas, previo aviso de enunciación referida, y otras están a medio camino entre relatar y realizar la acción relatada. El factor común de todos estos procedimientos enunciativos 
es un sujeto de la enunciación configurado por la puesta en relieve de la representación.

Marina asume la voz de la narradora y nos habla en una primera persona que integra al personaje, a la autora y a la directora de la obra utilizando el estilo indirecto libre. Un sujeto enunciador que afirma el yo como un "ejercicio permanente de reciprocidad" desde la subjetividad en el lenguaje analizada por Benveniste (Ducrot 1982). Con la autorreferencia del enunciado, Marina inserta el discurso escénico en el marco general del reconocimiento mutuo de los individuos, erigiendo la representación como una apuesta a la intersubjetividad. Encarnación lingüística de la utopía de proximidad planteada por Bourriaud (2013), tejida con todo el material escénico, los objetos, las imágenes, el cuerpo de la intérprete y el relato, a partir de la iconicidad indicial que hace del triple presente una experiencia colectiva.

Bourriaud retoma la cuestión de los modos de subjetivación de la modernidad y del modernismo, para reinventar una idea de lo plural y pensar en el contexto actual nuevos modos de estar-juntos, ya no desde la emancipación de los individuos sino desde la emancipación de la comunicación humana. Recordar para vivir... invita más al uso que a la contemplación con su autorreferencialidad y sus procedimientos de escenificación icónico-indiciales, postulando nuevos modos de estar-juntos a partir de la intersubjetividad de la dimensión lingüística. Sin embargo, la potencialidad política de su planteo relacional desborda el estudio general de Bourriaud y se identifica con dos aspectos que Claire Bishop critica de la estética relacional. El primero es el problema de la noción de estructura en Bourriaud, que para Bishop (2004: 5179) "establece una relación errática con el tema explícito de la obra", afirmando la falsedad de que el solo hecho de generar instancias de encuentro supone una democratización de la comunicación. El análisis estructural de Recordar para vivir... integra la esfera temática de la obra en la configuración conjunta de un yo a partir de esa erraticidad plagada de tropiezos que, lejos de presentarse como un modelo, nos ofrece su falta como carta de presentación. En el contexto neoliberal constituido por los "desinhibidos impulsos del yo y del rendimiento", según Byung-Chul Han (2014: 43), el relato del derrotero de Marina parece invertir la pregunta apriorística de "¿a quién puede interesarle un relato íntimo de alguien?". Recordar para vivir... se sitúa en el vértice opuesto de la hipervisibilidad del sujeto, multiplicado y desmembrado en las redes sociales como manifestación del "excesivo narcisismo de la propia mismidad" (Han 2014: 9-10). Al sujeto configurado por el imaginario neoliberal Marina lo confronta con el éxito de una obra construida desde el fracaso, surgida de escenas que rozan el ridículo, con un proceso creativo que le llevó un tiempo inconcebible en términos productivos, y con la plenitud de una carrera artística que no logra responder a sus preguntas. 
El otro aspecto de Bishop (2004) que tomaremos aquí es su postulado del "antagonismo relacional", basado en la teoría de la subjetividad de Ernesto Laclau y Chantal Mouffe. Para ellos la subjetividad es un proceso de identificación de entidades incompletas que dependen del otro para constituirse, a la vez que constatan en él su propia imposibilidad de encarnar una totalidad completa. El antagonismo relacional muestra que Recordar para vivir... no evoca una propuesta vincular intrínsecamente democrática como una comunidad de subjetividades acabadas buscando su estar-juntos, al estilo de Bourriaud, sino más bien todo lo contrario. Los procedimientos de identificación y empatía que analizamos a lo largo de este trabajo constituyen una política de comunicación basada en el recurso de lo íntimo: la clave de toda cualidad incompleta, conflictiva y opuesta al binarismo de lo individual. Marina expone su relato con un montaje inestable que exhibe su inestabilidad para ser compartida, de tal modo que la erraticidad del yo que contituye y tematiza la obra despliega en su intimidad una fuerte posición de resistencia asociada al antagonismo relacional de Bishop, por afirmarse incompleta y por requerir del otro.

La noción de intimidad presenta múltiples vías de acceso y tiene su productividad teórico-artística en el campo del análisis literario, en estudios como los de Julia Kristeva y Tamara Kamenszain ${ }^{3}$. Pero en relación con las artes performativas nos interesa particularmente la perspectiva filosófica y psicoanalítica. Desde la filosofía, José Luis Pardo (2012: 7) propone las políticas de la intimidad partiendo de la hipótesis de que la ciudad y la intimidad son conceptos irreductibles a la vez que inseparables: "allí donde no hay política, no puede haber en sentido estricto intimidad; y allí donde la intimidad está amenazada, estas amenazas expresan una crisis del espacio civil". Su trabajo elabora un modelo de raíz lingüística para pensar una relación entre poder e intimidad que permita despejar las confusiones surgidas de la clásica dicotomía entre público y privado. La intimidad, aquí, no es un secreto pudoroso, sino un efecto de lenguaje que presupone una comunidad, donde la referencia a sí mismo lejos de ser una firmeza, implica estar apoyado en falso, a punto de saltar al vacío (Pardo 1996). El origen lingüístico que la fuerza de la intimidad tiene para Pardo refiere justamente a aquello que se encuentra por fuera de los acuerdos que hacen los hablantes sobre los significados explícitos que circulan en el lenguaje. Al contrario, "quienes comparten las mismas 'resonancias' implícitas se sienten partícipes de una misma comunidad lingüística involuntariamente compartida [íntima], mientras que quienes pactan acuerdos explícitos constituyen una asociación pública deliberadamente sostenida" (Pardo, 2012: 56). Allí reside, para él, la diferencia entre lo público y lo íntimo, que es compartido, pero en condiciones de connotación y resonancia internas que no son dominio del

${ }^{3}$ Desarrollados en trabajos como La revuelta íntima. Literatura y psicoanálisis, de Kristeva, o Una intimidad inofensiva. Los que escriben con lo que hay, de Kamenszain. 
hablante por completo, sino que provienen del interior de la lengua.

Desde el psicoanálisis, François Jullien (2016) piensa el recurso de lo íntimo como una potencia, como una resistencia que se abre entre dos. Precisamente por eso no guarda relación alguna con la idea de confesión o de secreto, figuras que nada tienen que ver con nuestro objeto de estudio. Jullien parte de la contradicción que plantea la lengua alrededor de lo íntimo, cuya definición reúne lo más apartado y oculto, a la vez que la más estrecha de las relaciones. En esta dialéctica postula el quiebre de la oposición tradicional del adentro y el afuera, sosteniendo que "cuanto más íntimo es lo que está en juego, más profundo es lo compartido (...) [y que] solo lo que es íntimo quiere ofrecerse y puede hacerlo" (Jullien 2016: 24). Solo el discurso íntimo puede aspirar a la reconstrucción del lazo social deshecho por la lógica neoliberal, al mostrar entidades incompletas que precisan del otro para subjetivarse, que se obstinan en la falla para retener la productividad del rendimiento, que se niegan a la competencia inividualista del afuera y el adentro como lógica binaria. Dice Jullien (2016: 27): "lo íntimo requiere que nos detengamos en ello, tanto más en la medida en que vemos lo que nos hace ganar con respecto a todo pensamiento de la intro-(spección) y de lo interior (la famosa "vida interior", etc.). (...) [Es necesario] poner de relieve lo íntimo en contra de la interioridad y de su culto, para desembarazarnos de ellos".

Cuerpo, objeto y tecnología son el soporte artístico de una política de la comunicación que apuesta a la intimidad como un grito de guerra. Da acceso a lo íntimo como el acto subversivo que desbarata la posibilidad de un "YO-sujeto bloqueado en su solipsismo" (Jullien 2016: 27), desintegrando el individualismo reinante. Así, se despliega un plan estratégico que tiene por finalidad "hacer experimentar (...) que el otro es conciencia al unísono conmigo mismo, lo que entonces se aprehende de manera inmediata (...) en ese adentro compartido" (Jullien 2016: 28). Ante el recurso de lo íntimo reaparece la idea de vanguardia (Foster 2017), por su carácter innovador y de resistencia ante el statu quo de las modalidades vinculares neoliberales, y por su espíritu transgresor y propositivo, opuesto al régimen de la productividad capitalista. Pero, fundamentalmente, por su fuerza corrosiva, inmanente a los modos relacionales de la hipervisibilidad y la presencia del sujeto en las redes sociales. El arte contemporáneo hunde sus garras en las fracturas de este orden para utilizar las tecnologías falsamente vinculares y presionar sobre ellas con una intimidad arrolladora.

\section{Bibliografía}

BARTHES, Roland. 2013. La cámara lúcida. Buenos Aires: Paidós.

BENJAMIN, Walter. 1989. Tesis de filosofía de la historia. En Discursos ininterrumpidos I. Buenos Aires: Taurus. 
BISHOP, Claire. 2004. Antagonismo y estética relacional. En revista Octubre. Traducción de Carlota Beltrame. Cambridge: Ltd. y el Instituto de Tecnología de Massachusetts. Otoño 110, p. 51-79.

BOURRIAUD, Nicolás. 2013. Estética relacional. Buenos Aires: Adriana Hidalgo.

DIDI-HUBERMAN, Georges. 2008. Cuando las imágenes toman posición. El ojo de la historia, 1. Madrid: Machado.

DUCROT, Oswald. 1982. Decir y no decir. Barcelona: Anagrama.

FISCHER-LICHTE, Érika. 2017. Estética de lo performativo. Madrid: Abada Editores.

FOSTER, Hal. 2017. Malos nuevos tiempos. Arte, crítica, emergencia. Madrid: Akal.

HAN, Byung-Chul. 2014. La agonía del eros. Barcelona: Herder.

JULLIEN, François. 2016. Lo íntimo. Lejos del ruidoso amor. Buenos Aires: El cuenco de plata.

KAMENSZAIN, Tamara. 2016. Una intimidad inofensiva. Los que escriben con lo que hay. Buenos Aires: Eterna cadencia.

KRISTEVA, Julia. 2001. La revuelta íntima. Literatura y psicoanálisis. Buenos Aires: Eudeba.

LARIOS, Shaday. 2018. Los objetos vivos. Escenarios de la materia indócil. México: Paso de Gato.

PARDO, José Luis. 1996. La intimidad. Valencia: Pre-textos.

PARDO, José Luis. 2012. Políticas de la intimidad (Ensayo sobre la falta de excepciones). Madrid: Escolar y Mayo.

RICOEUR, Paul. 2004. Tiempo y narración. Configuración del tiempo en el relato histórico. Buenos Aires: Siglo XXI.

SADIN, Éric. 2018. La silicolonización del mundo. La irresistible expansión del liberalismo digital. Buenos Aires: Caja Negra.

SCHAEFFER, Jean-Marie. 1990. La imagen precaria. Madrid: Cátedra.

SCHECHNER, Richard. 2000. Performance. Teoría y prácticas interculturales. Buenos Aires: Libros del Rojas. Ediciones de la Secretaría de Extensión Universitaria y Bienestar Estudiantil de la Universidad de Buenos Aires. 


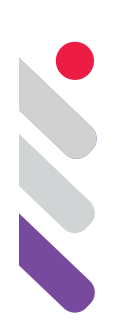

\title{
Danza en primera persona. El giro autobiográfico en obras del under porteño
}

DOI: 10.24308/IASS-2019-4-025

\author{
María José Rubin \\ Universidad Nacional de las Artes \\ rubinmariajose@gmail.com
}

\section{Introducción}

Este trabajo presenta avances de una indagación iniciada en 2016 en torno a los modos de inscripción de la materia verbal en obras de danza contemporánea producidas en Buenos Aires en el ámbito independiente. Posibilitado por la cercanía que habilitan los escenarios de las pequeñas salas del under local (Durán y Jaroslavsky 2012), este fenómeno comporta particularidades observables que pueden resumirse brevemente como una tendencia a privilegiar los rasgos materiales del discurso verbal y el consecuente efecto de opacidad de la palabra,por sobre el sentido que construye a partir del código lingüístico (Rubin 2017).

Desde los inicios, este análisis de la danza contemporánea de Buenos Aires ha buscado dar cuenta de la especificidad actual de su lenguaje artístico como precondición para pensar, en los casos en que resulte pertinente, su relación con otros lenguajes: en este momento histórico cuando, en línea con los debates contemporáneos, la crítica tiende a orientar sus lecturas de estos fenómenos a partir de nocionescomo "hibridación" o "interdisciplinariedad", consideramos de vital importancia desplegar previamente una descripción y análisis de los debates y modificaciones al interior del propio terreno de la danza contemporánea local, para entonces poder especificar de qué manera dialogarían con las tradiciones y discusiones de otras disciplinas.

Para el siguiente análisis sobre la presencia narrativa autobiográfica en obras de danza recientes se trabajará sobre un corpus de piezas del circuito independiente o subsidiado de la Ciudad de Buenos Aires montadas en el período 2012-2018. Cuatro de ellas compondrán el corpus de esta primera instancia de investigación:Recordar 30 años para vivir 65 minutos, de Marina Otero (2014); María sobre María, de Lucía Llopis (2016); Mi fiesta, de Mayra 
Bonard (2018); Acróstico, de Diego Rosental (2018). También se tomarán como referencia tres obras que construyen narraciones autobiográficas, en sentido amplio, sin recurrir para elloa la forma relato o al soporte verbal de manera privilegiada: Villa Argüello, de Celia Argüello Rena (2011); Lugar propio, de Iván Haidar (2013) yFamilyGame, de YaninaRodolico (2016). Se recurrirá al herramental teórico propuesto por la semiótica veroniana, especialmente sus desarrollos en torno a objetos artísticos y sus últimas indagaciones acerca de las relaciones entre narratividad y mediatización.

\section{La danza habla y dice: nuevo dispositivo, nuevas posibilidades}

La danza contemporánea independiente de Buenos Aires se emplaza en centros culturales y espacios teatrales caracterizados por contar con "[...] salas pequeñas, con pocas butacas" y escenarios dispuestos a la misma altura o por debajo del nivel de la platea: todos estos rasgos dan lugar a una "cercanía con el espectador" (Ana Durán y Sonia Jaroslavsky2012: 114). En la danza, también implican cuerpos de baile de número reducido, con bailarines claramente identificables, apartados del recurso de homogeneización de grandes masas de intérpretes propio de, por ejemplo, el ballet o propuestas modernas o posmodernas en teatros de gran porte con escenario a la italiana.

Este escenario próximo del circuito under local, por oposición con el escenario a la italiana como emplazamiento para la danza, hace posible la inclusión del discurso verbal como materia significante (Verón 1974) sin la necesidad de incorporar costosos equipos de amplificación del sonido, algo hasta entonces inviable. El abandono creciente de la música como elemento omnipresente en las obras de danza contemporánea y la clara audición del ritmo respiratorio de los bailarines, alterado por el esfuerzo de sus cuerpos, seguramente acompañaron a la incursión en la palabra hablada como parte del metier del bailarín.

En determinados momentos de algunas de las obras se produce un cambio de escala (Verón 2002) por el cual la relación uno a muchos de la enunciación escénica muta para entablarse en un vínculo uno a uno con integrantes del público. En María sobre María, la intérprete solicita a alguien del público que lea indicaciones para ejecutar una escena; en Recordar 30 años para vivir 65 minutos, la intérprete invita a integrantes del público a ingresar al escenario y les da instrucciones para llevar a cabo la escena; Acróstico comienza, en su versión montada en el Centro Cultural Rojas, con el intercambio de objetos que funcionan como documentos de su pasado; en Villa Argüello, asimismo, los intérpretes reciben al público con mates y criollitos, y muchas funciones, especialmente las realizadas en el club social de la Asociación Vecinal Benito Nazar, terminaban con el público bailando en el escenario junto a los bailarines. Así, el vínculo enunciativo (Traversa 2006) se transforma, al menos 
momentáneamente, y aquello que hasta entonces se había configurado como un texto cerrado, de forma previa a la presencia de una audiencia determinada, con la cual establece un vínculo restringido, pasa a constituirse en un vínculo pleno con algunos de sus miembros. Es de interés que un efecto comparable se observa en casos de obras transmitidas en internet. Tanto FamilyGame como Lugar propio se ofrecen en streaming en vivo desde el hogar de los creadoresintérpretes. Así, la audiencia debe conectarse en un determinado horario a través de la página web indicada para acceder a un vínculo que, sumado a la tematización del ámbito hogareño y de medios de contacto semirrestringidosa través de otros dispositivos en escena, como la videoconferencia, construye un efecto enunciativo en el plano textual, pese a que el vínculo efectivamente construido a través del dispositivo no deja de ser restringido.

Si bien es cierto que este fenómeno no se observa en la totalidad de los casos analizados, es notable que forme parte de muchos de ellos. No es menos relevante, por otra parte, que todas las obras analizadas se generaron en un momento de la historia de la danza local en la que esta posibilidadya está extendida entre los artistas de la comunidad y, por lo tanto, forma parte de sus condiciones de producción.

\section{Conociendo a la recién llegada: primeras regularidades de la materia significante en soporte verbal}

En un trabajo anterior (Rubin 2017), se abordó la materialidad discursiva en la danza contemporánea local en sentido amplio, delimitando un corpus de obras que presentaban discurso hablado articulado según un código lingüístico, excluyendo así los casos en que la voz humana era utilizada solo sonoridad. Se trabajó desde la perspectiva de las discusiones con la tradición que la presencia de esta nueva materia significante constituía: discusiones en torno al problema de los materiales disponibles a su campo de desempeño artístico. Se observaron, entonces, los modos particulares de abordar la palabra hablada en la danza contemporánea local, delineando una primera serie de regularidades que pusieron a prueba la hipótesis de un trabajo que privilegia la materialidad de la palabra hablada en detrimento de su sentido verbal.

En este contexto, se describió una serie de operaciones por las cuales las piezas danzadas articulan la voz humana en vivo: el privilegio de las características rítmicas como criterio para la escritura y la declamación, las estrategias de restricción de la inteligibilidad del discurso, la escisión entre los cuerpos que pronuncian y los locutores (en términos de Ducrot 1988) construidos en la enunciación fueron los primeros elementos que permitieron delinear un campo de efectos enunciativos que acentúan la función poética (Jakobson 1981) a través del distanciamiento (Shklovski[1916] 1978). Los enunciados resultantes son textos en los que no resulta sencillo (o posible) hallar una clave narrativa del 
discurso que les da marco (la obra de danza) en términos de relato; en cambio, esto supone un movimiento que inscribe el discurso hablado no como narración, sino como parte constitutiva de la narratividad de la obra(Fabbri1999).

Que el funcionamiento de estos discursos, según se los ha caracterizado brevemente hasta aquí, se haya presentado en un ámbito de creación coreográfica contemporánea, en el cual la lógica narrativa en términos de relato no suelen ser principios rectores, no parecía casual. El uso de la voz humana como otro de los recursos disponibles de un cuerpo y no como el medio expresivo principal parecía haber beneficiado estos tipos de funcionamiento del texto hablado, más poéticos que referenciales. En un medio como la danza contemporánea, en la que los cuerpos se presentan antes por sí mismos que como encarnación de un personaje construido en un texto narrativo, anterior y exterior a la obra (como sí ocurre en el ballet), con escenografías magras compuestas por pocos y sugerentes elementos que proponen -más de lo que disponen- un posible escenario para los eventos de la obra, el discurso comenzaba a tomar la misma clave: una vocación principalmente poética.

Así concluía aquella primera etapa de la investigación, que hoy sirve de marco general al fenómeno específico que ocupa a esta nueva instancia: el desarrollo creciente de discursos verbales (y también compuestos por otras materialidades que, en ocasiones, no incorporan la palabra o lo hacen secundariamente) que constituyen relatos de carácter autobiográfico.

\section{La autobiografía: un fenómeno genérico incipiente y en tensión}

En este marco, numerosas obras de danza contemporánea desarrolladas en los últimos años exhiben un fenómeno de creciente presencia en la producción artística local: la configuración del discurso en primera persona del singular y el abordaje de temáticas asociadas con la intimidad. Si bien los rasgos antedichos permitirían inscribir las obras o los discursos verbales que las integran al universo genérico de la autobiografía o la narración testimonial, estos se presentan modelados por operaciones retóricas que ponen en tensión las regularidades de géneros como el testimonial o el autobiográfico (Steimberg 2013).

Existen en estas obras rasgos enunciativos que guardan relación con aquellos observados anteriormente, en tanto sostienen el distanciamiento de los modos de declamación respecto del enunciado y privilegian el trabajo con la materialidad del discurso verbal; sin embargo, las obras que comportan este nuevo fenómeno tienden a habilitar la inteligibilidad de discursos con forma relato y construyen, en ocasiones por obra de las mismas operaciones que distancian al locutor de su discurso, un efecto enunciativo íntimo.

Un recurso habitual, observable en Acróstico, y en mayor medida en $\mathrm{Mi}$ fiesta y en Recordar 35 años..., pero presente también en otras obras de danza 
con discurso hablado independientemente de que construyan un universo temático autobiográfico, es la puesta en evidencia de que los intérpretes recitan textos previamente escritos y memorizados. Al exacerbar las marcas de este proceso de mediatización (Verón 2015) del relato en primera persona, toman distancia de aquello que confiesany se constituyen en enunciadores de una biografía que, sin dejar de presentarse como propia, es puesta a resguardo de una modalización emotiva en su vocalización. Estos relatos dan cuenta de una historia vivida tanto como del proceso por el cual se convirtieron en una materia significante de la obra a la que ahora pertenecen.

Colabora con esta lectura el hecho de que muchas de las obras que integran este corpus se inscriben en la tendencia creciente de la comunidad de la danza contemporánea local a presentar, con la ayuda de magros subsidios a la creación y la correlativa exigencia de estrenar obra, unipersonales autocoreografiados, autoproducidos y autodirigidos. En consecuencia, al observar la vida paratextual de las producciones, es habitual que coincidan el nombre de una sola persona en la mayoría o todos los lugares cargados de valor autoral con aquel o aquella que enuncia la primera persona de un texto que no elude su origen autobiográfico a la vez que denuncia, como se ha dicho, su mediatización.

Así, el efecto enunciativo íntimo se desplaza de la autobiografía a la autorreferencialidad de un texto que remite a su propio proceso de producción. Se abre de esta manera una vía para observar la "intimidad" de la obra. Esta exposición de la creación artística recupera la estrategia de una cercanía enunciativa con los mismos recursos con los que establece una distancia respecto del discurso autobiográfico.

\section{La danza en diálogo con otras disciplinas artísticas}

Las características antes mencionadas permiten pensar la relación de estas obras con otras áreas de producción artísticas que les son contemporáneas. Por un lado, es habitual que se las describa descripción como cruces entre la ficción y la verdad, reponiendo de alguna manera la búsqueda de las vanguardias de reunir arte y praxis vital, y su relación con géneros como el biodrama, surgido en el contexto del teatro como exploración en escena de límites relacionados con la construcción ficcional del texto dramático (Cornago 2005). Si bien es innegable que ciertos modos de hacer participan de la producción narrativa contemporánea en sus diversos lenguajes (por ejemplo, el recurso a hechos de la "vida personal" como fuente privilegiada), no es menos evidente que la discusión iniciada por el biodrama con la tradición teatral abreva de un interés por expandir categorías de la dramaturgia a la teatralidad de la vida cotidiana, mientras que la danza recién comienza a explorar esta nueva materia de la expresión en la que ha decidido incursionar. 
Si consideramos sus rasgos retóricos y enunciativos, además de los temáticos que las obras de danza analizadas comparten con el biodrama, resulta de interés el abordaje de ciertos fenómenos de la literatura actual ${ }^{1}$ enmarcados en la idea de un giro autobiográfico (Giordano 2008), que no atiende a la autobiografía como género o como fuente, sino que describe una tendencia que responde a los "valores que promueve la cultura de lo íntimo [...] Confiese lo que quiera, expóngase descarnadamente, con tal de que no tengamos dudas o podamos jugar sin inquietudes a que el que vivió y el que se escribe son el mismo" (Giordano 2008: 9). La operación autobiográfica se dirime no en la veracidad de la confesión, sino en su efecto de sentido: la confesión en sí puede ser "ladina [...] si los juegos retóricos también sirven para la realización imaginaria de ciertas experiencias" (Giordano 2008: 48). Esto es lo que se observa en los textos de la danza, en obras que se proponen como un espacio de confesión, a diferencia del biodrama, que hace público algo personal, privado, pero que no mueve por su carácter confesional y que, por otra parte, perdería su valor si se dudase de su veracidad.

Por otra parte, interesa atender a otra línea de trabajo de la danza contemporánea que abreva del arte contemporáneo, en tanto deja de lado la producción "de representaciones" o "diseños abstractos que resulten en objetos fijos" para en cambio "construir dispositivos de exhibición de fragmentos de mundo, que se presentan de modo tal que las posiciones de sujeto que se constituyen en la escena que componen difieran de las que el largo siglo XIX les había atribuido a productores y receptores; la tendencia común entre artistas a construir menos objetos concluidos que perspectivas, ópticas, marcos que permitan observar un proceso que se encuentre en curso" (Laddaga 2007: 14).

Muy al contrario de esta tendencia, el riguroso trabajo dedicado a la incorporación de discursos verbales se enmarca en obras cerradas (en términos de Adorno 2004), cuidadosamente coreografiadas, y no en aquellas otras ocurrencias escénicas que se definen como "presentaciones" para distinguirse de toda representación y que, en consecuencia, hacen de la indeterminación del lugar del espectador su único modo de concebirlo. El objetivo del artista es "estar presente" para ofrecerle al público la posibilidad de presenciar junto a él un "acontecimiento", necesariamente indefinido, que suturaría de alguna manera la escisión arte-vida mediante la "ruptura de las barreras tradicionales en la circulación y la recepción de obras de arte" (Burello 2012: 177), y que por lo tanto solo deja lugar, si acaso, a una recepción intelectual.

Así, tanto la caracterización de este tipo de obras de danza por su

\footnotetext{
${ }^{1}$ Aunque no es este el móvil principal para poner en relación danza y literatura contemporáneas de Buenos Aires, permítase la observación de que escritores locales -Pablo Ramos en Recordar 30 años..., Pedro Mairal en Mi fiesta-han tenido una importante incidencia como acompañantes en la producción textual de las obras analizadas.
} 
inclusión de narraciones de la intimidad como hibridación de lenguajes escénicos como la que ve en ellas un movimiento vanguardista que viene a abolir aun la autonomía artística de la práctica ocultan una complejidad subyacente. En los recursos utilizados y en los resultados obtenidos se evidencia un hacer propio de un conjunto de artistas que integran una comunidad aún reconocida y reconocible como "de la danza", distinta de otras y, más aún, en ese hacer reconocible es que se observa la continuidad de un recorrido común: la búsqueda de discutir no con el teatro, al menos de manera privilegiada, sino con la danza, a la que pertenecen y quieren hacer hablar. En cualquier caso, en la construcción compartida de un universo temático y de una retórica de la intimidad se evidencia una alianza con la literatura actual y, para que tal alianza sea posible, como lo ha sido durante tanto tiempo en la historia de las artes, es necesario que danza y literatura permanezcan distintas (algo que, aún, nadie se ha atrevido a negar). Reconocer estos modos de la creación es el camino para que pueda pensarse y enseñarse críticamente en lugar de heredarse como un modo natural de hacer, un dogma invisible, mientras se sostiene a la vez, quizás porque habilita a no pensar su especificidad, la disolución de las barreras entre las artes y entre estas y "la vida".

\section{Propuestas para la ampliación del estudio: el nivel metadiscursivo}

Existe también otra característica de ocurrencia habitual del discurso hablado en la línea de la enunciación distanciada que se ha postulado, presente incluso en una de las obras abordadas: la operación autorreferencial, es decir, la referencia de la propia obra en la que se inscribe. En Boceto para la siesta de un fauno (Ruggeri 2016), la coreógrafa y directora de la pieza se ubica en escena y, además de cumplir un rol como bailarina, relata la historia de Preludio a la siesta de un fauno, la obra de VaslavNijinsky en la que se inspira su trabajo.

En María sobre María (Llopis 2016), por su parte, la bailarina solista relata un proceso de sistematización del repertorio de María Fux, cuyo resultado entrega en forma de lista a un miembro del público para que lea cada paso como indicación para que ella los ejecute. Basura (Herrero 2013), por su parte, presenta un caso que combina una fuerte presencia del ritmo en el discurso que vira desde un habla acompasada hacia un rap, pero cuya letra reviste, además, un carácter explicativo de ejes que permitirían guiar la lectura de la obra como una operación de reciclaje. Es notable, en este caso, que esta noción está presente también en el texto de gacetilla.

Sin uso del discurso verbal, Otra línea (Haidar 2018) produce efectos de sentido semejantes a través de la articulación entre danza en vivo y registro audiovisual, también ejecutado y reproducido en vivo. De esta manera, la obra parece plegarse sobre sí, retomando en espiral lo ya acontecido y de significando 
lo mediante la alusión en otro contexto.

Este uso metadiscursivo produce un extrañamiento en el sentido en que lo entiende el formalismo ruso (Shklovski 1916): en la medida en que los intérpretes señalan su propia práctica de manera explícita y, en consecuencia, también evidencian el rol del público en tanto espectadores de una obra, se propone una desfamiliarización (ostranenie) que establece distancia crítica respecto de la escena. Es posible considerar que sus efectos se ubican en línea con las características del discurso descrito hasta aquí como poético: obtura o reduce la probabilidad de que el discurso hablado pueda ser leído de modo análogo a un texto dramático, como constitutivo de la obra en términos de relato.

Se espera abordar esta característica de las obras recientes en un estudio ampliado que permita articular ambas dimensiones -la poética y la metadiscursiva- como tendencias propias de la narración autorreferencial a partir de la mediatización, entendida en su trayecto largo, del discurso hablado y de la tecnología del contacto en la danza contemporánea local, que puedan además ponerse en relación con experiencias tempranas, desde la danza futurista hasta piezas como Black Cake, de Hans Van Manen, y la mencionada obra Momentos, de Estela Maris Siroli.

\section{Obras del corpus y de referencia}

ARGÜELLO Rena, Celia. 2011. Villa Argüello.

BONARD, Mayra. 2018. Mi fiesta. Idea, interpretación, coreografía y texto de Mayra Bonard, este último en colaboración con Pedro Mairal.

HAIDAR, Iván. 2013. Lugar propio.

2018. Otra línea.

LLOPIS, Lucía. 2016. María sobre María.

OTERO, Marina. 2014. Recordar 30 años para vivir 65 minutos. Idea, dirección, interpretación, coreografía y texto de Marina Otero, este último en colaboración con Pablo Ramos.

RODOLICO, Yanina. 2016. FamilyGame.

ROSENTAL, Diego. 2018. Acróstico. Idea, dirección, interpretación, coreografía y texto de Diego Rosental.

RUGGERI, Mariela. 2017. Boceto para la siesta de un fauno. 
SIROLI, Estela Maris. Circa 1972. Momentos.

VAN MANEN, Hans. 1989. Black Cake.

\section{Bibliografía}

AGAMBEN, Giorgio. 2000. El archivo y el testimonio. Lo que queda de Auschwitz. El Archivo y el testigo. Homo Sacer III, 143-180. Valencia: Pre-Textos.

ARTAUD, Antonin. 2001 [1978]. El teatro y su doble. Barcelona:Edhasa.

BARTHES, Roland. 1972. Introducción al análisis estructural de los relatos.Análisis estructural del relato. Buenos Aires: Tiempo contemporáneo.

CATENA, Alberto. 2004. El siglo XX está marcado por un ataque al cuerpo, entrevista a Susana Tambutti. Cuadernos del Picadero, 3, 16-21. Buenos Aires: Ediciones del Instituto Nacional del Teatro.

CERVERA BORRÁS, Juan. 2003. Recitación y declamación. Teoría y técnica teatral. Alicante: Biblioteca Virtual Miguel de Cervantes.

CORNAGO, Óscar. 2005. Biodrama. Sobre el teatro de la vida y la vida del teatro. Latin American Theater Review, 1(39), 5-28. Kansas: Kansas University.

DE SAUSSURE, Ferdinand.2003[1945]. Curso de lingüística general. Buenos Aires: Losada.

DUCROT, Oswald. 1988. La polifonía en lingüística. Polifonía y argumentación. Cali: Universidad del Valle.

DURÁN, Ana y JAROSLAVSKY, Sonia.2012. Cómo formar jóvenes espectadores en la era digital. Buenos Aires: Leviatán.

FABBRI, Paolo. 1999. El giro semiótico. Barcelona:Gedisa.

GENOVESE, Alicia. 2011. Poesía y modernidad. La poesía como discurso inactual. Leer poesía. Lo leve, lo grave, lo opaco. Buenos Aires: Fondo de Cultura Económica.

HARDING, Denys. 1976. Words into Rhythm. English Speech Rhythm in Verse and Prose.Cambridge:Cambridge UniversityPress.

ISSE MOYANO, Marcelo. 2002. Cuadernos de danza III. Buenos Aires: Instituto de Artes del Espectáculo, Facultad de Filosofía y Letras, Universidad de Buenos Aires. 
2013. La danza en el marco del arte moderno/contemporáneo: los nuevos modelos de producción. Buenos Aires: Instituto Universitario Nacional del Arte.

JAKOBSON, Roman. 1981. Lingüística y poética. Ensayos de lingüística general. Barcelona:Seix Barral.

LÁBATTE, Beatriz. 2006. Danza-teatro - ¿teatro-danza? EnCuadernos del Picadero, 10, 18-19. Buenos Aires: Instituto Nacional del Teatro.

LANGER, Susanne. 1953. Form and Feeling: A Theory of Art. New York: Scribner's. Citado en Barretta, Claudia, Miramontes, L. y Zorrilla, A. 2013. Ritmando danzas. Análisis rítmico de la danza. Buenos Aires:Autores de Argentina.

LÁZZARO, Ana.2011. Cuerpos imaginados: danza, transformación y autonomía. EuropeanReview of ArtisticStudies, 4(2). Vila Real:Universidade de Trás-osMontes e Alto Douro.

MIRAUX, Jean-Philippe. 2005. La autobiografía: las escrituras del yo. Buenos Aires: Nueva Visión.

PEIRCE, Charles. 1974 [1965]. La ciencia de la semiótica (fragmentos). Buenos Aires: Nueva Visión.

ROCHA ALONSO, Amparo. s.f.Entre la voz y la voz. La voz y el canto: materia y expresividad.Inédito.

RUBIN, María José. 2017. El discurso hablado en la danza, aproximaciones entre la narratividad y la mediatización, ponencia presentada en el II Congreso Revueltas del Arte, Buenos Aires, Universidad Nacional de las Artes, 4-6 octubre.

2018. Pantallas en escena, escenas en pantalla: dos casos de interacción danza-transmisión en directo, ponencia presentada en el II Congreso Internacional de Artes: Límites y Fronteras, Chaco, Facultad de Artes, Diseño y Ciencias de la Cultura de la Universidad Nacional del Nordeste, 18-20 julio.

SHKLOVSKI, Victor. 1978 [1916]. El arte como artificio. En Todorov, Tzvetan (comp.). Teoría de la literatura de los formalistas rusos. México: Siglo XXI.

TEMPERLEY, Susana. 2017. Videodanza, complejidad y periferia. Buenos Aires:RGCediciones.

TRAVERSA, Oscar. 2009. Dispositivo-enunciación: en torno a sus modos de articularse. Figuraciones, 6.

2016. El trayecto del gesto a la plena mediatización de la escritura, 
Foro Mediatización y Narratividad del Congreso internacional de Semiótica "Miradas, recorridos, y nuevos objetos de conocimiento", Federación Argentina de Semiótica, Santa Fe-Paraná, 15-17 septiembre.

2019. Ficción narrativa y mediatización: acerca de sus relaciones. Cuadernos del Instituto. Investigación y Experimentación en Arte y Crítica, 4, 7-16.

VERÓN, Eliseo. 1974. Para una semiología de las operaciones translingüísticas. Lenguajes, 2. Buenos Aires: Nueva Visión.

2002. Efectos de agenda II. Espacios mentales. Buenos Aires:Gedisa.

WEISZ, Gabriel. 1994. Palacio chamánico. Filosofía corporal de Artaud y distintas culturas chamánicas. México: UNAM/Grupo Editorial Gaceta. 


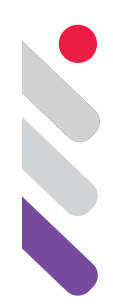

\section{Historia, montaje, archivo: para una performatividad de la memoria}

DOI: $10.24308 /$ IASS-2019-4-026

Mgtr. Cecilia Tosoratti

Universidad Nacional de las Artes (UNA)

c.tosoratti@una.edu.a

El arte no ha de representar las cosas ni como evidentes (hallando aprobación sentimental), ni como incomprensibles, sino como comprensibles, pero todavía no comprendidas.

(Brecht en Didi-Huberman 2008)

En los últimos años el pasado reciente de la Argentina se ha repensado desde diversas producciones artísticas. Abordar la memoria desde la realización escénica, la exhibición visual o la realización audiovisual conlleva la pregunta acerca de si el arte permite un tipo particular de cognoscibilidad y decibilidad de la historia. A partir de los debates que se produjeron tanto desde la estética francesa con autores como Jacques Rancière y George Didi-Huberman como del posicionamiento de Claude Lanzmann respecto de las imágenes de archivo, podemos afirmar que la reactualización del pasado traumático implica, siempre, una tensión problemática entre la posibilidad o imposibilidad de su (re)presentación. En este marco, me propongo analizar el tratamiento del pasado y de producción de memoria en tres obras presentadas en la Sala PAyS del Parque de la Memoria: "Investigación del cuatrerismo", de la muestra Operación fracaso y el sonido recobrado, de Albertina Carri (2015); "Cadena nacional", de la exhibición Doble de riesgo, de Lola Arias (2016) y "Habeas Sonus. La memoria auditiva", de Mariano Speratti, en el marco de la muestra EI futuro de la memoria (2018).

\section{1. "Cadena nacional"}

Esta videoinstalación recorre, en nueve televisores dispuestos casi en semicírculo, cuarenta años de historia argentina, de Videla al último presidente electo en 2015. Las cadenas nacionales no son reproducidas por los presidentes sino por performers que doblan sus discursos. Son ciudadanos que han estado afectados por las circunstancias históricas que desencadenaron dichos 
discursos: Mariano Speratti, hijo de desaparecidos, imita la primera cadena nacional de Videla; un excombatiente de Malvinas dobla a Galtieri; un joven baleado en los enfrentamientos del 2001 hace el play-back de De la Rúa; el hijo de Julio López gesticula la cadena de Néstor Kirchner; una niña cuya madre fue despedida del CCK dobla a Macri. En la imagen se ve al performer sentado en el sillón presidencial, detrás de un escritorio con una bandera argentina a su izquierda. Los performers hacen la mímica del discurso presidencial con mayor o menor sincronía. Recrean los gestos en un arco variado de afectos: algunos con frialdad, otros con bronca, con ironía y hasta con empatía, como en el caso de la actriz recientemente viuda que dobla a Cristina en la cadena después de la muerte de Néstor. Los discursos oficiales llevan un subtítulo en tercera persona con la identidad del performer y la historia de vida afectada por la circunstancia histórica.

En el centro entre las dos series de televisores se recrea la escenografía: el sillón presidencia, el escritorio y la bandera. El espectador puede sentarse en el sillón de Rivadavia y realizar su propia cadena nacional, una cámara registrará la imagen y la proyectará en el último televisor.

La obra pone en juego un dispositivo que conjuga tiempos y espacios heterogéneos: el tiempo pasado (1976, 1982, 2001, 2015, etc.); un espacio/ tiempo desde el que el performer dobla el discurso de los jefes de estado; y el presente del espectador que funciona como futuro -en relación con el discurso histórico-. De esta forma, el sonido trae el pasado al presente, la imagen del performer lo interpreta, lo cuestiona y problematiza, y espectador interviene en la obra con su cuerpo para tener un lugar en la historia.

La distancia entre archivo sonoro e imagen produce un extrañamiento que evidencia el estatuto de representación y provoca, en términos de DidiHuberman, "una cuestión de conocimiento y no de ilusión" (2008: 77). La disociación entre el discurso sonoro, la imagen y el zócalo, expande el sentido y permite dar cuenta de la existencia de una red de relaciones que el espectador tiene que establecer para multiplicar heurísticamente sus puntos de vista y posibilitar una mirada crítica el pasado reciente.

\section{2. "Investigación del cuatrerismo"}

Es una videoinstalación con cinco pantallas que proyectan en simultáneo una serie de imágenes históricas junto a imágenes del cine, de la publicidad, incluso imágenes banales y cotidianas. Aparecen audiovisuales de la dictadura de Videla; del Mundial de Fútbol '78; publicidades del momento; paisajes de Chaco; escenas gauchescas; afiches de películas; rostros sonrientes de figuras del cine; películas en blanco y negro; noticieros de los años setenta.

En paralelo a las imágenes, un relato en off encarnado por la actriz Elisa Carricajo relata la búsqueda infructuosa sobre el pasado de Roberto Carri, de 
una película perdida y su director desaparecido, Pablo Szir ${ }^{1}$. Para ser más clara, en 1968 Roberto Carri escribe su primer libro, Isidro Velázquez. Formas prerevolucionarias de la violencia, sobre el bandido Isidro Velázquez, un "Robin Hood" criollo que operaba en la provincia de Chaco a mediados del siglo pasado. Albertina quiere hacer una película sobre Isidro Velázquez. En esa búsqueda aparecen varios guiones fallidos, viajes absurdos a Chaco, encuentros extraños -el hijo de Velázquez, el hijo de Elisa Carrió, fantasmas familiares-, relatos no dichos. La única película que pudo hacerse sobre Velázquez, la de Szir, está desaparecida como su director, Roberto Carri, como mencioné antes. El monólogo leído por Carricajo en tono monocorde refiere a las experiencias emocionales e íntimas de Albertina asociadas al fracaso que conlleva la búsqueda sobre el pasado. ${ }^{2}$ Albertina dice sentir incomodidad, vergüenza, confusión, torpeza, desorientación, espanto, al intentar de acceder al material perdido.

En la yuxtaposición de materiales que se proyectan en la pantalla no hay rangos diferenciales entre historia pública y privada. El orden y las jerarquías de los archivos de origen se derrumban en la superposición constante de imágenes históricas junto a otras de relativa relevancia; no hay distinción entre lo superfluo y lo históricamente importante. Carri siente frustración al intentar reconstruir el archivo. Las emociones ligadas al fracaso develan el rechazo de generar algún tipo de legibilidad del pasado, alguna forma de resignificación. Según Cecilia Macón, "el modo en que se introduce esta sucesión/superposición de fracasos involucra así un arco particular de afectos capaces de constituir el contra-archivo que presenciamos proyectado en las cinco pantallas y el monólogo que las hila en tanto imposibilidad" (2017: 425). Operación fracaso -título del nombre de una operación policial de 800 efectivos que no logró detener a Velázquez- es también el nombre de la exhibición y alude tanto a la derrota de la generación de los años setenta como al fracaso de la generación de Albertina al intentar reconstruir la vida de sus padres desaparecidos.

\section{3. "Habeas Sonus. La memoria auditiva"}

A diferencia de las anteriores, la instalación de Mariano Speratti busca pensar la memoria no ya desde las imágenes, sino mediante el registro sonoro.

\footnotetext{
1 "A partir del primer libro que escribió mi padre, Isidro Velázquez formas pre-revolucionarias de la violencia, viajo a Chaco a buscar los pasos de Isidro y por qué no de mi padre y su proyecto político también. Quiero hacer una película y paso cinco años escribiendo guiones que no son filmables. Me encuentro con muchas películas sobre Velázquez que no pudieron hacerse, solo una y ella está desaparecida también, como mi padre y el director de la misma".

2 "Resistencia fue una pérdida de tiempo pero me sirvió para visitar a la tía Margarita, una prima de mi padre que se fue a vivir a Chaco cuando se casó con un antropólogo misionero. La tía me llevó a su jardín y me mostró una cruz escondida entre los rosales que ostentaba una chapa labrada a mano con la inscripción '1823-1835'. Con tono bajo me soltó su secreto: 'es de mi hijo muerto'".
} 
La instalación se plantea como una posible banda sonora de la memoria retransmitida al futuro. En la sala se exhibe un video que muestra la llegada de un grupo de niños al Parque de la Memoria, cien años después del inicio de la dictadura. En ese futuro posible de la ficción, las imágenes se han apagado y los chicos buscan los rastros sonoros del pasado. Llevan lentes que los protegen de las imágenes en un parque repleto de íconos. Allí desentierran un objeto que contiene los sonidos del pasado. Por momentos, la única imagen del video es el Río de La Plata en su movimiento.

Por medio de auriculares los visitantes acceden a los spots publicitarios de la dictadura. Speratti indaga sobre los sentidos comunes que instalaba el régimen dictatorial: "el orden, el trabajo y la familia como pilares de la sociedad"; "enemigo interno"; "anticuerpos"; "cada uno en lo suyo"; "un país para los argentinos". Además, mediante los celulares es posible acceder acuatro archivos sonoros -"Los sonidos del silencio"; "Manteniéndose vivo"; "El sonido y la furia" y "Los sonidos del río"- diseñados para componer la banda sonora original de la memoria. Estos links recopilan los sonidos de ciudadanos cuyas vidas marcadas por la cárcel, la desaparición o el exilio, eligen guardar en la cápsula que mandarían al futuro como ejercicio de supervivencia y memoria.

En "Habeas Sonus: punto de partida y derivas" Speratti dice: "Escuchar una voz grabada trae a la persona de un modo contundente, es como un acto de médium haciendo presente al espíritu que golpea tres veces para señalar su presencia. Doy con algunas publicidades de la dictadura. Primero, las más conocidas, las que me resultan familiares, una parte ineludible de la educación sentimental de los niños criados en los setenta. Vuelvo a encontrarme con muchas de ellas después de tanto tiempo. Cierro los ojos, momentáneamente borro las imágenes. Escucho con el cuerpo y más allá de las palabras". ${ }^{3}$

En el dislocamiento entre la imagen del futuro y el archivo sonoro -que hace presente el pasado-se genera sentido. Pero además las huellas del pasado penetran directamente en el cuerpo del espectador provocando reacciones físicas y afectivas. El sonido atraviesa el límite corporal y encuentra su caja de resonancia en el cuerpo de quien escucha. Los sonidos instauran lugares y tiempos; reconstruyen lo que no se puede ver, lo que escapa a la representación: la puerta del ascensor que se abre antes de la detención; los ecos de la cárcel; los ruidos de las armas golpeando sobre el asfalto; el silencio de las noches de terror; los sonidos de la vuelta de Perón; los sonidos del río que va y viene.

El archivo sonoro de la memoria aparece asociado a las experiencias emocionales vinculadas al pasado traumático: los sonidos del miedo, de la ausencia, del silencio, pero también los sonidos asociados a la vida y a la humanidad: "los sonidos que nos recuerden "quiénes somos" y "que somos

${ }^{3}$ https://www.espaciomurena.com/9960/ 
humanos", dice la hermana de una detenida-desaparecida. O el sonido del río que recuerda los veranos de la infancia de Valentina en Córdoba cuando su madre estaba presa. El sonido del río adquiere una dimensión simbólica por su movimiento de ir y venir como el flujo de la memoria.

Por último, quisiera señalar un punto de contacto entre "Habeas Sonus" con Mi vida después (Lola Arias, 2010), cuando la voz del padre de Mariano Speratti, Horacio, que en esa obra participaba como actor, irrumpe en escena como un fantasma de la historia. En ese momento Mariano decía: "Esta es la parte que más me gusta: mi padre diciendo mi nombre". La escena cobraba mayor fuerza simbólica porque era Moreno Speratti, de 4 años, hijo de Mariano, quien encendía el grabador para dar lugar a esa especie de reliquia sonora que volvía presente la figura ausente. En el mismo sentido, el título "Habeas Sonus" -"sonido presente"- remite al Habeas Corpus, procedimiento jurídico al que apelaban los familiares de detenidos ante los arrestos ilegales durante la dictadura. Una vez más el archivo sonoro hace presente el cuerpo ausente del detenido-desaparecido.

Siguiendo a Jacques Derrida (1998), sólo es posible una política de la memoria en la contemporaneidad del presente vivo con el pasado y el porvenir. $\mathrm{Y}$ es nuevamente Moreno, hoy adolescente, que viene del futuro para conectar a las generaciones con el pasado. La instalación sonora de Speratti establece así esa conexión necesaria e imperativa de vivir con los fantasmas de nuestra historia.

\section{Historia, archivo y memoria}

Las instalaciones analizadas ponen en cuestión una temporalidad lineal de la historia mediante la yuxtaposición de tiempos y espacios. Se montan discursos oficiales con historias de vida; imágenes de archivo audiovisual con imágenes cotidianas y poca relevancia; publicidades y marchas militares con los sonidos del recuerdo de los sobrevivientes. Estas conexiones generan un extrañamiento que desarma y pone en cuestión la percepción habitual de las relaciones entre situaciones aparentemente desconectadas entre sí.

Desde la perspectiva dialéctica de Walter Benjamin (2008), el pasado debe pensarse en el movimiento del tiempo, con sus interrupciones y discontinuidades, a partir de sus bifurcaciones en múltiples direcciones y sentidos. Esta mirada traslada el punto de vista del pasado como "hecho objetivo al pasado como hecho de memoria"4 (2008a: 155). El pasado no se presenta como recuerdo, sino como debate del recuerdo y, en este sentido, la memoria se produce en su performatividad; en su hacer-se en el presente.

El espectador dis-pone, desconecta y reconecta situaciones, tiempos, imágenes y sonidos con sus propios recuerdos, incluso con sus proyecciones

${ }^{4}$ Las cursivas son del autor. 
imaginativas sobre el futuro.

En un sentido clásico, el archivo conservaba, jerarquizaba, legitimaba textos, imágenes y objetos del pasado; en las obras, la experiencia del pasado se produce en un proceso de conexión y desconexión, de yuxtaposición, bifurcación y montaje, que da cuenta de lo incompleto, de la fragmentación, incluso de la imposibilidad del control del archivo, en la posición más radical de Carri.

Quisiera destacar aquí la revitalización que produce para la restitución de memoria el trabajo sobre el sonido. En ese juego de imaginar un futuro sin imágenes, Speratti propone al espectador acceder a la experiencia del pasado con el cuerpo. Es la presencia del cuerpo propio, del estar allí, que se convierte en lugar de conocimiento de la historia.

La dimensión estético-política de las obras analizadas reside en exponer la paradoja entre la totalidad y la fragmentación; entre lo que se puede mostrar, lo que se puede oír y lo que queda como resto, como fuga de apertura al sentido.

En el ejercicio de resistencia frente al olvido es la herencia y las generaciones futuras quienes deban refundar nuevos territorios de memoria. La presencia de los niños nos permite pensar la posibilidad de alguna transmisión de saber y memoria. En palabras de Carri: "Mi hijo le dice a una amiguita que vino a jugar a casa la siguiente sentencia: 'con las cámaras y los proyectores es al revés que con los caballos, siempre se pasa por atrás". Escuché eso y sentí que ahora había llegado a algún lado".

\section{Bibliografía}

BENJAMIN, Walter. 2007. Conceptos de filosofía de la historia. Buenos Aires: Caronte Filosofía.

BENJAMIN, Walter. 2002. Dialéctica en suspenso. Fragmentos sobre la historia. Santiago de Chile: ArcisLom.

BENJAMIN, Walter. 2007. Libro de los pasajes. Madrid: Akal Editores.

BRECHT, Bertold. 2008. Sobre el distanciamiento. En DIDI-HUBERMAN, Georges. Cuando las imágenes toman posición. El ojo de la historia I. Madrid: Antonio Machado Libros.

DIDI-HUBERMAN, Georges. 2008a. Ante el tiempo, Buenos Aires, Adriana Hidalgo.

DIDI-HUBERMAN, Georges. 2008b. Cuando las imágenes toman posición. El ojo de la historia I. Madrid: Antonio Machado Libros. 
DERRIDA, Jacques. 1998. Los espectros de Marx. Madrid: Editorial Trotta.

MACÓN, Cecilia. 2017. Archivos alterados: Lola Arias o Albertina Carri. Imagofagia (16), 420-438.

RANCIÈRE, Jacques. 2005a. Sobre políticas estéticas. Barcelona: Universidad Autónoma de Barcelona.

RANCIÈRE, Jacques. 2005b. Las poéticas contradictorias del cine. Pensamiento de los confines (17), 9-17. 


\section{MEDIACIONES}

C. OPERACIONES EN FOTOGRAFÍA, HISTORIETA Y PINTURA 



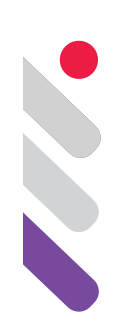

\title{
Innovaciones discursivas y nuevas estéticas de la historieta argentina contemporánea ${ }^{1}$
}

DOI: 10.24308/IASS-2019-4-027

\author{
Gaspar Buono \\ Universidad Nacional de las Artes, Argentina \\ gasparbuono@gmail.com \\ Laura Amarilla \\ Universidad Nacional de las Artes, Argentina \\ lauranoeliaamarilla@gmail.com \\ Andrea Acosta Camargo \\ Universidad Nacional de las Artes \\ Universidad de Buenos Aires, Argentina \\ liralyra@gmail.com
}

\section{Abstract}

La vasta trayectoria del lenguaje de la historieta evidencia un recorrido de múltiples cambios y mutaciones que han sido objeto de variadas investigaciones. Sin embargo, se ha detectado un espacio teórico de vacancia en el estudio de las disrupciones en la historieta argentina del siglo XXI. El punto de partida de este trabajo es la identificación metadiscursiva de producciones artísticas contemporáneas -encuadradas bajo el género novela gráfica y/o historieta- que presentan ciertas innovaciones y se alejan de los esquemas de representación históricamente convencionalizados. Estas innovaciones son puestas en tensión con un concepto general de la historieta tradicional y del paradigma productivo imperante en el mercado local, la novela gráfica, ambos relacionados con una concepción en especial narrativa de este lenguaje. La herramienta utilizada para efectuar la indagación resulta de la combinación del análisis en tres niveles de Oscar Steimberg (2013), con algunas categorías

\footnotetext{
${ }^{1}$ El presente trabajo es una versión resumida de la investigación desarrollada en 2018 en el marco de nuestro proyecto de graduación en la Licenciatura en Crítica de Artes de la U.N.A., en colaboración con otros dos colegas (Facundo Carmona y Eugenia Lino). La investigación allí disponible expone el marco teórico y el abordaje metodológico de forma detallada, tiene la definición de cada una de las variables usadas en el cuadro analítico y una explicación más amplia de los modelos discursivos.
} 
de la teoría peirceana de los signos (1986), conceptos inherentes a la relación enunciativa según Eliseo Verón (2004) y otras nociones extrapoladas de las teorías del cine y la literatura. En vistas a un análisis sincrónico, que no pretende la reconstrucción histórica de su objeto ni de las condiciones de su circulación, la comparación entre los textos permitió identificar regularidades y diferencias en los niveles retóricos y enunciativos para establecer una serie de tipologías y agrupamientos de las historietas analizadas y articular las modalidades específicas de sus transgresiones. Las conclusiones alcanzadas son modelos conceptuales que, sostenidos en operaciones observables, permiten ponderar la justa trayectoria discursiva entre la tradición y la novedad, así como distinguir la cualidad constructiva o deconstructiva de esta última.

Palabras claves: novela gráfica, comic, vanguardia, ruptura, semiótica de las artes, lenguaje historietístico, análisis retórico, análisis enunciativo.

\section{Identificación del objeto de estudio}

La identificación del objeto de estudio surge de tres maneras. En primera instancia, la utilización del término "vanguardia" o "disruptivo" al respecto de ciertas manifestaciones de la historieta contemporánea lo implementan en España una serie de reconocidos críticos, teóricos y periodistas especializados, en el período que va del 2012 al 2016 (García, Vilches, Beáres, Muñoz Fernández). Luego, en 2017, el debate sobre la idoneidad del concepto y del vocablo "vanguardia" se instala en Argentina en la publicación especializada Revista Kamandi. La polémica es consecuencia de la inadecuación historiográfica de la etiqueta. Sin embargo, ninguno de los participantes niega la existencia no-excepcional de un tipo de historieta distinto al cristalizado históricamente. La emergencia de un fenómeno estético novedoso resulta evidente para todos ellos.

En segundo lugar, a partir de 2014 se advierten expresiones de la prensa argentina (la especializada y la generalista) que dan cuenta del asombro, la incomprensión, el rechazo, la admiración y, en general, el esfuerzo interpretativo al que impelen esta clase de discursos. La variedad de reacciones no deja de señalar lo innovador de las historietas involucradas, entre las que se cuentan cada uno de los integrantes de corpus contemplado para este análisis. Al concepto teórico antes identificado se le suman entonces las referencias puntuales sobre determinadas historietas argentinas por parte de los actores del campo.

Por último, se puede establecer la característica discursiva que abarca todos estos casos (valiéndose de las palabras de O. Steimberg) como el hecho de que proponen un ejercicio de lectura distinto al convencional y suscitan, por lo tanto, una lectura diferente. La definición semiótica de innovación en este trabajo es: todo recurso discursivo que obliga a un cambio fundamental (muchas 
veces radical) de las gramáticas de lectura implicadas, al menos para que se propicie un reconocimiento dentro de lo pertinente (la absoluta incomprensión siempre es una opción). Esto es posible saberlo a priori, inclusive antes de comprobar la recepción efectiva. Son operaciones constitutivas fuera de todo horizonte de expectativas, puesto que alteran el funcionamiento enunciativo del artefacto discursivo - para este caso la historieta- como tal.

\section{Corpus}

Los criterios utilizados para la selección consisten en que son obras editadas entre el 2014 y el 2018 en libro impreso, respaldadas por una casa comercial. Se eligió una sola obra por autor y se buscó la diversidad (a priori) de los recursos disruptivos observables.

- BELLINI, Muriel y VON CHUYO, Gustavo. 2017. Exes. Buenos Aires: El Waibe. 27 p. B/N.

- CALVI, Fernando. Altavista. Buenos Aires: Hotel de las Ideas. 190 p. Color.

- DEPETRIS, Manuel. 2015. ¿Qué clase de casa es esta? Buenos Aires: La Pinta. 180 p. B/N.

- FREGA Muriel y MAGUREGUI, Carina. 2017. Modus Operandi. Buenos Aires, Mala Praxis. 47 p. Color.

- GONZÁLEZ, Hernán y SANTAMARINA Luis. 2015. Misterios. Buenos Aires: Buen Gusto Ediciones. 80 p. B/N.

- LEPKA, Nicolás. 2016. La casa de la risa. Buenos Aires: Buen Gusto Ediciones. 97 p. B/N.

- MANCINI, Pedro. 2016. Ultradeformer. Córdoba: Prendefuego Colectivo Editorial. 46 p., B/N.

- MEALLA, Nicolás. 2017. Curso de pensamiento paranoico. Buenos Aires: Panxa Comics. 122 p. B/N.

- QUIEN, Jorge. 2015. Los Sofistas. Santiago de Chile: Ril Editores. 94 p. $\mathrm{B} / \mathrm{N}$.

- RISKIN, Iván. 2016. Fragmentos y distorsión. Buenos Aires: Wai Comics. 65 p. B/N.

- VEGETAL, Juan. 2017. Ciber- city: Internet Pseudo-sistem. Buenos Aires: Wai Comics. 51 p. Color.

\section{El abordaje metodológico y analítico}

Se llevó a cabo un análisis en tres niveles (aunque uno de ellos fue finalmente descartado) tal como fue formulado por Steimberg (2013a) y aplicado a las historietas por Federico Reggiani (2009), pero que no se ha utilizado para estudiar las operaciones discursivas innovadoras de la historieta 
contemporánea argentina. El objetivo inicial fue determinar cuáles son los rasgos de la historieta tradicional que usan o desusan los casos examinados y de qué modo y, en segunda instancia, en qué nivel semiótico operan estas disrupciones. Se confeccionó un cuadro analítico de doble entrada (Tabla 1) en el que se desagrega el lenguaje historietístico en 26 variables discursivas y se le asigna el estado de cada una de ellas (con un gradiente de 5 niveles) a las obras analizadas, para compararlas a su vez con un modelo genérico de historieta convencional. El nivel temático fue excluido porque no puede conformar una ruptura al nivel del lenguaje por sí mismo. No hay temas que puedan funcionar como rupturistas en la dimensión disciplinar sin estar asociados a una estética transgresora. Las variables marcan una tendencia, no son excluyentes entre sí ni de carácter absoluto.

\section{Conclusiones puntuales: $\mathbf{1 1}$ modelos discursivos de ruptura}

Muchas de las innovaciones que representan una transgresión a los criterios convencionalizados en la producción de historietas resultan del grado o estado de una sola variable, mientras que otras dependen de la interacción compleja entre varias de ellas. Los primeros son modelos discursivos simples y los segundos complejos. Una vez identificadas las regularidades y diferencias entre los casos observados de ambos tipos de dinámicas se ha construido una tipología de modelos discursivos. Estos modelos agrupan a las $26^{2}$ historietas estudiadas según su operatoria disruptiva y, en conjunto con la explicación del funcionamiento de cada uno, definen un comportamiento discursivo específico y son las conclusiones puntuales de esta investigación. La hipótesis de este trabajo es que estos modelos constituyen el factor decisivo de la ruptura. En otras palabras, puede que varios de los otros rasgos configuren en parte la novedad en el funcionamiento discursivo de los textos observados, pero lo hacen en combinación necesaria con el comportamiento señalado sin el cual su carácter disruptivo global no sería posible.

\footnotetext{
${ }^{2}$ En esta instancia de análisis se han tenido en cuenta las historias cortas que integran dos de los libros y que se consideran por separado debido a que el funcionamiento discursivo en el que operan difieren entre sí.
} 


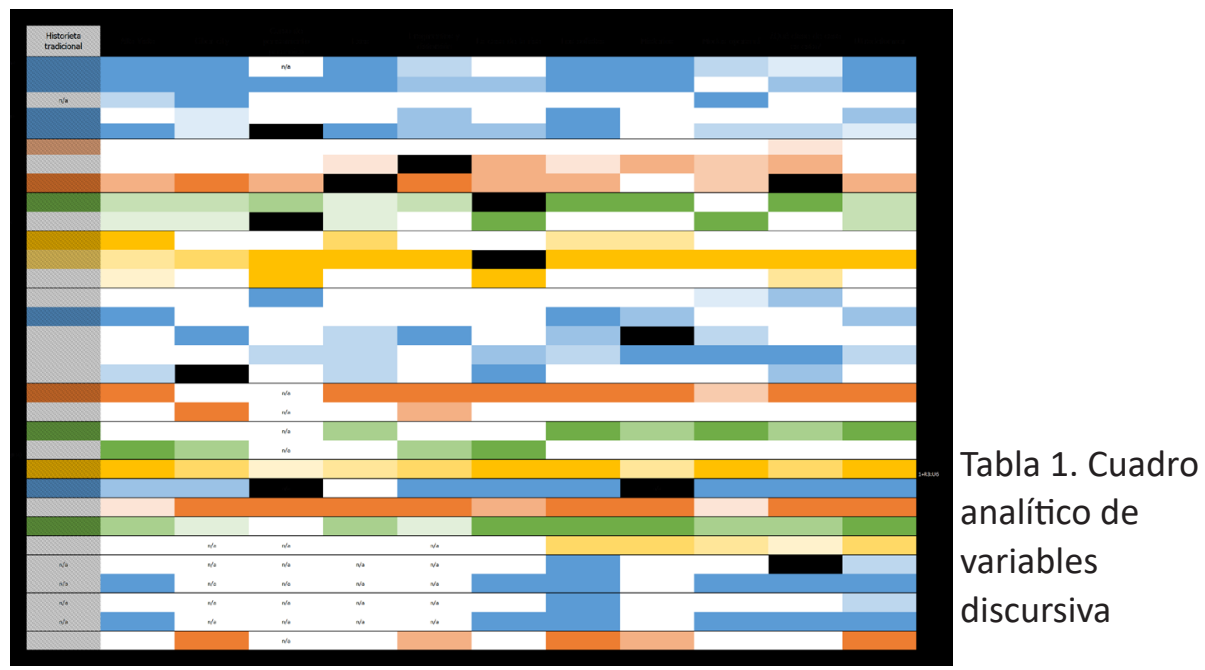

Ruptura gráfica (retórica, modelo simple): es aquella que se distingue a simple vista ya que surge por la extremación legisígnica o el carácter cualisígnico del grafismo utilizado, es decir, por lo pictórico de las imágenes o por la extrema reducción convencional. Es perceptible en una única viñeta. La variable discursiva de la que depende para constituirse es el tipo de representación icónica y está asociado a la función discursiva plástica. La primera variante está representada en el corpus, en su versión más radical, por la obra de I. Riskin (Fig. 1). Mientras que la segunda tiene sus ejemplos máximos en los dibujos de M. Depetris, $\mathrm{H}$. González y M. Bellini. (Fig. 2, 3 y 4).

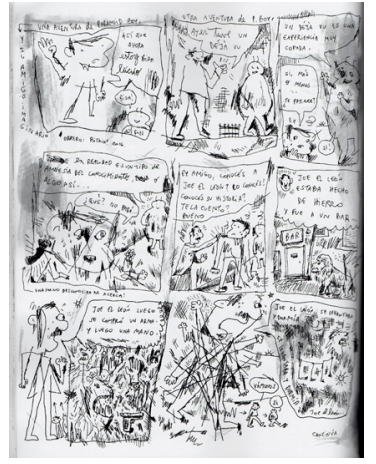

Fig. 1. Riskin

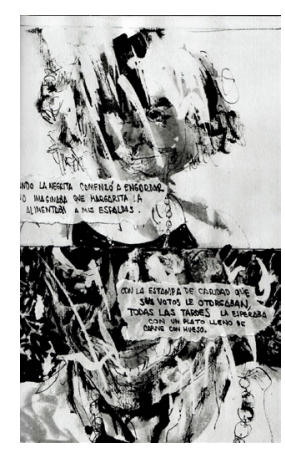

Fig. 2. Depetris

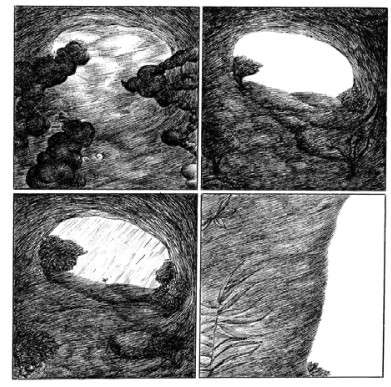

Fig. 3. González

Ruptura figurativo referencial (retórica, modelo complejo): surge de la combinación de una capacidad de referencia baja con un dibujo convencional. ¿Cómo es esto posible? Una imagen convencional es por definición una representación transparente, un esquema visual de lo referenciado. De modo que solo puede ser que lo opaco ya no sea la representación sino aquello que representa. Sin dudas en Curso de pensamiento paranoico lo que se muestra 


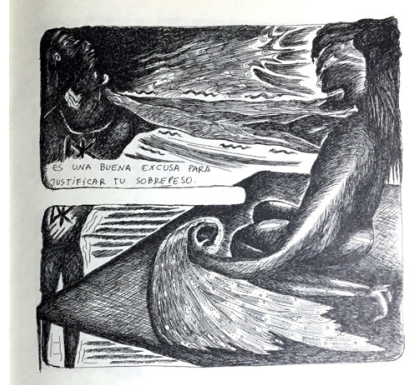

Fig. 4. Bellini

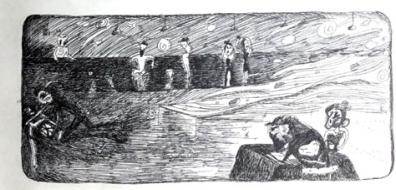

son seres, entidades u objetos vivos, pero que en contadísimas ocasiones se reconocen del todo (Fig. 5). La referencia es clara en partes, unos ojos, una mano, una pistola, pero estas cosas conocidas conforman una figura mayor integrada por muchos otros elementos extraños.
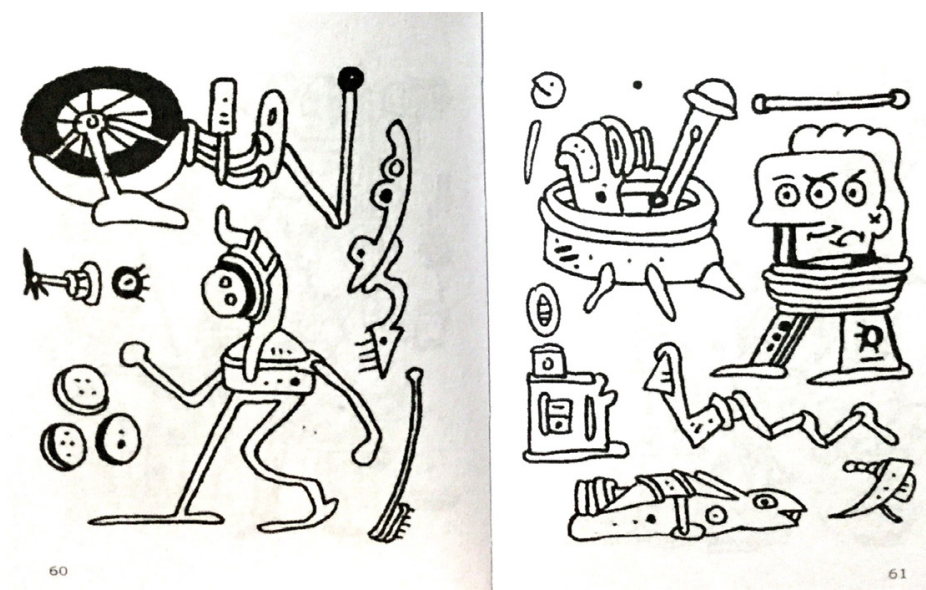

Fig. 5. Mealla

Ruptura sintáctica (retórica, modelo simple/complejo): Se distingue tanto a simple vista como en la lectura. Atañe a la relación de una serie de imágenes en secuencia. Las variables discursivas fundamentales para esta ruptura son la direccionalidad, el tipo de lectura secuencial y las unidades significantes utilizadas. Puede ser un modelo simple, ya que la multi-direccionalidad o el esquematismo bastan por si solos para sacarlo de una retórica convencional. De hecho, en Altavista (Fig. 6) y La casa de la risa (Fig. 7) la disrupción consiste en proponer una sintaxis que no construye escenas en las secuencias de viñetas, cualidad que suele ser señalada como intrínseca y esencial para la historieta tradicional como disciplina. 

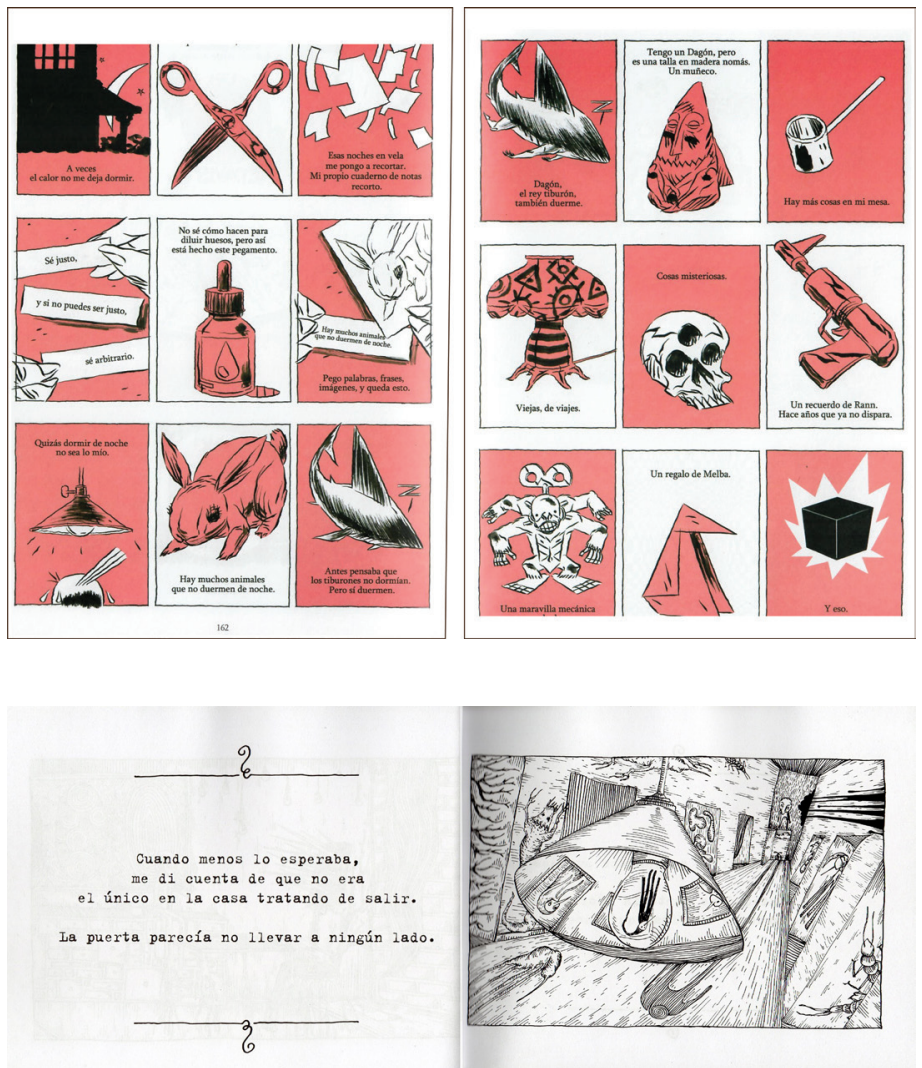

Fig. 6. Calvi

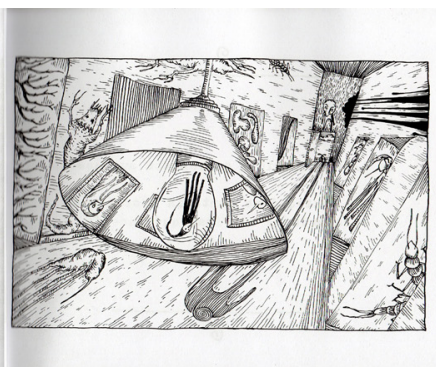

Fig. 7. Lepka

Cuando se combinan una lectura multi-direccional y un tipo de lectura secuencial esquemático se configura una ruptura sintáctica compleja que puede Ilamarse función diagramática. Es el caso Ciber-city. La función diagramática asemeja la puesta en página a un cuadro sinóptico con imágenes. Altera la direccionalidad lineal de una lectura sostenida en el ordenamiento espacial (en esquema) mediante indicaciones tales como flechas, líneas lógicas, etc. La página se conforma como un mapa de relaciones de sentido. (Fig.8).

Palabra híper-significante (ruptura retórica, modelo simple): en Los sofistas aparecen construcciones verbales como "radiación conductista", "sistema de texturas", "prestaciones orgásmicas", etc. Cada término considerado de manera individual es un vocablo conocido y perteneciente a un área temática o conceptual determinada. Es su combinación la que produce un extrañamiento respecto de ese universo semántico en el que se insertan y en el que su significado original se ve extrapolado. En este nuevo universo conceptual ¿las texturas hacen sistema? ¿Los colores se pueden desclasificar como archivos? ¿La demanda de un mercado puede ser gasificada como un líquido? Los significados no se pierden ni resultan inaccesibles, más bien se multiplican dentro de una determinada área de sentido que a su vez conforman. 


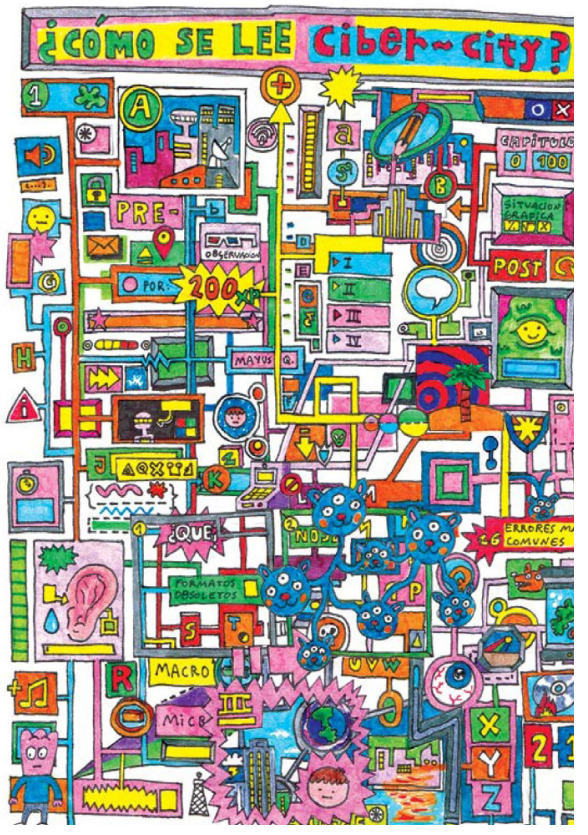

Fig. 8. Vegetal
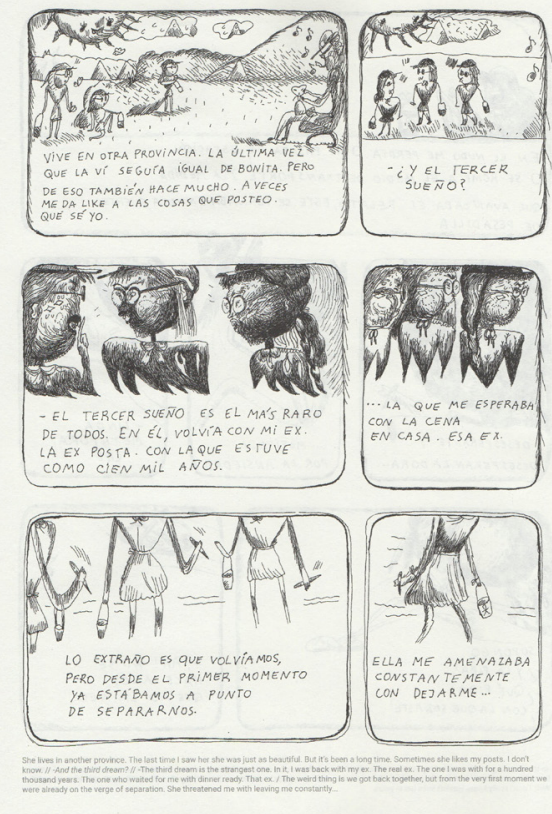

Fig. 9. Bellini

La enunciación paralela (ruptura enunciativa, modelo simple): es la cualidad revulsiva fundamental de Exes, una enunciación sin relación evidente entre el texto y los dibujos. Es un rasgo considerado en la variable concordancia temática entre texto e imagen. En esta obra es constante el casi inexistente contacto temático entre ambas materias significantes. (Fig. 9).

Efecto diegético mínimo (ruptura enunciativa, modelo complejo): es la incapacidad que muestran ciertas obras para construir un espacio-tiempo, o, en otras palabras, una escena (ya sea en la secuencia o en una única imagen). Es un modelo complejo asociado, en general, a tres rasgos discursivos: la representación icónica legisígnica, el tipo de lectura secuencial esquemático y una capacidad inmersiva baja. La obra de Vegetal, la de Riskin y la de Mealla, son aquellas en las que la página misma como espacio no-ficcional del enunciado emerge con mayor nitidez y hace imposible el efecto implícito de expansión del universo ficticio llamado diégesis.

Diégesis visual figurada (ruptura enunciativa, modelo complejo): se constituye cuando hay reiteración insistente en la representación icónica indirecta, de modo que se construye un espacio-tiempo que en la dimensión visual es casi por completo metafórico, metonímico, hiperbólico, simbolista o figurado de alguna manera (en cuanto implementa figuras retóricas sobre la imagen). Resulta de la combinación de las variables representación metafórica/ simbólica con un tipo de lectura secuencial escénico y cierta capacidad 
inmersiva. Hay dos historietas dentro del corpus que presentan tal combinación de manera suficiente para configurar una ruptura, son Modus Operandi y "El hombre que no podía bailar inventa la máquina de desaparecer", contenida en Ultradeformer.

Dentro de la obra de Maguregui y Frega los médicos son representados como espantapájaros con barbijo, los instrumentos quirúrgicos como rastrillos y sierras circulares, etc. (Fig. 10). Por otra parte, la historieta de P. Mancini hace explícito el valor simbólico de la representación visual al plantear en los textos un tema del todo cotidiano que las extrañas imágenes ilustran (la dificultad para bailar). (Fig. 11)
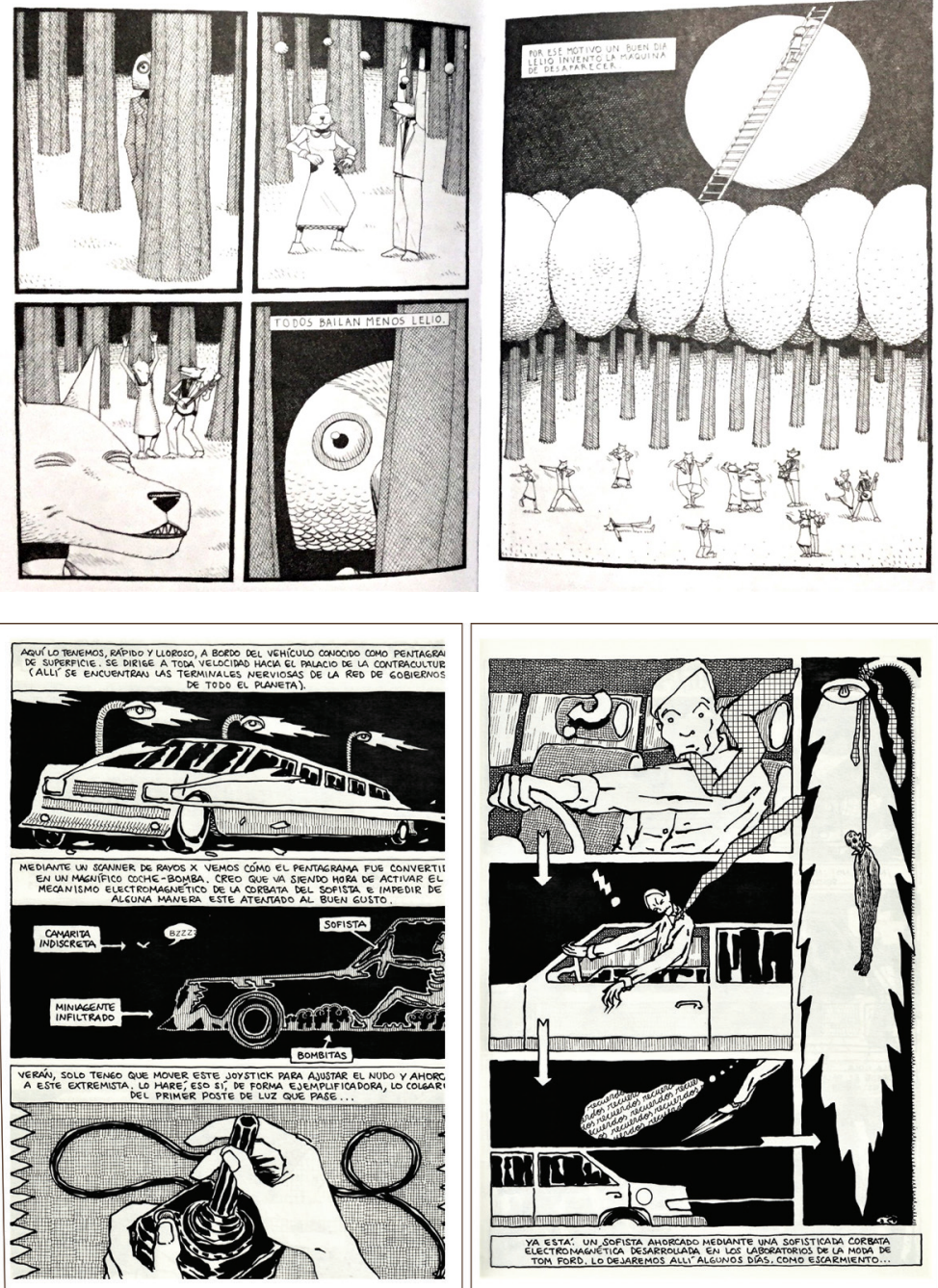

Fig. 10.

Maguregui y Frega

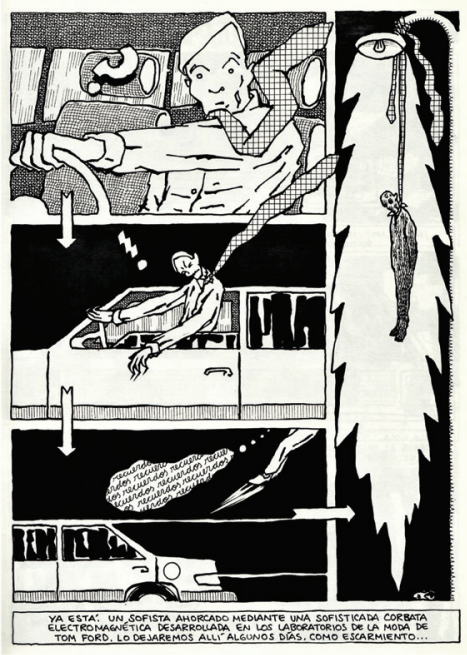

Fig. 11

Mancini 
Ambiguación del status diegético enunciador-personaje (ruptura enunciativa, modelo complejo): resulta por el comportamiento del narrador extra-diegético como personaje activo o viceversa. Lo que lo transforma al mismo tiempo en un elemento intra-diegético o al revés. No hay ambigüedad en que el mismo personaje sea actor dentro de la ficción y narrador fuera de ella, sino en que estas instancias de la enunciación estén comunicadas. Para el tipo de enunciador-actante anómalo ambas dimensiones son una sola a través de la que se mueve con libertad. No se trata de un personaje contando su historia como narrador extra-diegético (ubicándose así en dos niveles paralelos de la enunciación), sino viviendo la historia en simultáneo desde fuera de la diégesis o bien afectando "el fuera" desde dentro. Sirvan como ejemplo las páginas 18 y 19 de Los sofistas (Fig.12), en las que el narrador ahorca a uno de los sofistas mediante un artilugio tecnológico mientras se dirige en segunda persona al lector por fuera de la diégesis "en tiempo real" al respecto de sus acciones dentro de ella, interviniendo de forma activa y volitiva de un nivel enunciativo a otro. El caso inverso puede observarse en "Traumaturgo", historia que forma parte de Misterios. En ella un personaje se adueña del rol de enunciador macro, tomando responsabilidad por la posición del marco de la viñeta, el borramiento del borde y otros elementos extra-diegéticos. (Fig. 13). Es una ruptura asociada a una capacidad inmersiva y un carácter metalingüístico altos, y, por lo tanto, una diégesis accesible.

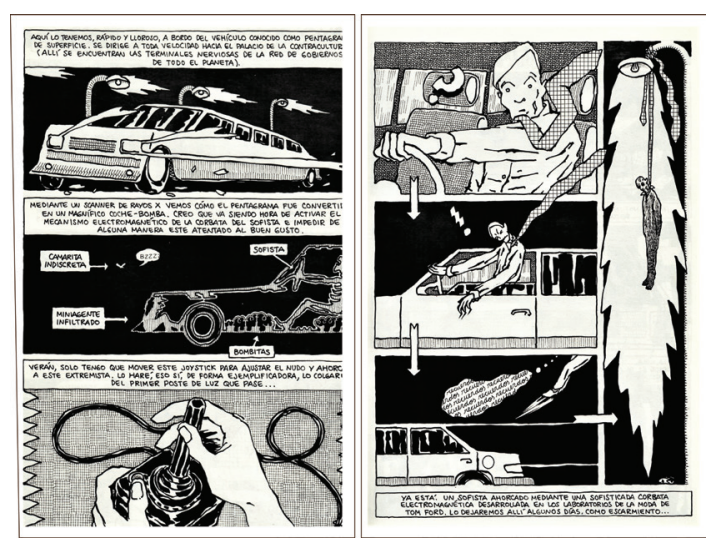

Fig. 12. Quien

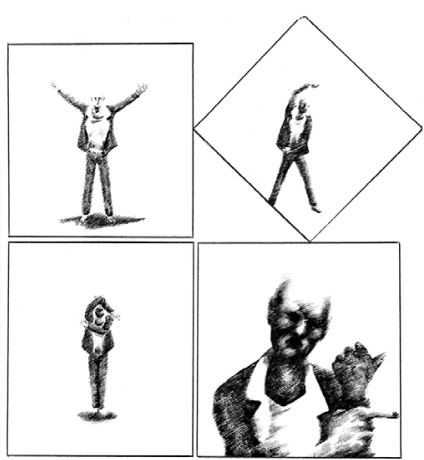

Fig. 13. González

Inestabilidad del sentido narrativo (ruptura enunciativa, modelo complejo): este modelo es propio de las narraciones que por la imposibilidad de establecer una relación de causalidad inequívoca entre las diferentes escenas que la componen construye un enunciatario que carece de los elementos necesarios para asignar un sentido narrativo seguro al discurso. Es una ruptura semántica difícil de percibir en el cuadro de variables discursivas pero que implica 
de manera necesaria una función narrativa y una alta opacidad enunciativa.

Un ejemplo radical es la historia "Mosquitos", contenida en Misterios. Interpretar las relaciones al interior de lo que se cuenta está más allá de las posibilidades de lectura ofrecidas. Los sentidos del relato, permanecen inestables, inexplicados, misteriosos, múltiples o cambiantes. "Misterio de Krang", de Ultradeformer; "Desierto", de Misterios, y Exes también son, en distintas medidas, ejemplos de este comportamiento.

Acentuación de la dinámica ideológica mediante la ambiguación ontológica de los referentes extraordinarios (ruptura enunciativa, modelo complejo): configuración del discurso que se sustenta en una dinámica ideológica particular. Aquí, el tema presenta una incidencia necesaria pero no suficiente para conformarla. En "Viaje extraordinario en tren" (Ultradeformer), el autor/personaje toma un tren, por motivos mundanos y termina en otra realidad denominada "ultramundo" (Fig. 14). En "Espacio", uno de los capítulos de Misterios, un astronauta atraviesa un límite hacia otro espacio existencial inclusivo (que puede ser el blanco de la página) para que luego surja desde dentro de él una gran estructura que lo deja desinflado, como un estuche vacío (Fig. 15). En "Traumaturgo" (Fig. 13), también de Misterios, sucede algo similar. En Ciber-city, una conexión a internet hace emerger un tentáculo de la cara del protagonista para ser enchufado a la computadora (Fig. 16). En Los sofistas, los delirantes sintagmas de texto, que enuncian los personajes de los sofistas, se transforman en unas figuras abstractas y flotantes de cerámica ultra liviana y luego conforman un humanoide gigante (Fig. 17). Estos son algunos ejemplos que ilustran este modelo disruptivo. A partir de estas observaciones puede considerarse que el tema de todas estas historietas es algún tipo de transmutación.
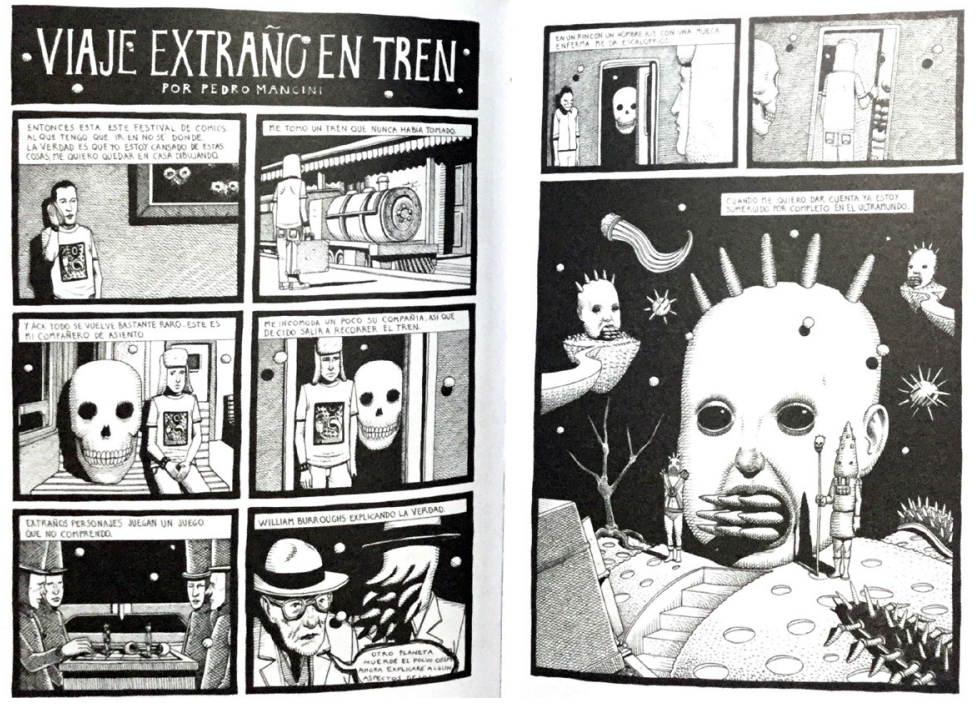

Fig. 14.

Mancini 

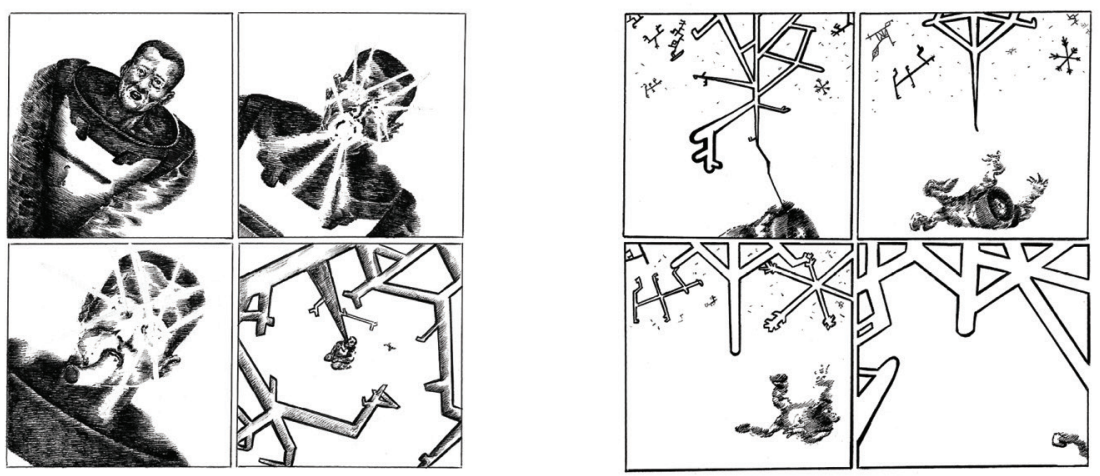

Fig. 15. González
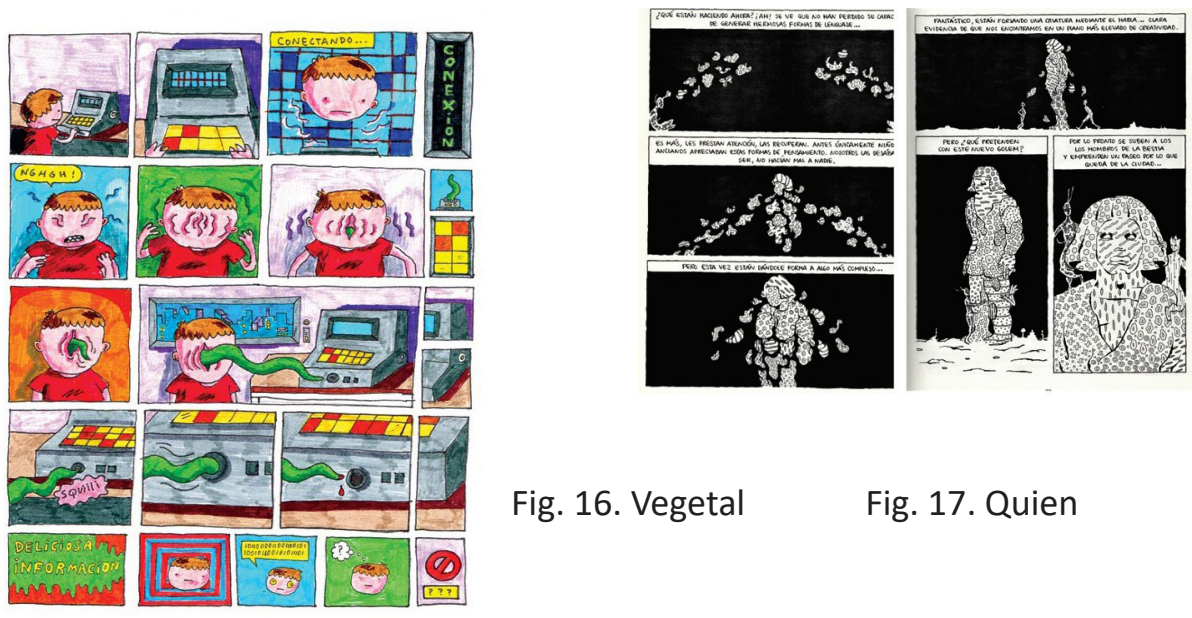

Fig. 16. Vegetal

Fig. 17. Quien

La transmutación tematizada (ya sea corporal, espacial o cognitiva), consistente en géneros como la fantasía o la ciencia ficción, implica siempre una dinámica ideológica que rompe con el verosímil social de lo real. Esta cualidad ideológica es acentuada por los mencionados integrantes del corpus mediante maniobras que tienden a exhibir los hechos extraordinarios como un predicado de la realidad. Esta característica discursiva (la referencia a la realidad socioexistencial) es inherente a toda consideración de la condición ideológica de un discurso (por ejemplo, entender a las clásicas historietas de Superman como una defensa ficcionada de la propiedad privada), pero que en las obras que implementan el presente modelo se ve reforzada al poner en cuestión el status ficcional de los referentes extraordinarios de maneras más o menos explícitas (en el humor gráfico político es frecuente lo segundo pero carece de lo primero). En 
Ultradeformer, como se dijo antes, la estrategia es la autorreferencia biográfica. En cambio, Misterios se vale del metalenguaje, rasgo enunciativo que por su misma definición conecta la realidad del lector con la ficción del enunciado. Ciber-city lo consigue mediante una fuerte tendencia a generar identificación (con la utilización de una jerga "joven" y citas a la cultura gamer). Por último, Los sofistas satiriza sin cesar varios comportamientos sociales reconocibles, sistema humorístico-reflexivo que solo funciona al asumir su referencia. También se vale de continuas maniobras enunciativas metalingüísticas. Es una ruptura que requiere de una alta accesibilidad a la diégesis.

El modelo sustractivo simple: es notable cómo los instrumentos de análisis implementados dicen poco y nada sobre la historieta Curso de pensamiento paranoico de N. Mealla (Fig. 18). En todo caso, el hecho de que utilice una sola de las cuatro materias significantes posibles y de que no le resulten aplicables ninguna de las posibilidades de la secuencia, ni seis de las variables enunciativas, es el dato primordial que surge de esta apreciación. No tiene narración, ni texto, ni marcos en las viñetas ¿tiene viñetas? ni fondos, casi no tiene personajes o acciones: son solo figuras en el blanco de la página.
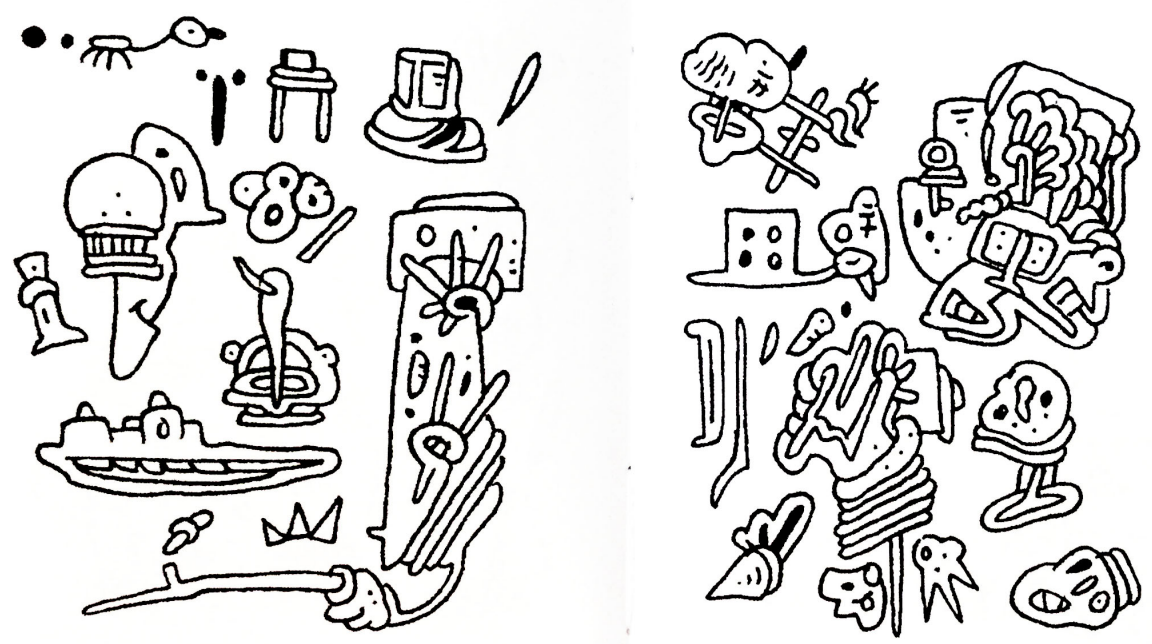

Fig. 18 Mealla

En este punto es de utilidad la distinción concebida por K. Walton (1992) para las artes plásticas y la música. El teórico entiende a todas las características de una obra como clasificables en tres categorías: standart, variable, y contrastandart. A la primera corresponden los rasgos habituales en una disciplina, a la 
segunda corresponden los rasgos que pueden cambiar sin poner en cuestión su pertenencia a un determinado lenguaje, mientras que a la tercera corresponden los rasgos que rompen u omiten a aquellos considerados standart. Se observa en el cuadro analítico que, si los elementos del lenguaje que corresponden a la historieta tradicional son características standart, el resto del corpus los comparte, pero utilizados de forma distinta. Es decir, el corpus está compuesto por obras con una gran cantidad de rasgos variables. Curso de pensamiento paranoico es la excepción. La obra de Mealla, en cambio, prescinde de tantos elementos del lenguaje standart que su identificación como objeto "historieta" entra en el terreno de lo problemático.

\section{Conclusiones generales: dos tipos de innovación/complejización discursiva}

Además de Curso de pensamiento paranoico no hay otras obras dentro del corpus que sean contra-standart de modo general, pero todas tienen viñetas o páginas que sí lo son. Páginas abstractas, negras, pictóricas o geométricas sirven para estudiar este comportamiento discursivo (Fig. 17). Se percibe como resultado que todas las páginas con abundancia de elementos contra-standart se adecuan al modelo sustractivo antes mencionado. En ese sentido, toda esta clase de obras representarían a un solo tipo, sin la amplitud ni variedad (infinita en potencia) de las innovaciones sustentadas en la interacción compleja propia de las obras con abundancia de rasgos variables. En otras palabras, la innovación discursiva compleja es resultado de la variación al respecto de lo standart e implica una sofisticación del lenguaje, mientras que la innovación por sustracción tiende, en cambio, a una precarización de la disciplina que puede alcanzar su completa anulación. Por consiguiente, se puede hablar de una innovación constructiva y otra deconstructiva.

Las historietas del corpus ejercen innovaciones constructivas no solo porque sus operaciones disruptivas se basan en la interacción entre variables del lenguaje que conforman modelos discursivos complejos, sino porque estos se combinan con otros modelos para constituir la particular y compleja ruptura de cada obra. La conclusión de este acercamiento es que la complejización discursiva propia de la innovación constructiva es la cualidad más característica y generalizada entre las historietas identificadas como disruptivas en el panorama nacional de los últimos cinco años.

\section{Los trayectos de la innovación en la historieta contemporánea argentina}

Para recorrer la trayectoria discursiva propuesta en este trabajo sobre la historieta es necesario convenir que en ningún momento se hace referencia a un devenir temporal o cronológico. La trayectoria a la que se alude es la que va de la tradición a la ruptura, es una distancia formal. Se abre en el espacio 
comprendido entre los extremos de la historieta más tradicional y la más disruptiva. En términos de Walton, la trayectoria abstracta de la innovación es la que parte en zona discursiva standart, cruza lo variable y atraviesa el límite de la disciplina para alcanzar la zona contra-standart. A la luz de las conclusiones arribadas, se puede afirmar que solo Curso de pensamiento paranoico atraviesa el límite disciplinar (y tal vez La casa de la risa, pero por cuestiones de clasificación más que de innovación), el resto se mantiene del lado de lo variable, pero fuera de lo standart. ¿Cómo se delimita está zona? Es evidente que termina con lo aceptado como historieta de manera segura, pero su límite inicial es hasta cierto punto arbitrario. ¿Cuándo los rasgos se modifican lo suficiente para ser variables y cuándo una variación es innovadora? Fue una elección al llevar a cabo esta investigación fijar la distinción en el punto en que una modificación afecta al funcionamiento de la historieta como artefacto enunciativo al requerir unas dinámicas de lectura muy diferentes. Este criterio permitió abarcar todos los casos identificados por la prensa y los teóricos que fueron analizados, pero supone un área bastante angosta, que se achica a medida que lo variable se normaliza. También se puede agrandar, cuando se corre el límite para ampliar la categoría y aceptar nuevos casos en su interior, pero tal corrimiento tiene un campo muy reducido, acotado a preservar la existencia del lenguaje. Entonces ¿por qué se ha dicho antes que la innovación constructiva observada es infinita en potencia?

El confinamiento de la innovación a una zona de frontera, al borde, pero sin rebasarlo, es su área discursiva por excelencia. Si se visualiza la creciente complejización discursiva (identificada como un factor clave en la conformación de las disrupciones) dentro del hipotético "mapa" de los recorridos del discurso historietil propuesto, esta representaría un movimiento no a través del límite, sino a lo largo de él, un movimiento perpendicular a la dirección que escapa del lenguaje, un recorrido que amplía sus posibilidades mediante las complejidades de lo variable y que supone la multiplicación de los puntos de conflicto por los cuales la frontera podría ser traspasada.

\section{Bibliografía}

BARTHES, Roland; GREIMAS, Algirdas J.; ECO, Umberto; GRITTI Jules, et al. 1970. Análisis Estructural del relato. Buenos Aires: Editorial Tiempo Contemporáneo.

BERONE, Lucas. 2007. La semiótica en cuestión, o sobre cómo leer al Pato Donald. Ponencia presentada en el VII Congreso Nacional y II Congreso Internacional de la Asociación Argentina de Semiótica, Rosario, 7 al 10 de noviembre. https://bit.ly/38tPrwl (accedido: 7 de marzo de 2020). 
BERONE, Lucas. 2009. El discurso sobre la historieta en Argentina. Intertextualidad, conciencia y mercado. Ponencia presentada en el III Foro de Investigación e Intervención social Intertextualidad, conciencia y mercado, Universidad Nacional de Córdoba, 24 y 25 de noviembre. https://bit. ly/3aCYcWA (accedido: 7 de marzo de 2020).

DE PABLOS PONS, Juan. 2009. La diégesis cinematográfica y sus implicaciones didácticas. Enseñanza \& Teaching: Revista Interuniversitaria de Didáctica 7, 9-15. https://revistas.usal.es/index.php/0212-5374/article/view/3456 (accedido: 7 de marzo de 2020).

GANDOLFO, Amadeo y TURNES, Pablo, et al. 2017. Historieta y Vanguardia, un debate. (1ra parte) https://bit.ly/38AIIRk (2da parte) https://bit.ly/2PYbuoF (accedido: 7 de marzo de 2020).

GARCÍA, Santiago. 2010. La novela gráfica. Madrid: Astiberri.

GARCÍA L., Óscar. 2016. Por qué lo llaman ícono cuando quieren decir diagrama, CuCo, Cuadernos de Cómic. 7, https://bit.ly/3cHdL1e (accedido: 7 de marzo de 2020).

GUBERN, Román. 1979. El lenguaje de los comics. Barcelona: Ediciones Península.

PEIRCE, Charles. 1986. La ciencia de la semiótica. Buenos Aires: Ediciones Nueva Visión.

REGGIANI, Federico. 2007. El espesor del signo: Historietas y enunciación. Ponencia presentada en las V Jornadas de Encuentro Interdisciplinario: Las ciencias sociales y Humanas en Córdoba, Universidad Nacional de Córdoba, 10 y 11 de mayo. https://bit.ly/3cByTpH (accedido: 6 de marzo de 2020).

REGGIANI, Federico. 2009a. Análisis, síntesis y velocidad: la construcción de la secuencia en historieta como lugar de emergencia de la instancia de enunciación. Revista académica de la federación latinoamericana de facultades de comunicación social 78, 1-12.

REGGIANI, Federico. 2009b. La historieta como pariente pobre: Sistemas de enunciación y Jerarquía de los géneros o la historieta frente a la literatura y el cine. En MACCIUCl, Raquel (ed.) Crítica y literatura hispánicas entre dos siglos: Mestizajes genéricos y diálogos intermediales (Arbor, vol. CLXXXVI, Anexo I), 407-426. Madrid: Consejo Superior de Investigaciones Científicas.

RYAN, Marie-Laure. 2004. Introducción y Conclusión: la literatura en el campo mediático en La narración como realidad virtual. Barcelona: Paidós.

SEGRE, Cesare. 1988. Principios de análisis del texto literario, Barcelona: Crítica. 
STEIMBERG, Oscar. 2013a. Leyendo historietas. Buenos Aires: Eterna Cadencia.

STEIMBERG, Oscar. 2013b Semióticas. La semiótica de los géneros, de los estilos, de la transposición, Buenos Aires: Eterna Cadencia.

TASSARA, Mabel. 2001. El Castillo De Borgonio. Buenos Aires: Atuel.

VERÓN, Eliseo 2004. Fragmentos de un tejido. Barcelona: Gedisa.

WALTON, Kendall. 1992. Catégories de l’art. En GENETTE, Gerard (ed.). Esthétique et poétique. París: Seuil. 


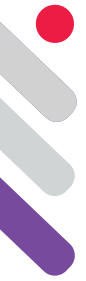

\section{Pierre Dupras, bédéiste caricaturiste engagé}

DOI: 10.24308/IASS-2019-4-028

\author{
Mira Falardeau \\ mir.falardeau@videotron.ca
}

\section{Introduction}

Pierre Dupras (1937-) s'impose comme une des têtes d'affiche de l'humour engagé au Québec. Sa position comme l'un des premiers caricaturistes à avoir utilisé le langage de la bande dessinée dans les média grand public durant les années 1970-1980 en font un leader dans ce domaine. L'analyse sémiologique de certains aspects de son discours contestataire permettra de comprendre la force de son approche pour exprimer le désir d'indépendance des Québécois durant cette période politique mouvementée. L'article débutera par une présentation générale de l'œuvre de Dupras et une mise en perspective de sa carrière face à la situation générale de la démarche caricaturale à cette époque. Puis, une analyse sémiologique de ses deux œuvres fondamentales suivra : les deux albums La bataille des chefs (1972), recueil de ses BD publiées d'abord dans le journal Québec-Presse et Oui ou non (1980), à propos de la bataille référendaire de 1980 au sujet de l'éventuelle indépendance du Québec par rapport au Canada. Il faut noter que Dupras mixe les deux langages de la caricature et de la bande dessinée et une attention toute particulière sera donnée à sa façon personnelle de marier ces deux langages. Deux unités du discours typiques de la BD seront décryptées en fonction de leur intensité rhétorique au diapason de l'intention contestataire : la bulle et la séquentialité. Dans un deuxième temps, seront présentés des extraits de la bande dessinée théorique de Dupras " La bande dessinée politique " parue en seize pages dans le premier livre théorique sur la BD québécoise, "La bande dessinée kébécoise " numéro spécial de la revue littéraire La Barre du Jour paru en 1975.Il y expose ses idées sur sa pratique et sur les écueils à éviter, de son dessin à l'esquisse entouré d'explication touffues calligraphiées à la main. Précurseur, il innove en reliant son discours à sa philosophie de l'art engagé, des années avant le bédéiste théoricien américain Scott Mac Cloud et son Art invisible (1993). II sera fort instructif de considérer 
ici par quels artifices du langage Dupras traite simultanément du fond et de la forme, en usant de procédés pédagogiques mais à saveur humoristique. $\mathrm{Ce}$ faisant, Dupras prend la stature de maître à penser dans le domaine trop peu fréquenté de la bande dessinée politique. Encore de nos jours, il fait figure de pionnier solitaire, aucun autre caricaturiste québécois ne s'étant prêté jusqu'à maintenant à l'exercice de la théorie à l'intérieur de la pratique.

\section{Présentation}

En France et au Québec, Mai 68 et la Révolution Tranquille des années 60 furent l'occasion d'un réveil politique de la nouvelle génération qui donnera naissance à la BD d'avant-garde et à la BD politisée.

Au Québec, le plus pur représentant de ce mouvement est Pierre Dupras, né en 1937. Il débute dans le dessin contestataire dans le journal des étudiants de I'Université de Montréal, Le Quartier Latin, de 1966 à 1969. À la même époque, il publie déjà de façon professionnelle en prenant fortement position en faveur de l'indépendance du Québec de 1964 à 1967, il produit des caricatures pour Dimanche-Matin, le journal du rassemblement pour l'indépendance nationale. En 1967, il publie son premier recueil de caricatures, Vive le Québec Libre, en allusion à la fameuse phrase gaullienne qui a fait couler tant d'encre.

C'est de 1969 à 1974 qu'il se fait davantage connaître en livrant une bande dessinée politique hebdomadaire dans le journal indépendantiste Québec-Presse. Précurseur, il est l'un des premiers dessinateurs québécois à associer clairement BD et caricature. Dupras met au point un style unique, marqué de forts aplats de noir et d'un trait à l'esquisse dans la tradition des Reiser et Wolinski. II s'amuse à détourner les exercices de physiogonomie du fameux Lavater en esquissant les métamorphoses progressives des visages des politiciens les plus honnis selon sa vision, car fédéralistes, en bêtes grotesques.

Les trois ouvrages suivants constituent notre corpus. La Bataille des chefs (1972) casse du sucre sur le dos des politiciens qui se présentent aux élections fédérales. En 1980, il publie un commentaire satirique sur les errances de électeurs québécois en matière d'indépendance avec Oui ou non sur le référendum.

Enfin, dans l'article "La bande dessinée politique ", qu'il publie dans le premier livre théorique sur la BD québécoise, La bande dessinée kébécoise, paru en 1975 à La Barre du Jour, il expose ses idées sur sa pratique et sur les écueils à éviter en seize pages bien tassées, avec son dessin clair entouré d'explications touffues calligraphiées. Ainsi, il innove bien avant Scott McCloud et ses œuvres L'art invisible (1993) et Réinventer la bande dessinée (2000). Il y mixe avec dextérité ses considérations personnelles sur les affres de la création et les principes de base de la création d'une bande dessinée. 


\section{Analyse}

Les deux codes qui permettent de distinguer la BD de la caricature sont tout d'abord labulle, soit cet espace circonscrit par une ligne de contour, la plus souvent ronde d'où le nom de ballons, dans lequel sont inscrites les paroles

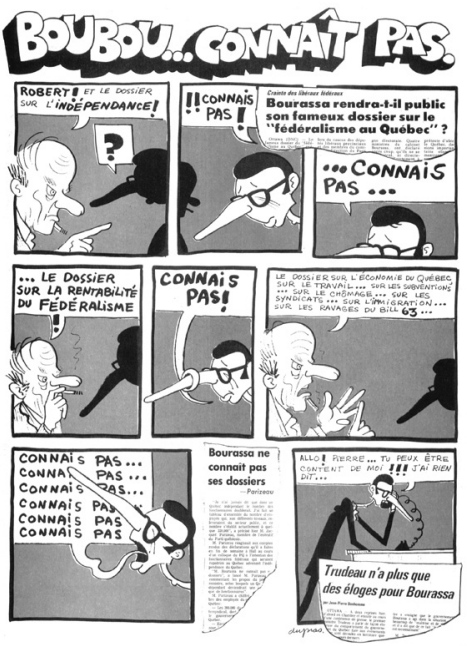
des personnages, et la séquentialité, soit le sectionnement de la narration en espaces définis par des cases placées côte à côte, dont le nom de « bandes dessinées ».

IMAGE .I. «Boubou...connais pas », La bataille des chefs, 1972.

Considérons tout d'abord l'apport de la bulle dans une œuvre de combat telle l'œuvre de Dupras. La bulle a plusieurs fonctions. La plus utilisée est la bulle de dialogue : ici, ce sont des paroles dialoguées, ce qui implique de montrer la réciprocité de visions. Les deux opinions fondamentalement opposées croisent ici le fer (Boubou). Le comique provient du fait que Boubou ne fait que répéter la même phrase tout au long de la BD. Mais unautre usage de la bulle est présenté à la fin de la bande: c'est ici la parole imprimée de la presse. La fonction référentielle, qui offre des extraits des journaux, donne une parole plus neutre. Elle apporte une vision des faits vus de façon objective. Ici, deux extraits, l'un au sujet de Bourassa, amplement ridiculisé par ses allures stupides qui répète comme une machine : la figure
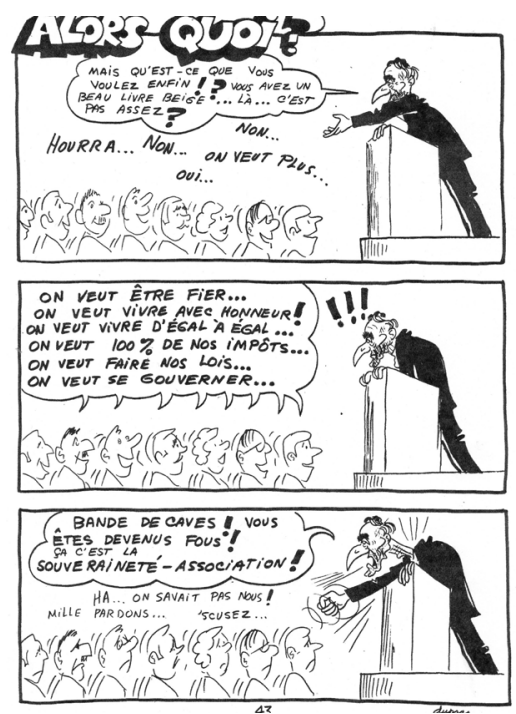

rhétorique de la répétition est en effet associée à l'effet mécanique, sans âme, désincarné en fait;l'autre, de Trudeau, premier ministre du Canada et allié de Bourassa. Donc, deux articles qui donnent la " position officielle » du gouvernement, et non la position de ceux qui demandent l'indépendance.

IMAGE .II. "Alors quoi? ", Oui ou non, 1980

Enfin, la bulle peut également être dispersée dans l'espace signifiant qu'elle est 
une parole partagée par la foule, comme dans Alors Quoi?Alors, la pluralité de points de vue est traduite par une pluralité de voix. Cette polyphonie donne une texture au discours engagé. II y a l'orateur, qui dispense lemessage. Le public qui émet diverses opinions. Enfin, les journaux qui émettent une parole plus neutre et participent à une vision plus objective de la situation. Dans Alors Quoi, Dupras donne la parole à deux visions, il instaure le dialogue entre l'orateur et le « peuple».

Il y aurait évidemment plusieurs autres éléments faisant partie de la bulle que nous aurions pu souligner telles les variations de lettrage selon l'intensité de la voix, ou même les inventions subtiles de Dupras qui, dans Boubou, enroule la flèche du ballon autour du nez de Bourassa (case 5), comme s'il était étouffé par son mensonge, ou lui donne la forme sinueuse d'un serpent (case 7), évoquant le caractère douteux de l'animal. Mais nous voulions nous concentrer sur la polyphonie, soit cette multiplication des voix qui donne une dimension orchestrale à la bataille politique à laquelle se livre le dessinateur.
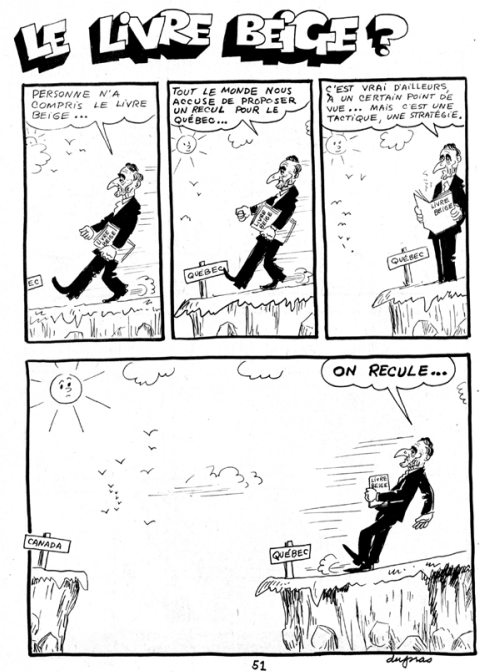

IMAGE .Illa. " Le livre beige », Oui ou non, 1980
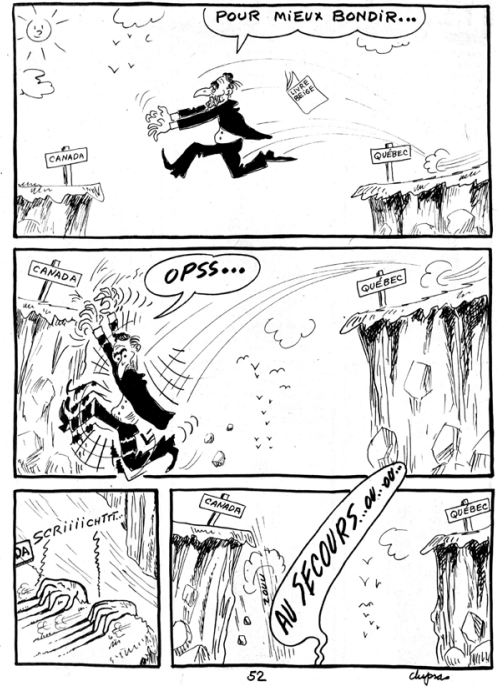

IMAGE. IIlb. "Le livre beige ", Oui ou non, 1980

Enfin, dans La bande dessinée politique, c'est encore d'autres formes de bulles que Dupras met en scène : d'abord la bulle autobiographique. Elle est inscrite dans une écriture manuscrite, ce qui donne déjà un indice de la personnalisation de cette bulle qui évoque soit le premier jet d'un écrit, soit une lettre privée que l'on destine à une connaissance proche; n'oublions pas que nous sommes dans les années 70 où le courriel n'existait pas. De plus, Dupras 
se dessine lui-même dans cette scène, ce qui ajoute à l'intimité du propos. En effet, Dupras nous livre ici la difficulté de créer, la recherche d'inspiration.

Enfin, c'est à une seconde sorte de bulle référentielle que Dupras nous convie ici : le carnet de croquis de l'artiste est présenté feuille après feuille. La recherche systématique des attitudes et mimiques fait en effet partie de l'attirail de tout dessinateur.Mais il y a aussi la bulle référentielle plus informative, comme les deux images du haut, images des hommes célèbres, De Gaulle et Duplessis, un premier ministre conservateur québécois très influent durant les années 1940 et 1950. De toutes façons, les carnets de croquis du dessinateur révèlent un pan de son âme secrète, et les ouvrir publiquement équivaut à révéler son vocabulaire de base. On ne peut manquer de remarquer que l'une des caractéristiques du dessin de Dupras sera l'exagération en longueur des appendices nasals, il en fait ici la démonstration. Le nez est dans les faits le moins mobile des éléments du visage, mais l'artiste le modèle à l'extrême dans le but de ridiculiser sa cible.

Si le discours des deux premiers albums étudiés était très orienté politiquement, c'est par contre à une plongée dans l'intimité du créateur que Dupras nous invite dans sa BD théorique.

La séquentialité est de deuxième élément sur lequel nous porterons notre attention. Contrairement à la caricature où une image égale un moment précis, la BD présente plusieurs images qui découpent le temps en plusieurs étapes qui racontent véritablement une histoire. Le développement de l'action permet d'atteindre plus de profondeur, de faire le tour d'une situation donnée en y apportant la dimension temporelle. La question est souvent : "Qu'est-ce qui arriverait dans l'avenir si... "? ?Le livre beige), tiré de Oui ou non?en donne un bel exemple. Évidemment, on se situe dans le monde de la métaphore.

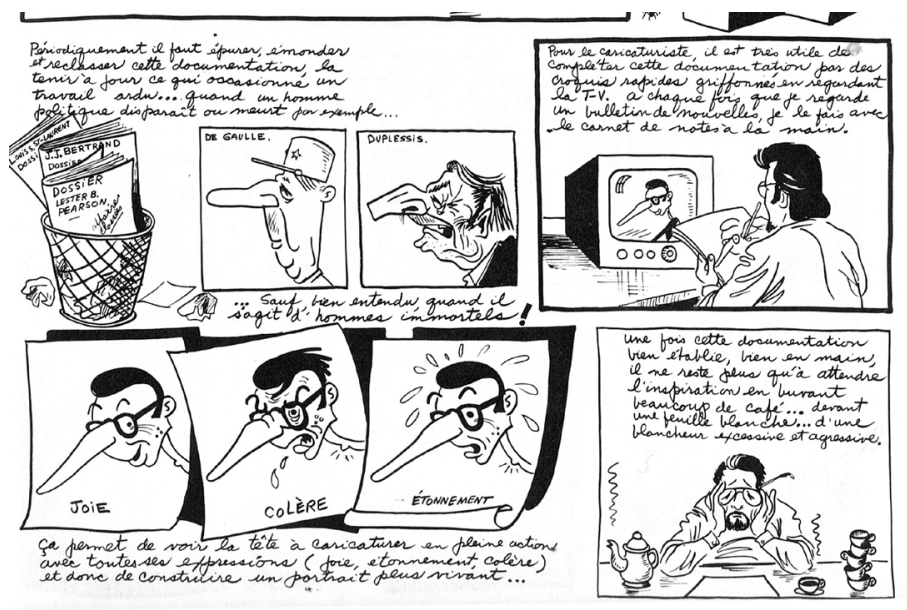

IMAGE .IV. "La BD politique ", La bande dessinée kébécoise,p. 121, 1975 
Le comique est apporté par l'absurdité de la situation où le pauvre Ryan, stratège avéré du fédéralisme, soit le parti du " Non », propose une stratégie ridicule où le fait de reculer doit apporter la victoire, ce qui est le contraire du bon sens. Ce faisant, après un saut au-dessus du vide, ce qui illustre finement la distance d'opinions entre les deux options politiques, il tombe en fait dans le néant, car que peut-il y avoir entre les deux propositions? C'est soit oui, soit non. Mais le plus drôle dans cette métaphore, quand on la lit des années plus tard, ce qui est notre cas, c'est qu'elle reflète assez justement la position de la majorité des Québécois qui sont en ce moment, ni oui, ni non, c'est-à-dire dans un no man's land idéologique par rapport à cette question si chaude de l'indépendance dans les années 1980.

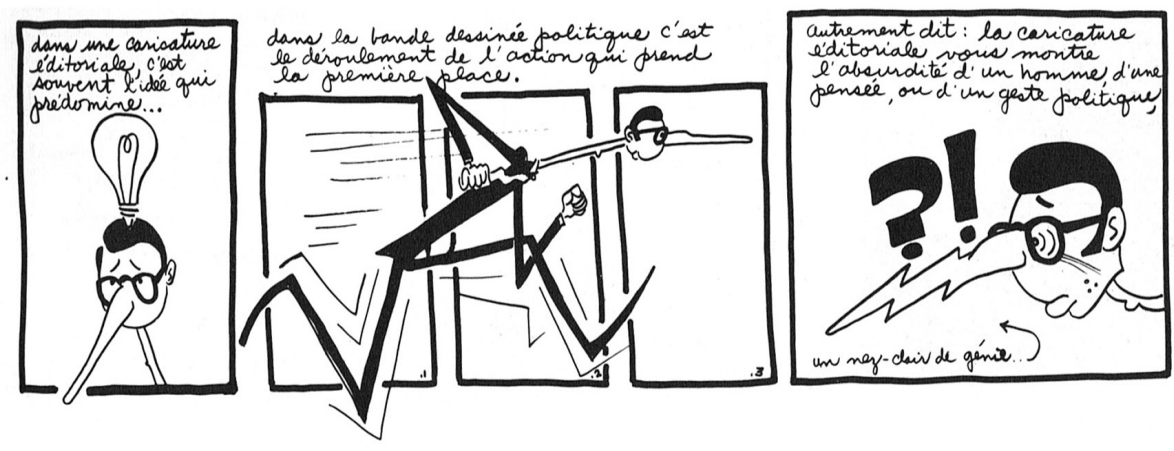

IMAGE .V. «La BD politique », La bande dessinée kébécoise, p. 119, 1975

Dans son analyse théorique, Dupras souligne d'ailleurs lui-même l'apport de la narrativité dans cette différence apportée par le langage de la BD en caricature politique: en exposant en trois cases la nature du « déroulement de I'action ", il ironise en fait sur la méthode en extirpant le corps du pauvre Bourassa des 3 cases où il se démène. Ce faisant, il superpose deux temporalités : le temps classique de la narration en strip, découpé en 3 étapes. Puis, en superposition, le temps unique de cette silhouette d'homme politique en lignes presqu'abstraites qui court après son destin. L'artiste le dit dans sa $3^{\mathrm{e}}$ case $: c^{\prime}$ 'est l'absurdité des hommes politiques qu'il veut démontrer, et il vient de le faire à sa façon en mixant deux dimensions temporelles avec astuce. Ce " bonhomme allumette » qui court dans le vide va-t-il réussir à avancer? Fait-il du " sur place " ou se trouve-t-il hors du temps, et par conséquent, de la réalité? Pourquoi n'est-il pas dans l'image? Tous ces questionnements viennent forcément à l'esprit quand on regarde le message polysémique que Dupras lance dans ce court extrait. Ses réflexions s'étendent ainsi pendant des pages, mariant métaphores et notations référentielles en un brillant exposé. 


\section{Conclusion}

En guise de conclusion, voici une caricature de Dupras : on y voit l'ancien maire de Montréal, Jean Drapeau, l'une des têtes de turc de Dupras, qui écrase " la presse " sous une presse (ce qui créé un jeu de mots en français). La vision sanguinaire serait bien impensable de nos jours, en cette ère du « politiquement

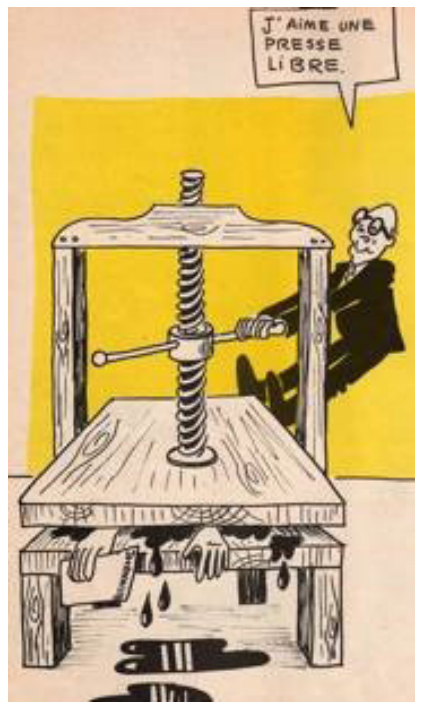

correct » où, par exemple, les caricaturistes ont été définitivement bannis d'un journal prestigieux tels le New York Times international, en juillet dernier, en représailles contre une caricature excessive selon le goût de certains, annonçant la fin d'une époque pour la liberté d'expression.

Dupras a bâti une œuvre forte en métissant deux langages, celui de la BD, un art réputé populaire et facilement accessible autant par son vocabulaire que par ses thématiques, et la caricature politique, un art beaucoup plus intellectuel, avec des références constantes à la politique nationale ou internationale. En ouvrant les portes entre ces deux langages, comme je l'ai démontré dans ce court exposé, il a apporté un vent de fraicheur et de dynamisme, en construisant des ponts entre le langage de la BD et dela caricature. Mais à l'inverse, il a aussi démontré que l'on peut exprimer des mondes idéologiques puissants par la $\mathrm{BD}$, en osant transposer les codes de la caricature dans le neuvième art. Ces passages qu'ils a créés n'ont malheureusement pas été très fréquentés dans les années suivantes. II reste dans les faits l'un des rares artistes ayant osé ce métissage, au service d'une œuvre de combat.

Références

DUPRAS, Pierre. 1967. Vive le Québec libre. Montréal : Éditions de I'homme.

1972. La bataille des chefs. Montréal : Éditions Québec-

Presse. 
1971. La Drapolice. Montréal : Éditions Québec-Presse.

1980. Oui ou non. St-Lambert : Héritage.

1975. La bande dessinée politique. In André Carpentier

(dir.), La bande dessinée Kébécoise. La Barre du Jour (46,47,48,49), 118133. 


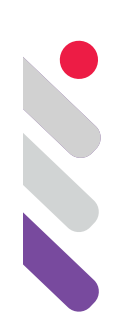

\title{
Trayectorias de la abyección en el arte posmoderno
}

DOI: 10.24308/IASS-2019-4-029

\author{
Amparo Latorre Romero \\ Sapienza Università di Roma, Italia \\ amparometrallas@gmail.com
}

\section{1. ¿Qué es la abyección?}

Intento dar respuesta con este artículo, cuyo propósito es explicar el concepto, la trayectoria que sigue y se pregunta por qué la sociedad tiende a enmascararlo o directamente a esconderlo.

\section{1. ¿Por qué es un tema que molesta tanto y del que no se quiere hablar?}

Este texto pretende poner de manifiesto que el concepto de la abyección es real y absolutamente necesario para que el cuerpo y el ser humano sobrevivan. Y como no podía ser de otro modo en el arte, convención social de expresión, esto se manifiesta con un lenguaje propio, semántica lingüística con sus propios semas y signos y con su propia semántica visual. Para poder entender el concepto principalmente me centro en los textos Pouvoirs de l'horreur, de Julia Kristeva (1980), y The return of the real, de Hal Foster (1996). La idea fundamental que encierra el concepto de la abyección es que sirve para cruzar los límites, jugar con las prohibiciones, más concretamente con la transgresión.

La abyección es humana; en su función corporal lo abyecto regula y sostiene, se deshace de lo sobrante y permite que el cuerpo viva. Es polifacética e inabarcable. La perspectiva es diferente según se observe a partir de su presente histórico o a partir de una evolución todavía inacabada.

Es interesante notar cómo el arte, rechazando el pensamiento y centrándose en las emociones, favorece una continua reflexión acerca de la hermenéutica del cuerpo como sujeto activo y pasivo. La tesis que sostiene este artículo es demostrar que la abyección sigue pasajes fundamentales: pasar por el trauma, sublimarlo y hacer arte.

Como nos explica Hal Foster en The return of the real,citando a Lacan, lo real es traumático y denomina tuchè al punto traumático en clave semiótica; 
Roland Barthes lo denomina punctum, como explica en La chambre claire. Note sur la photographie (p. 137).

\section{2. ¿Por qué es importante hablar del abyecto en clave posmoderna hoy?}

Contrariamente a lo que se piensa, la abyección es real, está siempre presente y se confronta directamente con nuestra condición de cultura postraumática; es un dato objetivo. Por el peso de una insostenible memoria colectiva que provoca angustia, que a menudo se esconde. Quiero poner en evidencia la contrariedad del hecho, solo considerando el concepto de abyección presente en la realidad. Se puede reconocer y afrontar y solo así se demuestra como un testimonio estético en el arte, se confronta con el trauma y se sublima.

El proceso de reconocimiento lleva a aceptar y en consecuencia a comprender que el cuerpo y la sociedad tienen necesidad de los desechos para poder sostenerse y poder sobrevivir. La abyección es cíclica, repetitiva y paradójica; tiene una función reguladora y nos acerca a su principal cualidad: la transgresión. Sin ejercitar nuestra capacidad y sin generar mecanismos de abyección, estaríamos condenados a una sociedad panóptica en la cultura y destinada a la regulación de los pensamientos.

Tanto el texto L'informe de 1996, de Krauss y Bois, como el de Hal Foster, The return of the real:the avant-garde at the end of the century, tambien de 1996, realizan unas contribuciones básicas a la interpretación del signo respecto a las marcas iniciales; marcas a modo de huellas que establecen su significado mediante relaciones directas con el referente. Krauss es vehemente respecto a este concepto en su libro The originality of the avant-garde andother modernist myths, de 1986.Y por su parte Hal Foster realiza lo propio más concretamente en el capítulo tercero, titulado "La pasión del signo":

El arte avanzado de los años sesenta estaba atrapado entre dos imperativos opuestos: por un lado, conseguir una autonomía del arte como demanda la lógica dominante de la tardo modernidad: por otra, desbordar este arte autónomo hasta invadir un campo expandido de la cultura que era de naturaleza ampliamente textual, textual por cuanto el lenguaje se hizo importante (como en gran parte del arte conceptual) y por cuanto devino primordial un descentramiento tanto del sujeto como del objeto (como en gran parte del arte específico para un sitio) (Foster 1996:75).

Estos textos han sido fundamentales para este estudio, ya que permitieron obtener parámetros de comparación especialmente del contexto social y cultural. Lingüística, sexo, ética y moral: todos esos elementos, por tanto, contribuyen a definir una sociedad occidental y encuentran sus paralelos en el arte como una forma de expresión social. 


\section{Trayectorias de la abyección}

En los años noventa, gracias a la exposición Repulsion and desire in American art, realizada en el 1993 en el New York Whitney Museum of American Art, ${ }^{1} \mathrm{el}$ arte abyecto empezó a difundirse como verdadera y tendencia artística como tal.

Tratamos nuestro discurso de la abyección con Bataille, del cual podemos nombrar, por ejemplo, L'histoire de l'oeil (1994), donde encontramos voyerismo, orgías, sadomasoquismo...: una narración que raya en el horror.

Este concepto de sacrificio, respecto a la abyección corporal, se trata específicamente en el ensayo Surrealismo // (Crescentini et al. 1995: 5-18), en el que Carla Subrizi reflexiona sobre la experiencia de la imagen y analiza los escritos de Baudelaire, flanqueado por Michel Leiris, Carl Einstein, Marcel Griaule, publicado en la revista Documents.Citando a Subrizi: "Documents quería proponer un continuo demontage theorique en vista de un sucesivo montage figuratif. Es a través de este montage que los artículos singulares e imágenes eran restados a su parcialidad para ser puestos en un incesante juego de relaciones, de contactos implícitos y solo entrevistos en una estupefaciente y alarmante red de relaciones" (Subrizi 1996:7).

Podemos encontrar un análisis similar en el libro de Carlo Pasi La comunicazione crudele da Baudelaire a Beckett, escrito en 1998, especialmente en el pasaje de la escritura-sacrificio (pp. 168-234). Otro ejemplo más lo tenemos en Bataille, que va aún más lejos en el libro L'esperienza interiore, en este caso con respecto a la crueldad:

Ante el exceso de crueldad, tanto de los hombres como del destino, es natural rebelarse, gritar (nos falta valor): “¡Esto ya no debe suceder!” y llorar, tómalo con Chimnon Center. Es más difícil decir: lo que llora y maldice en mí es mi sed de dormir en paz, mi enojo por ser molestado. Los excesos son las Señales, de repente adheridas a lo que el mundo es soberano (Bataille 1978:178).

\section{Análisis de la abyección en el arte posmoderno}

El posmodernismo fue una reacción que surgió contra el modernismo. Consiste en todo aquello que se dio después de lo moderno; recicla técnicas, ideologías y temáticas desde un punto de vista estético actual.

De acuerdo a la historia, la posmodernidad se volvió más popular a partir de la publicación en 1979 del libro de Jean Françoise Lyotard La condition postmoderne: rapport sur le savoir. Después de dos guerras mundiales, esta teoría sobre la posmodernidad empezó a circular en occidente, excluyendo de esta manera muchas ideologías viejas y dando paso a una mayor representación de las experiencias humanas.

\footnotetext{
${ }^{1}$ Véase el catálogo de la exposición Abject Art: Repulsion and Desire in American Art (Ben-Levi et al. 1993).
} 
En Gusto, de Giorgio Agamben (2015: 58), se menciona el desarrollo de la filosofía occidental a través de una reflexión que también es aplicable al arte: "En el destino de la filosofía occidental, en eso, más allá del colapso metafísico del significante y el significado, de la apariencia y el ser, de la adivinación y

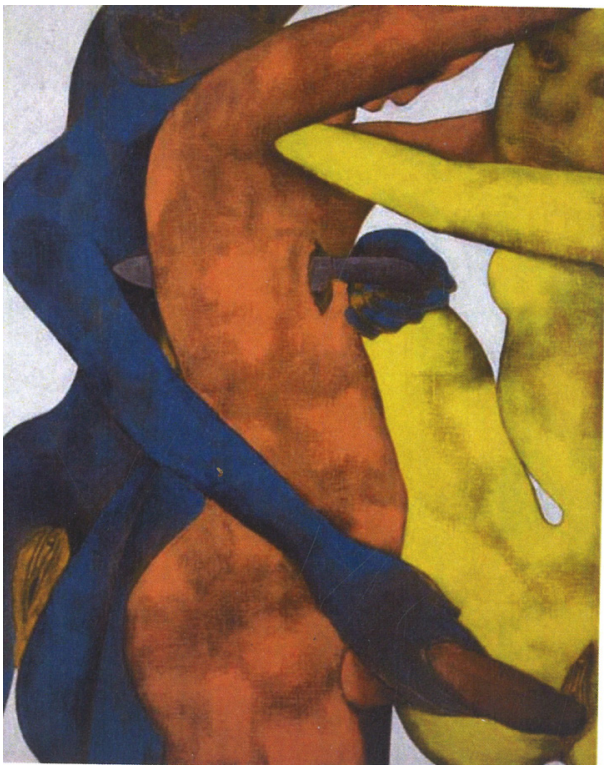
la ciencia, se refiere a una salvación integral de los fenómenos".

Figura 1, Francesco Clemente.

Meditation, 1991. Técnica mixta sobre lienzo, $76 \mathrm{~cm} \times 61 \mathrm{~cm}$. Colección del artista.

Este cuadro aúna el mundo visible, el pensamiento y la emoción. Los instintos primarios dicotómicos: Eros y Thánatos, las pulsiones de placer y muerte, en este caso, representados mediante la sexualidad y la agresión; la pulsión hacia la atracción y reproducción; Thánatos hacia la repulsión y la muerte. Interpreta el ineludible significado de la condición humana desde los deseos más oscuros: morbosidad, envidia, odio, crueldad.

El cuerpo femenino amarillo está siendo penetrado por el cuerpo naranja masculino que, a su vez, está siendo penetrado con un cuchillo por el cuerpo azul femenino, cuya vulva amarilla simboliza la envidia por la falta del falo.

El cuerpo naranja penetra y es penetrado, es emisor y receptor de la semiótica de las pasiones. Es un paradigma cíclico y de concatenación dicotómica: dentro-fuera, femenino-masculino, dar-recibir, odiar-amar, comenzar-finalizar. Es una escena que transgrede y va más allá de los límites, por lo tanto, con un alto grado de abyección.

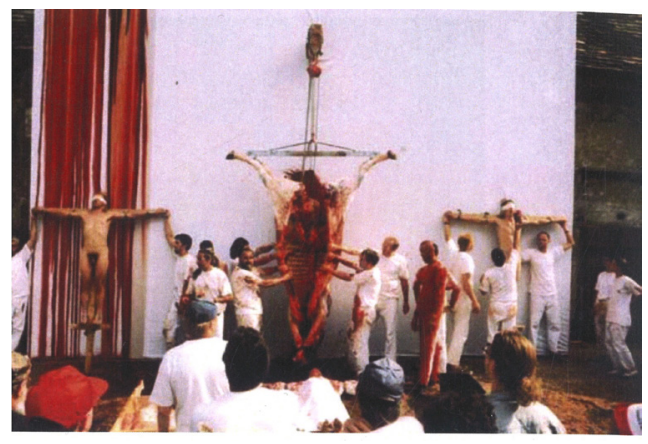

Figura 2, Herman Nitsch, Tales of ordinary madness, Action, 1970.

Este autor actúa como la figura del carnicero, que es pagada por la sociedad para no tener que mancharse las manos de sangre y desempeña la función social de nutrirnos. 
Al expiar las culpas y apaciguar la discordia el chivo expiatorio a menudo fue divinizado tras ser sacrificado. En las sociedades laicas esta función sacra en ocasiones se desliza hacia el terreno del arte, asumiendo los artistas el papel de evangelistas, narradores de mitos y oficiantes de rituales, o bien, encarnándose en los propios herejes, penitentes o desheredados (Adell 2011:7).

Para ahorrarle al espectador la bajeza de bajar a los territorios límite, extremos. Él se sacrifica por el espectador. En este punto, Herman Nitsch expresa la función social del artista, que él mismo se atribuye.

En la siguiente afirmación: "Me he fundido, he identificado con ella, toda agonía y lujuria combinadas [...] me impregnarán y de ahí a TI" (Nitsch 2007:11), se centra en la función catártica del artista (performer), que le pasa sus sensaciones a un público ávido de experimentar la denigración, pero demasiado conservador y burgués para realizarla.

En el VI de sus estatutos, expresa que desea liberar a la humanidad de sus instintos animales y los quiere reducir de una manera científica. Es como extrapolar una sensación liberadora pero sin heridos. Sería como descargar adrenalina; es como una pelea de boxeo - algo socialmente aceptado- en vez de una pelea callejera-condenado socialmente-.

El acto del desgarro del cordero representa el exceso, representa abrir todo lo malo y extirparlo. Lo considera tan importante que le dedica un manifiesto. La pintura en este caso sería la sanadora, es capaz de llegar hasta el "exceso", como lo define Nitsch.

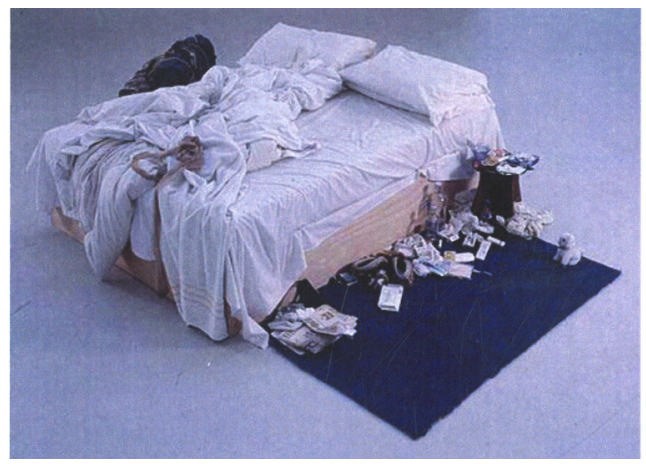

Figura 3, Tracy Emin. My Bed, 2000. Instalación: Turner Prize Exhibition, 2000, colchón, sábanas, almohadas, cuerda, varios objetos de interés, $79 \times 211 \times 234 \mathrm{~cm}$. Tate Gallery, Londres.

La obra es una cama con detritos orgánicos de la artista, de su vida sin ocultaciones ni retoques estéticos de buenas maneras. Nos muestra sin tapujos sus miedos físicos e incluso sus aspectos psicológicos más íntimos. La cama es un elemento simbólico que representa nuestra vida íntima. Es el lugar donde dormimos, soñamos, mantenemos relaciones sexuales, tenemos pesadillas, nos entran ganas de vomitar. Por lo tanto, es un elemento de entrar y salir del nivel de consciencia y precipitarse en otros estados corporales. 
La artista muestra su cama, además de una alfombra azul sucia sobre la cual hay tampones, botellas vacías de vodka, zapatillas, ropa interior, paquetes de cigarrillos, preservativos, anticonceptivos, pantys, sábanas manchadas, una Polaroid con retratos de un juguete blanco, bragas usadas...: la sangrienta secuela de un ataque de nervios. Objetos que normalmente tiraríamos o esconderíamos por pudor en esta obra se muestran para enseñarnos la realidad corporal; son los restos de un cuerpo y una vida.

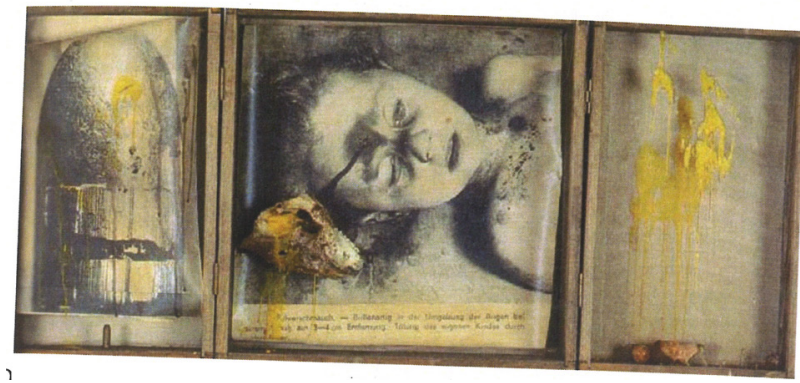

Figura 4, Daniel Spoerri, Humo de pólvora (Pulverschmauch). De la serie Investigación criminal, 1971.Técnica mixta, $54 \times 120 \times 120 \mathrm{~cm}$. Colección del artista.

Las pulsiones de muerte y los instintos más bajos del ser humano suelen estar contenidos y guardados, por ello no nos sorprende que el artista nos presente su propuesta en formato tipo caja.

En esta obra se narra el asesinato de un niño. Si cualquier asesinato es abyecto porque hace visible la amoralidad y maldad humana, el asesinato de un niño es lo más ominoso que pueda realizar el hombre, porque se aprovecha de su indefensión. El tiro en la frente del niño es espantoso.

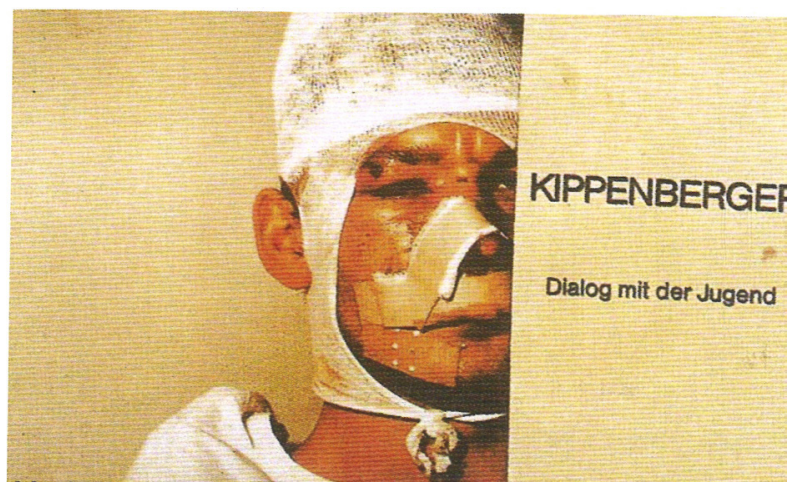

Figura 5, Martin Kippenberger. Dialogue with Youth, 1981. Fotografía, dimensionesvariables. The Museum of ModernArt, NewYork.

Esta tarjeta muestra a una persona apaleada, maltratada, con la cabeza vendada, con apósitos y esparadrapo en nariz y boca, con la camiseta blanca manchada de sangre seca. En 1981, el artista tuvo que ser hospitalizado a consecuencia de una paliza violenta de algunos de sus clientes. 
Nos narra un capítulo autobiográfico. Comercializaba con su vida en el arte, incluso mostrando su cuerpo enfermo hasta su final, muerto de cáncer de hígado. El poder de la imagen es sublime, tan evidente que el texto es fútil, vano.

Kippenberger cree que la obra debe seguir siendo incompleta, autodestructiva, pretendía plasmar la imperfección. El espectador siente la

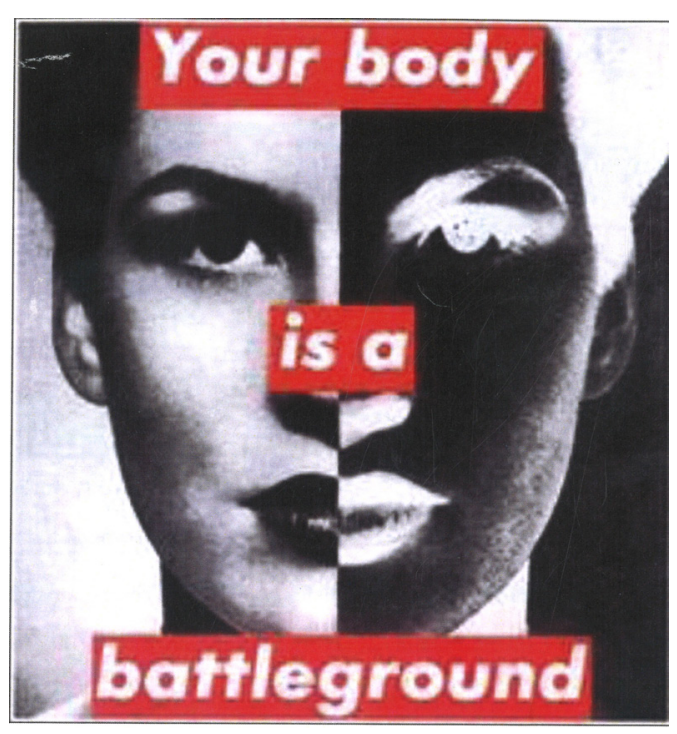

violencia salvaje que ha padecido este joven.

Figura 6, Barbara Kruger. Your body is a battleground, 1989. Serigrafía fotográfica en vinilo, $284.5 \mathrm{~cm} \times 284.5 \mathrm{~cm}$. Santa Mónica, CA: The BroadArt Foundation.

Kruger expresa sus preocupaciones sobre temas feministas a través de audaces imágenes y textos magistralmente combinados. Este documento analiza los valores patriarcales, los discursos de la mirada, trabaja el tema y su relación con el poder masculino.

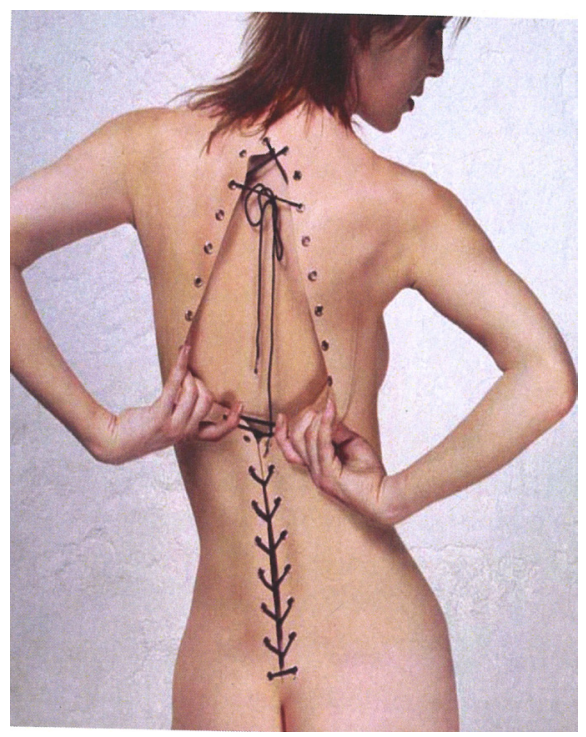

A través de la mirada, los hombres son capaces de obtener el control sobre los cuerpos de las mujeres, creando una tensión entre los dos sexos. Kruger vincula esto con una crítica del consumismo, en el que en la cultura occidental todo puede ser comprado, vendido y, por lo tanto, es de tu propiedad. Esta ideología se extiende a las relaciones interpersonales.

Figura 7, Nicole Tran Ba Vang. Collection Printemps/Eté 2001, Sin Título 06. Fotografía a color, $120 \mathrm{~cm} \times 80$ cm. Colección privada. 
La imagen es tremendamente siniestra y muy impactante. Pensar en que nos desollaran nos da escalofríos, pero auto-desollarnos y, además, como un proceso pautado por repetición es muy abyecto.

Además de la ambivalencia espacial (incertidumbre dentro/fuera), produce miedo, horror, temor. Es una amenaza al yo desde la psicosis y la fobia o, más bien, nos hace reflexionar hacia el significante vacío y la disociación psicocorporal. Se puede establecer la auto-abyección, los falsos yo, como falsos objetos de significación: la cultura, la educación, el cinismo, etc. ¿Hacemos del cuerpo una entidad mutable? Lo bronceamos, lo tatuamos, tenemos cicatrices, cortes, marcas...

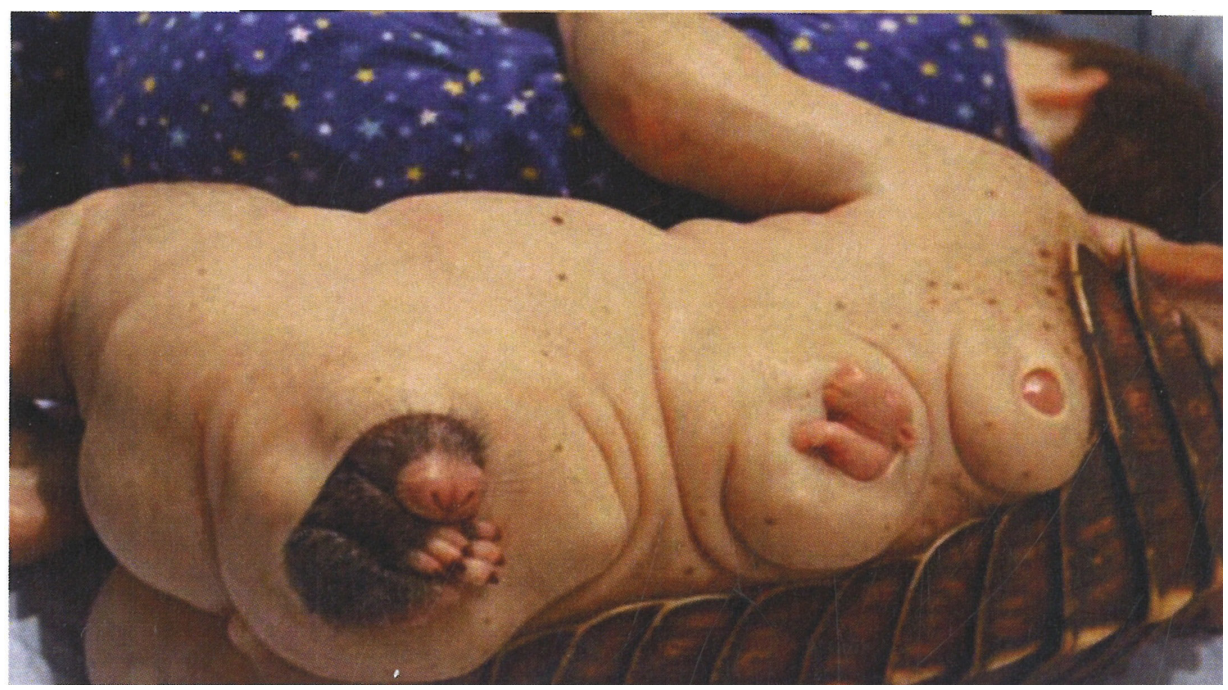

Figura 8, Patricia Piccinini. Undivided, 2004. Instalación, silicona, pelo humano, franela, osito y ropa de cama, $101 \times 74 \times 127 \mathrm{~cm}$. Haunch of Venison.

La madre cariñosamente abraza al niño dormido, con su hocico apoyado en su cuello. El reposo se altera por la visión de los bultos en la espalda de la criatura, que recibe a sus crías en diferentes etapas de desarrollo. La mayoría dela gente no puede manejar orificios desnudos tan expuestos.

De su serie Nature's little helpers, nos resulta siniestro porque nos recuerda elementos cotidianos. Incluso la criatura podría tener reminiscencias de una figura humana, tiene extremidades y piel humanas, hasta un par de pechos con pezones invertidos. Es un híbrido y nos sugiere que, si seguimos en una trayectoria de la innovación tecnológica sin ninguna ética, los humanos se pueden convertir en híbridos. 


\section{Conclusiones}

Concluyendo, podemos afirmar que existe una clara tendencia artística en la que se utiliza el concepto de abyecto para crear una tendencia artística que sigue y traza su propia trayectoria como queda demostrado en el análisis realizado de las obras. La tesis que tiene más sentido con respecto a la abyección es su función reguladora; sostiene, se deshace de lo sobrante y su principal cualidad es la transgresión.

En esta investigación queremos reivindicar que, a menos que nosotros ejerzamos nuestra capacidad de abyección y generemos mecanismos de transgresión, estamos condenados a una sociedad panóptica en la cultura, las ideas y la regulación de los pensamientos. La sociedad y el arte deben ser sometidos a un análisis crítico y unas reformas estructurales; nunca a disciplinas cerradas.

\section{Bibliografía}

ADELL, A. 2011. El arte como expiación. Madrid: Casimiro.

AgAmben, G. 2015. Gusto. Macerata: Quodlibet.

BatAllle, G. 1978. L'esperienza interiore. Bari: Nuova Biblioteca Dedalo.

BatAille, G. 1994. Historia del ojo. México: Ediciones Coyoacán.

BARTHES, R. 1980. La chambre claire. Note sur la photographie. Seuil: Gallimard.

BEN-LEVI, J.; JONES, L. C.; TAYLOR, S. \& Houser, C. 1993. Abject art: Repulsion and desire in American art: Selections from the permanent collection. New York: Whitney Museum of American Art.

Crescentini, C.; Ferraris, P.; Lux, S.; Mania, P.; Marocchini, R.; Mirolla, M.; PIERonI, A.; SCACCO, L. \& SUBRIZI, C. 1995-1996. II Surrealismo II. Roma: Lithos Editrice.

KRAUSS, R. 1986. The originality of the avant-garde and other modernist myths. Massachusetts, Cambridge: MIT Press.

Krauss, R. \& BoIS, Y. A. 2003. L'informe. Milán: Bruno Mondadori.

KRISTEVA, J. 1980. Pouvoirs de l'horreur. Editions de Seuil.

FOSTER, H. 1996. The return of the real: The avant-garde at the end of the century. MIT Press. 
PASI, C. 1998. La comunicazione crudele da Baudelaire a Beckett.Torino:Bollati Boringhieri Editore.

LYOTARD, J. F. 1979.La condition postmoderne: rapport sur le savoir. París: Les Éditions de Minuit.

NITSCH, H.2007. Orgien. Mysterien. Theater.Bologna:Galleria de Foscherari. 


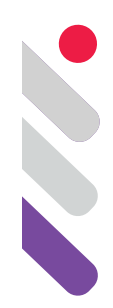

\title{
Un no lugar para la fotografía: sobre la serie Archivo Utopía - El proyecto Brasilia
}

DOI: $10.24308 /$ IASS-2019-4-030

\author{
Vanesa Magnetto \\ Universidad Nacional de las Artes - CONICET \\ vanesamagnetto@gmail.com
}

\section{Presentación}

Este trabajo se propone pensar la serie fotográfica Archivo Utopía. El proyecto Brasilia (2003 - 2009) producida en conjunto por el fotógrafo Alemán Michael Wesely y la artista Brasilera Lina Kim, con el fin de analizar algunas cuestiones en torno a la fotografía, el archivo y la imagen urbana. Tanto el archivo, en cuanto documento, como el imaginario urbano moderno, fueron asociados a la fotografía desde sus orígenes. Ambos se sirvieron de la fotografía para atestiguar diferentes procesos: en el caso de los archivos, el rol de la fotografía fue testimonial y de reconocimiento; en el caso de la ciudad estuvo (y está) atado a la construcción de un espacio con marcas incipientes de modernización y progreso, actuando varias veces también de modo testimonial. Se postula que Archivo Utopía tensiona el vínculo con estos dos tópicos y propone una imagenfotográfica de ciencia ficción, una imagen con valor artístico que se escurre del modelo fotográfico temporal.

La serie estudiada tiene la particularidad de estar producida a partir de un dispositivo diseñado por los propios artistas que permite la toma de fotografías con tiempos larguísimos de exposición ${ }^{1}$, generando una imagen que se caracterizada por una temporalidad no cronológica, ni sucesiva, sino acumulativa, que se evidencia en diversos elementos visuales plásticos: la textura, los colores, la trama, las formas. Estos elementos tensionan algunas cuestiones respecto del archivo y del imaginario urbano moderno. A modo de

\footnotetext{
${ }^{1}$ Por tiempo largo de exposición me refiero al extenso tiempo en que el obturador de la cámara fotográfica se mantiene abierto, permitiendo el ingreso de luz que produce la imagen e impacta sobre el soporte a utilizar. Si bien a nivel técnico no hay un tiempo predeterminado que defina a los tiempos largos, considero que una toma que exceda el segundo de duración entra dentro de este marco.
} 
hipótesis,se propone que el uso del recurso del tiempo largo de exposición genera, en estas imágenes, una concepción espacio-temporal que se corre del modelo icónico canónico (instantáneo) de la imagen fotográfica, y, construye una temporalidad particular, entendida como acumulación, no perceptible por el ojo humano.

A partir de un enfoque semiótico, que se acerca a la fotografía en tanto un signo, más precisamente un texto, este trabajo piensa a la imagen fotográfica en función de un esquema dinámico que actualiza continuamente este signo en su instancia pragmática, es decir, a la fotografía como un acto. Se rescata la propuesta de Vilem Flusser en torno a la actividad fotográfica como "modo de búsqueda de posibilidades no descubiertas por el programa"(1990: 37) para encontrar imágenes que escapen a la lógica que impera en el dispositivo fotográfico. Esto se liga con la noción dialéctica propuesta por Eduardo Cadava (2014) quien, siguiendo a Walter Benjamin, recupera la potencia de ciertas imágenes para cuestionar la capacidad de interrumpir "La Historia" y desplegar otras historias posibles. En las fotos de Archivo Utopía esto se entiende como historias fotográficas que trastocan el tiempo y, en consecuencia, al espacio. Para abordar este tiempo- espacio se parte del concepto cinematográfico de Gilles Deleuze de "imagen-tiempo" (2012) para ir hacia lo quese denominaimagentiempo fotográfica. ${ }^{2}$

\section{Un primer acercamiento al Archivo Utopía. El proyecto Brasilia}

Al igual que gran cantidad de las series fotográficas realizadas por el fotógrafo alemán Michael Wesely, Archivo Utopía. El proyecto Brasilia fue producida a partir de los tiempos largos de exposición con una cámara de formato grande, construida por él mismo ${ }^{3}$. En esta ocasión, el trabajo fue hecho en conjunto con la artista Brasilera Lina Kim, entre los años 2003 y 2009. La participación de Kim en la serie marcó nuevos rumbos respecto al proyecto fotográfico original, orientado exclusivamente a una nueva producción fotográfica de la ciudad de Brasilia. El especial interés de Kim respecto a los aspectos sociológicos y antropológicos en torno a lo urbano derivó en una intensa búsquedaen diferentes archivos de Brasil. Entre los años 2003 y 2005, los artistas rastrearon imágenes de archivo que dieran cuenta dela construcción de Brasilia. Esta búsqueda se complementó con la idea original de la producción de fotos en Brasilia y dio como resultado dos trabajos muy diferentes.

\footnotetext{
${ }^{2}$ Este trabajo se enmarca dentro de una tesis de doctorado en curso, en torno al tiempo y el dispositivo fotográfico, en la fotografía argentina contemporánea. Allí, desarrollo el concepto de imagen-tiempo fotográfica para poder abordar y pensar las diferentes manipulaciones temporales del corpus de la tesis, que escapan al instante fotográfico, y se construyen a través de la acumulación.

${ }^{3}$ Para más información respecto a otras series de Michael Wesely véase Magnetto 2016; Magnetto 2018.
} 
En la revisión de los archivos, los artistas visualizaron alrededor dediez mil fotografías. Cuatro mil fueron digitalizadas y catalogadas, finalmente, mil cuatrocientas fotografías históricas fueron restauradasy han pasado a conformar el libro Archivo Brasilia,publicado en el año 2010. El libro en sí configura un archivo que reúne y pone en diálogo material que originalmente se encontraba disperso en diferentes archivos públicos y privados de Brasil. Al año siguiente, en el 2011, el museo Kunsthalle de la ciudad de Kiel, Alemania, presentó la exhibición Archivo Utopía. El proyecto Brasilia 4 . En paralelo, la editorial Kehrer en conjunto con la editorial del museo, publicó el libro catálogo homónimo. Se trata de untrabajoque reúne las treinta y dos fotografías producidas por Michael Wesely y Lina Kim, junto con un grupo pequeño defotografías provenientes de los archivos.

Si bienel presente texto se concentra en analizar la imagen- tiempo fotográfica propuesta por las fotografías producidas por los artistas, no se puedeomitir el hecho de que el proceso de producción de esta serie haya derivado en otro proyecto que, excede alaproducción fotográfica y da cuenta de un importante trabajo de recuperación de archivos documentales, del cual se recuperarán brevemente algunos aspectos. Hasta aquí se desea subrayar que enla convivencia de estos dos trabajos (artístico y búsqueda documental) cobra lugar una impertinencia predicativa,en términos de Paul Ricoeur (2001, p. 281), poco habitual en el medio fotográfico. Se posibilita una imagen metafórica que condensa diferentes usos, el artístico y el documental, a través de una nueva imagen que evoca una mirada peculiar sobre la ciudad de Brasilia y sus alrededores, esta novedad radica en la forma visual en la que estas imágenes documentan la ciudad.

\section{Las imágenes de archivo}

Históricamente la fotografía ha estado relacionada con el archivo, tanto en virtud de su condición de documento como en torno a su evidencia de la realidad (John Tagg, [1988] 2005:87). La fotografía ha sido, y es, utilizada en varios ámbitos como imagen de valor testimonial. En el caso de las fotografías relevadas en los archivos de Brasil, éstas surgieron a partir de la necesidad de registrar el proceso de construcción de la ciudad y, con ellas, generar un imaginario visual en torno a dicho proceso y a la ciudad.

Este primer acercamiento al material de archivo se realiza en función de las fotografías que conforman el libro catálogo de la muestra Archivo Utopía. El proyecto Brasilia. Estas imágenes, en algunos casos en blanco y negro, y otros

\footnotetext{
${ }^{4}$ La exposición fue realizada entre el 14 de mayo y el 28 de agosto del 2011. Todas las fotografías exhibidas se mostraron a gran tamaño, de 1 metro por 1 metro y medio aproximadamente, al igual que otras exhibiciones individuales de Michael Wesely.
} 
casos en color con tendencia al sepia, construyen un relato que da cuenta del esfuerzo y la amabilidad con la que se intentó generar una ciudad con una arquitectura moderna, comparable con los estándares internacionales de la década de 1950 y 1960. Se advierte variedad de medios de transporte en las imágenes: autos, buses, avionesy helicópteros abundan en ellas (imagen I); se ven también personas que habitan felizmente el espacio, en algunos casos se trata de los registros de la construcción de las obras con los obreros en acción, los niños en movimiento de juego, en otros, se observa el paisaje natural deshabitado en espera de sus nuevas estructuras. Hay varias imágenes en las que aparecen obreros en espacios naturales, los espacios satélites que habitaron durante la construcción. A pesar de evidenciarse las condiciones precarias en las que vivían, la sonrisa, en compañía de una cálida pose, prima en todas las imágenes (Imagen II). Se encuentra también una fotografía en donde un grupo de indígenas desnudos recibe cordialmente unas plantas entregadas por los nuevos habitantes (o constructores de la ciudad), una imagen réplica del diálogo de "la civilización y la barbarie" (Imagen III). Y varias fotografías del paso a paso en la construcción de cada una de las instituciones: la catedral, la universidad, el Congreso Nacional, los ministerios. A su vez, hay gran cantidad de imágenes aéreas producidas por un aviador Ilamado Mario Fontenelle; si bien

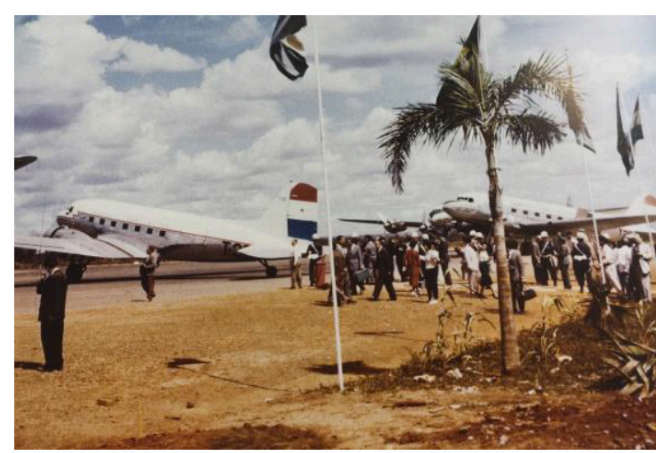

Fig. 1

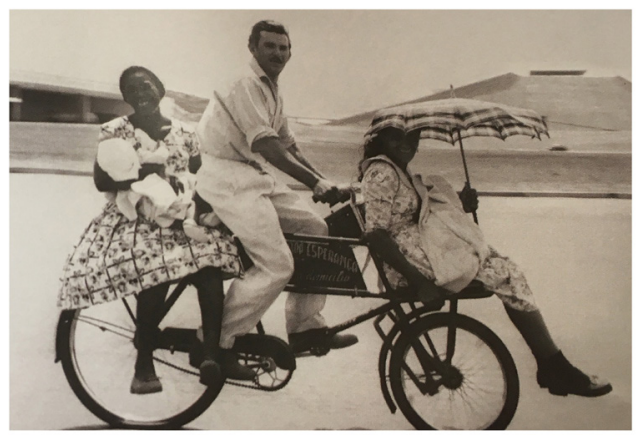

Fig. 2 éste no era fotógrafo profesional se interesó activamente por la construcción de la ciudad y tomó muchas fotografías que reponen un nuevo punto de vista, sumamente moderno, sobre el diseño y el armado de Brasilia (Imagen IV).

Este conjunto de imágenes de archivo, con carácter de registro documental por formar parte de varios repositorios, construye un sentido en extremo positivo respecto al proyecto Brasilia y su concreción. Como lo sugiere Tagg "Desde sus inicios a la fotografía se la identificó no solo con la aspiración a un lenguaje universal, sino con la administración de archivos globales y repositorios, fue un elemento producido $y$ 
apropiado por los discursos de los aparatos de dominación, es decir, ha formado parte de la tecnología del poder - conocimiento" ([1988] 2005:87) En este sentido, y sin lugar a titubeos, estas imágenes de archivo de Brasilia reponen la esencia de la búsqueda de un símbolo de nuevo gobierno; el esfuerzo en la construcción de un sentido de nacionalidad cosmopolita que, abraza e incluye tanto a los originarios como a los nuevos habitantes. A la vez que construyen

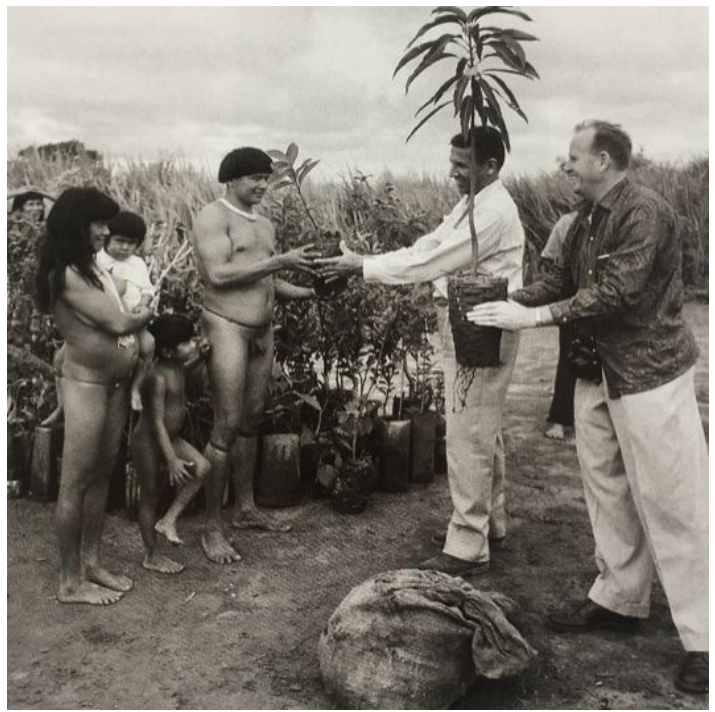

Fig. 3

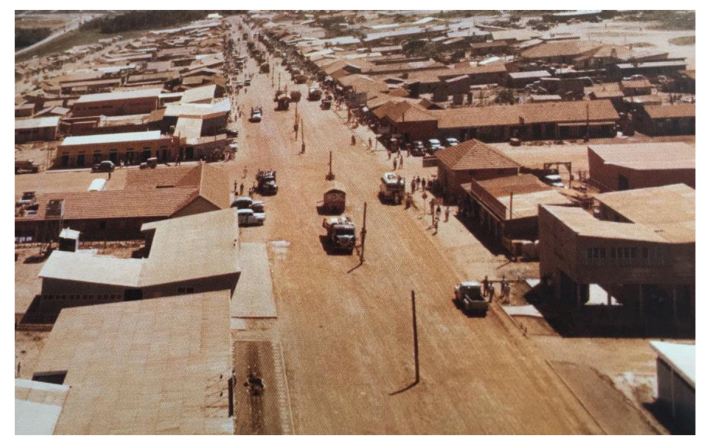

Fig. 4 esta imagen de la felicidad del progreso, estas fotografías dejan en sombra la explotación y la muerte de gran cantidad de los obreros que participaron en la cimentación de la ciudad, como así también excluye las exigencias e imposiciones que se dieron en la población de su espacio a través de la migración.

Las sonrisas tiñen las fotografías respondiendo a un tipo de imagen pre - urbana que el Estado deseó reflejar. En este sentido, y siguiendo con el planteo de Tagg, resulta necesario comprender que, el papel de la fotografía en las prácticas documentales de las instituciones equivale a repensar la historia de un conjunto de creencias y afirmaciones sobre la naturaleza de la fotografía que configuran un "régimen de verdad" ([1988] 2005:81). Y, más precisamente "que no se trata del poder de la cámara sino de los aparatos del Estado local que hacen uso de ella, garantizando la autoridad de las imágenes que construye para mostrarlas como una prueba" ([1988] 2005: 85). Para pensar entonces las posibilidades de otros tipos de archivos se indagará a continuación en el trabajo realizado por Wesely y Kim, el cual plantea nuevas versiones respecto del "aparato de verdad" fotográfico. 


\section{El Archivo Utopía}

\subsection{Claves conceptuales}

Luego de visualizar atentamente esta especie de arqueología imaginaria (configurada por el material de archivo original) los artistas eligieron las locaciones a fotografiar y utilizaronlos tiempos largos de exposición como base técnica para producir esta ciudad utópica. En este sentido, es importante subrayar que ambos artistas coinciden en destacar a la desorientación como guía central de su trabajo (2011:34), ligada principalmente a que Brasilia es habitualmente referenciado en contextos utópicos y es leída en tanto utopía modernista respecto a la arquitectura. Esta desorientación empapa también a los espectadores de las imágenes y es generada, principalmente, por la técnica utilizada. Se explicará entonces en qué consiste esta técnica, para pensar luego las imágenes en función del concepto de imagen-tiempo fotográfica.

La serie Archivo Utopía. El Proyecto Brasiliafue producida con una cámara de gran formato, realizada por los artistas. Cada fotografía de la serie fue generada con una velocidad muy lenta: doce horas de exposición, desde las 6 am hasta las 6 pm aproximadamente. Esta manipulación temporal extensa fuerza al instante fotográfico hegemónico y traduce el objeto fotografiado recreándolo. Los aspectos visuales plásticos (los colores, la trama, la textura, las formas) problematizan la iconicidad de la imagen abriendo nuevas formas de ver a la ciudad y al archivo.

Para pensar la noción de traducción resulta necesario recuperar la idea de Eduardo Cadava

Tal como propone Walter Benjamin [...] en «La tarea del traductor» (Die Aufgabe des Übersetzers) la traducción debe resistir el deseo de "comunicar algo", debe resistir a su deseo de entregar al sentido del original [...] lo que justifica la traducción es un acto de traducción que permanece fiel a la movilidad, la extrañeza y la incomprensibilidad tanto del original como del lenguaje en general [...] el original le da a la traductora la libertad de ser infiel, la libertad incluso de inventar la lengua misma (Cadava, 2014, p. 12).

Es inspirador pensar el acto fotográfico a partir de este enfoque, ya que abre el camino para preguntarnos por las maneras de producir sentido del aparato fotográfico y, a la vez, hace tambalear la idea dereproducción del original. ${ }^{5} \mathrm{~A}$ su vez, este uso de tiempos extensos nos acerca a la propuesta de Flusser, quien

\footnotetext{
${ }^{5}$ Más allá de estas fotografías de tiempo largo de exposición, considero inviable la noción de reproducción del original, aún en el uso habitual de velocidad rápida del dispositivo fotográfico. Ya que, si bien las imágenes instantáneas reproducen de forma icónica indicial al congelar el objeto fotografiado, sostengo que siempre opera un punto de vista, un recorte, una angulación (entre otras decisiones) que construye una mirada propia sobre lo fotografiado. Esta idea ya proviene, entre otros, de los postulados del primer Roland Barthes en su análisis del mensaje fotográfico y de la teoría de la Enunciación, en términos generales.
} 
invita a los fotógrafos adesempeñarsecomo jugadores del aparato (1990:27). Wesely y Kim aceptan este desafío; se corren del rol de operadores(que entra dentro del horizonte de expectativa del diseño del dispositivo) para hacer un uso innovador del aparato y generar imágenes que apilan el tiempo, produciendo un espacio depurado, un detritus urbano, en clave de ciencia ficción.

Este tiempo acumulado en cada imagen produce una cualidad temporal específica que se ha denominado imagen-tiempo fotográfica. Se parte del concepto desarrollado por Gilles Deleuze respecto al tiempo en el cine. Luego de haber descripto en La imagen movimiento ([1984]1994) el tiempo subordinado al movimiento, en La Imagen Tiempo ([1985] 2012) el autor arriba a una nueva reflexión sobre una profundidad temporal, que forma directamente una región de tiempo a partir de un continuo de duración propia. Esta duración ya no está asociada a una sucesión (imagen movimiento), sino que, posee formas de tiempo propias. En este sentido es que aquí, en este trabajo, se piensa en una imagen que no sea producidapor el tiempo instantáneo que forjó el modelo fotográfico moderno. ${ }^{6}$ Si no, en una imagen-tiempo fotográfica quedé cuenta de una forma de la duración hecha por un tiempo largo de exposición en donde emerja la materialidad del tiempo.

\subsection{Las imágenes de ciencia ficción}

A partir de aquí, y teniendo en cuenta las claves de lectura recién desarrolladas, se analizarán algunas de las imágenes de larga duración, que conforman el libro Archivo Utopía. El proyecto Brasilia. La intención esdesplegar ciertos aspectos de la fotografía de archivo y hacer una puesta en diálogo (para este caso puntual) con el rol que cumplió la fotografía en el registro y creación de las ciudades modernas.

La fotografía que da inicio al catálogo Archivo Utopía. Proyecto Brasilia se denomina "Aeropuerto" (2004) (Imagen V). Lejos de exhibir una estructura en relación con este espacio, da cuenta y refuerza, a partir de su encuadre apaisado, la vista del horizonte en donde predomina una tierra rojiza típica de estas zonas de Brasil. El punto de vista bajo de la toma, rasante a la tierra, incrementa la percepción de esta tierra húmeda que, invade toda la foto sin presentar una forma que aluda al título de la obra. A su vez, el tiempo largo de exposicióngenera esta imagen - tiempo fotográfica en donde ninguna sombra habita; la salida y la puesta del sol se conjugan en un brillo indeterminado que puede ser identificado con una hora particular del día. El color del cielo, producto también de la extensa exposición, se traduce en un celeste lavado

\footnotetext{
${ }^{6}$ El tiempo de exposición asociado al modelo fotográfico moderno se corresponde con un tiempo breve que reproduce imágenes estáticas, formalmente similares a su objeto referente.Este tiempo de exposición oscila entre $1 / 60$ segundos y $1 / 125$. Las cámaras de foto automáticas y los dispositivos que incluyen esta función y no tienen opciones manuales, como los teléfonos celulares, por ejemplo, obturan siempre con esta velocidad.
} 
que contrasta y acrecienta el color terracota del suelo. Esta imagen de la tierra desierta tiene resonancias con el espacio original sobre el que la ciudad fue construida, lejos del eje San Pablo - Río de Janeiro (eje altamente politizado), Brasilia fue alzada en el medio del enorme país, en "las tierras de nadie".

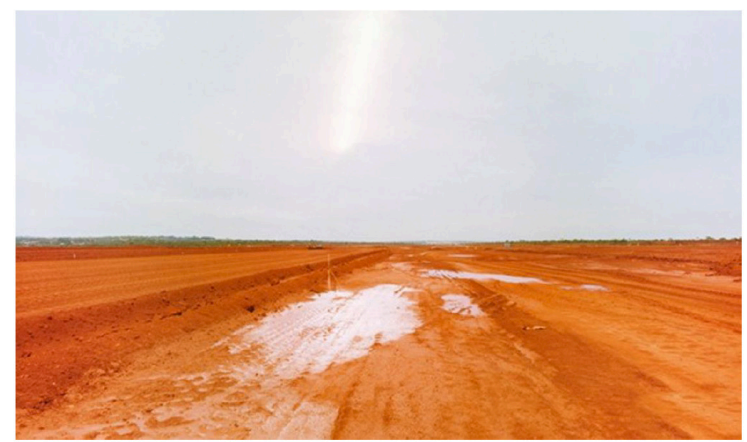

Fig. 5

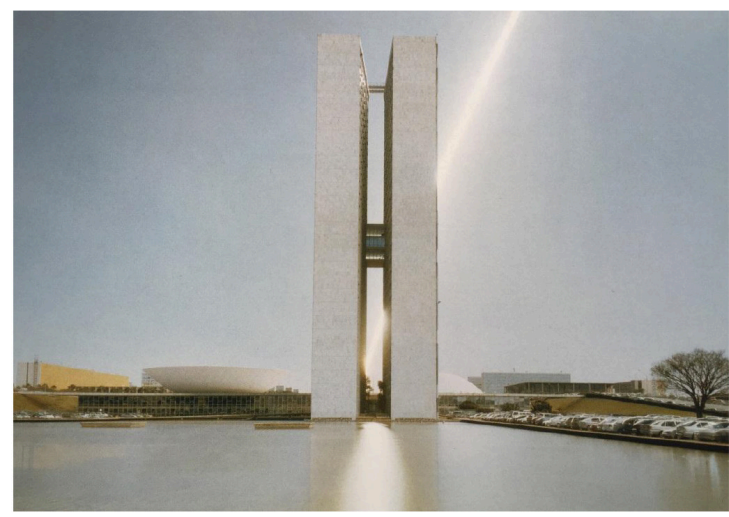

Fig. 6

Resulta peculiar que esa imagen desértica sea la que abre el relato visual. La fotografía que la sucede contrasta, se denomina "Congreso Nacional" (2004) (Imagen VI) y construye un espacio enrarecido en donde el edificio es ubicado en el centro de la imagen, definiendo la lectura de la misma. El congreso en sí no presenta diferencias sustanciales respecto a una foto producida por una velocidad rápida, instantánea, lo que desorienta es el fondo de la imagen. Se advierte una línea diagonal producto de las doce horas de exposición fotográfica y del movimiento de la tierra respecto al sol; esta línea se esconde por detrás de la estructura rodeada por un cielo de un celeste lavado homogéneo. A su vez, parte de este edifico se refleja en un lago artificial que ocupa la zona inferior de la imagen, a su derecha se encuentran un conjunto de autos que parecen vibrar, al presentar un contorno indefinido. Si bien las formas mantienen su aspecto icónico (se reconocen los autos y los edificios del fondo porque mantienen su similitud formal con el objeto) la imagen tiempo - fotográfica producida por los tiempos largos de exposición comienza a difuminar y marear la percepción del espectador.

Las imágenes siguientes van presentando diversos espacios de la ciudad, y también de Candagolandia, ubicado en los alrededores de Brasilia7. Hay un

${ }^{7}$ En la entrevista que da inicio al catálogo Archivo Utopía. El Proyecto Brasilia Lina Kim insiste sobre la importancia de incluir en las tomas fotográficas no sólo a la ciudad de Brasilia, sino también a los pueblos y ciudades satélites que albergaron y albergan gran parte de la gente que 
aspectoque insiste en todas las tomas, y especialmente en las tomas de veredas y calles: un vacío general visitado por espectros vehiculares. Se torna evidente la falta de peatones que se apropien del espacio. Este vacío humano es un aspecto a destacar en la serie y da cuenta de un rasgo característico del proyecto que dio forma a la ciudad de Brasilia. A diferencia de las ciudades surgidas durante la modernidad, especialmente en los siglos XIX y XX, cuando la muchedumbre definía la impronta de estos espacios, siendo un signo de progreso del cual el binomio fotografía ciudad dio cuenta, Brasilia responde a un proyecto modernista racional que persigue el concepto arquitectónico de Oscar Niemayer y Lucio Costa. Como señala James Holston hay un contraste entre el urbanismo modernista y el preindustrial de estilo barroco en Brasil, porque Brasila fue diseñada para transformar, tanto arquitectónica, como socialmente, una forma de vida urbana que se había establecido en las ciudades preindustriales (2008: 262). Brasilia fue pensada para el tránsito exclusivo de vehículos, razón por la cual carece de esquina para peatones y de plazas centrales.

Dada su ubicación puntual, Brasilia fue funcional al gobierno militar entre los años 1964 y 1984 para generar descentralización política, aislación y separación político-civil en la sociedad ${ }^{8}$. Los habitantes eran, en su mayoría, civiles y políticos que fueron conminados a moverse allí, en consecuencia, la ciudad no participó de las manifestaciones en torno a la crisis política del 1964, en contraste con el eje San Pablo - Río de Janeiro que intervino activamente en diferentes resistencias. Brasilia, en cambio, se mantuvo al margen de estos movimientos y resultó sumamente funcional para el dispositivo político-militar. En este sentido, esta despolitización del espacio es sugerida en la serie a partir del vacío humano (y su dimensión espectral) generado plásticamente por los

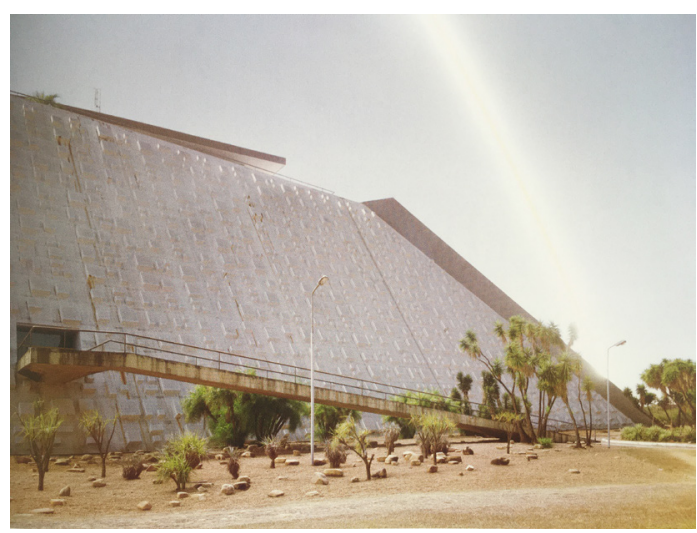
tiempos largos de exposición. La imagen-tiempo fotográfica invisibiliza a los peatones que transitan por Brasilia, tornando visible un modelo de ciudad que abraza el axioma futurista del "hombre muliplicado por el motor" y subraya un dominio público que es restringido en pos de espacios cada vez más privados.

Fig. 7

construyó la ciudad y que trabaja allí actualmente. (Wesely - Kim, 2011, p. 34).

${ }^{8}$ El artículo "Brasilia's political dimension" es una de las reflexiones que acompaña el libro catálogo de la muestra Archivo Utopía. Proyecto Brasilia. 


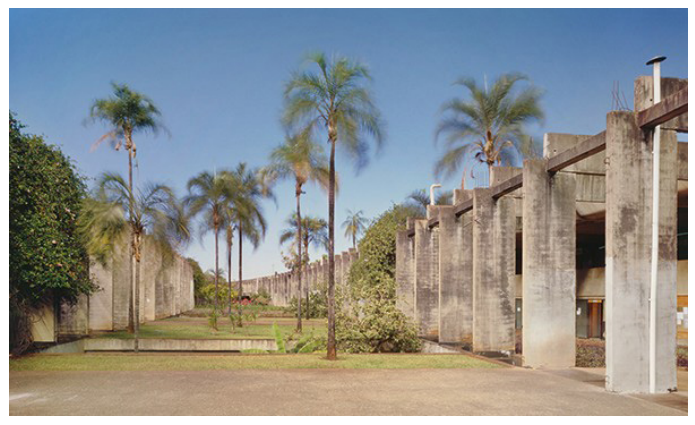

Fig. 8

Se postula que las fotografías producidas por Wesely y Kim para Archivo Utopía. El proyecto Brasilia construyen una ciudad que se distancia de la imagen fotográfica urbana característica de la modernidad. Si bien en las fotos se incluyen varios de los edificios institucionales asociados a la idea de progreso de fines del siglo XIX y principios del siglo XX, (momento de auge ideario del proyecto moderno): El teatro Nacional, La Universidad de Brasilia (Imagen VII y VIII), la forma en que están construidas las imágeneshace de estas instituciones una especie de monumento que sobrevive al tiempo vacío que lo rodea. La falta de presencia humana y de un anclaje temporal concreto relativiza estas imágenes. Laimagen-tiempo fotográficaen Archivo Utopía. El proyecto Brasiliadesarticula la iconicidad y solvencia que otras imágenes canónicas de ciudades presentan.

Las alteraciones cromáticas, la ausencia de sombras y el carácter espectral de todas las fotografías producen esta imagen que se ha caracterizado como una ciencia ficción fotográfica. Es una imagen que hace fluir y convivir el tiempo por fuera del instante. En ese sentido, retomamos a Mauricio Lissovsky quien, siguiendo a Benjamin, recupera el intento de disputar el instante a la modernidad, rescatándolo de tiempo crónico, para poder pensar a la fotografía como un dispositivo del retardarse que se abre y se torna futuro al hacer fluir el tiempo. (2007:17). Este retardarse es desplegado por Wesely y Kim como herramienta estratégica para apropiarse de sus imágenes e imaginarios y ponerlos en tensión. El título de la serie acarrea una utopía que es necesaria destacar, la serie se aleja sensiblemente del sueño moderno de Brasilia como ciudad del futuro y propone una ciudad futurista desierta; una ciudad que a partir de la extensa acumulación temporal depura los detritus urbanos.

A su vez, esta dimensión de ciencia ficción se condice con una dimensión espacio-temporal imposible de concebir para el ojo desnudo. Archivo Utopía genera una nueva concepción temporo-espacial dada por una manipulación no canónica de un dispositivo, diseñado por los mismos artistas, que, siguiendo a Flusser, "obliga al aparato a hacer lo que él no quiere, o no puede hacer, porque no está inscrito en su programa (...) esta subversión del programa, o esta rebelión contra él, se propone como una conquista de la libertad" (1990:25). Puede entonces considerarse como una ciencia ficción a la inversa. El usuario hace un uso subversivo del dispositivo, generando conceptos que trastocan y transgreden la intención original del aparato.Archivo Utopía genera una imagen enrarecida que, a la vez que se distancia de la fotografía de archivo propuesta y rescatada 
dentro del mismo proyecto, se aleja de la imagen fotográfica hegemónica que, junto con otras representaciones visuales, literarias y simbólicas, acompañó las transformaciones de las ciudades modernas durante el siglo XIX y principios de $X X$, contribuyendo a la construcción de imaginario urbano. Es en este sentido que se liga esta fotografía de ciencia ficción con la dimensión dialéctica propuesta por Benjamin (1972) en cuanto a la capacidad de interrumpir la Historia (con mayúscula) y desplegar otras historias posibles, historias fotográficas que hagan tambalear la representación instantánea del tiempo y de espacio. Es esta nueva amalgama espacio-temporal, que se denominó imagen-tiempo fotográfica, la que de manera dialéctica a partir de un uso "no apropiado" del dispositivo fotográfico propone otro imaginario urbano. ${ }^{9}$

\section{Breves conclusiones}

A modo de cierre de este texto se desea recuperar el título del mismo, esto que se ha dado en llamar "un no lugar para la fotografía" responde, en principio, a la definición de la palabra utopía. Un no lugar que aviva a seguir buscando y creando nuevas concepciones que contrasten y superen lo que se da en llamar realidad. Esto se actualiza en las fotografías en torno a la noción de archivo. Los fotógrafos recuperan y restauran un material documental que ponen a dialogar con la producción fotográfica propia que se ocupa de los mismos espacios fotografiados. Estos espacios se trastocan a partir de la imagen-tiempo fotográfica que invita a mirar esa ciudad de un modo enajenado. Un modo, también documental, que produce este no lugarde ciencia ficción que, a la vez que presenta otra imagen de Brasilia, presenta otro tipo de imagen documental, recurriendo a un uso forzado, no habitual del dispositivo.

En síntesis, la serie no sólo tensiona la construcción hegemónica de lo urbano, sino que, al ser puesta en diálogo con un corpus de fotografías provenientes de diferentes archivos nacionales oficiales permite ampliar el horizonte de expectativa de este tipo de imágenes, proponiéndose como un archivo utópico que excede la dicotomía de fotografía artística o de archivo para poder pensarse como un artefacto poético y documental que a la vez supera la frontera entre la ficción y el documento. Esta ficción científica se asume como tal y es puesta en acción en las fotos de Archivo Utopía. El proyecto Brasiliaal presentarse como un documento con forma de imagen - tiempo fotográfica.

\footnotetext{
${ }^{9}$ Por último, aunque se trate de una apuesta estético-conceptual bien distinta respecto de los fotógrafos aquí analizados, se desea mencionar el trabajo de Rosangela Rennó,Inmemorial (1994), que representa un antecedente interesante e insoslayable a considerar. Porque allí ella, mediante un trabajo con fotografías de archivo sobre trabajadores y niños que construyeron Brasilia y murieron en esa tarea, pone en escena a los actores invisibilizados durante el proceso, poniendo en cuestión los usos y valores del archivo sus efectos políticos, la relación entre fotografía y memoria. Otra forma de intervenir en los documentos, los relatos tramados a partir de ellos, y la ficción que ella monta a partir de usos novedosos del dispositivo.
} 


\section{Referencias}

BENJAMIN, Walter. 1972[1940]“Tesis de Filosofía de la Historia” En Discursos Interrumpidos I (pp. 175 - 191). Barcelona: Taurus.

CADAVA, Eduardo. 2014. Trazos de luz. Tesis sobre la fotografía de la historia. Buenos Aires, Argentina: Palinodia.

DELEUZE, Gilles. 1994 [1984]. La Imagen Movimiento. Barcelona: Paidós Comunicación.

2012 [1985]. La Imagen Tiempo. Buenos Aires: Paidós

Comunicación.

FLUSSER, Vilem. 1990. Hacia una filosofía de la fotografía. Ciudad de México: Trillas/SIGMA.

Holston, James. (2008). La ciudad modernista y la muerte en la calle. Revista Antípoda. Nro. 7 (pp. 257 - 292) recuperado de https://revistas.uniandes.edu. co/doi/pdf/10.7440/antipoda7.2008.11(acceso en junio de 2019).

LISSOSVSKY, Mauricio. 2003. "A maquina de esperar" (pp.15-23. En Gondar, Jô y Barrenechea, Miguel Ángel. (org.), Memória e Espaço: trilhas doContemporáneo. Rio de Janeiro, Brasil.

MAGNETTO, Vanesa. 2016. Fotografía y arquitectura: signos desarmados. Sobre la serie fotográfica Potsdamer y Leipziger Platz de Michael Wesely. Revista Atlas.

https://atlasiv.com/author/vanesa-magnetto/ (acceso en junio de 2019).

MAGNETTO, Vanesa. 2018. La imagen fotográfica como testimonio de lo invisible: sobre los tiempos largos de exposición. No Imagen (2), 58-70. http://noimagen.net/pdf/ revista02.pdf?fbclid=IwAR3JJvV6dM1uHpMuc5IxOoROlvkeC8k_ da_1X6RD6hhlcJL5gLVR6nBIFQ (acceso en Agosto de 2019).

TAGG, John. 2005 [1988]. El peso de la representación: ensayos sobre fotografías e historias. Barcelona: Gustavo Gili.

WESELY, Michael\&KIM, Lina.2011. “Archiv Utopia. Brasilia”. En Hüsch Anette ed: Archiv. Utopía. Berlin: Kehrer. 


\section{MEDIACIONES}

\section{CUERPOS Y SENTIDOS}





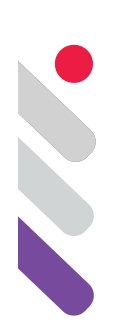

\title{
El gesto musical y la cognición corporeizada: articuladores del sentido en la discursividad musical
}

DOI: 10.24308/IASS-2019-4-031

\author{
Federico Buján \\ Universidad Nacional de Rosario (UNR) \\ Universidad Nacional de las Artes (UNA), Argentina \\ fbujan@gmail.com
}

La problemática de la significación musical ha sido abordada desde distintas perspectivas en el campo de los estudios musicales, intensificándose en las últimas décadas los estudios y los debates que han instalado al gesto musical como un tópico central dentro de esa área-problema. En ese contexto, se observa una pluralidad de concepciones acerca del gesto musical y una gran variabilidad de sus alcances en el orden de la discursividad musical; desde concepciones centradas de manera casi exclusiva en su dimensión técnica y en la bio-mecánica que participa en la producción sonora (para luego, en algunos casos, indagar acerca de sus incidencias en el plano de los efectos de sentido) hasta aquellas que lo entienden, intradiscursivamente, como una configuración de sentido organizada a partir de unidades discretas de elementos propios del discurso musical. En cualquier caso, y más allá de las profundas diferencias que puedan suponer esas distintas concepciones, el gesto estaría operando como un movimiento o cambio de estado que se vuelve significante para un agente, participando de manera plena y determinante en las configuraciones de sentido desplegadas al interior de la semiosis musical.

En el presente trabajo se problematizará, desde una perspectiva semiótica, al gesto musical y a las complejas relaciones que establece en los procesos de producción de sentido en el marco de la discursividad musical. Se discutirán también sus alcances en el plano de la cognición musical corporeizada, definiendo aspectos específicos de ese tipo de discursividad, su relación con la participación del cuerpo y con su dimensión significante. Por esa vía se concebirá al gesto musical como un configurador de sentido que operará de manera constitutiva en las distintas instancias de los procesos discursivos, 
estableciendo particulares dinámicas en la circulación del sentido y entramando el despliegue de una singular narratividad.

Palabras clave: gesto musical, cognición corporeizada, semiótica musical, narratividad.

\section{Aproximaciones al gesto musical}

El presente trabajo se inscribe en el marco de dos proyectos de investigación en curso $^{1}$, que presentan diferentes características pero que encuentran líneas de investigación convergentes, y en los que particularmente me intereso, desde una perspectiva semiótica, en un conjunto amplio de problemáticas vinculadas a los procesos implicados en la significación musical.

La materialidad significante de los discursos musicales ha constituido, de entrada, una invariante de nuestras preocupaciones investigativas, proponiéndonos distintos caminos analíticos posibles a los efectos explorar las cualidades y comportamiento de los fenómenos objeto de estudio. En esta dirección, tempranamente pudimos advertir la complejidad de nuestro objeto y la heterogeneidad de los múltiples niveles en los que se desplegaban los procesos de significación musical: distintas instancias discursivas, distintos modos de organización de la materia sonora, distintas posiciones frente a los objetos sonoros, distintas competencias, desafíos y destrezas activadas en relación con los fenómenos musicales, distintas concepciones, tradiciones y modalidades interpretativas, distintas aproximaciones investigativas... en fin, un inmenso universo discursivo que admitía múltiples posibilidades de aproximación analítica. Pero en el centro de todo, nuevamente, nuestra insistente preocupación por la materialidad significante de los discursos musicales.

A su vez, dicha dimensión también presentaba diversas modalidades de manifestación y de existencia, lo cual abría nuevamente diversos caminos posibles para su abordaje analítico, modulando los modos de pensar y construir el objeto así como de proyectar estrategias metodológicas acordes a tales constructos. Teníamos en claro desde el inicio que el foco sobre las configuraciones de sentido que se constituyen a partir de la materia sonora y sus modalidades de representación asociadas, que organizan formaciones simbólico-sonoras a partir del despliegue de complejos procesos de producción de sentido, desplegaban modalidades específicas de significación que eran

\footnotetext{
${ }^{1}$ Nos referimos a los siguientes proyectos de investigación: "Gestualidad, corporeidad y mediatización de la interpretación musical: aproximaciones semióticas", radicado en la Facultad de Humanidades y Artes de la Universidad Nacional de Rosario (UNR), Director: Dr. Federico Buján; y "Narratividad: relaciones Arte y Mediatización", radicado en el Área Transdepartamental de Crítica de Artes de la Universidad Nacional de las Artes (UNA), Director: Dr. Oscar Traversa.
} 
propias de este tipo de discursividad, generando organizaciones sintácticodiscursivas a través de la materia sonora y, derivado de ello, desencadenando procesos específicos de organización del sentido.

La literatura específica vinculada con nuestras preocupaciones, por su parte, manifestaba un particular énfasis puesto sobre la noción de gesto musical. Pero no se requería avanzar tanto en la exploración bibliográfica para rápidamente notar la gran heterogeneidad de concepciones vinculadas con dicha noción. La noción de gesto, en este sentido, implicaba una enorme pluralidad de significaciones en distintos contextos teóricos, por lo que las categorías que se pueden encontrar para organizar sus diversos comportamientos responden a la gran diversidad de concepciones, perspectivas e intereses teóricos en juego. Se configura así un extenso territorio conceptual en torno a la noción de gesto musical que abarca desde la dimensión netamente física del fenómeno, poniendo énfasis en la corporalidad y su comportamiento como soporte significante, focalizando por ejemplo en las operaciones que participan de manera directa en la producción sonora o de gestualidades auxiliares asociadas en diversos grados a las mismas, y que se tornan determinantes en el plano de la expresividad o de fenómenos asociados a estas dimensiones (por ejemplo: el caso en que los estudiantes terminan adoptando cualidades posturales o gesticulaciones de sus docentes en los procesos de aprendizaje o en el funcionamiento comunicacional de gestualidades en la praxis musical grupal), pasando por estudios que comprenden a la gestualidad intradiscursivamente a partir de los elementos del lenguaje musical que se ponen en juego para organizar su discursividad, hasta concepciones centradas en los procesos cognitivos que operan en la construcción mental o imaginaria de los fenómenos, y en donde se despliega todo un enorme dominio que incluye desde el estudio de las metáforas conceptuales y sus funcionamientos discursivos hasta las estrategias puestas en obra en los procesos de reconocimiento de rasgos estilísticos. Como se puede ver, el campo de estudios es amplio y heterogéneo, y en él se ponen en obra concepciones muy diversas del gesto musical que definen aproximaciones analíticas igualmente diversas.

En esta dirección, la pluralidad de concepciones ha dado lugar a distintas categorizaciones referidas a las tipologías del gesto musical (Sullivan 1984; Delalande 1988; Hatten 2003, 2004, 2006; Zampronha 2005; Gritten \& King 2006; Jensenius 2007; Peñalba 2010; Jensenius, Wanderley, Godøy \& Leman 2010), enfocando la problemática desde diversas perspectivas y aportando diferentes matices sobre la problemática, y por supuesto, atendiendo a sus múltiples modalidades de existencia. Sea como fuere, desde una u otra aproximación, la naturaleza semiótica del gesto implica, en sus múltiples concepciones y modalidades de existencia, una inexorable capacidad significante, participando 
de manera determinante en el complejo entramado de la semiosis musical, en sus diversos niveles y dimensiones.

\section{Cognición corporeizada y narratividad}

Durante la última década se ha desarrollado y fortalecido en el campo de la investigación musical un paradigma de gran alcance y especificidad para el estudio de la significación musical: el paradigma de la cognición musical corporeizada. Desde este paradigma, que procura superar las visiones reduccionistas que separan las dimensiones del cuerpo y de la mente en lo que refiere a la emergencia y procesualidad de la significación musical, se enfatiza que los procesos de producción de sentido que se despliegan en relación con las diversas prácticas vinculadas a los fenómenos musicales están profundamente marcados por la participación y mediación corporal, siendo esta última determinante en los modos en que se entreteje la discursividad musical.

El desarrollo de este paradigma, hasta llegar a su actual estado, fue transitando un largo camino en el intento de superar una visión ingenua y reduccionista acerca del papel que desempeña el cuerpo en la praxis musical, centrada en la corporalidad como simple condicionamiento material y biológico, hasta múltiples concepciones acerca de la corporeidad y de las maneras en que ésta última participa en la producción de sentido en la experiencia musical. En términos fenomenológicos, corporalidad y corporeidad constituirían dos aspectos diferentes, aunque interrelacionados de nuestra condición de seres encarnados: corporalidad como condición material de posibilidad de la corporeidad (Pelinski 2005). El doble aspecto del cuerpo como corporalidad física y corporeidad vivida es el punto de partida de perspectivas diversas en el estudio de la consciencia perceptiva. Entre ellas destacan, como polos opuestos, la fenomenología y el reduccionismo neurocientífico (Pelinski 2005).

Superar las concepciones reduccionistas implica, en el contexto de nuestra problematización, profundizar el estudio de las relaciones que operan entre gestualidad y corporeidad en el despliegue de la semiosis musical. En este contexto, la experiencialidad se constituye en una dimensión determinante respecto de los modos en que se produce sentido en y a través del cuerpo, y en el modo en que la gestualidad permite organizar nuestra comprensión de los fenómenos musicales.

Queda expresada así la complejidad de nuestro objeto, en tanto que no se reduce a un aspecto meramente físico ni a una representación mental del fenómeno musical, sino que nos adentramos en las operaciones complejas que participan en el despliegue de la semiosis musical en un amplio espectro de relaciones que se establecen en distintos niveles. Tal como señala López Cano (2014): "la semiosis musical articula materia sonora con emociones, imágenes mentales de estructuras y formas, movimiento corporal efectivo o simulado. 
Lo importante no son los gestos, ni el sonido, ni las emociones por separado. Tampoco lo es su unión. Lo relevante es el vínculo que se establece entre todos ellos y su interacción: su función como interpretantes unos de otros" (pp. 56). En esta dirección, la importancia de la problemática no radica en las unidades discretas que conforman los signos y gestos musicales, sino en las relaciones que se establecen en la red de interpretantes, en los órdenes de sentido involucrados en la semiosis musical (en términos peirceanos: primeridad, secundariedad y terceridad).

La gestualidad y la corporeidad constituyen interpretantes, y participan en la producción de nuevos interpretantes musicales, siendo susceptibles de generar organizaciones narrativas en el despliegue de la semiosis. Las distintas operaciones puestas en obra en la construcción del discurso musical, que resulta de una particular gramática sonora, conducirán a la emergencia de expectativas (que se cumplirán o se frustrarán) relativas a las gramáticas de reconocimiento de los oyentes y sustentadas en sus múltiples y variables condiciones de reconocimiento (indeterminación inherente a la discursividad musical). Este complejo proceso significante define modalidades específicas de funcionamiento de la narratividad musical.

La narratividad musical, en esta dirección, constituye una experiencia de naturaleza cognitiva (Hauer 2015), en la que se despliega el sentido en base a una experiencialidad que encuentra como soporte al cuerpo significante de los actores sociales, destacándose así la relevancia del desempeño de la corporeidad en los procesos de significación musical. De ese modo, la relación corporeidad-experiencia musical adquiere una relevancia determinante en estos procesos de producción de sentido, inscribiéndose de manera constitutiva en los esquemas de significación de los actores sociales.

Desde esta perspectiva, vale decir, la narratividad musical constituirá un fenómeno cognitivo por excelencia, que desencadenará procesos de producción de sentido a partir de formaciones simbólico-sonoras resultantes de la activación de una compleja actividad sígnica (semiosis musical). La narratividad musical, de ese modo, pondrá en juego significantes sonoro-musicales que serán investidos de sentido de manera muy variable en sus emplazamientos sociales, según reglas culturales más o menos estabilizadas así como también en función de las experiencias particulares de los actores individuales, que definirán gramáticas de reconocimiento ampliamente variables.

\section{Territorios cognitivos y significación musical}

Hemos referido en el acápite anterior a la relevancia del paradigma de la cognición musical corporeizada en la actualidad y esbozamos algunos de sus alcances y articulaciones en relación a la narratividad como experiencia cognitiva. Ahora quisiéramos enfatizar un aspecto más específico acerca del 
modo en que interviene una dimensión operativa nuclear de la significación musical, que refiere particularmente a los intérpretes y al modo en que se vinculan con ciertos aspectos específicos de la discursividad musical: el de la percepción háptica como dimensión determinante en esta particular área de la producción de sentido. Nos interesan particularmente estos aspectos por la escasa atención y estudio que ha recibido esta dimensión dentro del campo específico, a pesar de su valor y pertinencia semiótica.

Dentro del amplio espectro de las teorías de la mente en el marco de las ciencias cognitivas, y del largo trayecto que lleva del modelo cognitivo representacionista clásico hasta el modelo de la mente enactiva, la problemática de la corporeidad se va tensionando y se va poniendo de relieve la importancia de la participación de mecanismos sensomotores específicos en el desarrollo de la cognición. Particularmente, los postulados de la teoría enactiva ${ }^{2}$ nos resultan de gran utilidad para dimensionar la implicancia de la percepción háptica en la interpretación musical y sus alcances en los procesos de significación específicos en ese dominio.

Referimos a la percepción háptica, que se encuentra dentro del conjunto de ámbitos de la percepción del movimiento. Se incluyen también dentro de ese gran dominio de la percepción del movimiento las propiocepciones y la percepción espacial. De manera específica, la percepción háptica se ubica dentro de la percepción del tacto, integrando la percepción táctil y la kinestésica. ${ }^{3}$

Este modo de percepción, que es la que ponemos en obra habitualmente a través del sentido del tacto de forma activa y voluntaria, está particularmente implicada en la interpretación musical, entramada en niveles profundos de la cognición corporal y de la sensibilidad sensomotora de los dedos y de las manos que organizan complejas configuraciones de sentido. Nos referimos a que, gran parte de los procesos de producción de sentido implicados en la

\footnotetext{
2 Resumimos a continuación algunos de sus principales postulados y recomendamos, para una profundización al respecto, la lectura de Bedia \& Castilla Ossa (2010) que se indica en la bibliografía: a) que la mente está anclada realmente a través del cuerpo; b) que las representaciones internas no se definan en información proposicional, más bien deberán ser entendidas como estructuras preconceptuales organizadas desde la experiencia corporal; c) quela situacionalidad involucra corporalidad en todo proceso cognitivo; d) que la cognición implica patrones de conducta de un organismo en un entorno.

3 "La percepción táctil hace referencia a la información adquirida exclusivamente a través del sentido cutáneo (postura estática que se mantiene a lo largo de todo el tiempo que dura el proceso de la estimulación).

La percepción kinestésica se refiere a la información proporcionada por los músculos y tendones. Ejemplos de este tipo de percepción son aquellos en los cuales se ha eliminado cualquier información adquirida a través del sentido cutáneo mediante anestesia, o cuando se cubre el dedo o la mano con algún tipo de material que impide que las sensacionesadquiridasatravésdelapielseancaptadas porel sujeto" (Bedia \& Castillla Ossa 2010: 112 y 113).
} 
cognición musical corporeizada a partir de los cuales los intérpretes funcionan dentro de la discursividad musical, se activan a través de estas vías en las que la corporalidad y la corporeidad del intérprete, su gestualidad y su percepción háptica se imbrican de manera insoslayable en la construcción de interpretantes discursivo-musicales.

Volviendo sobre el gesto musical y su dimensión significante, en muchos trabajos relevados (particularmente, aquellos que se centran en la dimensión más física del fenómeno), advertimos que ponen el foco en la dimensión visual del gesto, y no se ha profundizado lo suficiente respecto a sus implicancias significantes a partir de la percepción háptica, su articulación con el plano sonoro y la emergencia de interpretantes. Frente a esto, estamos proponiendo una aproximación que podríamos caracterizar como una verdadera fenomenología del tacto (y del movimiento), orientada sobre la especificidad de la semiosis musical.

No es que la dimensión visual y sus alcances comunicacionales no sean relevantes en este dominio (muchos estudios de excelente nivel han realizado grandes aportes sobre dicha dimensión), pero a los efectos de los procesos de producción de sentido propios de los intérpretes la articulación de la dimensión háptica con la sonora se tornan de enorme relevancia y de un profundo nivel de especificidad respecto de los procesos implicados en la significación musical en dicha instancia, contribuyendo a la comprensión de un pensamiento sintácticomusical específico que atiende nuclearmente a la semiosis musical.

Estamos hablando de la construcción de formas simbólicas en las que la participación del cuerpo no es accesoria sino, muy por el contrario, es realmente medular, ya que esa producción de sentido se genera en y a través del cuerpo (un cuerpo significante como invariable atravesada por la experiencialidad). Está claro que toda producción de sentido se produce en el cuerpo, pero en este nivel en particular no estamos entendiendo al cuerpo como mero soporte físico para el despliegue de la mente, sino que se plantea situar a la mente en el cuerpo y dimensionar en toda su complejidad al cuerpo como un cuerpo significante, en el que emerge el sentido a través de la experimentación sensible.

Volvemos así al corazón del asunto: la materialidad de la discursividad musical, pero abordando una de las modalidades de manifestación de esa materialidad poco explorada. Debemos considerar así también a la problemática de la técnica interviniendo en el transfondo de esta discusión y de considerar a la mano como un verdadero órgano de la percepción háptica (más allá del micronivel neurofisiológico implicado por vía de los receptores cutáneos). Lo que intentamos indicar es que en este nivel corporal y, particularmente, de la corporeidad, a modo de dispositivo (Traversa 2014), se articula la técnica y las organizaciones discursivas de sentido que se entraman en la semiosis musical; 
en otros términos, a partir de este nivel se desencadena la procesualidad de la semiosis.

El gesto, en este contexto, también emerge como un configurador clave del sentido, operando como la expresión de un movimiento que se vuelve significante para alguien. Encontramos así una gran diversidad de entidades, relaciones y procesos que se entraman en la actividad significante mediante la praxis interpretativa: las distancias físicas, los movimientos de la mano, la fuerza aplicada en cada caso, las tensiones (sonoras y musculares), la temporalidad, la espacialidad... Es por esta vía que la capacidad de la mente se hunde en las capacidades del cuerpo, y se desenvuelve un saber propio del cuerpo: se despliega un territorio de trayectos, un mapa cognitivo, en el que se emplazan la memoria y la sensibilidad interpretativa de los intérpretes, en el marco de la compleja red de interpretantes que se entraman dinámica y procesualmente en la semiosis musical.

Se elaboran por esa vía estructuras conceptuales significativas que van conformando mundos sonoros, horizontes de sentido, territorios cognitivos. Las relaciones sonoras que se establecen a través de la percepción háptica van constituyendo así modalidades organizativas del material discursivo que abren dominios cognitivos que estructuran el discurso musical de manera multidimensional. Se configura así un particular agenciamiento de eventos sonoros, de sus cualidades y de su secuenciación temporal, se registran patrones, relaciones sígnicas en múltiples niveles, modalizaciones del carácter y de la dinámica de la discursividad (entre otros aspectos específicos), que van configurando, procesualmente, un dominio cognitivo específicamente musical.

Nos interesa poner el foco en esta dimensión de la significación y de la narratividad musical, en el entendimiento de que allí se desenvuelve una particular lógica operante, claramente diferente a las lógicas de otros sistemas semióticos y merecedora de una exploración en mayor profundidad, pues allí radica una parte importante de la especificidad de su discursividad.

\section{Referencias bibliográficas}

BEDIA, Manuel \& Luis Fernando CASTILLO OSSA. 2010. Hacia una teoría de la mente corporizada: la influencia de los mecanismos sensomotores en el desarrollo de la cognición, Revista Ánfora, Universidad Autónoma de Manizales, Año 17, Nro. 28, 101-124.

DELALANDE, François. 1988. La gestique de Gould. Éléments pour une sémiologie du geste musical. In Ghyslaine GUERTIN (ed.) Glenn Gould pluriel, 83-111. Montréal: Louise Courteau Editrice Inc. 
GONZÁLEZ AKTORIES, Susana \& LÓPEZ CANO, Rubén (eds.). Reflexiones sobre semiología musical. 2008. (Serie: Breviarios de Semiología Musical). México: BUAP.

GRITTEN, Anthony \& KING, Elaine (eds.). Music and gesture. 2006. Burlington: Ashgate Publishing.

HATTEN, Robert. 2003. Musical Gesture: Theory and Interpretation. Course notes, Indiana University.

HATTEN, Robert. 2004. Interpreting musical gestures, topics and tropes. Bloomington: Indiana University Press.

HATTEN, Robert. 2006. A theory of musical gesture and its application to Beethoven and Schubert. In: Anthony GRITTEN \& Elaine KING (eds.) Music and gesture, 1-23. Burlington: Ashgate Publishing.

HAUER, Christian. 2015. Une approche cognitive de la narrativité musicale. Cahiers de Narratologie 28. http://narratologie.revues.org/7194 (accessed 10 April 2019).

JENSENIUS, Alexander. 2007. ACTION - SOUND. Developing methods and tools to study music-related body movement. Osclo: Departamento de Musicología. Universidad de Oslo (Tesis doctoral).

JENSENIUS, Alexander, Marcelo WANDERLEY, Rolf Inge GOD $\varnothing$ Y \& Marc LEMAN. 2010. Musical Gestures: concepts and methods in research. In Rolf Inge GOD $\varnothing Y$ \& Marc LEMAN (eds.), Musical gestures: Sound, movement, and meaning, 12-35. New York: Routledge.

LOPEZ CANO, Rubén. 2013. El error de Descartes y las tres venganzas de René. Introducción al Dossier Cognición Musical Corporeizada. Epistemus, 2, 9-21.

LOPEZ CANO, Rubén. 2014. Música, mente y cuerpo. De la semiótica de la representación a una semiótica de la performatividad. In Marita FORNARO (ed.) De cerca, de lejos. Miradas actuales en Musicología de/sobre América Latina, 41-78. Montevideo: Universidad de la República.

NOGUEIRA, Marcos Vinício. 2016. Música e semântica incorporada: em busca de um método. Epistemus. Revista de Estudios en Música, Cognición y Cultura, 4 (2), 9-37.

PELINSKI, Ramón. 2005. Corporeidad y experiencia musical. Trans. Revista Transcultural de Música 9. https://www.sibetrans.com/trans/articulo/177/ corporeidad-y-experiencia-musical (accessed 24 January 2018).

PEÑALBA, Alicia. 2008. El cuerpo en la interpretación musical. Valladolid: Facultad de Filosofía y Letras, Universidad de Valladolid (Tesis doctoral). 
PEÑALBA, Alicia. 2010. Nuevas relaciones gestuales del intérprete. Trans. Revista Transcultural de Música 14. https://www.sibetrans.com/trans/ articulo/15/nuevas-relaciones-gestuales-del-interprete (accessed 11 February 2018).

SHIFRES, Flavio. 2015. El pensamiento musical en el cuerpo. Epistemus. Revista de Estudios en Música, Cognición y Cultura. 3 (1), 45-56.

SULLIVAN, Mark. 1984. The performance of gesture. Musical gesture, then, and now. Urbana-Champaign: University of Illinois.

TRAVERSA, Oscar. 2014. Inflexiones del discurso. Buenos Aires: Santiago Arcos.

VERÓN, Eliseo. 1988. La semiosis social. Fragmentos de una teoría de la discursividad. Barcelona: Gedisa.

ZAMPRONHA, Edson. 2005. Gesture in contemporary music on the edge between sound materiality and signification. Trans. Revista Transcultural de Música 9. https://www.sibetrans.com/trans/articulo/181/gesture-incontemporary-music-on-the-edge-between-sound-materiality-and-signification (accessed 14 March 2019). 


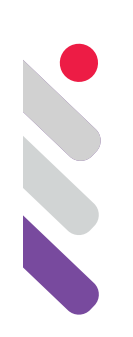

\title{
The body as medium: the subversive self- portraitsof Francesca Woodman
}

DOI: 10.24308/IASS-2019-4-032

\author{
Patrícia Fonseca Fanaya \\ Universidade Federal de Santa Catarina (UFSC), Brazil \\ patriciafanaya@gmail.com
}

\section{The Personal is Political or The Private is Political: a context to Francesca}

In 1970, Carol Hanisch, a member of the New York Radical Women and Women's Liberation Movement, both groups directly linked to the feminist movement, published an essay entitled The Personal is Political. This article was responsible for popularizing the expression that would become the slogan for the second-wave feminism itself. The idea behind that expression was to correlate women's personal experiences with broader social and political issues in force at the time and, thus, provide the opening of private spaces in their home, family and also in their interpersonal relationships to political discussion and analysis.

The so-called second-wave feminismand the counterculture movements of the 1960s and 1970s were closely related, at leastin the United States. Many of the women activists for the anti-Vietnam war movements in the late 1960s, for example, ended up putting the military cause asideto fight for the feminist cause. The lessons learned from the anti-war mobilizations profoundly influenced the feminist movement not only bymotivatingwomen to seek liberation from the prevailing gender norms in society, but also making them rejectinequality of power between men and women.

This is the broad political and cultural setting in which Francesca was born and nurtured. Although some art curators consider Francesca to be a feminist artist, I resist to classify her in these terms because at least until now, and as far as I know, there is no evidence that she has been involved with any political movement or that her work was guided by any political motivation.

In what concerns her private and familiar setting, Francesca was born into a family of artists. Her mother, Betty Woodman, was a celebrated ceramist; her father, George Woodman, was a painter, a ceramist, and a photographer; 
her older brother, Charles, became an electronic art teacher a bit later in life. Francesca got her first camera from her dad when she was thirteen years old. Since that time, she kept photographing until her suicide, in 1981, when she was twenty two years-old.

\section{Francesca and her work}

Francesca Woodman has become one of the most important and celebrated photographers of the 20th century. During her brief life, she produced a disturbing, original, and technically daring body of work. What amazes many people the most in her artistic trajectory is to realize that her monumental production came to light between her thirteen and twenty-two years of age. Out of the more than ten thousand negatives and eight hundred enlargements that make up the artist's collection, only one hundred and twenty images were put to public view until recently. This is to say that most of her work is yet to be unveiled.

The artist is most notably known for her nude and ghostly self-portraits; thus, to point out the importance of the body in Francesca's work sounds like a kind of tautology. The images of her body appear always hidden and/or blurred, and in motion - due to the slow exposures she was experimenting with.

Woodman blurred and changed her body shapes through an extraordinary ability to master the technique of prolonged single exposures. In many of the images, especially those of the Space 2 (1976) andRome (1977-8)series, her fragile body crosses dilapidated rooms, or is part-hidden behind remains of ripped wallpaper; it can yet appear to be moving through space with its contours melting under the fog, and interacting with broken or forgotten objects. The whole atmosphere she creates transforms her into the protagonist of very impacting and haunted scenes.

It comes as no surprise that some critics and art curators have considered Francesca's work to be either neurotic or painfully autobiographical - due to the line they draw between her work, her emotional conflicts and suicide. However, Betty Woodman, her mother, has called this a "basic fallacy". SloPlum, Francesca's close friend, claims that she did not suffer from depression. Instead, Francesca's creative process was like an explosion and the images she produced were the result of her intense commitment to art.

It is always prudent to clearly distinguish between an artist's personal life from her work. Although works of art somewhat speak about the artists' perspective towards the world or about being in the world, it is a dangerous misconception to assume that art is a true expression of the self.

Art is art and must be taken exactly as such. Woodman's work goes far beyond this hurried analysis based on assumptions about her mental states. What is relevant to my analysis is that Francesca seems to have found a way 
to transcend the canonical aestheticism of self-portraits, by technically defying complicated concepts such as self, body image, and identity through her carefully conceived and produced ghostly like figures. Those concepts are some of the matters that artists have been discussing for as far as one can remember, but they become even more relevant to be taken into account in today's image(un)conscious' society.

\section{The self-portrait genre}

Self-portraiture is a distinct genre of art and a fascinating one. Although there are pieces of evidence that show self-portraits already appeared in Ancient Greece, Egypt, and Rome, it is curious that, as a genre, it is not thoroughly discussed among curators and art critics. ${ }^{1}$

The self-portrait genre flourished with the development of the method of making glass mirrors. It is well documented that mirrors became available in Europe during the 15th century, although they were extremely expensive goods by the time. The artisans in Venice perfected the method of making mirrors and since then artists have been portraying themselves in many creative and unsettling ways.

A self-portrait refers to a painting or photograph that depicts the artist who produced it. It can either be a portrait of the artist or her portrait included in a larger work - such as a group portrait. All self-portraits have a tone, and therefore they are open to interpretation and convey meaning. They can be farfetched or playful; they can represent a person in a successful or auto-indulgent situation; or portray an artist's at work or in self-mockery. The way a person dresses or smiles, the setting and the light, the objects present in the scene, all of these elements are loaded with meanings, and in a faithful or loosely manner also represents elements like time and space.

Johannes Gumpp $(1646)^{2}$, for example, was responsible for a very surprising self-portrait composition known as the Triple self-portrait. Shockingly, in this painting there are three heads and two mirrors portrayed at once. It is a very intriguing image because the observer can understand that to be able to paint himself, the artist needed a mirror, but the faces on the mirrors looking back at the observers are looking in different directions and the painter shows his back to the audience. ${ }^{3}$

Although there are hundreds of examples of original and curious self-

\footnotetext{
${ }^{1}$ Museum's curators have found some remains of self-portraits produced in Ancient Greece, Egypt and Rome. However, it is difficult to establish the exact periods of production for those works. This is due both to a lack of information concerning the artists involved, and to the small number of paintings that survived from those historic periods.

${ }^{2}$ Austrian painter, born in Innsbruck in 1626. He died in Italy in 1728.

${ }^{3}$ https://commons.wikimedia.org/wiki/File:Johannes_gumpp.jpg - /media/File:Johannes_ gumpp.jpg
} 
portraits one can offer, usually, there are some main characteristics that remain the same and I refer to them as canonical characteristics. They are as such: selfrepresentation, identity, pose and pause. Those characteristics are intertwined in portraits and self-portraits, and I will try to better distinguish them only to demonstrate ahead how Francesca Woodman subverted all of them at once.

\subsection{Self-representation}

The artist represents himself both to himself and others. Usually, he registers the way he would like others to see him.

Salvador Dalí, e.g., portrayed himself (1954) naked, with his left hand lightly touching the water, kneeling underwater and looking up in ecstasy in a pose of adoration. There is a dog underwater sleeping beside him, mountains behind his left side and an explosion of spheres floating in the air in front and above him. We can recognize traces of Gala's face scattered through the floating spheres. In the end, he seems to be paying homage not only to the cosmos but to Gala - who is his muse and means the universe to him. ${ }^{4}$

\subsection{Identity}

There is a strong relationship between the face and the essence of the artist-subject. It is "as if" the captured physical image of a subject on a canvas or photograph could faithfully represent his own self in its unique, complex and individual formula. This conception has a long-living tradition in the figurative arts and is related to the belief that a face can faithfully express the secrets of the human soul.

Balzac, for example, believed that bodies were made out of many layers of specters. Once an image could not arise from out of nowhere, each one of them captured by a camera corresponded to the loss of one of those layers, i.e., to the loss of a fundamental element of the "essence" of an individual. (FABRIS 2009: $181-2)^{5}$

\subsection{Pose and pause}

Philippe Bruneau (1982: 77-81 apud FABRIS, 2009: 157-8) claims that a portraitis at the same time pose and pause and establishes contraposition between a person, who is the product of the social and the cultural; and the subject, who is a body in a morephysical and biological sense. He gives relevance to the idea of the social interfering in the verisimilitude of a portrait

\footnotetext{
${ }^{4}$ https://www.salvador-dali.org/en/artwork/catalogue-raisonne-paintings/1954/687/dali-nudeentranced-in-the-contemplation-of-five-regular-bodies-metamorphosed-in-corpuscles-in-whichsuddenly-appears-leonardo-s-leda-chromosomatised-by-the-face-of-gala ${ }^{5}$ Fabris indirectly cites a biography of Nadar in this paragraph: Nadar Quandoerofotografo. Roma: EditoriRiuniti, 1982, p. 6-7.
} 
or self-portrait. This happens, according to him, because the social layer introducesissues such as economic class and social roles in the image. For him, the pose is the image of the person and not of the subject and this is useful to understand why he considers a portrait from a fictional narrative perspective.

As much as I agree with Bruneau's sociological approach in several aspects, no one can ignore that portraits and self-portraits maintain a relation of contiguity between the personand the subject portrayed. It can be the case of a completely produced and fictional portrait or self-portrait, but even then I consider this situation an imagistic self-representation of the subject(s). Semiotically speaking, there is invariably an indexical relation present in portraits and self-portraits either in painting or in photographs analogically produced. It seems to me that the point Bruneau ignores is that one should distinguish between the contiguity, which preserves traces of the captured actuality (or indexicality), and the "truth" about the essence of the person - if such a thing is possible to distinguish by an image.

A portrait or self-portrait may tell us a story about a person, and this can be an accurate or inaccurate one, but it will always be about the one(s) portrayed. The subject does not disappear behind the fictional character, as Bruneau suggests. I consider that there is a fine line separating what he refers to as "a piece of fiction", in a critical way, and what I would call self-representation in a broader sense.

\section{Francesca's subversive self-portraits}

As it has been briefly explained in the first section of this article, the context of the 1970s and 1980s is the one in which Francesca's work is embedded. Fabris (2009: 158-9) claims:

It is in this double pose-pause axis that some artistic experiences from the 1970s and 1980s develop focusing peculiarly on the problem of portraiture, or rather, self-portraiture, conceived, in most cases, as the absolute externalization of the person at the expense of the subject. These are experiences that encompass the dimension of behavior, which make the body the starting and endpoint of every action, so that the aesthetic operator is, at the same time, creator and creature. The body that emerges from these operations, despite directly engaging the artist's self, is a body conceived as "anti-nature", as "artifice", as "simulacrum" and, for that very reason, capable of being analyzed in the light of the categories proposed by Bruneau. ${ }^{6}$

Fabris's considerations about Bruneau's categories can be relatable to other photographer's from that period, but not exactly to Francesca, although she uses her body as the starting and ending point of action for her pictures.

${ }^{6}$ My translation for the exclusive purpose of this article. 
Woodman's self-portraits are unconventional by any criteria one looks at them. She defies both the canonical categories of self-portraits and the observer: the former by producing images of unidentifiable faces and faceless bodies in motion - i.e., there is no pose or pause; and the latter by deconstructing any idea of both a unified identity for her ghosts or of self-representation of herself.

In the first place, a self-portrait is about a subject/person who is portrayed and in the scene, despite composition or used techniques. This is the most basic definition of self-portrait.In analogic photography ${ }^{7}$, there is a link between the image and the captured subject which is, so to speak, existential; i.e., the photographer captures the subject who exists there, posing and pausing for her lens, at that exact instant. Thus, semiotically speaking, a self-portrait is primarily an indexical sign or,to be more specific, a dicent sin-sign.

Any produced photographic image contains several different kinds of indexes exceeding the elements representing or resembling the subject

[...] photograph, like any other object, contains a number of indices: it is thus an index of the angle from which the photograph was taken, of the lighting conditions at the moment of taking the photograph, of the film type used, and so on [...] but we will naturally attend to those facts only later, after having read it as an index of that which it is a picture of. (SONESSON, 1989:71-2)

Let us now consider Francesca's House \# $4(1976)^{8}$ picture to illustrate what Sonesson is claiming. The first thing an observer sees on the image is a body in movement trying to get in or off a fireplace opening. An actual body of a person/subject was captured by Francesca's lens in a room. There are no subtitles to the picture and no museum-like tag beside it to tell anything to me, the observer. Some indexes on the picture tell me it is a feminine body: the hair, the dress, and the shoes. Some indexes tell me that it is probably a young woman: the dress, the shoes, the flexibility and movement of the body. Some indexes tell me that the room is decayed: the ripped flower wallpaper, the uneven wood floor, and the fireplace's mantle which is loose to the point a body can pass behind it to enter the fireplace opening. All those indexes refer directly to the represented subject on the picture.

I, the observer, can also pay attention to some indexes that tell me that

\footnotetext{
${ }^{7}$ I refer here to the photography produced before digital images where possible. This is an important differentiation from a semiotic perspective because digitally produced images require an entirely different discussion and analysis.

${ }^{8}$ The title of the picture I used here is the same used in TOWNSEND, Chris. 2006. Francesca Woodman:Scattered in space and time.London \& New York:Phaidon, p. 108. Originally, most of Francesca's photographs were untitled, but this made very difficult for anyone to refer to any of her images. The problem is that there are lots of different "titles" given to the images depending on the source one uses. The image is available at: https://www.artsy.net/artwork/francescawoodman-self-portrait-with-fireplace-mantlealthough with another title.
} 
it was day and not night: the bright light outside the windowand the fact that I can see a neighboring building.I can infer that either someone took the picture of the young woman in movement or the camera had a timer set to take the picture. Indexical relations are clear and predominant until this point. Sonesson (ibid. 131) reminds us that indexicality is " [...] the general principal of perceptual experience, humanity has certainly since time immemorial been accustomed to thinking in indexical terms."

As I get further with my mind's eye over the image, however, can I claim that it is Francesca's body on House \# 4? By only looking at the picture, I cannot tell at all that there is her body. If I, the observer, am aware of the fact that the body is hers, I can think about the image as a self-portrait; if I am not aware of this information, I can think about the image as only a portrait of a body in movement. The moving female body is coming in or off the fireplace opening? Is it a ghost?An angel? Can anyone tell the gender of angels or ghosts? Can I claim that it is a woman portrayed in the picture? The scene does not look real, it reminds me of a mental picture I formed of Alice when I readLewis Carrol's Through the Looking Glass. When I, the observer, start asking those questions, lam entering a stage of doubting what I see. I then almost forget that I am looking at a self-portrait or a portrait.From that moment, the strong indexical relations of the genre itself begin to fall behind in a distant background and this distancing gives way to my interpretation of what is not present, exposed or said in the image, and to which I will only metaphorically relate.

Semiotically speaking, maybe the prototypical dicent Secondness of this self-portrait may be tending to an argumentiveThirdness. ${ }^{9}$ According to Santaella (2008:150), this happens when an image do not represent any reality but instead offer a metaphorical argument in which two single propositions a body in movement in a decayed room - are linked to a third that should be metaphorically understood - specters/ ghosts.

Francesca explores the dyads ${ }^{10}$ of presence and absence and existence and non-existence in her self-portraits - especially those produced in Providence, R.I., from 1975 to 1978, which is the case of House \# 4, and in Italy between 1977 and 1978 -albeit she does not seem to regard them as opposite conditions but as possibilities. The ephemeral atmosphere she creates with her phantasmagoric figures floating across decayed rooms allows a kind of liberation from identity. Ghosts or angels are ethereal, ambiguous, non-human and they have no gender. They can also presumably move across any physical

\footnotetext{
${ }^{9}$ For those not familiar with Peirce's philosophy, Firstness, Second and Thirdness refer to his three phenomenological categories. To learn more, please search http://www.commens.org/search/ content/thirdness

${ }^{10}$ As Abraham Kaplan reminds us in the introduction of Art as Experience (2010:15), Dewey held that not every dyad define a dualism but it rather serves to specify the two poles between which a certain conceptual domain can be established.
} 
boundaries, and live among humans without being noticed; they areobscure and, therefore, do not represent her flesh and blood body. If one is not familiar with the fact that it is Francesca's body on the photographs, those spectral figures on the images could be from anybody, therefore, identity vanishes. Woodman's ghostly figures are inaccurate, unpredictable and unsettling, and do not reveal any identity at all.

Most of Francesca's self-portraits from the 1975 to 1978 period do not refer directly to her or to any flesh and blood embodied human female. On the contrary, the representation of the feminine on those images is based only on her fruitful imagination made possible through technical experiments with the long exposures she was seeking to master. The sense of movement that Woodman impresses on her images helps the observer to take a bold flight away from the predominant indexical relations so typical of the self-portrait genre.

\section{Final remarks}

The expressive action that constitutes a work of art is a construction in time and it is not instantaneous (Dewey 2010:153). It requires long periods of activity, practice, and effort for the clarification of ideas because although the aesthetic experience is emotional (ibid.: 119), emotion alone is not sufficient in art. An artist's work requires also observation, reflection, and sifting of meaningful emotions from prior experiences (ibid.:157). An activity to be converted into an artistic expression needs first the excitement to stir up the meanings of previous experiences to make them enter a stage of consciousness. Emotions are not in themselves finished within an individual, they are always about objective situations and require different instances of reflection (ibid.: 156).

Taking all this into account, Francesca's images convey only vague ideas about the specter of emotional and physical conditions and situations she was exploring; therefore, they do not refer to any personal reality or seek any resemblance with it. The images speak for themselves and suffice to the observer, who understands that what prevails is the experiences she is willing to make with a body in movement, with the natural light that touches it, with the set of objects she includes in the scenes, etc. Thus, her body is a medium for her experiments with the camera and the technique of long exposures; and, as a medium, it is intrinsically linked to her expressive act.

Francesca does not allow the observers to be directly drawn to any conclusion about or find any easy meaning for her images. On the contrary, she gently invites us to engage with her artistic imagination, and actively experience her extremely demanding images. Some hurried analysts believe her selfportraits mirror, in a way, a tormented suicidal mind. However, as Dewey (2010: 
159) would agree with me, those are cases of imprecise analysis that mistakenly conclude that emotion is the significant content of Francesca's work.

The work of the artist is to build an experience that will be experienced aesthetically, and that is exactly what Francesca does.

\section{References}

BOUCHER, Georgie. 2009.Transitory Ghosts and Angels in the Photography of Francesca Woodman (2007) https://americansuburbx.com/2009/05/theorytransitory-ghosts-angels-in.html (accessed: 15, 16 February 2020).

DEWEY, John.Jo Ann BOYDSTON(org.). 2010.A arte como experiência. (Coleção Todas as Artes). São Paulo: Martins Fontes.

FABRIS, Annateresa. 2009. Fotografia e arredores. Florianópolis: Letras Contemporâneas - Oficina Editorial Ltda.

REBEL, Ernst, Norbert WOLF (eds.). Auto-retratos.2009. Hong Kong, Koln, London, Los Angeles, Madrid, Paris \& Tokio: Taschen.

SANTAELLA, Lucia\&WinfriedNöth (2008). Imagem: cognição, semiótica e mídia. São Paulo: Iluminuras.

SONESSON, Göran (1989). Semiotics of Photography: on tracing the index. Lund: Lund UniversityPress.

TOWNSEND, Chris. 2006. Francesca Woodman:Scattered in space and time. In Francesca Woodman, 6-71. London \& New York: Phaidon.

WOODMAN, Francesca. 2006. Extracts from Francesca Woodman's journals. In Francesca Woodman, 240-245. London \& New York: Phaidon. 


\section{MEDIACIONES}

\section{E. SONIDOS Y SENTIDOS}

a. Música popular 



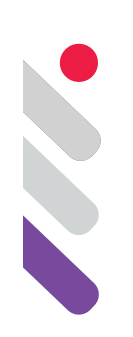

\title{
La construcción del tango como género musical en los medios masivos
}

DOI: 10.24308/IASS-2019-4-033

\author{
Jimena Jauregui \\ Universidad de Buenos Aires, Argentina \\ jimenajauregui@gmail.com
}

\section{Presentación}

El tango fue prontamente mediatizado a comienzos del siglo XX a partir del fonografismo y de su posterior articulación con la radio, el cine sonoro y la televisión entre las décadas de 1920 y 1960. En ese proceso, se constituyó en un producto masivo y multimediático que protagonizó momentos fundacionales de la historia de los medios en Argentina. El objetivo de la presente ponencia es brindar un acercamiento conceptual y metodológico desde la sociosemiótica al estudio de su construcción histórica como género musical.

La problemática planteada se fundamenta en que la noción de género entabla acepciones diversas en la investigación sobre música popular. En una revisión de los principales posicionamientos en este campo, realizaremos una aproximación al término desde la semiótica de los medios. Para nuestra disciplina, los géneros constituyen una categoría analítica y un eje central de indagación de diversos objetos culturales, con especial desarrollo en la semiótica local.

A fin de presentar una entrada metodológica que posibilite el estudio del género en su recorrido histórico, a la vez que atienda a la especificidad de diferentes etapas de su mediatización y de las relaciones con otros géneros, nos basaremos en el análisis metadiscursivo a partir del modelo semiohistórico planteado por José Luis Fernández (2008) (articulación de las series de los dispositivos técnicos, los géneros y estilos y las prácticas de intercambios discursivos) ${ }^{1}$. Considerado aquí para el caso del tango, el enfoque propuesto busca problematizar el estudio de la conceptualización e historización de todo género mediatizado.

${ }^{1}$ La metodología propuesta fue desarrollada en extenso en mi tesis de doctorado El tango en los medios masivos. La construcción broadcasting de un género musical. FSOC-UBA, 2019. 


\section{Aproximación a la noción de género en los estudios de música popular}

La relevancia de la categoría de género se evidencia en su utilización para el análisis de productos culturales diversos. Tal es el caso de los estudios en música popular en los cuales, a pesar de su uso habitual, no existe un consenso sobre el término. Como explica Ana María Ochoa (2003), la problematización de la idea de género en la música popular es relativamente reciente. No obstante, la preocupación por su aprehensión conceptual se inscribe en la propia conformación del campo. El trabajo A Theory of Musical Genres: Two Applications presentado por Franco Fabbri en 1981 en la Conferencia fundacional de la Asociación Internacional de la Música Popular es considerado pionero en la formulación de una definición.

Según esta primera acepción, "un género musical es un conjunto de hechos musicales, reales y posibles, cuyo desarrollo se rige por un conjunto definido de normas socialmente aceptadas" (Fabbri 2006: 3). En su funcionamiento rigen al menos cinco tipos de reglas que si bien no presentan un orden determinado pueden tener una importancia diferencial en la descripción de cada género en particular: las formales y técnicas, las semióticas, las de comportamiento, las sociales e ideológicas y las comerciales y jurídicas.

Las reglas formales y técnicas son señaladas por Fabbri como las únicas contempladas en la mayoría de la literatura musicológica. A esta restricción le atribuye la común confusión, sobre la que volveremos, de la utilización de las categorías de género, estilo y forma como sinónimos. Estas reglas desempeñan un rol fundamental a nivel compositivo en todos los géneros musicales y no sólo, como aclara, en los denominados "cultos". Aquí se incluyen las técnicas de ejecución, la instrumentación y la habilidad del músico, transmitidas tanto por la escritura como por tradición oral.

La segunda clase de reglas son denominadas semióticas, si bien entiende que todas las reglas del género son de carácter semiótico en tanto códigos que crean relaciones entre la expresión de un evento musical y su contenido. El énfasis de la denominación remite a aquellas reglas que comprenden al género como texto, no sólo en cuanto al texto verbal conectado con la música, sino a todos los códigos implicados en el evento musical, como la proxémica y los códigos mímico-gestuales. Menciona también en este punto la posibilidad de caracterizar a un género según la función del lenguaje dominante, siguiendo la clasificación propuesta por Roman Jakobson en sus estudios de lingüística².

En tercer lugar, se ubican las reglas de comportamiento, que incluyen tanto a la psicología de los músicos como a las reacciones psicológicas y el comportamiento de la audiencia en cada género. Se diferencian de un cuarto tipo de reglas que define como sociales e ideológicas y que se corresponden

${ }^{2}$ Así, por ejemplo, se indica que la función fática domina en la "música de fondo" (Fabbri 1982: 57). 
con la comunidad que acepta las reglas del género y que participa del evento musical. La perspectiva sociológica ha estudiado al respecto la diferenciación entre géneros en relación a sus funciones sociales, las clases, los grupos o las generaciones. En último lugar, se identifican las reglas comerciales y jurídicas que otorgan un marco de garantía para la supervivencia y prosperidad de un género respecto a las compañías discográficas, los derechos de autoría y difusión, las ganancias, la promoción y demás aspectos vinculados a la comercialización musical.

Esta noción pionera de género desarrollada por Fabbri propuso, como destaca Juliana Guerrero (2012), una descripción amplia que incorporó factores que hasta entonces no habían sido considerados por la musicología, como la instrumentación, las diferencias en la ejecución de los músicos y las variables de consumo, acentuando el carácter social de los géneros musicales e incorporando la instancia performativa al análisis del lenguaje musical. Su planteo permitió que la determinación del género fuera concebida como el resultado de una negociación entre aspectos sonoros y otros surgidos de la experiencia de los individuos involucrados en el hecho musical.

El propio Fabbri, veinticinco años después y luego de incorporar los aportes de la ciencia cognitiva, ha concluído en enfatizar los fundamentos semióticos de aquella primera definición basados en la obra de Umberto Eco. "Sigo estando convencido de que los géneros musicales son -en cuanto tiposunidades culturales, definidas por códigos semióticos, que asocian un plano de la expresión a un plano del contenido". A su vez, ha ponderado el aporte que una teoría de los géneros puede significar para el estudio histórico. Para Fabbri, la vida musical de una época puede ser reconstruida a partir del "sentido común" del momento en relación a la emergencia de los géneros como reconocimiento y codificación de prácticas existentes, como oposición a otros géneros o en virtud de su transformación y articulación en subgéneros.

Además de la reflexión del autor, su trabajo fundacional ha sido discutido y retomado por otras definiciones de género en los estudios de música popular. Guerrero (2012) reconstruye las principales y destaca los trabajos de Charles Hamm en su introducción de la performance como variable y la posibilidad de asignar más de un género a una obra musical bajo la idea de flexibilidad; la perspectiva sociológica de Simon Frith centrada en cómo funcionan las etiquetas de género en el mercado de la música popular organizando el proceso de ventas; el planteo de Keith Negus sobre cómo la industria del entretenimiento organiza las categorías y los sistemas de clasificación condicionando la experiencia musical; el trabajo de Fabian Holt Genre in popular music, donde formula una definición amplia del género como práctica cultural no sólo vinculada a la música sino también a rituales, territorios, tradiciones y grupos y, finalmente, la propuesta de Rubén López Cano de abordar el problema de los géneros 
musicales en términos de los procesos de categorización cognitiva.

Sin posibilidad de profundizar aquí, a estas perspectivas puede agregarse el enfoque de Ochoa (2003) en su estudio de las "músicas locales". Sus postulados reúnen tres aspectos que atraviesan a la discusión entre los autores citados y revisten un especial interés para nuestro acercamiento conceptual y metodológico: la mirada histórica y social, la relación con la noción de estilo y la injerencia de la industria en la clasificación de la música popular. Para la etnomusicóloga, el género musical se constituye históricamente, tanto en su marco estético de definición sonora como en su marco valorativo. Sobre este punto, advierte que las formas de definir los géneros y sus fronteras musicales e ideológicas aceptadas es un proyecto siempre construido.

Las violentas luchas que se dan cuando hay dificultades de frontera en los géneros musicales, tales como las que se dan entre los adeptos al tango gardeliano versus al tango de Piazzolla, o al bambuco instrumental al estilo de Morales Pino, músico colombiano de comienzos del siglo $\mathrm{XX}$, versus las experimentaciones instrumentales de los músicos bogotanos contemporáneos, atestiguan este carácter construido (Ochoa 2003: 86).

Lo que puede observarse en este planteo es la estrecha relación en la utilización de los conceptos de género y estilo. Algo similar a lo que ocurre en lo referido a los géneros musicales nacionales, en los cuales para Ochoa se eliminan las diferencias estilísticas no deseables a través de un proceso estético e ideológico. Esto supone que a nivel compositivo existe una forma y una estética musical del género que va a ser la más válida. Este problema de la distinción entre el género y el estilo se presenta, asimismo, en forma recurrente en las diversas perspectivas planteadas. De igual modo, pueden identificarse las dificultades que se han presentado en los estudios de música popular para definir la noción de género vinculadas al carácter mediatizado de estas músicas en su producción y recepción social frente a la caracterización formal de sus rasgos sonoros. Veremos a continuación cuáles pueden ser los aportes que la semiótica de los medios puede brindar para la aproximación teórica y metodológica a la categorización de los géneros mediatizados.

\section{La noción de género en la semiótica de los medios}

Uno de los primeros trabajos que sentó las bases del estudio semiológico de los medios de comunicación en su discusión con la tradición lingüística fue el realizado por Metz en su aproximación al análisis del cine. Publicado en la revista LENGUAjes en 1974, su texto explicita las problemáticas que se presentan al lingüista frente a un objeto como el lenguaje cinematográfico que carece de las propiedades de la lengua. Los géneros, junto con las configuraciones semiológicas constituyen en la regularidad de sus rasgos una 
entrada metodológica para poder caracterizar y vincular diferentes films en su significación. A fin de establecer este punto de vista del cientista sobre un producto mediático, Metz parte de una premisa: el usuario social reconoce una secuencia de señales como un film. La tarea principal del semiólogo no es otra que explicitar aquello que, sin estar formulado, funciona en la sociedad de manera real y que el usuario social reconoce por intuición semiológica.

En continuidad con esta perspectiva en Argentina, Oscar Traversa ha realizado diversos estudios sobre el cine y ha destacado la importancia analítica de la categoría de género. Siguiendo a Tzvetan Todorov, considera que las principales dificultades de la noción radican en que todo texto forma parte de una combinación ya existente, y es a la vez una transformación de esa combinación. Se pregunta entonces Traversa: “¿Cómo definir un género -una combinatoria-? ¿Cuándo podemos afirmar que esta combinatoria -este géneroha sido transgredido?" (2000: 262). En busca de una respuesta específica para el caso del cine remarca la escasa problematización de la cuestión del género en la "teoría cinematográfica" y la dispersión de su definición ${ }^{3}$ respecto a la desarrollada por la literatura. Sostiene entonces la relevancia para el estudio de la significación cinematográfica de lo que ha denominado "filme no fílmico" (Traversa 1983), aquellos metadiscursos que acompañan la producción y recepción del filme proyectado en la pantalla.

La construcción metadiscursiva del género se presenta, de este modo, como un aspecto clave de la concepción teórica y metodológica en el estudio semiótico de los productos de los medios de comunicación. Su carácter diferenciador, a su vez, de la noción de estilo fue explicitada por Oscar Steimberg (1993) quien realiza un diagnóstico concordante pero desde una perspectiva más amplia, en la cual plantea que la presencia de los géneros en los medios, y no sólo en el cine, ha tenido menor reflexión teórica que la suscitada en los estudios literarios, pictóricos y etnológicos. A pesar de la evidencia de que todos los medios presentan géneros ya consolidados por la cultura, identifica la persistencia de obstáculos para su investigación en los estudios de comunicación derivados de la mirada sobre el impacto tecnológico, de la concepción de los géneros mediáticos como un deterioro cultural y de la confrontación entre las clasificaciones silvestres y las científicas donde "en un mismo movimiento se rechaza la conversión de las costumbres de género en teoría y la producción de una teoría del género" (Steimberg 1993: 42).

En este marco, su trabajo presenta una formalización conceptual que, si bien se desprende del interés acerca de los modos de recepción del género

\footnotetext{
3 "El género en cine se definiría a través de una mezcla de nociones que abrevan en el teatro, la literatura, las frases del sentido común, etc. Se podría postular que en ese espacio de dispersión se expande la "intuición social de los géneros" (Traversa, 2000: 265).
} 
por parte de la audiencia televisiva, resulta abarcativa para todo producto de los medios. En términos de Steimberg los géneros pueden ser definidos como:

Clases de textos u objetos culturales discriminables en todo lenguaje o soporte mediático, que presentan diferencia sistemáticas entre sí y que en su recurrencia histórica instituyen condiciones de previsibilidad en distintas áreas de desempeño semiótico e intercambio social (1993: 45).

También recurriendo a los avances desarrollados por la teoría literaria, la previsibilidad de los géneros se apoya en lo que Mijaíl Bajtín ha caracterizado como horizontes de expectativas, puntualizando, a su vez, que los géneros no suelen ser universales sino que las expectativas están determinadas por restricciones culturales, a excepción de los denominados géneros primarios como el saludo o la adivinanza. Los rasgos que permiten describir un género son para Steimberg de tipo retórico, temático y enunciativo, los mismos que permiten caracterizar un estilo. Sin embargo, el estilo se define como un modo de hacer, un espacio de diferenciación entre diversos objetos de la cultura.

Con lo dicho hasta aquí, ya puede señalarse una distinción respecto a la habitual sinonimia entre ambos conceptos en los estudios de música popular y la discusión en torno a que el estilo suele asociarse al "cómo" es una obra de arte y el género al "qué" se propuso hacer. Nos acercamos, en cambio, a la observación de Guerrero: "el estilo difiere del género en tanto permite asociar una obra con un autor, un período, un lugar o una escuela mientras que el género se trata de otra categoría de clasificación" (2012: 11).

Algunas de las proposiciones planteadas por Steimberg permiten especificar estas diferencias ${ }^{4}$. En primer lugar, "es condición de la existencia del género su inclusión en un campo social de desempeños o juegos de lenguaje; no ocurre lo mismo con el estilo" (1993: 65). Todo género debe restringirse en su "forma de contenido" o en su soporte perceptual, agregando de este modo previsibilidad a su acotación temática, retórica y enunciativa. Este carácter es confirmatorio de los límites de un área de intercambios sociales que es propio del género. Los estilos, en cambio, son trans-semióticos, no se circunscriben a ningún lenguaje, práctica o materia significante sino que su condición es centrífuga, expansiva y abarcativa como rasgos característicos de una manera de hacer.

En segundo lugar, la vida social de los géneros supone la vigencia de fenómenos metadiscursivos permanentes y contemporáneos que se registran tanto en la instancia de producción como en la de reconocimiento. Los

\footnotetext{
${ }^{4}$ Bajtín (1982) también aborda el problema de la relación entre género y estilo como un vínculo orgánico e indisoluble que se manifiesta en el problema de los estilos lingüísticos o funcionales, estilos genéricos de determinadas esferas de la actividad y comunicación humana. En cada esfera existen y se aplican sus propios géneros a los que les corresponden diferentes estilos.
} 
metadiscursos acotan el género de la obra a la que se refieren y son tanto intra como extremediales. En este sentido, como fuera mencionado, Traversa refiere al "filme no filímico" y Steimberg señala a los títulos y paratextos como los principales elementos metadiscursivos de los géneros literarios, pictóricos y de las artes combinadas, mientras los programas de televisión son ubicados en espacios genéricos por textos periodísticos gráficos y radiales o definidos en el propio medio a través de anuncios y avances. Los estilos, por su parte, también se articulan en operaciones metadiscursivas internas y externas pero, a diferencia de los géneros, las que son contemporáneas en su momento de vigencia no son universalmente compartidas ni permanentes sino fragmentarias, valorativas y no evidentes por su articulación con las opiniones conflictivas de la producción de época.

En tercer lugar puede destacarse que, a diferencia de los estilos, los géneros hacen sistema en sincronía. Ello supone que su estudio sólo puede realizarse dentro del sistema de correlaciones que establece con otros géneros en un momento determinado. En la historización del concepto, Steimberg remarca que desde Aristóteles la definición de género se basó en la comparación y oposición de sus rasgos con los de otro género con el que pudiera confrontarse. A su vez, retoma los postulados de Todorov de que en cada momento de la historia literaria cada género se redefine en su relación con los otros géneros existentes.

En esta diferenciación de los conceptos de género y estilo, Steimberg (1993) postula que la relación de tipo sistemática no se presenta para los estilos ya que no pueden reconocerse socialmente en términos de sentido de conjunto por su condición expansiva y centrífuga así como por la disputa que genera su carácter valorativo en torno a las preferencias individuales y a lo considerado legítimo. Por el contrario, un estilo puede caracterizar un determinado momento histórico en el cual un género puede convertirse en dominante como efecto de las relaciones sistemáticas de primacía, secundariedad o figura-fondo establecidas en sincronía.

\section{El modelo semiohistórico y el estudio del tango}

¿Cómo estudiar entonces un género en su sistema y a la vez en su desarrollo histórico ${ }^{5}$ Esta pregunta resulta fundamental ante un género como el tango que ha atravesado diferentes mediatizaciones a lo largo del siglo XX. Nuestra propuesta analítica se basa en el modelo semiohistórico desarrollado por

\footnotetext{
${ }^{5}$ La discusión entre las nociones de sistema e historia es central en las Ciencias Sociales. Referimos a la crítica al estructuralismo respecto a la interacción sincronía-diacronía en el abordaje metodológico de los hechos sociales a la cual se le atribuye cierto formalismo y ahistoricidad en la búsqueda de lo invariable. No obstante, Lévi-Strauss atendió a estas observaciones siendo la historia un componente y una perspectiva que ha atravesado gran parte de su obra con el planteo de una "historia estructural" (Lévi Strauss, 1987: 32).
} 
Fernández (2008) como la articulación de tres series de relativa independencia que bajo un mismo estilo de época permiten el estudio de la construcción de un nuevo medio de comunicación: la serie de los dispositivos técnicos ${ }^{6}$, la serie de los géneros y estilos y la serie de las prácticas de intercambio discursivo. Ello supone que la instauración social de un medio depende de la conjunción de un avance técnico, así como de la adecuación o creación de géneros discursivos específicos y de la consolidación de prácticas sociales vinculadas.

Bajo este enfoque, al posicionarnos sobre un determinado estilo de época en un corte sincrónico podremos establecer la relación sistemática entre los géneros musicales como clasificaciones nativas y explicitar sus rasgos como producto de su articulación histórica. Para el caso del tango, con esta metodología pueden establecerse los vínculos entre la novedad mediática y su construcción como género musical atendiendo a su desarrollo en los diferentes medios de masas. A modo de breve descripción, pueden distinguirse los siguientes rasgos de la mediatización del género siguiendo las tres series del modelo semiohistórico.

Primeramente, el dispositivo fonográfico consolidó su uso social en la conformación de la industria musical hacia 1920, siendo el tango el principal género grabado por las compañías discográficas en su producción local, seguido del vals, la ranchera, el estilo y la zamba, entre otros. El dispositivo radiofónico, por entonces, otorgó la posibilidad de la toma directa, convirtiendo al oyente en partícipe en tiempo real (Fernández 2008). En su programación, hacia la década de 1930 se destacó el género del show radiofónico donde convivió el tango en grabado con la orquesta típica tocando en vivo en el estudio, alternando tango y jazz. La masividad y popularidad de la radio como medio central en la vida de la época fue acompañada por gran cantidad de metadiscursos gráficos, principalmente publicaciones especializadas donde el tango y sus músicos adquirieron imagen.

Por los mismos años, la relación establecida entre tango y cinematógrafo desde comienzos de siglo e internacionalizada por Carlos Gardel, se plasmó en las primeras películas sonoras nacionales. iTango! y Los tres berretines estrenadas en 1933 tuvieron al tango como protagonista, mientras films como ídolos de la radio de 1934 dieron cuenta de los vínculos de sus figuras en el conjunto de los medios sonoros. Por último, la televisión con la posibilidad del directo audiovisual, incorporó el show musical en vivo. Atravesando un período

\footnotetext{
${ }^{6}$ El dispositivo técnico comprende al herramental tecnológico como campo de variaciones que posibilita en todas las dimensiones de la interacción comunicacional -variaciones de tiempo, de espacio, de presencias del cuerpo, de prácticas sociales conexas de emisión y recepción- que modalizan el intercambio discursivo cuando este no se realiza cara a cara, teniendo en cuenta su dimensión material en la intersección entre aspectos tecnológicos y aspectos semióticos (Fernández 1994; 2016).
} 
de crisis, con el auge de la Nueva Ola, el tango no dejó de presentarse desde la década del sesenta en programas televisivos específicos del género como Grandes valores del tango, Copetín de tango y Yo te canto Buenos Aires, entre otros.

De este modo, en su aparente abstracción, descorporización y desvisualización al despegar al sonido de su fuente, el sistema fonográfico y el radiofónico en su producción y difusión musical han estado siempre acompañados por metadiscursos visuales o audiovisuales desplegados en otros medios masivos. Por consiguiente, el análisis metadiscursivo resulta inherente al estudio del género musical. Un género mediatizado no puede concebirse en forma aislada frente al entramado de mediatizaciones que lo constituyen y definen en un momento histórico.

\section{Conclusiones}

Eltangoes, en una de sus dimensiones que aquínos interesa especialmente, un género musical. Tanto en producción como en reconocimiento puede ser diferenciado de otras expresiones artísticas y culturales y, en particular, de otras músicas. Sin embargo, la noción de género presenta diferentes acepciones en la investigación sobre música popular que cruzan la noción de estilo y encuentran dificultades para su aprehensión conceptual en tanto producto mediático. La revisión de las principales discusiones desarrolladas en este campo y el acercamiento al concepto desde la semiótica de los medios ha permitido fundamentar la perspectiva metodológica propuesta basada en el modelo semiohistórico y el modo de análisis metadiscursivo de la presencia del tango en los medios masivos.

Si bien no hemos abordado la totalidad de las proposiciones planteadas por Steimberg (1993) que permiten diferenciar género y estilo y que demuestran la compleja relación que se establece entre ambos conceptos ${ }^{7}$, lo recuperado hasta aquí nos permite fundamentar los principales aspectos de nuestra propuesta analítica y las implicancias de la asunción de esta concepción sociosemiótica del género para pensar la construcción del tango en los medios masivos. Una primera premisa es que no atendemos a los rasgos formales o musicológicos para formular una definición canónica del género. En su anverso, proponemos partir de las clasificaciones sociales del tango construidas en su circulación mediática para intentar una formalización de sus rasgos.

Nuestro interés se centra en la construcción social del género a través de los metadiscursos que lo caracterizan en diferentes momentos históricos y en

\footnotetext{
7 Parte de la complejidad en la distinción se halla en que un estilo puede convertirse en género cuando se produce la acotación de su campo de desempeño y la consolidación social de sus dispositivos metadiscursivos. Asimismo, Steimberg (1993) identifica las obras antigénero y su pronta estabilización como géneros al ingresar en una circulación socialmente previsible.
} 
vinculación con los distintos medios. Ello supone situar al tango en un campo de desempeño discursivo acotado a lo musical, diferenciándolo de otras de sus manifestaciones artísticas y culturales, a fin de sostener su definición a partir de aquellos otros discursos que circularon en su mediatización por la prensa, el cine, la radio y la televisión. El análisis de los metadiscursos visuales y audiovisuales que acompañaron la mediatización sonora del tango resulta fundamental para dar cuenta de sus rasgos en los momentos de conformación de los medios que lo construyeron discursivamente como género musical.

Finalmente, la concepción del género en su sistema de relaciones implica un estudio correlacional con aquellos otros géneros con los que convivió en cada período de su mediatización. Desde este enfoque, no es posible la aprehensión de un género en forma aislada ya que es la visión de conjunto y por oposición la que permite la definición de sus rasgos. Los cortes sincrónicos establecidos a través del modelo semiohistórico en los diferentes momentos de la relaciones entre músicas y medios posibilitan ubicar y caracterizar al tango dentro del sistema genérico de la música popular en la tensión figura-fondo, es decir, en su posicionamiento diferencial respecto a otras músicas. Asimismo, el abordaje diacrónico de los rasgos adquiridos en cada período permite comparar los sistemas de relaciones en su correlato histórico.

\section{Bibliografía}

BAJTín, Mijaíl. 1982. El problema de los géneros discursivos. En Estética de la creación verbal, 248-293. México: Siglo XXI.

FABBRI, Franco. 1982. A Theory Of Musical Genres. Two Applications. En D. Horn, P. Tagg (eds.) Popular Music Perspectives, 52-81. Göteborg and Exeter: International Association for the Study of Popular Music.

2006. Tipos, categorías, géneros musicales. ¿Hace falta una teoría. Paper presentado en el VII Congreso IASPM-AL, La Habana. Traducción de Marta García Quiñones.

FERNÁNDEZ, José Luis. 1994. Los lenguajes de la radio. Buenos Aires: Atuel.

2008. La construcción de lo radiofónico: modos de producción de la novedad discursiva. En J. L. Fernández (dir.). La construcción de lo radiofónico, 9-74. Buenos Aires: La Crujía.

2012. La captura de la audiencia radiofónica. Buenos Aires:

Liber Editores. 
GUERRERO, Juliana. 2012. El género musical en la música popular: algunos problemas para su caracterización. TRANS- Revista Transcultural de Música/ Transcultural Music Review 16. https://www.sibetrans.com/trans/public/docs/ trans 16 09.pdf (Accedido 2 de marzo 2020).

LÉVI-STRAUSS, Claude. 1987. Antropología estructural. Barcelona: Paidós.

METZ, Christian. 1974. El estudio semiológico del lenguaje cinematográfico. En: Lenguajes, 2 (1). Buenos Aires: Ediciones Nueva Visión.

OCHOA, Ana María. 2003. Músicas Locales en Tiempos de Globalización. Buenos Aires: Norma.

STEIMBERG, Oscar. 1993. Semiótica de los medios masivos. Buenos Aires: Atuel.

TRAVERSA, Oscar. 1983. Cine: el significante negado. Buenos Aires: Hachette. 2000. La aproximación inicial al filme: el contacto con el género. Cuadernos de Información y Comunicación. 5, 262-266. 


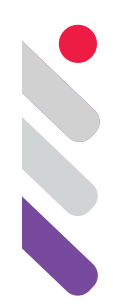

\title{
Cuerpos y palabras en el ritmo: la escena de la voz en el rap freestyle
}

DOI: $10.24308 /$ IASS-2019-4-034

\author{
Amparo Rocha Alonso \\ IIEAC, Departamento de Crítica, UNA \\ Universidad de Buenos Aires \\ rocha.amparo@gmail.com
}

Nos interesa dar cuenta de la persistencia de la voz (Zumthor, 1985) en la cultura urbana del capitalismo tardío. Para ello, nos enfocaremos en una práctica cultural juvenil en vías de artificación (Heinich y Schapiro, 2012): el rap freestyle.

El rap, parte sustancial de la cultura del hip hop, ha logrado trascender -como el rock en su momento-, las coerciones del inglés, y se ha instalado en gran parte del mundo de habla hispana. En cuanto a su práctica en Argentina, en los últimos tres años asistimos a su veloz crecimiento y visibilización mediática. Actualmente, la cultura rap -rimas, gestualidad, vestuario, imágenes- alimenta nuevas y poderosas formas identitarias entre niños y jóvenes urbanos.

Dentro del rap, se destaca una modalidad enteramente vocal: la competencia o "batalla" de freestyle, combate verbal basado en la improvisación ingeniosa de dos o más contendientes sobre una base de beatboxing. Un teatro de la voz y de los cuerpos que anuda una antigua tradición presente en numerosos folklores del mundo con elementos de la cultura citadina hipermediatizada. Una puesta en escena en la plaza pública que en su pasaje a las redes sociales asume una masividad inédita.

\section{El freestyle argentino}

Actualmente, en Buenos Aires y en numerosas localidades grandes y medianas del país es frecuente ver en plazas y parques a grupos de jóvenes, mayormente varones ${ }^{1}$, convocados por una práctica poético-musical ${ }^{2}$ que

\footnotetext{
${ }^{1}$ A partir de los años 2017 y 2018, con las históricas movilizaciones del Ni una menos y por el aborto legal, seguro y gratuito, el número de mujeres competidoras se ha incrementado notablemente, lo cual se observa en videos y fotos anteriores y posteriores a los hitos mencionados.

2 Ante la objeción que podría hacérsenos de que el freestyle no es propiamente musical, como sí lo es el rap, respondemos que entendemos musical en sentido general como abordaje rítmico-
} 
es también un combate. Nos referimos a las competencias de rapfreestyle, improvisación verbal ingeniosa que desarrollan dos o más contendientes en su esfuerzo por imponerse al otro y al favor de jurado y público.

Nos interesa esta práctica porque, a la vez que guarda parentesco con variantes antiquísimas de la disputa verbal, se articula con el fenómeno de la mediatización ${ }^{3}$, particularmente en cuanto a la apropiación que hacen de ella grupos juveniles de usuarios de plataformas sociales como YouTube, Facebook e Instagram. Ha sido tal su visibilización pública y mediática en Argentina en los últimos tres años ${ }^{4}$ que nos atrevemos a postularla como una de las modalidades de discursividad juvenil que ha tomado la delantera en la expresión de los gustos y demandas de las nuevas generaciones en Buenos Aires y el país, replicando lo que sucede en gran parte del mundo.

\section{Un circuito}

Para abordar esta práctica, aplicamos el modelo de circuito de música (Rocha, 2016), asimilado al de sistema productivo (Verón, 1987). En esta perspectiva, los circuitos artístico-musicales implicarían una esfera de la producción, una de la circulación/ divulgación y otra del consumo. Asimismo, relaciones de intercambio simbólico-material en las que participan gran variedad de actores.

Partimos de la noción de discurso como configuración espacio-temporal de sentido (Verón, 1987). Esto nos servirá para dar cuenta de las expresiones performáticas de las competencias de rap freestyle como así también de los metadiscursos verbales, visuales, audiovisuales que participan activamente de cada circuito en la forma de discurso crítico, publicitario, artístico y que contribuyen a la contextualización y legitimación de las diversas expresiones.

Correlativa a la noción de circuito-y a las estéticas que pueden asociársele, aunque no de manera mecánica-, trabajamos con la de sensibilidad, es decir, una cierta disposición afectiva ante los discursos (en este caso el poético-musical) y todo aquello que involucren: palabra, prosodia, gestualidad, movimiento, accesorios, vestuario etc. (Rocha,2016). La noción de circuito nos resulta de

melódico de la palabra poética. Agregamos que ya la poesía puede ser entendida como "la música de la palabra".

${ }^{3}$ Eliseo Verón define la mediatización como "progresiva incorporación de tecnologías mediáticas en la sociedad, como "transferencia de los tres órdenes del sentido a otras materias autónomas en relación con el cuerpo significante" (1987) y como "exteriorización-materialización de las capacidades cerebrales del sapiens" (2013). En cada una de estas caracterizaciones observamos la acentuación en algún aspecto de su teoría: el sociológico, el psicoantropológico y el cognitivista de su última etapa.

${ }^{4}$ Las competencias de freestyle se desarrollan hace mucho más tiempo, pero durante bastante, se desenvolvieron en un circuito absolutamente under. El crecimiento de un evento particular, El quinto escalón (domingos en Parque Rivadavia de la ciudad de Buenos Aires hasta fin de 2017) fue el detonante para su visibilización en medios masivos: prensa gráfica, radio (Vorterix) y TV. 
utilidad pues permite abordar objetos artísticos soslayando los debates sobre géneros y estilos, que no son pertinentes desde la perspectiva sociosemiótica que sostenemos en el presente artículo. Entendemos que en un circuito se desenvuelven uno o más géneros (entendidos de manera laxa, como formatos), que en él priva una determinada estética, como conjunto de rasgos estilísticos de bordes lábiles, y que los actores comparten una sensibilidad común. En el interior de todo circuito se definen valores, prácticas, límites y posibilidades de la producción de sentido; los circuitos nacen, se estabilizan y pueden desaparecer si las condiciones que les dieron vida lo hacen; son relativamente abiertos, ya que guardan vínculos diversos con otros: de derivación, inclusión, cruce, etc.

En cuanto al circuito de las competencias defreestyle, se trata específicamente deun subcircuito del de rap y del hip hop. En comparación con otros artístico-musicales complejos, el circuito de rap ha sido, hasta hace dos años aproximadamente, muy simple y homogéneo: raperos y seguidores, algunos promotores de eventos y poco periodismo especializado; espacios públicos e hipermediáticos, eventos regulares under y unos pocos de mayor envergadura y dimensión comercial. ${ }^{5}$ En el momento de la escritura del presente texto, la escena se ha ampliado por el interés que viene despertando el rap argentino y el crecimiento del público. A eso hay que sumarle el desprendimiento del género trap, variante más comercial del rap con matices musicales de reggaetón y otras músicas latinas, que vino a conmover el espacio más tradicional del rap "auténtico". En consecuencia, tanto por el auge de las competencias en plazas como por el trap y sus variantes, que van del festejo machista a la militancia feminista, se ha perforado el piso de los medios masivos ${ }^{6}$ y por ello el nivel de conocimiento del rap freestyle es mucho mayor que hace relativamente poco.

\section{Una traducción exitosa}

Observamos numerosas coincidencias entre el surgimiento de esta expresión artística juvenil y la emergencia del rock argentino a fines de los años sesenta. ${ }^{7}$ En ambos casos se trata de expresiones alternativas, minoritarias, contraculturales, con una ideología difusa antisistema que interpela a jóvenes y les ofrece un discurso identitario en el que refugiarse. En ambos se trata de una traducción exitosa -en tanto creció y se consolidó- de formas poéticomusicales del inglés afroestadounidense, por la que el castellano debió torcerse y adaptarse a la fluidez de esa lengua hasta encontrar sus propios recursos.

En cuanto a las diferencias, el rock progresivo-nacional-argentino-como

\footnotetext{
${ }^{5}$ La Red Bull, evento internacional que se hace en espacios cerrados, con sonido (micrófonos, amplificación), escenario y sponsor (la bebida energizante que le da nombre); competencias en Tecnópolis y algún otro espectáculo.

6 Para profundizar la relación circuito-medios ver Rocha (2016).

7 Se suele considerar la salida del simple La Balsa (Los Gatos, 1967) como el inicio del rock nacional. Ver Grimberg (2008) y Pujol (2002).
} 
se lo bautizó sucesivamente- fue pionero en Iberoamérica y funcionó como modelo para el rock español y de diversos países de la región; en cuanto al rap de habla hispana con todas sus variantes, está comúnmente aceptado que comenzó en la década de los ochenta en Venezuela, seguido muy rápidamente por España. En Argentina hay antecedentes que se remontan a los noventa como una práctica "subterránea" muy minoritaria, con algunos casos de popularidad (JazzyMel, Illia Kuriaky and the Valderramas). Esta situación de "subalternidad" de nuestro rap en relación con otros de habla hispana se evidencia, por ejemplo, en el uso de figuras tonales que suenan "latinas". Sin duda, de la década del sesenta argentina, época de modernización cultural en el país (Terán, 1991; Pujol, 2002) ${ }^{8}$ al post 2001 hay una distancia considerable: Argentina perdió su lugar de faro de cultura en Latinoamérica y va a la zaga de fenómenos globales que han recalado anteriormente en otros países de la región.

En cuanto a la mediatización, el surgimiento de nuestro rock se da en una década de crecimiento de las industrias culturales, entre ellas la discográfica. Como fenómeno de culto fue tomado en cuenta por las multinacionales del disco y por algunos editores alternativos (Jorge Álvarez y su sello Mandioca); del mismo modo, publicaciones de avanzada como La Opinión y Primera Plana informaban a sus lectores de estas nuevas modalidades juveniles. En cuanto a la radio y la TV, solo esporádicamente hacían oír la nueva música en unos pocos programas radiales y alguna participación en la pantalla chica.

Por su parte, el freestyleen Argentina hace uso de toda la batería de recursos hipermediáticos de que se dispone en la actualidad, de tal modo que genera fenómenos de consumo que involucran a miles de seguidores y que generan efectos conductales (ropa, gestualidad, jerga especializada, accesorios como tatuajes, collares, consumo de sustancias, etc.).

\section{De la plaza a la pantalla}

En plazas y parques de la ciudad se reúnen a una hora pautada ${ }^{9}$ un grupo de jóvenes en edades que van de los 10, 12 años hasta los 30 . Algunos competirán de a uno o en dúos, tríos y hasta cuatro participantes; otros serán el jurado. La mayoría presenciará la contienda arengando con gritos y vítores, asintiendo o rechazando los "acotes" de los "gallos". La improvisación es enteramente verbal, al igual que la base rítmica, que es ejecutada por uno o varios beatboxers con gran maestría. Hasta los aplausos, como signo de aprobación, son reemplazados por manifestaciones vocales.

\footnotetext{
${ }^{8}$ Para Oscar Terán, los sesenta argentinos se dan entre dos golpes de estado: 1955, la llamada "Revolución Libertadora" o "Fusiladora", y 1966, el golpe de Onganía.

${ }^{9}$ La convocatoria se hace vía redes y por el boca a boca. La mayoría de las competencias tiene un día y horario fijo: Irlanda freestyle, sábados a la tarde en Plaza Irlanda; El quinto escalón, domingos a la tarde en Parque Rivadavia; Las Vegas, "competencia de contra punto (Sic) de rima improvisada sábado de por medio", Barrancas de Belgrano.
} 
Es un teatro de la voz que va de la vocalidad a la oralidad (Zumthor, 1984) o de lo vocal a lo verbal (Chion, 1990), vale decir, de la pura emisión vocal a la palabra con toda su historicidad. Y esa voz, que es parte del cuerpo significante (Verón, 1987; Rocha, 2000, 2010), o que no es ni del todo cuerpo ni del todo signo (Dólar, 2006) se despliega en el espacio. El cuerpo las expresiones faciales y su gestualidad, la vestimenta, los accesorios y la coreografía codificados por la tradición rapera, todo corresponde a una escenificación en la que se participa como en una orquesta, conociendo la partitura (Winkin, 1980). La belleza de la voz, sospechada en la Antigüedad clásica (Dólar, 2007), así como el "exceso del cuerpo" perseguido en el Medioevo (Zumthor, 1984), retornan intensamente en la performance del freestyle.

En Argentina, como en casi todo el mundo, este fenómeno de cultura popular, con la sola potencia de sus formas novedosas ha venido conquistado la escena cultural del país y, como dijimos anteriormente, ha logrado la cobertura de los medios tradicionales, que se asoman a él para entender de qué se trata: una modalidad de combate verbal cara a cara y una puesta en escena que solo requieren de un espacio y los cuerpos presentes, sin necesidad de amplificación, iluminación ni escenografía. En este sentido, actualiza intercambios cara a cara, que conjugan el juego verbal y vocal, el desafío que llega a la injuria ${ }^{10}$ y la danza gestual.

Asimismo, a la crudeza y espontaneidad de las competencias se le suma la mediatización en las redes sociales, que introducen su lógicahipertextual y proliferante. Las competencias, como sucede con gran cantidad de prácticas en las sociedades urbanas contemporáneas, se graban espontáneamente con celulares y se suben casi sin edición a redes sociales como YouTube, Instagram, FB, "plaza" ampliada y expandida en que se desenvuelve el fenómeno de consumo y retroalimentación entre público y raperos. De ahí su capacidad de viralización que alcanza miles o cientos de miles de visitas de acuerdo al nivel de popularidad de los participantes.

Lo que el usuario ve en su pantalla es la captación mediante cámara casi fija (por su punto de vista único) y móvil o movida (por las condiciones de producción: alguien grabando celular en mano) del combate. A lo sumo, se agrega una placa al comienzo de cada video y en algunos casos se subtitulan partes de la competencia para su mejor audición y comprensión. También hay numerosas compilaciones de momentos descollantes de algún participante en la forma de "Lo mejor de..." o "El rey de la plaza...", videos que son muy apreciados.

El material se considera valioso en sí mismo y, evidentemente, la falta de

10 E inclusive a la calumnia, ya que los competidores y el público suscriben tácitamente un pacto de autenticidad, por lo que cada uno se presenta como lo que es en el universo fáctico, aunque mediado por su seudónimo. Vale decir, cada uno es un personaje, pero anclado en la vida real. 
esteticismo, fotogenia y otros procedimientos de embellecimiento audiovisual no conspira contra su consumo. ${ }^{11}$ Debe decirse que se trata de eventos absolutamente subterráneos, que solo se publicitan vía redes y que sin embargo consiguen miles y decenas de miles de visitas.

En algunos casos, hay youtubers que se especializan en estos videos y que se hacen conocidos por su labor difusora del género. Funcionan como canales, con mínima intervención sobre el material. Otros, más sofisticados, comentan, desde el margen del cuadro, la performance de los raperos en sincronía con los sucesos, como periodistas de un match de box.

Entre ambos mundos, el que llamaremos "real" y el virtual se establece un feedback permanente. El combate cuerpo a cuerpo, palabra a palabra se proyecta al mundo web, aprovechando las posibilidades inéditas que éste ofrece: el circuito entero con sus instancias de Producción, Circulación y Recepción al alcance de los usuarios (y de los analistas del discurso). Palabra en juego y cuerpo en danza, el freestylees un teatro de las pasiones que anuda lo arcaico con la contemporaneidad del universo en red.

\section{Un arte popular}

Si bien en el freestyle se conjugan diversas tradiciones -a veces no reconocidas- con centro en la palabra espontánea, éstees parte explícita de la cultura hip hop (la cultura, como le dicen sus adeptos) y en tal sentido, una expresión del rap nacido en los setenta en el Bronx neoyorquino y exportado al mundo con posterioridad. ${ }^{12}$

Las competencias implican en su escena primera la interacción cara a cara de intersubjetividad plena (Traversa, 2014); la riña verbal y gestual en lugares públicos; el consumo popular; la improvisación basada en el recurso madre de la repetición (del que la rima es su expresión más llamativa); el uso de un cúmulo de figuras retóricas.

Entendemos que el freestylees un género en proceso de artificación (Heinich y Schapiro, 2012), que combina una larga tradición adversativa verbalmusical presente en gran parte de los folklores del mundo con procedimientos novedosos propios de la cultura urbana mediatizada. Para decirlo grosso modo: este fenómeno de consumo juvenil no sería ni por mucho tan potente como lo es si no mediara la intervención de las redes sociales y todo lo que estas conllevan.

Como práctica popular, los desafíos de elogios o insultos se ven en numerosos folklores del mundo, ya que se hallan íntimamente ligados a la

\footnotetext{
${ }^{11}$ Evocamos algunos procedimientos de tratamiento de la imagen fotográfica o procedimientos de connotación que señalaba Barthes en su artículo pionero "El mensaje fotográfico" (1961).

12 Históricamente, se entiende que el rap, el breakdance, el DJ (hacer música con bandejas o "cortando, pegando y superponiendo") y el graffiti son las cuatro ramas que constituyen el mundo del hip hop.
} 
cultura de oralidad primaria, de matices agonísticos (Ong, 1993). En los discursos de los contendientes se combina la autoafirmación con la polémica: la identidad se configura en oposición al otro. ${ }^{13}$

En cuanto a la exhibición de la destreza y agudeza verbales contamos con una vastísima tradición que proviene de la cultura oral, pero que se enriquece cuando entran a jugar las posibilidades de la cultura caligráfica y tipográfica. Fue abordada en Occidente como objeto de interés ya en la Antigüedad grecolatina ${ }^{14}$, adquirió brillo en los salones cortesanos de la Francia del siglo XVII y de la Ilustración y tiene en América ejemplos de cultura popular como la payada criolla latinoamericana, la piquería colombiana y el contrapunteo venezolano. En cuanto a los rasgos estilísticos propios del rap, los participantes, ("gallos") hacen uso de la variada gama de figuras retóricas ya cristalizadas en las numerosas artes retóricas de Occidente. Por lo general, desconocen este origen, aunque muchos de ellos luego avancen en un estudio más fino de la poética. Hay que poner el acento en que el rap constituye una escuela, en tanto conjunto de referencias culturales que se abren a la búsqueda y a la curiosidad de los seguidores (raperos y público): tanto a nivel de los procedimientos poéticos como de la amplia gama de referencias intertextuales, el rap, como género antropofágico, brinda a sus cultores educación y un imaginario que va desde Aristóteles a Malcolm X, pasando por Voltaire.

En cuanto a los recursos poéticos, la rima es, sin duda, el más llamativo, tal que a menudo rimar se usa como sinónimo de rapear. Sin embargo, un abordaje más exhaustivo nos permite observar el abanico de figuras retóricas que se ponen en juego en el rap, y que los improvisadores tienen in mente luego de practicar día tras día- a la hora de la réplica espontánea: “Conjugá los verbos bien/ si querés que te festejen más de cien/ que lo escuchen/ que digan ¡bien!/ que después no se quejen cuando deje el levél(sic)"

En un análisis de la poética del grupo español Violadores del Verso, en particular de su rapero estrella KaseO, Pujante Cascales (2009) encuentra numerosas figuras fonológicas tales como la aliteración, el homotéleuton, la rima interna, la paragoge o adición de un sonido al final para rimar y la diástole o cambio de acentuación. La repetición de sonidos sobre el beat (pulso) marcado

\footnotetext{
13 "Comunes en las sociedades orales de todo el mundo, los insultos recíprocos tienen un nombre específico en la lingüística: flyting (o fliting). Crecidos en una cultura todavía predominantemente oral, ciertos jóvenes negros, el Caribe y otras partes practican lo que se conoce como "dozens", "joning", "sounding", competencia que consiste en superar al rival en insultos a su madre. El dozens no es un verdadero combate sino una manifestación artística, al igual que las demás agresiones verbales estilizadas de otras culturas."(Ong, 1993: 50) En Senegal, Galicia y Portugal se han registrado ya de hace siglos estos combates verbales. Ejemplo de ello son las célebres Cantigas de escarnio y maldizer del Cancionero de Alfonso El Sabio (siglo XIII) escrito en galaicoportugués.

${ }^{14}$ No podemos obviar la Retórica de Aristóteles, los tonos del orador (que van de la ira a la empatía con el contrincante, pasando por el humor), la polémica o guerra de palabras.
} 
por las voces de los beatboxers es predominante en la expresión de los raperos. Podría decirse que la rítmica, generalmente binaria, y el gusto por los colores de cada sonido o grupo sonoro que vuelven una y otra vez son el corazón del rap. A eso se suman figuras gramaticales, semánticas y pragmáticas ${ }^{15}$ : la entera tradición retórica occidental se reformula bajo ropajes nuevos porque no es cuestión solo de jugar con la rítmica y los sonidos, sino también de enunciar un saber. El decir sentencioso se mezcla con la autodescripción y la polémica: "Yo, que soy mejor que vos, te digo que la vida (los hombres, los humanos, etc.) es así".

En el freestyle, tanto como en el rap, el ritmo lo es todo, un ritmo que respeta el beat, pero que excede la métrica tradicional y en el que las unidades de la versificación juegan con enorme libertad. Eldecirentonativo (Tatit, 2014) entreverado rítmicamente hace que lo musical se conciba de otro modo. Antes que hablar de palabra hablada y de palabra cantada -entendiendo por canto la emisión y articulación tónicas- podríamos pensar en un continuo que se acerca más a una o a otra, pero siempre musicalmente. Todo es musical en este género.

Por su parte, y en relación con la performance corporal, las danzas que semejan lucha cuerpo a cuerpo en una ronda cuyo centro ocupan los contendientes están en el origen de la cultura afroamericana, posiblemente importadas de Africa (Ortiz Oderigo, 1952, 27-28).

Finalmente: si la escena primera se da en espacios públicos, en segunda instancia tenemos la escena virtual: la interacción entre el dueño de la cuenta de YouTube o de Instagram ${ }^{16}$ con sus usuarios, que a su vez dialogan, debaten y confraternizan entre sí convocados por un interés común.

\section{La mediatización}

La plaza virtual es de los usuarios: elogio, fanatismo, análisis especializado, pequeñas polémicas, todo confluye en la pantalla, arena hipertextual que se ramifica entre cuerpos e imágenes, palabras y sonidos mediatizados. A su vez, todo va configurando un relato con protagonistas y coro que se retroalimenta con cada nuevo posteo. Los participantes de las competencias son los héroes de estas historias narradas por los dueños del canal, quienes reciben pedidos y agradecimientos.

\footnotetext{
${ }^{15}$ Figuras gramaticales: hipérbaton, asíndeton, elipsis; por adición: pleonasmo o redundancia y enumeración; anáfora, anadiplosis (misma palabra al final y al comienzo de verbos sucesivos); homeóptoton (repetición del mismo morfema flexible) y poliptoton (misma raíz con distintas desinencias); calambur o disemia ("y tu voz, quemadura")

Figuras semánticas: metáforas, alegorías o metáfora continua, sinestesia, hipérbole (especialmente en la autoafirmación), símil, antítesis, oxímoron, paradoja

Figuras pragmáticas: diálogo beligerante o polémico con el oyente, con otro rapero, la sentencia generalizante, personificación (Pujante Cascales, 2009).

${ }^{16}$ En general, las competencias no son subidas a la red por los participantes sino por mediadores (comentaristas, editores) que ofrecen una edición titulada a los potenciales usuarios.
} 
En cuanto al caso que nos ocupa, los videos retoman con tecnología audiovisual un evento único e irrepetible que sucede en el ámbito público. En la pantalla, a su vez, el video, titulado y comentado apropiadamente, se enmarca automáticamente (a partir de programas algorítmicos (Levy, 2013) que procesan la nueva información con el historial de búsqueda de cada usuario) en una serie o red de otros videos que linkean infinitamente a otros contenidos. El video es contextualizado, entonces, a la vez que recibe gran cantidad de likes (o de dislikes) y de comentarios.

Plataformas como Youtube han demostrado ser lo suficientemente elásticas como para resistir el paso vertiginoso del tiempo en épocas hipertextuales: YT compensa la falta de calidad de gran parte de sus videos con su capacidad de albergar un sinnúmero de expresiones discursivas que van del registro en crudo a los productos HD. A diferencia de las redes sociales como FB e Instagram, que se basan en el principio de reciprocidad (Gurevich, 2018), YT mantiene un lazo más fuerte con los medios de estructura broadcasting tales como la radio y la TV, ya que se sostiene en la estructura de uno a muchos simbolizado en el slogan broadcastyourself (Jáuregui, 2014: 53). Sin embargo, como todo medio digital, es interactivo, y en ese carácter radica la posibilidad que tiene el análisis de abordar el circuito entero de Producción, Circulación yRecepción de un discurso, o al menos parte de la última instancia: aquella que es posible visualizar en pantalla en la forma de likes/dislikes y comentarios.

Vale agregar que el comentario, como práctica discursiva, se ha ido autonomizando como género y ocupando cada vez mayor espacio en la semiosishipermediática (Scolari, 2008). En tal sentido, este nuevo género de participación ciudadana presente en el ciberespacio responde a la lógica de comunicación de los nuevos medios (Sal Paz 2016). Los comentarios que aparecen en las plataformas sociales toman, amplifican y ponderan fragmentos de la performance registrada. Al igual que lo que sucede en Twitter y en los foros que siguen a las notas periodísticas en los sitios de los diarios on line, se habilita un espacio para expresar opinión y sentimientos, sostener el contacto (función fática de Jakobson) y alimentar de ese modo la conversación social. ${ }^{17}$

\section{Conclusiones}

Nos abocamos a una práctica poético-musical que convoca tradiciones muy antiguas propias del estadio de oralidad primaria (Ong, 1993; Havelock, 1996) al tiempo que las escenifica en una de las modalidades más usuales de consumo hipermediático en la actualidad: las plataformas sociales.

\footnotetext{
${ }^{17}$ A contramano de lo que podría suponerse, los comentarios sobre el freestyle manifiestan, con un estilo crudo y a menudo escatológico, mucho más afecto y sentimiento comunitario que aquellos que uno encuentra en los periódicos on line.
} 
Entendemos que las competencias de freestyle son un objeto de sumo interés para estudiar la circulación de los discursos juveniles en un espacio que se entreteje entre lo real y lo virtual, a la vez que se afectado por la intervención incipiente de los medios masivos - prensa, radio y TV.

Es en la discursividad que atraviesa plataformas como YouTube, Instagram y FB donde encontramos material para entender formas novedosas de apropiación cultural de grupos de jóvenes urbanos. Discursos que involucran el cuerpo y la palabra que convocan a miles de usuarios a quienes interpelan fuertemente, mientras que el mundo off line y el de los medios masivos apenas toma cuenta de ello.

\section{Bibliografía}

BARTHES, Roland. 1986.El mensaje fotográfico.En Lo obvio y lo obtuso, Barcelona: Paidós.

CHANG, Jeff.2014.Generación hip hop. De la guerra de pandillas y el grafiti al gangsta rap. Buenos Aires: Caja Negra.

CHION, Michel. 2008.La Audiovisión.Buenos Aires:Paidós.

FABBRI, Paolo. 1998.El giro semiótico. Barcelona:Gedisa.

FERNÁNDEZ, José Luis. 2014.Posbroadcasting. Innovación en la industria musical.Buenos Aires: La Crujía.

GRIMBERG, Miguel. 2008 [1977]. Cómo vino la mano. Orígenes del rock argentino. Buenos Aires: Gourmet Musical.

GUREVICH, Ariel. 2018. La vida digital. Intersubjetividad en tiempos de plataformas digitales.Buenos Aires: La Crujía.

JAKOBSON, Roman. 1981.Lingüística y poética.En Ensayos de lingüistica general. Barcelona:Seix Barral.

JÁUREGUI, Jimena. 2014. Convergencias broadcasting del tango en YouTube. En Pos broadcasting. Innovación en la industria musical (Fernández, José Luis, coord.),Buenos Aires, La Crujía.

HAVELOCK, Erik. 1996. La musa aprende a escribir.Barcelona:Paidos Studio.

HEINICH, Nathalie Y SCHAPIRO, Roberta. 2012. De l'artification. Enquêtessur le passage à l'art.Paris:Éditions de l'EHESS. 
LEVY, Pierre. 2013. El medio algorítmico.En RevistaSociétés, París.

(Traducción del francés: Carlota Ornani)

ONG, Walter. 1993.Oralidad y Escritura. Tecnologías de la palabra. México: FCE.

PARRET, Herman. 1995.De la Semiótica a la Estética. Buenos Aires:Edicial.

ORTIZ ODERIGO, Néstor. 1952. Historia del jazz. Buenos Aires:Ricordi.

PUJANTE CASCALES, Basilio.2009. La retórica del rap: análisis de las figuras retóricas en las letras de Violadores del verso. En: Tonos. Revista electrónica de estudios filológicos, Murcia, $\mathrm{N}^{\circ} 17$, julio.

PUJOL, Sergio. 2002.La década rebelde. Los años 60 en la Argentina. Buenos Aires:Emecé.

ROCHA ALONSO, Amparo. 2000. MeredithMonk: el Arte en las fronteras. En Mujeres fuera de quicio (López Gil, Marta, compiladora).Buenos Aires: Adriana Hidalgo, pp.237-252.

2010. De lo indicial, lo icónico y lo simbólico en las manifestaciones del sentido.En Intersecciones en Comunicación, Año 4, № 4, 99-126, Olavarría, FACSO, UNICEN.

2016. Proyecto burbujas: circuitos de música en Buenos Aires.En LIS. Letra. Imagen. Sonido. Ciudad mediatizada, Año VIII, № 15, Buenos Aires, Primer semestre, pp. 35-48.

TATIT, Luiz. 2014. Ilusão enunciativa nacanção. En Per Musi, Belo Horizonte, $n$ 29, pp.33-38.

TRAVERSA, Oscar. 2001. Aproximaciones a la noción de dispositivo. Signo y Seña. $N^{\circ}$ 12. Buenos Aires: abril.

2014.Inflexiones del discurso. Cambios y rupturas en las trayectorias del sentido. Buenos Aires: Santiago Arcos.

TERÁN, Oscar. 1991. Nuestros años sesentas.Buenos Aires:Puntosur.

VERÓN, Eliseo. 1987.La Semiosis Social. Barcelona: Gedisa.

WINKIN, Ives.1980. La nueva comunicación. Barcelona: Kairós.

ZUMTHOR, P. 1985. "Permanencia de la voz" en Correo de la UNESCO No.8, (págs.4-9)

2006 [1984]. La poesía y la voz en la civilización medieval, Madrid, Abada Editores. 


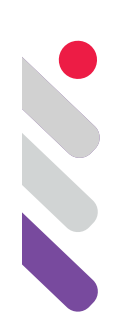

\title{
Procedimentos retóricos e semióticos na canção Retrato em branco e preto, de Chico Buarque e Tom Jobim
}

DOI: 10.24308/IASS-2019-4-035

\author{
Robson Costa Bessa \\ Universidade Federal de Minas Gerais (UFMG) \\ robsonbessa@yahoo.com.br \\ Alfredo Werney Lima Torres \\ Universidade Federal de Minas Gerais (UFMG) \\ alfredo.lima@ifpi.edu.br
}

\section{Introdução}

O diálogo entre música e retórica teve um grande desenvolvimento no período Barroco, principalmente com o surgimento da monodia, ou seja, uma melodia sustentada por um baixo ou acompanhamento. Essa relação excedeu os limites da música erudita do século XVII e pode ainda ser observada em diversos processos criativos da canção popular. No contexto do Brasil, este gênero musical consolidou-se como uma das principais formas de expressão do ethosnacional, o que levou o pesquisador José Miguel Wisnik a denominá-lo de "uma nova forma de gaia ciência". Em sua visão, a canção brasileira configurase "um saber poético-musical que implica uma refinada educação sentimental" (WISNIK, 2004: 18).

Em um estudo sobre as origens da canção urbana, José Ramos Tinhorão (2011) apontou a modinha e o lundu como as primeiras formas de música popular tipicamente urbana do mundo moderno. Segundo o pesquisador,as aventuras da vida setecentista reproduzida nos folhetos permitem concluir que "em tal época de novas modas qualquer tipo de música que surgisse era uma moda nova. E entre elas figuravam as próprias modinhas [...] levadas do Brasil juntamente com o lundu cantado pelo mulato poeta e tocador de viola Domingos Caldas Barbosa". Na perspectiva dos estudos musicológicos de Tinhorão, portanto, a modinha pode ser considerada como o "primeiro gênero de música popular urbana de massa" (TINHORÃO, 2011: 191). Este gênero 
tornar-se-ia um paradigma para o desenvolvimento da música popular brasileira de séculos posteriores.

No século XX é que a canção torna-se, efetivamente, um dos gênerosmusicais mais apreciados pelo público. Essa ligação orgânica entre música popular e cultura brasileira proporcionou, inclusive, a utilização do samba como estratégia política, principalmente pelo governo de Getúlio Vargas na década de 1930, para forjar uma identidade nacional (WISNIK, 1982). O fato é que a música popular sempre esteve associada ao debate sobre a formação da cultura do Brasil.

Não raro, os compositores populares utilizam-se de procedimentos retóricos em suas canções.Dentre estes compositores, destacamos o trabalho músico-literário de Chico Buarque de Holanda. Seu cancioneiro está permeado de vozes dramáticas e de personagens que tentam persuadir o ouvinte para o conteúdo de sua fala. É notória a forte ligação intertextual de suas obras com elementos advindos da tradição literária brasileira e mesmo da literatura canônica ocidental. A análise das canções de Chico Buarque a partir da observação de seus componentes retóricos nos permite compreendê-las de forma mais orgânica, posto que os elementos da oralidade e as tentativas de persuasão utilizadas pelo cancionista são fundamentais para a construção do seu estilo composicional (TORRES, 2013).

O pesquisador e compositor Luiz Tatit, em concordância com conceitos da semiótica, evidencia que a função principal de uma canção popular é a eficácia, isto é, o "êxito de uma comunicação entre destinador e destinatário" (TATIT, 1987: 3). Para se estabelecer essa relação persuasiva, os compositores precisam descobrir formas de compatibilidades entre componentes linguísticos e melódicos. Desse modo, eles procuram articular as palavras e os sons musicais de uma maneira que "encante" os ouvintes e se gere um efeito de verdade no que está sendo enunciado. Baseado nesses procedimentos semióticos e retóricos utilizados pelos autores de música popular, o objetivo desse trabalho é realizar uma análise da canção "Retrato em branco e preto", de Chico Buarque e Tom Jobim. Desejamos compreender quais estratégias discursivas, musicais e literárias foram utilizadas pelos cancionistas para revelar um sujeito lírico em desilusão amorosa e, desse modo, mover os afetos dos interlocutores. Como aporte teórico, elegemos os trabalhos de semiótica da canção desenvolvidos por Luiz Tatit, além de conceitos da Retórica e da Teoria dos afetos.

Compreendemos a canção aqui na perspectiva da semiótica, isto é, como um sistema de comunicação híbrido cujo sentido é construído por meio da articulação de, pelo menos, dois domínios semióticos: a melodia e a letra. Portanto, entendemos que é essencial examinar a obra de Chico Buarque enquanto canção, embora ela esteja estreitamente ligada à série literária, pois o seu julgamento como sendo um poema feito para ser lido é incapaz de descortinar 
os seus efeitos de sentidos. Na mesma perspectiva de Flávio Barbeitas (2007: 37), consideramos que "a vinculação corpórea, vocálica, patente na palavra cantada, problematiza o texto como código linguístico e o insere num outro campo de relações tradicionalmente desprezado pela epistemologia".

\section{Retórica e música nas canções de Chico Buarque e Tom Jobim}

A canção popular urbana foi o gênero que dominou a cena musical brasileira no século XX. Ela se tornou um lugar privilegiado da aplicação de elementos retóricos como forma de se estabelecer uma comunicação mais direta com os apreciadores de música popular. Ainda que não se possa visualizar um quadro teórico bem delineado, é significativa a quantidade de estudos atuais de retórica aplicada à chamada MPB. Em geral, estuda-se o uso de figuras retóricas nas canções, a construção do ethos, além de elementos referentes à retórica das paixões. No que se concerne à obra de Chico Buarque, notamos que os trabalhos, muitas vezes, limitam-se ao estudo do ethos feminino no discurso de suas obras musicais, suplantando outros recursos estilísticos usados pelo autor.

A relação da retórica com a música popular é manifesta, visto que processos estéticos como mudanças de tonalidade, desenhos melódicos que representam situações "extramusicais", harmonias que procuram expressar diversos estados de espírito, figuras retóricas, são constantemente utilizados por compositores populares - sejam de maneira consciente ou inconsciente - no intuito de mover as paixões do interlocutor. As técnicas largamente empregadas pelos estudiosos da Retórica, sobretudo no século XVI e XVII, podem ser observadas no processo de composição de canções populares. Nessas composições, em geral, os cancionistas procuram construir uma mensagem verbal clara e eficiente, no sentido de descobrir compatibilidades entre melodia e letra que fiquem retidas na memória do interlocutor e estabeleça com este uma comunicação fluente. Mais adiante, identificaremos alguns procedimentos retóricos presentes no cancioneiro de Tom Jobim e Chico Buarque.

Segundo Rubén López Cano (2000: 43), um dos objetivos fundamentais da aplicação de princípios retóricos na música foi o de "proporcionar ao discurso musical a possibilidade de despertar, mover e controlar os afetos do público, tal como os oradores faziam com o discurso falado". Na mesma linha argumentativa, Robson Bessa (2017: 12), observa que:

A relação entre a poesia e a música foi alvo de intensos debates no Barroco, e recebeu uma grande teorização, principalmente no início do século $\mathrm{XVII}$, onde a literatura teve um papel decisivo na transformação da linguagem musical. A polifonia já não atendia aos anseios de expressar a variedade de afetos que a literatura podia exprimir. No surgimento do Barroco, vários compositores como Cláudio Monteverdi, e teóricos ligados à Camerata Bardi, como Vicenzo Galilei, propuseram a adoção de uma nova relação entre a poesia e a música 
para expressar os afetos que estavam bem delineados na literatura barroca(grifo nosso).

Com efeito, mover e controlar os afetos do público parece ser ainda o ponto nodal do discurso dos cancionistas populares. Em muitas obras de Chico Buarque e Tom Jobim há a presença de procedimentos retóricos que intentam chamar a atenção do interlocutor para o que está sendo dito. Vejamos alguns exemplos, para que possamos compreender tais elementos de forma mais clara.

Na obra "Piano na mangueira", a escala ascendente da melodia indica o próprio caminho do instrumento musical que é levado ao morro, o que engendra um sugestivo efeito icônico. Esse efeito, que suscita a própria imagem do piano ao ser levado até o morro da Mangueira, pode ser entendido como uma Hypotyposis, figura retórico-musical empregada com constância no período Barroco $^{1}$

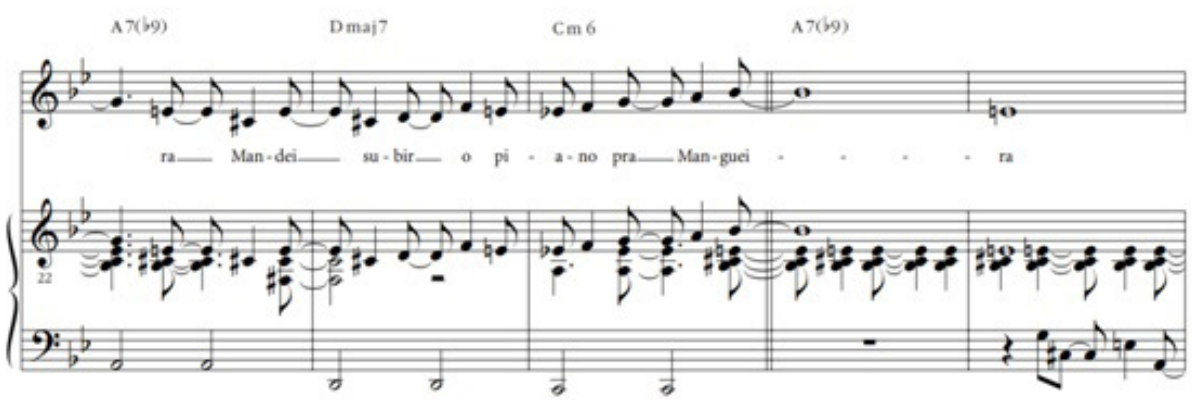

A letra da canção "Sabiá", mais uma parceria de Chico/Jobim, revela-nos o desencanto do sujeito lírico em virtude da situação política vivida pelo seu país no final da década de 1960. Através de um diálogo intertextual com a "Canção do Exílio", poema do escritor Gonçalves Dias, Chico Buarque denuncia o clima de desesperança e desencanto instalado em sua nação. Nos aspectos musicais, observamos uma melodia composta de notas longas e de intervalos musicais repleto de saltos, um ritmo lento e monótono, além de um acompanhamento harmônico marcado por acordes dissonantes e tensões não resolvidas ${ }^{2}$. Os recursos musicais de Tom Jobim dão uma maior concretude ao conteúdo da letra, estabelecendo efeitos de sentido decisivos para comover o público:

\footnotetext{
${ }^{1}$ Partitura editada por Paulo Jobim. In: www.jobim.org. Acesso em: 20 de set. de 2019.

2 Entendemos essas passagens harmônicas não-resolvidas como uma figura retórica, mais precisamente uma elipse, que consiste na omissão de elementos expressivos do discurso poéticomusical
} 

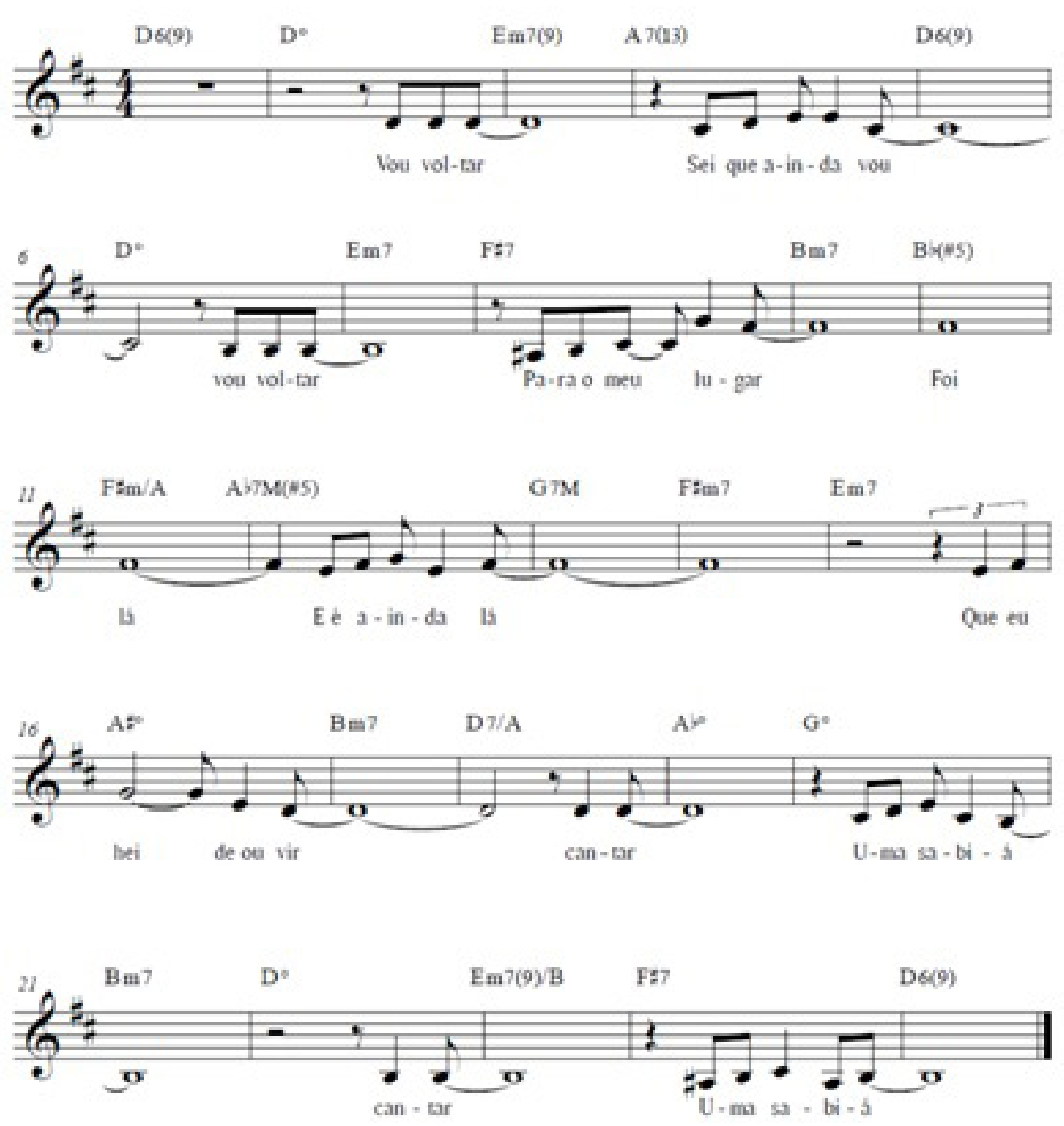

Em "Águas de março", um dos maiores sucessos de Tom Jobim, identificamos uma sintonia total entre elementos musicais e linguísticos. 0 texto é tecido por imagens concretas da natureza, formadas por um discurso que não visa construir um conteúdo inteligível, pois o que está em jogo é o que a palavra representa como unidade sonoro-visual. A letra, que não possui uma mensagem verbal explícita, exalta os fenômenos naturais como a chuva, o vento, as árvores, os pássaros, revelando-nos a força que deles emana. Musicalmente, o conteúdo da letra é reforçado por um ritmo circular que remete a gotas de água pingando, através da sucessão de colcheias e semicolcheias (figura retórica Hypotiposys). A harmonia, pensada também em aspectos retóricos, é composta por um encadeamento de acordes que se repetem de forma circular, como o próprio ciclo da água descrito no texto ("São águas de março fechando o verão, são promessas de vida no meu coração") ${ }^{3}$.

\footnotetext{
${ }^{3}$ Partitura presente em www.jobim.org. Acesso em: 20 de set. de 2019.
} 

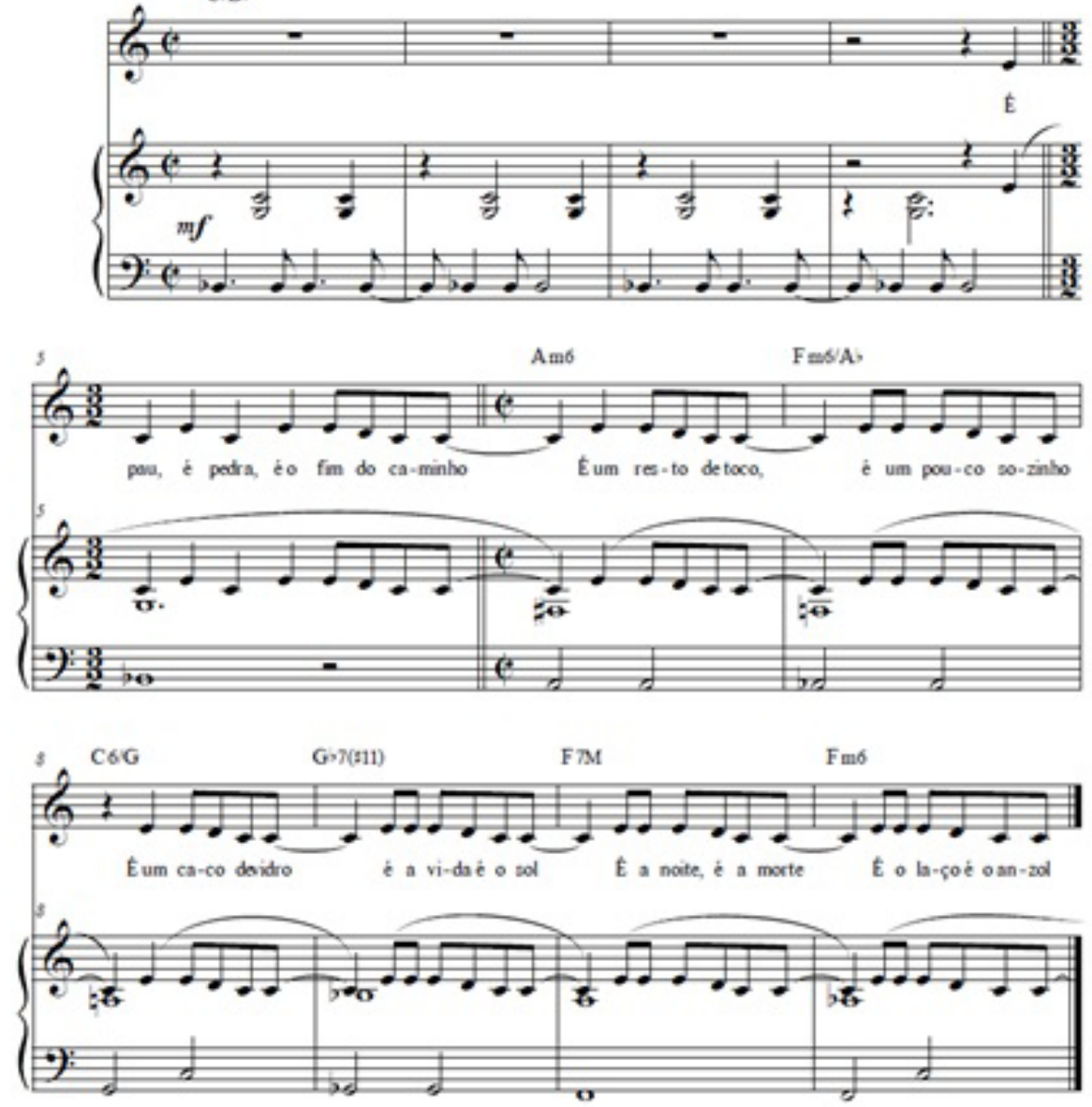

No final da canção "Gota d'água", presente na peça homônima de Chico Buarque e Paulo Pontes, observamos também um procedimento retórico muito expressivo. A personagem Joana volta-se em fúria para Jasão, seu amante, e fala sobre o seu sofrimento. A repetição do verso "Pode ser a gota d'água", aliada às frases melódicas que vão de uma região mais grave para uma região cada vez mais aguda, potencializa a dor do sujeito lírico, dando-nos a sensação do seu "transbordamento interior". A tensão é provocada por conta de seu objeto de desejo ter ultrapassado o limite da tolerância, fato explicitado pela expressão popular "gota d'água" e pela nota aguda atingida pela melodia (figura retórica chamada Gradatio). 


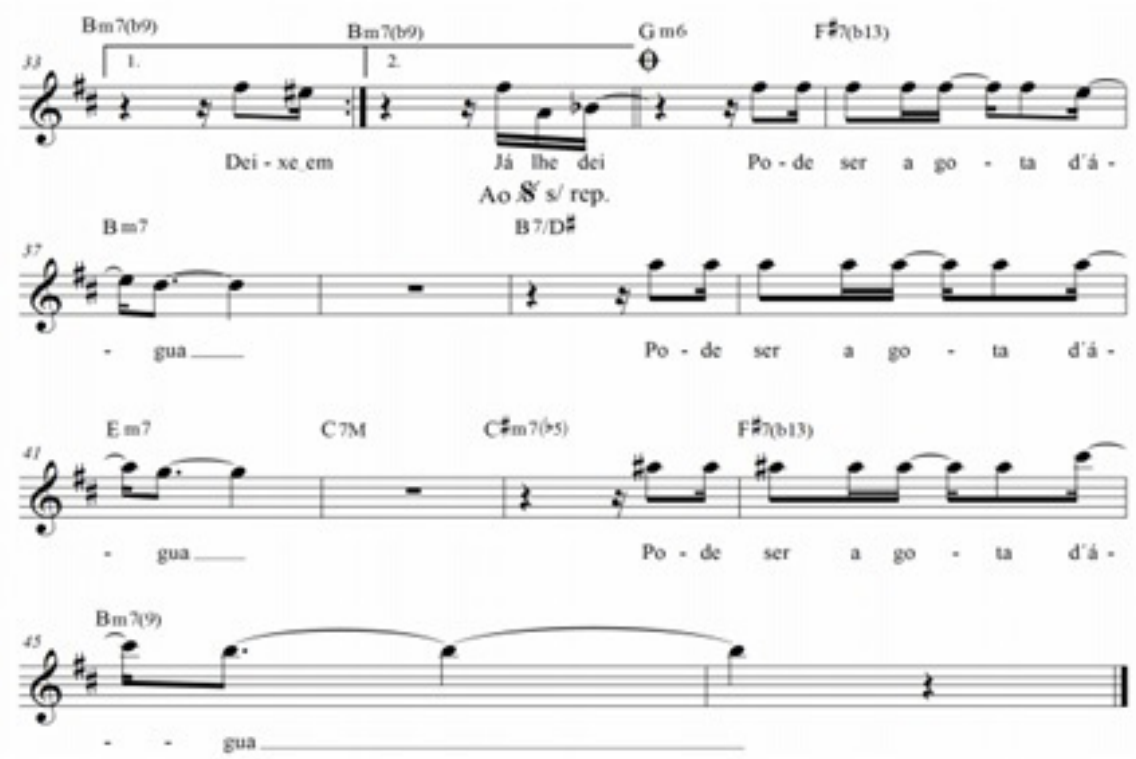

Enfim, entendemos que parte significativa da obra de Chico Buarque e Tom Jobim aponta para um projeto consciente de articulação de elementos retóricos e musicais, como uma forma de se conseguir efeitos músico-literários que despertem a atenção e mobilizem os afetos dos interlocutores de música popular.

\section{A análise da canção na perspectiva da semiótica}

Os estudos sobre a canção popular, de modo geral, mostram-se fragmentados, pelo fato de desmembrarem os componentes literários dos componentes musicais ${ }^{4}$. A crítica literária tende a abordar o fenômeno voltandose apenas para o universo do texto, enquanto os estudos musicológicos detêmse nas questões que envolvem harmonia, melodia, arranjo, interpretação, deixando de lado, muitas vezes, os elementos discursivos que compõem a letra. As pesquisas sobre canção popular tornaram-se mais coesas após o surgimento dos estudos de semiótica musical. Conforme notou Lauro Meller (2010) é recente a aparição da canção no escopo de interesse das academias, além do que os métodos de análise especificamente voltados para este gênero musical são esparsos,estão ainda em desenvolvimento. Por isso mesmo, as canções continuam sendo "rotineiramente analisadas de modo parcial, como se fossem

\footnotetext{
${ }^{4}$ Para ficar apenas na obra de Chico Buarque, citemos exemplos de trabalhos que não articulam texto e música: Chico Buarque - análise poético-musical - Gilberto de Carvalho; Figuras do feminino na canção de Chico Buarque - Adélia Bezerra de Meneses; A poética de Chico Buarque - Anazildo Vasconcelos. Vale ressaltar que não estamos discutindo a qualidade analítica destas pesquisas, o que desejamos mostrar é que elasse voltam exclusivamente para o texto poético.
} 
textos escritos" (MELLER, 2010: 11).

Procurando superar as análises que fazem uma cisão entre o estrato musical e o verbal, a semiótica musical defende que o sentido da canção é construído exatamente por meio da relação entre os dois domínios semióticos (texto e música) ${ }^{5}$ e que a análise separada não é suficiente para compreendermos o discurso do cancionista. Em resumo, a leitura de uma letra como sendo um componente independente, dotado de um sentido próprio, pode provocar impressões distintas da que provocaria se a ouvíssemos junto com a música stricto senso. Por este motivo,"sua avaliação por critérios unicamente poéticos redunda, quase sempre, em julgamento desastroso" (TATIT, 2007: 237).

A teoria de base dos estudos de semiótica da canção foi desenvolvida por Luiz Tatit (2007). Para esse pesquisador, o estudo analítico da canção deve estar centrado em torno de duas categorias do plano da expressão musical: "tessitura" (que está relacionado à altura) e o "andamento" (que está relacionado com a duração). A tessitura pode ser concentrada (saltos intervalares curtos) ou expandida (saltos intervalares longos) e o andamento acelerado ou desacelerado. Luiz Tatit (2007) elencou e analisou uma grande quantidade de canções populares do Brasil e as delimitou em três modelos de configuração. São eles: I) "Canções tematizadas" - quando elas possuem andamento acelerado e tessitura concentrada. II) "Canções passionalizadas" - quando elas possuem andamento desacelerado e tessitura expandida. III) "Canções figurativizadas" - obras em que há a predominância dos elementos emergentes da fala. A oralidade ocupa um lugar central nestas canções, em detrimento da "tessitura" e do "andamento".

A teoria da semiótica da canção propõe uma análise isotópica dos elementos do plano da expressão e do plano do conteúdo ${ }^{6}$, isto é, uma análise em que se compreenda texto e música como elementos de igual valor na produção de sentido. Desta forma, melodia e letra são compreendidas como elementos de estruturas equivalentes. Luiz Tatit (1997), em seus estudos, relacionou os aspectos do plano da expressão com os do plano do conteúdo. Nas "canções tematizadas", o pesquisador observou que o conteúdo das letras está relacionado a estados de conjunção entre "sujeito" e "objeto", por isso tratam, geralmente, de momentos de euforia e de satisfação com a vida ("Meu refrão", de Chico Buarque). Nas "canções passionalizadas" as melodias verticalizadas coadunam-

\footnotetext{
${ }^{5}$ Assim como no surgimento da monodia do Barroco. Isso nos revela que há, de fato, uma permanência e atualidade da monodia e da associação entre música e poesia proposta nos séculos XVI e XVII na concepção de determinadas canções populares urbanas.

${ }^{6}$ Segundo a teoria de Louis Hjelmslev (2003) o plano da expressão é o plano da linguagem em que se articulam os procedimentos formais que dão concretude ao conteúdo (no caso do texto verbal, podemos citar a construção rítmica, as figuras retóricas, a aliteração e a assonância, etc.). O plano do conteúdo é aquele que está vinculado ao plano da expressão e mantém com este uma relação de reciprocidade.
} 
se com estados de disjunção entre "sujeito" e "objeto". Dessa maneira, o que se observa é o efeito de sentido inverso das canções tematizadas: disforia, fechamento e insatisfação ("Carolina", "Atrás da porta", "Sem fantasia"). Em relação às "canções figurativizadas", o que se observa é a tentativa do sujeito de chamar atenção para o conteúdo de sua fala, o que faz com que o enunciado musical se adapte às inflexões sonoras do discurso falado. Dessa forma, os elementos prosódicos sobrepõem-se aos elementos melódicos, fazendo com que "o enunciador se projete no discurso e simule a presença da enunciação no enunciado" (TATIT, 1997: 121). É o caso de "Conversa de Botequim", de Noel Rosa e de "Meu caro amigo", de Chico Buarque.

É fundamental perceber que estes modelos de configuração podem se misturar, pois o que existe, na realidade, é a predominância de um deles no processo de criação poético-musical. Dessa forma, a semiótica não propõe categorias fechadas em si mesmas, já que na prática diária da elaboração de canções, os cancionistas tendem a mesclar modelos, articular diferentes processos em uma mesma obra, muitas vezes de modo bastante espontâneo.

\section{4. "Retrato em branco e preto": uma análise dos procedimentos retóricos Retrato em branco e preto}

Já conheço os passos dessa estrada

Sei que não vai dar em nada

Seus segredos sei de cor

Já conheço as pedras do caminho

E sei também que ali sozinho

Eu vou ficar, tanto pior

O que é que eu posso contra o encanto

Desse amor que eu nego tanto

Evito tanto

E que no entanto

Volta sempre a enfeitiçar

Com seus mesmos tristes velhos fatos

Que num álbum de retratos

Eu teimo em colecionar

Lá vou eu de novo como um tolo

Procurar o desconsolo

Que cansei de conhecer

Novos dias tristes, noites claras

Versos, cartas, minha cara

Ainda volto a lhe escrever

Pra lhe dizer que isso é pecado

Eu trago o peito tão marcado

De lembranças do passado

E você sabe a razão 
Vou colecionar mais um soneto

Outro retrato em branco e preto

A maltratar meu coração

"Retrato em branco e preto" (1968)é a canção inaugural da parceria entre Chico Buarque e Tom Jobim, que juntos compuseram oficialmente doze canções. Essa composição surgiu como uma peça instrumental de autoria de Tom Jobim, intitulada "Zíngaro". Chico Buarque, ao conhecê-la, decidiu elaborar uma letra para a melodia jobiniana. Composta por um texto tenso, o eu lírico relata sua experiência amorosa fracassada e mostra ter consciência da impossibilidade de junção com o seu objeto de desejo ("Sei que não vai dar em nada" / "Seus segredos sei de cor"). Nas camadas mais abstratas do texto, vemos a oposição semântica "encanto / desencanto". O sujeito do discurso afirma que procura evitar a relação amorosa, mas sabe que esse amor "volta sempre a enfeitiçar". Portanto, temos aí um jogo ambíguo entre o desejo e a repulsão. E é exatamente essa hesitação que dilacera o sujeito lírico ("Vou ficar tanto pior", "Lá vou eu de novo como um tolo" / "procurar o desconsolo").

No próprio título da canção, "Retrato e branco e preto", há uma tensão entre elementos simbólicos: o branco e o preto, que formam um contraste. Por meio de um breve intertexto com o famoso poema "No meio do caminho", de Carlos Drummond de Andrade, oeu lírico revela que "já conhece as pedras do caminho", mas não tem o poder de se desvencilhar do seu objeto de desejo ("O que eu posso contra o encanto" / "desse amor que nego tanto" / "evito tanto").Esta experiência dolorosa vem à tona cada vez que o sujeito depara-se com objetos que lembram o seu fracasso do passado, como "cartas", "sonetos", "álbum de retrato". O uso da figura retórica catabasis" nos versos "O que é que eu posso contra o encanto/ Desse amor que eu nego tanto/ Evito tanto", acentua mais ainda os afetos negativos vivenciados pelo eu lírico ${ }^{8}$ :

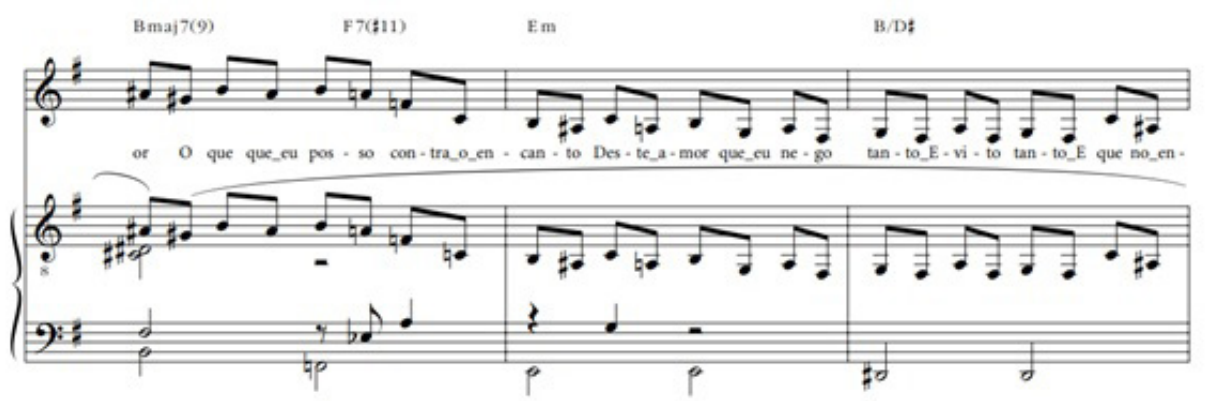

7 Segundo Bartel (1997, p.214) a Catabais é uma passagem musical descendente, que expressa imagens ou afetos negativos, de lamento, submissão ou humildade.

${ }^{8}$ Partitura presente em www.jobim.org. Acesso em: 20 de set. de 2019. 
Os sintagmas listados para mostrar o estado de espírito do eu lírico são sintomáticos: "tristes", "velhos fatos", "pecado", "peito tão marcado", "noites claras", "dias tristes". Como podemos perceber, existem traços passionais na construção de "Retrato em branco e preto", como a disjunção entre sujeito e objeto de desejo, o conteúdo melancólico, além do alongamento da duração de algumas notas da melodia. Contudo, há uma dominância do elemento prosódico, ou seja, a canção procura simular a expressão dramática do sujeito do discurso. Isto pode ser observado em alguns trechos da letra, os quais predominam os elementos emergentes da fala: "O que é que eu posso contra o encanto" / "desse amor que eu nego tanto". Em outros versos há claramente um desejo de se "mandar um recado" a alguém: "trago o peito tão marcado [...] e você sabe a razão". Em outros termos, notamos que a canção está permeada de dêiticos, que são "os elementos linguísticos que servem para caracterizar uma situação de locução" (TATIT, 1987, p. 15).

A tensão e a dor do enunciador podem também ser observadas no plano da música, principalmente no que se refere aos seguintes elementos compositivos: desenho melódico feito por meio da repetição constante de colcheias, ritmo insistente, harmonia dissonante e uso do cromatismo (Passusduriusculus) ${ }^{9}$ :

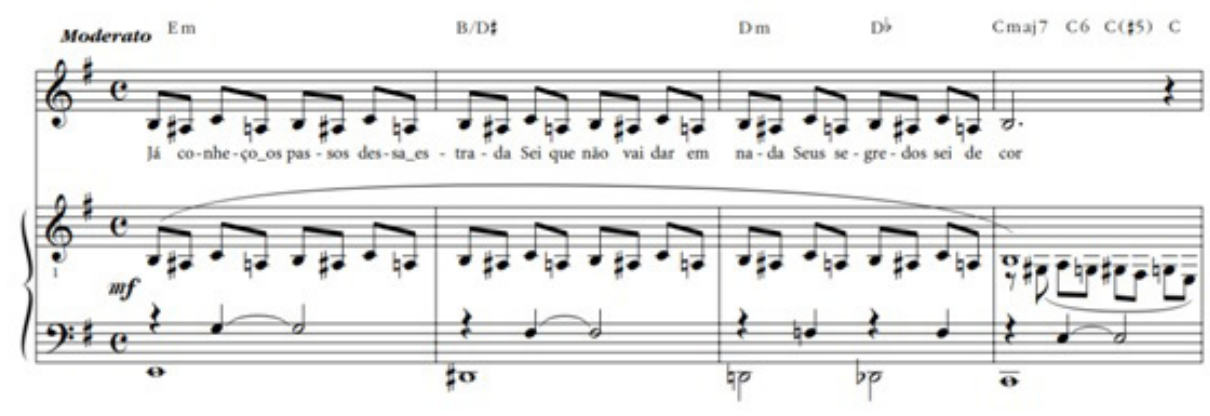

Compreendemos que a própria estrutura da canção, que não contém partes bem definidas, nem mesmo a recorrência de algum trecho que possamos identificá-lo como um refrão, também se relaciona com o espírito caótico da letra. Isto é, a "desestruturação" da canção remete-nos à desestruturação psicológica do enunciador, o que se configura, em nossa compreensão, como mais um procedimento retórico. Como observa Peter Dietrich "uma peça organizada em partes bem definidas pressupõe um sujeito organizado, em conjunção com um /saber fazer /" (2008: 172). No caso de "Retrato em branco e preto", o desenvolvimento harmônico e melódico não passa para o enunciatário

${ }_{9}^{9}$ Partitura presente em www.jobim.org. Acesso em: 20 de set. de 2019. 
a sensação de equilíbrio e firmeza. Pelo contrário, esses elementos enfatizam a "desorientação" e o desespero do enunciador. Vale notar que até mesmo o estrato fônico da letra de "Retrato em branco e preto" traduz tais sentimentos. A presença ostensiva de " $R$ " $e$ " $T$ " imprime ao fluxo verbal uma sensação de aspereza. A consoante linguodental " $T$ " funciona como um componente sonoro que interrompe o efeito de continuidade do verso (Vou colecionar mais um soneTo/ OuTRoReTRaTo em bRanco em pReTo/ A maltTRaTar meu coração).

Para visualizarmos de forma mais orgânica as correspondências estabelecidas entre elementos musicais e retóricos, elaboramos o seguinte quadro de inter-relações semióticas:

\begin{tabular}{|l|l|}
\hline Plano da letra (conteúdo) & Plano da música (expressão) \\
\hline $\begin{array}{l}\text { O sujeito lírico insiste em reviver um amor } \\
\text { trágico, que "não vai dar em nada". }\end{array}$ & $\begin{array}{l}\text { Melodias elaboradas com o uso de ostinatos } \\
\text { (padrões de repetições insistentes). Emprego da } \\
\text { figura Repetitio. }\end{array}$ \\
\hline $\begin{array}{l}\text { O sujeito lírico vive a experiência de um } \\
\text { tempo cíclico, no qual volta sempre a } \\
\text { reviver as mesmas desilusões. }\end{array}$ & $\begin{array}{l}\text { Ritmo repetitivo, composto com a predominância } \\
\text { de colcheias (Repetitio e circulatio). }\end{array}$ \\
\hline $\begin{array}{l}\text { Há uma desestruturação psicológica do } \\
\text { sujeito enunciador, o que gera angústia. }\end{array}$ & $\begin{array}{l}\text { Falta de uma estruturação clara da canção. Em } \\
\text { sua forma, não há refrão e nem partes uniformes. }\end{array}$ \\
\hline $\begin{array}{l}\text { O passado amoroso do sujeito lírico é } \\
\text { tenso, dramático. }\end{array}$ & $\begin{array}{l}\text { Harmonia em modo menor, composta de acordes } \\
\text { com sétima e nona diminutas, além de passagens } \\
\text { cromáticas (Passusduriusculus). }\end{array}$ \\
\hline $\begin{array}{l}\text { Os afetos negativos sofridos pelo sujeito vão ficando cada vez mais intensos, } \\
\text { mas ele não consegue se desvencilhar do } \\
\text { seu objeto de desejo. }\end{array}$ & $\begin{array}{l}\text { Uso de frases melódicas ascendentes, } \\
\text { (Aumento gradual na sonoridade e altura, criando } \\
\text { umento na intensidade). Uso da figura } \\
\text { retórica Catabasis para acentuar o sentimento } \\
\text { negativo. }\end{array}$ \\
\hline
\end{tabular}

A partir da visualização do quadro de inter-relações, verificamos que a canção "Retrato em branco e preto" está pautada por uma rigorosa sintonia entre os dois planos de sentido. Essa relação isotópica entre elementos discursivos e musicais pode nos ajudar a entender como os elementos próprios da retórica musical do século XVII ainda encontram eco no discurso da canção popular. Por meio destes recursos é que os cancionistas continuam provocando sensações, despertando paixões, criando ilusões enunciativas e encantando os interlocutores, embora estes nem sempre tenham consciência do artesanato poético-musical empregado no processo de composição. 


\section{Considerações finais}

O percurso analítico traçado no presente trabalho mostrou-nos que a música popular e a retórica são sistemas de comunicação que estabelecem variados diálogos, por isso entendemos que é pertinente o estudo da canção por meio de elementos da oratória. Procuramos demonstrar, desse modo, que a canção "Retrato em branco e preto" é composta por vários procedimentos retóricos, como o uso das figuras catabasis, circulatioe gradatio. Observamos que há em sua composição uma dominância dos elementos emergentes da fala, isto é, um processo de figurativização. Verificamos que o enunciador deseja "mandar um recado" para um enunciatário e falar sobre o seu sofrimento. Essa forma de organização faz com que o ouvinte se concentre na letra, ocultando, de certa maneira,os elementos estritamente musicais. Notamos, portanto, que os compositores Chico Buarque e Tom Jobim empregaram estratégias retóricas para colocar em destaque a fala do sujeito do enunciado.

A interpretação de Elis Regina, presente no disco Elis \& Tom (1973), reforça as ideias aqui apresentadas. A intérprete não canta as notas com uma duração uniforme (colcheias), mas sim de maneira flexível musicalmente. Esse procedimento retórico faz com que fala e canto aproximem-se, tornando mais perceptível as inflexões rítmicas próprias do discurso oral. Ao tornar as durações mais fluentes e dar ênfase à prosódia, a cantora brasileira convoca a atenção do ouvinte para o conteúdo do seu canto e instaura uma naturalidade no processo de transmissão da mensagem.

No que se refere especificamente aos componentes musicais, notamos que "Retrato em branco e preto" possuium contorno melódico repleto de notas cromáticas, em sua maioria intervalos de segunda menor. As notas movimentam-se a partir de saltos intervalares curtos, embora a segunda parte da obra contenha saltos de maior distância. Essas passagens musicais cromáticas, aliadas aos ostinatos melódicos e rítmicos, são essenciais para nos transmitir o espírito conflitante do texto, já que elas geram uma sensação de algo circular e angustiante. A harmonia, seguindo esta mesma linha estilística, é elaborada com acordes dissonantes (nona diminuta e sétima diminuta), o que contribui para acentuar a dramaticidade poética da canção.

Em última análise, podemos afirmar que a "Retrato em branco e preto"possui uma rigorosa articulação entre componentes retóricos e musicais. Eles são tecidos por meio de diversos recursos músico-literários, para que resulte em uma linguagem marcada pela homogeneidade e por uma notável coesão estética. Dito de outro modo: letra e melodia formam um laço indissolúvel, o que engendra uma naturalidade no dizer do cancionista e amplia o efeito de verdade do que é dito pelo enunciador. 


\section{Referências}

BARBEITAS, Flávio. 2007. A música habita a linguagem: teoria da música e noção de musicalidade na poesia. Tese. Belo Horizonte: UFMG, Faculdade de Letras (Doutorado em Estudos Literários - Literatura Comparada).

BARTEL, Dietrich. 1997. Musica Poetica: musical-rethorical figures in German Baroque. Lincoln: Universityof Nebraska Press.

BESSA COSTA, Robson. 2017. A importância da oratória, da retórica e da Teoria dos afetos na gênese e na fruição lítero-musical das cantatas de Alessandro Scarlatti. Tese. (Doutorado em Teoria da Literatura e Literatura comparada) Programa de Pós-graduação em Literatura- Poslit-UFMG.

CANO, Rubén López. 2000. Musica y Retórica enel Barroco. México: Universidad Nacional Autonoma de México.

CHEDIAK, Almir (org.). 1999. Songbook Chico Buarque Vol. 2 e 4.3 ed. Rio de Janeiro: Lumiar.

DIETRICH, Peter. 2008. Semiótica do discurso musical: uma discussão a partir das canções de Chico Buarque. 256 f. Tese (doutorado em Semiótica e Linguística Geral). FLCH-USP, São Paulo.

HJELMSLEV, Louis. 2003. Prolegômenos a uma teoria da linguagem. Trad. de José Teixeira Coelho Netto. 2ed. São Paulo: Ed. Perspectiva.

TATIT, Luiz. 2007. A semiótica da canção: melodia e letra. 3 ed. São Paulo: Editora Escuta.

1997. Musicando a semiótica. 2 ed. São Paulo: Annablume.

1987. Canção: eficácia e encanto. 2 ed. São Paulo: Atual.

TINHORÃO, José Ramos. 2011. As origens da canção urbana. São Paulo: Editora 34.

TORRES, Alfredo Werney Lima. 2013. Música e palavra nas canções de Chico Buarque e Tom Jobim. São Paulo: Max Limonad.

WISNIK, José Miguel. 1982. Getúlio da Paixão Cearense. In: O nacional e o popular na cultura brasileira. Música. Enio Squeff e José Miguel Wisnik. São Paulo: Brasiliense. 


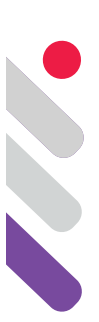

\section{Música y producción de sentido en el cine de Woody Allen. La presencia de obras musicales representativas de un determinado momento como reenvío a manifestaciones culturales del pasado}

DOI: 10.24308/IASS-2019-4-036

Carolina Inés Rochi

Universidad Nacional de las Artes, Buenos Aires, Argentina carolinarochi@live.com.ar

\section{Introducción}

El presente trabajo se contextualiza en una tesis de maestría centrada en el estudio de las distintas modalidades de vinculación e interpenetración entre la música y el conjunto de los elementos que integran una producción de sentido audiovisual, lo cual implica observar procedimientos específicos ligados a la organización retórica de las obras. Específicamente, la tesis se focaliza en un corpus de filmes dirigidos por Woody Allen. Para cumplir con los objetivos propuestos se definió una metodología de análisis en dos lineamientos teóricos complementarios. Por un lado, se siguió una línea centrada en la lectura que Eliseo Verón (1987) realiza de la obra de Charles Peirce, atendiendo a que todo análisis textual es siempre un análisis discursivo y debe ser considerado en relación a la "semiosis social". Por las características del corpus las posiciones de Verón sobre los "discursos de reconocimiento" se hacen particularmente enriquecedoras. Ello en cuanto a que en las películas de este autor es recurrente la remisión a composiciones musicales que conectan al filme con épocas y espacios culturales específicos. En estos textos existe un reenvío relevante a manifestaciones culturales diversas.

Por otra parte, para el análisis textual, se atendió al marco teóricometodológico que propone Oscar Steimberg (2013) al circunscribir tres niveles discursivos comprometidos con la producción de sentido: temático, retórico y enunciativo. Esta delimitación primera permitió luego acceder a otros autores que aportan desarrollos dentro de esas dimensiones. En primer lugar, los 
abordajes al relato llevados a cabo por Roland Barthes (1994) y Tzvetan Todorov (1970). También Cesare Segre (1985), quien estudia la relación entre temas y motivos como generadora de sentido. Si bien este autor toma ambos conceptos del ámbito de la música para aplicarlos a la literatura, en un análisis audiovisual podemos encontrar, por ejemplo, que un determinado motivo, característico de un personaje, se manifiesta, entre tantas otras posibilidades, a través de la música como vía de expresión. De esta manera, la música conecta con el nivel de la narración y es útil a los fines de una determinada función dramática. Por otro lado, son imprescindibles los aportes de Christian Metz en referencia al estudio del lenguaje cinematográfico (1974, 1991, 2002a, 2002b). En líneas generales, esta segunda perspectiva se centra en la construcción interna de la obra y por esta razón, a ella se integran también, los estudios sobre música y cine.

En este espacio, luego de la revisión de un conjunto de textos cuyos autores son referencia en la materia, se entiende que existe una tradición en la consideración de la música como serie expresiva, que como uno de los elementos de la banda sonora (conformada también por voces y ruidos), se integra en el entramado de operaciones de producción de sentido de la discursividad fílmica. En los textos de Eisenstein (2010), Adorno - Eisler (2005), Burch (2008), Mitry (2002a, 2002b), Bordwell (1993), Chion (2008), Gorbman (1987) y Saitta (2002), entre otros, puede observarse que lo audiovisual se despliega como un todo orgánico e integrado. Se destaca la importancia de la banda sonora como necesaria para la comprensión global del filme ya que la música, y el sonido en general, habilitan una gran variedad de posibilidades expresivas.

\section{Metodología. Categorías de análisis}

Propuesta metodológica para un análisis de las modalidades de inserción musical en filmes narrativos.

Se esbozó una propuesta metodológica para el análisis de filmes narrativos focalizada en la interrelación entre imagen y sonido. La categorización, que no pretende ser definitiva ni exhaustiva, toma herramientas provenientes del análisis textual y se centra en la intervención de la música en la construcción dramática / narrativa de los filmes. Las categorías de esta tipología, que pueden complementarse o superponerse y establecer o no dominancias, se segmentan en distintos niveles de análisis.

\subsection{Nivel sintagmático}

La música puede tener una función conectiva, es decir, abrir, cerrar o enlazar escenas o secuencias. Dentro de esta función se sitúan las remisiones anafóricas y catafóricas, importantes en muchos filmes, cuando la música recuerda o anticipa secuencias, motivos temáticos, personajes, etc. 


\subsection{Nivel dramático- narrativo}

Una segunda intervención, dentro de un análisis narrativo, es en función de indicio, en el sentido que Barthes da a este término, como un significado implícito, un concepto difuso "necesario, sin embargo para el sentido de la historia" (1994: 174). En ese contexto, la música puede aportar elementos que hacen a una caracterización de los personajes o de las situaciones. La tercera categoría, vinculada a la anterior, corresponde a la función de informante. Lo musical puede actuar como un indicador de época, lugar, etc.; es también una función indicial, pero como diferencia con los indicios propiamente dichos, los informantes aportan "datos puros, inmediatamente significantes" (Barthes, 1994: 177). La música interviene asimismo como actante narrativo, identificando este término una significación que no se corresponde con la habitual definición del personaje, sino que un actante se entiende como un nucleador de una esfera de funciones (Greimas, 1973), pudiendo extenderse este carácter a la dimensión musical. La música se involucra en un filme como actante narrativo cuando su participación afecta a la sucesión y transformación de los acontecimientos.

Desde la perspectiva de la puesta en escena dramática, la que refiere a la configuración de los personajes y las situaciones desde el punto de vista de los conflictos que se desarrollan y los sentimientos puestos en juego, la música también puede intervenir como actante dramático.

\subsection{Nivel retórico-expresivo}

La música cumple habitualmente una función de ambientación, es un elemento más de la puesta en escena cinematográfica. Pero puede tener otras modalidades de intervención, por ejemplo, como remisión figural. En este caso, lo musical puede aludir metafórica o metonímicamente a algo que está fuera de ella. Por ejemplo: un personaje puede ser recordado mediante un fragmento musical, ya sea porque él lo ejecutaba, o porque se ejecutaba cuando estaba presente, en el caso de la metonimia, o una música puede dar cuenta de las cualidades de alguna cosa porque algo tienen en común, en el caso de la metáfora.

\subsection{Nivel enunciativo}

Por último, la música puede intervenir también, como comentario. Sucede cuando esta confiere énfasis, quita relevancia, introduce matices irónicos o genera tensión, entre otras posibilidades, a lo que sucede en lo dramático y lo narrativo, pero también puede asumir roles más complejos, como ocurre, por ejemplo, cuando es un elemento central en una articulación metaléptica (Genette, 2004). Aquí, la dimensión enunciativa se vuelve más evidente, es una "enunciación manifiesta" (Metz, 1991). 


\section{Delimitación de rasgos de estilo}

La aplicación del encuadre teórico - metodológico al mencionado corpus posibilitó observar constantes en las modalidades de intervención musical. Esta delimitación permite trazar rasgos que se proponen como propios de un estilo autoral.

En ese sentido ha sido clave la consideración de las contribuciones que distintos autores realizaron sobre el concepto de estilo, como la de Oscar Steimberg, que lo entiende "como un modo de hacer, postulado socialmente como característico de distintos objetos de la cultura y perceptible en ellos", definido por características temáticas, retóricas y enunciativas, o la de Roland Barthes, que propone "ver al estilo en la pluralidad del texto" ya que el problema del estilo solo puede tratarse en relación a lo que llamará " el hojaldre del discurso". Asimismo Tzvetan Todorov, con una mirada similar a estos autores, entiende el estilo como una dimensión transversal a la obra, situándose tanto en el plano del enunciado como en el de la enunciación. A través de sus diversas modalidades de inserción la música participa de ambos niveles.

A partir de análisis previos en esta investigación de carácter exploratorio se observaron ciertos aportes particulares de la música en el corpus de filmes delimitado. Por ejemplo el que realiza en la producción de efectos de sentido fantásticos y en la construcción de realidades alternativas. También, se observó que una misma obra musical identifica un tipo de situación o un vínculo entre personajes en distintos filmes y la utilización de canciones cuyas letras ofician de comentario al desarrollo dramático.

En este caso, a partir de un corpus de filmes situados temporalmente en la actualidad del momento representado por la diégesis, interesó delimitar cómo en la caracterización de ciertos personajes, la música, ocupa un lugar destacado. Esta puede aparecer en lugar de una producción semántica que no se expresa de otro modo, es decir, determinado efecto de sentido se genera sólo con la música como vehículo o medio para el alcance del mismo, o expandiendo esa producción semántica, es decir, es ese caso habría una profundización y una expansión porque una producción semántica (la musical) se añade y se integra a lo transmitido por otras series de producción de sentido. Es así como, en algunos de los casos observados, sólo la música, o una melodía, caracterizan particularmente a un personaje, y en otros casos, el elemento musical es un aporte que se integra a otros aspectos en el trazado de la personalidad de un personaje

Asimismo, en esta delimitación, la música suele remitir a ciertos momentos particulares de los últimos siglos de la historia cultural de occidente. En ese sentido, es notorio el desencanto de ciertos personajes por el momento actual en el que viven y esto puede verse particularmente ilustrado a través de la intervención de estilos musicales representativos de un pasado que se 
proyecta como añorado. Entonces, se observó la presencia de algunas formas musicales que arrastran, además de información sobre épocas históricas y estratos culturales, una carga emotiva que interviene activamente en la producción semántica de los filmes.

\section{Análisis de casos}

El corpus seleccionado es un recorte que en esta instancia no pretende ser exhaustivo. Está conformado por las siguientes películas: Interiores (1978), Manhattan (1979), Hannah y sus Hermanas (1986), Otra Mujer (1988), Crímenes y Pecados (1989), Match Point (2005), Medianoche en París (2011) y Blue Jasmine (2013). Para esta presentación se seleccionaron cuatro de los títulos mencionados.

\subsection{Blue Jasmine}

Obra musical: "Blue Moon" canción compuesta en 1934 por Lorenz Hart y Richard Rodgers

Jasmine (Cate Blanchet) es un personaje que se construye a partir de recuerdos. Tanto esos recuerdos como su presente se articulan a partir de las variadas modalidades de intervención de la canción "Blue Moon". A la manera de un leitmotiv la música en todas sus intervenciones reenvía al pasado estableciéndose como un elemento constructivo de este. Sus primeras participaciones son relevantes en la caracterización de ese momento aparentemente feliz en la vida de la protagonista. Luego, a partir de la tercera aparición de la melodía su presencia conlleva una inversión de significación: ante "Blue Moon" sabemos que ese pasado era un engaño y a su vez, la canción articula con el presente desolado de Jasmine. La impresión que establece la canción en el inicio del filme porta un romanticismo que se va desvaneciendo en el desarrollo de la trama. La música interviene fuertemente tanto en la construcción del personaje principal como así también, en el nivel de la narración.

\subsection{Medianoche en París}

Obras musicales: "Let's do it (Let's fall in love)" y "You do something to me" compuestas en 1928 y 1929 por Cole Porter

En este filme, el intenso anhelo de Gil (Owen Wilson), su protagonista, por la París de los años Veinte con sus ídolos musicales, literarios y pictóricos, definen al personaje. A través de diversos procedimientos metalépticos la historia se desarrolla en distintos niveles narrativos situados temporalmente en la contemporaneidad (año 2010), en los años Veinte y en la Belle Epoque. 
Interesan aquí dos escenas que suceden en época actual en una feria de antigüedades entre Gil y una vendedora de discos. Se trata de Cole Porter y sus canciones "Let's do it (Let's fall in love)" $\mathrm{y}$ "You do something to me" para cada una de las escenas. En el primer encuentro Gil le comenta a la vendedora de que le gusta pensar que pertenece al círculo íntimo del compositor norteamericano (ya que Gil, Porter y sus amigos "compartieron" una fiesta en los Veinte), mientras a través de un tocadiscos se escucha You do something to me. En este caso, además de formar parte de la ambientación, la música es vehículo de un comentario enunciativo. Avanzado el filme, en la otra escena en la feria, la reaparición de "Let's do it (Let's fall in love)" (se la escucha previamente en aquella fiesta), esta vez fuera de la diégesis desde la enunciación, marca un punto importante de conexión entre niveles narrativos. Es así como, en un momento importante en el desarrollo del conflicto, a través del tema de Porter se retoma el chiste sobre la amistad entre Gil y el compositor y se consolida una afinidad entre el protagonista y la vendedora de discos. Ambas escenas ilustran claramente la posibilidad que tiene la música como medio expresivo de remitir a un cierto momento histórico-cultural con el cual el personaje se siente identificado. En consecuencia, y como efecto de sentido, cuando esa música vuelve, rápidamente vuelve ese mundo.

\subsection{Manhattan}

Obras musicales: una extensa selección de canciones de George Gershwin compuestas en las décadas del 20' y del 30'y Rhapsody in Blue (1924) obra para piano y orquesta del mismo compositor.

El protagonista de este filme que transcurre a fines de los años setenta, Isaac (woody Allen), está convencido de que la versión más bella de Manhattan es una conjunción audiovisual de esa ciudad en blanco y negro con música de George Gershwin durante los años veinte. Tanto desde la diégesis como desde la enunciación, y desde un primerísimo momento, se procura que estos dos elementos de la cadena de significación audiovisual, música y fotografía, confluyan para producir ese efecto de sentido en la Manhattan actual. El filme irrumpe con el inconfundible glissando de clarinete de Rhapsody in Blue y un fotograma del Empire State. La película apela a la música como serie de producción de sentido para retrotraerse al imaginario de la nueva york de los años 20 y lo refuerza con otras series como la fotografía y el color, pero lo únicamente propio de esa época, como signo de supervivencia es la música. Luego de esas primeros planos, el narrador en off en el prólogo, refuerza esa idea con palabras que subrayan esa mirada romántica de una ciudad que es en blanco y negro y suena como las melodías de Gershwin. Idealización que va a 
derivar en el desarrollo del filme en el que se da una convergencia del antaño y del ahora a través del personaje protagónico que valora la cultura previa.

\subsection{Hannah y sus Hermanas}

Obra musical: Concierto para clave $n^{\circ} 5$ en Fa menor compuesto en 1742 por Johann Sebastian Bach

Varios de los personajes de este filme son asociados a determinados géneros musicales. Los casos más notorios son los de Mickey (Woody Allen) identificado con un jazz de impronta rítmica muy marcada, el llamado estilo "Kansas City", Holly (Dianne Wiest) con el punk rock de los ochentas y Lee (Barbara Hershey) con música académica, particularmente con dos conciertos de Bach. Interesa principalmente el caso de Lee por la importancia que asume la presencia de la música en el desarrollo del conflicto dramático de su personaje ,en especial, el segundo movimiento del Concierto para clave $n^{\circ} 5$ en Fa menor. Finalizando el primer tercio del filme aparece por primera vez en diégesis como actante dramático por el espacio que tiene en esa escena y en sus próximas dos apariciones. Si bien identifica el vínculo romántico entre Lee y su cuñado, y la explícita afinidad por compartir determinado tipo de música, esta pieza musical es de ella, es quien la trae a escena y es su personaje quien va a estar asociado a la música de Bach en momentos reflexivos y decisivos en relación al vínculo afectivo con su cuñado y con su vida.

\section{Conclusiones preliminares}

A partir del corpus de filmes indicado se observaron diversas cuestiones: la música es un factor de relevancia en la construcción dramática de personajes, no únicamente en los protagónicos, también, se comparten entre filmes ciertas modalidades de incidencia musical en esa construcción. Asimismo, se advierte la dominancia de ciertos estilos musicales arraigados en épocas pasadas. A grandes rasgos se pueden mencionar como recurrencias la ópera italiana del siglo XIX, diversas variantes del jazz como el swing, la canción, el estilo "Kansas City" y la música académica desde Bach hasta principios del siglo XX. Todos los factores mencionados contribuyen a la conformación de este rasgo estilístico en particular.

\section{REFERENCIAS BIBLIOGRÁFICAS}

BARTHES, Roland. 1994a. "Lenguajes y estilo", en El susurro del lenguaje. Más allá de la palabra y la escritura. Barcelona: Paidós. 
1994b. "Introducción al análisis estructural de los relatos", en La aventura semiológica. Buenos Aires: Planeta.

GREIMAS, Algirdas Julius. 1973. Semántica estructural, Madrid, Gredos.

SEGRE, Cesare. 1985. Principios de análisis del texto literario. Barcelona: Crítica.

STEIMBERG, Oscar. 2013. Semióticas. Las semióticas de los géneros, de los estilos, de la transposición. Buenos Aires: Eterna Cadencia.

TODOROV, Tzvetan. 1970. "Las categorías del relato literario" en Análisis estructural del relato (pp. 155 - 192). Buenos Aires: Tiempo Contemporáneo.

2014. "Estilo", en Diccionario enciclopédico de las ciencias del lenguaje. Buenos Aires: Siglo Veintiuno Editores.

VERÓN, Eliseo. 1987. La semiosis social. Barcelona: Gedisa. 


\section{MEDIACIONES}

\section{E. SONIDOS Y SENTIDOS}

b. Música académica 



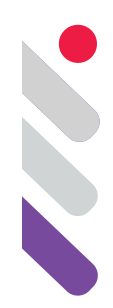

\title{
La cadena significante de los cuerpos en los bomarzos argentinos
}

DOI: 10.24308/IASS-2019-4-037

\author{
Jerónimo Brignone \\ Universidad de Buenos Aires, Argentina \\ jbrignone@hotmail.com
}

\section{Introducción}

El presente trabajo releva documentos visuales de la ópera Bomarzo compuesta por Alberto Ginastera con libreto de Manuel Mujica Lainez sobre su novela homónima de 1962, desde su estreno en Washington en 1967 con la gestión del gobierno argentino de facto, la prohibición en Buenos Aires por la cabeza de aquel gobierno, el general Juan Carlos Onganía, las representaciones sucesivas en el Teatro Colón de 1972, 1984 y 2003, y su versión experimental filmada en 2007 in situ en el pueblo y los jardines que inspiraron al novelista y con la dirección de quien escribe con su nombre artístico Jerry Brignone ${ }^{1}$.

Utiliza una investigación realizada para la Maestría en Comunicación y Cultura de la Universidad de Buenos Aires con material original de archivo del Teatro Colón, la hemeroteca de la Biblioteca Nacional, imágenes de la web y elementos personales recogidos en mi larga relación con la obra estudiada. Las imágenes refieren al clima cultural y político de los 40 años transcurridos entre el primer evento de 1967 y el último de 2007, con alusiones explícitas a instancias anteriores que conforman así un continuum en una trama de producción artística que, más que a la noción de obra, remite a la de un work in progress sin la noción tradicional de autoría y, por ello, productor de subjetividad.

\subsection{Antecedentes}

La palabra Bomarzo estuvo por décadas cargada de múltiples connotaciones para el imaginario argentino e internacional, fueren vagas o muy precisas e intensas, dado que episodios políticos insólitos resemantizaron y llevaron al ámbito del discurso público masivo el nombre del pueblito italiano con ese nombre.

\footnotetext{
1 Jerónimo Brignone. Lic. Prof. Letras UBA 2008. Actor y director teatral y cinematográfico.
} 
En el siglo XVI el duque Pier Francesco Orsini construyó allí, al lado de su castillo, un jardín con extrañas figuras de piedra que siglos después desaparecieron cubiertas por la maleza. Redescubierto en los 30, el Bosque Sagrado, conocido como El parque de los monstruos, fue admirado por Cocteau, Breton y Dalí, quien hizo algunas tomas, así como el fotógrafo Herbert List. Cuando, atraído por esas imágenes, el autor argentino Manuel Mujica Lainez hizo su primer viaje a Italia, con la certeza de ser la reencarnación del duque escribió una novela (1962) de más de 600 páginas, la primera obra argentina extensa con temática no local y que fue desde su publicación y hasta hoy un best seller, con premios como el Nacional de Literatura.

El músico argentino Alberto Ginastera la musicalizó, primero con una cantata en 1965 y luego una ópera con libreto de Mujica Lainez que tuvo su estreno en Washington en 1967, organizado por el gobierno militar de Juan Carlos Onganía, en el poder con un golpe de estado pocos meses antes. Con el éxito llegaron rumores y alguna imagen de desnudos y perversiones sexuales, magia negra, astrología y violencia, y éste ordenó anular su estreno local en el Teatro Colón. Prohibida para estupor de todos por la reputación de sus creadores, hubo gran revuelo, críticas y aplausos al censor, roces diplomáticos con Estados Unidos y condenas internacionales que deterioraron la imagen del dictador, quien dos años después renunció. En palabras de Mujica Lainez (1968), "uno de los capítulos más extraños de la historia del arte en nuestro país", documentado por Esteban Buch (2003).

Preparando el regreso de la democracia, el presidente de facto Lanusse levantó la censura sobre la ópera, que se estrenó en el Colón en 1972 con la puesta y el elenco originales del estreno y picos de rating en su televisación. Otras pocas versiones en el extranjero pasaron desapercibidas, hasta que luego de la larga dictadura de la Junta Militar del 76 al 83, se decidió abrir la temporada del Colón con una nueva puesta en escena, dado el valor simbólico de libertad perdida y recobrada que Bomarzo portaba para los argentinos; y en 2003, superada la crisis económico-política del país de 2001, el gobierno nacional y municipal de entonces la pusieron nuevamente en escena con ese mismo espíritu.

Yo la vi a los 9 años en su televisación, y después devine en uno de esos fanáticos operísticos del libro de Benzecry (2011). Cuando tuve adolescente la versión en vinilo con el elenco del estreno de Washington, no me entusiasmó, y tampoco en 2003, cuando la vi con un gestor de eventos artísticos italiano que había pasado su infancia entre los monstruos de piedra. Durante el intervalo decidimos filmar in situ la obra en Bomarzo, dada su buena relación con el municipio, y esto se plasmó velozmente en 2007 como versión experimental performática filmada por mí sin fondos con artistas argentinos y los pobladores de Bomarzo, proyectada con la ayuda de los Ministerios de Relaciones Exteriores 
argentino e italiano en varios ámbitos públicos con el título Bomarzo 2007 y que se puede ver en su sitio web².

Buch señala (2003) que la proyección inusitada de la ópera en el imaginario colectivo obedeció a la prohibición del gobierno de facto y al prestigio de sus autores en el ámbito de la alta cultura, así como al éxito de ventas de la novela, siendo la ópera nacional más conocida por personas no vinculadas al mundo de la lírica. Esta dimensión allende a los códigos restringidos de ese mundo le confiere a sus imágenes un alcance inusual de semiosis social más abarcativa.

\section{Las imágenes}

\subsection{Bomarzo antes de Bomarzo}

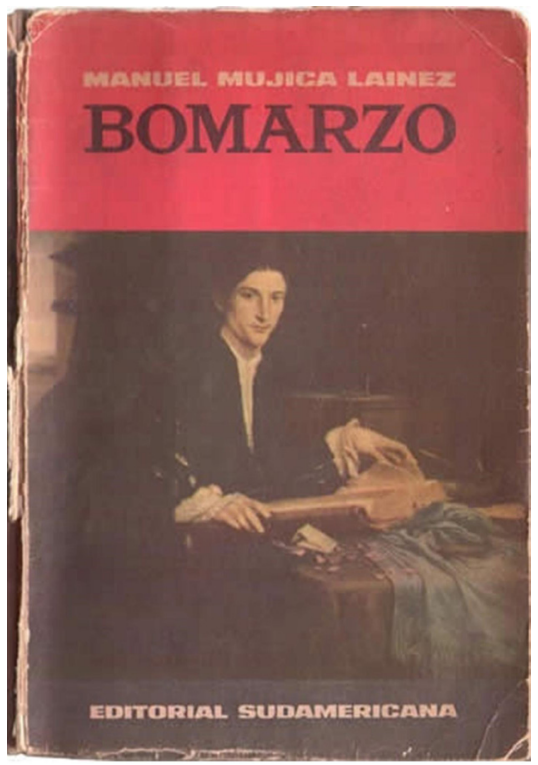

Fig. 1. Imagen de la tapa de la primera edición de la novela Bomarzo (1962)

La ópera tuvo como antecedente visual la tapa (fig. 1) de la novela (Mujica Lainez 1962a) que la inspiró, con la imagen de un retrato del pintor Lorenzo Lotto, implausiblemente adjudicado a Pier Francesco Orsini como retratado, el duque de Bomarzo que la protagonizaba. Muy tematizado en el libro, el retrato intitula uno de los cuadros de la ópera, reapareciendo reproducido en el largometraje, y su uso como ícono autorreferencial de la novela la representa: vasto fresco renacentista que inventa la vida de un duque del cual hay muy pocos datos históricos, exceptuando la construcción del jardín poblado de extrañas figuras de piedra que fascinó a Mujica Lainez, quien dijo que sus imágenes lo "transportaron con su extraña maravilla" (1968b). Quizás las difundidas por Salvador Dalí en 1948, quien hizo un pequeño cortometraje (fig. 2), presentándolas como antecesoras del surrealismo, así como al año siguiente Michelangelo Antonioni (fig. 3), nutriendo las mitificaciones de Cocteau y Breton que llevaron a que Herbert List produjera en 1952 sus propias imágenes. La del muchacho con unas ovejas dentro de la boca de la estatua más icónica (fig. 4), conocida como La Boca del Infierno y usada en la tapa de varias ediciones de la novela, inspiró a Mujica Lainez el elemento narratológico del niño pastor como alter ego y contraste con el protagonista y luego, el principio y el fin de la ópera.

${ }^{2}$ http://www.bomarzo2007.com.ar 


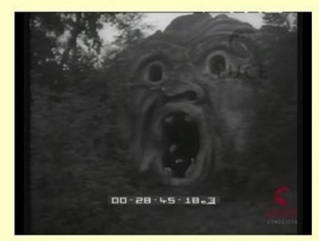

1949

1949
El cineasta Michelangelo Antonioni rueda un cortometraje de diez minutos sobre las figuras que surg
intitulado "Bomarzo" (luego "La villa dei mostrn", 1950) y que jamas fue estrenado en vida del director
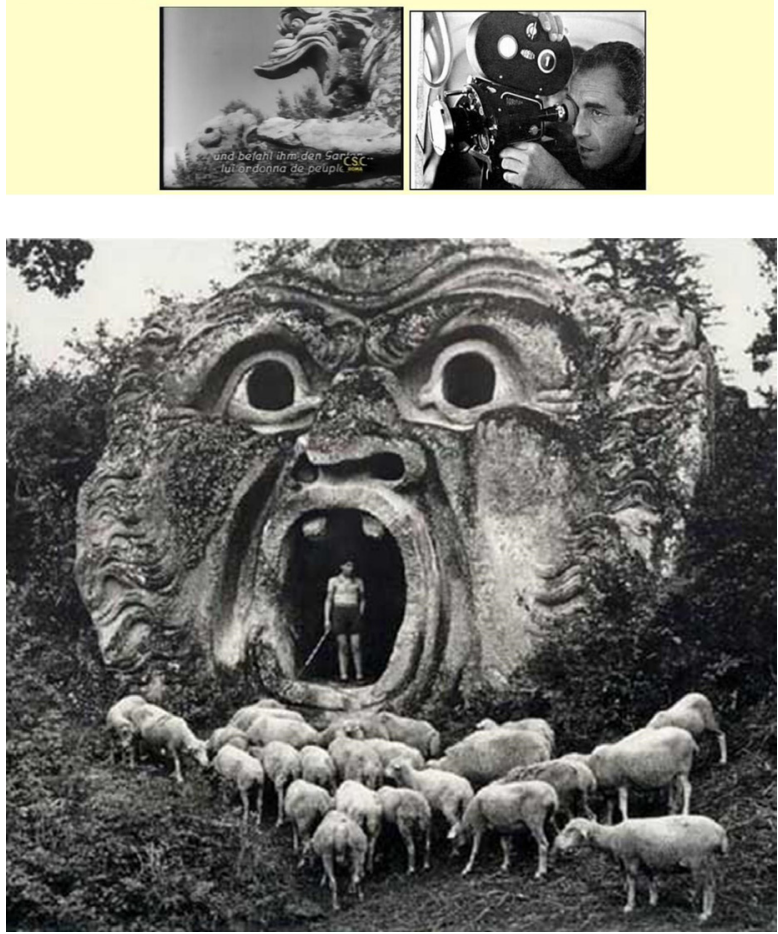

Fig. 2 y 3. Bomarzo y Dalí (1948) y Bomarzo y Antonioni (1949). Capturas de pantalla del video en www. bomarzo2007.com.ar
Fig. 4. Fotografía de Herbert List (1952)

Las imágenes prefiguran rasgos estilísticos y temáticas de la ópera: el juego artificioso de la novela con la cultura visual del Renacimiento italiano, muy manierista (coherente con la época), resumido en el retrato de la tapa y su adjudicación improbable al protagonista ${ }^{3}$, con lo que el autor hace un guiño al recreo lúdico de las ficciones, y la fusión de la oscuridad del fondo con la espalda del retratado le permite crear una joroba de la que no hay registro y sobre la que centra la trama. Resumido también en las imágenes de Dalí y su atribución al mundo de lo onírico, otra operación artificiosa de autopromoción y legitimación histórica de su surrealismo. La de List también contrapone de modo manierista la ficción de aquel arte del pasado que recreó seres reales o fantásticos en el Jardín con el presente histórico del cuerpo vivo del muchacho con sus ovejas, actual y subproletario. Mujica Lainez retoma ese contrapunto temporal al

${ }^{3}$ El Retrato de un gentilhombre en su estudio de 1530 mal corresponderse con Pier Francesco Orsini, en cuanto las fuentes más autorizadas datan su nacimiento en 1523 ó 1528. 
redactar el texto en primera persona del singular como autobiografía de Pier Francesco Orsini con anacronismos porteños, justificados por la reencarnación del noble italiano en el autor y como otra forma de autorreferencialidad.

\subsection{El primer Bomarzo}
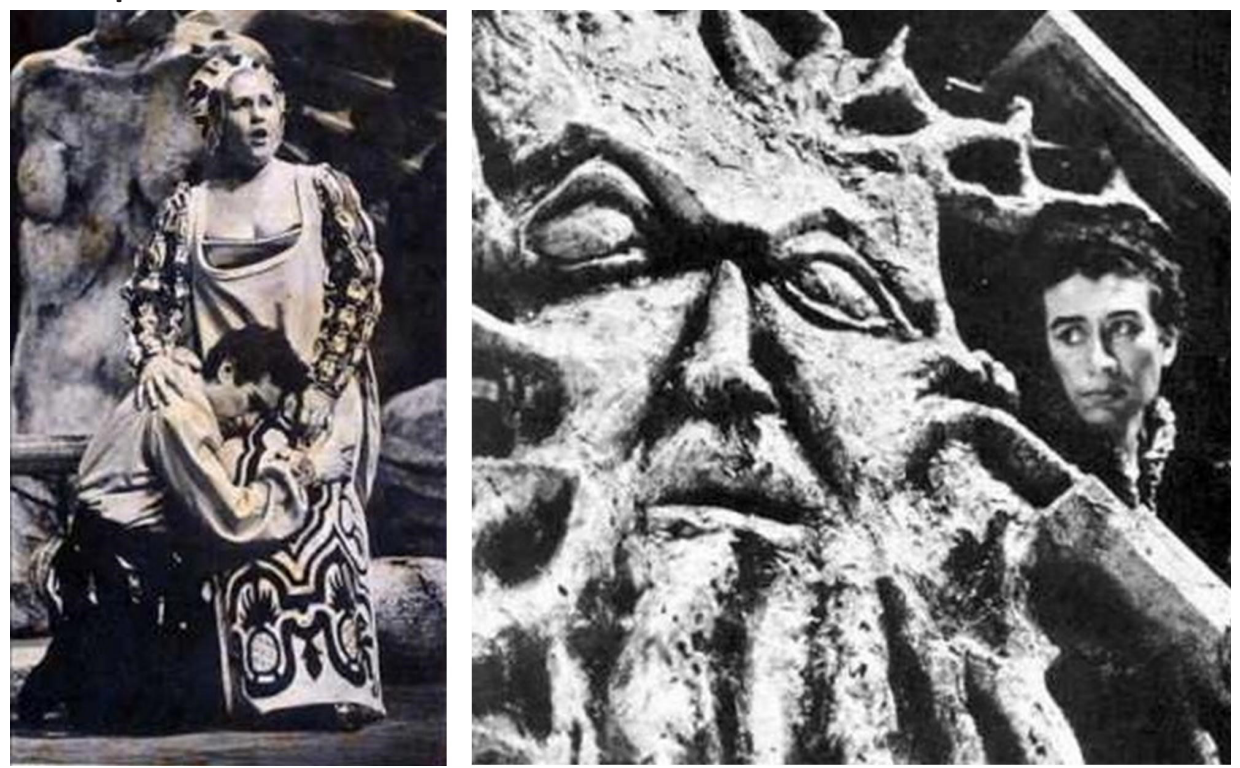

Figs. 5 y 6 . Imágenes del estreno en Washington (1967)

El escenógrafo Ming Choo Lee y el regisseur Tito Capobianco retoman en el estreno en Washington del 19 de mayo de 1967 (figs. 5 y 6) el protagonismo de las esculturas de piedra, y el vestuario destacado sobre fondos oscuros como la malla de crímenes y magia negra es el de una puesta relativamente convencional de una trama cortesana del siglo XVI, apenas más estilizada o geometrizada de lo habitual.

La ópera no tematiza explícitamente lo político, pero expresa una ideología: un exitoso músico argentino católico y conservador, internacionalmente reconocido por sus experimentos con el folklore nacional e innovaciones de vanguardia, musicaliza una novela también exitosa, de grandes pretensiones (por tema y extensión) de un autor consagrado e identificado con la aristocracia local y una retórica decadente, en una autocelebración de la alta burguesía con el estreno sudamericano en un espacio elitista pero público como el Colón, a través de una trama nobiliaria europea atrevida made in Argentina estrenada en la capital del poder político y económico del momento ante la presencia del vicepresidente de EEUU y con el apoyo del gobierno argentino. Hubiera sido sólo un evento más de la alta cultura porteña y del afianzamiento de la imagen 
del gobierno militar de Onganía si no hubiera mediado la prohibición que éste impuso días antes del estreno en el Colón, programado para el 4 de agosto, a raíz de las pocas imágenes y jirones de críticas de EEUU que aludían a escenas subidas de tono (una prostituta mostrando sus pechos muy abundantes, un baile orgiástico entre hombres y mujeres desnudos y una clara relación homosexual entre el protagonista y su esclavo Abul), así como referencias poco católicas a la magia negra y a la astrología.

Los detalles del proceso ya fueron desarrollados (Buch 2003), aquí cabe apuntar que las primeras imágenes de Bomarzo adquirieron una insospechada resignificación política en el imaginario de los argentinos por el escándalo de su censura y manifestaciones locales y pronunciamientos internacionales sostenidos que abrevaron en la caída del coronel Schettini, intendente de la ciudad, y erosionaron la imagen de Onganía en modo mucho más notorio que la mucho más grave y violenta Noche de los Bastones Largos. Cobraron un ávido protagonismo en el imaginario de la ópera de la que todos hablaban y que nadie había visto, sustraída a la mirada de los ciudadanos por sus peligrosas alusiones al cuerpo desnudo y deseante. Cuando fue grabada al año siguiente, la tapa de la caja argentina (fig. 7) ubicaba focalmente a la prostituta (aunque sin los pechos al aire), y la memoria construida con esa tímida imagen refería a a un derecho alienado, a lo que debía ser y no fue. Así como la trama de la ópera es una rememoración del protagonista de su propia vida al morir, el narrador

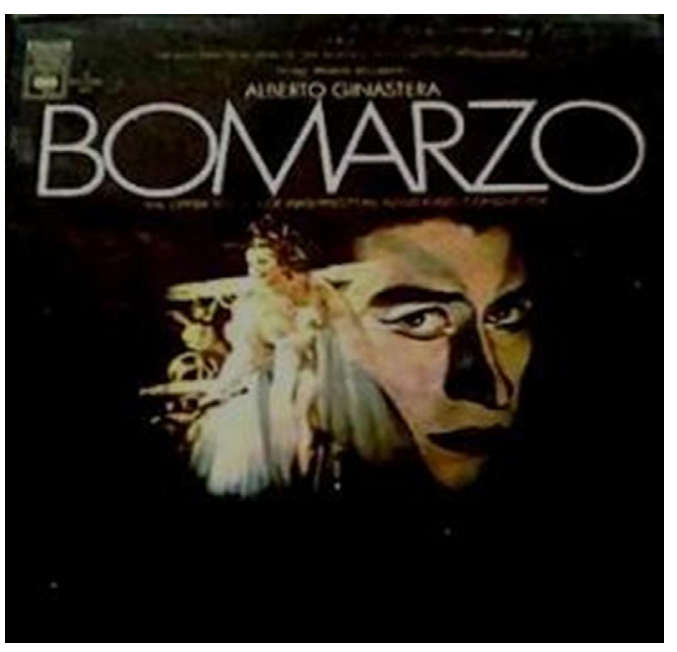
invoca la memoria en la última frase de la sinopsis argumental del programa de mano, escrita por Mujica Lainez: "Un día vendrá aquí un soñador y recordará todo esto. Con él estaré yo aquí y ya para siempre, siempre, porque quien recuerda no ha muerto".

Fig. 7. Tapa argentina de la grabación comercial original de la ópera en vinilo

$Y$ recordó el general Lanusse la significación política de Bomarzo cuando programó su estreno sudamericano para el 29 de abril de 1972 como apertura de temporada y reafirmar la intención del régimen de restaurar la democracia. El elenco y la producción escénica fueron los programados para 1967 y sus imágenes lo duplican: los mismos decorados renacentistas y las mismas imágenes del éxito, ahora locales (fig. 8). El público 
argentino pudo ver por fin los cuerpos en vivo y en directo, incluida la joroba (fig. 9), satisfaciendo su curiosidad y sin escandalizarse (el verbo más escuchado fue aburrirse), incluida la televisación de la última función con récords de ratings impensables para una manifestación de la alta cultura (fig. 10).

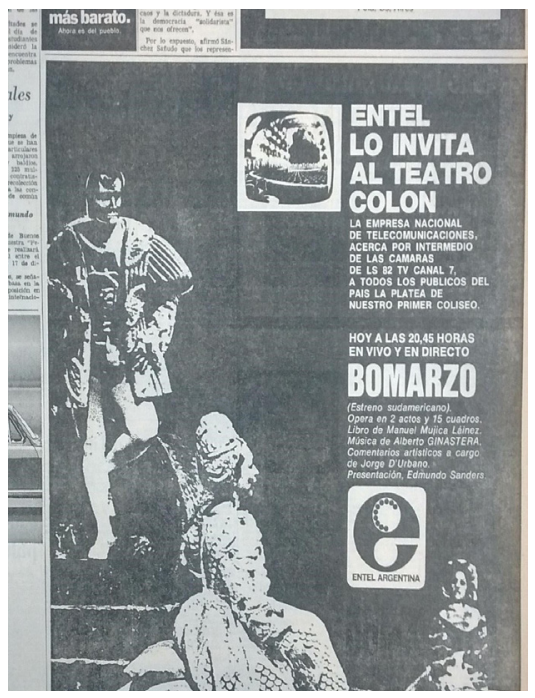

Fig. 8. Mujica Lainez y Ginastera aplaudidos en el estreno en el Teatro Colón (1972)

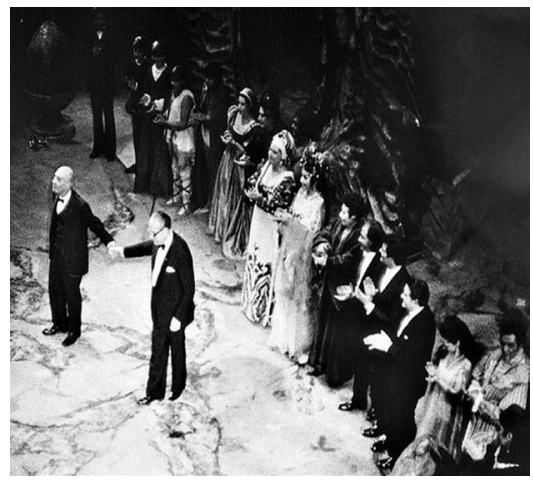

Fig. 9. Crítica de La Nación en ocasión del estreno argentino (1972)

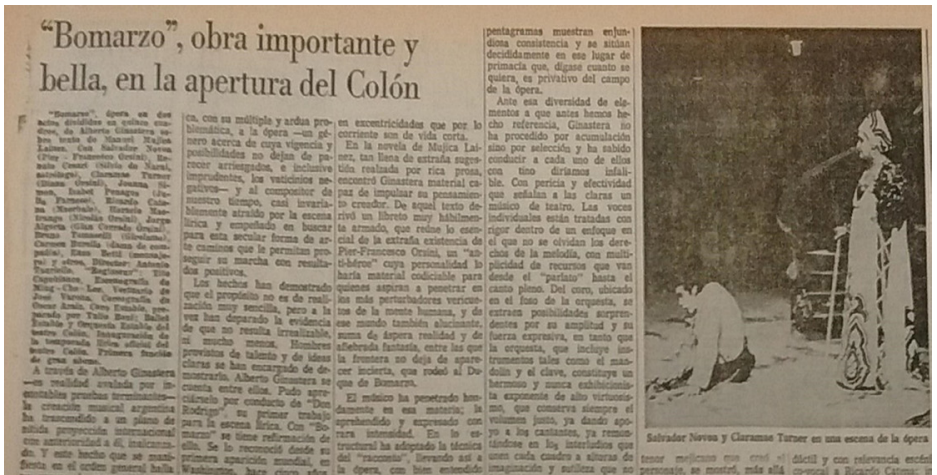

Fig. 10. Anuncio en Clarín el día de la televisación de Bomarzo (1972) 


\subsection{Bomarzo en democracia}

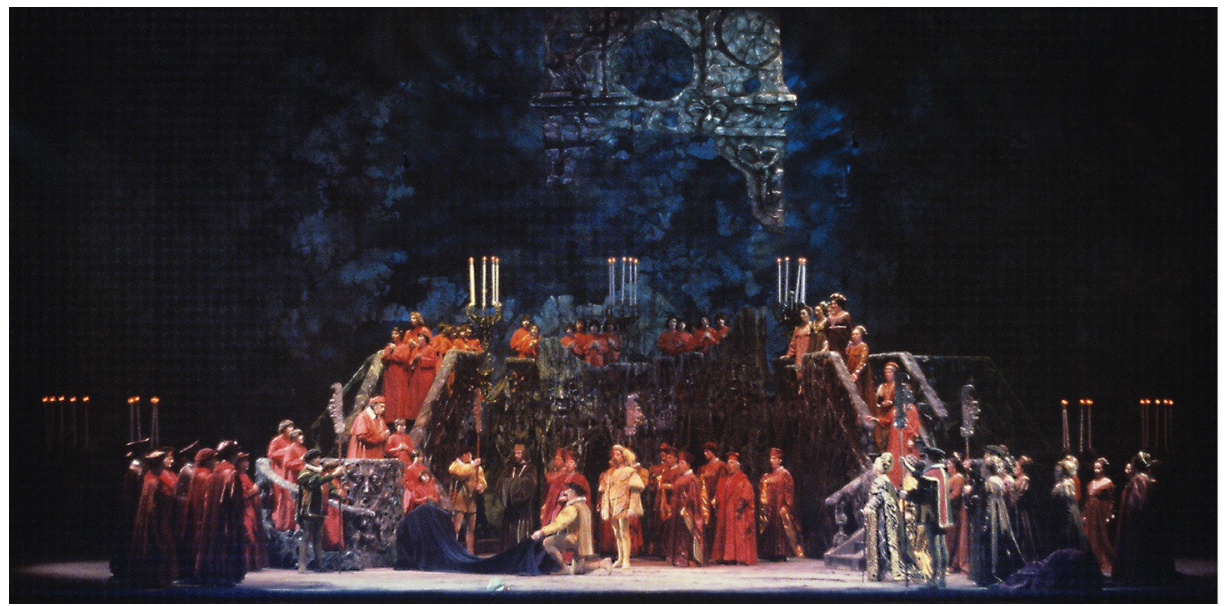

Fig. 11. Imagen de la puesta de Roberto Oswald (1984)

El regreso de Bomarzo a la Argentina estuvo signado por su simbolización del regreso de la democracia y la libertad. La nueva puesta de Roberto Oswald del 15 de mayo de 1984 seguía la misma línea renacentista, un poco más colorida (fig. 11), pero con un elemento cuya autorreferencialidad sería marca de las versiones posteriores en cuanto construcción de un linaje simbólico de la obra: se proyectaba a menudo en el telón transparente de proscenio un mapa

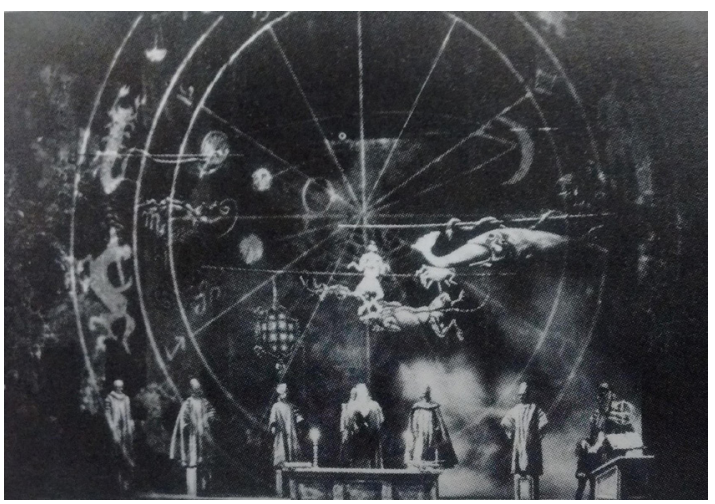
astrológico, la carta natal del duque (fig. 12) que según mis informantes se rumoreaba que era la de Mujica Lainez, siguiendo la línea de identificaciones que éste proponía en la novela.

Fig. 12. Boceto de Roberto Oswald con la omnipresente carta natal (1984)

Y otras imágenes construían materialmente la historia de la obra y su significación política: las del programa de mano, pleno de evocaciones de la presencia del conjunto de los artistas y técnicos que habían plasmado la versión censurada y el demorado estreno argentino, cuerpos recuperados en la estampa de los protagonistas desaparecidos a la mirada de los argentinos y ahora simbólicamente repuestos en la nueva etapa recién iniciada (fig. 13). 


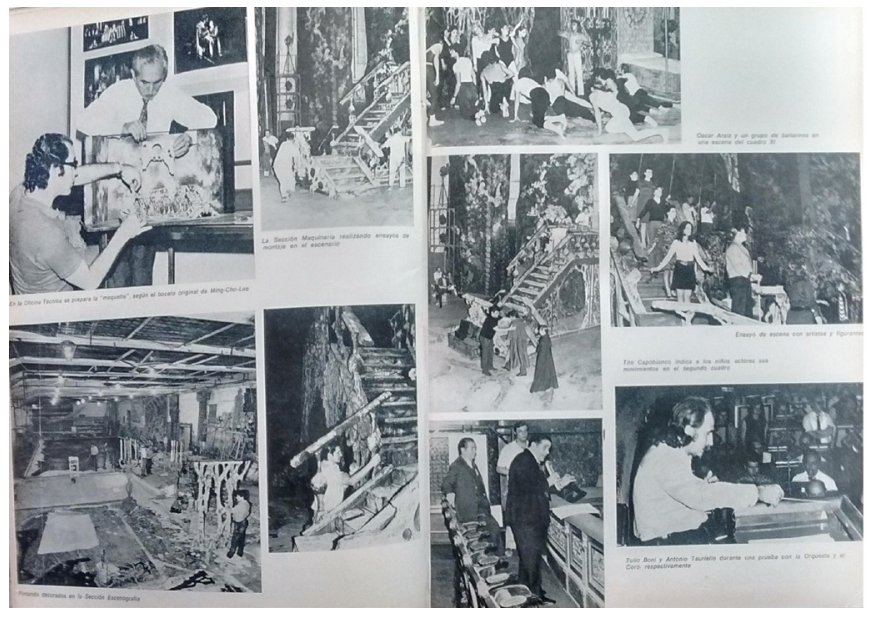

Fig. 13. Programa de mano de Bomarzo (Teatro Colón 1984)

La autorreferencialidad recursiva fue central en la siguiente reposición del 13 de junio de 2003, a cargo de Alfredo Arias en la reggie y con escenografía de Roberto Plate, artistas argentinos consagrados en Francia que abandonaron el país durante la dictadura de Onganía, y tuvo de nuevo el propósito de simbolizar la libertad recuperada para el stablishment, de democracia afianzada tras haber sufrido peligro: luego de la crisis de diciembre de 2001, el bienestar económico y la paz social comenzaban a dar un respiro a la clase media, que podía autocelebrarse con este nuevo retorno de la ópera. La puesta evocaba visualmente al mítico Instituto Di Tella que protagonizó las protestas por la prohibición y del que había participado Ginastera. Con una estética minimalista posmoderna

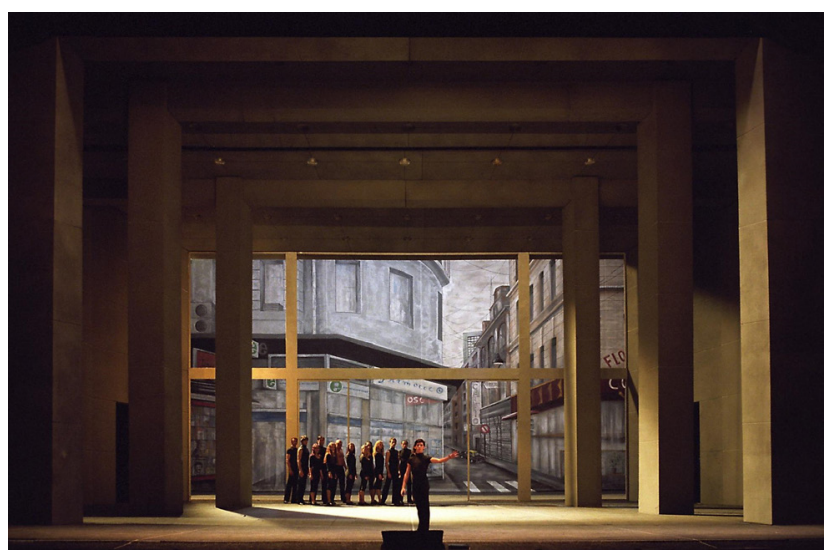

cool se celebraba la transgresión modernista argentina de los 60 colocando al Di Tella con la calle Florida como fondo (fig. 14).

Fig. 14. Imagen de la puesta de Arias y Plate (2003)

Las imágenes evitan iconografía referencial al mundo del Renacimiento (y a los monstruos: apenas un telón pintado con la Boca del Infierno y una miniatura minimalista estilo Ronconi): los protagonistas eran heroicos artistas de los 60 con mohines contemporáneos neomanieristas propios de esas clases más acomodadas sentadas ahora en la platea (fig. 15). Los cuerpos proliferaban metastásicamente en el escenario y Pantasilea mostraba los pechos (fig. 16), así 
como abundaban los desnudos en el sueño orgiástico (fig. 17) y al protagonista sus hermanos lo violaban de niño en escena y por el ano: esas cosas ya no escandalizaban a nadie, ni siquiera en el pacato Colón. Y el programa abundaba en imágenes y datos de archivo en una autorreferencialidad posmoderna coherente con la puesta.
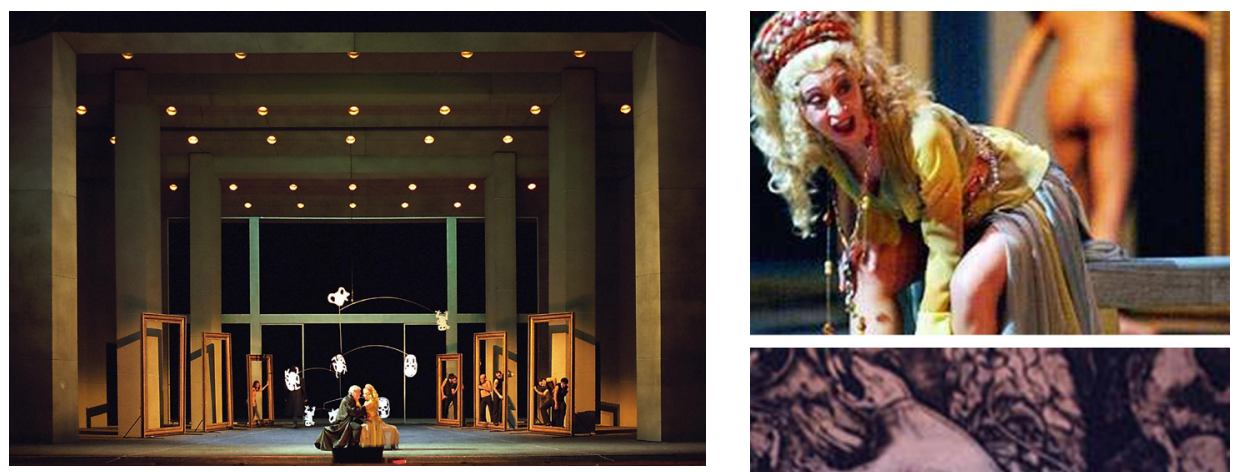

Fig. 15. Imagen de la puesta de Arias y Plate (2003)

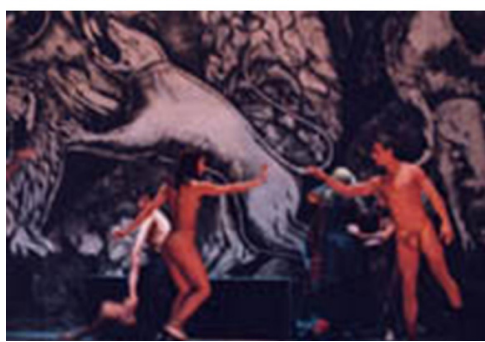

Figs. 16. Pantasilea y 17. El sueño orgiástico (2003)

\subsection{El proyecto cinematográfico}

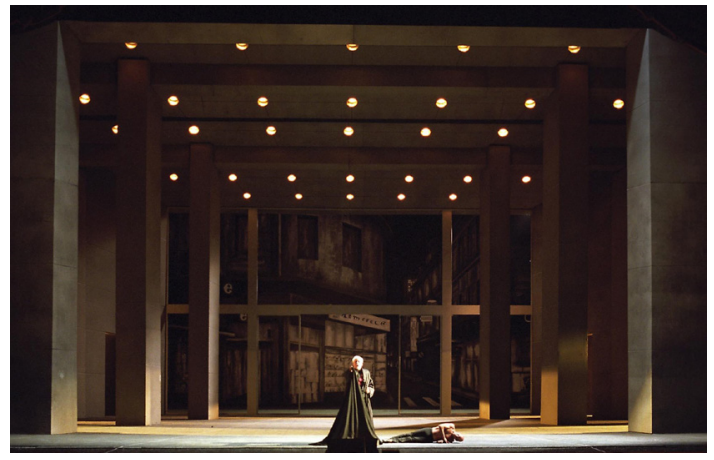

Fig. 18. Imagen de la puesta de 2003

Presencié la función del domingo 20 de junio con mi amigo italiano Massimo Scaringella, para quien Bomarzo era también parte de su historia personal. Yo temía que la ópera le resultara ridícula, y ya el único intervalo nos encontró debatiendo sobre la impresión negativa que nos produjo la puesta por dejar afuera a los monstruos (fig. 18), evidenciando la debilidad de la obra. De niño él jugaba con otros chicos entre esas figuras y ahora uno de ellos era el alcalde y le había pedido hacer algún evento para promocionar la restauración del castillo, el Palazzo Orsini, inaugurado seis días atrás. Se nos ocurrió hacer 
una versión in situ entre las esculturas y en el castillo, televisada en vivo con mi dirección y un par de amigas. El proyecto se redimensionó en 2007 a proporciones más factibles (el único recurso material era la buena voluntad del municipio): filmación en tiempo récord in situ en video en los escenarios originales actuada por los pobladores del lugar y mis dos amigas con playback

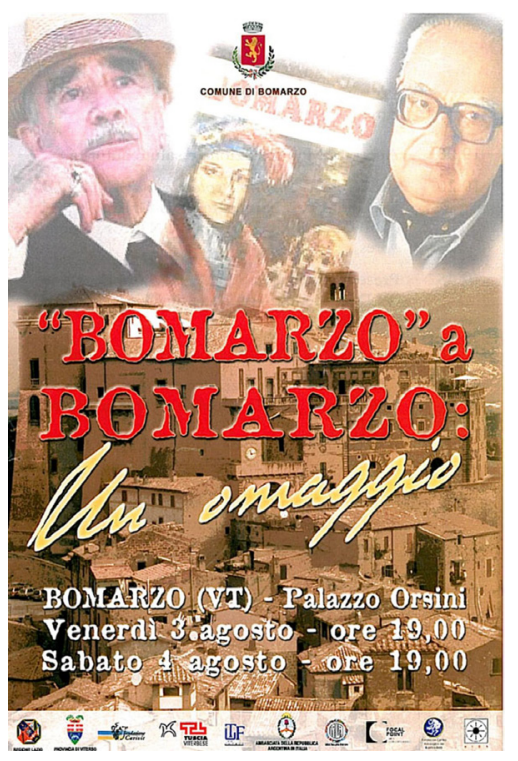
sobre la grabación de los artistas del estreno, editada en tiempo récord para dar el vértigo de una representación en vivo y proyectada luego en pantalla gigante en el pueblo como autocelebración y homenaje a Mujica Lainez y a Ginastera, quien cuando visitó por primera vez el lugar en 1973 le escribió a aquél: "Si nuestro país promocionara a sus artistas ya tendría el Congreso que haber votado el presupuesto para filmar nuestro Bomarzo en ese lugar, en colores. En todo caso, me queda el consuelo de pensar que alguna vez se hará." (Ginastera 1973).

Fig. 19. Afiche del acto cultural Bomarzo a Bomarzo (2007)

Llegamos a Italia el 25 de julio de 2007 para filmar y editar el largometraje de dos horas y media a estrenarse diez días después ante diplomáticos (el embajador argentino en Italia y el embajador italiano en Argentina), funcionarios ${ }^{4}$ y el pueblo de Bomarzo, con elenco no resuelto, ningún ensayo, diferencias idiomáticas y guión de imágenes y plan de trabajo definitivo de cuatro días seguidos de rodaje que no tuvieron horas de sueño y que escribí en el avión: el riesgo sólo podía salvarse presentándolo como un happening comunitario y su documentación en video con una estética de cine bizarro, con Wood, Corman, Bo y los montajes abruptos de Pasolini como modelos. En las antípodas, el videasta italiano Anton Giulio Onofri, responsable de las imágenes y luego del elaborado montaje, abominaba de mi "estética de la fealdad" y, pese a la agitación de las premuras, intentaba dar a cada toma un cuidado esteticista estilo Visconti o Zeffirelli inspirado en el Renacimiento y determinante en el resultado final, que cosechó excelentes críticas en Argentina, Italia y otros países, así como trabajos académicos ${ }^{5}$.

\footnotetext{
${ }^{4}$ Como estrategia de realización apostamos con Scaringella no sólo al homenaje público y gratuito a los dos autores de la ópera por parte de todos los artistas, que trabajábamos ad honorem para diluir y posponer así el asunto de los derechos, sino también al marco de un acto cultural (fig. 19) en homenaje al intenso intercambio histórico entre los dos países.

${ }^{5}$ Un documental de media hora de la UNTREF (Zuzulich 2013); una ponencia en un congreso
} 


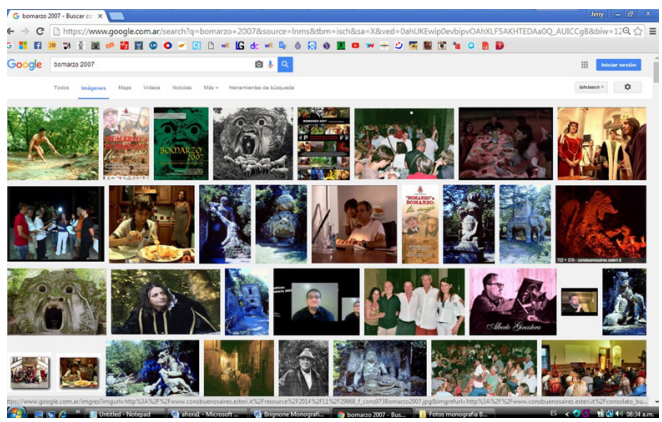

Fig. 20. Captura de pantalla de Google-Imágenes para la búsqueda "Bomarzo 2007" (30-72019)

Dado que es infinita la cantidad de imágenes del largometraje, disponible desde el principio en la web, apelo a lo público de ésta analizando una captura de pantalla del resultado de la búsqueda de Bomarzo 2007 en Google (fig. 20). Refiero las 33 imágenes con A, B, C, y D para las filas de arriba abajo, y con 1 al 9 de izquierda a derecha (p. ej., la imagen con dos personas ante una computadora es $\mathrm{B} 5$ ). Las de la película en sí que no son ni afiche ni alusiones paratextuales son la A1, A7, A8; B1, B2, B5, B9; C2, C6; D1, D2.

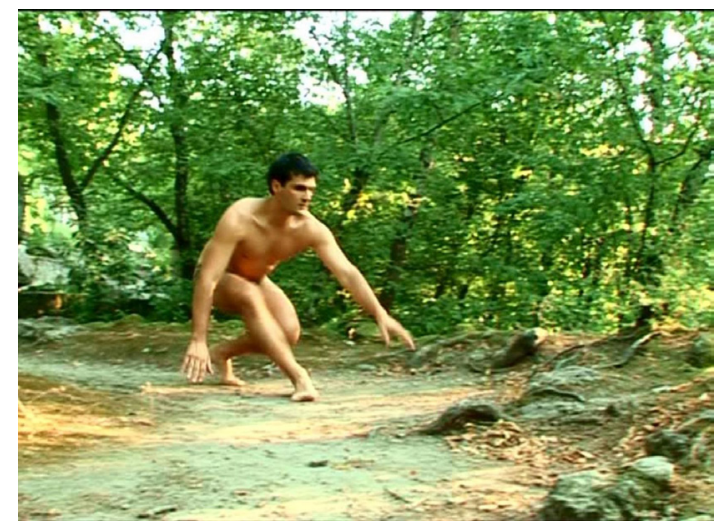

Fig. 21. Imagen de Bomarzo 2007

En primer lugar se halla, significativamente, un cuerpo que parece desnudo (fig. 21; el ángulo del fotograma oculta los calzoncillos). Los cuerpos sexuados, deseantes y deseados insinuados en la puesta del estreno y cuya visión fue censurada por el gobierno militar, otorgándole a la obra una potencia semiótica duradera, aparecen tematizados en la película por la materialidad del nuevo soporte, con su imagen directa y menos mediada que permite un contrapunto entre aquéllos y las de los monstruos y de la materialidad arquitectónica y paisajística del pueblo de Bomarzo y sus alrededores, el verdadero protagonista

en la Universidad de Salamanca (Parralejo Masa 2008); varias páginas en un grueso volumen, su tesis doctoral sobre la relación de Ginastera y el cine (Schartz-Kates 2011), más una conferencia en la Universidad de Miami por la directora del Departamento de Musicología de esa universidad; proyecciones y análisis en clases de la Academia de Bellas Artes de Florencia, así como y exhibiciones en ámbitos muy prestigiosos, incluidas tres facultades de la Universidad de Buenos Aires (www.bomarzo2007.com.ar, acc. 10 de marzo 2020) . 
de esta nueva versión, que retoma el recurso de la novela de anclar una continuidad con el presente (como la ópera, donde el protagonista recuerda su pasado con una música atonal y modernista sobre una narración emplazada en una Europa pretérita), así como en 1984 se identificaba la carta natal del protagonista con la del autor y en 2003 se recreaba el contexto de producción de 1967 con modismos y alusiones a sus análogos contemporáneos. Por ello se llamó Bomarzo 2007, aludiendo a las condiciones materiales de re-producción y re-creación de la novela y ópera. El estreno en la plaza pública ante niños y ancianos con sus habitantes como personajes implicaba cierta autocensura sobre la exhibición del cuerpo, aunque, dado el contenido homosexual del libreto

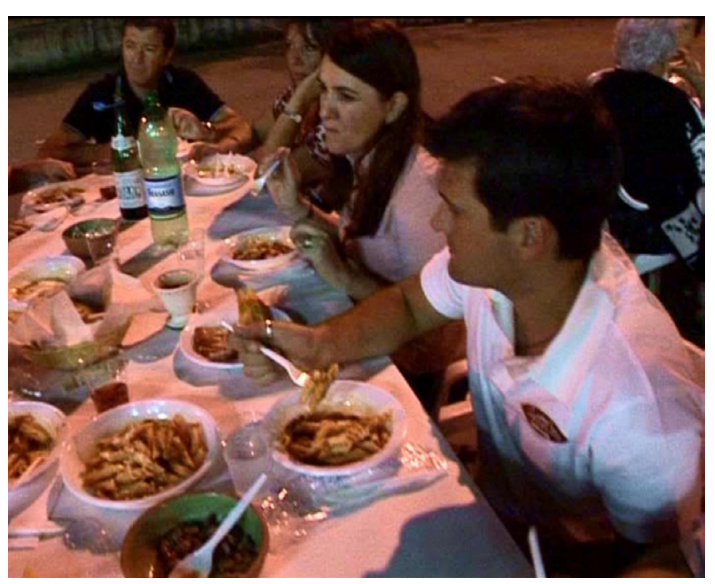

y que los varones del pueblo tenían menos objeciones en sacarse la ropa que las mujeres, se abundó en la mostración de sus cuerpos semidesnudos como tematización del cuerpo mostrado y ocultado, ofrecido y sustraído que había generado la prohibición original.

Fig. 22. Imagen de Bomarzo 2007

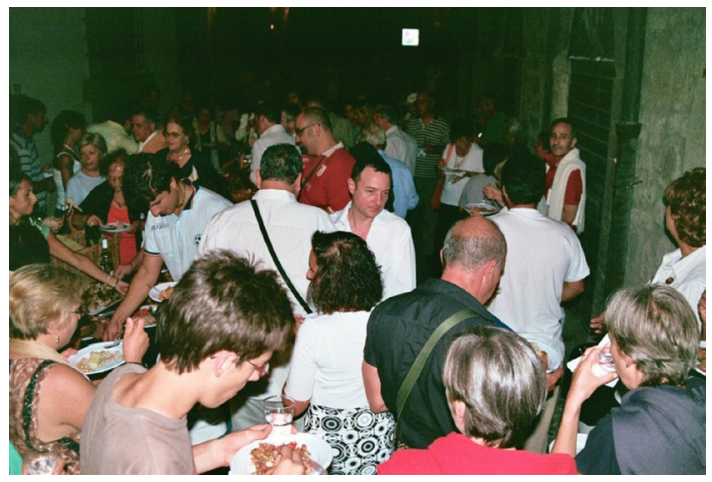

Fig. 23. Cena comunitaria inmediatamente posterior al estreno de Bomarzo 2007

Pero la indicialidad de la materialidad de los cuerpos estaba más bien dada en la presencia constante de los pobladores y su entorno, como en A7 (fig. 22), donde en una cena comunitaria que ocupa una escena entera de la película, la pretérita soledad torturada del protagonista noble contrasta con la multitudinaria solidaridad relajada de los pobladores actuales, captados en su cotidianeidad (contraste anticipado por Mujica Lainez al contraponer al duque y el joven pastor; en la misma línea la A6 [fig. 23] muestra otra cena comunitaria de todo el pueblo en el estreno). 

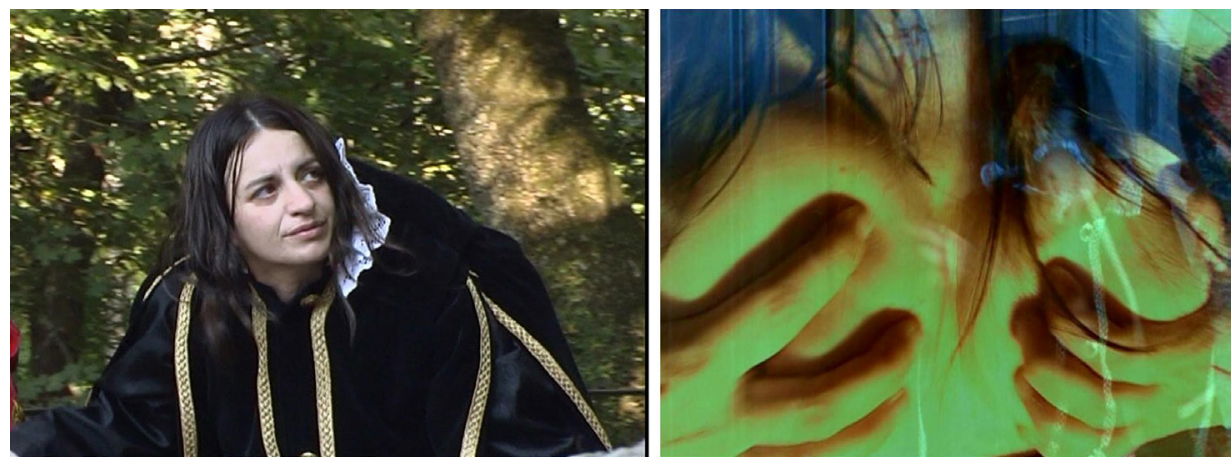

Figs. 24 y 25. Imágenes de Bomarzo 2007

Otro cuerpo visibilizado por extrañamiento es el del protagonista, encarnado por una actriz, enfatizando la artificialidad de la propuesta (como la de Mujica Lainez) y los prejuicios y asociaciones de cierto imaginario sobre la falta de virilidad que obsesiona a los personajes. C2 (fig. 24) la muestra con su joroba, sin disfrazar ni realzar su feminidad (ropas masculinas renacentistas sin maquillaje). Cuando un demonio le reprocha sus faltas, la misma actriz lo encarna masajeando lúbricamente sus pechos (fig. 25, detalle ampliado de A5), con el vestido de mujer que sus hermanos le pusieron cuando lo violaron. En las muchas alusiones autorreferenciales al teatro dentro del teatro que articulan la narración visual, cuando no encarna el papel del Duque, es inconfundible su apariencia femenina, mientras que en dos escenas en que la acción del siglo XVI es actuada en ropa de fajina moderna, sus pechos se marcan por la remera.

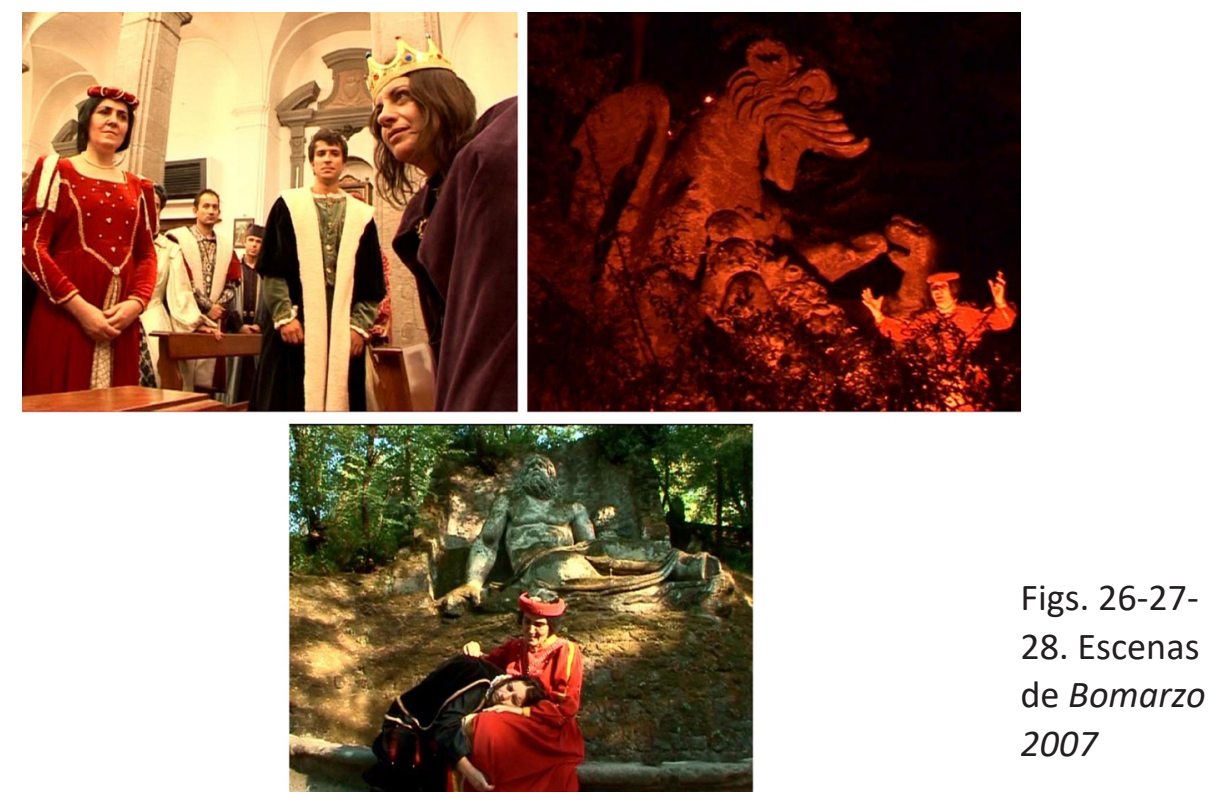



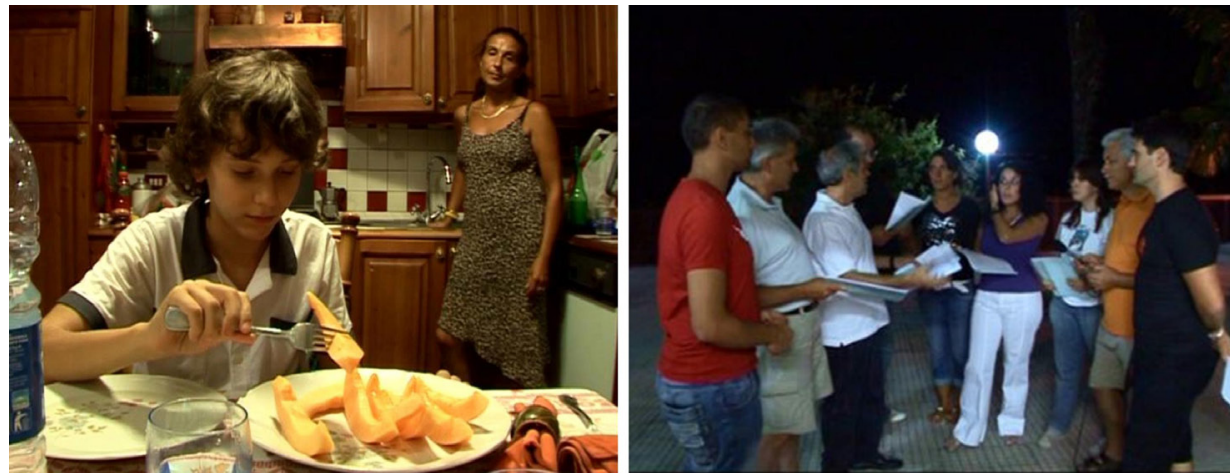

Figs. 29 y 30. Escenas de Bomarzo 2007
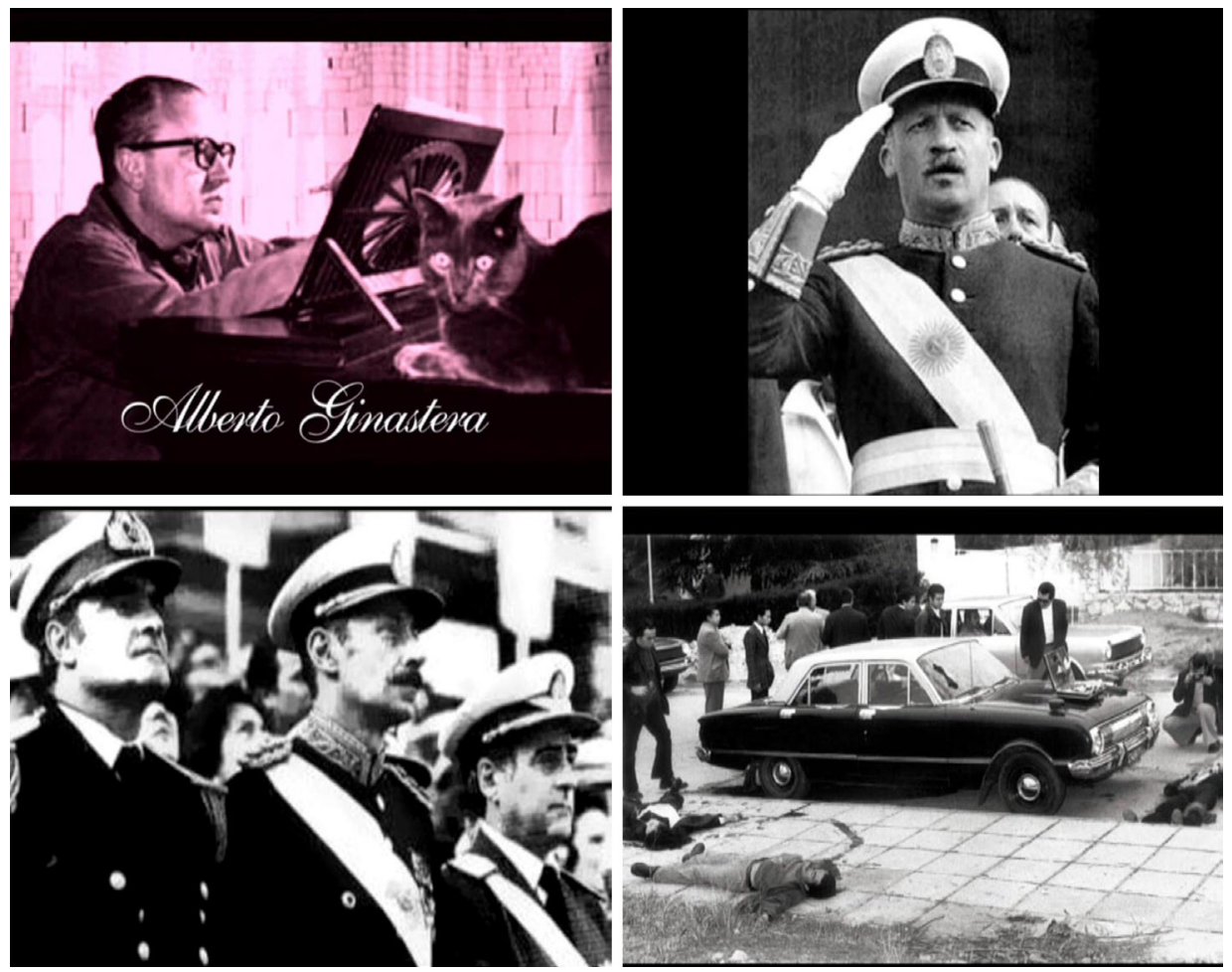

Figs. 31-32-33-34. Imágenes de Bomarzo 2007

La autorreferencia, autorrecursividad, intertexto, cita, intervención y palimpsesto del posmodernismo ya están implicados en los juegos de lenguaje, referencias y recursos de Mujica Lainez, y se continúan aquí con la mezcla y yuxtaposición que contrapone el Bomarzo ficcional del siglo XVI (sus restos arqueológicos in situ reciclados: figs. 26, 27 y 28: A8, B9 y ampliación de A5) 


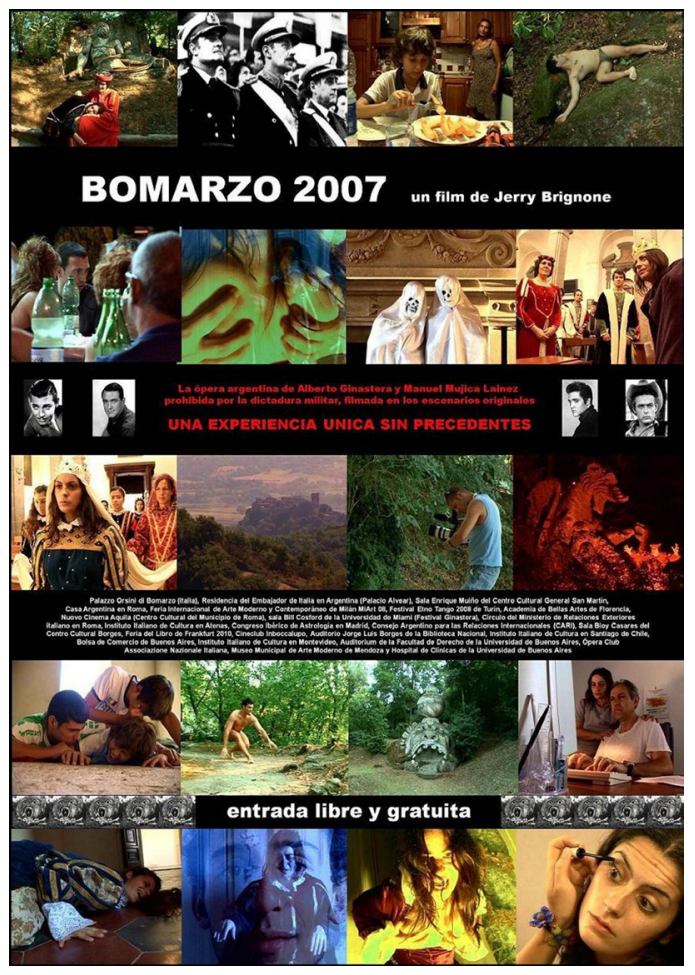

con los habitantes de Bomarzo de 2007 (figs. 29 y 30; B2 y B1, de un ensayo del grupo de teatro) y algunos sujetos de las condiciones de producción y prohibición de 1967 y el acaecer político que las rodeaba y sus continuidades icónicas (figs. 31 a 34), con juegos especulares al estilo de Las Meninas de Velázquez, incluidas cuando al protagonista se le aparece uno de sus temidos espejos en la película, de cuya condición híbrida intentaba dar cuenta el afiche promocional de $\mathrm{A} 5$ (fig. 35).

Fig. 35. Afiche promocional de Bomarzo 2007
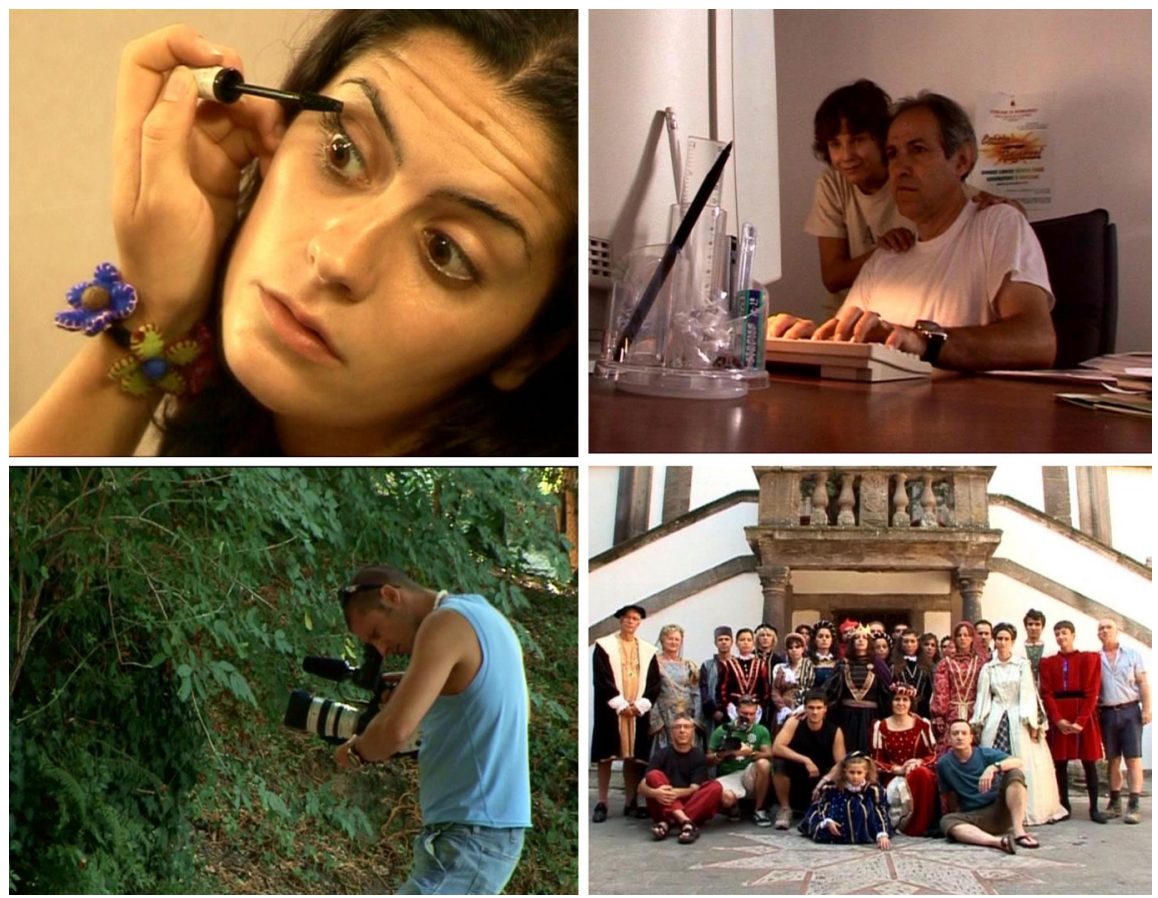

Figs. 36-37-38-39. Imágenes de Bomarzo 2007 
La presencia camp en A5 de íconos hollywoodenses (C. Gable, R. Hudson, Elvis P. y J. Dean; aparecían además R. Valentino, Marilyn M., R. Hayworth y J. Crawford) exacerba la autocontemplación narcisista y la artificialidad, como también la imagen de una actriz maquillándose en su casa (fig. 36), el joven que hace de sí mismo, del duque de niño y del niño pastor, en la computadora con la que van a matar al padre del protagonista en un ritual instrumentado por un sitio web astrológico (fig. 37), uno de los cameraman filmando a los actores (fig. 38) y buena parte del equipo de trabajo posando en la escena final (fig. 39). La memoria de los hechos ocurridos en 1967 y sucesivos en Argentina que fundamentan la película (expuestos allí como documento y metáfora), se articula tanto a través de lo especular como de la palabra recurrente Bomarzo en carteles de tránsito, remeras y tapas de libros: en el libreto los personajes leen, y en la película leen al Bomarzo de Mujica Lainez en algunas de las catorce ediciones que conseguí usadas y que doné al pueblo (figs. 40 a 42), literaturidad también dada en los subtítulos sobreimpresos en italiano para el público del estreno y los hispanoparlantes que no pudieran entender el castellano con pronunciación inglesa de los cantantes originales del estreno.
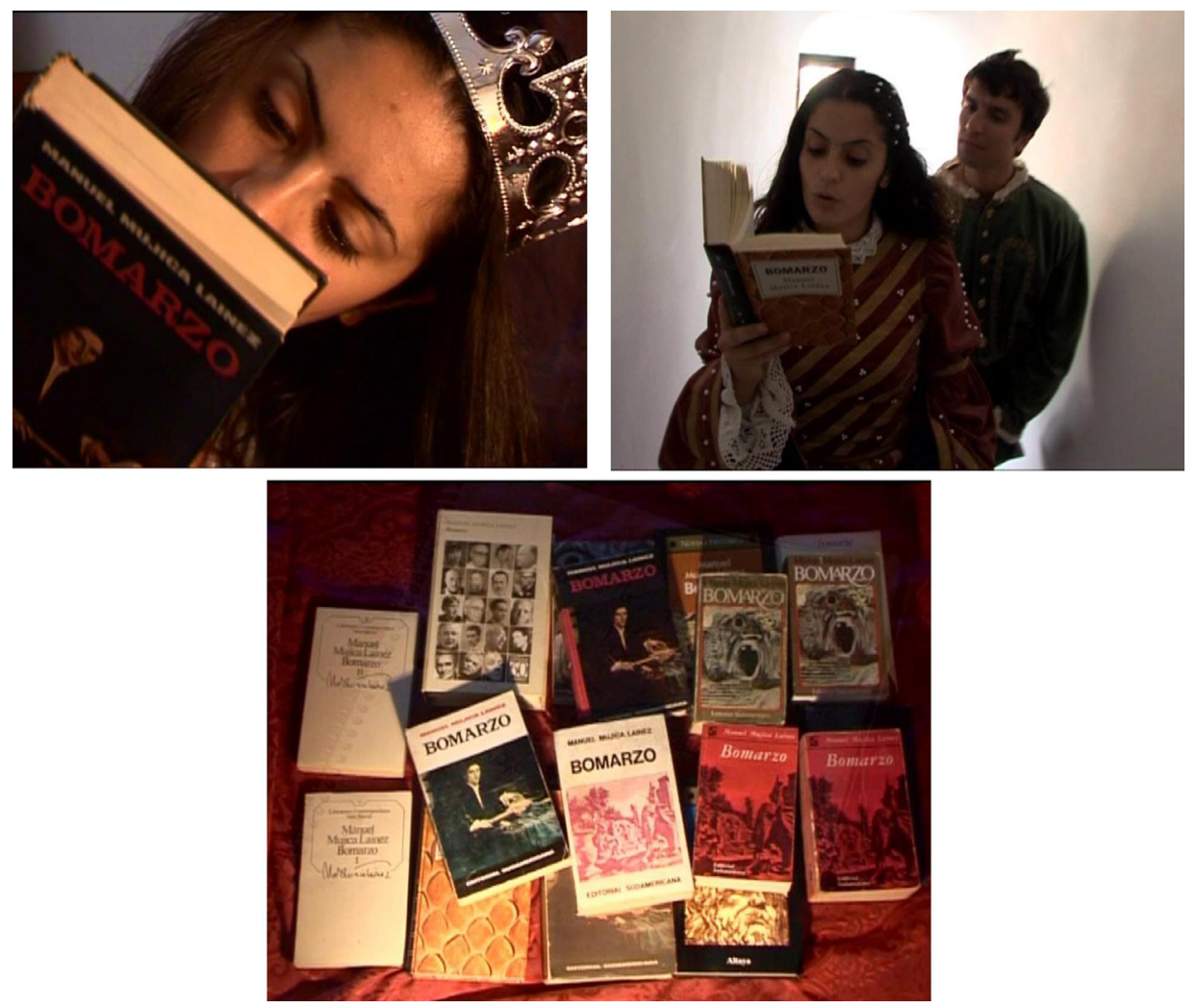

Figs. 40-41-42. Imágenes de Bomarzo 2007 
Según el director del Departamento de Arte y Cultura de la Universidad Nacional Tres de Febrero UNTREF: "Mujica trajo el Renacimiento a Buenos Aires, y de alguna manera este proyecto Scaringella-Brignone implica una devolución de ese Renacimiento a Bomarzo" (Zuzulich 2013), y el investigador de la Universidad de Salamanca que la eligió para ilustrar en un congreso en esa universidad su tesis de que una ópera filmada "es una obra esencialmente distinta" a la original en la que se basa (Parralejo Masa 2008), destacó de la película la lectura "multiforme" y "polisémica", también señalada por el director del Master de Periodismo de la Universidad de Columbia en Barcelona en su crítica del diario Clarín: "Derriba fronteras entre las artes (...) Una sucesión de espejos que amplifican los sentidos (...) Juega y hace jugar al espectador con el Bomarzo actual en un rico trayecto intelectual entre la permanencia y el cambio" (Herrscher 2012).

\section{Conclusión}

En suma, el relevamiento de instancias visuales documentadas desde la tapa de la novela Bomarzo de 1962 y las versiones argentinas de la ópera de 1967 a 2007 dan cuenta de cómo una obra, a partir de haber sido objeto de una instancia política represiva, cobró en sus diversas transposiciones y versiones una mayor relevancia semiótica colectiva construyendo significatividad por medio de la autorreferencia y la inclusión de referencias cada vez más explícitas a sus instanciaciones anteriores y al contexto político de producción contemporáneo y pretérito, materializadas en la presencia de los cuerpos de los involucrados: censurados y recuperados, como símbolo del cuerpo social que protagonizó dichos procesos políticos, en una cadena significante que enlaza a una con la otra y cada vez más con su contexto de producción, articulando y reelaborando en la imagen su propia historia e identidad imaginaria a través de los sujetos, trascendiéndolos.

\section{Bibliografía}

BENZECRY, Claudio E. 2011. El fanático de la ópera. Etnografía de una obsesión. Buenos Aires: Siglo XXI.

BUCH, Esteban. 2003. The Bomarzo affair. Ópera, perversión y dictadura. Buenos Aires: Adriana Hidalgo editora.

Cruz, Jorge. 1996. Genio y figura de Manuel Mujica Lainez. Buenos Aires: Eudeba.

GINASTERA, Alberto. 1973. Carta a Mujica Lainez, 5 de septiembre de 1973, Archivo El Paraíso. 
HERRSCHER, Roberto. 2012. "Una película del todo diferente", diario Clarín, 27 de agosto de 2012.

MUJICA LAINEZ, Manuel. 1962a. Bomarzo. Buenos Aires: Sudamericana. 1962b. Suplemento literario diario La Nación, 3 de junio de 1962. 1968. “Un brindis por 'Bomarzo'”, Diario La Razón, 5 de abril de 1968

PARRALEJO MASA, Francisco. 2008. “De 'Bomarzo' a 'Bomarzo 2007' (o los caminos imprevisibles de la ópera-film)" en Reflexiones en torno a la música y la imagen desde la musicología española, Matilde Olarte Martínez (ed.), Actas del IV Simposio Internacional "La creación musical en la banda sonora". Salamanca: Plaza Universitaria Ediciones.

PARRALEJO MASA, Francisco. 2008b. “Mutaciones dramáticas: de 'Bomarzo' a 'Bomarzo 2007' ", comunicación en video conferencia, IV Simposio Internacional "La creación musical en la banda sonora", Universidad de Salamanca, noviembre 2008. En https://www.youtube.com/watch?v=a-ArzNj2l-w (acc. 10 de marzo de 2020)

SCHWARTZ-KATES, Deborah. 2011. Alberto Ginastera. A research and information guide. Londres: Rouletdge.

VV. Sitio web del largometraje Bomarzo 2007: http://www.bomarzo2007.com.ar (acc. 10 de marzo de 2020)

ZUZULICH, Jorge (ed.). 2013. Del pensamiento continuo: apuntes de/sobre Norberto Griffa. Sáenz Peña: Universidad Nacional de Tres de Febrero UNTREF. 


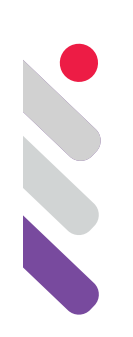

\title{
Villa-Lobos: symbolical and semiotical
}

DOI: 10.24308/IASS-2019-4-038

\author{
Cleisson Melo \\ Universidade Federal de Campina Grande - UFCG \\ cleisson.melo@ufcg.edu.br
}

\section{Introduction}

Heitor Villa-Lobos was born on March 5, 1887, son of Noemia Monteiro and Raul Villa-Lobos. He is one of the fundamental figures in the history of Brazilian music, with works present in most of the studies on Brazilian musical nationalism, or in the search for elements that confirm this endeavor. This may be since, in the process of building the Brazilian musical memories, Villa-Lobos and his mixed Brazilianness is always a constant personality.

His approaching and sensibility pushed himself to use and dare the complex musical universe, especially in the construction of music works full of significations, signifiers, dramatic plots, symbologies, and characters that think over his impetus and pride of Terra Brasilis (Brazilian land).

The multiple expressions in the formation of the Brazilian nation as people, with historical constructions linked to the feeling of belonging to the Portuguese-speaking community, bring up sentiments that are often "subjectified" (nostalgia, Saudade, loss, and so) as a conscious expression of shared values. These sentiments/feelings or emotions can be evoked by categories, allowing articulation with different meanings or even symbolisms. This feeling of being Brazilian in Villa-Lobos appears as attitudes based on the belonging in the process of building his discourse.

The connection strategies between intra and extra-musical identify specific singularities of a composer. In this sense, Villa-Lobos was very efficient in designing a very particular sound, developing a sound identity based on the identity of society; the appropriation of immanent elements of Brazilian imagination, which was fundamental in the representativeness of cultural elements present in his compositional processes. This can be pointed out as Villa-Lobos' desire of building a Brazil (as country and nation) sound, symbolically immersed in the essence of Brazilian multiplicity dialectic. At the 
same time, we must consider the duality of creating something very "yours", but, universal. This desire present in the appropriation of cultural and folkloric elements can be translated as the desire to reconstruct a sonorous nation, an identity. These recapitulations of Saudade ${ }^{1}$ (here as memories of old times), of representing miscegenation diversity, are rooted in a nostalgic collectivity as an element of distinction for those peoples - representation of African, Portuguese and Indigenous influences, for example.

\section{Symbolic and Semiotic}

Dedicated, Villa-Lobos built a musical identity, present in his lines, discourses, and life. A Brazilian researcher, Darcy Ribeiro (1995), already said about the necessity to build a strong definition of a country as we people want. It is noticed in Villa-Lobos' life stories, and in his drive to reinvent "a Brazil", as well. His bohemian experience in Rio de Janeiro's nights close to several popular musicians is a major factor in the consolidation of a composer engaged with his community and its elements. However, Villa-Lobos' appropriation process goes beyond the simple melody use, and/or popular/folk rhythms. This representative and re-significance ${ }^{2}$ process makes these popular-folk elements take on a new meaning. Thus, surrounded by external influences, distinct realities of a continental dimensions country, and its miscegenation, VillaLobos engages in an overview of cultures and different universes through an extraordinarily numerous and original musical works. On the other hand, the possibilities of disruption with ideologies and idealisms boosted his imagination, which, based on folklore/popular, grounded a more kinetic perception of the formal techniques used until then. It is Villa-Lobos' ways of rereading styles and techniques filtered by Brazilian sensitivity, directly reflected in his choice processes.

Simultaneously, all of that influences his compositional processes, and it reflects on the sound construction of a "primitivism" present in the social imagination as a stereotype. This imagery-symbolic language seeks to consider the Brazilian plural universe, enabling to identify some elements of his speech as folkloric.

These social rhetoric representations are a portrait of the one's attributions as being within a collectivity. In other words, in Villa-Lobos, this appears as an icon of the socio-cultural representation of Brazil. The composer sought to portray these individuals, characters, and myths with which he had contact.

The symbolic representation of this universe of realities is very present in Villa-Lobos' works, as an active voice. His musical language comes through

\footnotetext{
${ }^{1}$ Saudade is the sentiment of lonely, missing someone or something.

${ }^{2}$ Re-significance as re-signification: signifying again.
} 
social use, folk/popular influences, cultural matrices, and preference for Brazilian nature. His musical narratives embedded by popular/folk ethos define Villa-Lobos' personalism - a reflection of Brazilian nature.

Villa-Lobos' aesthetic and position follow a vanguard and explosive way, modern, result of hard adaptation work. In the context of emerging music changes, which pointed to ongoing disruption of the tonal system of Western music combined with a very rhythmic proposal, end up in works such as Choros and the Bachianas Brasileiras.

With this in mind, talk about symbolism in Villa-Lobos is to consider that the symbolic and the semiotic are components of signification, as Julia Kristeva (1993) claims. Thus, the semiotic element is the corporal impulse, a quality of signification source; associated with rhythm, movement, i.e., corporeal of significance practices. The symbolic element of signification is directly related to structure (and grammar) of signification. Semiotics elements are modes of expression, while symbolic ones are consciousness. But it is hard to disconnect both elements, the symbolic one needs the semiotics one to transmit sense/ meaning, with both elements interconnected within the language signification process.

France semiotics, especially greimasian one, presented as a model of sense description, considers the relation between subject and object, since "a subject only exists as far as it is related to the object" (Fiorin 2000a, p.178), and the subject is in conjunction of disjunction to the object.

For Greimas, the space between two subjects in dialogue is fulfilled by modalities. In other words, this "act of language" emerges the modalities. His semiotics approaching treats the subject from the viewpoint of both skills and existence. "Modalization has the role of expressing the enunciator's position concerning what one says" (FIORIN 2000b, 171). Thus, four modalities are presented: want; can; know; and must.

Based on concepts of modalities, in some points, ideas apparently fragmented can present themselves as narrative elements linked to music form/ structure and production of values. What I am trying to say is the modalities as procedural notions are dynamic for nature, which allow an intersection with other approaches, for example.

According to Eero Tarasti (2012a), values need modalities to become signs. To "crystalize" values is needed a subject action/intervention. The subject can realize those values as signs. Thus, Want means to connect one value $X$ to signified of action $X$, but it can also signify do not want the action. It is the desire to accomplish something or denial it. Know is the knowledge of the existence of this value $X$, without that knowledge the subject cannot want to make it concrete. 
It can mean to be able to connect value $X$ to an action $X$. Finally, Must means the internalization of values.

For this paper, I should only describe only two modalities: want and can, extremities of this approaching, pointing to a possible bright between symbolical and semiotical. For that, I will not address the aspects/processes of the generative path viewpoint that may result. The main point is to keep generative thinking as semiotics theory, establishing only some levels of invariance susceptible to representation.

\section{Villa-Lobos: symbolic-semiotic}

This all makes it evident that the Villalobian appropriation process of values, symbols and imaginary (realities), goes through the process of reinvention. It is important mentioning that in Villa-Lobos the processes of appropriation of popular, folk, erudite elements, and so on, go through the use (in terms of appropriation) of this "material", and, at the end, it crystallizes in the process presenting itself as part of the composer's aesthetics or identity. Thus, he appropriates codes in the way they appear, even abstractly, as originally his own.

In this case, the appropriation process comes through different aspects. It goes forward and establishes relations with a dramatic plot of musical work, orchestration, textures, and so on, and all of them develop straight relations with deconstructing to construct something new, "original" in the sense of possession, transformation, appropriation.

Arminda Villa-Lobos claims that Villa-Lobos "was interested to show a sonorous Brazil though his music" (2004, n.p.). She said, "if we take a look at Villa-Lobos' first works, there is a portrait of Brazil there" (2004, n.p.). That construction of a Brazilian portrait based on Villa-Lobos' life experience, desires, crossing Brazilian sensibility, it allows us to show an attitude of recomposing a sonorous Brazil and its several elements. It becomes more evident when VillaLobos says: "I compose music according to an inner mandate. I compose Brazilian music because I feel possessed by Brazil's life, its songs, sons and dreams, hope, and realizations (VILLA-LOBOS apud NEVES, 1977, 15).

This impetus, place of invention, the want of "construct" a sonorous Brazil, when it can take "not want", the Villalobian expression will be expressed through his intention of recomposing Brazil sonorously, as a desire of developing his language; designing Brazil though his eyes.

In Danças Características Africanas [African Dances], the first movement, it is possible to point out whole tone scales in contrast with an obstinate and seductive rhythm. This apparent duality, delaying harmonic resolutions, breaking expectative, and taking away the attention of rhythm, shows VillaLobos' personality bringing representative elements to his music in the sense of 
developing a characteristic language presented as the deny in conjunction with continuity expectative, pushing a new harmonic sonority.

In the example (Figure 1) one gesture with three plans which demonstrate a tonal expectative break, we notice into s spatiality with atonal tendencies, and modernism traces, merged to a language to portray a specific cultural aspect, here as dances of indigenous community Karipuna. In this context, aspects of community and indicial related to Brazilian existing reality. In the same way, this gesture points out to others movement with equal valuation, bringing a network of narrative connections through interocepty, as well as between measures 102 and 105 , for example.

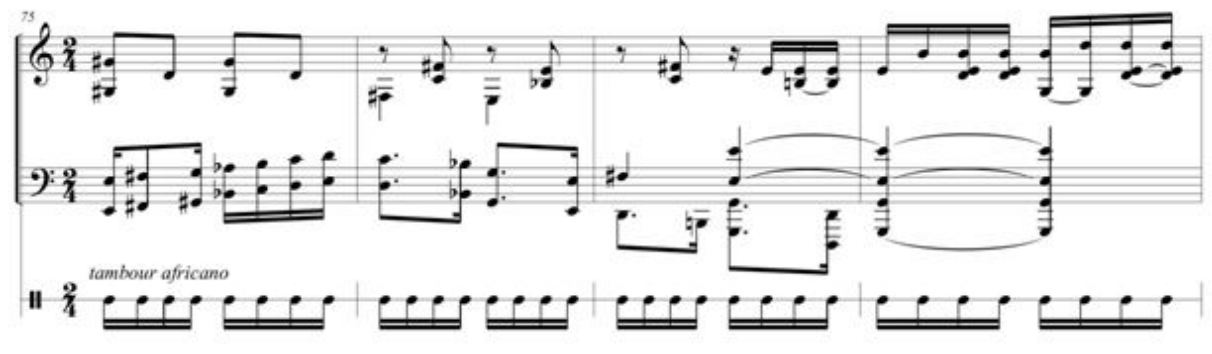

Figure 1:Danças Características Africanas 1.Mov. Comp. 75-78 (redução).

Another important point is introduced by Muniz Sodré (1988) in the book A Verdade Seduzida, presenting a study about African influences culture in Brazil from several points. In this study, Sodré suggests that terriero ${ }^{3}$ is a way to save, preserve heritages; it is a kind of resistance of losing cultural heritage. May it was one of several ways found by Afro-Brazilian people to save their culture, as a parallel form of socio-cultural organization. Considering the changes and adaptations undergone over time, perhaps we can think of these mixtures and organizational adaptations as what we know (today) by Afro-Brazilian culture. In this sense, even if in an epistemic character, when we refer to something related to the rituals of terreiros, etc., I think this can be a way of preserving the heritage.

If one looks at the rhythm ostinato as moving element within some topics, this ritual character of Afro-Brazilian characteristics included in this music throughout repetitions and syncope variations, within dances contexts acquires a ritual character in the religious sense. It brings us to a memorable cultural heritage pushed by nostalgic preservation.

It could be seen as the communality principle expressed in repetition strategies, clear seem in careful rhythm using and its variations. These communality traces are kinetic personification and embodiment as elements of

\footnotetext{
${ }^{3}$ Yard, farmyard, candomblé grounds.
} 
a sonorous portrait, as well as traces of Villa-Lobos' personality. This intention of using rhythm repetitions is part of the construction strategy of a discourse based on the Brazilian accent. The rhythm acquires a high level of interoceptive indexicality, but it also promotes a singular image related to extramusical elements; as signs related to the imaginary of this event (Figure2).

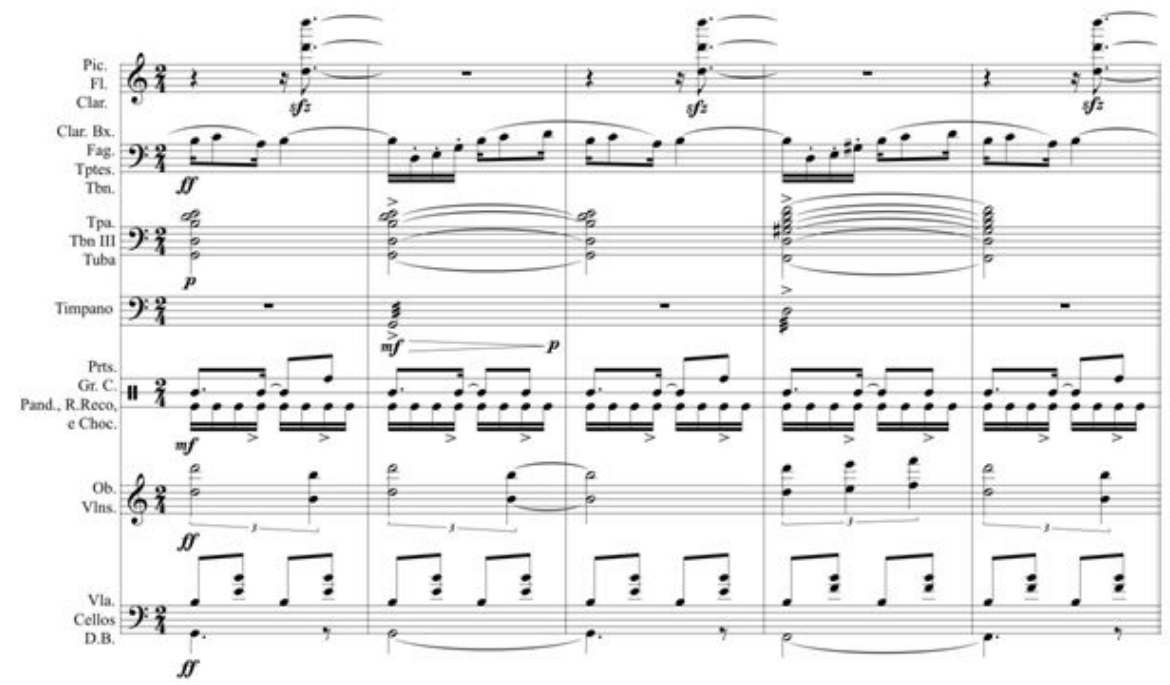

Figure2: Danças Características Africanas 1.Mov. Comp. 34-38 (redução).

Rhythm Works like a booster element in linearity flux through repetitions (ostinato), increasing dance character and ritualistic in this example. There is, as well, a not so obvious rhythm - three against two/four on violins and oboes, in contrast to this gesture as a whole. Considering orchestration and texture used, I should point a plot of representation of Karipunas people and their dances. It emerges from Villalobian impetus and gestural applicability in the composition process; building textures, layers, rhythms, and so.

Next example, Amazonas, coming from a complex sound environment with some chaos, in Dança Sensual da Jovem Índia (part) there is a disruption on orchestral density, open (literally) space for viola d'amore (Figure3). The reduction of dynamic and textural energy is a strategy of structural pointing, i.e., textural is a structural marker. This orchestral emptying strategy is related to the music programme. It is a compositional act in the personification of a character musically, setting up viola d'amore connotation with an Amazon Indian woman. 


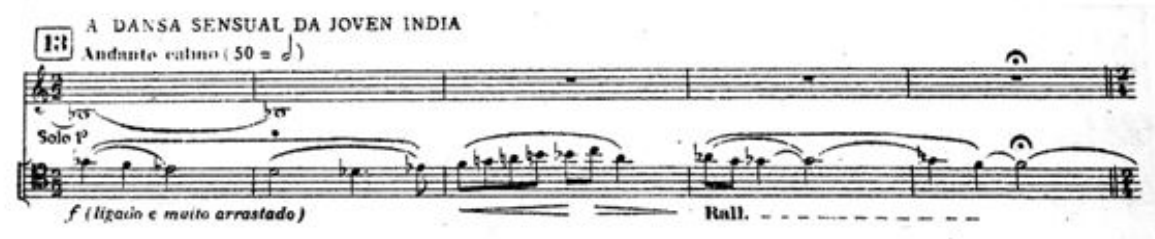

Figure3: Amazonas - A Dança Sensual da Jovem Índia

Here we can see a Villalobian pattern - composing motives using white and black keys (piano) separated by major second: $G$ flat $-F$; E flat $-D$. The whole tone scale breaks expectative, as well, but at the same time, it seems a representation of the Indian woman dance steps. I cannot point it as an exact representation, but just because of hard typical schemes of musical notation. On the other hand, this music is based on listening to significations, where "listening of sound proposes to clarify a more intriguing facet of this music" (Salles 2009, 189).

This strong density changing (orchestra to a few solo instruments) makes a sound and timbre predictability break. It indexes signification to that gesture though orchestration, allowing the embodiment of that longing dance by the Indian woman viewpoint. The orchestral environment is not only considering the idea but motives. The compositional know, even without complexity, is attached to the gestural in the communicative sense, clarifying derivate capacity related to the musical environment.

Orchestral colors and timbre valuation, the interrelation between lines and layers, increase textures and could be pointed as strong points in that music. Timbre and textural manipulation follow the myth imagistic constructions with simple textures focusing in transmit a thematic idea, reinforcing contrasts with other complexes gestures within a development context.

These "virtual" environments acquire wide breadth in Villa-Lobos' discourse, creating tools in the development of his narrative that supports it. As Villa-Lobos seems to define narrative parameters for the linearity of his ideas, this attitude of environments and potential soundscapes can reach the level of a discursive tool. His musical object manipulations became intentional reality (and worlds) creation symbolically and/or representatively. So, In short, VillaLobos conducts musical parameters in each situation it develops communicative power, in a better way, any musical proceeding has a connotation related to any content (object).

In Lembrança do Sertão (Bachiana n.2), the representation of a sertaneja (bushland) reality fulfills this whole movement. Rhythmic ostinato on violins and violas appears as a symmetric element as a result of regular rhythm, providing 
a sound movement continuous, leading an accompanying plan allowing the melody to "float" through sound space.
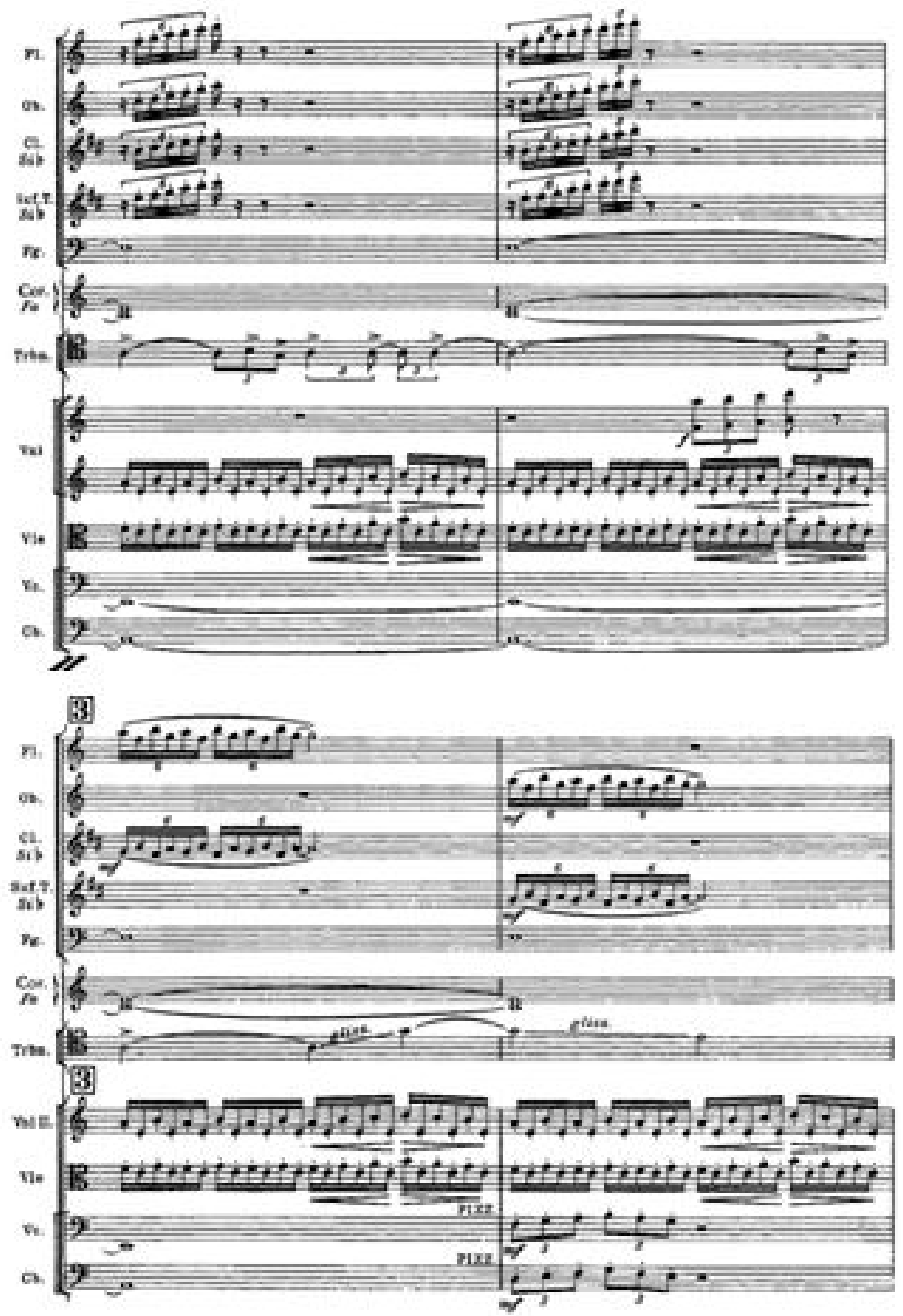

Figure4: Bachiana Brasileira No. 2. Lembrança do Sertão(m.15-18). 
In this simultaneity plans (front and back), part of the representative textural environment, there are some levels of concept by Villa-Lobos related to the sertanejo universe; cultural experience, belonging dialoguing with imagistic of the audience. The idea of sonorous Brazil composes, in addition to trading intent, it cross expression, life experience, and finally personify metaphorically these cultural normative elements.

Rich and complex environments present in Villa-Lobos' narrative are attached to experiences, reflected on his compositional making. Symbolically, it works as a deconstruction of paradigms in the benefit of voices multiplications. The division marked by rhythm layers enforcing texture separation in the creation of a representative of a specific environment/reality/character.

Next example, (Figure5), it is possible to point out a clean connotation/ representation of indigenous elements, especially in the use of eighth and sixteenth notes emphasized by marcato, creating an indigenous rhythmic environment (exteroceptive). It is aurally clear the rhetoric effect of that musical except, even if we consider that "in the choreography argument idealized by Villa-Lobos for that piece of music, just in the B part a group of indigenous attack sertanejos until they are waiting for the train. (Cherñavsky 2009, 442).

At the same time, this kind of representation establishes a symbolic representative connection, as a sign is linked to intramusical elements unfolding nature elements present in the first part of the music.

It brings us some pieces of evidence of how Villalobian gestures represent his Kinect persona, in the same way, the wide and rude, and the smooth Brazilian sensibility. So, even using detachment of the bachiana atmosphere, baroque rhetoric present on it becomes a tropical sign. It is the way how folk elements within musical rhetoric become metaphoric, bringing Brazilianness to the Villa-Lobos' music works, considering combine it with gesture diversity understanding that in Villa-Lobos' process those elements are actors in the construction of his discourse, represented by the sense of belonging. This way, the bachiana atmosphere detachment, imagistic and descriptive emerge in Villa-Lobos' processes. The compositional material/object present in these images and panoramas manifest appropriation using to enhance an idea. 

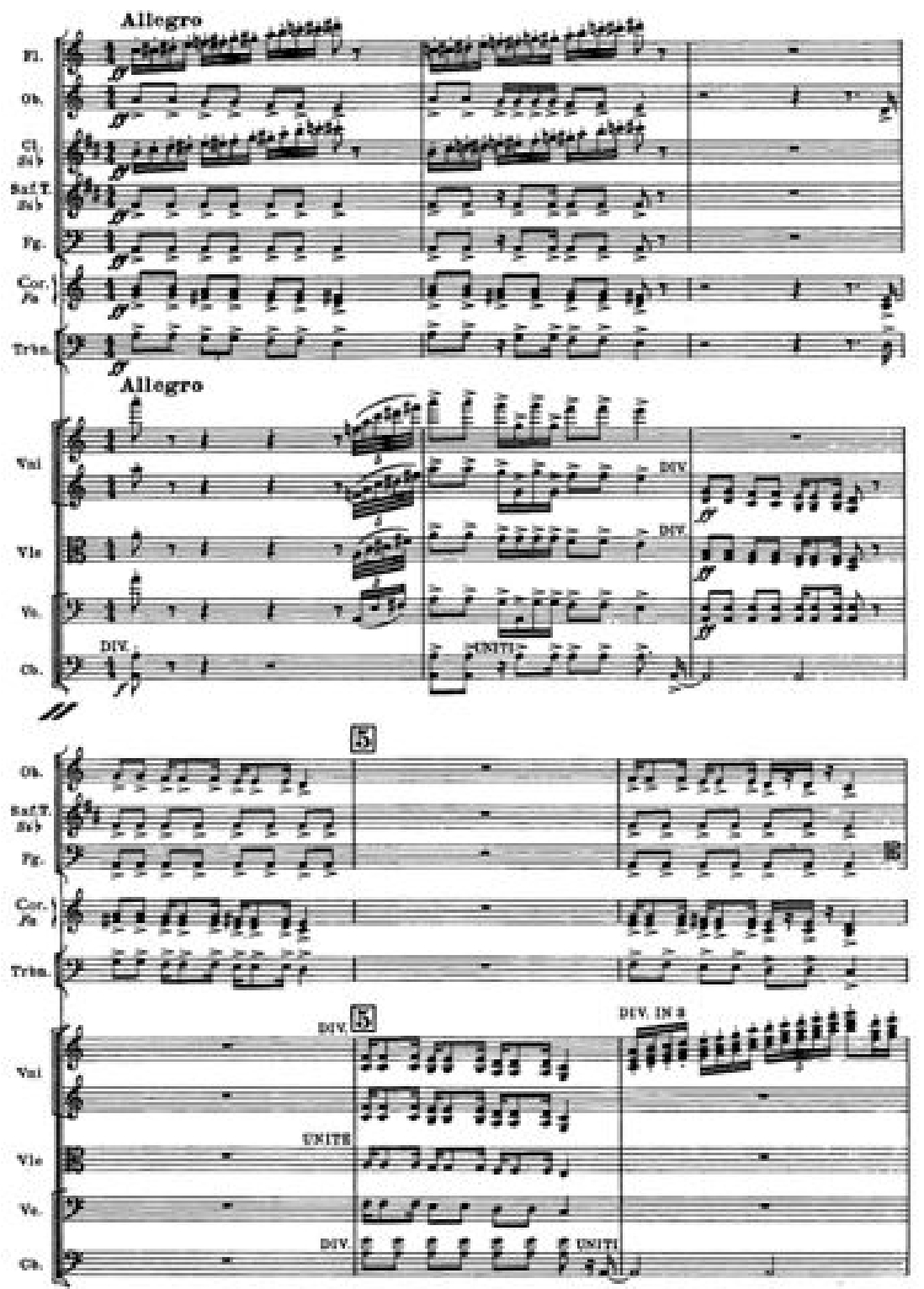

Figure5: Bachiana Brasileira No. 2. Lembrança do Sertão. Comp. 24-29.

Even know Brazil does not have a unique reality, but a kaleidoscope of realities of comings and goings, this belonging can be seen in the junction of constitutive elements of Brazilian panorama. The Índio 'Indian' and Sertanejo, nature and urban city, are reflections of Brazilian logic contrasts. This contrast can be noted between parts A and B in this movement. Thus, it presents a more aggressive tone toward other movements. 


\section{Considerations}

Due to the great number of Villa-Lobos' music works, there is so much to talk about and to analyze about him and his work. But, it was possible to see by this paper some points about symbolic aspects of Villalobian compositional making through semiotics. There is a Villa-Lobos more conscious of himself by his way, where his kinetic energy articulation finds his style.

Villa-Lobos always used several symbolisms and representative signs as a way to bring external realities to his works. It allowed setting and producing significant virtual entities in the development of a possible sonorous Brazil. That is to say, he was able to create a narrative base on signs, myths, folk/popular elements, as those were his own, and on the production of original material used as popular or folk influences.

The impetus of Villa-Lobos to create music pieces with great representation and signified seems to be a very objective. These developments lead to sound imagery, which consists of his narrative. Want as a place of intention, coming from the desire to build a sonorous Brazil. Nature, forest, is in the impetus to portray Brazil in its diversity, and it can be pointed as a representative way of Villa-Lobos' kinetics as a style - the desire to develop his language, as well as design a Brazil on its aesthetic basis.

Virtual environment as discursive tools and based on narrative elements spotlight compositional material using within the sphere of aesthetic. Thus, highlighted some soundscapes and manipulations of mythic aspects of it, it is possible to understand this sound object in the building of the illusion of the absence object.

Hence, I agree with Paulo Salles (2009) when he claims that Villa-Lobos has used representations of national to evoke a sound environment that goes beyond the simple figuration of the rhythm accompaniment and the concept of melody, establishing a construction of realities, which are his own.

\section{References}

CHERÑAVSKY, Anália. 2009.Em busca da alma musical da nação: um estudo comparativo entre os nacionalismos musicais brasileiro e espanhol a partir das trajetórias e das obras de Heitor Villa-Lobos e Manuel de Fala. 2009.Campinas, SP: Universidade Estadual de Campinas thesis.

FIORIN, José Luiz. 2000.Elementos de análise do discurso. 8a edição. São Paulo: Contexto.

44,171-192.

2000b. Modalização: da língua ao discurso. In: Alfa, São Paulo, 
KRISTEVA, Julia. 1993.Desire in Language: A Semiotic Approach to Literature and Art. Oxford: Blackwell Publishers.

NEVES, José Maria. 1977.Villa-Lobos, o Choro e os Choros. São Paulo: Ricordi.

RIBEIRO, Darcy. 1995.O povo brasileiro: A formação e o sentido do Brasil. 2a edição. São Paulo: Companhia das Letras.

SALLES, Paulo de Tarso. 2009. Villa-Lobos: processos composicionais. Campinas: Editora Unicamp.

TARASTI, Eero. 2012a. Semiotics of classical music: How Mozart, Brahms, and Wagner talk to us. Berlin: De Gruyter Mouton.

2012b.Existential Semiotics and Cultural Psychology. In: VALSINER, J. (Ed.). The Oxford Handbook of Culture and Psychology. Oxford: Oxford University Press.

VILLA-LOBOS, Arminda. 2004. Entrevista concedida ao Diário do Nordeste em 12 de junho de 2004. 2004. Disponível em: <http://diariodonordeste.verdesmares. com.br/cadernos/caderno-3/pela-musica-brasileira-1.40219>. Accessed:02 nov. 2018. 


\section{Índice general de las Actas}

\section{TOMO 1}

\section{TRAYECTORÍAS Y TEORÍAS}

COORDINADORES: MARÍA TERESA DALMASSO Y CLAUDIO GUERRI

LOS ARCHIVOS PERSONALES DE ELISEO VERÓN. Gastón Cingolani

DE LAS OPERACIONES SEMIÓTICAS A UNA SEMIÓTICA DE LAS OPERACIONES. María Elena Bitonte

LAS "SEMIOSIS SOCIALES" Y LAS TRANSFORMACIONES EN LOS PROCESOS COMUNICATIVOS. Gustavo Aprea

ELISEO VERÓN ENTRE DOS SEMIOSIS: DEL CUERPO SIGNIFICANTE AL CEREBRO DEL SAPIENS. Amparo Rocha Alonso

THE SEMIOTIC THEORY OF A.J. GREIMAS IN MAINSTREAM ORGANIZATION THEORY AND ORGANIZATION RESEARCH. Pertti Ahonen

ÉCOLE RUSSE ET ÉCOLE FRANCAISE DE SÉMIOTIQUE. VALEURS, FORMES DE VIE ET TRAJECTOIRES HISTORIQUES. Inna Merkoulova

TRAJECTÓRIAS DO LEITOR NO ESPAÇO TEXTUAL.

Maria Augusta Babo

DE LAS PASIONES EN LA ENUNCIACIÓN. TEORIZACIÓN E IMPLICANCIAS PARA EL ANÁLISIS SEMIÓTICO DE LOS DISCURSOS. Cristian Cardozo

ALIQUID PRO ALIQUO. ASOCIACIÓN, REPRESENTACIÓN Y SIGNIFICACIÓN. Fernando Rodríguez

DUALISM IN AL-FARABI'S WRITINGS AND LANGUAGES.

Driss Bouyahya

ALGUNAS OBSERVACIONES SOBRE EL GIRO LINGÜÍSTICO EN LA HISTORIA INTELECTUAL. Norma Fatala 
MASS-MEDIACIÓN: FORMATO Y DISPOSITIVO. Marcelino García

SOBRE LA VERDAD SEMIÓTICA Y PRESEMIÓTICA DE LA IMAGEN. Fernando Fraenza y Valentino Indorato

PROSPECTIVE AND SIGN IN ITS EVOLUTIONARY NATURE. Bianca Suárez Puerta

SEMIÓTICA DAS ORGANIZAÇÕES: ENTRE AS TESSITURAS TEXTUAIS E AS REDES DE SENTIDO. Elisangela Carlosso Machado Mortari

LA FILIGRANA MOMPOSINA: PRESERVACIÓN DE LA TRADICIÓN A TRAVÉS DEL APRENDIZAJE. Denis Senith Cabrera Anaya

SIGNS IN ACTION: OLD HERITAGE CRAFTS AND NEW

"SENSE KEEPERS". Nicolae-Sorin Drăgan

TRAYECTORIAS DE UN MODELO OPERATIVO: NONÁGONO SEMIÓTICO. Claudio F. Guerri

REORIENTANDO LA MÚSICA: UN ABORDAJE PEIRCEANO DE LA PERFORMANCE MUSICAL. Juan Pablo Llobet Vallejos y Pablo Stocco

APROPIACIÓN MATERIAL. TRAYECTORIAS, PROFANACIONES Y ESTRATEGIAS EN EL ARTE CONTEMPORÁNEO DE AMÉRICA LATINA. Guadalupe Ailén Álvarez

TRAYECTORIAS PERFORMÁTICAS DEL ARCHIVO EN LA ERA DIGITAL. \#VIVAS: TECNOLOGÍAS DIGITALES PARA LA CONSTRUCCIÓN DE MEMORIA COLECTIVA.

Guadalupe Ailén Álvarez, Maximiliano Cortés y Micaela Flavia Paz

GESTIONAR LA SOSTENIBILIDAD DE LAS ORGANIZACIONES COMO UNA TRAYECTORIA HACIA LA RESPONSABILIDAD SOCIAL.

Raquel Felisa Sastre

NONAGONO SEMIÓTICO DEL SIGNO GOBIERNO: UNA PROPUESTA PARA RECONOCER Y MINIMIZAR RELACIONES DE DOMINACIÓN. Juan Emilio Ortiz

¿"BOLUDA" O "BOLUDA DE MIERDA"? CONVERGENCIAS Y DIVERGENCIAS EN LAS TRAYECTORIAS DE DOS SIGNOS. Paula Elizabeth Fainstein 
ARCHIVOS QUE PERFORMAN. APROXIMACIONES SEMIÓTICAS A LAS PRÁCTICAS DE ARCHIVO. Claudio Guerri, Martín Acebal y Cristina Voto

THE TRAVELER'S GAZE: A SEMIOTIC ANALYSIS OF INSTAGRAM'S TRAVEL PHOTOGRAPHS. Fernanda Carvalho Ferrarezi

NEUROSEMIOSIS - TRANSITION FROM PHYSICAL TO MENTAL STATES. Karl Gfesser

PEIRCEAN SEMIOSIS AND THE ENGINEERING OF CONSENT AS PARALLEL TRAJECTORIES. Tony Jappy

SEMIÓTICA Y HERMENÉUTICA: REFLEXIONES METODOLÓGICAS EN BASE AL CONCEPTO DE SIGNO EQUÍVOCO. Roxana Cecilia Ynoub

SYNALETHISM AND UNLIMITED SEMIOSIS. Titus Lates

SEMIOTIC APPROACH TO IRONY. Evelyn Vargas

THE POWER OF IMAGINATION. NEW APPROACH TO CHARLES PEIRCE'S ABDUCTION. Reni Yankova 


\section{TOMO 2}

\section{ALTERIDADES, IDENTIDADES}

COORDINADORES: MARITA SOTO Y FEDERICO BAEZA

NO ES LO QUE PARECE. EDUARDA MANSILLA, VOCES FEMENINAS DESDE LA FRONTERA INTERIOR. Laura Sacchetti

LA MIRADA SEMIÓTICA AL DISCURSO SUFRAGISTA EN MÉXICO (1916-1923). Olga Nelly Estrada y Griselda Zárate

LOS AMORALES Y LAS "BUENAS COSTUMBRES": MEMORIA DISCURSIVA Y CLASIFICACIÓN DE LA DISIDENCIA SEXUAL EN LA DIPPBA. Paulina Bettendorff y Laura Bonilla

ENCYCLOPEDIC ANTHROPONYM AS THE SIGN OF CULTURE. Svetlana Bogdanova y Elena Ignatieva

THE CORSET AND THE HIJAB: ALTERNATIONS OF ABSENCE AND PRESENCE IN THE 19TH AND 20TH-CENTURY FASHION SYSTEM. Marilia Jardim

ENTRE ORILLAS. TRAYECTORIAS DISCURSIVAS DE LA IDENTIDAD GALLEGA EN LA ARGENTINA. Claudia López

LOS VARRIOS DE SAN DIEGO CALIFORNIA. RESISTENCIA CHICANA-CONCHERA. José Luis Valencia González

LA PREGUNTA POR EL CUERPO EN LA SEMIÓTICA CONTEMPORÁNEA: PERFORMATIVIDAD, VINCULACIÓN Y MEMORIA. Susana Temperley

INTERSUBJETIVIDAD, MULTIMODALIDAD Y ADQUISICIÓN DEL LENGUAJE. Fernando Gabriel Rodríguez

TRAJECTORIES OF POSSIBILITIES. SEMIOTICS OF THE UNPREDICTABLE FUTURE. Katarzyna Machtyl 
BETWEEN SEMEIOTICS AND SEMIOTICS: THE BODY AS A SIGNIFYING TEXT. Simona Stano

LA PRAXIS ENUNCIATIVA Y LO REAL: ARTICULACIONES INTERDISCIPLINARIAS PARA UN MODELO DE ANÁLISIS DEL DISCURSO. Marcos Javier Mondoñedo Murillo

LIBIDINAL INTELLIGENCE: CINEMA AND LITERATURE. Roseli Gimenes

SEMIOTIC STRATEGIES TO CREATE HERITAGE: LUXURY FASHION BRANDS IN THE AGE OF SOCIAL NETWORKS. Daria Arkhipova

LA ESCENOGRAFÍA DEL CUERPO EN EL DISEÑO DEL DESFILE DE MODA. Mihaela Radulescu de Barrio de Mendoza

TRAYECTORIAS DISCURSIVAS: LA ALIMENTACIÓN ENTRE CIENCIA Y COMUNICACIÓN. Simona Stano

A CIDADE COMO ESPAÇO DE COMUNICAÇÃO MERCADOLÓGICA: O POTENCIAL DE PRODUÇÃO DE SENTIDO DAS MARCAS A PARTIR DE INTERVENÇÕES PUBLICITÁRIAS NO CONTEXTO URBANO. Sergio Marilson Kulak y Rui Torres

\#YOSOYDIVERSO, MÁS QUE UN HASHTAG, UN LLAMADO A LA TOLERANCIA DESDE LA PERSPECTIVA DEL PLURALISMO CULTURAL EN LA VIRTUALIDAD.

Norberto Fabián Díaz Duarte y Antonia María Moreno Cano

BARRIOS EN FOCO: EL DISCURSO AUDIOVISUAL ENTRE LO TRANSLINGUISTICO Y LO TRANSDISCIPLINAR. Valeria Car, Alfredo Isasmendiz - Preti y Cinthia Naranjo DISCURSOS, PIQUETES Y ORDEN DEMOCRÁTICO. Liliana Pazo ANÁLISIS SEMIÓTICO DE LA REPRESENTACIÓN DE GÉNERO EN LA PELÍCULA PERSÉPOLIS. Lucía Leticia Anaya Avilés

LA PERSISTENCIA DEL AMOR ROMÁNTICO: ANÁLISIS DE SU REPRESENTACIÓN E INFLUENCIA EN LOS ROLES DE GÉNERO TRADICIONALES EN RUBY SPARKS Y LA LA LAND DESDE LAS FIGURAS DE EROS Y PSIQUE.

Itzel Mayelli Flores Urzua y José Honorio Cárdenas Vidaurri 


\section{TOMO 3}

\section{ESCRITURAS E HISTORIAS}

COORDINADORA: VANESA PAFUNDO

THE JEALOUS NARRATOR: ANALYSIS OF THE ENUNCIATION STRATEGIES IN ROBBE-GRILLET'S NOVEL LA JALOUSIE. Ludmila Lacková

UN NO- LUGAR COMÚN EN LA LITERATURA: LO INFINITO. Karina B. Lemes

LA TRAYECTORIA DE LA MIRADA SARAMAGUIANA. UN ANÁLISIS DEL DISCURSO SOBRE EL ARTE EN LOS CUADERNOS DE LANZAROTE, DE JOSÉ SARAMAGO. Marisa Leonor Piehl

ALGUNOS APUNTAMIENTOS DE JOSÉ SARAMAGO DESDE LA EMOCIÓN DE LOS SUCESOS DEL PROCESO REVOLUCIONARIO EN CURSO - PORTUGAL, 1974-1975. María Victoria Ferrara

FORMAS DE LA "AUTORÍA TRANSMEDIA" ACERCAMIENTOS SEMIÓTICOS. María Clara Lucifora

WHO IS THE DREAMER? TEXTUAL AND METHODOLOGICAL SEMIOTIC TRAJECTORIES IN TWIN PEAKS: THE RETURN. Giacomo Festi

ELENA SABE: LA EXHIBICIÓN DE UNA SOCIEDAD EN CRISIS. Karina Lemes

PROSA MESTIZA. CONFIGURACIONES DE LA FRONTERA EN TRES NOVELAS ARGENTINAS CONTEMPORÁNEAS. Froilán Fernández

MONSIEUR PAIN. NARRATIVA DE ORILLA.

Natalia Vanessa Aldana

HARRY POTTER: ANÁLISE DAS CAPAS DOS LIVROS.

Júlia Meister Barichello 
DO OBJETO LIVRO AO LIVRO-OBJETO LITERÁRIO:

UMA RESSEMANTIZAÇÃO SENSÍVEL. Marc Barreto Bogo

ENTRE O VERBAL, O GRÁFICO E O ESCULTÓRICO:

INTERSEMIOTICIDADE NA PUBLICAÇÃO TREE OF CODES. Marc Barreto Bogo

SALOMÉ: UN CASO DE RECURRENCIA DISCURSIVA. Oscar Traversa

EL HÉROE CONTEMPORÁNEO - NUEVAS TRAYECTORIAS

DE SIGNIFICADO ÉTICO. Rafael Zanlorenzi

REPRESENTATION AS A CATALYST FOR CULTURE CHANGE PROCESSES: THE SEMIOTICS OF CULTURE CHANGE.

Hamsini Shivakumar

CONTRAPUNTOS CRÍTICOS TERRITORIALES. ESCRITURA, RITMO, SONORIDAD. Carmen Guadalupe Melo

TRAVESÍAS Y ENCRUCIJADAS DEL ARCHIVO: DISCURSIVIDADES POÉTICAS Y TERRITORIALES. Carla Vanina Andruskevicz

IDENTIDAD Y FRONTERAS DENTRO DE LA OBRA: MEMORIAS DEL SUR - PRIMEROS RESULTADOS DE INDAGACIÓN.

María Leticia Scarpa

ESTRATEGIAS NARRATOLÓGICAS PARA EL ANÁLISIS DE MATERIAL AUTOBIOGRÁFICO: ¿A QUIÉN ESCRIBEN LOS QUE SE ESCRIBEN? Maité Delfina Lluch

A CONSTRUÇÃO DOS ATORES E SUA PROJEÇÃO NO ESPAÇO-TEMPO EM A CIDADE DORME, DE LUIZ RUFFATO. Marcela Ricardo y Vera Lucia Rodella Abriata

PASADOS EN TRÁNSITO: RELATAR DESDE EL OLVIDO. Sergio Rojas

SEMIÓTICA NARRATIVA E IMAGINARIO HUMANO: REFLEXIONES METODOLÓGICAS EN BASE A LOS APORTES DE GREIMAS Y PROPP. Maité Delfina Lluch, Miguel Adrián Romero y Roxana Ynoub

HACÉ MEMORIA, NO MONUMENTOS. HACIA LA CONSTRUCCIÓN DE ARTEFACTOS ESTÉTICO-SEMIÓTICOS (DES)EMPLAZADOS. Ariel Barbieri 
SEMIOTIC MULTIMODALITY AND THE PERCEPTION OF THE PAST. Jimena Biga

FOUR SPECIES OF SPANISH PATRIOTIC SONGS OF THE SPANISH WAR OF INDEPENDENCE 1808-1814. Aleksi Jari Ilmari Haukka

LA IDENTIDAD NACIONAL DEL PARTIDO COMUNISTA CHINO EN 1949: UNA APROXIMACIÓN A TRAVÉS DEL ANÁLISIS DE IMÁGENES. Ignacio Robba Toribio 


\section{TOMO 4}

\section{ARTES Y LENGUAJES}

COORDINADORES: MÓNICA KIRCHHEIMER Y GUSTAVO APREA

EL ESTUDIO DE LAS TRANSPOSICIONES DE LA LITERATURA AL CINE: LOS APORTES QUE DISTINTAS VERIENTES SEMIÓTICAS EFECTUARON AL CAMPO. María Rosa Del Coto

INTRODUCCIÓN FÍLMICO-LITERARIA DE VIAJES Y TRANSPOSICIÓN(ES). María Silvina Tatavitto

RETOMAS DEL CINE DE LOS 80: PROCEDIMIENTOS TRANSPOSITIVOS DE UN FENÓMENO PARTICULAR. José Tripodero

LA DESPEDIDA DE LOS AMANTES EN LA ESTACIÓN DE TREN. PERVIVENCIA Y MUTACIÓN DE FORMAS FÍLMICAS. Marina Locatelli

TEMPORALIDADES FICCIONALES - UNA EXPLORACIÓN DE LAS PARADOJAS TEMPORALES EN EL CINE DE FICCIÓN.

M. Laura Ragucci

POSIBLES PATHOSFORMELN EN LA HISTORIA DEL CINE. Mabel Tassara

CONFIGURACIONES DEL CINE REGIONAL EN LA PRENSA DE LA NORPATAGONIA DE LOS AÑOS OCHENTA. Ignacio Dobree

TUNCHES, PISHTACOS Y JARJACHAS: FORMAS ENUNCIATIVAS DEL MIEDO EN EL CINE REGIONAL ANDINO PERUANO. Miguel Ángel Torres Vitolas

LE CINÉMA ET SON DOUBLE OU LE PRINCIPE DE L'ASYNCHRONISME REVISITÉ. Ivan Capeller

WHAT'S IN THE NAME LIVE CINEMA? Marga van Mechelen 
TRÂNSITO E COMPLEXIDADES SENSORIAIS EM IMAGENS COMTEMPORÂNEAS. Lívia Machado

OPERACIONES DE LUDICIDAD Y AUTORREFERENCIA EN DOS CASOS DE ANIMACIÓN DIGITAL CONTEMPORÁNEA.

Maria Alejandra Alonso

SI SOLO SI: LA DISCAPACIDAD EN LA FICCIÓN TELEVISIVA ARGENTINA. Carolina Casali

CASI UNA SERIE. APUNTES TRASNOCHADOS SOBRE REALISMO Y CINE EN DOS MINISERIES MISIONERAS. Mauro Figueredo

TÉLÉVISION ET JUSTICE : UNE TRAJECTOIRE MÉDIATIQUE CONTROVERSÉE? Yannick Lebtahi

FORMAS DE VIDA MIGRATORIAS: ARTE E INTIMIDAD. Jaime Cordero

LO LÚDICO, LO SOCIAL Y LO POLÍTICO EN DOS CASOS DE ANIMACIÓN CONTEMPORÁNEA. Mónica Kirchheimer

SNUFF 2.0: SOBRE LOS VIDEOS DE VIOLENCIA Y MUERTE EN REDES SOCIALES. Julián Tonelli

DISPOSITIVOS Y ENUNCIACIÓN EN LA POSTFOTOGRAFÍA: ALGUNAS TRAYECTORIAS DE LA IMAGEN FOTOGRÁFICA DIGITAL EN REDES SOCIALES. Mariano Zelcer

LA AUTOPOIESIS DEL ACONTECER ARTÍSTICO QUE EMERGE A TRAVÉS DEL DIÁLOGO ENTRE DIFERENTES DIMENSIONES DE LA CORPORALIDAD. Daniela Lieban

TRASUNTO \#1: POESÍA EN TRÁNSITO. Valentina Paillaleve

LECTURAS DEL BIOARTE EN CLAVE SEMIÓTICA: AVANCES DE INVESTIGACIÓN. Lucía Stubrin

LA INTIMIDAD COMO APUESTA POLÍTICA EN RECORDAR 30 AÑOS PARA VIVIR 65 MINUTOS, DE MARINA OTERO. Luciana Estevez

DANZA EN PRIMERA PERSONA. EL GIRO AUTOBIOGRÁFICO EN LAS OBRAS DEL UNDER PORTEÑO. María José Rubin

HISTORIA, MONTAJE, ARCHIVO: PARA UNA PERFORMATIVIDAD DE LA MEMORIA. Cecilia Tosoratti 
INNOVACIONES DISCURSIVAS Y NUEVAS ESTÉTICAS DE LA HISTORIETA ARGENTINA CONTEMPORÁNEA.

Andrea Acosta Camargo, Laura Amarilla y Gaspar Buono

PIERRE DUPRAS, BÉDÉISTE CARICATURISTE ENGAGÉ.

Mila Falardeau

TRAYECTORIAS DE LA ABYECCIÓN EN EL ARTE POSMODERNO. Amparo Latorre Romero

UN NO LUGAR PARA LA FOTOGRAFIA: SOBRE LA SERIE ARCHIVO UTOPIA- EL PROYECTO BRASILIA. Vanesa Magnetto

EL GESTO MUSICAL Y LA COGNICIÓN CORPOREIZADA: ARTICULADORES DEL SENTIDO EN LA DISCURSIVIDAD MUSICAL. Federico Buján

THE BODY AS MEDIUM: THE SUBVERSIVE SELF-PORTRAITSOF FRANCESCA WOODMAN. Patrícia Fonseca Fanaya

LA CONSTRUCCIÓN DEL TANGO COMO GÉNERO MUSICAL EN LOS MEDIOS MASIVOS. Jimena Jauregui

CUERPOS Y PALABRAS EN EL RITMO: LA ESCENA DE LA VOZ EN EL RAP FREESTYLE. Amparo Rocha Alonso

PROCEDIMENTOS RETÓRICOS E SEMIÓTICOS NA CANÇÃO RETRATO EM BRANCO E PRETO, DE CHICO BUARQUE E TOM JOBIM. Robson Costa Bessa y Alfredo Werney Lima Torres

MÚSICA Y PRODUCCIÓN DE SENTIDO EN EL CINE DE WOODY ALLEN. LA PRESENCIA DE OBRAS MUSICALES REPRESENTATIVAS DE UN DETERMINADO MOMENTO COMO REENVÍO A MANIFESTACIONES CULTURALES DEL PASADO. Carolina Inés Rochi

LA CADENA SIGNIFICANTE DE LOS CUERPOS EN LOS BOMARZOS ARGENTINOS. Jerónimo Brignone

VILLA-LOBOS: SYMBOLICAL AND SEMIOTICAL. Cleisson Melo 


\section{TOMO 5}

\section{COMUNICACIÓN MEDIÁTICA, PUBLICIDAD Y DIGITALIDADES}

COORDINADORES: MABEL TASSARA Y ROLANDO MARTÍNEZ MENDOZA

LA IMPORTANCIA DE LOS ESTUDIOS SEMIÓTICOS EN EL DISEÑO DE INTERFACES INTERACTIVAS. Francisco V. C. Ficarra

THE READING CONTRACT FOR THE CUSTOMIZATION ALGORITHM. Gustavo Markier

THE LAWS OF SEMIOTICS AND DIGITALIZATION OF CULTURE: THE BIRTH OF THE NEW MEANINGS. Marina Merkulova

MEMÓRIA E ESQUECIMENTO: AMBIVALÊNCIAS DO DIGITAL ENTRE A WIKILEAKS E O FACEBOOK. Francisco Rui Cádima

ZONAS DE CONTACTO Y LAS NUEVAS FORMAS DE CIRCULACIÓN: TRAYECTORIAS DISCURSIVAS Y PARTICIPACIÓN EN LÍNEA. Eduardo Ruedell y Viviane Borelli

SEMIÓTICA DAS INTERAÇÕES NO AUDIOVISUAL: PRODUÇÃO DE SENTIDOS NO CLIPE INTERATIVO "SATURN BARZ".

Bárbara Heliadora Cavalcante Fontenelle y Murilo Scoz

ARI FOLMAN'S PROMISES OF TECHNOLOGICAL MEDIATION IN THE CONGRESS. Cassia Cassitas

A TRANSMÍDIA COMO SEMIOSFERA PARA A CONSTRUÇÃO ESTÉTICA. Gisele Frederico

CONFIGURACIONES DISCURSIVAS DE LA CRÍTICA CINEMATOGRÁFICA EN YOUTUBE. Laura Andrea Iribarren

FOLKLORE DIGITAL, PROSUMIDORES Y CREEPYPASTA. Sandra Sánchez 
SEMIÓTICA NARRATIVA EN EL DISCURSO PUBLICITARIO CONTEMPORÁNEO: ANÁLISIS DE LA LANDING PAGE DE "MANANTIALES" DEL GRUPO EDISUR. Belén Angelelli y Natalia Desirée Vaccaro

SMARTHPHONES Y AURICULARES PARA INSCRIBIR LA CIUDAD COMO ESCENOGRAFÍA. Mónica Berman

REFLECTIONS ABOUT NEW PERCEPTIONS ON SPACE AND TIME: THE USE OF MOBILE PHONE IN THE METRO DE SANTIAGO, CHILE. Catalina Largo González

SEMIÓTICA APLICADA: CAMPANHA PUBLICITÁRIA JOURNEY, COM ANGELINA JOLIE, SOB O ESPECTRO DA TEORIA PEIRCEANA.

Carolina Boari Caraciola

MODALIDADES DE INSERCIÓN DE EMERGENTES CULTURALES EN LA COMUNICACIÓN DE LAS MARCAS. Claudio Centocchi

LA CONSTRUCCIÓN DEL DESTINATARIO EN LA MARCA PAÍS ARGENTINA. Daniela Fiorini y Paula Socolovsky

SEMIÓTICA APLICADA: ANÁLISE DE PEÇAS DA MARCA GATORADE À LUZ DA TEORIA PEIRCEANA. Gabriel Moni de Souza, Heder SeitiOno y Maria Clotilde Perez

TRAJECTORIES AND MEANINGS IN SPECIALTY COFFEE PACKAGING: A SEMIOTIC EXPLORATION OF THE BRAZILIAN MARKET. Maria Collier de Mendonça, Flavia Cardoso y Richard Perassi

ESTRATEGIAS, TRANSACCIONES Y SÍMBOLOS EN LA PUBLICIDAD ELECTORAL AUDIOVISUAL. María Ernestina Morales

RACISMO Y CLASISMO EN LA PUBLICIDAD MEXICANA. Carl Winston Jones

ADVERFILMS Y FENÓMENOS DE RETOMA: UNA APROXIMACIÓN SOCIOSEMIÓTICA A LA DISCURSIVIDAD PUBLICITARIA EN PLATAFORMAS INTERACTIVAS. Lorena Steinberg 


\section{TOMO 6}

\section{ESPACIALIDADES Y RITUALIZACIONES}

COORDINADOR: JOSÉ LUIS CAIVANO

POETIC SYMBOLS OF UNLIMITED TIME. Richard Trim

FUNDAMENTOS SEMIÓTICOS, ONTOLÓGICOS Y COGNITIVOS PARA UNA TEORÍA SEMIÓTICA DEL ESPACIO GEOGRÁFICO: APORTES DE UNA TESIS DOCTORAL. Emilas Darlene Carmen Lebus

SIGNIFICACIONES Y ACCIÓN SEMIOTÉCNICA EN LOS PROCESOS PRODUCTIVOS AGRARIOS DEL NORDESTE SANTAFESINO EN EL ESCENARIO DEL NORTE GRANDE ARGENTINO. TENDENCIAS Y CONTEXTOS DE SENTIDO. Emilas Darlene Carmen Lebus

DISCURSO JURÍDICO DE LA PLANEACIÓN DEL TERRITORIO EN COLOMBIA. ANÁLISIS SEMIO-DISCURSIVO: ESTUDIO DE CASO. Lucila Reyes Sarmiento y Camilo Alejandro Rodríguez Flechas

APUESTA ANALITICO TRANSDISCIPLINARIA FRENTE A LA HIBRIDACIÓN DE LAS AMENAZAS EN LA FRONTERA COLOMBOECUATORIANA EN CLAVE PROSPECTIVA. María Fernanda Noboa González

EL SUELO ES LAVA: REPRESENTACIÓN DE LOS FENÓMENOS VOLCÁNICOS EN RELATOS AUDIOVISUALES. Ignacio Dobrée y Ailén Spera

"SANTANDER AYER Y HOY, MEMORIAS DEL PATRIMONIO", UNA EXPERIENCIA CROSSMEDIA DEL ENTORNO FÍSICO AL DIGITAL. Norberto Fabián Díaz Duarte y Carolina Raigosa Díaz

EL ACTO DE LA REPRESENTACIÓN VISUAL MUSEAL COMO PUENTE ENTRE EL CONOCIMIENTO SOCIOLÓGICO Y EL SOPORTE SEMIÓTICO. Sebastián Chávez Hernández

APROXIMACIÓN AL CAMPO DE INTERTEXTOS EN LA OBRA DE TOMÁS SARACENO. María Rosa More 
LAS CULTURAS DE LOS PIXADORES Y DE LOS ESCRITORES DE GRAFFITI. Marco Tulio Pedroza Amarillas

MAPAS, CIDADES, MUROS: IMPRESSÕES DO/NO ESPAÇO. Kati Caetano y Adriana Tulio Baggio

CULTURAL LANDSCAPE AS METAPHOR. Olga Lavrenova

A SEMIOTIC JOURNEY THROUGH THE CONCEPT OF TRAJECTORY IN LATOUR'S THEORY. Giacomo Festi

TRANSCULTURALIDAD E IDENTIDAD EN LA MESOAMÉRICA CONTEMPORÁNEA. Horacio Mendizábal García

A SEMIOTIC AND GEOGRAPHICAL APPROACH TO MONUMENTS AN ANALYSIS OF THE MULTIPLE MEANINGS OF MONUMENTS IN TALLINN, ESTONIA. Federico Bellentani

SPACE, POWER AND INTER-SEMIOTIC TRANSLATION: THE SYMBOLISM OF ROME AND THE FASCIST REGIME. Pierluigi Cervelli

LA ITINERANCIA PÚBLICA Y EFIMERA COMO MODELO DE REPRESENTACION POPULAR Y POTENCIADORA EN LA PERFORMANCE CULTURAL Y POLITICA DE LOS FESTEJOS DEL BICENTENARIO. Daniela Lieban

LA SEMIÓTICA DE LOS HIMNOS PATRIOS Y SU INCIDENCIA EN LA CONFIGURACIÓN DE LA MENTALIDAD COLECTIVA. Julio César Rivera Dávalos

LA NOSTALGIA DEL SEXO FELIZ O REFLEXIONES SOBRE LA NOCHE DE LA NOSTALGIA EN URUGUAY. Claudia Mera Rodríguez

LA SANTIDAD COMO UNA FORMA DE VIDA Y LA FIGURA DE SANTA GIANNA BERETTA MOLLA. Jenny Ponzo

JAMES THE APOSTLE ICON: TRAJECTORIES IN HISPANIC LITERATURE (12TH-16TH CENTURIES). Lidia Raquel Miranda

SEMIOTIC INTERPRETATIONS OF THE SQUARE AND THE CIRCLE IN RELIGIOUS CULTURAL HERITAGE. Hee Sook Lee-Niinoja

SEMIOTICS AND AESTHETICS AS A DISCOURSE ON ARCHITECTURE CASE STUDY: MINIMALISM IN ARCHITECTURE. Dragana Vasilski 
INTER-SEMIOTIC APPROACH TO TEXTS-IMAGES OF FOOD SEALER ZIPPER BAGS. Hee Sook Lee-Niinioja

THE ESTHESIC TRANSFORMATION OF THE BUBBLE TEA: FROM EAST TO WEST. Rafael G. Lenzi

AT THE CROSSROAD OF BIOSIMULATION AND DESIGN: NOVEL CODES IN BI-MODAL REPRESENTATION OF BLOOD FLOW. Dolores A. Steinman y David A. Steinman 


\section{TOMO 7}

\section{PALABRAS PÚBLICAS}

COORDINADORES: MARIA ALEJANDRA ALONSO Y SERGIO RAMOS

LLORANDO EN EL COLÓN. RETOMAS DISCURSIVAS DEL G-20 EN LOS INTERNET MEMES. Nicolás Canedo, Verónica Urbanitsch y Daniel Sierra

SEMIÓTICA Y NARRATIVAS POLÍTICAS: PERSUASIÓN Y PROPAGANDA EN LA CONFIGURACIÓN DISCURSIVA DE LA IDENTIDAD DE ACTORES POLÍTICOS DEL CHACO A TRAVÉS DE LOS MEDIOS DE COMUNICACIÓN DE MASAS. Natalia Virgina Colombo y Romina Gisel Gayoso

LA DIMENSIÓN POLÉMICO/ANTAGÓNICA DEL DISCURSO PERONISTA. LA POLÉMICA PERÓN/LANUSSE. Hugo José Amable

VERIDICÇÃO E DISCURSO: INFORMAÇÃO E DESINFORMAÇÃO NO "JOGO DA VERDADE" DAS AGÊNCIAS DE CHECAGEM DE FATOS (FACT-CHECKING). Simone Bueno da Silva y Valdenise Leziér Martyniuk

¿GOLPE O IMPEACHMENT? LA POLARIZACION MEDIA DE LAS REVISTAS VEJA Y CARTA CAPITAL. Hélen Rodrigues Simões

JORNAIS REGIONAIS E A CONSTRUÇÃO DE VÍNCULOS COM SEUS LEITORES. Fabiana Sparremberger y Viviane Borelli

LA REVISTA TÍA VICENTA COMO EXPERIENCIA SEMIÓTICA CRÍTICA QUE DESVELA UNA REALIDAD POLÍTICA Y SOCIAL. María Lourdes Gasillón

EL ENCIERRO COMO ESPACIO NARRADO. Valeria Vivas Arce

LA SEMIÓTICA DEL ESPACIO POLÍTICO: UN ESTUDIO DE CASO EN AMÉRICA HISPANA TARDO-COLONIAL. Carmen Susana Cantera

AÇÃO COLETIVA E GERAÇÃO DE SENTIDO: OS DESAFIOS DE GESTÃO DE UM ESPAÇO PÚBLICO EM CRISE. Karin Vecchiatti 
TERRITORIOS EDUCATIVOS: LA LECTURA Y LA ESCRITURA EN LOS UMBRALES. Carla Vanina Andruskevicz

MANIOBRAS Y OPERACIONES SEMIÓTICAS EN LOS UMBRALES DE LA ALFABETIZACIÓN INICIAL. REFLEXIONES ACERCA DE PRÁCTICAS Y RELATOS EN LA FRONTERA. Raquel Alarcón y Froilán Fernández

APROXIMACIÓN DESDE LA SEMIÓTICA VISUAL EN EL DISEÑO DE MATERIALES DIDÁCTICOS PARA SORDOS. Lucero Fabiola García Franco

JÓVENES QUE CUENTAN: ANÁLISIS DE RELATOS AUDIOVISUALES DE ESTUDIANTES DE SECUNDARIOS. Corina llardo

EL GÉNERO AUDIOVISUAL ESCOLAR. CONTINUIDADES EN EL ANÁLISIS DE PRODUCCIONES PERIFÉRICAS Y PROPUESTA TEÓRICOMETODOLÓGICA. Diego Agustín Moreiras

COMPARATIVE ANALYSIS OF THE STATE OF AFFAIRS IN THE FIELD OF ART SEMIOTICS: SEMIOTICS OF VISUAL, AUDIOVISUAL AND PERFORMANCE LANGUAGES BETWEEN THE NATIONAL UNIVERSITY OF CORDOBA, ARGENTINA AND THE INSTITUTE OF ROMANCE LANGUAGES AND CULTURES, UNIVERSITY OF POTSDAM, GERMANY. Fabiola C. de la Precilla

ALFABETIZACIÓN SEMIÓTICA EN LA UNIVERSIDAD: DEVENIRES DE LA ENSEÑANZA DE LA SEMIÓTICA EN LAS CARRERAS DE LETRAS DE LA FACULTAD DE HUMANIDADES DE LA UNNE. Natalia Virginia Colombo

ENSEÑANZA DE LA SEMIÓTICA APLICADA A LA PLANIFICACIÓN DE PROYECTOS DE COMUNICACIÓN. EL DEVENIR DE UNA TRAYECTORIA ESPECÍFICA DE LA SEMIÓTICA ARGENTINA. Maria Alejandra Alonso, Rolando Martínez Mendoza y Sergio Ramos

DE QUÉ SIRVIÓ LA SEMIÓTICA. SEMIÓTICA APLICADA A LA PLANIFICACIÓN DE PROYECTOS DE COMUNICACIÓN EN UN ENTORNO VIRTUAL DE ENSEÑANZA Y APRENDIZAJE. Maria Alejandra Alonso y Sergio Ramos

LA HETEROGENEIDAD EN LA COMUNICACIÓN CIENTÍFICA. UN ANÁLISIS DISCURSIVO DESDE LA SEMIÓTICA DE LA CULTURA. Carina Itzel Gálvez García 


\section{TOMO 8}

\section{CONFERENCIAS PLENARIAS}

COORDINADORES: OSCAR STEIMBERG, OSCAR TRAVERSA Y

GASTÓN CINGOLANI

PAOLO FABBRI (1939-...). Tiziana Migliore

(traducción al español Claudio Guerri)

METALOGUES MEET INTERVIEW: IT TAKES THREE TO TANGO. Myrdene Anderson

MATRICES IDEOLÓGICAS Y COMPONENTE RETÓRICO EN LA DISCURSIVIDAD POLIITICA: LAS EMOCIONES EN MAURICIO MACRI Y CRISTINA FERNÁNDEZ DE KIRCHNER, AGOSTO DE 2019. Elvira Narvaja de Arnoux

A GRADUALIST PERSPECTIVE FOR A SEMIOTIC APPROACH TO VISUAL IMAGES. José Luis Caivano

TRAYECTORIA Y CONTINUIDAD DE LA TEORÍA TEXTUAL DE UMBERTO ECO EN LAS NUEVAS NARRATIVAS Y SUS ESTRATEGIAS TEXTUALES. Alfredo Tenoch Cid Jurado

LUIS PRIETO. LA RECUPERACIÓN DE UNA TEORÍA MUY PERTINENTE. María Teresa Dalmasso

EPISTEMOLOGÍA PARA UNA SEMIÓTICA DEL ESPACIO: CÉSAR JANNELLO. Lucrecia Escudero Chauvel

CURSOS SEMIÓTICOS: CAMINOS Y TRAYECTORIAS ANTRÓPICAS. Jacques Fontanille

APPLYING PEIRCE. FROM THE THREE CATEGORIES TO THE SEMIOTIC NONAGON. Claudio F. Guerri

TRAJECTOIRES DE LA SÉMIO-LINGUISTIQUE. Anne Hénault

A NON-ANTHROPOCENTRIC SEMIOTICS OF THE WRITING IN THE ERA OF THE POSTHUMAN LITERACY. Sung do Kim 
¿POR QUÉ HAY SENTIDO Y NO MÁS BIEN NADA? EXPERIENCIA, COGNICIÓN, SENTIDO. Jean-Marie Klinkenberg

PRESENTACIÓN DEL PROYECTO SEMIÓTICO: ACTUALIDAD DE RENÉ THOM. Isabel Marcos

THE SEMIOTIC METHOD. Tiziana Migliore

TRAJECTORIES OF MEANING IN SPACE AND VALUE SYSTEMS. Pierre Pellegrino

TRANSDISCIPLINARY TRAJECTORIES: THE AUDACITY OF DESIGN AND THE RESILENCE OF SIGNS. Farouk Y. Seif

READING TRAJECTORIES AND SEMIOSIS, GRAPHIC DESIGN AND IDEOLOGY. Evripides Zantides

SEMIÓTICA DE UN PROCESO UTÓPICO Y OTRO DISTÓPICO EN AMÉRICA LATINA: DOS SENDEROS ANTITÉTICOS HACIA LA AUTENTICIDAD. Fernando Andacht

TERRITORIOS ARTÍSTICOS EN DISPUTA. LA OBRA DE EDUARDO KAC. Pampa Arán

SEMIOSIS OF THE BODY IN ARAB SEXOLOGICAL LITERATURE. Mohamed Bernoussi

TRAYECTORIA DE LA SEMIÓTICA DE LAS MEDIATIZACIONES HACIA LAS PLATAFORMAS MEDIÁTICAS. José Luis Fernández

LE WEB 2.0 : UNE NOUVELLE TRAJECTOIRE POUR LA SÉMIOLOGIE AUDIOVISUELLE? François Jost

VECINDADES DIGITALES. HACIA QUÉ OBJETOS APUNTAN LOS ÍNDICES. María del Valle Ledesma

ROSTROS GIGANTES: TAMAÑO VERSUS PROPORCIÓN EN LA SEMIÓTICA DEL PODER. Massimo Leone

SEMIOSIS DE LAS ARTES PERFORMATIVAS: A PARTIR DEL CUERPO DE LAS ENVOLTURAS. Rocco Mangieri

DEL ESPACIO A LA CIUDAD. TRAYECTORIAS SEMIÓTICAS. Isabella Pezzini 
PRESENCIA, IDENTIDAD Y AFECTIVIDAD EN LOS HERALDOS NEGROS, DE CÉSAR VALLEJO. APUNTES DE HERMENÉUTICA SEMIÓTICA.

Óscar Quezada Macchiavello

CONTINUIDADES Y RUPTURAS EN LA NARRATIVA DE LA HISTORIETA COSTUMBRISTA. Oscar Steimberg

SALOMÉ Y JUDIT: DOS MILENIOS DE RECURRENCIA DISCURSIVA. Oscar Traversa

LOS LUGARES DE LA MEMORIA EN UN MARCO SEMIÓTICO. LA EXPERIENCIA DE SPEME. Patrizia Violi

FROM BUFFY TO A DISCOVERY OF WITHCHES. SEMIOTIC CONSIDRATIONS ON VAMPIRES, WITCHES, AND PRETERNATURAL PHENOMENA IN LITERATURE AND TELVISION. Gloria Withalm 


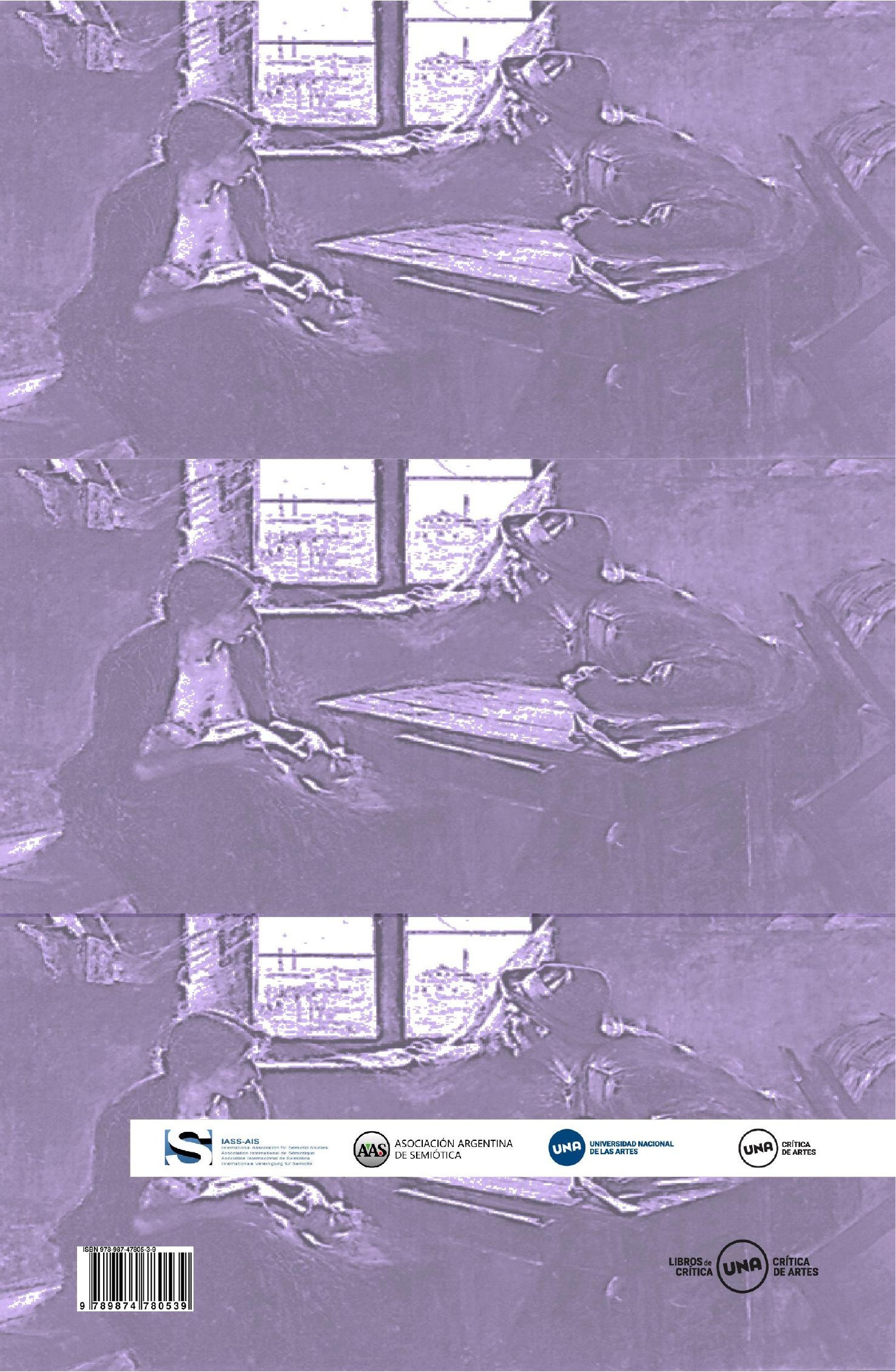

